\title{
Rapid Bioassessment Methods for Assessing Stream Macroinvertebrate Community on the Savannah River Site
}

by

W. L. Specht

Westinghouse Savannah River Company

Savannah River Site

Aiken, South Carolina 29808

M. H. Paller

\section{RECEIVED \\ DEC 061999 \\ OSTI}

DOE Contract No. DE-AC09-89SR18035

This paper was prepared in connection with work done under the above contract number with the U.S. Department of Energy. By acceptance of this paper, the publisher and/or recipient acknowledges the U. S. Government's right to retain a nonexclusive, royalty-free license in and to any copyright covering this paper, along with the right to reproduce and to authorize others to reproduce all or part of the copyrighted paper. 



\section{DISCLAIMER}

This report was prepared as an account of work sponsored by an agency of the United States Government. Neither the United States Government nor any agency thereof, nor any of their employees, makes any warranty, express or implied, or assumes any legal liability or responsibility for the accuracy, completeness, or usefulness of any information, apparatus, product or process disclosed, or represents that its use would not infringe privately owned rights. Reference herein to any specific commercial product, process or service by trade name, trademark, manufacturer, or otherwise does not necessarily constitute or imply its endorsement, recommendation, or favoring by the United States Government or any agency thereof. The views and opinions of authors expressed herein do not necessarily state or reflect those of the United States Government or any agency thereof.

This report has been reproduced directly from the best available copy.

Available for sale to the public, in paper, from: U.S. Department of Commerce, National Technical Information Service, 5285 Port Royal Road, Springfield, VA 22161

phone: (800) 553-6847

fax: (703) 605-6900

email: orders@ntis.fedworld.gov

online ordering: http://www.ntis.gov/ordering.htm

Available electronically at http://www.doe.gov/bridge

Available for a processing fee to U.S. Department of Energy and its contractors, in paper, from: U.S. Department of Energy, Office of Scientific and Technical Information, P.O. Box 62, Oak Ridge, TN 37831-0062 phone: (865)576-8401

fax: (865)576-5728

email: reports@adonis.osti.gov 


\section{DISCLAIMER}

Portions of this document may be illegible in electronic image products. Images are produced from the best available original document. 


\section{TABLE OF CONTENTS}

\section{Page}

Executive Summary

1.0 INTRODUCTION 1

2.0 DESCRIPTION OF STUDY SITES 3

3.0 SAMPLING METHODOLOGY 4

3.1. Hester-Dendy Multiplate Samplers . 4

3.2 RBP Methods 6

3.2.1 RBP II Methods

3.2.2 RBP III Methods 7 .

4.0 RESULTS 8

4.1 Hester-Dendy Multiplate Samplers 8

4.1.1 Data Overview 8

4.1.2 Development of a Biotic Index for Hester-Dendy Data 14

4.1.2.1 Data Analysis 14

4.1.2.2 Results 16

4.1.2.3 Description of the Index 16

4.1.2.4 Evaluation of the Index $\quad 19$

4.1.2.5 Discussion 22

4.2 RBP II Protocol 25

4.3 RBP III Protocol $\quad$. . . . 25

4.3.1 Data Overview 30

4.3.2 RBP Scores 30

4.3.3 Statistical Analysis of RBP Metrics and Selected Other Metrics 38

4.4 Comparison of RBP III and Hester-Dendy Data 38

$\begin{array}{lll}5.0 & \text { CONCLUSIONS } & 40\end{array}$

6.0 REFERENCES 40

APPENDIX A MACROINVERTEBRATE DATA

APPENDIX B EPA RAPID BIOASSESSMENT PROTOCOL METHODS 


\section{LIST OF TABLES}

Page

Table 2-1 Sampling Locations and Impact Status $\quad 6$

Table 4.1-1 Summary of Hester-Dendy Data, September 1994 . 9

Table 4.1-2 Dominant Taxa on Hester-Dendy Multiplate Samplers 13

Table 4.1-3 Average Characteristics of Macroinvertebrate Samples $\quad 17$ Collected from Unimpacted Streams, Polluted Streams, and Post-thermal Streams

Table 4.1-4 Metrics and Scoring Criteria Used in the Macroinvertebrate $\quad 20$. Biotic Index

Table 4.1-5 Metrics Included in Three Biotic Indices Developed for Use 24 in Different Geographic Areas

Table 4.2-1 Summary Statistics for RBP II Data 26

Table 4.2-2 Dominant Taxa at Each Station, RBP \| 27

Table 4.2-3 Summary Statistics for RBP II and III 28

Table 4.3-1 Summary Data For RBP III

Table 4.3-2 Dominant Taxa, RBP III 35

Table 4.3-3 RBP III Ratings, All Stations vs. Meyer's Branch 36

Table 4.3-4 RBP III Scoring Criteria 37

Table 4.3-5 Probability Values for Significant Differences of Kruskal- $\quad 39$ Wallis Tests on RBP III Metrics (Including Station 16 Rosemary Creek Just Below a Sanitary Treatment Plant)

Table 4.3-6 Probability Values for Significant Differences of Kruskal- 39 Wallis Tests on RBP III Metrics (Excluding Station 16 Rosemary Creek Just Below a Sanitary Treatment Plant) 


\section{LIST OF FIGURES}

Page

Figure 3.1-1 Hester-Dendy Multiplate Sampler 5

Figure 4.1-1 Biotic Index Values for Macroinvertebrate Data Collected 21 with Multiplate Artificial Substrates from Unimpacted (U), Post-thermal (PT) and Polluted (P) Streams on the Upper Coastal Plain of South Carolina

Figure 4.1-2 Biotic Index Values for Macroinvertebrate Data Collected with Multiplate Artificial Substrates from Two Streams on the Upper Coastal Plain of South Carolina During and After They Were Impacted by Releases of High Temperature Cooling Water from Nuclear Reactors 


\section{EXECUTIVE SUMMARY}

Macroinvertebrate sampling was performed at 16 locations in SRS streams using Hester-Dendy multiplate samplers and EPA Rapid Bioassessment Protocols (RBP). Some of the sampling locations were unimpacted, while other locations had been subject to various forms of perturbation by SRS activities. In general, the data from the Hester-Dendy multiplate samplers were more sensitive at detecting impacts than were the RBP data. We developed a Biotic Index for the Hester-Dendy data which incorporated eight community structure, function, and balance parameters. When tested using a data set that was unrelated to the data set that was used in developing the Biotic Index, the index was very successful at detecting impact .

We also evaluated the sensitivity of the RBP methods in detecting impact in coastal plain streams. Of the eight metrics used, only one was statistically significant in detecting differences between impacted and unimpacted streams. However, the eight metrics combined were able to detect some degree of impact at most impacted stations, but often detected impact at locations that were not impacted by SRS activities. We evaluated six additional metrics for possible incorporation into the RBP index. Two of the metrics did not detect differences between impacted and unimpacted locations, while the remaining four were as sensitive as most of the RBP metrics in detecting impacts.

\subsection{INTRODUCTION}

One of the problems that is inherent to assessing the health of an aquatic community is that although many parameters may be measured, there is no one perfect measure of community health. While the values for some parameters may suggest perturbation, the values for others may suggest little or no perturbation. Thus judging the overall health of an ecosystem can be very subjective, and largely based on best scientific judgment. There have been many attempts made to develop indices that combine many different parameters to yield one number that can then be used to quantify the degree to which a stream may be impacted.

In 1989, the U.S. Environmental Protection Agency published rapid bioassessment protocols for fish and aquatic macroinvertebrates (Plafkin et al., 1989). These protocols were designed to provide cost-effective screening methods for collecting fish and macroinvertebrate data from lotic systems that could be used for assessing stream quality. These rapid bioassessment protocols provide a means. of integrated assessment by comparing habitat features (physical structure, flow regime, etc.) and biological measures with empirically defined reference conditions. The primary advantage of this integrated approach is that since biological communities reflect the overall ecological integrity of an ecosystem, the cumulative effects of both physical and chemical stressors can be evaluated, thus providing a holistic measure of their aggregate impact over time.

The general approach that is used in all of the EPA rapid bioassessment protocols is to have a scientist who is familiar with the local faunal group of interest (fish or (macroinvertebrates) perform the stream surveys. Similar surveys are conducted at one or more unimpacted reference sites as well as at potentially impacted sites. 
Specific metrics are evaluated at each site, and the results are compared to the values obtained from the reference site. Based on the overall similarity of the metrics of the potentially impacted sites to those of the reference site, a site is categorized as nonimpaired, moderately impaired, or severely impaired.

Although these methods were developed primarily for use in the riffle-run areas of rocky-bottomed streams, Plafkin et al. (1989) state that "the final rapid bioassessment guidance should be generally applicable to all ecoregions of the United States, although specific elements and evaluation criteria may require modification for particular ecoregions".

Based on macroinvertebrate data collected from SRS coastal plain streams over the past twelve years, we believed that modifications of EPA's rapid bioassessment protocols would be necessary to customize them for use in our streams.

The shifting sand substrates present in southeastern coastal plain streams provide poor habitat for most species of macroinvertebrates. Instead, many species rely on structure provided by leafpacks, snags, aquatic vegetation, and root mats (Benke et al., 1984; Smock et al., 1985). Chironomids are also much more abundant in southeastern streams than in more northern rocky-bottomed streams, while stoneflies and mayflies are often less abundant. In many instances, chironomids are numerically the most abundant order of macroinvertebrates collected in our streams. Although the EPA rapid bioassessment protocols do not discriminate among subfamilies or tribes of chironomids, the sensitivities among these groups to perturbation are well documented. In general Tanytarsini chironomids are generally considered to be intolerant of stream enrichment and heavy metals (Heliovaara and Vaisanen, 1993), while Chironomini and Tanypodinae are generally recognized to be much more tolerant of most forms of perturbation. Most Orthocladiinae are generally considered to be intolerant of organic enrichment, but several species are reported to dominate in streams with elevated levels of heavy metals (Surber, 1959, Winner, et al, 1980).

With respect to functional feeding groups, southeastern coastal plain streams also differ from northern streams in that shredders are often found in extremely low numbers, even in headwater streams, while collector gatherers and collector-filterers are generally more abundant than in northern streams.

We investigated the use of aquatic macroinvertebrate data to evaluate environmental impacts to streams on and near the Savannah River Site (SRS), a U.S. Department of Energy (DOE) facility located in the sandhills/upper coastal plain region of west-central South Carolina, that was formerly used for the production of nuclear weapons materials. Some streams on the SRS have experienced various types of long-term chemical and/or physical degradation, including exposure to temperatures in excess of $70^{\circ} \mathrm{C}$. Although some streams are in various stages of recovery, others continue to receive effluent discharges and/or physical perturbations.

In order to identify and remediate perturbed streams, techniques are needed that rapidly and accurately assess their state of health in a cost-effective manner. The purpose of this study is to evaluate the utility of the existing EPA Rapid Bioassessment protocols in assessing aquatic macroinvertebrate communities in southeastern coastal plain streams that have been subjected to different kinds of stress, and if necessary, to develop modifications to the protocols to adapt them for use in these streams. 
To accomplish these objectives, we compared macroinvertebrate data that were collected using conventional multiplate samplers with data collected using the EPA's Rapid Bioassessment Protocols II and III. The data were then analyzed to develop biotic indices for multiplate sampler data and Rapid Bioassessment Protocol data that would allow for a rapid assessment of stream health in southeastern coastal plain streams.

\subsection{DESCRIPTION OF STUDY SITES}

The SRS includes six stream systems within a $780 \mathrm{~km}^{2}$ area located in the sandhills ecoregion on the upper coastal plain of South Carolina: Upper Three Runs, Beaver Dam Creek, Fourmile Branch, Pen Branch, Steel Creek, and Lower Three Runs. The streams in the sand hill and coastal plain ecoregions are characterized by low gradients, sandy bottoms, and lack of well defined pool-riffle-run habitats (Paller, 1994). Snags and other woody debris constitute the principal instream structure, together with rooted aquatic vegetation, root mats, undercut banks, overhanging shoreline vegetation, and leafpacks. Many coastal plain streams, including those on the SRS, are blackwater streams, with relatively low pH (4.5 to 6.9), specific conductance ( 11 to $104 \mu \mathrm{S} / \mathrm{cm}$ ), and hardness ( 5 to $25 \mathrm{mg} / \mathrm{las} \mathrm{CaCO}_{3}$ ), and relatively high concentrations of humic and fulvic acids, which give the streams their characteristic tea-colored water.

Streams on and near the SRS range in size from first.through fourth order (Strahler 1957), are approximately $2-15 \mathrm{~m}$ wide and $0.6-2.5 \mathrm{~m} / \mathrm{km}$ in average gradient. These streams support diverse macroinvertebrate communities, dominated by species in the orders Diptera, Ephemeroptera, Plecoptera, Trichoptera, and Coleoptera. Of the Diptera, the Tanytarsini chironomids are generally most abundant in unperturbed streams.

Because of its large size, restricted access, and former industrial activities, the Savannah River Site contains streams that range from virtually pristine to severely impacted. Impacts include:

Thermal and post-thermal: Several streams formerly received large volumes of hot $\left(70^{\circ} \mathrm{C}\right)$ secondary cooling water discharged from nuclear reactors, which resulted in near total elimination of aquatic biota and extensive scouring/channel erosion. After thermal discharges were eliminated between 1985 and 1988, the streams were rapidly recolonized by aquatic macroinvertebrates (Enwright, 1989a, 1989b, 1989c; Lauritsen and Starkel, 1989), but continued to suffer degraded instream habitat.

Impoundment related: Stream reaches below reactor cooling water reservoirs experienced alterations in discharge regime, water chemistry, and the introduction of reservoir biota:

Heavy metals and other industrial discharges: Several streams receive inputs of toxicants from coal piles, coal ash basins, seepage basins, and/or metal processing facilities. One stream was also channelized.

Secondary sewage effluent: Although several SRS streams receive treated sanitary effluent (Tim's Branch, Fourmile Branch, Upper Three Runs), these streams also 
receive other industrial effluents, which could mask the effects of nutrient enrichment on macroinvertebrate communities. For this reason, we also sampled two locations on Rosemary Creek, which is not on the SRS, but receives sanitary effluent from a secondary sanitary waste treatment plant. One sampling location was immediately downstream from the sanitary outfall, while the second location was about two km downstream from the outfall.

A total of sixteen sampling locations in first through fourth order streams were selected as study sites for Hester-Dendy sampling and testing of the RBP methods. Sampling was conducted in Upper Three Runs, four tributaries of Upper Three Runs (Tinker Creek, Mill Creek, Crouch Branch, and Tim's Branch), Beaver Dam Creek, Fourmile Branch (two locations), Indian Grave Branch, Pen Branch (two locations), Meyer's Branch, Lower Three Runs, and Rosemary Creek (two locations). Of these locations, six represent relatively unperturbed habitats, six are thermal or post-thermal habitat, one is located downstream from a reservoir, at least four are subject to varying degrees of perturbation by industrial discharges, and three are located at varying distances downstream from a sanitary wastewater treatment plant. As shown in Table 2-1. several of the sites have been impacted by more than one type of perturbation. An additional 24 sampling sites in first through third order SRS streams were sampled in 1993 with Hester-Dendy samplers only (Specht, 1994). These 24 sites represented unimpacted, post-thermal, and industrially impacted habitats. The data from these sites were also used in the development of the biotic index. In addition, macroinvertebrate multiplate data that were collected from SRS streams as part of other sampling programs were also used for validation of the biotic index.

\subsection{SAMPLING METHODOLOGY}

\subsection{Hester-Dendy Multiplate Samplers}

At each sampling location, five replicate Hester-Dendy multiplate samplers (Figure 3.1-1), each having a surface area of $0.179 \mathrm{~m}$ were deployed and allowed to colonize for 28 days. The samplers were retrieved and returned to the laboratory for processing. In the laboratory, the samplers were disassembled and organisms were gently removed from the plates using a soft brush or a stream of water from a wash bottle. Organisms were preserved in $70 \%$ ethanol until identified. Organisms were identified to the lowest practical taxon (usually genus). Parameters reported included total number of taxa collected at each station, mean number of taxa per sampler. density of organisms (number per $\mathrm{m}^{2}$ ), EPT (number of Ephemeroptera, Plecoptera, and Trichoptera taxa collected at a station), biotic index, ratio of scrapers to collectorfilterers, biomass ( $g$ ash free dry weight $/ \mathrm{m}^{2}$ ), relative abundance of functional feeding groups, relative abundance of functional feeding group biomass, relative abundance of major taxonomic groups (usually Order), and a listing of all taxa which comprised greater than $5 \%$ of the macroinvertebrates collected at each station. The raw data for each station are presented in Appendix A.

At the time of sampler retrieval, physical and chemical measurements were taken at each station. Parameters included water hardness, $\mathrm{pH}$, conductivity, dissolved oxygen, temperature, water velocity, stream width, and stream depth at one meter intervals across the stream (see Appendix A for physical/chemical data). 
TABLE 4.1-1 (cont). SUMMARY OF HESTER-DENDY DATA, SEPTEMBER 1994

\begin{tabular}{|c|c|c|c|c|c|c|c|c|}
\hline Parameter & 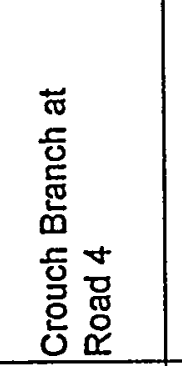 & 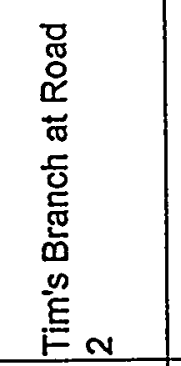 & 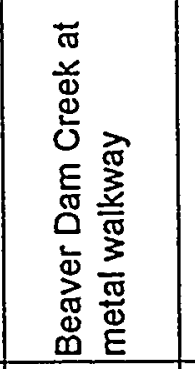 & 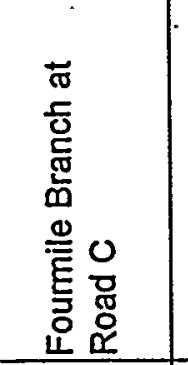 & 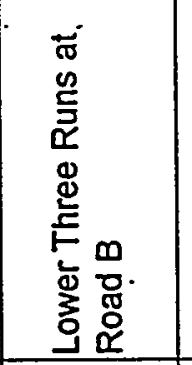 & 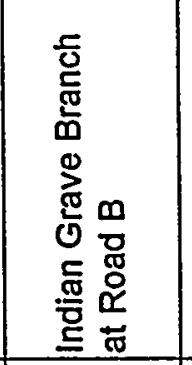 & 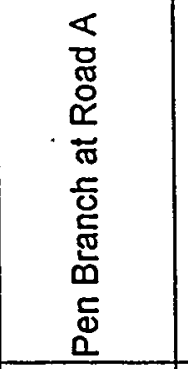 & 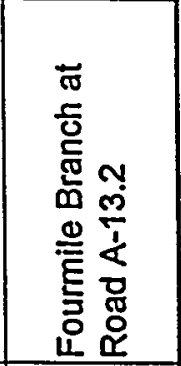 \\
\hline & Station 4 & Station 5 & Station 14 & Station 7 & Station 10 & Station 12 & Station 13 & Station 15 \\
\hline & IND & IND & IND & \begin{tabular}{|l|l|} 
IND \\
\end{tabular} & PT & PT & PT & PT \\
\hline Total \# of organisms & 223 & 1535 & 450 & 1754 & 1943 & 2256 & 2001 & 1726 \\
\hline Total \# of taxa & 25 & 39 & 27 & 55 & 23 & 38 & 51 & 48 \\
\hline Mean \#/sq. meter & 249.2 & 1715.1 & 502.8 & 1959.8 & 2171.0 & 2520.7 & 2235.8 & 1928.5 \\
\hline Number of samplers & 5 & 5 & 5 & 5 & 5 & 5 & 5 & 5 \\
\hline Mean \# taxa/sampler & 11.8 & 22.4 & 14.4 & 27.6 & 14.2 & 18.0 & 35.0 & 30.6 \\
\hline EPT & 3 & 6 & 9 & 11 & 4 & 9 & 15 & 17 \\
\hline $\mathrm{SC} / \mathrm{CF}$ & 2.00 & 0.01 & 2.53 & 0.12 & 0.14 & 0.67 & 0.16 & 1.11 \\
\hline Biotic Index & 8.46 & 6.64 & 4.86 & 6.92 & 7.60 & 7.73 & 6.50 & 5.63 \\
\hline Biomass (g/m2) & 0.0409 & 0.0327 & $0 . \dot{4} 422$ & 0.0904 & 0.1012 & 0.3462 & 0.5365 & 0.3176 \\
\hline \multicolumn{9}{|l|}{ TAXA } \\
\hline Hydra & 0.00 & 0.00 & 0.00 & 0.00 & 0.00 & 0.00 & 0.00 & 0.06 \\
\hline Hirudinea & 0.00 & 0.00 & 0.00 & 0.00 & 39.99 & 0.04 & 0.00 & 0.00 \\
\hline Nemertea & 0.00 & 0.13 & 0.00 & 2.79 & 0.46 & 2.26 & 2.45 & 0.81 \\
\hline Nematoda & 0.90 & 0.00 & 0.00 & 0.00 & 0.00 & 0.00 & 0.35 & 0.12 \\
\hline Oligochaeta & 17.94 & 3.65 & 3.56 & 13.00 & 0.00 & 71.81 & 25.04 & 4.69 \\
\hline Turbellaria & 1.79 & 0.00 & 0.00 & 8.95 & 1.03 & 0.00 & 0.20 & 0.23 \\
\hline Bivalvia & 0.00 & 0.00 & 0.00 & 0.00 & 0.00 & 0.00 & 0.00 & 0.00 \\
\hline Gastropoda & 1.35 & 0.07 & 1.11 & 0.11 & 0.05 & 0.53 & 0.55 & 0.00 \\
\hline Amphipoda & 0.00 & 0.00 & 0.22 & 0.40 & 0.00 & 0.00 & 0.00 & 0.00 \\
\hline Decapoda & 0.45 & 0.00 & 0.00 & 0.00 & 0.00 & 0.00 & 0.00 & 0.00 \\
\hline Hydracarina & 0.00 & 0.98 & 0.00 & 0.11 & 0.00 & 0.13 & 0.40 & 0.52 \\
\hline Ephemeroptera & 2.24 & 0.39 & 73.33 & 1.37 & 0.41 & 1.06 & 14.29 & 44.67 \\
\hline Plecoptera & 0.00 & 0.33 & 0.22 & 0.00 & 0.00 & 0.00 & 0.00 & 0.17 \\
\hline Trichoptera & 0.00 & 0.07 & 11.78 & 0.91 & 0.93 & 0.80 & 24.09 & 12.63 \\
\hline Odonata & 3.59 & 0.13 & 0.00 & 0.46 & 0.05 & 0.09 & 0.40 & 0.29 \\
\hline Coleoptera & 0.00 & 2.08 & 1.56 & 0.91 & 0.05 & 0.04 & 4.60 & 1.97 \\
\hline Megaloptera & 0.00 & 0.00 & 1.56 & 0.00 & 0.31 & 0.04 & 1.10 & 0.06 \\
\hline Lepidoptera & 0.00 & 0.00 & 0.00 & 0.00 & 0.00 & 0.00 & 0.15 & 0.00 \\
\hline Chironomini & 56.05 & 11.92 & 2.22 & 11.29 & 40.40 & 10.06 & 1.10 & 3.88 \\
\hline Diamesinae & 0.00 & 0.00 & 0.00 & 0.00 & 0.00 & 0.00 & 0.00 & 0.00 \\
\hline Orthocladiinae & 0.45 & 17.72 & 2.00 & 3.19 & 7.36 & 1.24 & 12.94 & 4.00 \\
\hline Pseudochironomini & 0.00 & 0.00 & 0.00 & 0.06 & 0.00 & 0.00 & 0.00 & 0.00 \\
\hline Tanypodinae & 9.87 & 3.65 & 0.67 & 14.42 & 7.31 & 4.65 & 3.30 & 5.45 \\
\hline Tanytarsini & 4.48 & 57.20 & 1.78 & 41.28 & 0.51 & 5.54 & 8.75 & 19.93 \\
\hline Other Diptera & 0.90 & 1.69 & 0.00 & 0.74 & 1.13 & 1.68 & 0.30 & 0.52 \\
\hline
\end{tabular}

IND - Receives industrial effluents

PT - Post-thermal 
TABLE 4.1-1 (cont). SUMMARY OF HESTER-DENDY DATA, SEPTEMBER 1994

\begin{tabular}{|c|c|c|c|c|c|c|c|c|}
\hline \multirow[t]{3}{*}{ Parameter } & 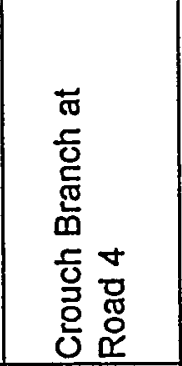 & 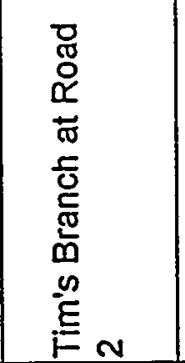 & 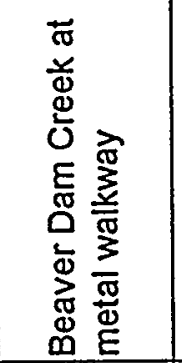 & 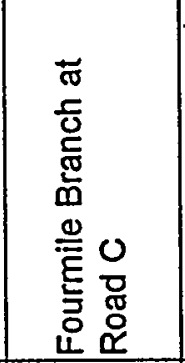 & 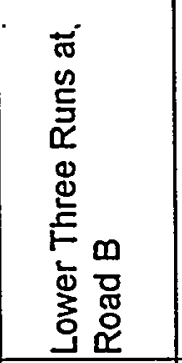 & 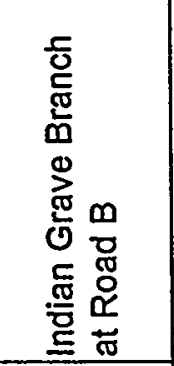 & 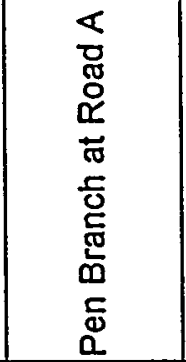 & 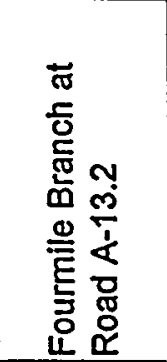 \\
\hline & Station 4 & Station 5 & Station 14 & Station 7 & Station 10 & Station 12 & Station 13 & Station 15 \\
\hline & IND & IND & IND & IND & \begin{tabular}{|l|} 
PT \\
\end{tabular} & PT & PT & PT \\
\hline \multicolumn{2}{|l|}{ FUNCTIONAL GR. } & & & & & & & \\
\hline Collector-gatherer & 78.48 & 62.93 & 54.67 & 66.19 & 88.68 & 88.70 & 56.62 & 55.97 \\
\hline Collector-filterer & 1.35 & 25.54 & 11.78 & 4.85 & 1.90 & 1.33 & 27.39 & 14.25 \\
\hline Predator & 16.59 & 6.71 & 2.44 & 27.82 & 9.16 & 7.45 & 8.60 & 8.69 \\
\hline Scraper & 2.69 & 0.33 & 29.78 & 0.57 & 0.26 & 0.89 & 4.25 & 15.76 \\
\hline Shredder & 0.00 & 4.50 & 1.11 & 0.40 & 0.00 & 1.24 & 0.50 & 0.98 \\
\hline \multirow[t]{2}{*}{ Herbivore } & 0.90 & 0.00 & 0.22 & 0.17 & 0.00 & 0.40 & 2.65 & 4.35 \\
\hline & & & & & & & & \\
\hline \multicolumn{9}{|c|}{ FUNC. GR. BIOMASS } \\
\hline Collector-gatherer & 49.18 & 47.44 & 13.95 & 47.71 & 21.08 & 18.55 & 21.01 & 26.35 \\
\hline Collector-filterer & 4.10 & 20.14 & 20.06 & 4.33 & 9.05 & 4.45 & 14.47 & 20.72 \\
\hline Predator & 13.66 & 15.02 & 20.59 & 35.35 & 68.87 & 5.65 & 43.82 & 5.80 \\
\hline Scraper & 7.38 & 2.73 & 26.12 & 6.43 & 0.99 & 4.26 & 10.29 & 29.41 \\
\hline Shredder & 0.00 & 11.26 & 16.17 & 3.46 & 0.00 & 66.34 & 5.91 & 7.11 \\
\hline Herbivore & 25.68 & 3.41 & 3.11 & 2.72 & 0.00 & 0.74 & 4.50 & 10.62 \\
\hline
\end{tabular}

IND - Receives industrial effluents

PT - Post-thermal 
3) total number of taxa and number of EPT (Ephemeroptera, Plecoptera, and Trichoptera) taxa;

4) proportional abundances of functional groups and functional group similarity to reference sites;

5 ) indicators of community balance including the North Carolina Biotic Index (NCBI, Lenat 1993), taxonomic similarity to reference sites, and a dominance index; 6) total density $\left(\mathrm{no} . / \mathrm{m}^{2}\right)$ and total biomass (g ash-free dry weight $/ \mathrm{m}^{2}$ ).

We selected the preceding variables on the basis of theoretical expectations, their use in other indices, and prior experience. We used the nonparametric, univariate KruskalWallis test to determined if each of them significantly differed among stream orders (which would necessitate the development of stream order based criteria) and between impacted and unimpacted streams. We did not correct for the increased probability of Type I error associated with multiple tests because we viewed these tests as preliminary and exploratory.

We used the Pinkham and Pearson community similarity index (Pinkham and Pearșon 1976, Plafkin et al. 1989) to measure community and functional group similarities between reference and ambient sites. For taxonomic group similarity, we calculated the average percent abundance at the subfamily, family, or ordinal level for the 15 most abundant taxa at the reference stations, then used the index to measure the similarity between these average abundances and the percent abundances at each station. Analogous procedures were used for functional group similarities.

The dominance index consisted of the percent contribution of the dominant taxa. The assumption is that high percent dominance by a single taxon indicates impairment (Plafkin et al. 1989, Barbour et al. 1992).

The North Carolina Biotic Index (NCBI) is a method for.summarizing the pollution tolerances of the invertebrates collected from a sample site based on preassigned values reflecting sensitivity to organic and/or toxic materials (Lenat 1993). Index values range from one to 10 with lower scores indicating better water quality. We based the tolerance values for the macroinvertebrates in our streams on the tolerance values for North Carolina stream macroinvertebrates given by Lenat (1993).

As an additional test of the usefulness of the taxonomic data, we employed canonical discriminant analysis (CDA) to determine if the densities (no. $/ \mathrm{m}^{2}$ ) of the 25 most abundant taxa could be used to distinguish among industrially impacted, post-thermal, and unimpacted streams. To better meet the criteria for multivariate normality, densities were $\log 10(x+1)$ transformed prior to analysis. The significance of differences among sites was tested with the Wilk's Lambda, Pillai Trace, Hotelling-Lawley Trace, and Theta procedures $(P<0.05)$.

We developed a multi-metric index employing a variety of assemblage level attributes following the general format presented by Karr et al. (1986) for fish and by Kerans and Karr (1994) for macroinvertebrates. Criteria for inclusion of a metric in the multi-metric index were that it accurately discriminated between impacted and unimpacted sites and was not highly redundant (Spearman $r>0.80$ ) with other metrics. Each metric was assigned a value of one, three, or five, and the biotic index was calculated by summing the scores for each metric. The score received for each metric was based on 
stream types and are well known to be sensitive to environmental perturbations (see Lenat 1988, Kerans and Karr 1994, Karr et al. 1986).

2) Community balance variables. Community balance variables included percent Tanytarsini, percent Trichoptera, percent Ephemeroptera, and community similarity using the Pearson-Pinkham community similarity index. The first three variables accurately discriminated impacted from unimpacted streams, with percent Tanytarsini separating both industrially impacted and post-thermal streams from unimpacted streams, percent Trichoptera separating post-thermal streams from unimpacted streams, and percent Ephemeroptera separating industrially impacted streams from unimpacted streams. The similarity index provided an integrative comparison of overall taxonomic similarity between the impacted and unimpacted streams.

3) Community function variables. Functional group composition in both industrially impacted and post-thermal streams deviated from that in the unimpacted streams, although the types of deviations exhibited by the industrially impacted and post-thermal streams differed. Therefore, we employed the Pinkham-Pearson similarity index to compute the similarity between each station and the average functional group composition at the 15 unimpacted sites, an approach that would be sensitive to any type of deviation from the expected condition. We also included density as a community function variable since it is sensitive to changes in nutrient levels (resulting in increases) as well as the presence of toxicants (resulting in decreases). Since both unusually high and unusually low densities are indicative of disturbed conditions (Table 4.1-3), we expressed the average density at each station as a standard deviate (Sokal and Rohif 1981) from the average density in the unimpacted streams.

Table 4.1-4 summarizes the index metrics and the scoring criteria for each metric. The criteria were somewhat arbitrary and chosen to maximize the separation between reference and impacted sites. There were other variables that significantly differed between impacted and unimpacted streams (Table 4.1-3) that were not included in the index because they were redundant (Spearman $r>0.80$ ) with the variables already in the index and/or because they failed to add to the index's ability to discriminate between impacted and unimpacted sites.

Spearman correlations among the eight variables included in the index ranged from 0.01 to 0.79 . The highest correlations were between number of EPT taxa and total number of taxa (0.79), number of EPT taxa and percent Ephemeroptera (0.69), community similarity and number of taxa $(0.60)$, number of EPT taxa and percent Trichoptera (0.59), and number of taxa and functional group similarity (0.56) indicating high to moderate redundancy among some metrics. However, we retained all of them in our index because they enhanced the ability of the index to discriminate between impacted and unimpacted sites.

\subsubsection{Evaluation of the Index}

Index values significantly $(P \leq 0.001)$ differed among unimpacted, industrially impacted, and post-thermal streams and overlapped very little between impacted and unimpacted streams (Figure 4.1-1). One relatively low index value (28) occurred at an ostensibly unimpacted site, probably because this site occasionally experienced low dissolved oxygen levels $(2.0 \mathrm{mg} / \mathrm{l})$ 
TABLE 4.1-4 METRICS AND SCORING CRITERIA USED IN THE MACROINVERTEBRATE BIOTIC INDEX.

\begin{tabular}{|c|c|c|c|c|}
\hline \multirow[b]{2}{*}{ Metrics } & \multirow[b]{2}{*}{1} & \multicolumn{2}{|c|}{ Scoring criteria } & \\
\hline & & 3 & $5^{\circ}$ & \\
\hline Number of taxa & $<35$ & $35-45$ & $>45$ & \\
\hline Standardized density ${ }^{a}$ & $>2.5$ & $>1.5-2.5$ & $\leq 1.5$ & \\
\hline Number EPT ${ }^{\mathrm{b}}$ taxa & $<10$ & $10-14$ & $>15$ & \\
\hline Tanytarsini (\%) & $<10$ & $10-25$ & $>25$ & \\
\hline Trichoptera (\%) & 0 or $>10$ & & $>0-10$ & \\
\hline Ephemeroptera (\%) & $<2$ & $2-7$ & $>7$ & \\
\hline Taxonomic similarity $^{c}$ & $<0.25$ & $0.25-0.45$ & $>0.45$ & $\cdot$ \\
\hline Functional group $^{d}$ & $<0.45$ & $0.45-0.55$ & $>0.55$ & \\
\hline
\end{tabular}

Individual metrics are assigned scores of one, three, or five. The biotic index is calculated by summing the scores for the individual metrics.

'Standardized density $=[(X-M) / S D \mid:$ where $X=$ density, $M=$ average density for the unimpacted station $\left(1309 / \mathrm{m}^{2}\right)$ and $\mathrm{SD}=$ standard deviation of the mean for the unimpacted stations $\left(396 / \mathrm{m}^{2}\right)$.

'Ephemeroptera, Plecoptera, and Trichoptera.

'Similarity to the average taxonomic composition at the unimpacted stations (calculated with Pinkham and Pearson index)

'Similarity to the average functional group composition at the unimpacted stations (calculated with Pinkham and Pearson index) 


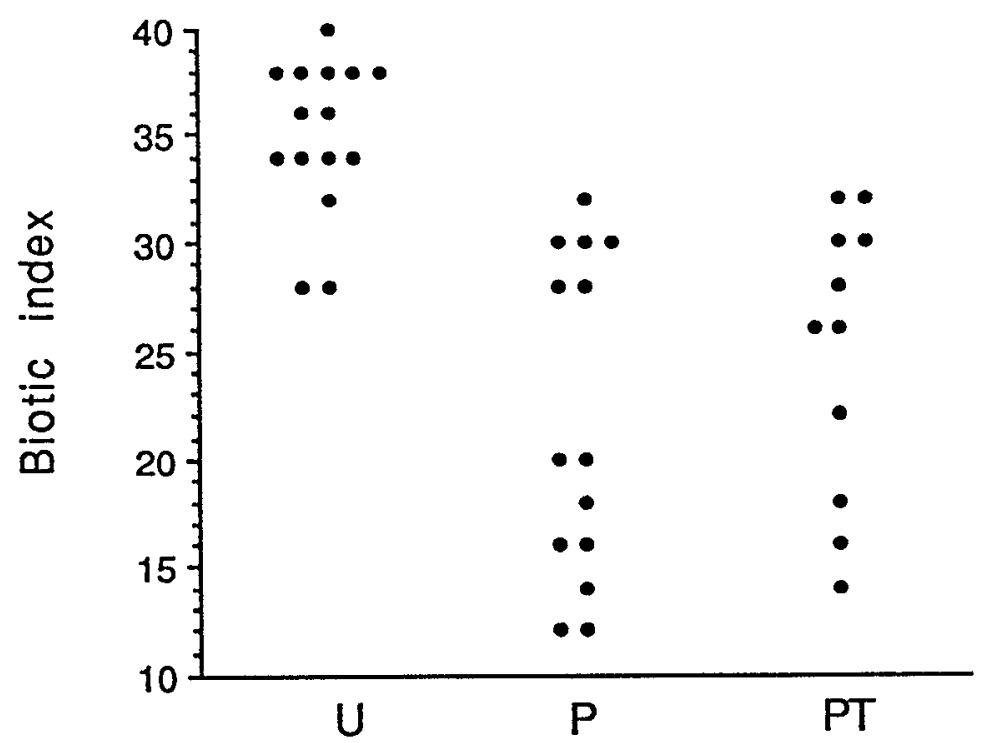

FIGURE 4.1-1. BIOTIC INDEX VALUES FOR MACROINVERTEBRATE DATA COLLECTED WITH MULTIPLATE ARTIFICIAL SUBSTRATES FROM UNIMPACTED (U), POST-THERMAL (PT) AND POLLUTED (P) STREAMS ON THE UPPER COASTAL PLAIN OF SOUTH CAROLINA.

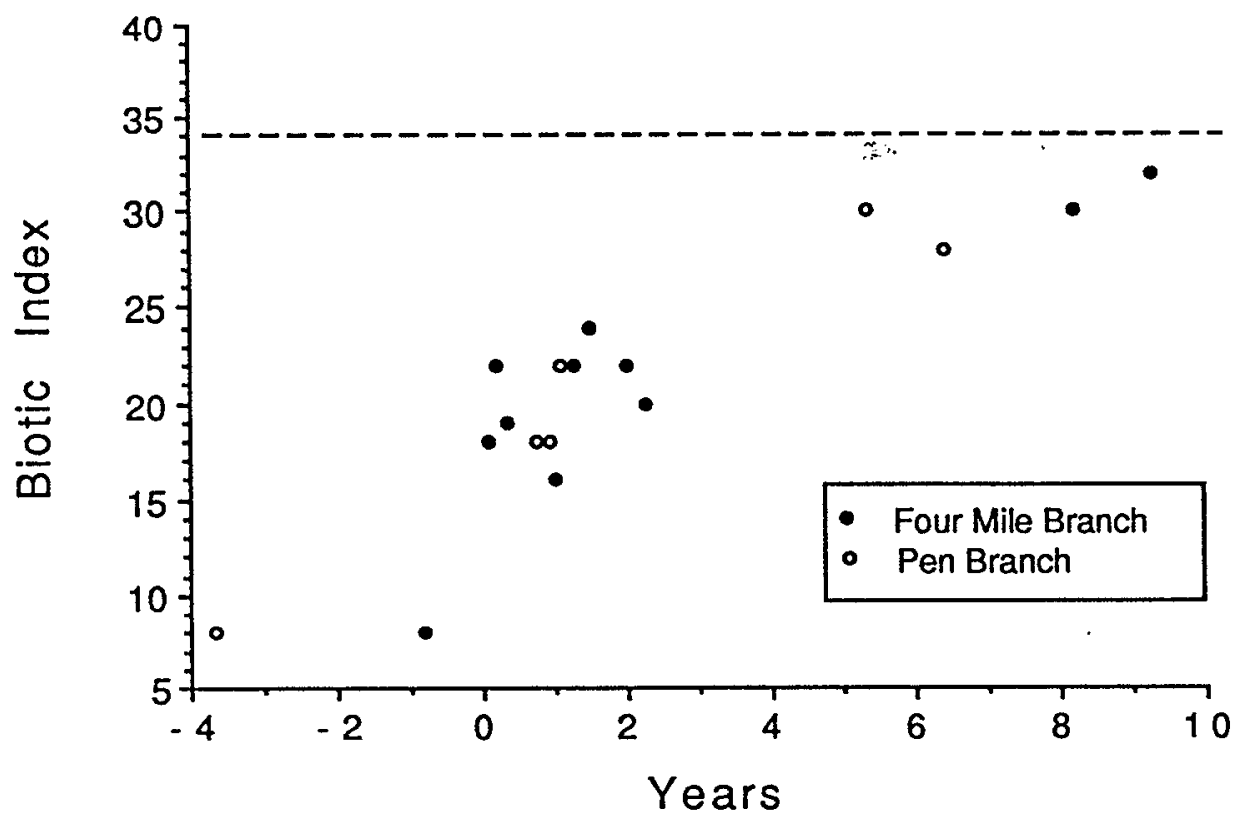

FIGURE 4.1-2. BIOTIC INDEX VALUES FOR MACROINVERTEBRATE DATA COLLECTED FROM TWO STREAMS ON THE UPPER COASTAL PLAIN OF SOUTH CAROLINA DURING AND AFTER THEY WERE IMPACTED BY RELEASES OF HIGH TEMPERATURE COOLING WATER FROM NUCLEAR REACTORS. ZERO ON THE X-AXIS DENOTES THE TIME AT WHICH THE REACTORS WERE SHUT DOWN. THE DOTTED LINE REPRESENTS TYPICAL MINIMUM BIOTIC INDEX VALUES FOR UNIMPACTED SITES. 
for unknown reasons. The lowest index values (8-16) occurred in several of the industrially impacted streams, at sites that formerly received the most severe thermal impacts (Kondratieff and Kondratieff 1985), and at one stream station located immediately downstream from a reservoir.

Additional data were collected from two SRS streams (Pen Branch and Four Mile Branch) during and at various times after they received thermal reactor discharge (Lauritsen and Starkel 1989, Kondratieff and Kondratieff 1985). These data were not used in index development and represented conditions not included in the first data set (i.e., periods of thermal discharge and early recovery phases). Therefore, we used them to test the bioassessment methodology developed with the first data set. Index values from both streams were extremely low (8) when heated reactor cooling water was being discharged (Figure 4.1-2). After discharge ceased, index values in Four Mile Creek rose rapidly (within approximately one month) to 18-22 as macroinvertebrates recolonized the stream. However, they failed to increase above this level for the next two years because of low taxa richness, low taxonomic and functional group similarity to the unimpacted streams, and abnormally high densities. Even after eight to ten years had elapsed, index values had not reached levels typical of unimpacted streams (Figure 4.1-2). A similar recovery pattern was exhibited in Pen Branch, although fewer data were collected from this stream. The preceding patterns made sense considering the history of the streams and the types of damage they incurred and strengthened our confidence in the index as a useful assessment tool.

\subsubsection{Discussion}

Multi-metric indices reflecting community structure, community function, and community balance are an effective method of summarizing macroinvertebrate data for assessment purposes. Because they include a variety of metrics that are sensitive to different environmental perturbations, multi-metric indjces reflect a wide range of chemical and physical impacts. For example, total number of taxa and number of EPT taxa were sensitive indicators of toxicity in the polluted streams but not of habitat alterations in the post-thermal streams. Conversely, percent abundance of Trichoptera and Tanytarsini were good indicators of habitat alterations in the post-thermal streams. Because the index included all of the preceding metrics, it effectively measured both types of impacts.

There are various factors to consider when choosing metrics to include in multi-metric indices. Ecological theory is important but empirical comparisons of impacted and unimpacted sites can sometimes identify useful metrics that might have been overlooked on the basis of apriori ecological considerations. For example, we found percent Trichoptera to be the best discriminator of impacted from post-thermal streams. In hindsight, we believe the ecological basis for this increased abundance of Trichoptera in post-thermal streams is that the trophic base in these streams has been altered. However, this link did not become obvious until empirical comparisons revealed large differences in the relative abundance of Trichoptera between unimpacted and post-thermal streams.

In addition to our index for streams in the upper coastal plain of South Carolina, two other multi-metric indices have recently appeared in the literature, one for rivers of the 
Tennessee Valley (Kerans and Karr 1994) and one covering a larger geographic area (Oregon, Colorado, and Kentucky, Barbour et al. 1992). It is significant that all three indices contain similar categories of metrics although the specific metrics within each category usually differ (Table 4.1-5). The categories are community structure, community balance, and community function. Community structure metrics generally consist of taxa counts. Community balance metrics are of three types, proportional abundance of indicator groups (with unusually high or low abundances indicating degradation), taxonomic similarity indices which relate taxonomic composition to the taxonomic composition expected in unimpacted reference streams, and biotic indices (such as Hilsenhoff's index (1987) or the NCBI (Lenat, 1993)) that summarize tolerances of the organisms in the macroinvertebrate community. Community function metrics are of three types, proportional abundances of different functional feeding groups, functional group similarity indices that relate functional group composition to functional group composition in unimpacted streams, and measures of total organism abundance. The fact that these metrics have been tested and proven useful in several geographic areas indicates that they accurately represent basic aspects of community structure and function that change in response to habitat degradation.

While multi-metric indices often include the same categories of metrics, the specific . metrics within each category usually differ (with the exception of total taxa richness and number of EPT taxa which seem to be of widespread applicability). As an example of differences, we found that the proportional abundances of Tanytarsini chironomids, Trichoptera, and Ephemeroptera were effective indicators of community balance in streams on the upper coastal plain of South Carolina. In contrast, Kerans and Karr (1994) found that the proportional abundances of Corbicula, Oligochaetes, and Chironomidae were good indicators of community balance in Tennessee Valley streams. Such differences result from the influence of ecoregion, stream size, habitat (e.g., pool vs. riffle) and sampling method (as a result of the biases associated with each method) on faunal composition and ecological processes. Therefore, metrics that are effective in one ecoregion/habitat combination may be ineffective in others. In summary, it is likely that multi-metric indices from different ecoregions (or for use with data collected by different methods) will include the same classes of metrics but (with some exceptions) not the same metrics. They will appear superficially different but measure the same things.

As previously noted, similarity indices are often included in multi-metric indices (see Plafkin et al. 1989 and Barbour et al. 1992 for more on the use of similarity indices). Taxonomic or functional group similarity is generally calculated between an individual reference site, chosen to be representative of unimpacted conditions, and each ambient site under evaluation. Where possible, we advocate that reference conditions be represented by average values for a number of unimpacted sites rather than a single site in order to accommodate variability among unimpacted sites. We found similarity indices to be particularly effective when degradation could be indicated by either positive or negative deviations from community attributes in unimpacted streams.

Most bioassessment protocols require that macroinvertebrates be collected from natural substrates. Collections may be restricted to certain habitats known to support types of invertebrates useful for bioassessment (e.g., riffles, see Hilsenhoff 1987) or 
TABLE 4.1-5. METRICS INCLUDED IN THREE BIOTIC INDICES DEVELOPED FOR USE IN DIFFERENT GEOGRAPHIC AREAS.

\begin{tabular}{|c|c|c|}
\hline $\begin{array}{l}\text { South Carolina coastal } \\
\text { plain streams } \\
\text { (Specht and Paller) }\end{array}$ & $\begin{array}{l}\text { Oregon, Colorado, and } \\
\text { Kentucky streams } \\
\text { (Barbour et al. 1992) }\end{array}$ & $\begin{array}{l}\text { Tennessee Valley Rivers } \\
\text { (Kerans and Karr 1994) }\end{array}$ \\
\hline \multicolumn{3}{|c|}{ Community structure } \\
\hline Taxa richness & Taxa richness & Taxa richness \\
\hline \multirow[t]{2}{*}{ Number EPT taxa } & Number EPT taxa & $\begin{array}{l}\text { Number EPT taxa } \\
\text { Number intolerant mussel } \\
\text { species } \\
\text { Sediment surface taxa } \\
\text { richness }\end{array}$ \\
\hline & \multicolumn{2}{|l|}{ Community balance } \\
\hline$\%$ Tanytarsini & $\begin{array}{l}\text { Hydropsychidael } \\
\text { Trichoptera }\end{array}$ & \% Corbicula \\
\hline \% Trichoptera & Hilsenhoff Biotic Index & $\%$ Oligochaetes \\
\hline \% Ephemeroptera & $\begin{array}{l}\text { Quantitative similarity } \\
\text { index }\end{array}$ & $\%$ Chironomids \\
\hline \multirow[t]{2}{*}{$\begin{array}{l}\text { Taxonomic similarity } \\
\text { (Pinkham and Pearson) }\end{array}$} & $\begin{array}{l}\text { Taxonomic similarity } \\
\text { (Pinkham and Pearson) } \\
\text { Proportion in the } \\
\text { dominant taxa }\end{array}$ & $\begin{array}{l}\text { Proportion in two } \\
\text { dominant taxa }\end{array}$ \\
\hline & Dominants in commơ & \\
\hline \multicolumn{3}{|c|}{ Community function } \\
\hline $\begin{array}{l}\text { Functional group } \\
\text { similarity (Pinkham and } \\
\text { Pearson) }\end{array}$ & $\begin{array}{l}\text { Scrapers/(scrapers \& } \\
\text { filterers) }\end{array}$ & $\begin{array}{l}\text { \% omnivores and } \\
\text { scavengers }\end{array}$ \\
\hline \multirow{7}{*}{$\begin{array}{l}\text { Total abundance } \\
\text { (standardized) }\end{array}$} & Shredders/total & $\%$ detritivores \\
\hline & $\begin{array}{l}\text { Quantitative similarity } \\
\text { index for functional } \\
\text { groups }\end{array}$ & \% shredders \\
\hline & & $\%$ collector-gatherers \\
\hline & & $\%$ collector-filterers \\
\hline & & $\%$ grazer-scrapers \\
\hline & & $\%$ predators \\
\hline & & Total abundance \\
\hline
\end{tabular}


may be apportioned among a variety of habitats to sample the full range of macroinvertebrate diversity in the reach under study (Lenat 1988). Using artificial substrates to collect macroinvertebrates (as we did) is more comparable to the former because artificial substrates tend to be selectively colonized by.certain taxa (Rosenberg and Resh 1982). This is not necessarily problematical for bioassessment providing that the taxa that colonize the substrates are sensitive to environmental degradation. Our experience indicates that the invertebrates that colonize multi-plate artificial substrates comprise an assemblage that is highly sensitive to a variety of environmental impacts. There are a number of logistical factors to consider when comparing bioassessment protocols employing samples from artificial versus natural substrates. Samples from natural substrates must be collected by skilled personnel, while (after initial site selection by skilled personnel), artificial substrates can be deployed and retrieved by relatively unskilled workers. Artificial substrates generally require colonization times of several weeks for assemblage structure to stabilize while sampling from natural substrates may be completed in several hours or less (Hilsenhoff 1987, Plafkin et al. 1989). Sample processing time (sorting and identification) is also likely to differ between samples collected from natural and artificial substrates, depending upon the type and quantity of natural substrate that is sampled and the number of specimens that are processed.

A final issue that must be addressed is sampling variability. In this study, we pooled the samples from each station to generate better estimates of actual taxa richness (because of the species-area effect) and a complete species list. However, this practice provides no information on inter-replicate variability which is needed to statistically compare sites and determine the precision of measurement. As the next step in our development of macroinvertebrate bioassessment tools, we will analyze unpooled multi-plate sampler data with the objective of assessing the precision of the index values. This will necessitate the modification of scoring criteria for taxa richness and other metrics that are area dependent.

\subsection{RBP II Protocol}

The RBP II data are summarized in Tables 4.2-1 and 4.2-2. The intent of using the RBP II Protocol was to compare the results obtained to those of the RBP III Protocol, to see if the less intensive and less costly method would yield comparable results. For this reason, fewer locations were sampled using the RBP II methods. One unimpacted and four potentially impacted locations were sampled using this protocol. However, the location that was chosen to represent unimpacted conditions showed definite signs of impact using the RBP methods. Based on the fish and Hester-Dendy data from the station, as well as data collected during other studies, we do not believe this station to be impacted. However, since we had no other unimpacted RBP II data to use for comparisons with the impacted stations, no further analyses were conducted with this data set. However, a cursory comparison of the RBP II and RBP III data sets for the same locations (Table 4.2-3) shows fairly good agreement for most of the metrics.

\subsection{RBP III Protocol}

The data collected using the RBP III methods were analyzed using the methods described in Section 3.2.2. Because the RBP methods require specific comparisons 


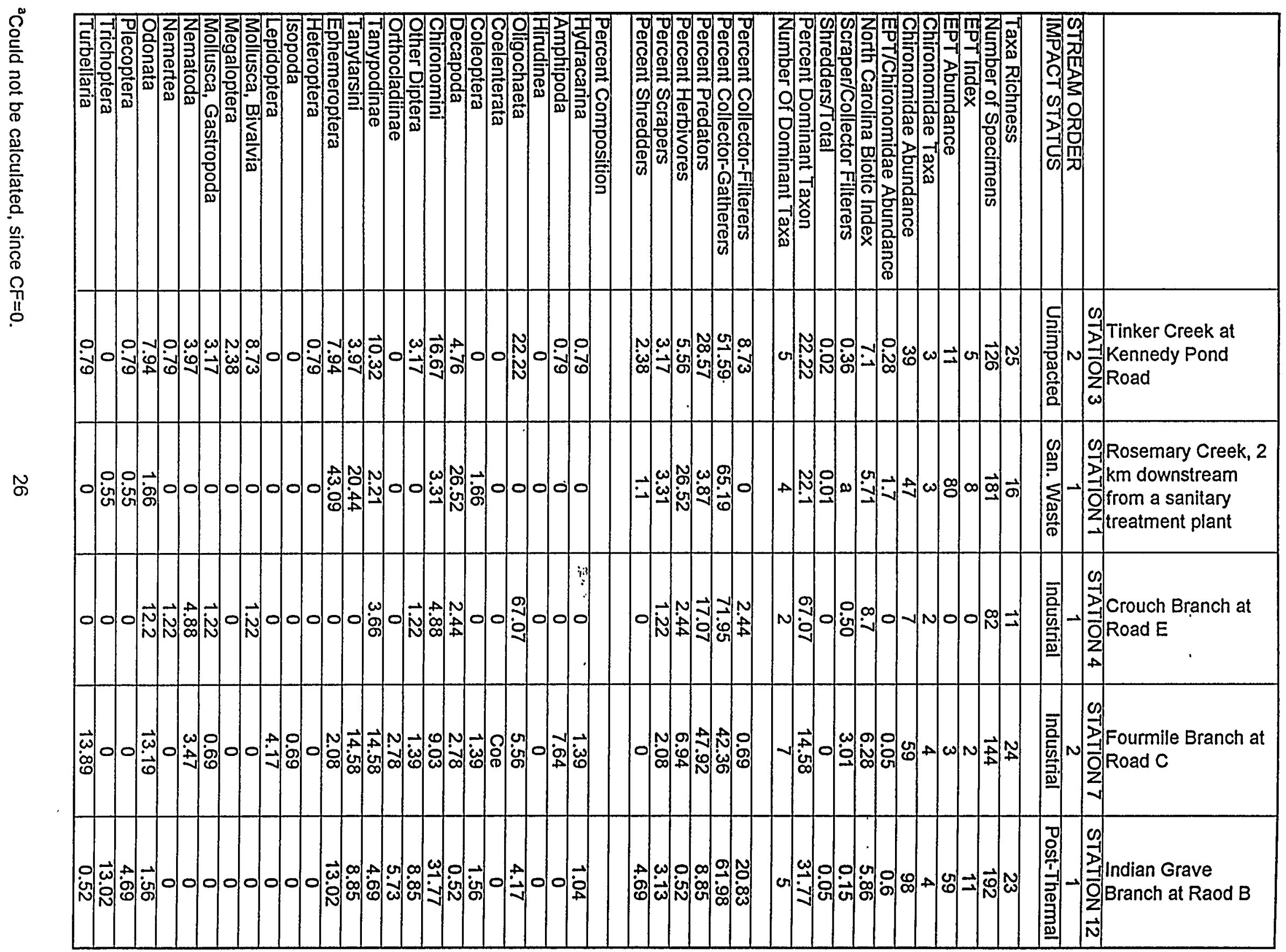


TABLE 4.2-2. DOMINANT TAXA AT EACH STATION, RBP \|

\begin{tabular}{|c|c|c|c|c|c|}
\hline & 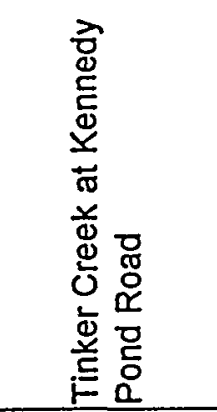 & 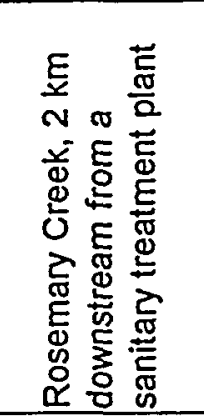 & 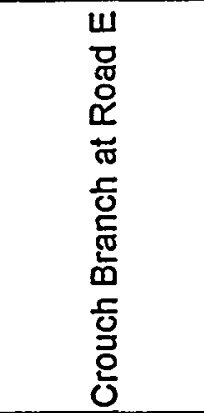 & 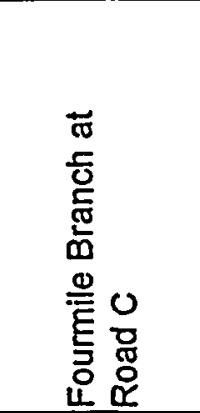 & 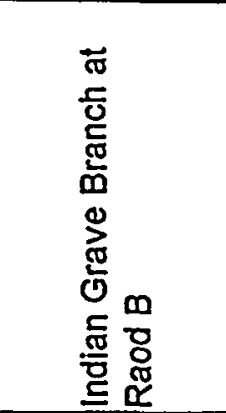 \\
\hline & STATION 3 & STATION 1 & STATION 4 & STATION 7 & STATION 12 \\
\hline STREAM ORDER & 2 & 1 & 1 & 2 & 1 \\
\hline IMPACT STATUS & Unimpacted & San. Waste & Industrial & Industrial & Post-Thermal \\
\hline \multicolumn{6}{|l|}{ EPHEMEROPTERA } \\
\hline Caenidae & & 21.55 & & & \\
\hline Leptophlebiidae & & 4.97 & & & \\
\hline Siphlonuridae & 5.56 & & & & \\
\hline Tricorythidae & & 11.05 & & & \\
\hline \multicolumn{6}{|l|}{ TRICHOPTERA } \\
\hline Hydropsychidae & & & & & 11.46 \\
\hline \multicolumn{6}{|l|}{ ODONATA } \\
\hline Coenagrionidae & & & 10.98 & 10.42 & \\
\hline \multicolumn{6}{|l|}{ DIPTERA } \\
\hline Tanytarsini & & 20.44 & & 14.58 & 8.85 \\
\hline Chironomini & 16.67 & & 4.88 & 9.03 & 31.77 \\
\hline Tanypodinae & 10.32 & & 3.66 & 14.58 & \\
\hline Orthocladiinae & & & & & 5.73 \\
\hline Simuliidae & & & & & 8.85 \\
\hline \multicolumn{6}{|l|}{ CRUSTACEA } \\
\hline Palaemonidae & & 22.10 & & & \\
\hline \multicolumn{6}{|l|}{ MOLLUSCA } \\
\hline Sphaeriidae & 8.73 & & & & \\
\hline \multicolumn{6}{|l|}{ WORMS } \\
\hline $\begin{array}{l}\text { Nemertea } \\
\end{array}$ & & & 4.88 & & \\
\hline Oligochaeta & 22.22 & & 67.07 & & \\
\hline Turbellaria & & & & 13.89 & \\
\hline
\end{tabular}




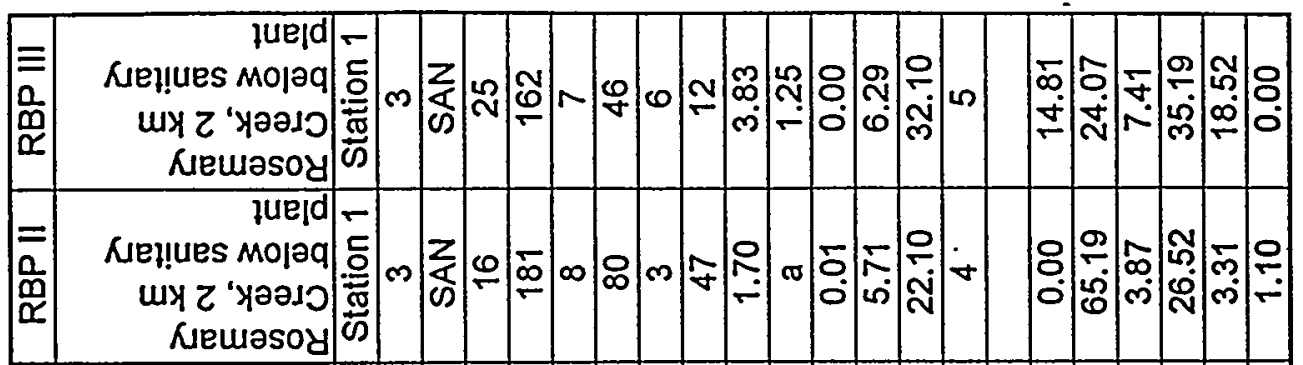

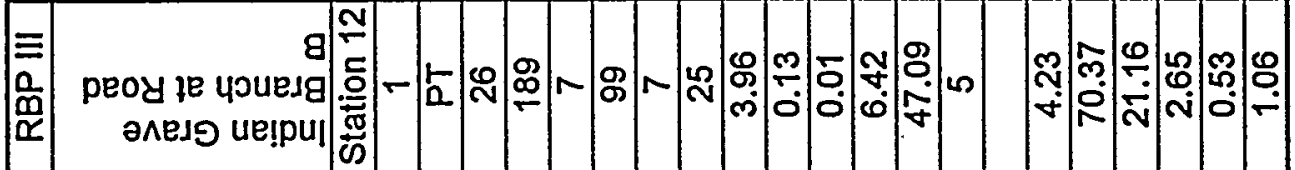

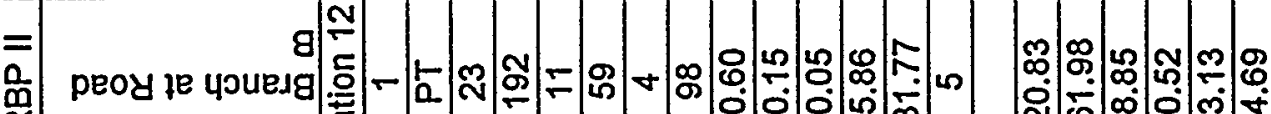

芷 ә^อנด Uе!pu

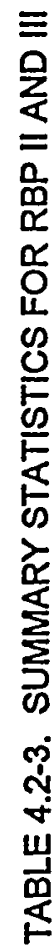

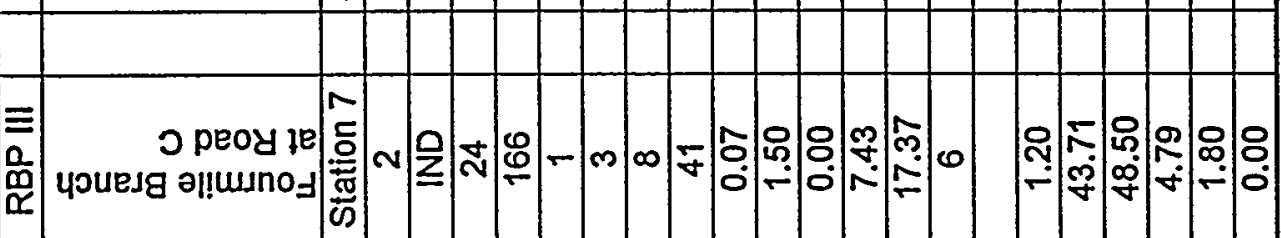

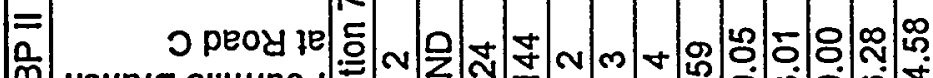

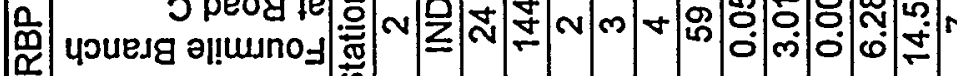

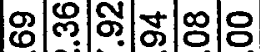

ơ $̛$ 守

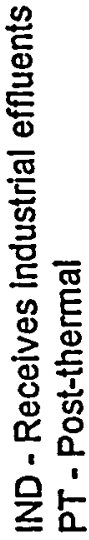

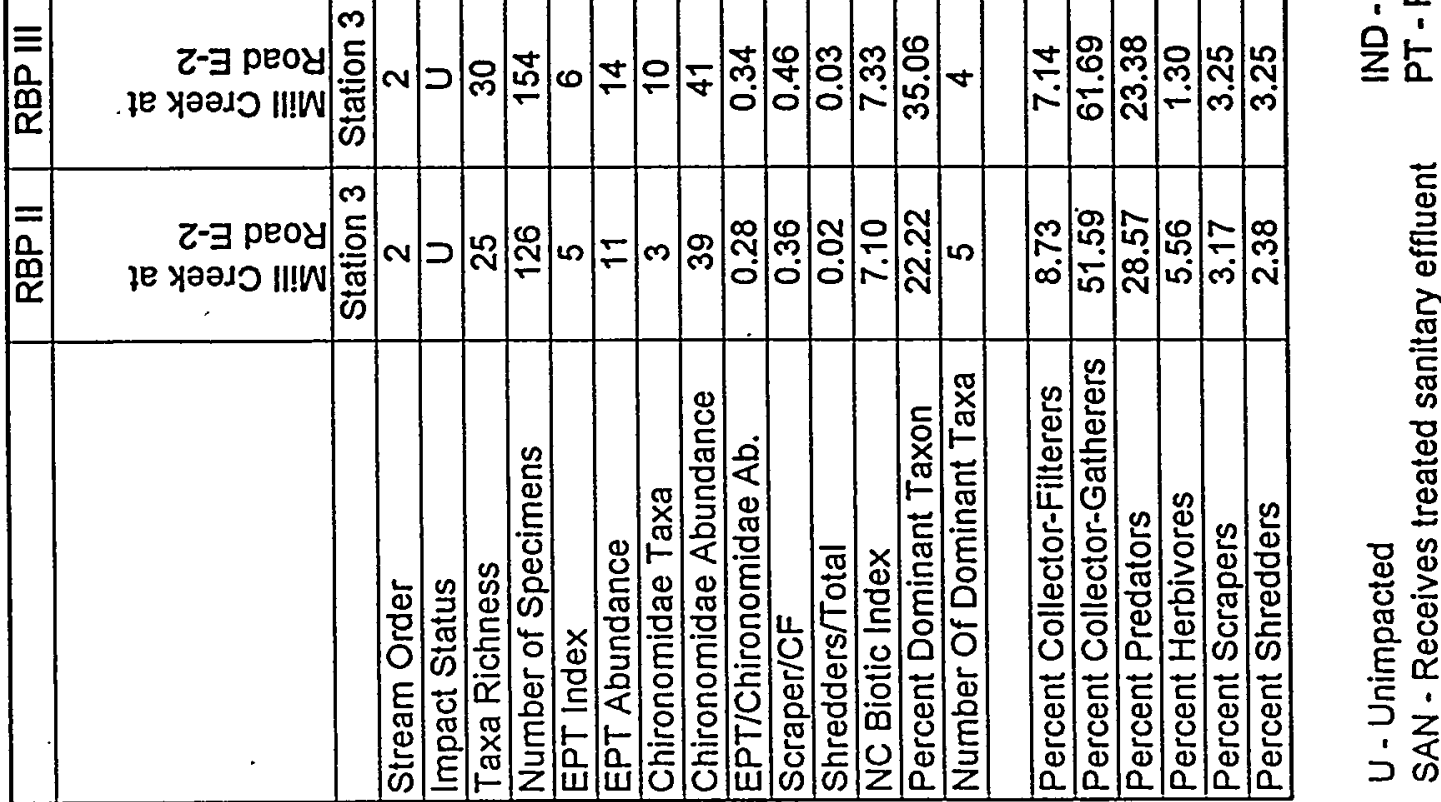




\begin{tabular}{|c|c|c|c|c|c|c|c|c|c|c|c|c|c|c|c|c|c|c|c|c|c|c|c|c|c|c|}
\hline$\left|\begin{array}{l}\equiv \\
\bar{a} \\
\mathbf{a} \\
\underline{\alpha}\end{array}\right|$ & 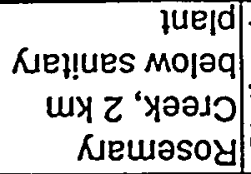 & : & $m$ & $\begin{array}{l}\frac{1}{3} \\
\mathbf{D}\end{array}$ & 잉 & $\begin{array}{l}8 \\
0 \\
0\end{array} \mid$ & $\begin{array}{c}8 \\
0 \\
0\end{array}$ & & $\begin{array}{l}8 \\
8 \\
\end{array}$ & & & & & : & & 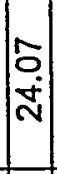 & 이 & & & & & 8 & & & & \\
\hline 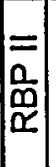 & 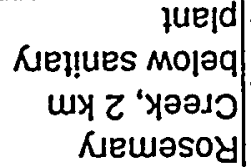 & 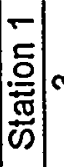 & $m$ & $\begin{array}{l}z \\
z \\
i\end{array}$ & $\mid \begin{array}{c}\circ \\
0 \\
\end{array}$ & $\left|\begin{array}{c}8 \\
0 \\
0\end{array}\right|$ & $\begin{array}{l}8 \\
\circ \\
\circ\end{array}$ & & $\begin{array}{l}8 \\
0 \\
\end{array}$ & 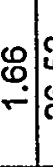 & $\begin{array}{l}N \\
\text { D. } \\
0 \\
0\end{array}$ & $\begin{array}{c}\bar{n} \\
\cdots\end{array}$ & $\begin{array}{l}8 \\
0 \\
0\end{array}$ & 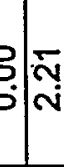 & : & 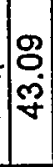 & : & 이 & & $\begin{array}{c}8 \\
\\
0\end{array}$ & : & $\begin{array}{l}8 \\
0 \\
0\end{array}$ & : & 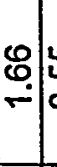 & 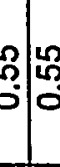 & 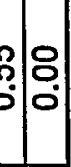 \\
\hline
\end{tabular}

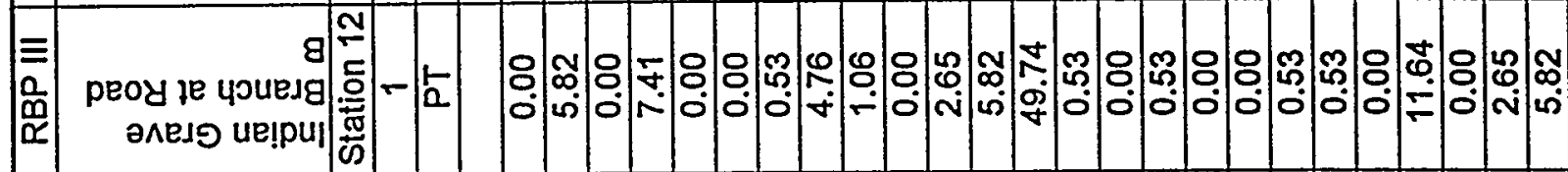

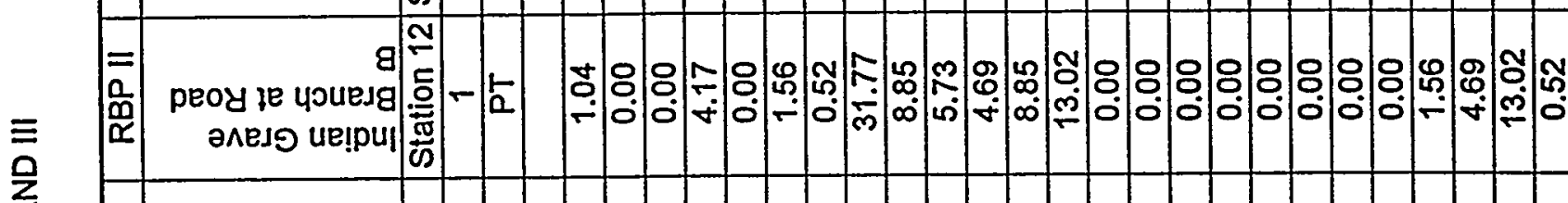

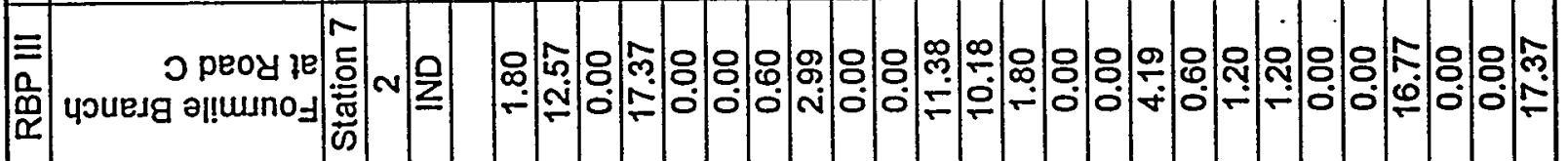

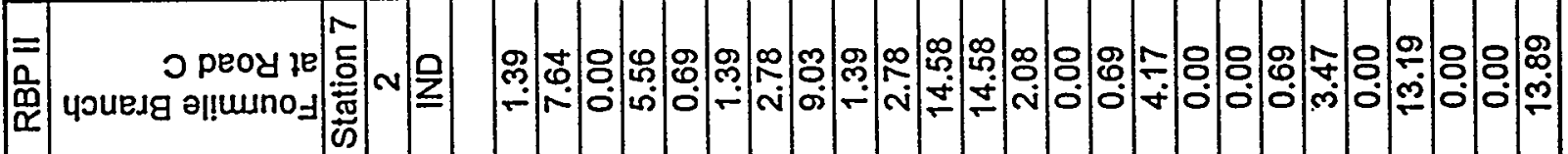

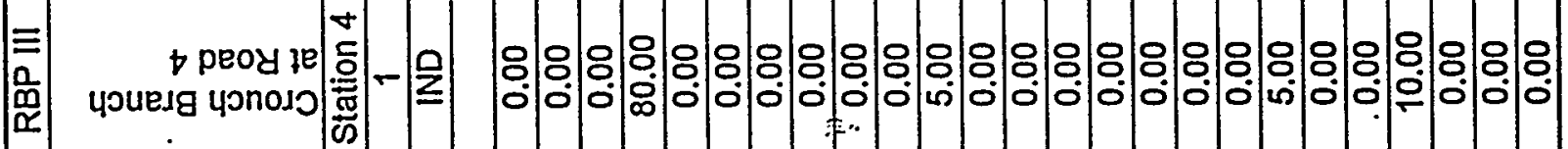
=

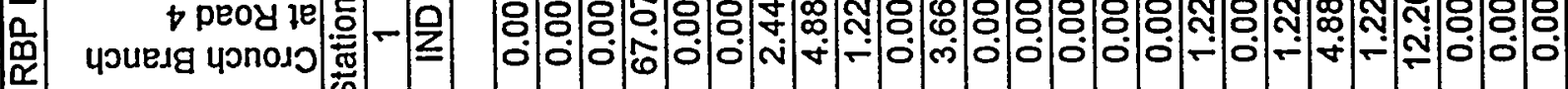
$\stackrel{\mu}{\frac{m}{0}}$

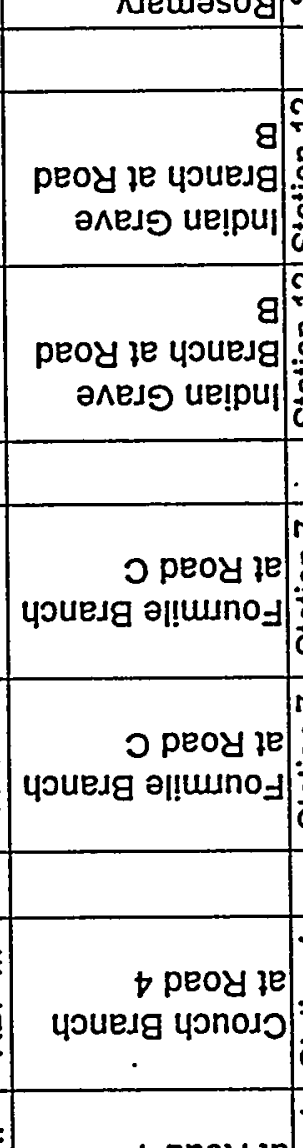

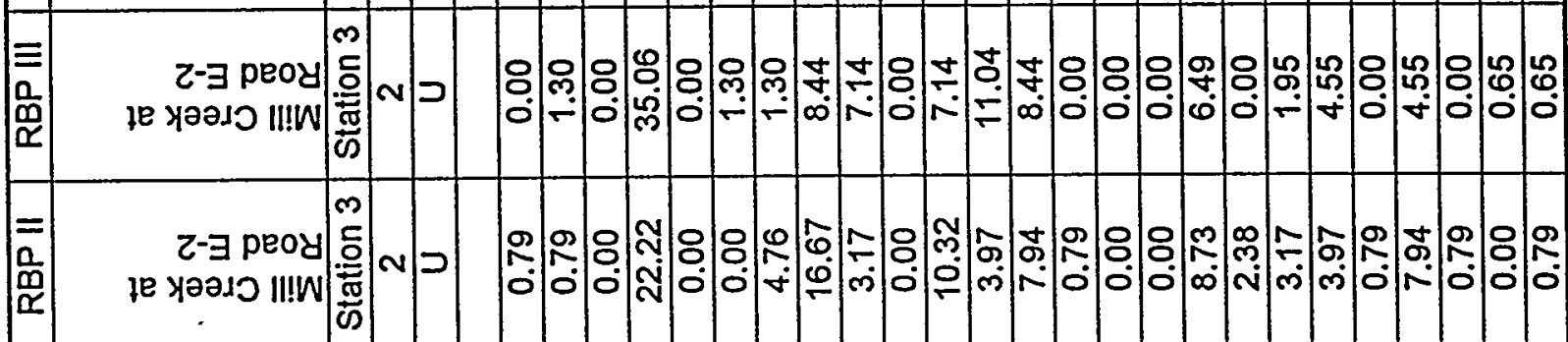

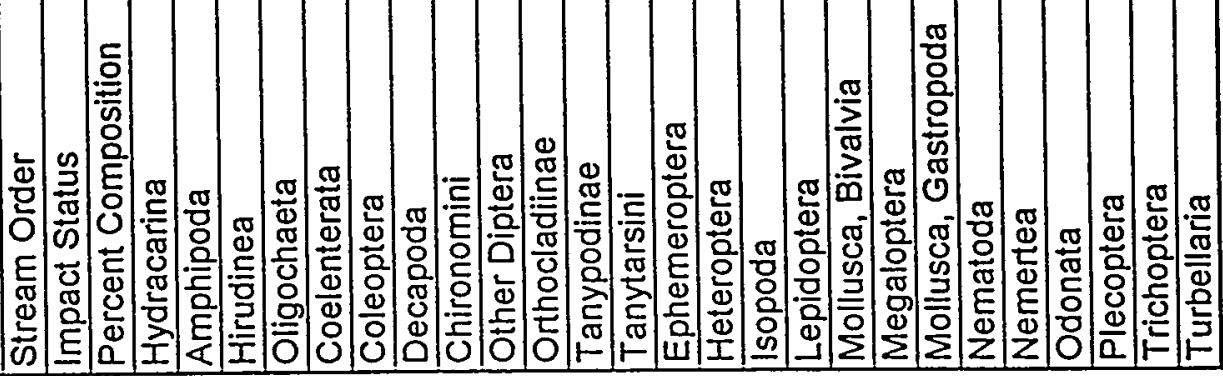

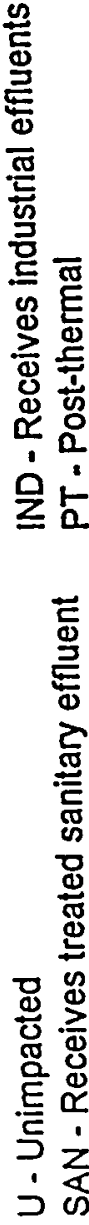


between an unimpacted and impacted location for calculating one of the parameters (community loss), mean values for the unimpacted stations as a group could not be used as they were with the multiplate data. We chose the Meyer's Branch station (Station 9) as a reference station to which all other stations were compared. Meyer's Branch was chosen because of its known history as a high-quality stream and because when sampled using the RBP III methods, it had the greatest number of taxa (46) and greatest number of EPT taxa (15) of any of the stations that were sampled.

Table 4.3-1 contains a summary of the results of the RBP III data, while Table 4.3-2 contains a list of the dominant taxa that were collected using the RBP III sampling methods. The RBP III ratings are presented in Table 4.3-3.

\subsubsection{Data Overview}

At the unimpacted stations (excluding fourth-order stream, Upper Three Runs) the total number of taxa collected with RBP III ranged from 26 at Pen Branch Road B to 46 in Meyer's Branch; EPT ranged from 5 to 15 taxa, and North Carolina Biotic Index values ranged from 5.62 in Meyer's Branch to 7.33 in Mill Creek. The percent abundance for the most dominant taxon ranged from 13.2 in Meyer's Branch to 35.1 in Mill Creek. EPT/Chironomid abundance varied widely, ranging from 0.34 in Mill Creek to 2.14 at Pen Branch Road B. Scraper/Collector-filterer ratios varied from 0.12 to 0.50 . Shredders were collected in low numbers at all of the stations, ranging from 2 to $4 \%$ of the organisms collected.

At the stations that were influenced by industrial discharges, slightly fewer taxa were collected (24 to 32), except at Crouch Branch, where only five taxa were found. The number of EPT taxa was also lower at most locations, ranging from 0 to 7 . North Carolina Biotic Index values ranged from 5.31 at Beaver Dam Creek to 8.06 at Crouch Branch. The percent abundance for the most dominant taxon was much higher at Crouch Branch $(80 \%)$, than at the other three industrial stations, where the values (17.4 to 36.5) were fairly comparable to the values at the unimpacted stations.

EPT/Chironomid Abundance (0 to 10.61) and Scraper/Collector-filterer ratios $(0.05$ to 0.69 ) both varied more at the industrial stations that at the unimpacted stations. Shredders comprised 0 to $3 \%$ of the organisms collected. The number of taxa collected at the post-thermal stations (23 to 31) and EPT (2 to 7) were similar to the data from the industrial stations. Biotic index values ranged from 6.9 to 7.26.

\subsubsection{RBP Scores}

As discussed in Section 3.2, eight metrics are used in the RBP III method. For each of the eight metrics, a station can receive a score of $0,2,4$, or 6 , with a score of 6 indicating equivalency to the reference station. For the eight metrics combined, a station can receive a maximum total of 48 points. The number of points that a station receives is then divided by 48 , (the number of points that the reference station automatically receives), and the results are expressed as a percentage value. These values are then compared to those in a table of ranges (Table 4.3-4), and assigned ratings of not impaired, slightly impaired, moderately impaired, or severely impaired.

When compared to Meyer's Branch, all of the other unimpacted stations received ratings of "slightly impaired", with scores ranging from $54.2 \%$ for Mill Creek to $70.8 \%$ for 
TABLE 4.3-1. SUMMARY DATA FOR RBP III

\begin{tabular}{|c|c|c|c|c|c|c|c|c|}
\hline & 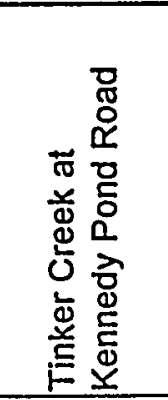 & 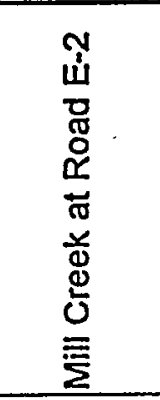 & 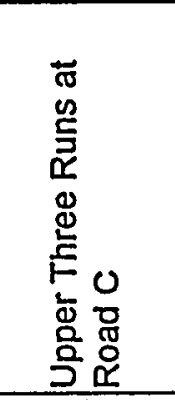 & 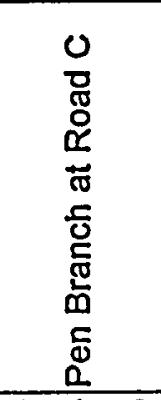 & 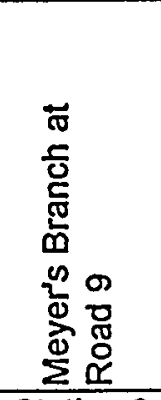 & 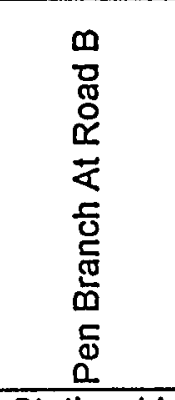 & 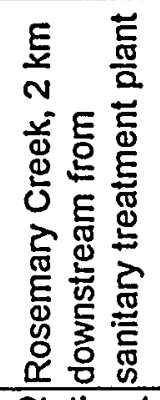 & 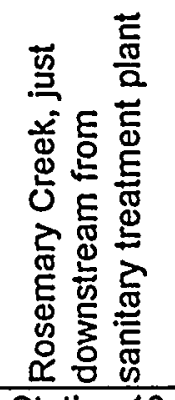 \\
\hline & Station 2 & Station 3 & Station 6 & Station 8 & Station 9 & Station 11 & Station 1 & Station 16 \\
\hline Stream Order & 3 & 2 & 4 & 2 & 3 & 2 & 3 & 2 \\
\hline Impact Status & $\mathrm{U}$ & $\mathrm{U}$ & $\mathrm{U}$ & $\bar{U}$ & $\mathrm{U}$ & $\mathrm{U}$ & SAN & SAN \\
\hline Taxa Richness & 37 & 30 & 21 & 39 & 46 & 26 & 25 & 40 \\
\hline Number of Specimens & 214 & 154 & 234 & 203 & 197 & 236 & 162 & 244 \\
\hline EPT Index & 10 & 6 & 5 & 10 & 15 & 5 & 7 & 12 \\
\hline EPT Abundance & 79 & 14 & 92 & 50 & 80 & 62 & 46 & 93 \\
\hline Chironomidae Taxa & 13 & 10 & 4 & 10 & 11 & 5 & 6 & 15 \\
\hline Chironomidae Abundance & 108 & 41 & 33 & 60 & 46 & 29 & 12 & 120 \\
\hline EPT/Chironomidae Abundance & 0.73 & 0.34 & 2.79 & 0.83 & 1.74 & 2.14 & 3.83 & 0.78 \\
\hline North Carolina Biotic Index & 5.92 & 7.33 & 6.40 & 6.60 & 5.62 & 6.85 & 6.29 & 5.95 \\
\hline Scraper/CF & 0.50 & 0.27 & 0.14 & 0.30 & 0.23 & 0.12 & 0.07 & 0.49 \\
\hline Shredders $/$ Total & 0.02 & 0.03 & 0.00 & 0.04 & 0.04 & 0.03 & 0.00 & 0.03 \\
\hline Percent Dominant Taxon & 17.76 & 35.06 & 36.75 & 13.79 & 13.20 & 27.97 & 32.10 & 11.89 \\
\hline Number Of Dominant Taxa & 6.00 & 4.00 & 5.00 & 6.00 & 7.00 & 5.00 & 5.00 & 8.00 \\
\hline & & & & & & & & \\
\hline Percent Collector-Filterers & 19.16 & 7.14 & 4.70 & 29.06 & 14.21 & 13.98 & 14.81 & 26.64 \\
\hline Percent Collector-Gatherers & 59.35 & 61.69 & 52.99 & 41.38 & 55.84 & 60.59 & 24.07 & 51.64 \\
\hline Percent Predators & 12.15 & 23.38 & 13.25 & 20.69 & 10.66 & 15.68 & 7.41 & 11.89 \\
\hline Percent Herbivores & 2.80 & 1.30 & 2.99 & 0.00 & 9.64 & 5.51 & 35.19 & 1.64 \\
\hline Percent Scrapers & 4.21 & 3.25 & 26.07 & 4.93 & 5.58 & 1.69 & 18.52 & 5.33 \\
\hline Percent Shredders & 2.34 & 3.25 & 0.00 & 3.94 & 4.06 & 2.54 & 0.00 & 2.99 \\
\hline
\end{tabular}

$U$ - Unimpacted

SAN - Receives treated sanitary effluent 


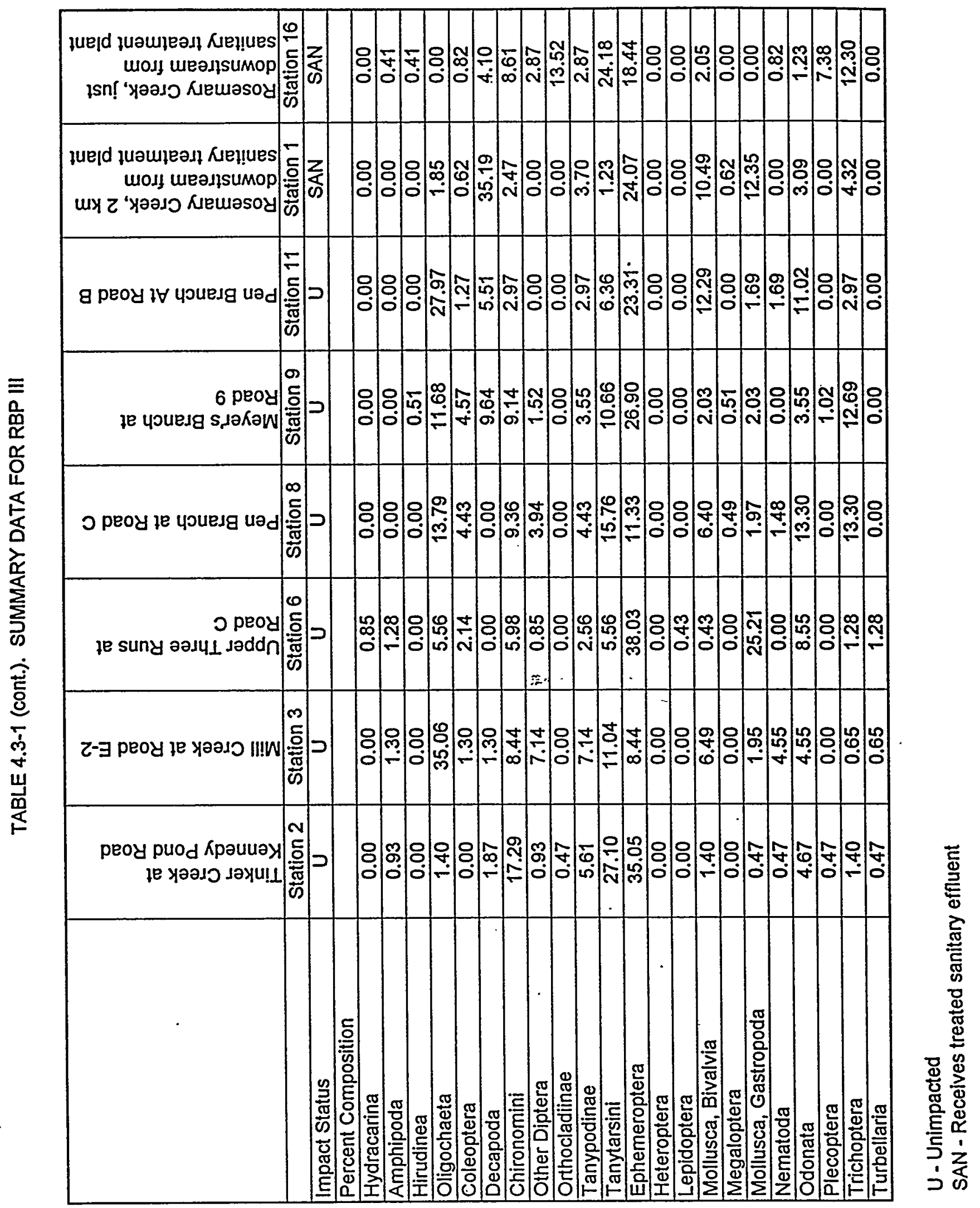


TABLE 4.3-1 (cont.). SUMMARY DATA FOR RBP III

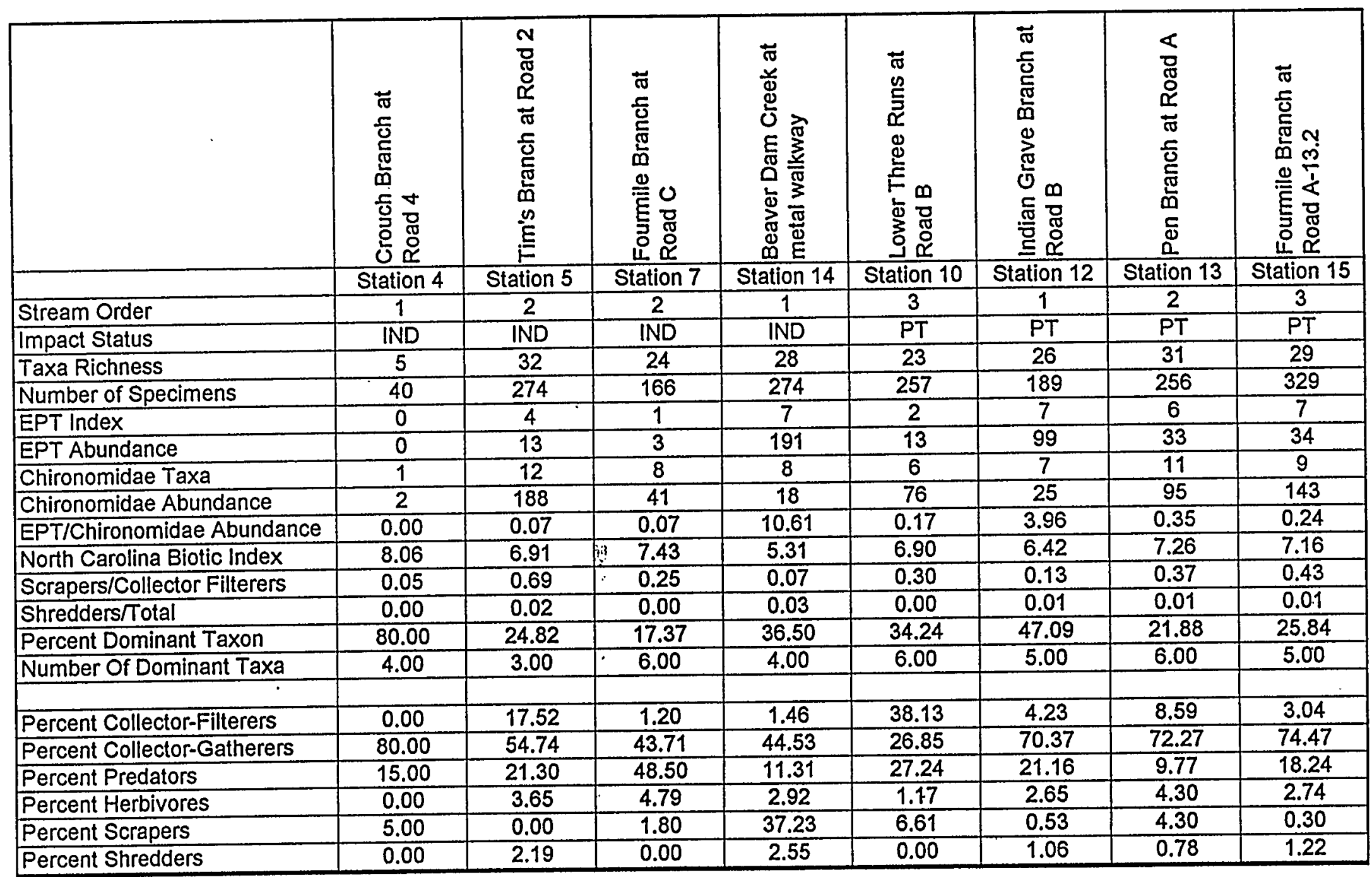

IND - Receives industrial effluents

PT - Post-thermal 


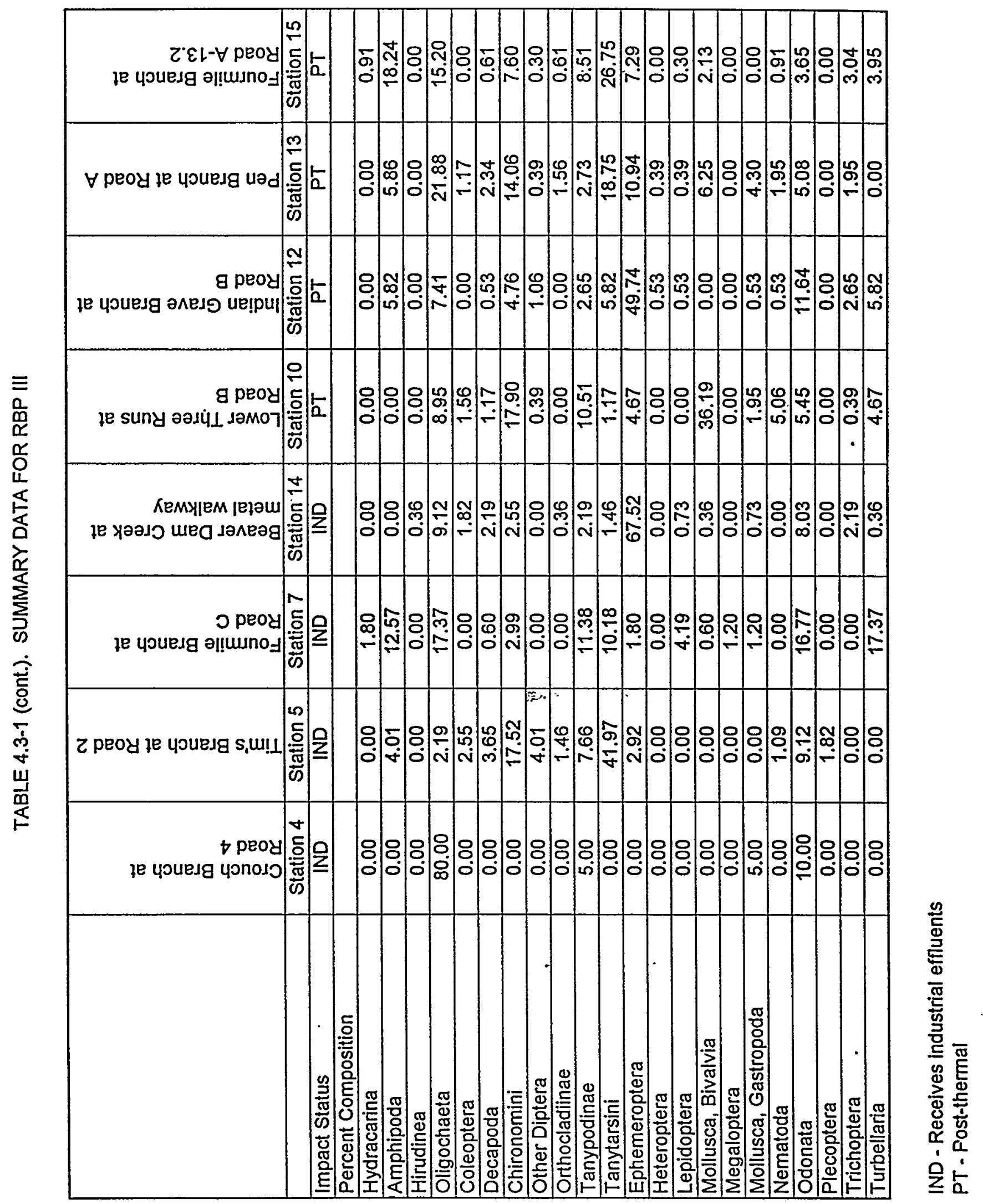




\begin{tabular}{|c|c|c|c|c|c|c|c|c|c|c|c|c|c|c|c|c|c|c|c|c|c|c|c|c|c|c|}
\hline $\begin{array}{r}\text { juejd } \\
\text { Kuej!ues molaq isn! } \\
\text { 'хәәјо Kuemasoy }\end{array}$ & $\left|\begin{array}{l}0 \\
\infty \\
5 \\
0\end{array}\right|$ & $N$ & $\begin{array}{l}z \\
0 \\
0\end{array}$ & & & $l_{0}^{2}$ & & & & & $\begin{array}{l}\tilde{c} \\
\sigma^{\circ}\end{array}$ & & 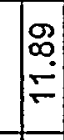 & $\mid$\begin{tabular}{l}
$\infty$ \\
$\infty$ \\
\hdashline \\
\hdashline
\end{tabular} & 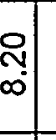 & & & & & & & & & & & \\
\hline 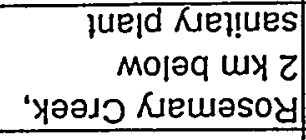 & $\begin{array}{l}- \\
\mathbb{6} \\
\infty \\
\end{array}$ & & & & & & $\int_{0}^{\infty}$ & & $\approx$ & & & & & & & & & & $\begin{array}{l}\frac{0}{2} \\
\text { ì }\end{array}$ & & & $\stackrel{P}{P}$ & & & & \\
\hline $\begin{array}{r}\tau \cdot \varepsilon\llcorner-\forall \text { peoy le } \\
\text { uouedg o!!unno }\end{array}$ & $\left|\begin{array}{l}\infty \\
\vdots \\
5 \\
0 \\
0\end{array}\right|$ & $m$ & $\frac{1}{2}$ & & & & & & & & & & & & \begin{tabular}{l|l}
$\infty$ & 0 \\
$m$ & 8 \\
0 & 4
\end{tabular} & & & & & 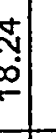 & & & & & $\begin{array}{l}\text { ㄱ. } \\
\text { దે }\end{array}$ & \\
\hline $\begin{array}{r}\forall \text { peoy } \\
\text { je youedg uəd }\end{array}$ & 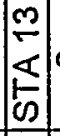 & $N$ & & & & & & & & & & & & $\mid \begin{array}{l}\infty \\
0 \\
0 \\
\\
\end{array}$ & 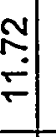 & & & & & $\begin{array}{l}0 \\
0 \\
0 \\
0\end{array}$ & $\left|\begin{array}{l}0 \\
\infty \\
\omega^{\circ}\end{array}\right|$ & & & & $\mid$ & \\
\hline $\begin{array}{l}\text { a poey je youesg } \\
\text { a^eנo ue!pul }\end{array}$ & $\mid \begin{array}{c}7 \\
\mathbb{5} \\
-\infty \\
\end{array}$ & - & $\frac{1}{2}$ & & & & & & & & 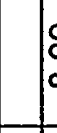 & | & & & & & & & & $\begin{array}{l}0 \\
0 \\
0 \\
0\end{array}$ & & & & & F寸 & $\left|\begin{array}{c}N \\
\infty \\
\vdots \\
\vdots\end{array}\right|$ \\
\hline $\begin{array}{r}8 \text { peoy } 1 e \\
\text { suny } 2 \partial \pm 4 \perp \text { JәMO7 } \\
\end{array}$ & $\mid \begin{array}{l}0 \\
\mathbb{5} \\
0 \\
0\end{array}$ & $m$ & 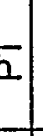 & & & & & & & & & & & & $\begin{array}{l}+ \\
m \\
0 \\
6\end{array}$ & 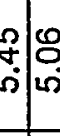 & & & & $\int_{9}^{2}$ & & & & & 吊 & \\
\hline $\begin{array}{r}\text { o peoy te } \\
\text { 4oụesg əl!uinos }\end{array}$ & $\mid \begin{array}{c}n \\
\frac{6}{\infty}\end{array}$ & $N$ & - & & & & & & & & & & & $\begin{array}{l}\infty \\
\infty \\
\infty\end{array}$ & & : & & & & âs. & & & & & & $\stackrel{s}{\sim}$ \\
\hline $\begin{array}{r}z \text { peoy } \\
\text { 10 чวuesg s.w!। }\end{array}$ & $\mid \begin{array}{l}\infty \\
\mathbb{5} \\
\infty\end{array}$ & $N$ & - & & & & & & & & & & $\frac{n}{\pi}$ & 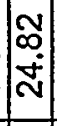 & $\begin{array}{l}\text { 인 } \\
\text { m. }\end{array}$ & $\begin{array}{l}\infty \\
m \\
y\end{array}$ & & & & & & & & & & \\
\hline 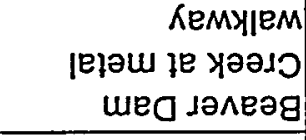 & $\frac{7}{\square}$ & - & - & & & & & & 员 & ָ̊. & & $\bar{c}$ & & & & & & & & & & & & & $\frac{N}{\sigma_{0}}$ & \\
\hline $\begin{array}{l}\rightarrow \text { peod } \\
\text { je uouesg uonoso }\end{array}$ & $\left|\begin{array}{c}8 \\
6 \\
6\end{array}\right|$ & - & - & & & & & & & & & 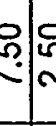 & & & & & 栗 & & & & & & is & & $\begin{array}{l}8 \\
0 \\
0 \\
\infty\end{array}$ & \\
\hline 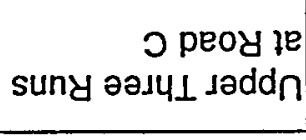 & $\left|\begin{array}{l}\infty \\
\mathbb{E} \\
\infty\end{array}\right|$ & + & כ & & مُ & & & & & & & $\mid \begin{array}{lll}0 \\
0\end{array}$ & & & $\begin{array}{l}\infty \\
\infty \\
\infty \\
\infty\end{array}$ & & & & & & & & 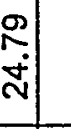 & & $\begin{array}{c}\infty \\
\infty \\
0 \\
0\end{array}$ & \\
\hline $\begin{array}{r}6 \text { peoy } \\
\text { je youesg s JaKaW }\end{array}$ & $\left|\begin{array}{c}0 \\
5 \\
5 \\
0\end{array}\right|$ & $m$ & ذذ & & & & & & & 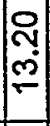 & & & & & $\begin{array}{l}8 \\
0 \\
6\end{array}$ & & & & $\mid \begin{array}{l}8 \\
0 \\
\infty \\
\infty\end{array}$ & & & & & & \begin{tabular}{l}
$\infty$ \\
0 \\
\hdashline
\end{tabular} & \\
\hline 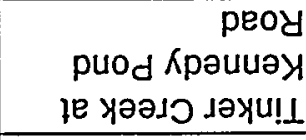 & $\mid \begin{array}{l}w \\
5 \\
\infty\end{array}$ & $m$ & $د$ & 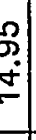 & & $\begin{array}{c}-5 \\
0 \\
0\end{array}$ & & & & & & & $\stackrel{0}{\stackrel{0}{*}}$ & $\begin{array}{l}\infty \\
\infty \\
\infty\end{array}$ & $\frac{\infty}{i}$ & & & & & & & & & & & \\
\hline $\begin{array}{r}\text { a peoy } \\
\text { fe youesg uad }\end{array}$ & $\mid$ & $N$ & د & & & & & of & & 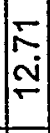 & & & & $\mid \begin{array}{l}\infty \\
0 \\
10\end{array}$ & & & & & & & $\left|\begin{array}{l}\mathscr{\infty} \\
\infty \\
\doteqdot \\
\doteqdot\end{array}\right|$ & & & & के & \\
\hline $\begin{array}{r}\text { o peod } \\
\text { fe uouedg uad }\end{array}$ & $\mid \begin{array}{l}\infty \\
\mathbb{1} \\
\infty \\
\infty\end{array}$ & $N$ & & & & & & & & & $\left|\begin{array}{c}\circ \\
0 \\
6\end{array}\right|$ & $\mid \begin{array}{r}\qquad \\
\alpha \\
0\end{array}$ & $\begin{array}{l}0 \\
\infty \\
\text { హె }\end{array}$ & \begin{tabular}{l}
$\mathbf{u}$ \\
0 \\
0 \\
0 \\
\hdashline
\end{tabular} & 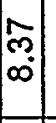 & & & & & & & & & & $\begin{array}{l}R \\
m \\
m\end{array}$ & \\
\hline 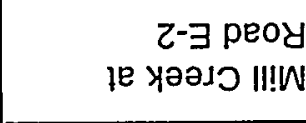 & $\mid \begin{array}{l}m \\
\vdots \\
\infty \\
\infty\end{array}$ & $N$ & & & & & & & & & & & & 艿 & & & & $\underset{\text { in }}{\stackrel{0}{\circ}}$ & & & $\mid \begin{array}{l}\stackrel{g}{\square} \\
\dot{0}\end{array}$ & & & & $\mid \begin{array}{l}\infty \\
0 \\
\dot{m} \\
m\end{array}$ & \\
\hline & 5 & 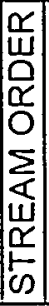 & 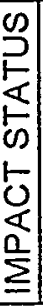 & Q & & $\mid$ & : & 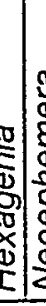 & 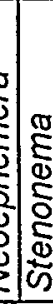 & 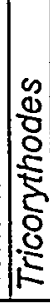 & 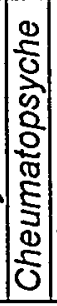 & : & 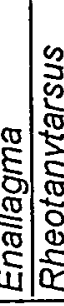 & 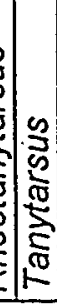 & 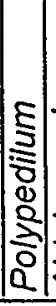 & 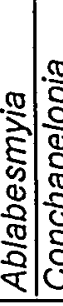 & $\mid$ & 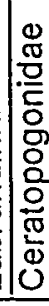 & 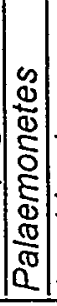 & 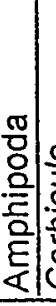 & 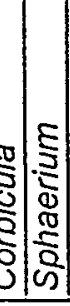 & 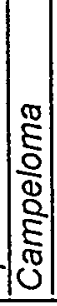 & 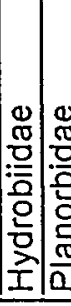 & 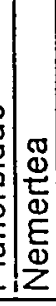 & $\left|\begin{array}{c}0 \\
\hdashline 0 \\
0 \\
\mathbf{0} \\
0 \\
0 \\
0 \\
0 \\
0 \\
0\end{array}\right|$ & 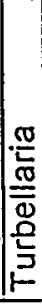 \\
\hline
\end{tabular}


TABLE 4.3-3. RBP III RATINGS, ALL STATIONS VS. MEYER'S BRANCH

\begin{tabular}{|c|c|c|c|c|c|c|c|c|c|c|c|c|c|c|}
\hline • & 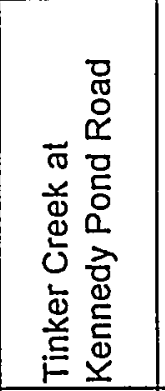 & 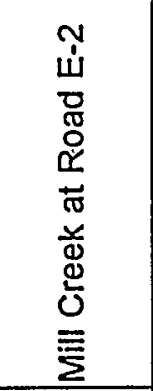 & 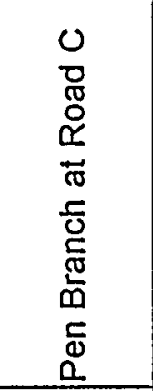 & 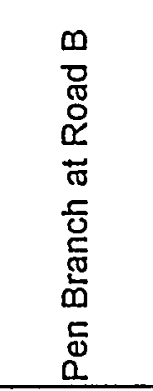 & 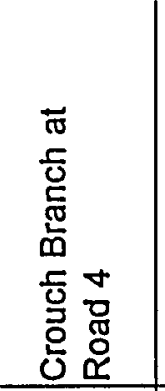 & 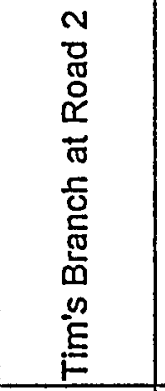 & 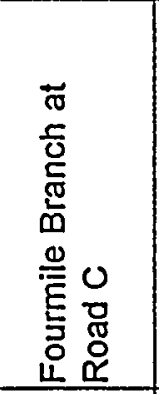 & 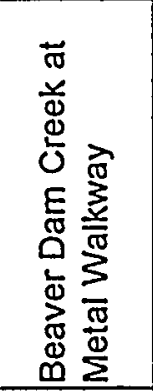 & 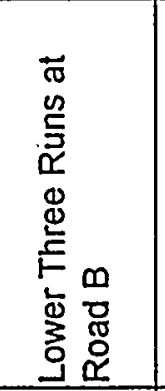 & 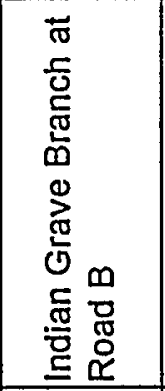 & 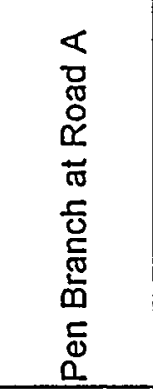 & 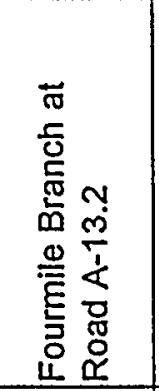 & 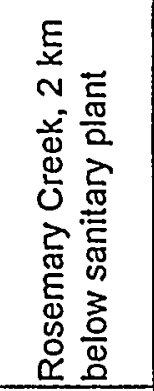 & 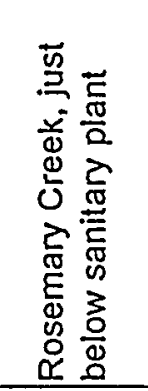 \\
\hline STATION & ST. 2 & ST. 3 & ST. 8 & ST. 11 & ST. 4 & ST. 5 & ST. 7 & ST. 14 & ST. 10 & ST. 12 & ST. 13 & ST. 15 & ST. 1 & ST. 16 \\
\hline Impact Status & $\mathrm{U}$ & $U$ & $\mathrm{U}$ & $U$ & IND & IND & IND & IND & PT & PT & PT & $\mathrm{PT}$ & SAN & SAN \\
\hline Taxa Richness & 6 & 4 & 6 & 2 & 0 & 4 & 2 & 4 & 2 & 2 & 4 & 4 & 2 & 6 \\
\hline $\mathrm{NCBI}$ & 6 & 4 & 4 & 4 & 2 & 4 & 4 & 6 & 4 & 6 & 4 & 4 & 6 & 6 \\
\hline$\overline{S c / C F}$ & 6 & 6 & 4 & 2 & 6 & 0 & 6 & 6 & 4 & 2 & 6 & 2 & 6 & 6 \\
\hline EPT/Chir & 2 & 0 & 2 & 6 & 0 & 0 & 0 & 6 & 0 & 6 & 0 & 0 & 6 & 2 \\
\hline \%Dominant & 6 & 2 & 6 & 4 & 0 & 4 & 6 & 2 & 2 & 0 & 4 & 4 & 2 & 6 \\
\hline EPT & 0 & 0 & 0 & 0 & 0 & 0 & 0 & 0 & 0 & 0 & 0 & 0 & 0 & 3 \\
\hline Comm. Loss & 4 & 4 & 4 & 4 & 0 & 4 & 4 & 4 & 2 & 4 & 4 & 4 & 4 & 4 \\
\hline Shredder/Total & 4 & 6 & 6 & 6 & 0 & ii3 4 & 0 & 6 & 0 & 2 & 2 & 2 & 0 & 6 \\
\hline Total & 34 & 26 & 32 & 28 & 8 & 20 & 22 & 34 & 14 & 22 & 24 & 20 & .26 & 39 \\
\hline Total/Ref $(48)^{\star}$ & $70.8 \%$ & $54.2 \%$ & $66.7 \%$ & $58.3 \%$ & $16.7 \%$ & $41.7 \%$ & $45.8 \%$ & $70.8 \%$ & $29.2 \%$ & $45.8 \%$ & $50.0 \%$ & $41.7 \%$ & $54.2 \%$ & $81.2 \%$ \\
\hline Rating & $\begin{array}{c}\text { Slightly } \\
\text { impaired }\end{array}$ & $\begin{array}{l}\text { Slightly } \\
\text { impaired }\end{array}$ & $\begin{array}{l}\text { Slightly } \\
\text { impaired }\end{array}$ & $\begin{array}{l}\text { Slightly } \\
\text { impaired }\end{array}$ & $\begin{array}{l}\text { Severely } \\
\text { Impaired }\end{array}$ & $\begin{array}{l}\text { Mod. } \\
\text { Impaired }\end{array}$ & $\begin{array}{c}\text { Mod. } \\
\text { Impaired }\end{array}$ & $\begin{array}{l}\text { Slightly } \\
\text { impaired }\end{array}$ & $\begin{array}{c}\text { Mod. } \\
\text { Impaired } \\
\end{array}$ & $\begin{array}{c}\text { Mod. } \\
\text { Impaired } \\
\end{array}$ & $\begin{array}{c}\text { Mod. } \\
\text { Impaired }\end{array}$ & $\begin{array}{c}\text { Mod. } \\
\text { Impaired }\end{array}$ & $\begin{array}{l}\text { Slightly } \\
\text { impaired }\end{array}$ & $\begin{array}{l}\text { Slightly } \\
\text { impaired }\end{array}$ \\
\hline
\end{tabular}

*All Stations are compared to Meyer's Branch (Station 9)

$U$ - Unimpacted

SAN - Receives treated sanitary effluent

IND - Receives industrial effluent

PT - Post-thermal 
TABLE 4.3-4. RBP III SCORING CRITERIA

METRIC

Taxa Richness

Biotic Index

Scraper/CF

EPT/Chironomidae

\% Dominant Taxon

EPT Index

Community Loss Ind.

Shredders/Total
BIOLOGICAL CONDITION SCORING CRITERIA

\begin{tabular}{|c|c|c|c|}
\hline 6 & -4 & 2 & 0 \\
\hline$>80 \%$ & $60-80 \%$ & $40-60 \%$ & $<40 \%$ \\
\hline$>85 \%$ & $70-85 \%$ & $50-70 \%$ & $<50 \%$ \\
\hline$>50 \%$ & $35-50 \%$ & $20-35 \%$ & $<20 \%$ \\
\hline$>75 \%$ & $50-75 \%$ & $25-50 \%$ & $<25 \%$ \\
\hline$<20 \%$ & $20-30 \%$ & $30-40 \%$ & $>40 \%$ \\
\hline$>90 \%$ & $80-90 \%$ & $70-80 \%$ & $<70 \%$ \\
\hline$<0.5$ & $0.5-1.5$ & $1.5-4.0$ & $>4.0$ \\
\hline$>50 \%$ & $35-50 \%$ & $20-35 \%$ & $<20 \%$ \\
\hline
\end{tabular}

$\%$ Comparison to Reference Score

$>83 \% \quad$ Non-impaired

$54-79 \% \quad$ Slightly Impaired

$21-50 \% \quad$ Moderately Impaired

$<17 \% \quad$ Severely Impaired

Source: Plafkin et al. (1989)

Tinker Creek at Kennedy Pond Road (Table 4.3-3). Somewhat surprisingly, Station 16 on Rosemary Creek, which is located immediately downstream from a sanitary treatment plant received a higher rating $(81.2 \%)$ than any of the reference stations. The more downstream station on Rosemary Creek also received a relatively high rating of $54.2 \%$. Beaver Dam Creek, which is impacted by elevated temperatures, coal ash, and treated sanitary waste also received a relatively high rating of $70.8 \%$, which was the same rating as the highest rated unimpacted reference station. All of the postthermal sampling locations and all but one of the locations that receives industrial effluents received ratings of "moderately impaired", with scores ranging from 29.2 to $50.0 \%$. Only Crouch Branch received a rating of "severely impaired", with a score of just $16.7 \%$.

These results suggest that although the RBP III method is capable of detecting impacts, it is also capable of erroneously concluding that there is impact at unimpacted locations. This error could possibly be corrected by adjusting the values for "unimpacted" in Table 4.3-4 slightly lower, although this could come at the expense of failing to detect impact at other stations, as well. The RBP scoring system groups stations into very broad categories, with stations receiving values of 29 and 50 both being rated as "moderately impaired". This weakness could be corrected by increasing the number of rating categories. The RBP method is also capable of not detecting impact, when a stream is impacted, as evidenced by the relatively high rating for Beaver Dam Creek. This station received the highest rating possible for four of the eight metrics, due in part to the dominance by a genus of tolerant mayfly. 


\subsubsection{Statistical Analysis of RBP Metrics and Selected Other Metrics}

The values of each of the eight metrics used in computing the RBP scores were compared for unimpacted and impacted stations using the Kruskal-Wallis test. Comparisons included: all unimpacted vs. all impacted stations and all unimpacted vs. industrial vs. post-thermal stations (Table 4.3-5). In addition to the eight metrics used in the RBP III methods, we performed statistical comparisons of six additional metrics to assess their utility in detecting impact. these metrics included changes in predator abundance, percent abundance of four groups of chironomids, and a ratio of two groups of generally sensitive chironomids (Tanytarsini and Orthocladiinae) to two groups of relatively tolerant chironomids (Tanypodinae and Chironomini). We focused on metrics that emphasized changes chironomid groups primarily because the dominance of chironomids in southeastern coastal plain streams. Although Station 16 on Rosemary Branch was originally grouped with the impacted stations, due to its proximity to the sanitary treatment plant, both the multiplate and RBP data suggest that this station is not impacted or is only minimally impacted. Therefore the Kruskal-Wallis tests were repeated without including the data from Station 16 (Table 4.3-6). The statistical results indicate that of the eight metrics used in the RBP index, only two (shredder/total, and possibly taxa richness) are significantly different between the unimpacted and unimpacted stations. We believe that the shredder/total metric results may be an anomaly, since shredders are not very abundant in our streams and comprised $<4 \%$ of the organisms collected using the RBP III methods. Due to the paucity of shredders, very small differences could result in differences that were statistically significant.

These results suggest that although each of the metrics alone is not very useful in detecting changes in the macroinvertebrate community, together, the eight metrics are reasonably good at detecting gross differences among macroinvertebrate communities, although as discussed in Section 4.3.2, in our study the RBP III detected impact when there was none, and also failed to detect much impact at one station that was moderately to severely perturbed.

Two of the six additional metrics that we tested (\% Tanytarsini and \% Orthocladiinae) performed as well as most of the eight RBP metrics (Tables 4.3-5 and 4.3-6). The addition of these two metrics to the RBP III suite of metrics, and elimination of the Scraper/Collector metric, which had significance values close to 1.0, should result in a stronger test that is more useful in southeastern coastal plain streams.

\subsection{Comparison of RBP III and Hester-Dendy Data}

A comparison of the Hester-Dendy data and the RBP III data indicates that almost without exception, fewer taxa and fewer EPT taxa were collected with the RBP III methods. We also found that at some stations, the RBP data suggested impacts where there probably were none. For example, the Hester-Dendy data for Mill Creek at Road E-2 show no evidence of impact, while the RBP III data for this location indicate that fewer total taxa and EPT taxa were collected at this station that three of the other five unimpacted stations and the biotic index value was 7.33 (Table 4.3-1), which strongly suggests that this location was impacted. In contrast, the station on Beaver Dam Creek that was clearly impacted, but contained high numbers of one genus of 
TABLE 4.3-5 PROBABILITY VALUES FOR SIGNIFICANT DIFFERENCES OF KRUSKAL-WALLIS TESTS ON RBP III METRICS (INCLUDING STATION 16 ROSEMARY CREEK JUST BELOW A SANITARY TREATMENT PLANT)

Parameter

Taxa Richness

$\mathrm{NCBI}$

$\mathrm{Sc} / \mathrm{CF}$

EPT/Chironomidae

$\%$ Dominant

EPT

Community Loss

Shredder/Total

Percent Predators

Chironomid Ratio ${ }^{a}$

\%Tanypodinae

$\%$ Tanytarsini

$\%$ Chironomini

$\%$ Orthocladiinae
Unimpacted vs. Impacted

$0.075^{\star}$

0.391

0.951

0.391

0.270

0.155

$0.010^{*}$

1.000

0.668

1.000

0.391

0.462

0.214
Unimp. vs. Industrial

vs. Post-thermal

0.172

0.590

0.717

0.590

0.533

0.314

$0.023^{*}$

0.298

0.898

0.613

0.677

0.403

0.395

-Marginally significant

- Significantly different at $p=0.05$

"(Tanytarsini + Orthocladiinae)/(Tanypodinae + Chironomini)

TABLE 4.3-6 PROBABILITY VALUES FOR SIGNIFICANT DIFFERENCES OF KRUSKAL-WALLIS TESTS ON RBP III METRICS (EXCLUDING STATION 16 ROSEMARY CREEK JUST BELOW A SANITARY TREATMENT PLANT)

Parameter

Taxa Richness

$\mathrm{NCBI}$

$\mathrm{SC} / \mathrm{CF}$

EPT/Chironomidae

$\%$ Dominant

EPT

Community Loss

Shredder/Total

Percent Predators

Chironomid Ratio ${ }^{a}$

\%Tanypodinae

\%Tanytarsini

\%Chironomini

\%Orthọcladiinae
Unimpacted vs. Impacted

$0.033^{* \star}$

0.317

1.000

0.386

0.125

$0.079^{\star}$

$0.006^{* *}$

0.841

0.423

0.739

0.257

0.463

0.312
Unimp. vs. Industrial

vs. Post-thermal

0.102

0.421

0.987

0.634

0.198

0.214

$.0 .021^{* *}$

0.373

0.503

0.676

0.418

0.298

0.600

- Marginally sig̀nificant

-* Significantly different at $p=0.05$

"(Tanytarsini + Orthocladiinae)/(Tanypodinae + Chironomini) 
tolerant mayfly scored only "slightly impacted" using the RBP III methods. However, both methods found the same taxon to be dominant at this station.

Although some of the differences may be due to the naturally patchy distribution of macroinvertebrates, and to limited numbers of replicates, it appears that the RBP III methods are less than ideally suited for use in coastal plain streams, which do not havethe riffle-run habitat for which the protocol was designed. However, we have developed a biotic index that can be used with multiplate data that appears to be very useful in detecting impacted macroinvertebrate communities in southeastern coastal plain streams.

\subsection{CONCLUSIONS}

In general, the data from the Hester-Dendy multiplate samplers were more sensitive at detecting impacts than were the RBP data. A Biotic Index for the Hester-Dendy data was developed which incorporated eight community structure, function, and balance parameters. When tested using a data set that was unrelated to the data set that was used in developing the Biotic Index, the index was very successful at detecting impact .

We also evaluated the sensitivity of the RBP methods in detecting impact in coastal plain streams. Of the eight metrics used, only one was statistically significant in detecting differences between impacted and unimpacted streams. Although, the eight metrics combined were able to detect some degree of impact at most impacted stations, at several sampling stations they erroneously detected impact when none was present (based on other macroinvertebrate and fisheries data, and operational data that indicate that absence of SRS activities upstream of the at locations that we believe to be unimpacted). Detecting impact when none is present is a serious shortcoming, and indicates that RBP results should be interpreted with extreme caution if used in southeastern coastal plain streams. We evaluated six additional metrics for possible

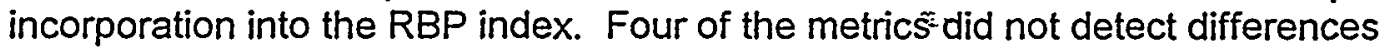
between impacted and unimpacted locations, while the remaining two were as sensitive as most of the RBP metrics in detecting impacts.

In conclusion, the Biotic Index that we developed for use with the Hester-Dendy multiplate data appears to provide a better means of detecting impacts to stream macroinvertebrate communities in southeastern coastal plain streams than the EPA Rapid Bioassessment Protocol methods.

\subsection{REFERENCES}

Barbour, M.T., J.L. Plafkin, B.P. Bradley, C.G. Graves, and R.W. Wisseman. 1992. Evaluation of EPA's rapid bioassessment benthic metrics: metric redundancy and variability among reference stream sites. Environmental Toxicology and Chemistry $11: 437-449$

Benke, A.C., T.C. van Arsdall, Jr., D.M. Gillespie, and F.K. Parrish. 1984. Invertebrate productivity in a subtropical blackwater river: the importance of habitat and life history. Ecological Monographs 54:25-63. 
Enwright Laboratories. 1986a. Quantitative Macroinvertebrate Survey of Pen Branch and Indian Grave Branch, February 1989.

Enwright Laboratories. 1986b. Quantitative Macroinvertebrate Survey of Pen Branch and Indian Grave Branch, March 1989.

Enwright Laboratories. 1986c. Quantitative Macroinvertebrate Survey of Pen Branch and Indian Grave Branch, May 1989.

Heliovara, K. and R. Vaisanen. 1993. Insects and Pollution. CRC Press, Boca Raton, FL.

Hilsenhoff, W.L. 1987. An improved biotic index of organic stream pollution. Great Lakes Entomol. 20:31-39.

Karr, J.R., K.D. Fausch, P.L. Angermeier, P.R. Yant, and I.J. Schlosser. 1986. Assessment of biological integrity in running water: a method and its rationale. Illinois Natural History Survey Special Publication No. 5, Champaign, Illinois.

Kerans, B.L. and J.R Karr. 1994. A benthic index of biotic integrity (B-IBI) for rivers of the Tennessee Valley. Ecological Applications 4:768-785.

Kondratieff, P. and B.C. Kondratieff. 1985. A lower food chain community study: thermal effects and post-thermal recovery in the streams and swamps of the Savannah River Plant. DPST-85-376. Savannah River Laboratory, Aiken, SC.

Lauritsen, D. and W. Starkel. 1989. A Study of Post-thermal Recovery of the Macroinvertebrate Community of Four Mile Creek, June 1985-September 1987. Normandeau Associates, Aiken, SC. ;

Lenat, D.R. 1988. Water quality assessment of streams using a quantitative collection method for benthic macroinvertebrates. Journal North American Benthological Society $7: 222-233$.

Lenat, D.R. 1993. A biotic index for the southeastern United States: derivation and list of tolerance values, with criteria for assigning water-quality ratings. J. North American Benthological Society 12(3):279-290.

Merritt R. W. and K.W. Cummins. 1984. An Introduction to the Aquatic Insects of North America. 2nd ed. Kendall/Hunt Publ. Co. Dubuque, IA

Paller, M.H. 1994. Relationship between fish assemblage structure and stream order in South Carolina coastal plain streams. Transactions of the American Fisheries Society 123:150-161.

Pinkham, C.F.A. and J.B. Pearson. 1976. Applications of a new coefficient of similarity to pollution surveys. Journal of the Water Pollution Control Federation. 48:717-723. 
Plafkin, J.L., M.T. Barbour, K.D. Porter, S.K. Gross, and R.M. Hughes. 1989. Rapid Bioassessment Protocols for Use in Streams and Rivers. U.S. Environmental Protection Agency. EPA/444/4-89-001.

Rosenburg, D.M. and V.H. Resh. 1982. The use of artificial substrates in the study of freshwater benthic macroinvertebrates. in: J. Cairns, Jr. (ed.), Artificial Substrates. pp 175-235. Ann Arbor Science Publishers, Inc., Ann Arbor, Michigan.

Smock, L.A., E. Gilinsky, and D.L. Stoneburner. 1985. Macroinvertebrate production in a southeastern United States blackwater stream. Ecology 66:1491-1503.

Sokal, R.R., and F.J. Rohlf. 1981. Biometry. Freeman Press, San Francisco.

Specht, W.L. 1994. Results of Macroinvertebrate Sampling Conducted at 33 SRS Stream Locations, July-August 1993. WSRC-TR-95-0006.

Strahler, A.N. 1957. Quantitative analysis of watershed geomorphology. Transactions American Geophysical Union 38:913-920.

Surber, E.W. 1959. Cricotopus bicinctus, a midgefly resistant to electroplating wastes. Trans. Am Fish. Soc., 89, 111.

Winner, R.W., M.W. Boesel, and M.P. Farrell. 1980. Insect community structure as an index of heavy-metal pollution in lotic ecosystems. Canadian Journal of Fisheries and Aquatic Sciences 37:647. 
APPENDIX A

MACROINVERTEBRATE DATA 


\title{
RESULTS OF MACROINVERTEBRATE SAMPLING AT SELECTED SAVANNAH RIVER SITE LOCATIONS AUGUST/SEPTEMBER 1994 SUBCONTRACT NO.AA86028N
}

\author{
SUBMTTTED TO: \\ WESTINGHOUSE SAVANNAH RIVER COMPANY \\ AIKEN, SOUTH CAROLINA \\ DECEMBER 1994
}

SUBMATTED BY:

SHEALY ENVIRONMENTAL SERVICES, INC. 106 VANTAGE POINTE DRIVE CAYCE, SOUTH CAROLINA (803) $791-9700$

SCDHEC LABORATORY CERTIFICATION NO. 26103 
TABLE OF CONTENTS

LIST OF FIGURES $\ldots \ldots \ldots \ldots \ldots \ldots \ldots \ldots \ldots \ldots$ ii

LIST OF TABLES $\ldots \ldots \ldots \ldots \ldots \ldots \ldots \ldots \ldots \ldots \ldots \ldots \ldots \ldots \ldots$

PART II. MATERIALS AND METHOD $\ldots \ldots \ldots \ldots \ldots \ldots \ldots \ldots \ldots$

Section I. PHYSICOCHEMICAL MEASUREMENTS . . . . . . . 8 SECTION II. HESTER-DENDY MULTIPLATE SAMPLING $\ldots \ldots \ldots \ldots 8$

SECTION III. RAPID BIOASSESSMENT PROCEDURE . . . . . . . . . 9

PART M. PHYSTCOCHEMTCAL DATA ............... 8 SECTION I. WATER CHEMISTRY $\ldots \ldots \ldots \ldots \ldots \ldots \ldots \ldots$ SECTION II. STREAM PROFILES $\ldots \ldots \ldots \ldots \ldots \ldots \ldots \ldots$

PART IV. HESTER-DENDY MACROINVERTEBRATE DATA AND SUMMARY

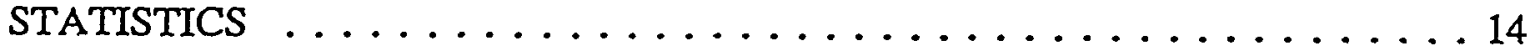

PART V. HESTER-DENDY ASH FREE DRY WEIGHT DATA AND SUMMARY

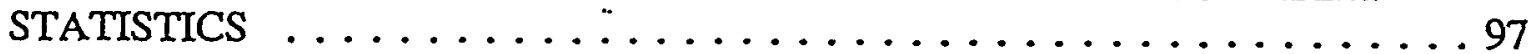

PART VI. RAPID BIOASSESSMENT PROTOCOL II DATA AND SUMMARY

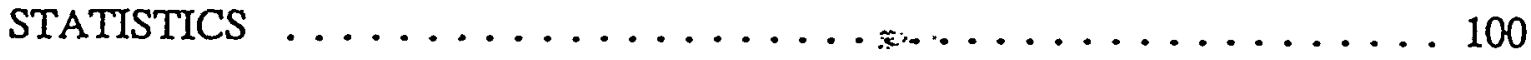

PART VII. RAPID BIOASSESSMENT PROTOCOL III DATA AND SUMMARY

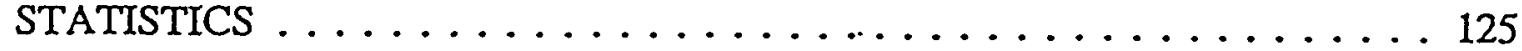




\section{LIST OF FIGURES}

\section{FIGURE}

1 DIAGRAM OF HESTER-DENDY MULTIPLATE SAMPLER USED IN THIS STUDY . . . . . . . . . . . . . . . . . 4

2 STREAM PROFILES OF THE SAMPLING STATIONS $\ldots \ldots \ldots \ldots .9-13$ 


\section{LIST OF TABLES}

\section{TABLE}

1 PHYSICOCHEMICAL MEASUREMENTS TAKEN IN CONJUNCTION WTTH THE MACROINVERTEBRATE SAMPLING AT THE SAVANNAH RTVER SITE. MEASUREMENTS WERE MADE ON SAMPLER RETRIEVAL DATE ......................

2 ABBREVIATIONS AND EXPLANATION OF TERMS USED IN THE MACROINVERTEBRATE DATA AND SUMMARY STATISTICS . . . . . 14 


\section{PART I}

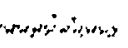

$\approx$ 


\section{Part 1. INTRODUCTION}

This report presents the results of the August-September 1994 macroinvertebrate samplingconducted by SHEALY ENVIRONMENTAL SERVICES, INC., as specified under section 5.2 of WESTINGHOUSE SAVANNAH RIVER COMPANY subcontract number AA86028N. A total of 15 sampling sites on 10 streams were included in this study. The study utilized five replicate Hester-Dendy multiplate samples and a UNITED STATES ENVIRONMENTAL PROTECTION AGENCY Rapid Bioassessment Protocol (RBP) III collection at all of the 15 sampling sites. An additional RPB Protocol II sampling was conducted at five sampling sites.

The report contains the results of the identification, enumeration and summary statistics for each of the 15 sampling sites as well as the ash free dry weightada of the functional feeding groups inhabiting Hester-Dendy samplers and the physicochemical data collected in conjunction with the macroinvertebrate sampling. The report is divided into eight parts. Part II presents the methods and materials used in the Hester-Dendy, physicochemical and rapid bioassessment sampling. Part III presents the physicochemical data and the stream cross-sectional profiles.

Part IV presents the Hester-Dendy sampler data for each location. Data is presented in four tables for each site. The first table gives of the taxa identified and the number of specimens collected for the five replicate samples. Table 2 presents the summary statistics, including the taxa richness, the EPT index, the biotic index and the relative abundance of the major taxonomic 
groups and the functional feeding groups. Table 3 is a list of taxa collected. Table 4 is a list of the dominant taxa collected. Part $\mathrm{V}$ presents the ash free dry weight data for functional feeding groups. Part VI presents the results of the RBP II sampling conducted on Rosemary Creek, Mill Creek, Four Mile Creek at Road C, Crouch Branch and Indian Grave Branch. The tolerance values utilized in the biotic index were obtained from Hilsenhoff (1988) and Plafkin et al. (1989). Part VII presents the results of the RBP III sampling. Part VIII presents the results of the RBP III site comparisons between the two sampling sites on Four Mile Creek (stations 7 and 15) and for the three Pen Branch sites (stations 8,11 and 13). The results of these three parts are arranged in five tables. The first table in each section presents the taxa list and the number of specimens collected. Table 2 presents the taxa richness, EPT index, relative abundance of the functional feeding groups and similarity indices calculated when appropriate. The tolerance values utilized in the biotic index calculated for these samples were obtained from Lenat (1993). Table 3 presents the relative abundance data for the major taxonomic groups and the functional feeding groups in the riffle-run sample and of the functional feeding groups of the CPOM sample. Table 4 presents the taxa list. Table 5 presents the dominant taxa and their relative abundance. 


\section{PART I. MATERIALS AND METHODS}

\section{Section I. PHYSICOCHEMICAL MEASUREMENTS}

Physicochemical parameters were measured at midstream and mid-depth at the time of HesterDendy retrieval and are presented in Table 1. Conductivity was measured using a Yellow Springs Instruments Model 57 meter checked for accuracy utilizing standard solutions of 98.5 , 1000 and $10,000 \mu \mathrm{mhos} / \mathrm{cm}$. Dissolved oxygen and temperature were determined using a Yellow Springs Instruments Model 33 meter and

pH with an Orion model SA210 meter. A separate water sample was collected and returned to the laboratory for determination of total hardness by EPA method 130.2. Stream width and depth measurements were taken at each sampling location in order to construct stream crosssection profiles. Depth was measured at 10 equidistant points for streams greater than five meters wide and at $50 \mathrm{~cm}$ intervals for streams less than five meters wide. Water velocity was measured at each point where depth was measured and aF'mid-channel using a Swoffer model 2100 flow meter.

\section{SECTION II. HESTER-DENDY MULTIPLATE SAMPLING}

Hester-Dendy multiplate samplers consisting of 14 square masonite plates measuring $7.6 \mathrm{~cm} \mathrm{x}$ $7.6 \mathrm{~cm} \times 0.3 \mathrm{~cm}$ separated by $0.3 \mathrm{~cm}$ thick nylon spacers were utilized for this part of the study and are illustrated in Figure 1. Five replicate samplers were suspended $0.5 \mathrm{~m}$ below the water surface at each sampling location and allowed to colonized for 29-30 days. Samplers were removed from the stream by slowly lifting the sampler to just below the surface where a $0.5 \mathrm{~mm}$ 


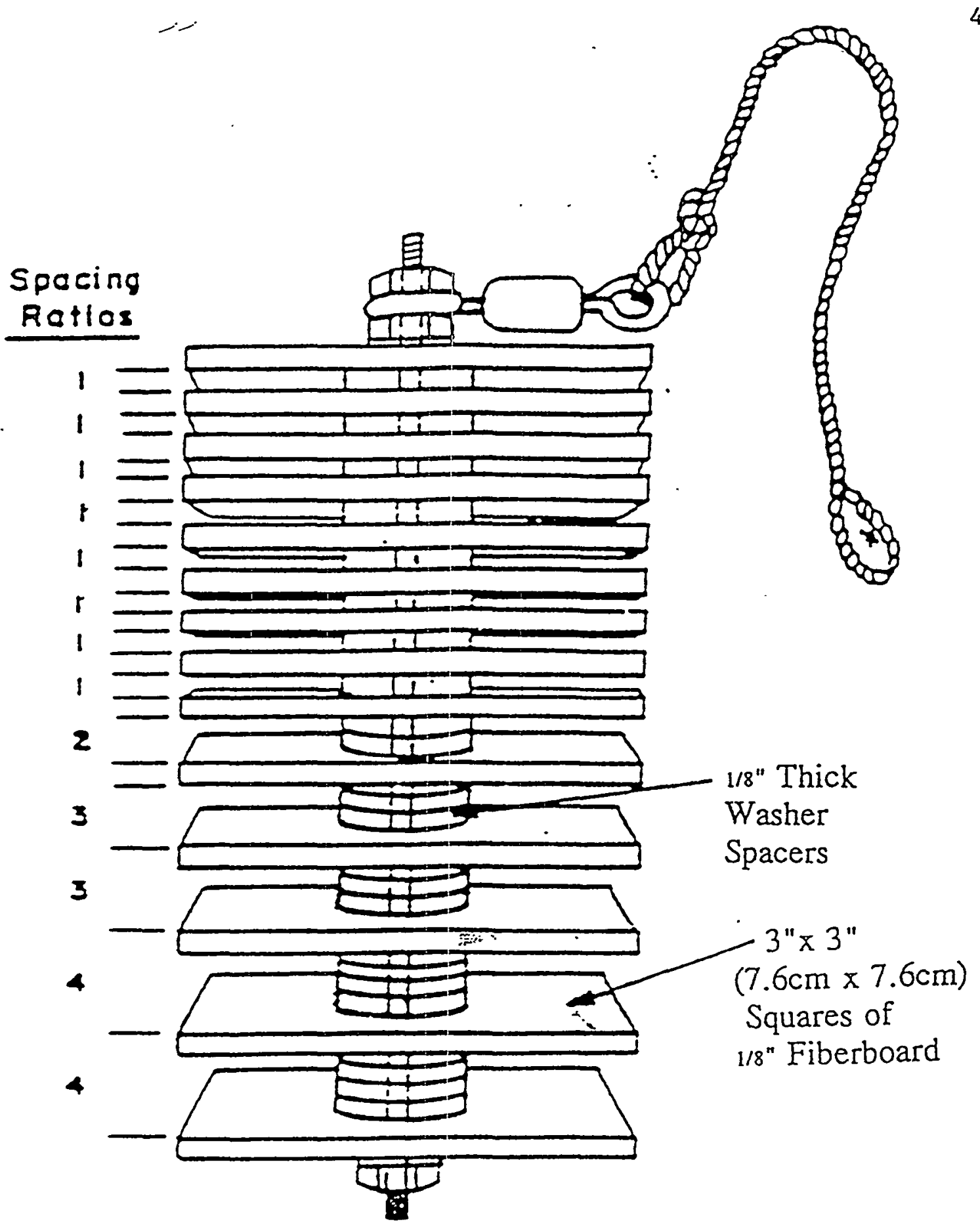

Figure 1. Diagram of Hester-Dendy iVIultiplate Sampler used in this study. 
mesh dipnet was placed under the sampler in order to prevent the loss of dislodged organisms. Once removed, the sampler was placed in a labelled plastic bag: and preserved with $10 \%$ formalin until processed in the laboratory. In the laboratory, each sampler was disassembled, the plates washed with a soft brush, and there moved material rinsed through a U.S. Standard No. 30 sieve $(0.6 \mathrm{~mm}$ mesh). The material retained on the sieve was then preserved with $70 \%$ ethanol stained with rose bengal.The macroinvertebrates were sorted from the remaining debris using a stereomicroscope, identified to the lowest positive taxon and enumerated. Quality control checks were performed on $10 \%$ of the samples in order to insure a sorting efficiency of greater than $90 \%$. After the organisms were enumerated, they were separated into functional feeding groups following Merritt and Cummins(1984), dried at $105^{\circ} \mathrm{C}$, weighed to the nearest milligram and then ashed at $500^{\circ} \mathrm{C}$. Ash free dry weight was determined by weighing the remaining ash to the nearest milligram and determining the difference between the dry weight and ash weight.

\section{2.}

\section{SECTION III. RAPID BIOASSESSMENT PROCEDURES}

Qualitative collections of macroinvertebrates were made utilizing the USEPA rapid bioassessment protocol II and III(Plafkin et al. (1989) which focus primarily on evaluating rifflerun or other hard surface habitats, supplemented with a separate coarse particulate organic matter (CPOM) sample. Samples were collected using a standard D-frame aquatic dipnet, placed in labelled plastic bags and preserved with $10 \%$ formalin. Upon return to the laboratory the samples were cleaned of large objects, washed through a U.S. Standard No. 30 sieve and then preserved with $70 \%$ ethanol stained with rose bengal. Samples were sorted in white developing 
trays which had a grid drawn on the bottom dividing the sample into $1 / 8$ subsamples. The samples were picked until approximately 200 organisms were removed and the subsampled area recorded.

Comparison of the macroinvertebrate community composition was based on the metrics outlined in the USEPA rapid bioassessment protocols (Plafkin et al. 1989). 


\section{LITERATURE CITED}

Hilsenhoff, W.L. 1988. Rapid field assessment of organic pollution with a family-level biotic index. J.N. Am. Benthol. Soc. 7:65-68.

Lenat, D.R. 1993. A biotic index for the southeastern United States: derivation and list of tolerance values, with criteria for assigning water-quality ratings. J.N. Am. Benthol. Soc 12:279-290.

Merritt, R.W. and K.W. Cummins, eds. 1984. An introduction to the aquatic insects of North America, 2nd ed. Kendall/Hunt Publishing, Dubuque, IA.

Plafkin, J.L., M.T. Barbour, K.D. Porter, S.K. Grossand, R.M. Hughes. 1989. Rapid bioassessment protocols for use in streams and rivers. USEPA Assessment and Watershed Protection Division, Washington, D.C. EPA/444/4-89/001. 
PART III 


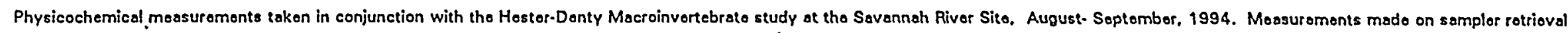
dato.

\begin{tabular}{|c|c|c|c|c|c|c|c|c|c|c|c|c|c|c|c|}
\hline Station $\#$ & 1 & 2 & 3 & 4 & 5 & 6 & 7 & 8 & 9 & 10 & 11 & 12 & 13 & 14 & 15 \\
\hline & & & & & & & & & & & & & & & \\
\hline Placoment Dato & $8 / 22 / 94$ & $8 / 22 / 94$ & $8 / 22 / 94$ & $8 / 22 / 94$ & $8 / 22 / 94$ & $8 / 22 / 94$ & $8 / 22 / 94$ & $8 / 22 / 94$ & $8 / 23 / 94$ & $8 / 24 / 94$ & $8 / 24 / 94$ & $8 / 22 / 94$ & $8 / 24 / 94$ & $8 / 23 / 94$ & $8 / 23 / 94$ \\
\hline Retrioval Dato & $10 / 20 / 94$ & $10 / 20 / 94$ & $10 / 20 / 94$ & $10 / 20 / 94$ & $10 / 20 / 94$ & $10 / 20 / 94$ & $10 / 20 / 94$ & $10 / 20 / 94$ & $10 / 20 / 94$ & $10 / 20 / 94$ & $10 / 21 / 94$ & $10 / 21 / 94$ & $10 / 21 / 94$ & $10 / 21 / 94$ & $10 / 21 / 94$ \\
\hline Hardnoss $(\mathrm{mg} /)$ & 12.7 & $<10.0$ & 23.3 & 14.2 & $<10.0$ & $<10.0$ & $<10.0$ & 20.7 & 16.2 & 20.2 & 19.2 & 12.8 & 14.7 & 14.4 & $<10.0$ \\
\hline $\mathrm{pH}(\mathrm{SU})$ & 7.23 & 7.44 & 7.59 & 7.00 & 7.24 & 7.20 & 6.95 & 7.24 & 7.80 & 6.99 & 7.78 & 7.50 & 7.44 & 7.35 & 7.26 \\
\hline Conductivity (umhos $/ \mathrm{cm}$ ) & 48.3 & 26.6 & 49.3 & 119.0 & 98.3 & 24.0 & 74.1 & 53.2 & 42.0 & 66.5 & 117.0 & 99.8 & 95.5 & 103.0 & 60.2 \\
\hline $0 O(\mathrm{mg} /)$ & 8.0 & 7.4 & 8.5 & 5.4 & 7.4 & 8.0 & 4.9 & 7.7 & 8.3 & 0.6 & 7.9 & 7.6 & 7.5 & 6.6 & 8.0 \\
\hline Tomperaturo (C) & 17.0 & 17.8 & 17.5 & 20.0 & 18.2 & 19.0 & 21.0 & 19.0 & 19.5 & 23.5 & 19.5 & 22.5 & 22.0 & 28.5 & 20.5 \\
\hline Flow $(\mathrm{m} / \mathrm{s})$ mid channol & 0.08 & 0.13 & 0.04 & 0.00 & 0.29 & 0.40 & 0.08 & 0.00 & 0.50 & 0.23 & 0.17 & 0.24 & 0.33 & 0.59 & 0.16 \\
\hline Flow $(\mathrm{m} / \mathrm{s})$ moan $(\mathrm{N})$ & $0.05(10)$ & $0.12(10)$ & $0.02(10)$ & 0.00111 & $0.18(3)$ & $0.34(10)$ & $0.05(10)$ & $0.00(3)$ & $0.18(8)$ & $0.13(10)$ & $0.13(10)$ & $0.14(10)$ & $0.16(10)$ & $0.44(10)$ & $0.10(10)$ \\
\hline Stroam Width $(\mathrm{m})$ & 4.94 & 8.99 & 6.16 &.$\quad 0.91$ & 2.07 & 15.64 & 7.25 & 1.10 & 4.05 & 5.18 & 3.38 & 12.12 & 10.81 & 4.82 & 13.11 \\
\hline \multicolumn{16}{|l|}{ (motere from lolt bank) Dopth } \\
\hline Dopth 1 & 1010 & (0) 0 & (0) 0 & 1010 & (0) 0 & (0) 0 & (0) 0 & 1010 & (0) 0 & 1010 & 1010 & $10) 0$ & (0) 0 & 10) 0 & (0) 0 \\
\hline oupth 2 & 10.310 .68 & 10.810 .27 & 10.610 .46 & 10.310 .12 & $(0.3) 0.49$ & 11.410 .82 & 10.710 .67 & 10.910 .61 & 10.510 .23 & 10.510 .09 & 0.610 .60 & 11.110 .30 & 11.010 .52 & 10.410 .09 & $11.2) 0.37$ \\
\hline Depth 3 & .0 .910 .61 & $(1.6) 0.46$ & $(1.0) 0.73$ & 10.510 .27 & 10.510 .46 & $12.8) 0.78$ & 11.310 .73 & $(1.9) 0.58$ & 10.910 .48 & 10.910 .21 & $(1.1) 0.09$ & 12.210 .55 & 11.910 .40 & 10.810 .40 & $12.4) 0.58$ \\
\hline Dopth 4 & 11.310 .58 & $12.5) 0.52$ & 11.710 .91 & 10.810 .08 & 11.010 .43 & $14.3) 0.70$ & 12.010 .91 & 12.9) 0.34 & $(1.3) 0.81$ & $19.4) 0.29$ & 11.710 .15 & $(3.3) 0.67$ & $12.9) 0.34$ & 11.210 .37 & $(3.0) 0.49$ \\
\hline Oogth 5 & $(1.8) 0.49$ & $(3.3) 0.04$ & (2.3) 1.01 & 10.910 & $(1.3) 0.34$ & $(5.7) 0.76$ & $(2.6) 1.16$ & (3.8) 0 & 11.810 .67 & 11.910 .34 & $(2.3) 0.12$ & $14.4) 0.70$ & $(3.9) 0.46$ & $(1.6) 0.49$ & $(4.8) 0.52$ \\
\hline Dopth 0 & $(2.5) 0.41$ & $14.1) 0.01$ & $(2.8) 0.82$ & & $(1.5) 0.15$ & $17.1) 0.91$ & (3.3) 1.18 & & 12.310 .53 & $12.3) 0.37$ & $(2.8) 0.15$ & $(5.5) 0.70$ & $(4.8) 0.52$ & 12.010 .46 & $15.9) 0.43$ \\
\hline Depth ? & 12.710 .30 & 14.910 .61 & 13.410 .79 & & 12.010 & 18.510 .79 & 14.011 .18 & & 12.710 .37 & 12.8) 0.37 & (3.4) 0 & $(0.8) 0.73$ & (5.8) 0.81 & $(2.4) 0.37$ & $(7.1) 0.37$ \\
\hline Dopth 8 & $13.1) 0.17$ & 15.710 .70 & (3.9) 0.67 & & & $(9.9) 0.70$ & $(4.6) 1.13$ & & 13.110 .30 & (3.3) 0.37 & & $(7.7) 0.79$ & $(6.7) 0.61$ & $(2.8) 0.34$ & $18.3): 0.43$ \\
\hline oopth 9 & $(3.6) 0.12$ & $(0.8) 0.73$ & 14.510 .07 & & & 111.310 .07 & $(5.3) 1.10$ & & $(3.8) 0.23$ & $(3.8) 0.34$ & & $(8.8) 0.73$ & 17.710 .70 & 13.210 & $(9.5) \quad 0.52$ \\
\hline Dopth 10 & $(4.0) 0.15$ & $(7.4) 0.67$ & $(5.1) 0.70$ & & & 112.810 .01 & $(5.9) 1.01$ & & $(4.1) 0$ & $(4.2) 0.24$ & & 19.910 .48 & $(8.7) 0.73$ & & 110.710 .61 \\
\hline Oepth 11 & 14.510 .12 & $(8.2) 0.40$ & $(5.0) 0.18$ & & & 114.210 .30 & $(8.6) 0.98$ & & & $(4.7) 0.12$ & & 111.010 .27 & $(9.6) 0.01$ & & 111.910 .52 \\
\hline Deper 12 & 14.910 & 19.010 & 10.210 & & & 115.810 & 17.310 & & & 15.210 & & 112.110 & $(10.6) 0$ & & (13.1)0 \\
\hline
\end{tabular}


Physicochemical measurements taken in conjunction with the Hester-Denty Macroinvertebrate study at Rosemary Creek downstream of Williston WWTP. 17 December 1994. Measurements made on sampler retrieval date.

\begin{tabular}{|l|r|}
\hline Rosemary Creek Statidn 16 \\
\hline Downstream Williston WWTP \\
\hline & \\
\hline Placement Date & Nov. 16, 1994 \\
\hline Retrieval Date & Dec. 17, 1994 \\
\hline & 92.5 \\
\hline Hardness (mg/l) & 6.69 \\
\hline pH (SU) & 45 \\
\hline Conductivity (umhos/cm) & 9.1 \\
\hline DO (mg/I) & 12.5 \\
\hline Temperature (C) & 0.18 \\
\hline Flow (m/s) Mid Channel & 4.08 \\
\hline Stream Width (m) & \\
\hline (motors from lott bank) Dopth & \\
\hline Depth 1 & 10.010 \\
\hline Dopth 2 & $(0.51) 0.30$ \\
\hline Depth 3 & $(1.02) 0.24$ \\
\hline Depth 4 & $(1.53) 0.18$ \\
\hline Depth 5 & $(2.04) 0.24$ \\
\hline Dopth 6 & $(2.55) 0.18$ \\
\hline Dopth 7 & $(3.06) 0.27$ \\
\hline Depth 8 & $(3.57) 0.21$ \\
\hline Depth 9 & $(4.08) 0$ \\
\hline
\end{tabular}




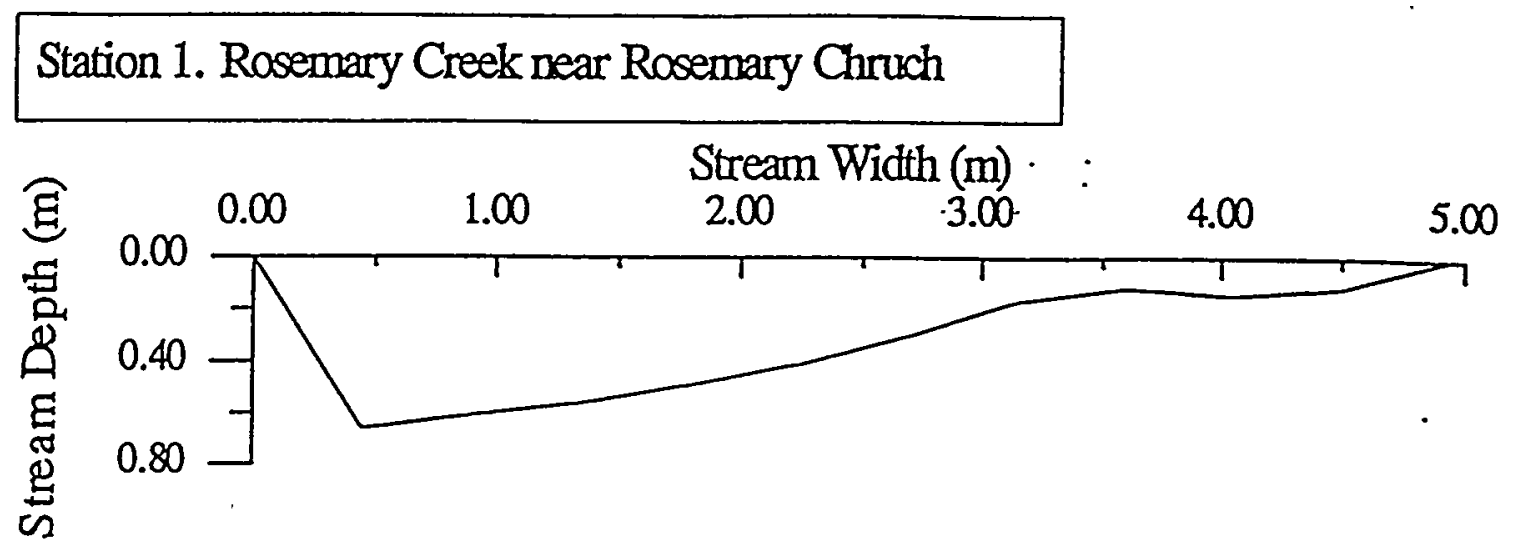

Station 3. Mill Creek @ Rd. E-2.

Stream width (m)

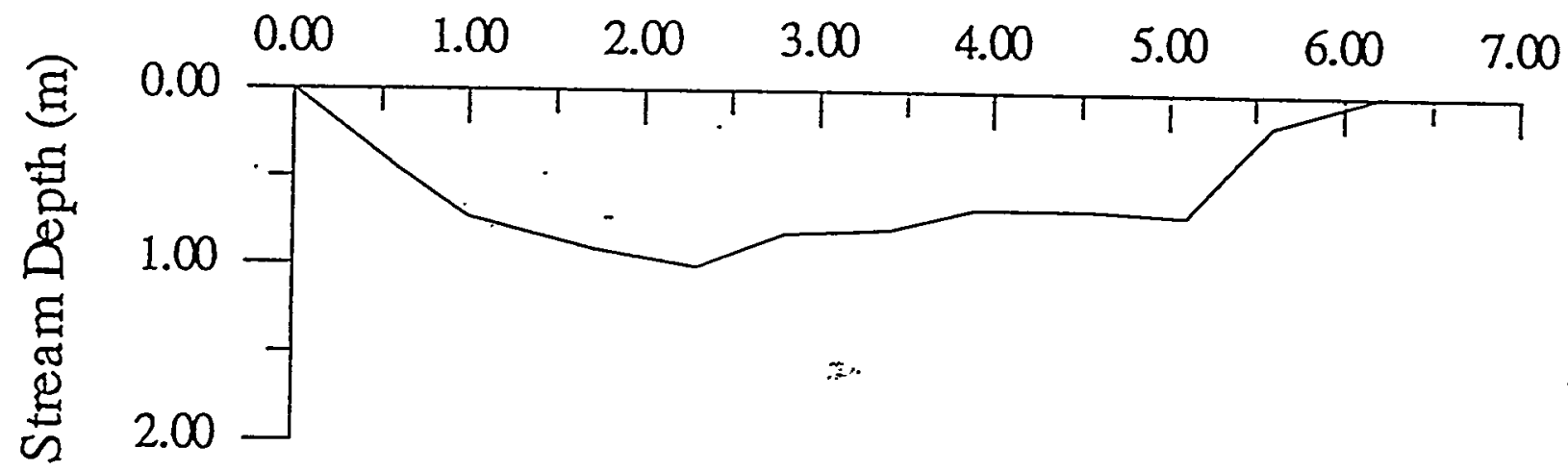

Station 2. Tinker Cr. @ Kennedy's Pond Rd.

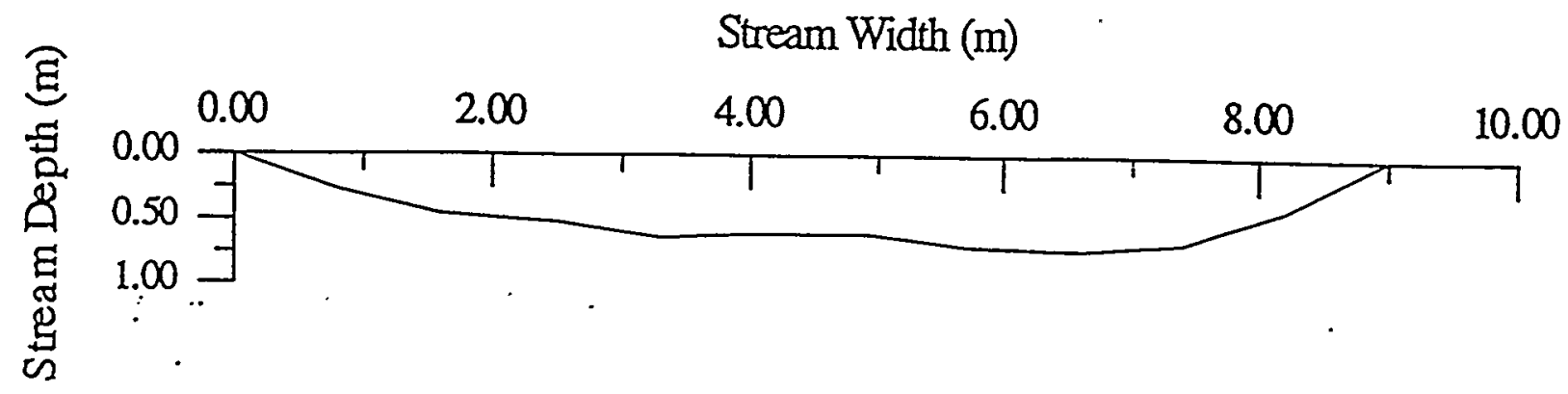


Station 4. Crouch Branch @ Rd. 4.

Stream Width (m)

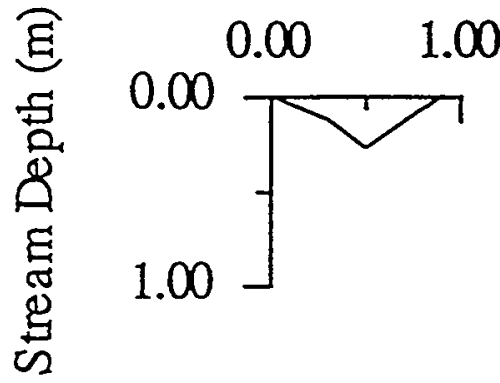

Station 5. Tims Branch @Rd. 2.

Stream Width (m)

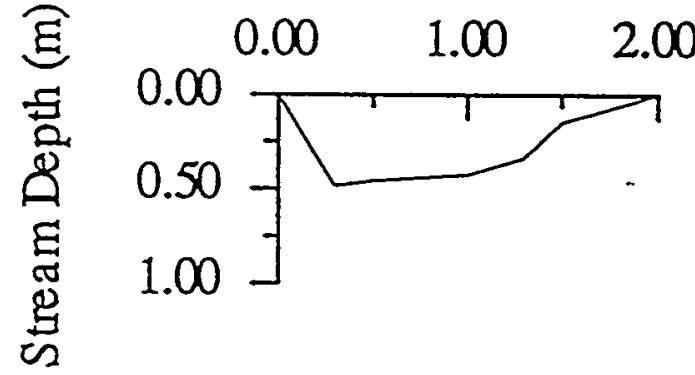

$\because$

Station 6. Upper Three Runs Cr. @ Rd. C

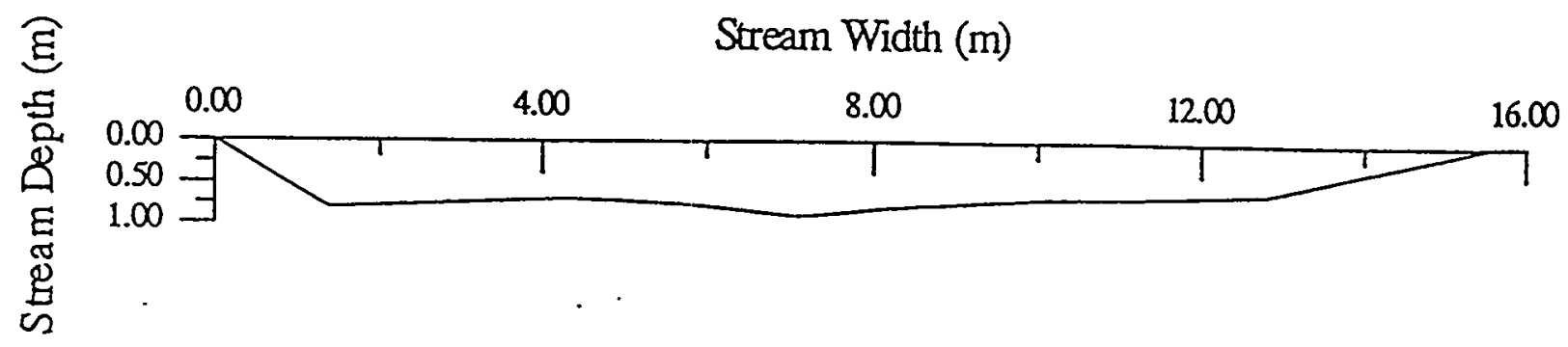


Station 7. Four Mile Creek @ Rd. C.

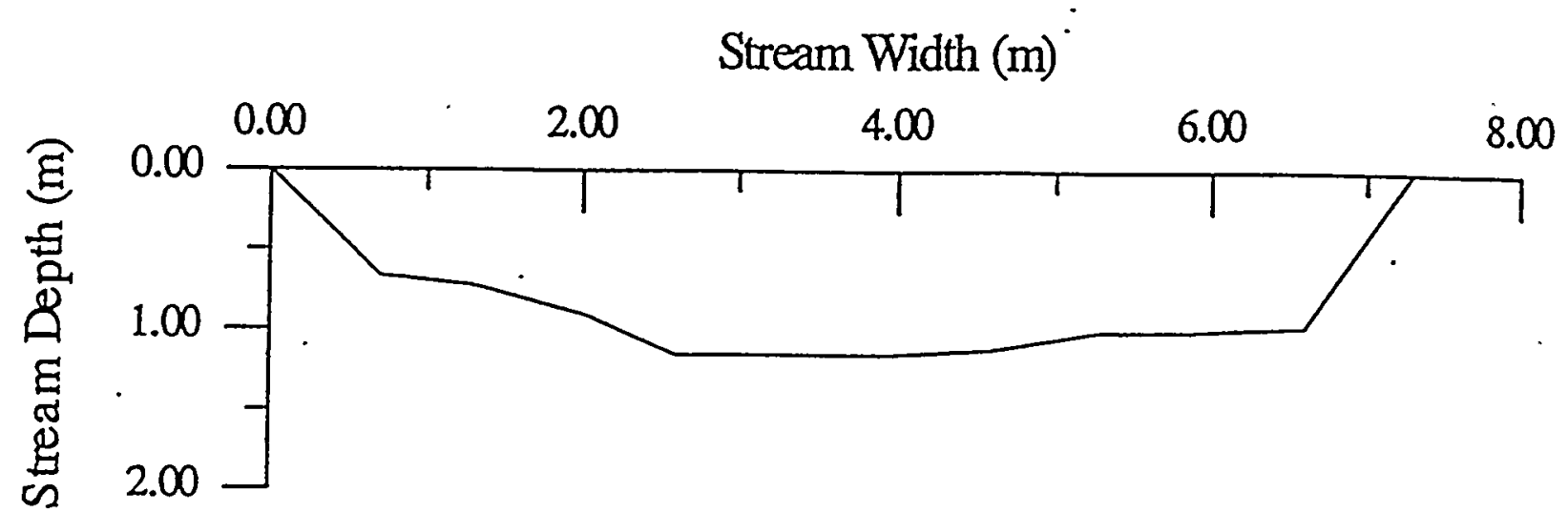

Station 8. Pen Branch @ Rd. C.

Stream Width (m)

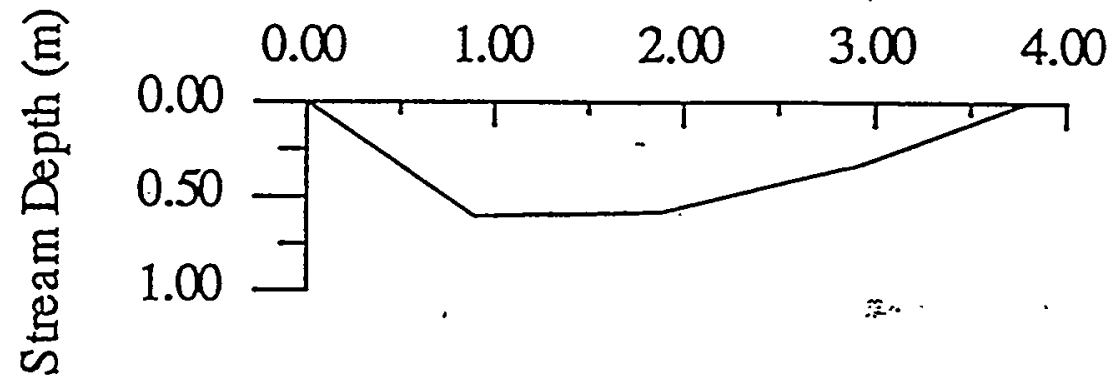

Station 9. Meyers Branch @ Road 9

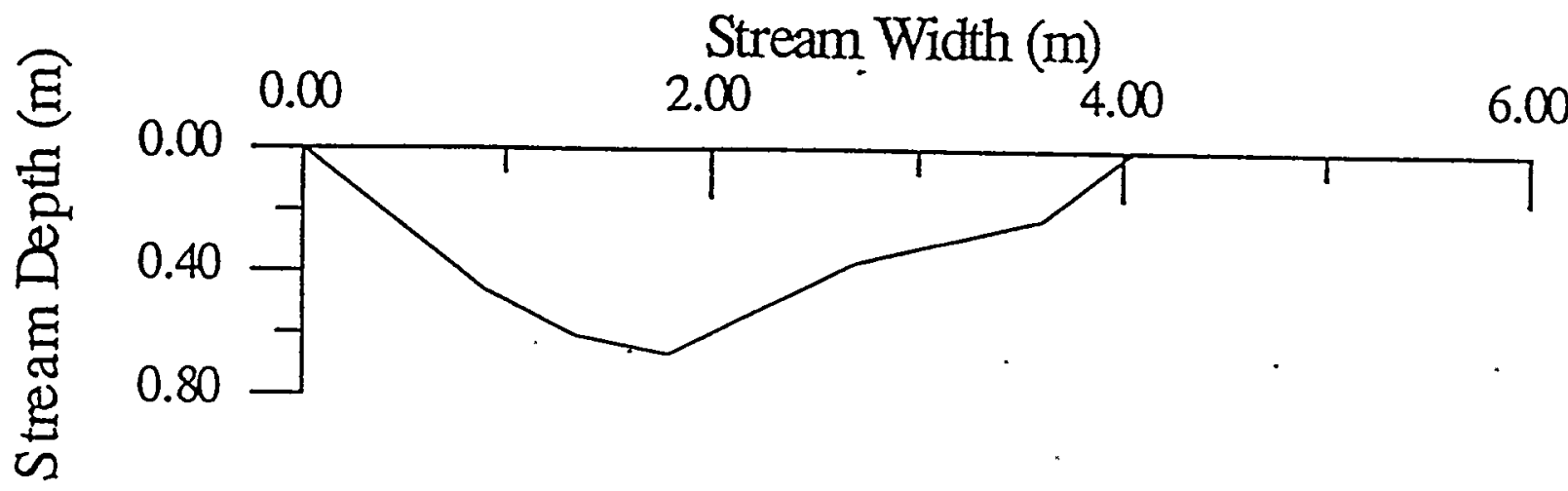


Station 10. Lower Three Runs Creek @ Road B

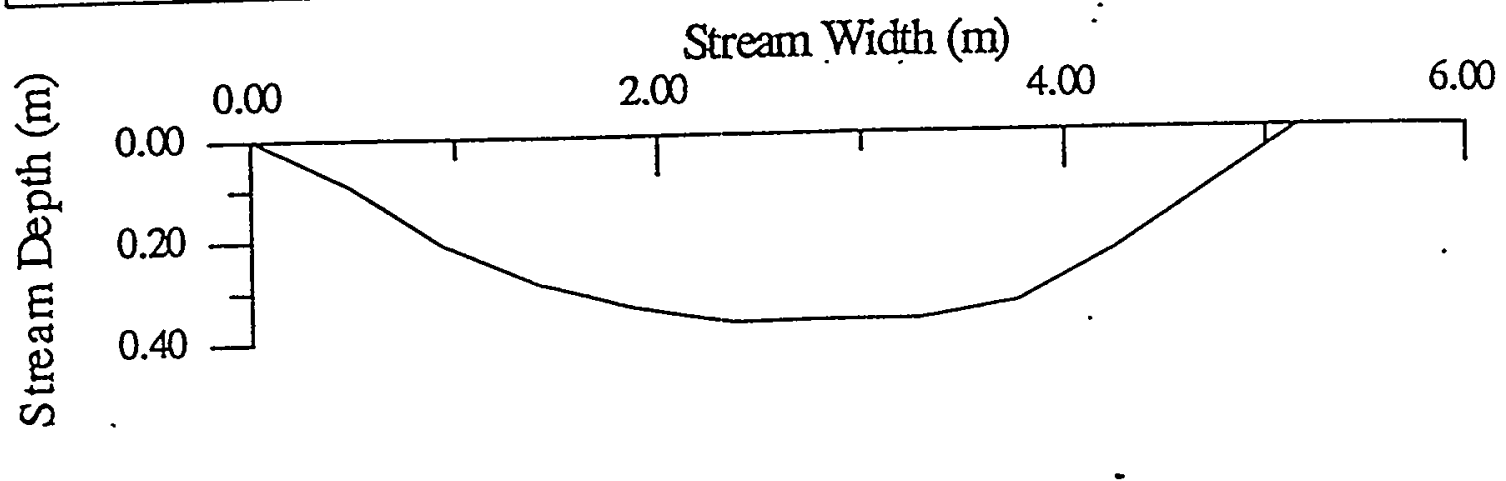

Station 11. Pen Branch @ Rd. B.

Stream Width (m)

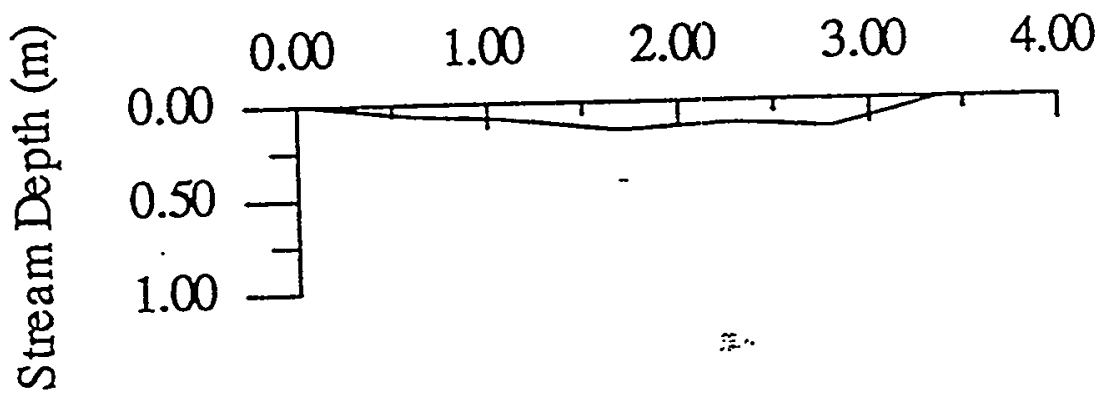

Station 12. Indian Grave Branch @ Rd. B.

Stream Width (m)

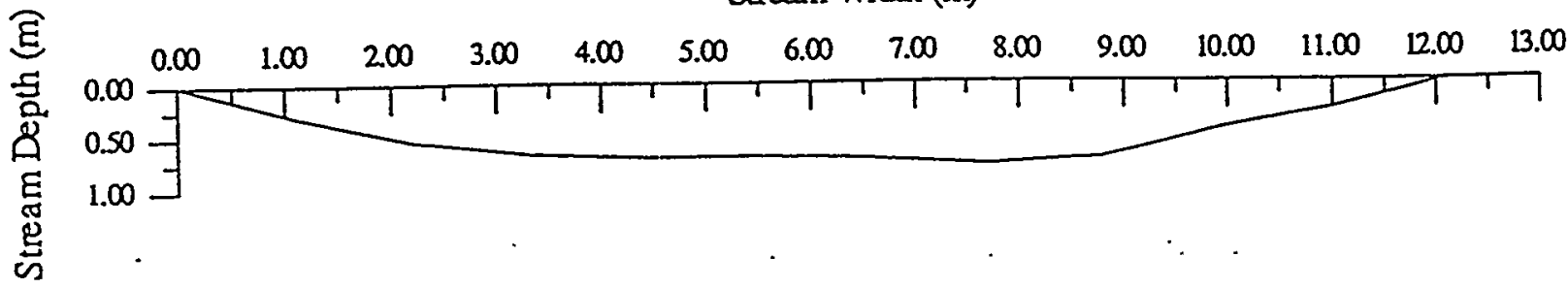


Station 13.Pen Branch @ Rd. A.

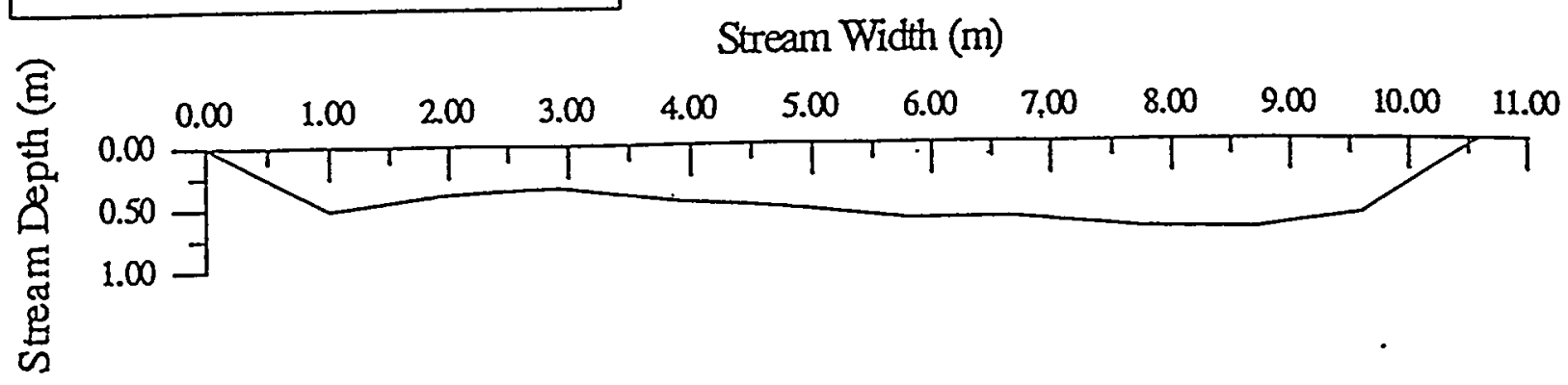

Station 14. Beaver Dam Creek near Metal Walkway

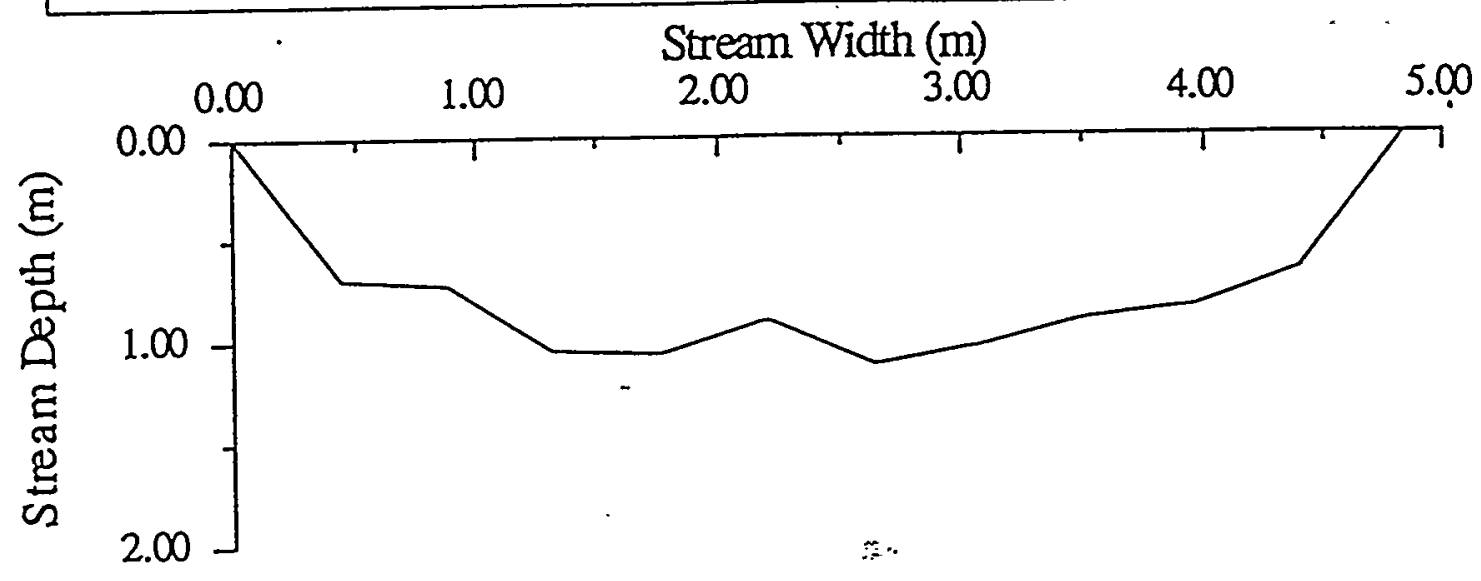

Statión 15. Four Mile Creek @ Rd.13.2.

Stream Width (m)

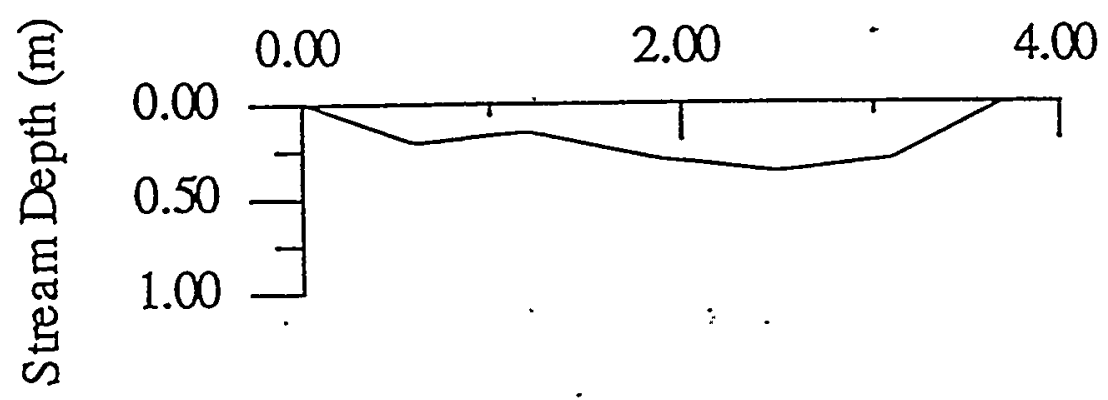




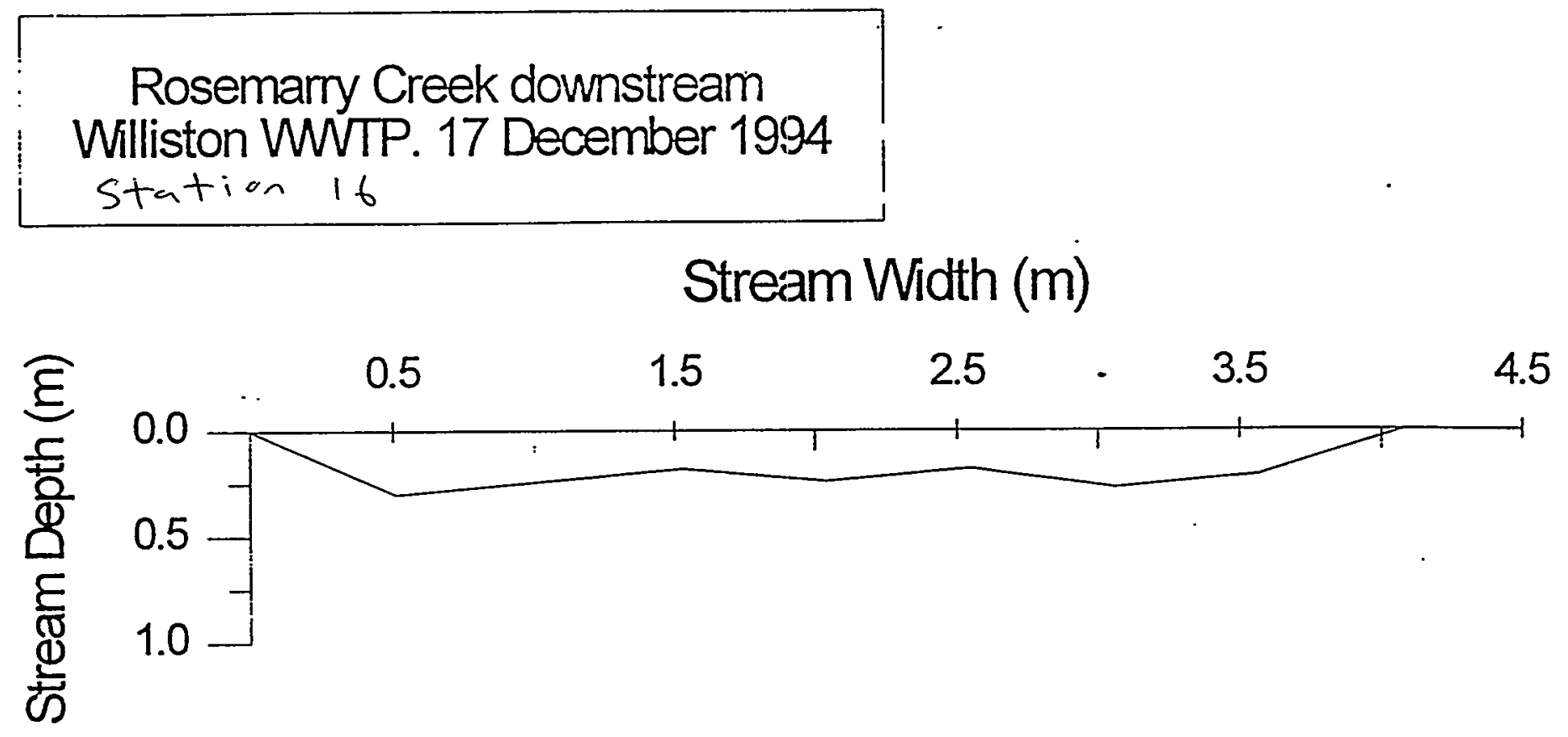


PART IV

$\therefore$ 
TABLE 2. ABBREVIATIONS AND EXPLANATION OF TERMS USED IN THE MACROINVERTEBRATE DATA AND SUMMARY STATISTICS

I. CODES OF MAJOR TAXA
1) ANO - Annelida, Oligochaeta
2) ANH - - Annelidae, Hirudinea
3) AHC - Acari, Hydracarina
4) AM - Amphipoda
5) DC - Decapoda
6) EP - Hexapoda, Ephemeroptera
7) OD - Hexapoda, Odonata
8) PL - Hexapoda, Plecoptera
9) $\mathrm{CO}$ - Hexapoda, Coleoptera
10) ME - Hexapoda, Megaloptera
11) TR - Hexapoda, Trichoptera
12) DO - Hexapoda, Diptera, Other
13) DTA - Hexapoda, Diptera, Chironomidae, Tanypodinae
14) DOR - Hexapoda, Diptera, Chironomidae, Orthocladiinae
15) DCC - Hexapoda, Diptera, Chironomidae, Chironomini
16) DPC - Hexapoda, Diptera, Chironomidae, Pseudochironomini
17) DTY - Hexapoda, Diptera, Chironomidae, Tanytarsini
18) DD - Hexapoda, Diptera, Chironomidae Diamesinae
19) HA - Hexapoda, Heteroptera
20) LEP - Hexapoda, Lepidoptera
21) MB - Mollusca, Bivalvia
22) MंG - Mollusca, Gastropoda
23) IS - Isopoda

II. FUNCTIONAL FEEDING GROUP CODES
1) CG - Collector/Gatherer
2) C - Collector/Filterer
3) $\mathrm{P}$ - Predator
4) $\cdot \mathrm{SC}-$ Scrapper
5) $\mathrm{SH}$ - Shredder
6) $\mathrm{H}$ - Herbivor 
III. STATISTICAL SUMMARY ABBREVIATIONS

1) Bio. Index - North Carolina Biotic Index $=\frac{\underline{\Sigma T V} N_{i}}{-T O T A L} N$

Where: $\quad \mathrm{TV}_{\mathrm{i}}=$ Tolerance Values

$\mathrm{N}_{\mathrm{i}}=$ Number of Individuals of a Taxon

$\mathrm{N}=$ Total Number of Individuals in the

Sample

2) Mean Tax/Samp -Mean number of taxa per sampler

3) Total Orgs. -Total number of organisms for the station

4) Tot. Tax -Total number of taxa for the station

5) Tot. Mean\# -Total mean number of organisms per $\mathrm{m}^{2}$

6) FG -Functional group

7) Rel. Abd. -Relative abundance

8) Community loss Index $=d-a / e$

9) Jaccard Coefficient of similarity $=a / a+b+c$

where: $\quad a=$ number taxa present in sample $A$ and $B$

$\mathrm{b}=$ number taxa present only in sample $B$

$c=$ number taxa present only in sample $A$

$\mathrm{d}=$ number taxa present in sample $A$

$\mathrm{e}=$ number present in sample $\mathrm{B}$ 


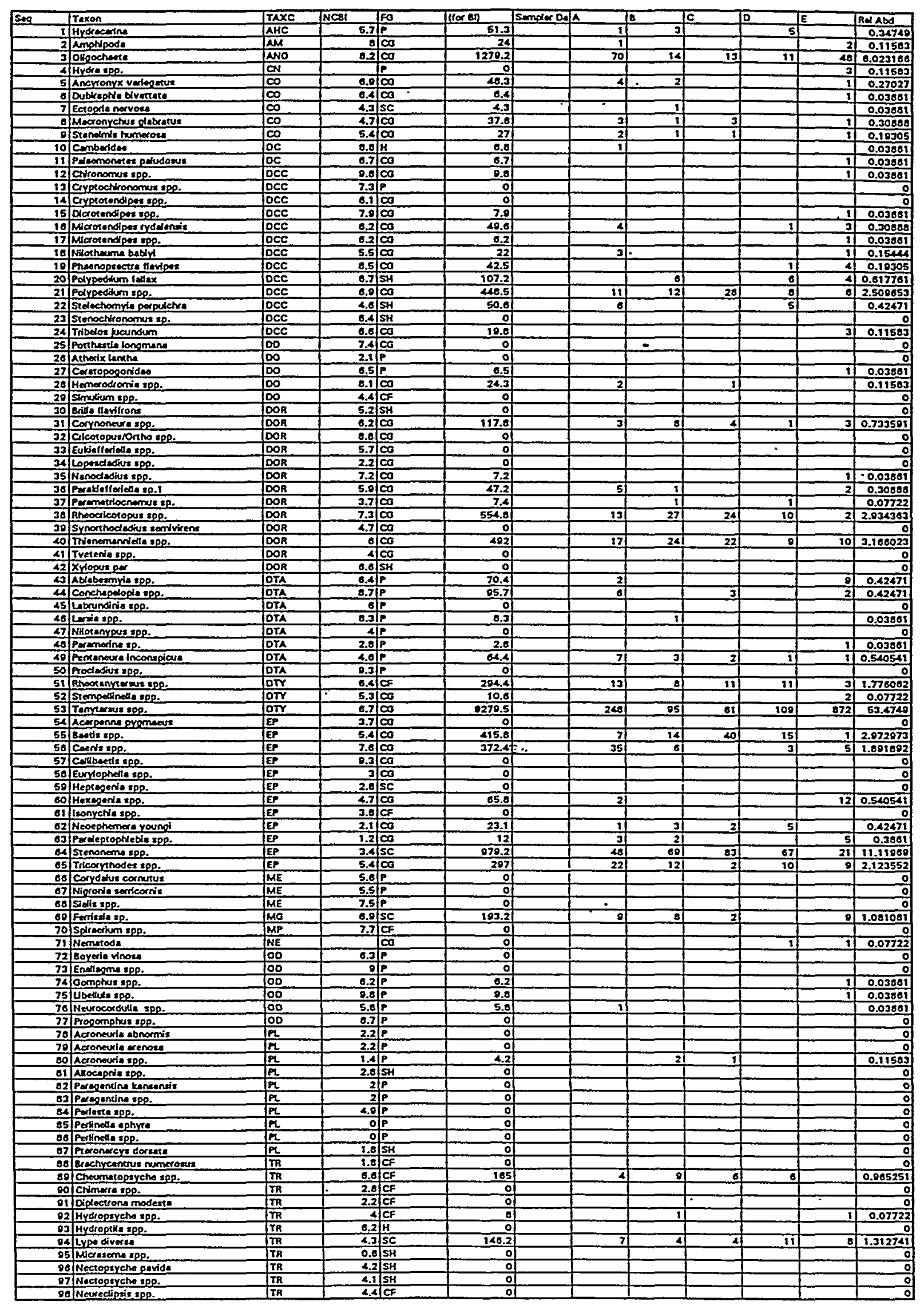




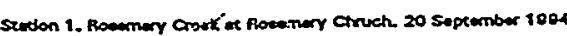

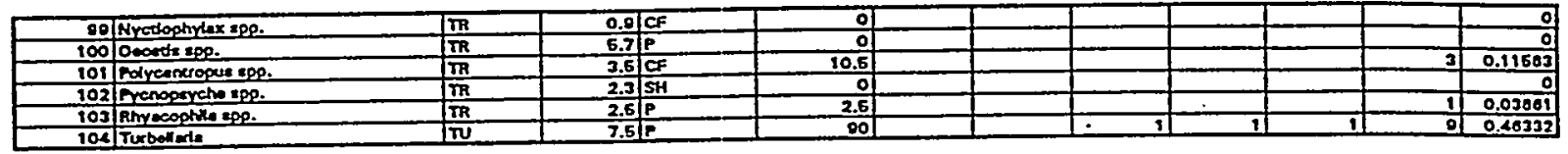

myecophthe s.p.

Tru 7.5 .

Pol 


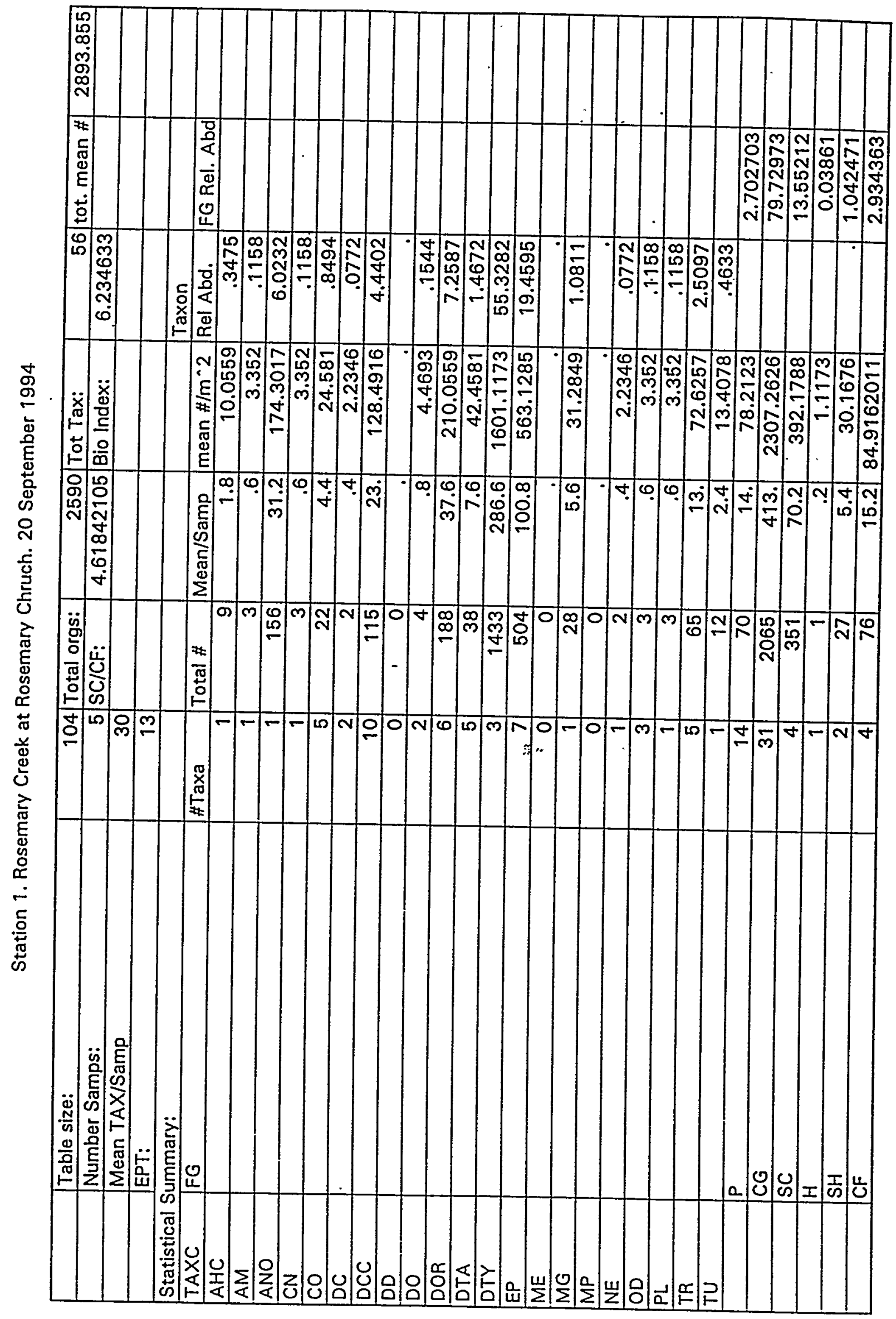




\begin{tabular}{|l|}
\hline Taxa List: \\
\hline Hydracarina \\
\hline Amphipoda \\
\hline Oligochaeta \\
\hline Hydra spp. \\
\hline Ancyronyx variegatus \\
\hline Dubiraphia bivattata \\
\hline Ectopria nervosa \\
\hline Macronychus glabratus \\
\hline Stenelmis humerosa \\
\hline Cambaridae \\
\hline Palaemonetes paludosus \\
\hline Chironomus spp. \\
\hline Dicrotendipes spp. \\
\hline Microtendipes rydalensis \\
\hline Microtendipes spp. \\
\hline Nilothauma babiyi \\
\hline Phaenopsectra flavipes \\
\hline Polypedilum fallax \\
\hline Polypedilum spp. \\
\hline Stelechomyia perpulchra \\
\hline Tribelos jucundum \\
\hline Ceratopogonidae \\
\hline Hemerodromia spp. \\
\hline Corynoneura spp. \\
\hline Nanocladius spp. \\
\hline Parakiefferiella sp.1 \\
\hline Parametriocnemus sp. \\
\hline Rheocricotopus spp. \\
\hline Thienemanniella spp. \\
\hline Ablabesmyia spp. \\
\hline Conchapelopia spp. \\
\hline Larsia spp. \\
\hline Paramerina sp. \\
\hline Pentaneura inconspicua \\
\hline Rheotanytarsus spp. \\
\hline Stempellinella spp. \\
\hline Tanytarsus spp. \\
\hline Baetis spp. \\
\hline Caenis spp. \\
\hline Hexagenia spp. \\
\hline Neoephemera youngi \\
\hline Paraleptophlebia spp. \\
\hline Stenonema spp. \\
\hline Tricorythodes spp. \\
\hline Nemissia sp. \\
\hline Gomphus spp. \\
\hline
\end{tabular}


Neurocordulia spp.

Acroneuria spp.

Cheumatopsyche spp.

Hydropsyche spp.

Lype diversa

Polycentropus spp.

Rhyacophila spp.

Turbellaria 
Station 1. Rosomary Creok at Rosemary Chruch. 20 September 1994

\begin{tabular}{|c|c|c|c|c|c|c|c|c|c|c|}
\hline Taxon & TAXC & NCBI & (for Bl) & Sampler $\mathrm{Da}$ & A & B & IC & D & $\mathrm{E}$ & Rel Abd \\
\hline \begin{tabular}{l|l}
1 & Tanytarsus spp. \\
\end{tabular} & DTY & \begin{tabular}{l|l}
6.7 & $\mathrm{CG}$ \\
\end{tabular} & 9279.5 & & 248 & 95 & 81 & 109 & 872 & 53.4749 \\
\hline $\begin{array}{ll}2 \text { Stanonema spp. } \\
\end{array}$ & EP & $3.4 \mathrm{SC}$ & 979.2 & & 48 & 89 & 83 & 87 & 21 & 11.11909 \\
\hline \begin{tabular}{c|c} 
Oligochaeta \\
\end{tabular} & ANO & \begin{tabular}{l|l|l}
8.2 & $C G$ \\
\end{tabular} & 1279.2 & & 70 & 14 & 13 & 11 & 48 & 0.023180 \\
\hline
\end{tabular}




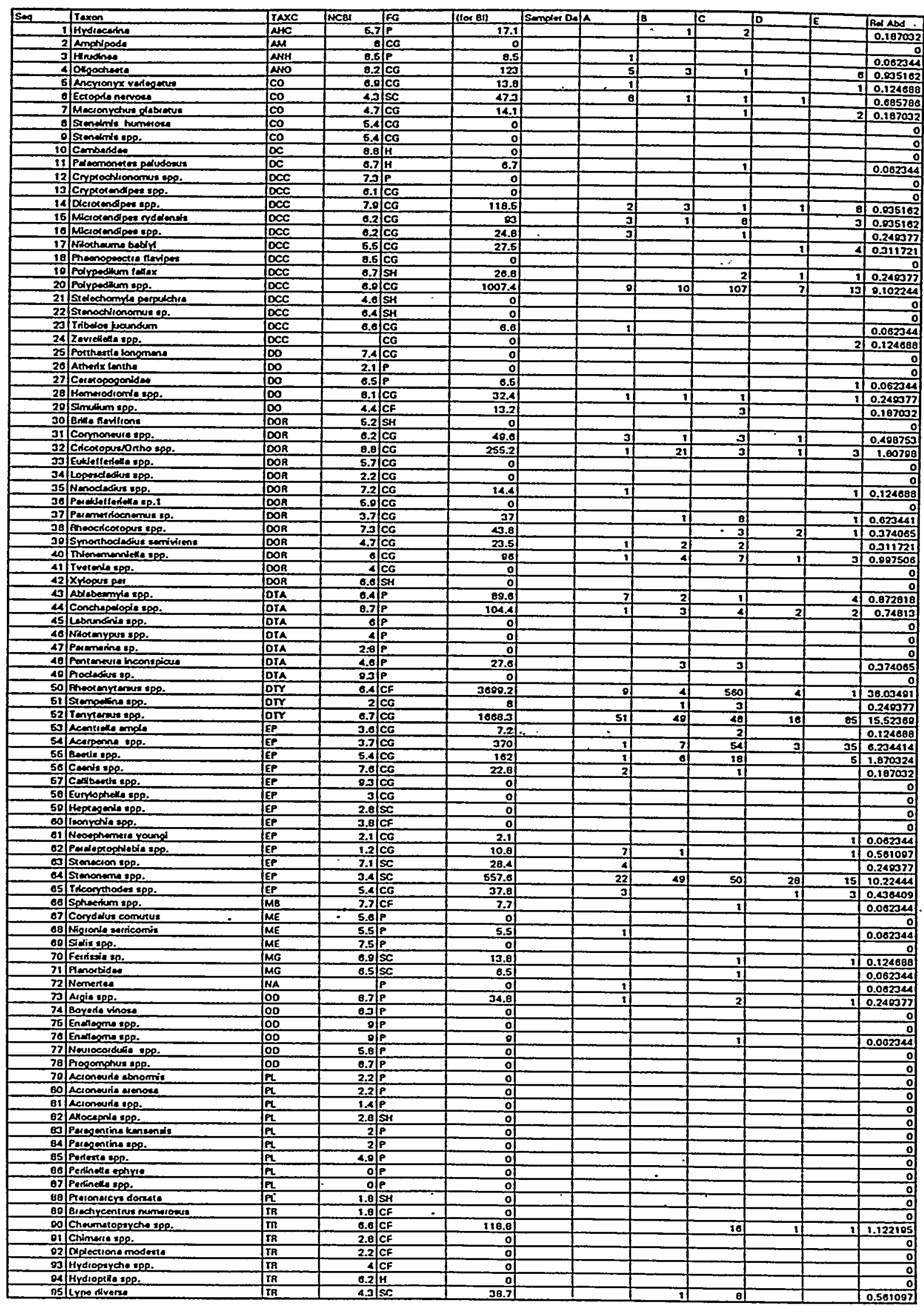




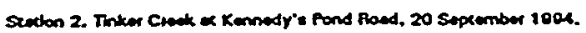

\begin{tabular}{|c|c|c|c|c|c|c|c|c|c|c|c|c|}
\hline$\infty$ & MHaceorma spg. & ITR & 0.0 & & of & & & & & & & 0 \\
\hline a7 & Neroogerethe exquelte & $\pi$ & 4.2 & & of & & & & & & & 0 \\
\hline 00 & Nectopernethe epp. & $\pi$ & 4.1 & SH & 36.0 & & g & & & & & 0.601007 \\
\hline 001 & Nowrectode spo. & $\pi$ & 4.4 & $\overline{\text { CF }}$ & e.8 & & & & & 1 & 1 & 0.124880 \\
\hline 100 & Nratophylex spp. & ITR & 0.0 & CF & of & & & & & & & 0 \\
\hline 101 & Oocente ipp. & $\operatorname{tin}$ & 6.7 & $P$ & 28.5 & & & 1 & 2 & 2 & & 0.211721 \\
\hline 102 & Oxyethlie spe. & $\pi$ & 6.2 & H & 18.0 & - & & & & 1 & 2 & 0.1870032 \\
\hline 100 & Polyeontropus sop. & TR. & 3.5 & CF & 7 & & 1 & & & & 1 & 0.124680 \\
\hline 104 & Tutretions: & tru & 7.5 & & 375 & & 12 & 31 & 28 & II & B & 3.117207 \\
\hline
\end{tabular}


Station 2. Tinker Creek at Kennedy's Pond Road. 20 September 1994.

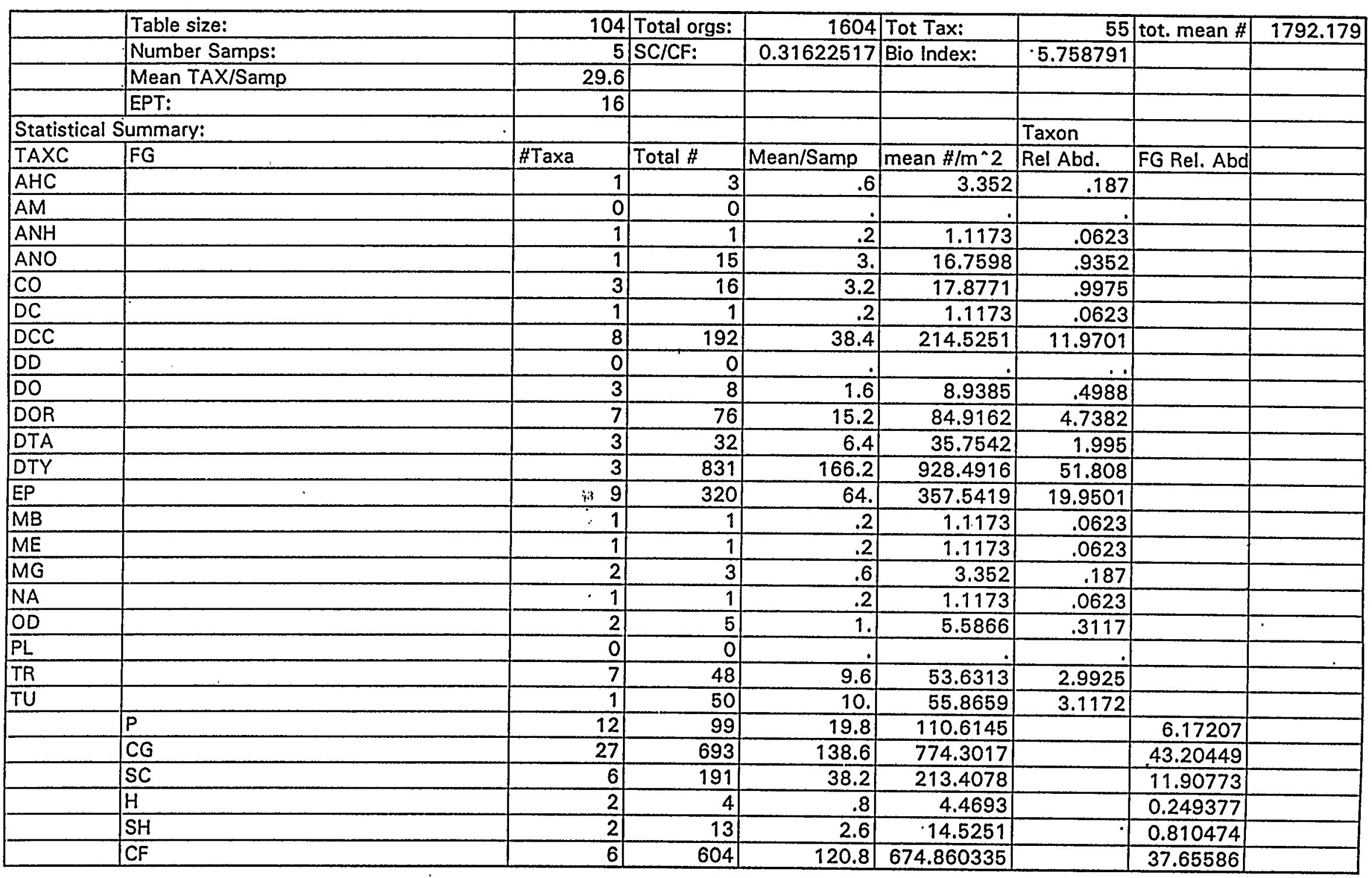


Station 2. Tinker Creek at Kennedy's Pond Road. 20 September 1994.

\begin{tabular}{|l|}
\hline Taxa List: \\
\hline Hydracarina \\
\hline Hirudinea \\
\hline Oligochaeta. \\
\hline Ancyronyx variegatus \\
\hline Ectopria nervosa \\
\hline Macronychus glabratus \\
\hline Palaemonetes paludosus \\
\hline Dicrotendipes spp. \\
\hline Microtendipes rydalensis \\
\hline Microtendipes spp. \\
\hline Nilothauma babiyi \\
\hline Polypedilum fallax \\
\hline Polypedilum spp. \\
\hline Tribelos jucundum \\
\hline Zavreliella spp. \\
\hline Ceratopogonidae \\
\hline Hemerodromia spp. \\
\hline Simulium spp. \\
\hline Corynoneura spp. \\
\hline Cricotopus/Ortho spp. \\
\hline Nanocladius spp. \\
\hline Parametriocnemus sp. \\
\hline Rheocricotopus spp. \\
\hline Synorthocladius semivirens \\
\hline Thienemanniella spp. \\
\hline Ablabesmyia spp. \\
\hline Conchapelopia spp. \\
\hline Pentaneura inconspicua \\
\hline Rheotanytarsus spp. \\
\hline Stempellina spp. \\
\hline Tanytarsus spp. \\
\hline Acentrella ampla \\
\hline Acerpenna spp. \\
\hline Baetis spp. \\
\hline Caenis spp. \\
\hline Neoephemera youngi \\
\hline Paraleptophlebia spp. \\
\hline Stenacron spp. \\
\hline Stenonema spp. \\
\hline Tricorythodes spp. \\
\hline Sphaerium spp. \\
\hline Nigronia serricornis \\
\hline Ferrissia sp. \\
\hline Planorbidae \\
\hline Nemertea \\
\hline Ergia spp. \\
\hline Cheumatlagma spp. \\
\hline
\end{tabular}


Station 2. Tinker Creek at Kennedy's Pond Road. 20 September 1994.

Lype diversa

Nectopsyche spp.

Neureclipsis spp.

Oecetis spp.

Oxyethira spp.

Polycentropus spp.

Turbellaria 


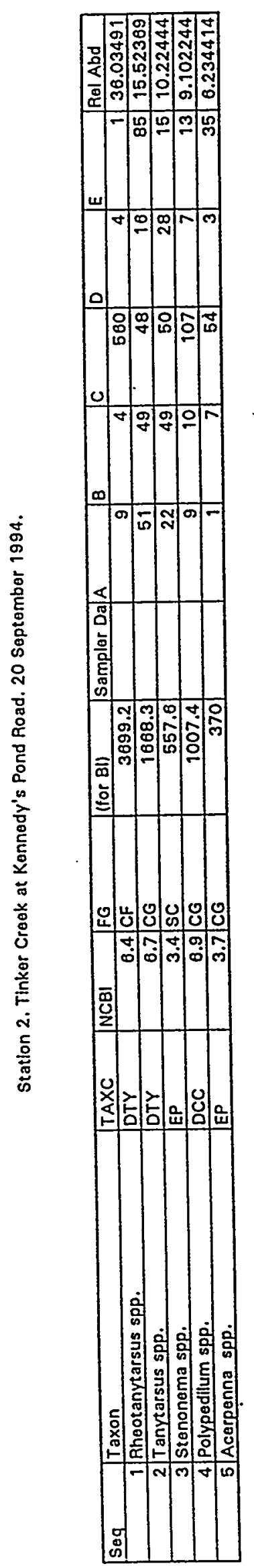




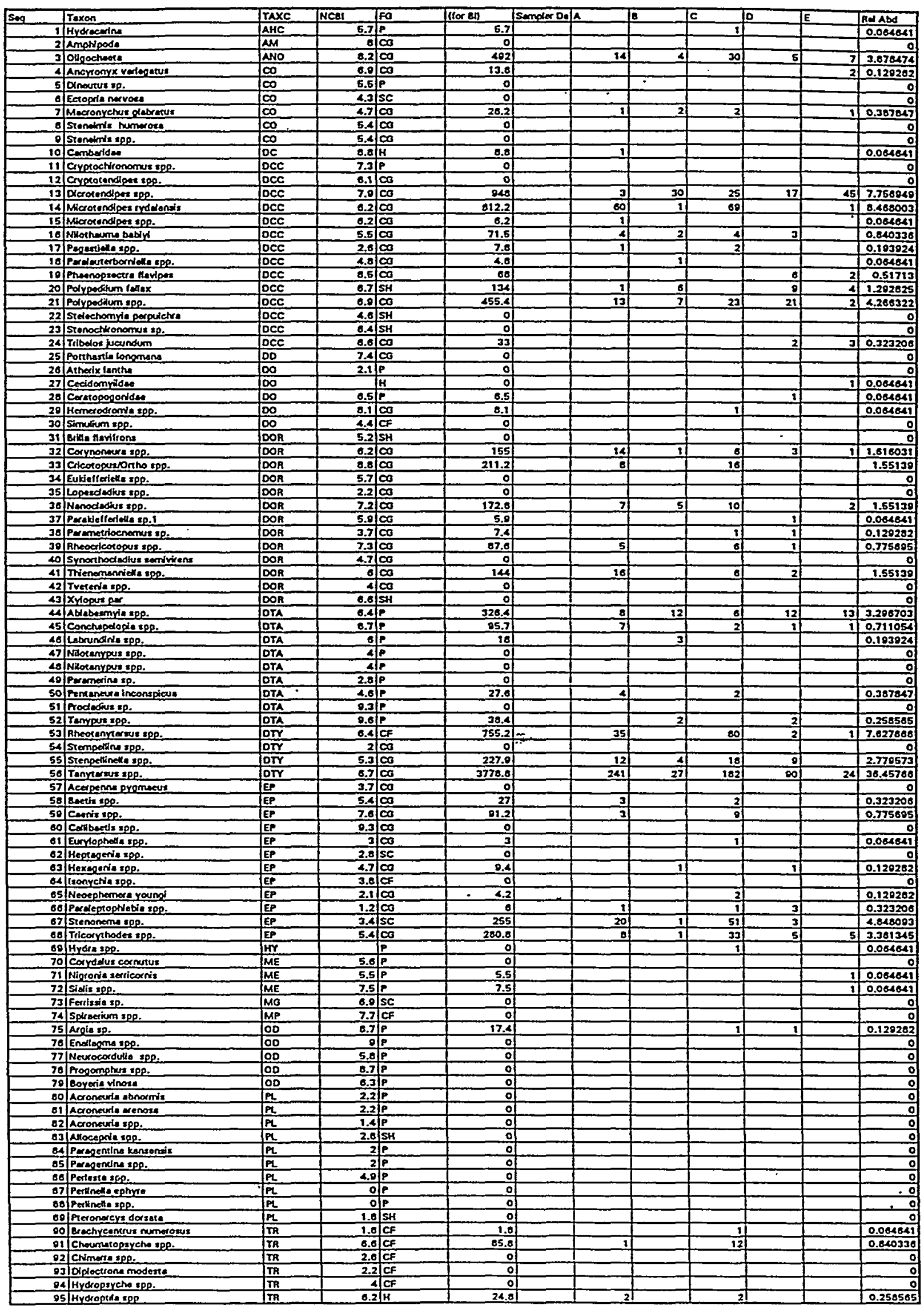


Studon 3. Max Crakk ax Rood E-2. 20 Septomber 1928.

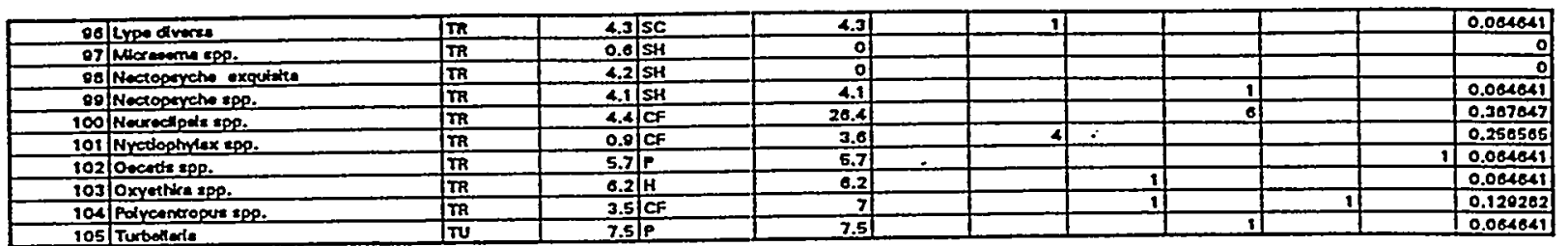


Station 3. Mill Creek at Road E-2. 20 September 1994.

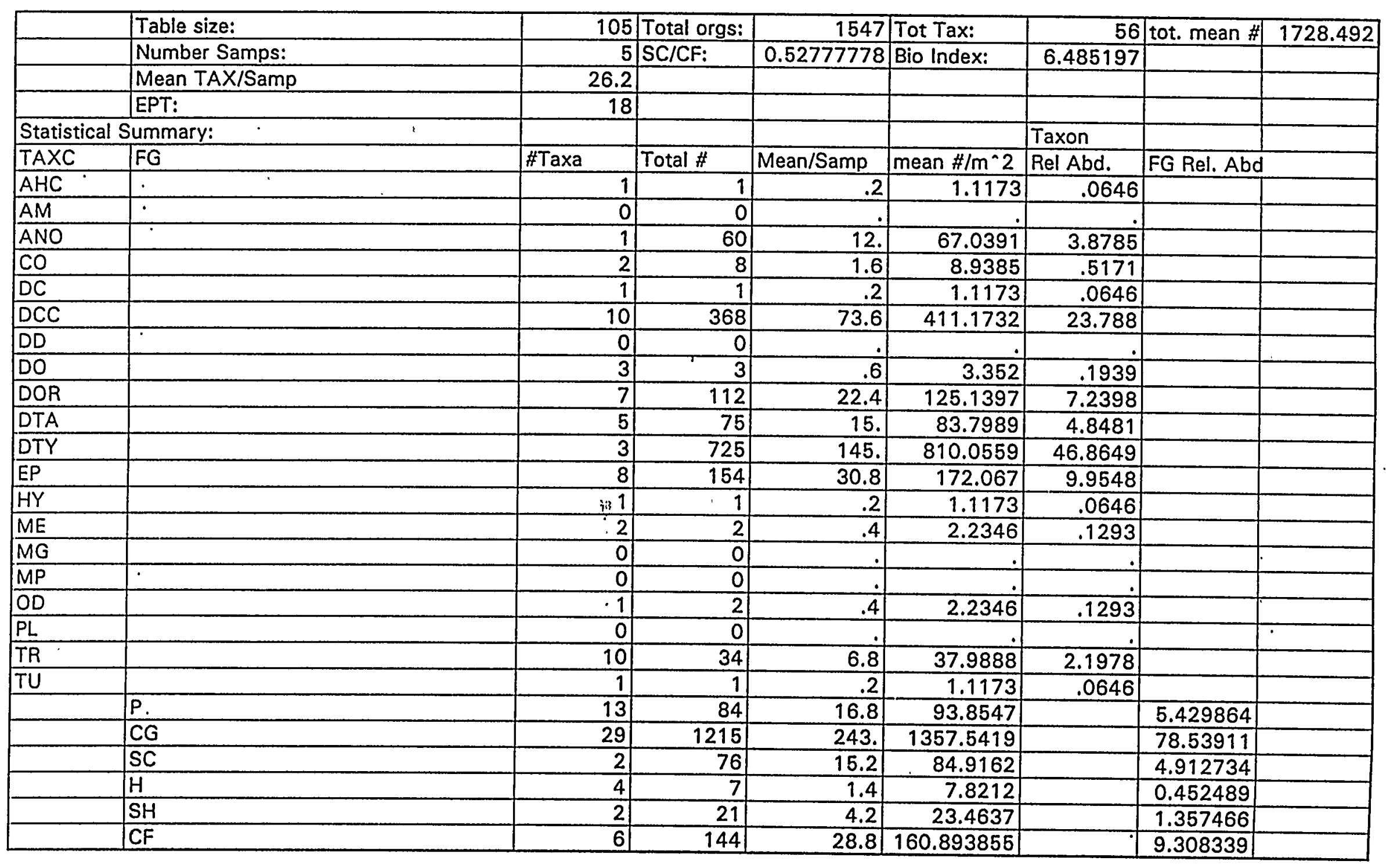


Station 3. Mill Creek at Road E-2. 20 September 1994.

\begin{tabular}{|l|}
\hline Taxa List: \\
\hline Hydracarina \\
\hline Oligochaeta \\
\hline Ancyronyx variegatus \\
\hline Macronychus glabratus \\
\hline Cambaridae \\
\hline Dicrotendipes spp. \\
\hline Microtendipes rydalensis \\
\hline Microtendipes spp. \\
\hline Nilothauma babiyi \\
\hline Pagastiella spp. \\
\hline Paralauterborniella spp. \\
\hline Phaenopsectra flavipes \\
\hline Polypedilum fallax \\
\hline Polypedilum spp. \\
\hline Tribelos jucundum \\
\hline Cecidomyiidae \\
\hline Ceratopogonidae \\
\hline Hemerodromia spp. \\
\hline Corynoneura spp. \\
\hline Cricotopus/Ortho spp. \\
\hline Nanocladius spp. \\
\hline Parakiefferiella sp.1 \\
\hline Parametriocnemus sp. \\
\hline Rheocricotopus spp. \\
\hline Thienemanniella spp. \\
\hline Ablabesmyia spp. \\
\hline Conchapelopia spp. \\
\hline Labrundinia spp. \\
\hline Pentaneura inconspicua \\
\hline Tanypus spp. \\
\hline Rheotanytarsus spp. \\
\hline Stenpellinella spp. \\
\hline Tanytarsus spp. \\
\hline Baetis spp. \\
\hline Caenis spp. \\
\hline Eurylophella spp. \\
\hline Hexagenia spp. \\
\hline Neoephemera youngi \\
\hline Paraleptophlebia spp. \\
\hline Stenonema spp. \\
\hline Tricorythodes spp. \\
\hline Hydra spp. \\
\hline Nigronia serricornis \\
\hline Sialis spp. \\
\hline Argia sp. \\
\hline Cheumatopsychoptila spp. \\
\hline
\end{tabular}


Station 3. Mill Creek at Road E-2. 20 September-1994.

Lype diversa

Nectopsyche spp.

Neureclipsis spp.

Nyctiophylax spp.

Oecetis spp.

Oxyethira spp.

Polycentropus spp.

Turbellaria

*⿻一㇉ 


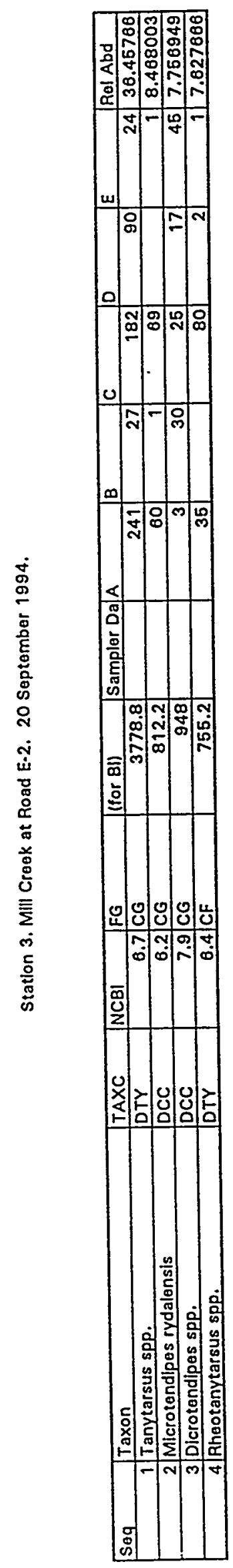

$\equiv$ 


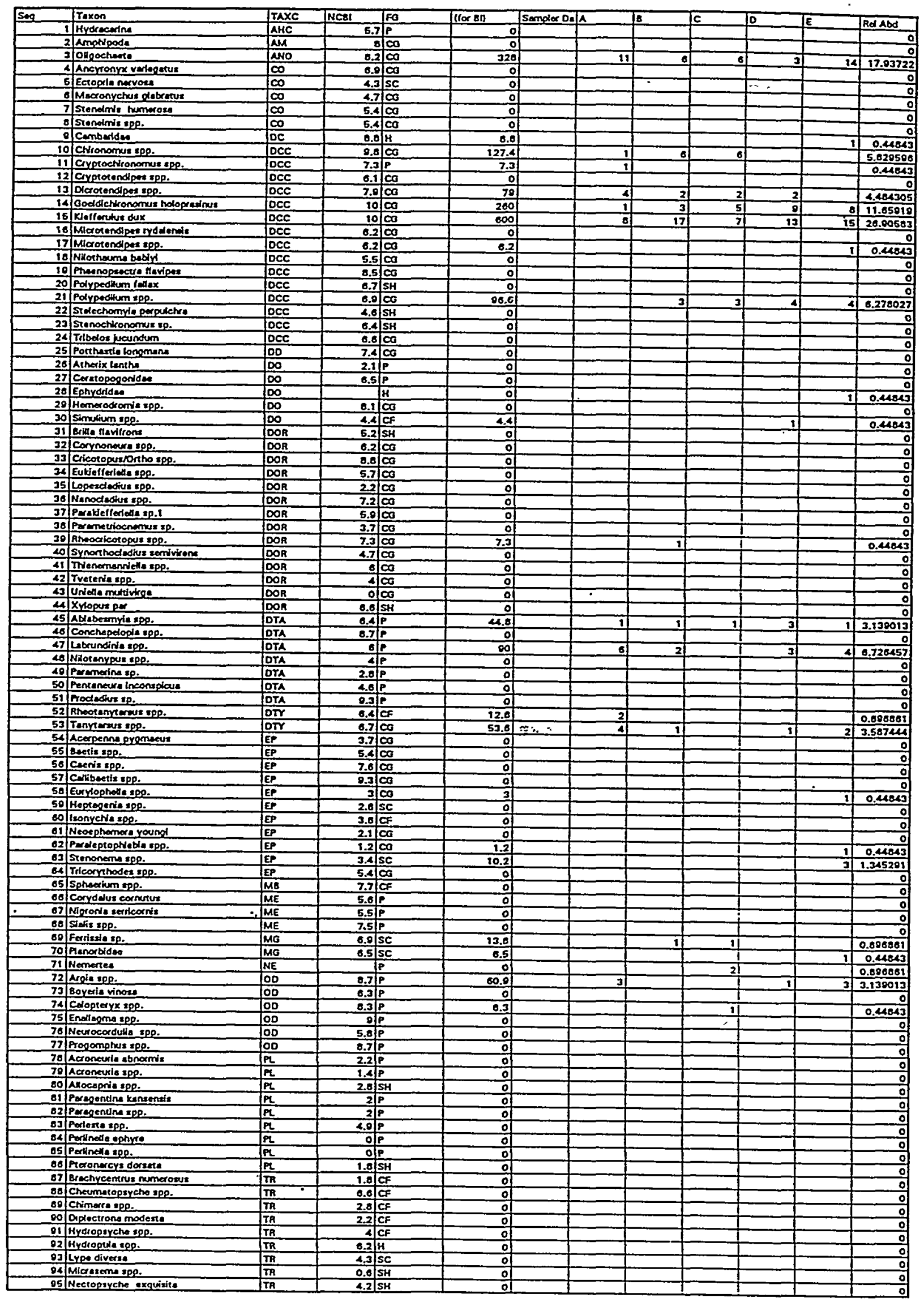




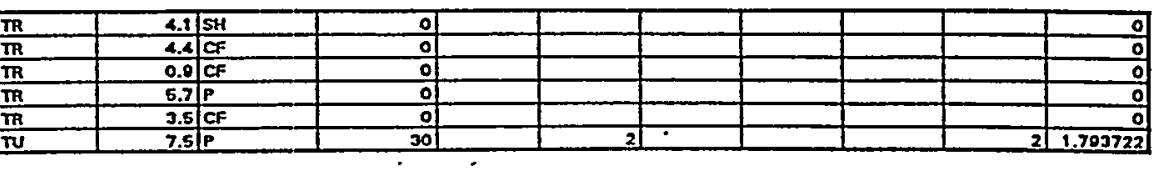


Station 4. Crouch Branch at Road 4. 20 September 1994

\begin{tabular}{|c|c|c|c|c|c|c|c|c|c|}
\hline & Table size: & & 101 & Total orgs: & 223 & Tot Tax: & 25 & tot. mean \# & 249.162 \\
\hline & Number Samps: & & 5 & SC/CF: & 2 & Bio Index: & 8.206726 & & \\
\hline & Mean TAX/Samp & - & 11.8 & & & & & & \\
\hline & EPT: & & 3 & & & & & & \\
\hline \multicolumn{2}{|c|}{ Statistical Summary: } & & & & & & Taxon & & \\
\hline TAXC & $F G$ & & \#Taxa & Total \# & Mean/Samp & mean $\# / m^{\wedge} 2$ & Rel Abd. & FG Rel. Abd & \\
\hline $\mathrm{AHC}$ & & & 0 & 0 &. & . &. & & \\
\hline$A M$ & $\therefore$ & & 0 & 0 &. &.+ & 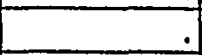 & & \\
\hline ANO & & & 1 & 40 & 8. & 44.6927 & 17.9372 & & \\
\hline $\mathrm{CO}$ & & & 0 & 0 &. & &. & & \\
\hline$D C$ & & & 1 & 1 & .2 & 1.1173 & .4484 & & \\
\hline DCC & & & 7 & 125 & 25. & 139.6648 & 56.0538 & & \\
\hline $\mathrm{DD}$ & & & 0 & 0 &. &. &. & & \\
\hline DO & & & 2 & 2 & .4 & 2.2346 & .8969 & & \\
\hline DOR & & & 1 & 1 & .2 & 1.1173 & .4484 & & \\
\hline DTA & & & 2 & 22 & 4.4 & 24.581 & 9.8655 & & \\
\hline DTY & & & 2 & 10 & 2. & 11.1732 & 4.4843 & & \\
\hline$E P$ & & & 3 & 5 & 1. & 5.5866 & 2.2422 & & \\
\hline $\mathrm{MB}$ & 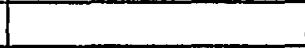 & & ii 0 & 0 &. & . &. & & \\
\hline ME & & & .0 & 0 &. &. &. & & \\
\hline$M G$ & & & 2 & 3 & .6 & 3.352 & 1.3453 & & \\
\hline NE & & & 1 & 2 & .4 & 2.2346 & .8969 & & \\
\hline$O D$ & $\cdot$ & & 2 & 8 & 1.6 & 8.9385 & 3.5874 & & \\
\hline$P L$ & & & 0 & 0 &. &. &. & & \\
\hline TR & & & 0 & 0 &. &. &. & & \\
\hline \multirow[t]{7}{*}{ TU } & & & 1 & 4 & .8 & 4.4693 & 1.7937 & & \\
\hline & $P$ & & 7 & 37 & 7.4 & 41.3408 & & 16.59193 & \\
\hline & CG & & 11 & 175 & 35. & 195.5307 & & 78.47534 & \\
\hline & SC & & 3 & 6 & 1.2 & 6.7039 & & 2.690583 & \\
\hline & $\mathrm{H}$ & & 2 & 2 & .4 & 2.2346 & & 0.896861 & \\
\hline & $\mathrm{SH}$ & & 0 & 0 &. &. & & 0 & \\
\hline & $\mathrm{CF}$ & & 2 & 3 & 0.6 & 3.35195531 & & 1.345291 & \\
\hline
\end{tabular}


Station 4. Crouch Branch at Road 4. 20 September 1994

Taxa List:

Oligochaeta

Cambaridae

Chironomus spp.

Cryptochironomus spp.

Dicrotendipes spp.

Goeldichironomus holoprasinus

Kiefferulus dux

Microtendipes spp.

Polypedilum spp.

Ephydridae

Simulium spp.

Rheocricotopus spp.

Ablabesmyia spp.

Labrundinia spp.

Rheotanytarsus spp.

Tanytarsus spp.

Eurylophella spp.

Paraleptophlebia spp.

Stenonema spp.

Ferrissia sp.

Planorbidae

Nemertea

Argia spp.

Calopteryx spp.

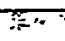

Turbellaria 
Station 4. Crouch Branch at Road 4. 20 September 1994

\begin{tabular}{|c|c|c|c|c|c|c|c|c|c|c|c|c|}
\hline Seq & Taxon & TAXC & NCBI & FG & (for BI) & Sampler Da & A & $B$ & $c$ & D & $E$ & Rel Abd \\
\hline 1 & Kiefferulus dux & DCC & 10 & CG & 600 & & 8 & 17 & 7 & 13 & 15 & 26.90583 \\
\hline 2 & Oligochaeta & ANO & 8.2 & CG & 328 & & 11 & 6 & 8 & 3 & 14 & 17.93722 \\
\hline 3 & Goeldichironomus holoprasinus & DCC & 10 & CG & 260 & & 1 & 3 & 5 & 9 & 8 & 11.65919 \\
\hline 4 & Labrundinia spp. & DTA & 6 & $P$ & 90 & & 6 & 2 & & 3 & 4 & 8.726457 \\
\hline 5 & Polypedilum Spp. & DCC & 8.9 & CG & 96.6 & & & 3 & 3 & 4 & 4 & 6.278027 \\
\hline 6 & Chironomus spp. & DCC & 9.8 & CG & 127.4 & & 1 & 8 & 8 & & & 5.829596 \\
\hline
\end{tabular}




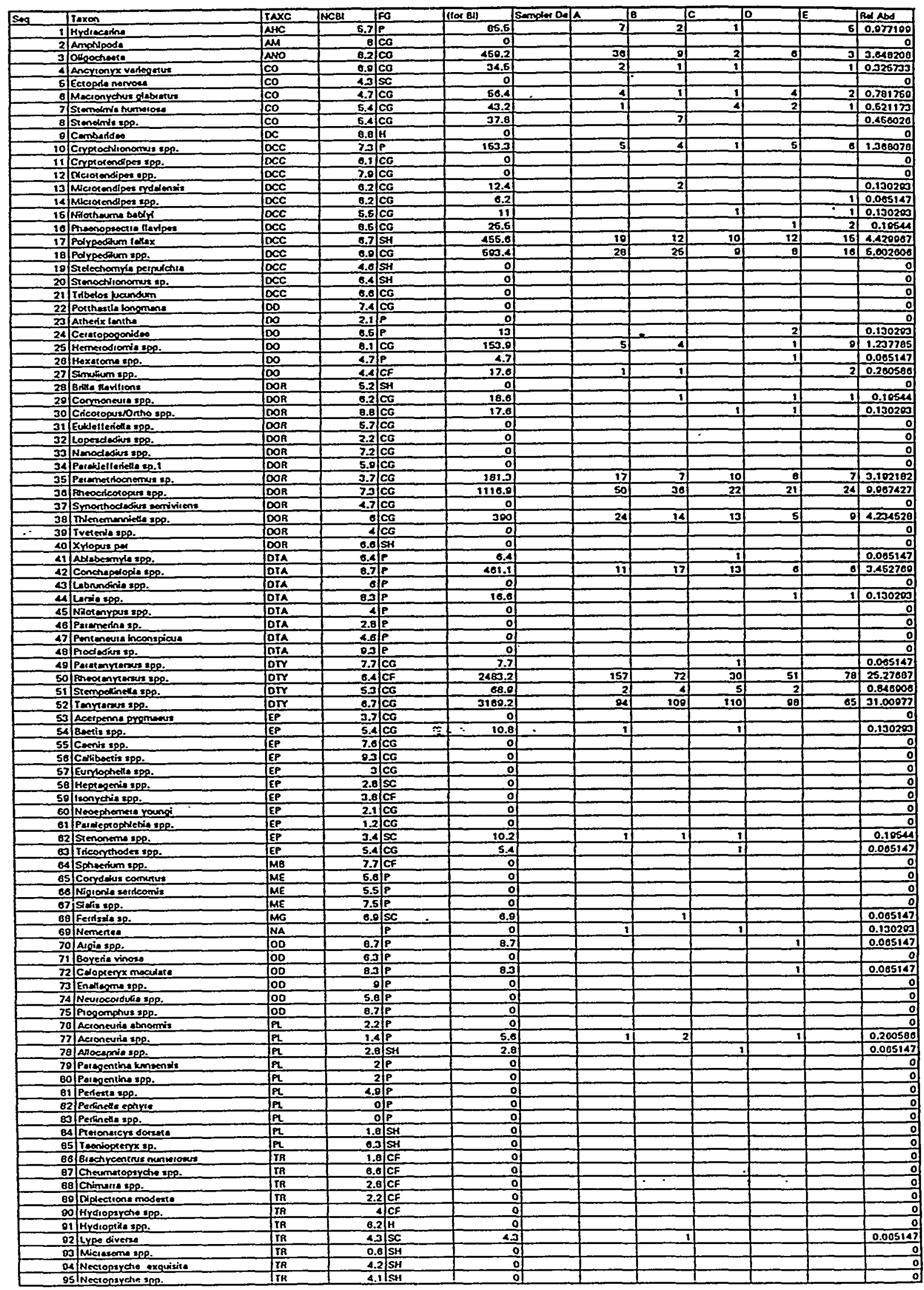




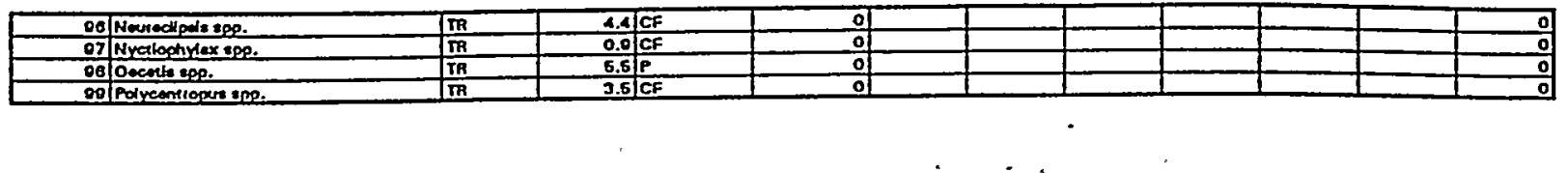

$\approx=$ 
Station 5. Tims Branch noar Road 2. 20 Soptembor 1994

\begin{tabular}{|c|c|c|c|c|c|c|c|c|c|c|c|c|}
\hline Sog & Taxon & TAXC & NCBI & FG & (for Bl) & Sampler Do & A & B & C & D & E & Rol Abd \\
\hline 1 & Tanytarsus spp. & DTY & 8.7 & CG & 3989.2 & & 94 & 109 & 110 & 98 & B5 & 31.00977 \\
\hline 2 & Rhootanytarsus spp. & DTY & 8.4 & $\overline{C F}$ & 2483.2 & & 157 & 72 & 30 & 51 & 78 & 25.27687 \\
\hline 3 & Rhoocricotopus spp. & DOR & 7.3 & CG & 1116.9 & & 50 & 36 & 22 & 21 & 24 & 9.967427 \\
\hline 4 & Polypedilum spp. & DCC & 8.9 & CG & 593.4 & & 28 & 25 & 9 & 8 & 16 & 5.602600 \\
\hline
\end{tabular}


Station 5. Tims Branch near Road 2. 20 September 1994

\begin{tabular}{|c|c|c|c|c|c|c|c|c|}
\hline & Table size: & 99 & Total orgs: & 1535 & Tot Tax: & 39 & tot. mean \# & 1715.084 \\
\hline & Number Samps: & 5 & SC/CF: & 0.0127551 & Bio Index: & 6.634332 & & \\
\hline & Mean TAX/Samp & 22.4 & & & & & & \\
\hline & EPT: & 6 & & & & & & \\
\hline \multicolumn{2}{|c|}{ Statistical Summary: } & & & & & Taxon & & \\
\hline TAXC & FG & \#Taxa & Total \# & Mean/Samp & mean $\# / \mathrm{m}^{\wedge} 2$ & Rel Abd. & FG Rel. Abd & \\
\hline$\overline{A H C}$ & & 1 & 15 & $\begin{array}{r}3 . \\
\end{array}$ & 16.7598 & .9772 & & \\
\hline $\mathrm{AM}$ & & 0 & 0 & . & 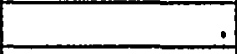 &. & & \\
\hline ANO & & 1 & 56 & 11.2 & 62.5698 & 3.6482 & & \\
\hline $\mathrm{CO}$ & & 4 & 32 & 6.4 & 35.7542 & 2.0847 & & \\
\hline$\overline{D C}$ & & 0 & 0 &. &. &. & & \\
\hline DCC & & 7 & 183 & 36.6 & 204.4693 & 11.9218 & & \\
\hline DD & & 이 & 0 &. &. &. & & \\
\hline DO & & 4 & 26 & 5.2 & 29.0503 & 1.6938 & & \\
\hline$\overline{D O R}$ & & 5 & 272 & 54.4 & 303.9106 & 17.7199 & & \\
\hline DTA & & 3 & 56 & 11.2 & 62.5698 & 3.6482 & & \\
\hline DTY & & 4 & 878 & 175.6 & 981.0056 & 57.1987 & & \\
\hline$E P$ & & 3 & 6 & 1.2 & 6.7039 & .3909 & & \\
\hline $\mathrm{MB}$ & & 30 & 0 &. &. &. & & \\
\hline$\overline{\mathrm{ME}}$ & & 0 & 0 &. &. &. & & \\
\hline MG & & 1 & 1 & .2 & 1.1173 & .0651 & $\dot{.}$ & \\
\hline$\overline{N A}$ & & 1 & 2 & .4 & 2.2346 & .1303 & & \\
\hline$O D$ & & 2 & 2 & .4 & 2.2346 & .1303 & & \\
\hline$\overline{P L}$ & & 2 & 5 & 1. & 5.5866 & .3257 & & \\
\hline \multirow[t]{7}{*}{ TR } & & 1 & 1 & .2 & 1.1173 & .0651 & & \\
\hline & $P$ & 11 & 103 & 20.6 & 115.0838 & & 6.710098 & \\
\hline & $\mathrm{CG}$ & 21 & 966 & 193.2 & 1079.3296 & .. & 62.9316 & \\
\hline & SC & 3 & 5 & 1. & 5.5866 & & 0.325733 & \\
\hline & $\mathrm{H}$ & 0 & 0 & .. &. & & 0 & \\
\hline & $\mathrm{SH}$ & 2 & 69 & 13.8 & 77.095 & & 4.495114 & \\
\hline & $\mathrm{CF}$ & 2 & 392 & 78.4 & 437.988827 & & 25.53746 & \\
\hline
\end{tabular}




\begin{tabular}{|l|}
\hline Taxa List: \\
\hline Hydracarina \\
\hline Oligochaeta \\
\hline Ancyronyx variegatus \\
\hline Macronychus glabratus \\
\hline Stemelmis humerosa \\
\hline Stenelmis spp. \\
\hline Cryptochironomus spp. \\
\hline Microtendipes rydalensis \\
\hline Microtendipes spp. \\
\hline Nilothauma babiyi \\
\hline Phaenopsectra flavipes \\
\hline Polypedilum fallax \\
\hline Polypedilum spp. \\
\hline Ceratopogonidae \\
\hline Hemerodromia spp. \\
\hline Hexatoma spp. \\
\hline Simulium spp. \\
\hline Corynoneura spp. \\
\hline Cricotopus/Ortho spp. \\
\hline Parametriocnemus sp. \\
\hline Rheocricotopus spp. \\
\hline Thienemanniella spp. \\
\hline Ablabesmyia spp. \\
\hline Conchapelopia spp. \\
\hline Larsia spp. \\
\hline Paratanytarsus spp. \\
\hline Rheotanytarsus spp. \\
\hline Stempellinella spp. \\
\hline Tanytarsus spp. \\
\hline Baetis spp. \\
\hline Stenonema spp. \\
\hline Tricorythodes spp. \\
\hline Ferrissia sp. \\
\hline Nemertea \\
\hline Argia spp: \\
\hline Calopteryx maculata \\
\hline Acroneuria spp. \\
\hline Allocapnia spp. \\
\hline Lype diversa \\
\hline
\end{tabular}




\begin{tabular}{|c|c|c|c|c|c|c|c|c|c|}
\hline Sog & Taxon & $\operatorname{TAXC}$ & NCB: & FG & $(10 \times 8 \|$ & Sempter Do & $\mathbf{A}$ & 8 & C \\
\hline 1 & Hydrecerine & AHC & 5.7 & $P$ & of & & & & \\
\hline 2 & Amphipods & AMG & 8 & CG & 0 & & & & \\
\hline 3 & Orgoctisals & ANO & B.2 & CG & 0.2 & & & & \\
\hline 4 & Ancyronyx veriogeture & CO & 6.9 & CG & of & & & & \\
\hline 5 & Ectopxil norvoce & $\mathrm{CO}$ & 4.3 & SC & of & & & & \\
\hline 6 & Mocronychers olebratus & $\mathrm{CO}$ & 4.7 & CG & 9.4 & & & & \\
\hline 7 & Slomolmis feumerose. & Co & 5.4 & CG & 21.6 & & 2 & & \\
\hline 日) & Stenalmir spp. & $\mathrm{CO}$ & 5.4 & CG & o & & & & \\
\hline 9 & Comberidoes & $D C$ & 8.8 & H & of & & & 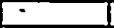 & \\
\hline 10 & Cyploctironomus cPp. & DCC & 7.3 & $\mathbf{P}$ & of & & & & \\
\hline 11 & Cryplotondipos spp. & DCC & 6.1 & CG & of & & & & \\
\hline 12 & Dicrotondipos spp. & DCC & 7.9 & TEG & 의 & & & & \\
\hline 13 & Microtondipos iydalonsis & OCC & 6.2 & CG & 의 & & & & \\
\hline 14 & Microtandipos spp. & OCC & 6.2 & CG & of & & & & \\
\hline 15 & Mlothruma bobiri & OCC & 5.5 & CG & 5.5 & & & 1 & \\
\hline 16 & Pheanopececira flavipos & DCC & 8.5 & $\overline{C G}$ & 0 & & & & \\
\hline 17 & Polypeditum follox & DCC & 6.7 & SH & 26.8 & & 11 & & 2 \\
\hline 18 & Polypoditum spp. & DCC & 6.9 & CG & 1152.3 & & 75 & 34 & 19 \\
\hline 19 & Stolochomyia perpuletra & DCC & 4.6 & $\mathrm{SH}$ & 0 & & & & \\
\hline 20 & Stenoctironomus co. & OCC & 6.4 & SH & of & & & & \\
\hline $2 \pi$ & Iriboloc juoundum & $\overline{\mathrm{OCC}}$ & 6.6 & CG & a & & & & \\
\hline 22 & Folthostio kngment & 00 & 7.4 & CG & of & & & & \\
\hline 23 & Athorix Lenthe & 00 & 2.7 & $\mathbf{P}$ & 4.2 & & & 2 & \\
\hline 24 & Corstopooonideo & 00 & 6.5 & $\mathbf{P}$ & 13 & & & & 2 \\
\hline 25 & Homerodkomia cpp. & 00 & 8.1 & CG & 8.1 & & 1 & & 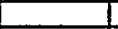 \\
\hline 26 & Simutum spp. & DO & 4.4 & CF & 352 & & 6? & 2 & \\
\hline 27 & Brila llavifrons & DOA & 5.2 & $\mathbf{S H}$ & 0 & & & & \\
\hline 28 & Corynonoure spo. & DOR & 6.2 & CG & 68.2 & & 8) & 1 & 1) \\
\hline 29 & Cicolopue/Ortho spe. & DOR & 8.8 & CG & 52.8 & & 5) & & \\
\hline 30 & Eukiofforiotla spp. & DOR & 5.7 & CG & o & & $\ldots$ & & - \\
\hline 31 & topoecladive spg. & DOA & 2.2 & CG & 의 & & & & \\
\hline 32 & Nanocledius spp. & DOR & 7.2 & CG & 0 & & & & \\
\hline 33 & Perakialforialle op.1 & DOR & 5.9 & CG & of & & & & \\
\hline 34 & Perametriocnemus ep. & DOR & 3.7 & CG & 0 & & & & 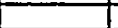 \\
\hline 35 & Rhoocrios lopus spo. & DOR & 7.3 & CG & 313.9 & & 22 & 9 & 1 \\
\hline 36 & Synorthoclediut comivicent & DOR & 4.7 & CG & 10.8 & & 4 & 7 & \\
\hline 37 & Ihienom enniolls spp. & DOR & $\theta$ & CG & 360 & & 45 & 2 & 4 \\
\hline 38 & Irotoria spp. & DOR & 4 & CG & 8 & & 11 & & \\
\hline 39 & Xylopurs per & DOR & 8.6 & $\mathbf{S H}$ & of & & 7 & & \\
\hline 10 & Ablobermyia cap. & DIA & 6.4 & $\mathbf{P}$ & of & & 7 & & \\
\hline a1 & Conchspelopis spo. & DIA & 8.7 & $\mathbf{P}$ & 69.6 & & 21 & I) & (4) \\
\hline 42 & Lebrundinie spp. & DIA & 8 & $\mathbf{P}$ & of & & & & \\
\hline 43 & Noblenypure spp. & DIA & 4 & $\mathbf{P}$ & 16 & & 2) & & \\
\hline 441 & Peramerina sp. & DTA & -2.8 & $\mathbf{P}$ & of & & T & & \\
\hline $45 \mid$ & Pententeura inconspiala & DTA & 4.6 & $\mathbf{P}$ & 4.6 & & II & & \\
\hline 46 & Froclodive sp. & DTA & 9.3 & $\mathbf{P}$ & of & & & & \\
\hline \begin{tabular}{l|l}
47 \\
\end{tabular} & aheolenyterase cep. & DTY & 6.4 & CF & 147.2 & & 16 & 1 & II \\
\hline 48 & Tonverase cpp. & DTY & 6.7 & CG & 154.1 & & 15 & 2 & 2 \\
\hline 49. & Acerpenns pyomioure & EP & 3.7 & CG & o & & & & \\
\hline 501 & Beati= spp. & EP & 5.4 & CG & 32.4 & & 3) & 1 & \\
\hline 51 & Coonis spo. & EP & 7.6 & CG & 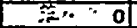 & & & 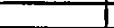 & \\
\hline 52 & Calibsotis spp. & EP & 9.3 & CG & of & & 7 & & \\
\hline 53 & Eurylophollo spe. & EP & 3 & CG & 18 & & 3 & 2 & \\
\hline 54$]$ & Hoptogonia zpp. & EP & 2.8 & SC & 8.4 & & 1 & 2 & \\
\hline 55 & Icomychis app. & EP & 3.8 & CF & o & & & & \\
\hline 58 & Noosphomers youngi & EP & 2.1 & CG & 10.5 & & 3) & II & \\
\hline 57 & Perstoplophlobis sop. & EP & 1.2 & CG & of & & & 4 & \\
\hline 58 & Stenoneme SpP. & EP & 3.4 & sc & 102 & & 9 & st & 7 \\
\hline 59 & Iricorythodoe spo. & EP & 5.4 & $\overline{c G}$ & 5.4 & & & & \\
\hline 60 & Sphserium spp. & MB & 7.7 & CF & of & & & & \\
\hline 61 & Corydelis cornuturs & ME & 5.6 & $\bar{P}$ & 10.8 & & 71 & & 1) \\
\hline 62 & Nigronia serricon nis & $M E$ & 5.5 & $\mathbf{P}$ & 0 & & & & \\
\hline 63 & Siofis spp. & ME & 7.5 & $P$ & of & & & & \\
\hline 64 & Forrissia sp. & $M G$ & 6.9 & SC & of & & & & \\
\hline 65 & Nomalode & NE & & CG & 야 & & & & \\
\hline 68 & Boyeria vinots & 100 & 6.3 & $P$ & of & & & & \\
\hline 67 & Enstlogme cpp. & 00 & 9 & $\mathbf{P}$ & of & & & & \\
\hline 68) & Hourocordufie spp. & $\infty$ & 5.8 & $P$ & of & & & & \\
\hline 69 & Progomphus spp. & 00 & 8.7 & $\mathbf{p}$ & of & & & & \\
\hline 70 & Acronouxia sbnormis & $P L$ & 2.2 & $P$ & 30.8 & & 8 & & 6) \\
\hline 71 & Acronockis spp. & $\overline{P L}$ & 1.4 & P & of & & & & \\
\hline 72 & Agnatine spe. & $P L$ & o & $P$ & of & & & & \\
\hline 73 & Allocapnia spe. & PL & 2.8 & SH & of & & & & \\
\hline 74 & Persogntino inmerginate & $\overline{P L}$ & & $\mathbf{P}$ & 14 & & & 5! & (1) \\
\hline 75 & Porgagantina kansoratis & Pl & 2 & $\mathbf{P}$ & a) & & & & \\
\hline 78 & Porbota spp. & $\overline{P L}$ & 4.9 & $P$ & of & & & & \\
\hline 72 & Petinallo aphyre & $\overline{P L}$ & 0 & $\mathbf{P}$ & of & & & & \\
\hline 78 & forlinolle spp. & $\bar{p}$ & 0 & $\mathbf{P}$ & of & & & & \\
\hline 79 & Froconerges docata & 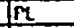 & 1.0 & SH & 1.8 & & & & \\
\hline 80 & Isoniopteryx to. & $\vec{M}$ & 6.3 & SH & 0 & & & & \\
\hline 81 & Beachycontrue mumerouse & IR & 1.8 & $C F$ & 3.6 & & 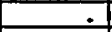 & & \\
\hline 82 & Chroumatoperiche spo. & TR & 6.6 & CF & of & & & & \\
\hline 83 & Chimorta spe. & ITR & 2.8 & CF & 2.8 & & 1 & & \\
\hline BA & diplocirona madosta & I8 & 2.2 & CF & of & & & & \\
\hline 85 & Hydropsyche sep. & IR & 4 & CF & 64 & & 9 & 2 & 2 \\
\hline 80 & Hydroptido spp. & th & 6.2 & $\mathrm{H}$ & 0 & & & & 1 \\
\hline 87 & Lype divoxes & IA & 4.3 & SC & 0 & & & & \\
\hline 日9 & Miornsomn spo. & I & 0.6 & SH & 1.8 & & & & 3 \\
\hline
\end{tabular}


Stetion 6. Upper Ttree Runsesreok at fioed C. 20 Septomber 1994

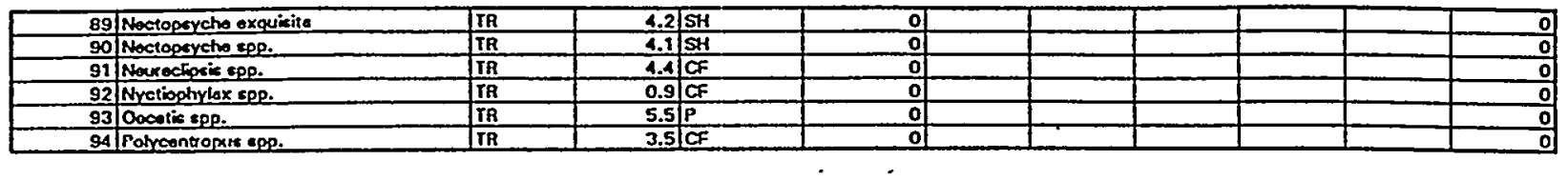


Station 6. Upper Three Runs Creek at Road C. 20 September 1994

\begin{tabular}{|c|c|c|c|c|c|c|c|c|}
\hline & Table size: & 94 & Total orgs: & 548 & Tot Tax: & 36 & tot. mean \# & 765.3631 \\
\hline & Number Samps: & 4 & SC/CF: & 0.2704918 & Bio Index: & 5.705474 & & \\
\hline & Mean TAX/Samp & 20.75 & & & & & & \\
\hline & EPT: & 13 & & & & & & \\
\hline \multicolumn{2}{|c|}{ Statistical Summary: } & & & & & Taxon & & \\
\hline$T A X C$ & $F G$ & \#Taxa & Total \# & Mean/Samp. & mean $\# / m^{\wedge} 2$ & Rel Abd. & FG Rel. Abd & \\
\hline $\mathrm{AHC}$ & & 0 & 0 & $\begin{array}{r}.1 \\
\end{array}$ & \begin{tabular}{|l|}
. \\
\end{tabular} & 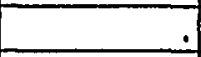 & & \\
\hline AMG & & 0 & 0 &. &. &. & & \\
\hline ANO & & 1 & 1 & .25 & 1.3966 & .1825 & & \\
\hline $\mathrm{CO}$ & & 2 & 6 & 1.5 & 8.3799 & 1.0949 & $\cdot$ & \\
\hline$\overline{D C}$ & & 0 & 0 &. &. & . & & \\
\hline DCC & 5 & 3 & 172 & 43. & 240.2235 & 31.3869 & & \\
\hline$D D$ & & 0 & 0 &. &. & & & $\therefore$ \\
\hline $\mathrm{DO}$ & & 4 & 85 & 21.25 & 118.7151 & 15.5109 & & \\
\hline DOR & & 6 & 126 & 31.5 & 175.9777 & 22.9927 & & \\
\hline DTA & & 3 & 13 & 3.25 & 18.1564 & 2.3723 & & \\
\hline$\overline{D T Y}$ & & 2 & 46 & 11.5 & 64.2458 & 8.3942 & & \\
\hline EP & & 6 & 51 & 12.75 & 71.2291 & 9.3066 & & \\
\hline$\overline{M B}$ & & iis & 0 &. &. &. & & \\
\hline$M E$ & $\div$ & 1 & 3 & .75 & 4.1899 & .5474 & & \\
\hline$M G$ & & 0 & 0 &. & &. & & \\
\hline NE & & 1 & 1 & .25 & 1.3966 & .1825 & & \\
\hline$O D$ & & 0 & 0 & . & &.+ & : & \\
\hline $\mathrm{PL}$ & & 3 & 22 & 5.5 & 30.7263 & 4.0146 & & \\
\hline \multirow[t]{7}{*}{ TR } & & 4 & 22 & 5.5 & 30.7263 & 4.0146 & & \\
\hline & $P$ & 8 & 41 & 10.25 & 57.2626 & & 7.481752 & \\
\hline & $C G$ & 18 & 344 & 86. & 480.4469 & & 62.77372 & \\
\hline & SC & 2 & 33 & 8.25 & 46.0894 & & 6.021898 & \\
\hline & $\mathrm{H}$ & 0 & 0 &. &. & & 0 & \\
\hline & $\mathrm{SH}$ & 3 & 8 & 2. & 11.1732 & & 1.459854 & \\
\hline & $\mathrm{CF}$ & 5 & 122 & 30.5 & 170.391061 & & 22.26277 & \\
\hline
\end{tabular}


Taxa List:

Oligochaeta

Macronychus glabratus

Stemelmis humerosa

Nilothauma babiyi

Polypedilum fallax

Polypedilum spp.

Atherix lantha

Ceratopogonidae

Hemerodromia spp.

Simulium spp.

Corynoneura spp.

Cricotopus/Ortho spp.

Rheocricotopus spp.

Synorthocladius semivirens

Thienemanniella spp.

Tvetenia spp.

Conchapelopia spp.

Nilotanypus spp.

Pentaneura inconspicua

Rheotanytarsus spp.

Tanytarsus spp.

Baetis spp.

Eurylophella spp.

Heptagenia spp.

Neoephemera youngi

Stenonema spp.

Tricorythodes spp.

Corydalus cornutus

Nematoda

Acroneuria abnormis

Paragentina immarginata

Pteronarcys dorsata

Brachycentrus numerosus

Chimarra spp.

Hydropsyche spp.

Micrasema spp. 
Station 6. Upper Throe Runs Croek at Road C. 20 September 1994

\begin{tabular}{|c|c|c|c|c|c|c|c|c|c|c|c|}
\hline Seq & Taxon & TAXC & NCBI & FG & (for BI) & Sampler D & $A$ & B & c & D & Rol Abd \\
\hline 1 & Polypedilum spp. & DCC & 6.9 & CG & $\begin{array}{r}1152.3 \\
\end{array}$ & & 75 & 34 & 19 & 39 & 30.47445 \\
\hline 2 & Simulium spp. & DO & 4.4 & $\mathrm{CF}$ & 352 & & 61 & 2 & & 17 & 14.59854 \\
\hline 3 & Thienemanniella spp. & DOR & 6 & CG & 360 & & 45 & 2 & 4 & 9 & 10.94891 \\
\hline 4 & Rheocricotopus spp. & DOR & 7.3 & CG & 313.9 & & 22 & 9 & 1 & 19 & 7.846715 \\
\hline & Stenonema spp. & EP & 3.4 & SC & 102 & & 9 & 5 & 7 & 9 & 5.474453 \\
\hline
\end{tabular}

4 Rheocricotopus spp.

EP

102 


\begin{tabular}{|c|c|c|}
\hline Seg & Texon & TAXC \\
\hline It & Hydreaense & ANC \\
\hline $21 \mathrm{~A}$ & Amptupose & $A M$ \\
\hline 30 & orfochente & ANO \\
\hline $4 \sqrt{A}$ & Ancyionyx redogencus & co \\
\hline EE & Ectopde mervora & Co \\
\hline of $\mathrm{G}$ & Gydrest spep. & co. \\
\hline $7 \mathbb{N}$ & Mecionyderes debresus & CO \\
\hline $0 \mid 5$ & 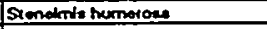 & co \\
\hline of 15 & Stomelnis spp. & co \\
\hline $101 \mathrm{c}$ & Comberden & DC \\
\hline 110 & Cxitonomess spp. & DCC \\
\hline 12$] \mathrm{c}$ & Cryptoctionomure seg. & Dec \\
\hline $131 \mathrm{c}$ & Cryprorendper spo. & DCC \\
\hline 140 & 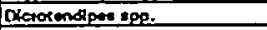 & DCC. \\
\hline 15.0 & 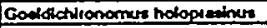 & Dec \\
\hline $101 \mathrm{~N}$ & Mlerodendpos mediondle & $D C C$ \\
\hline $17 \mid \mathrm{k}$ & Metcolombipes spo. & DCC \\
\hline $10 / \mathbb{R}$ & NRothecme bobiy & $\operatorname{loc}$ \\
\hline $10 / \mathrm{P}$ & Pequethele spo. & DCC \\
\hline $20 / P$ & Phemopeoctin Tavipes & DCC \\
\hline $21 / p$ & Polypodtum lisex & $D C C$ \\
\hline $22 / \mathrm{p}$ & Polypedaum zog. & OCC \\
\hline $23 \sqrt{5}$ & Sidechompie perpulchis & OCC \\
\hline 2415 & Sienocthionomins sp. & $D C C$ \\
\hline 2511 & Tribolos tuncicons & DCC \\
\hline 201 & Iribalos puandum & DCC \\
\hline $27 \mathrm{p}$ & Pasudoctiromomun seo. & DCP \\
\hline $28 / \mathrm{f}$ & Pothertia lonoment & no \\
\hline 202 & Atherix Lunthe & $\infty$ \\
\hline $301 \mathrm{c}$ & Cetretoporonides & $\infty$ \\
\hline 317 & Hemelodionia spp. & $\infty$ \\
\hline 325 & Sirnuthem spp. & $\infty$ \\
\hline $23 / 8$ & Brite thevilions: & DOR \\
\hline $34 \mid c$ & Corynoniculte app. & DOR \\
\hline $35 \mathrm{c}$ & Cricotopuriontho spp. & DA \\
\hline $36 \mid E$ & Eutiballentelin spg. & DOR \\
\hline 37 & Lopendidivas ipp. & DOR \\
\hline 38 f & Nenodective spp. & $\infty O R$ \\
\hline $30 \mid \mathrm{f}$ & Puctiolifortello $x p .1$ & DOR \\
\hline $401 \mathrm{~F}$ & Poumbetioconemut so. & DOR \\
\hline Aif & Froocricoropue spp. & DOR \\
\hline 125 & Smorthodedient conivions & $\infty$ \\
\hline 0 & Thienomemntete spp. & DOR \\
\hline 4 & Ivetenil spg. & TDOA \\
\hline 45 & Xylopus pen & DOA \\
\hline 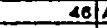 & Ablebeamian spe. & Din \\
\hline 47 & Conchispelopies sog. & DIA: \\
\hline 4812 & Lebrendinie spe. & Jota \\
\hline s9le & Lerkin spo. & DTa \\
\hline $50 / \mathrm{A}$ & Nedermypus spp. & Iora \\
\hline 51.P & Permorionesp. & Iora \\
\hline 62: & 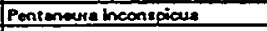 & Dora \\
\hline 501 & Fodosing sp. & Tota \\
\hline 54) & Codormprarmen spe. & Dry \\
\hline 55/ & Rrootun revers spp. & DTr \\
\hline 565 & Stempetingete spo. & ory \\
\hline 57 & Tenvereress epp. & for \\
\hline 58: & Acerponse promerus & EP \\
\hline 501 & Bectin spp. & JEP \\
\hline 80 & Ceonit spp. & EP \\
\hline 61 & Combectie spo. & EF \\
\hline 62 & Eungropheten spp. & EP \\
\hline G6 & Hepsegenin spp. & EP \\
\hline 64) & tsonychitiepo. & EP \\
\hline OSt & Neopphernetio roungi & EP \\
\hline 68) & Porelepropdstivin spp. & EP \\
\hline 67: & Stenonome spp. & EP $\cdot$ \\
\hline 68 & Iricorythodes 2po. & EP \\
\hline 6ol & Spheertum spo. & $M B$ \\
\hline 70 & Corydusus comurus & $M E$ \\
\hline 21 & Nolonis serricomis & ME \\
\hline 72) & Steils sop. & ME \\
\hline 73 & Ferritzina xp. & $M G$ \\
\hline 74 & Fimortider. & MG \\
\hline 75 & Nenveries & NA \\
\hline 78. & Aupie spp. & $O D$ \\
\hline$\pi$ & Boyerin vinoze & on \\
\hline 78 & Enetergene spp. & 100 \\
\hline 79 & Noulocordula spp. & 00 \\
\hline 80 & Progomphus sog. & on \\
\hline 81) & Acioneurie obmontris & $P L$ \\
\hline 82 & Aeronturie spe. & $p$ \\
\hline 8 & Agneshos s.cp. & $p$ \\
\hline BA & I Arocespile teg. & in \\
\hline esf & Porsgenthe kensensis & $\mathrm{PL}$ \\
\hline 86 & Pecegencine spp. & $P L$ \\
\hline 67) & Pedatin spep. & $F_{2}$ \\
\hline 88 & Pertinetie ephyce & a \\
\hline 80 & Perthelle spp. & $R$ \\
\hline$\infty$ & Preionercy doretera & PR \\
\hline 91 & Binctiveonirus numberosus & TA \\
\hline 02. & Cheunntompche spp. & Th \\
\hline 83 & Chimnalia supe. & TA \\
\hline 24 & 1 [xploctions nodesta & TR \\
\hline 95 & SHydiapayche sng. & ITA \\
\hline
\end{tabular}




\begin{tabular}{|c|c|c|c|c|c|c|c|c|c|c|c|c|}
\hline 28 & Hydioptle spe. & $\frac{\pi R}{m}$ & 0.2 & & 익 & & & & & & & 0 \\
\hline 07 & Lype diveres & $\pi$ & 4.3 & $s$ & 21.5 & & & 3 & & & 2 & 0.285000 \\
\hline 50 & Mleteneme app. & $\pi$ & 0.6 & SF & 0 & & & & & & & 0 \\
\hline 00 & Mectopayctive expuldite & $\pi$ & 4.2 & $\mathrm{SH}$ & 의 & & & & & & & 0 \\
\hline 100 & Necaopercthe ipp. & $I R$ & 4.1 & SH & 의 & & & & & & & 0 \\
\hline 101 & Nouleclipele spp. & IR & 4.4 & CF & 의 & & & I. & & & & 0 \\
\hline 102 & Wretioph Yax $=0 p$. & In & 0.0 & CF & of & & & & & & & 0 \\
\hline 100 & Ocomile epp. & TR & 5.5 & $\mathbf{P}$ & 27.5 & $\dot{-}$ & $\vdots$ & 3 & 1 & & & 0.205000 \\
\hline 104 & oxyethic top. & IA & 6.2 & $\mathbf{H}$ & 18.6 & & 1 & 2 & & & & 0.1710030 \\
\hline 105 & Podyeantiopuen spe. & $T_{A}$ & 3.5 & CF & 10.6 & & & & 11 & & 2 & 0.171009 \\
\hline 100 & Tuntrediarle & In & 7.5 & & 1177.5 & & 33 & 4 & 57 & 10 & 14 & 8.950969 \\
\hline
\end{tabular}


Station 7. Four Mile Branch at Road C. 20 September 1994

\begin{tabular}{|c|c|c|c|c|c|c|c|c|}
\hline & Table size: & 106 & Total orgs: & 1754 & Tot Tax: & 55 & tot. mean \# & 1959.777 \\
\hline & Number Samps: & 5 & SC/CF: & 0.11764706 & Bio Index: & 6.060034 & & \\
\hline & Mean TAX/Samp & 27.6 & & & & & & \\
\hline & EPT: & 11 & & & & & & \\
\hline \multicolumn{2}{|c|}{ Statistical Summary: } & & & & & Taxon & & \\
\hline TAXC & $F G$ & \#Taxa & Total \# & Mean/Samp & mean $\# / m^{\wedge} 2$ & Rel Abd. & FG Rel. Abd & \\
\hline $\mathrm{AHC}$ & & 1 & 2 & .4 & $\begin{array}{r}2.2346 \\
\end{array}$ & $\begin{array}{r}.114 \\
\end{array}$ & & \\
\hline$A M$ & & 1 & 7 & 1.4 & 7.8212 & .3991 & & \\
\hline ANO & & 1 & 228 & 45.6 & 254.7486 & 12.9989 & & \\
\hline $\mathrm{CO}$ & & 4 & 16 & 3.2 & 17.8771 & .9122 & & \\
\hline$\overline{D C}$ & & 0 & 0 &. & & & & \\
\hline DCC & & 11 & 198 & 39.6 & 221.2291 & 11.2885 & & \\
\hline$\overline{D C P}$ & & 1 & 1 & .2 & 1.1173 & .057 & & \\
\hline $\mathrm{DD}$ & & 요 & 0 &. & & ... & & \\
\hline DO & & 2 & 13 & 2.6 & 14.5251 & .7412 & & \\
\hline DOR & & 6 & 56 & 11.2 & 62.5698 & 3.1927 & & \\
\hline DTA & & 37 & 253 & 50.6 & 282.6816 & 14.4242 & & \\
\hline DTY & & 4 & 724 & 144.8 & 808.9385 & 41.2771 & & \\
\hline$E P$ & & 7 & 24 & 4.8 & 26.8156 & 1.3683 & & \\
\hline$\overline{M B}$ & & 0 & 0 &. & &. & 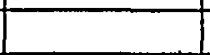 & \\
\hline ME & & 0 & 0 & .1 & & & & \\
\hline$M G$ & $\therefore$ & 2 & 2 & .4 & 2.2346 & .114 & & \\
\hline $\mathrm{NA}$ & & 1 & 49 & 9.8 & 54.7486 & 2.7936 & & \\
\hline$O D$ & & 2 & 8 & 1.6 & 8.9385 & .4561 & & \\
\hline$P L$ & & 0 & 0 &. & & & & \\
\hline TR & & 4 & 16 & 3.2 & 17.8771 & .9122 & & \\
\hline \multirow[t]{7}{*}{$T U$} & & 1 & 157 & 31.4 & 175.419 & 8.951 & & \\
\hline & $P$ & 16 & 488 & 97.6 & 545.2514 & & 27.82212 & \\
\hline & $C G$ & 30 & 1161 & 232.2 & 1297.2067 & & 66.19156 & \\
\hline & SC & 4 & 10 & 2. & 11.1732 & & 0.570125 & \\
\hline & $\mathrm{H}$ & 1 & 3 & .6 & 3.352 & & 0.171038 & \\
\hline & $\mathrm{SH}$ & 1 & 7 & 1.4 & 7.8212 & & 0.399088 & \\
\hline & CF & 3 & 85 & 17 & 94.972067 & & 4.846066 & \\
\hline
\end{tabular}




\begin{tabular}{|l|}
\hline Taxa List: \\
\hline Hydracarina \\
\hline Amphipoda \\
\hline Oligochaeta \\
\hline Ancyronyx variegatus \\
\hline Gyrinus spp. \\
\hline Macronychus glabratus \\
\hline Stenelmis spp. \\
\hline Chironomus spp. \\
\hline Cryptochironomus spp. \\
\hline Cryptotendipes spp. \\
\hline Dicrotendipes spp. \\
\hline Goeldichironomus holoprasinus \\
\hline Nilothauma babiyi \\
\hline Pagastiella spp. \\
\hline Polypedilum fallax \\
\hline Polypedilum spp. \\
\hline Tribelos fuscicorne \\
\hline Tribelos jucundum \\
\hline Pseudochironomus spp. \\
\hline Ceratopogonidae \\
\hline Simulium spp. \\
\hline Corynoneura spp. \\
\hline Cricotopus/Ortho spp. \\
\hline Nanocladius spp. \\
\hline Parakiefferiella sp.1 \\
\hline Parametriocnemus sp. \\
\hline Thienemanniella spp. \\
\hline Ablabesmyia spp. \\
\hline Conchapelopia spp. \\
\hline Labrundinia spp. \\
\hline Larsia spp. \\
\hline Paramerina sp. \\
\hline Pentaneura inconspicua \\
\hline Procladius sp. \\
\hline Cladotanytarsus spp. \\
\hline Rheotanytarsus spp. \\
\hline Stempellinella spp. \\
\hline Tanytarsus spp. \\
\hline Baetis spp. \\
\hline Caenis spp. \\
\hline Callibaetis spp. \\
\hline Nurylophella spp. \\
\hline Peoephemera youngi \\
\hline
\end{tabular}




\begin{tabular}{|l|}
\hline Argia spp. \\
\hline Enallagma spp. \\
\hline Lype diversa \\
\hline Oecetis spp. \\
\hline Oxyethira spp. \\
\hline Polycentropus spp. \\
\hline Turbellaria \\
\hline
\end{tabular}




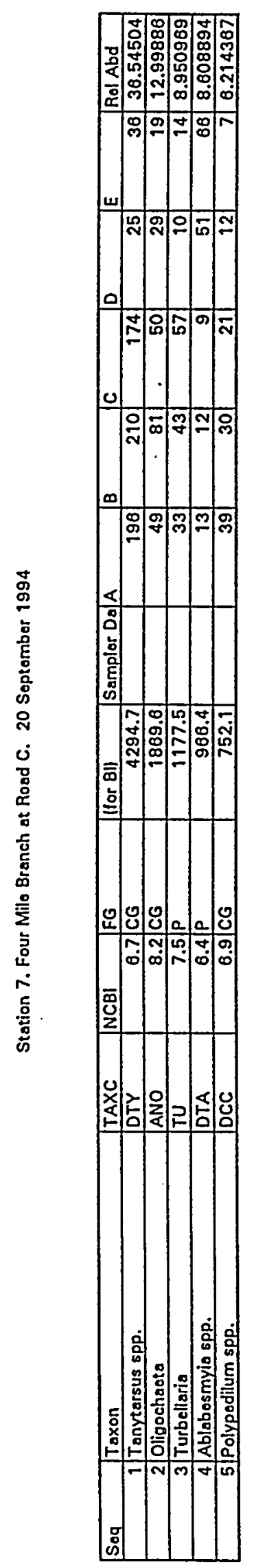




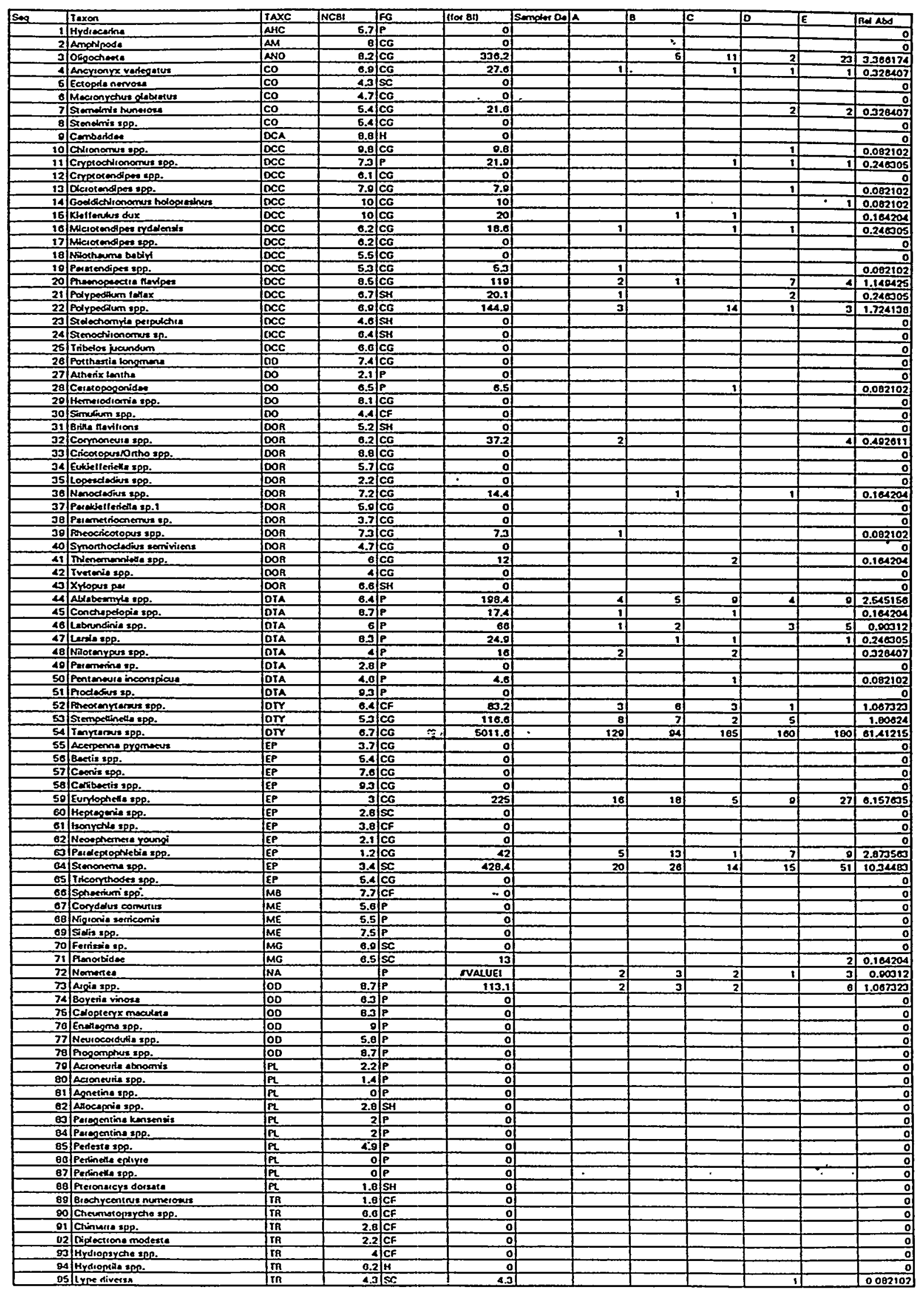




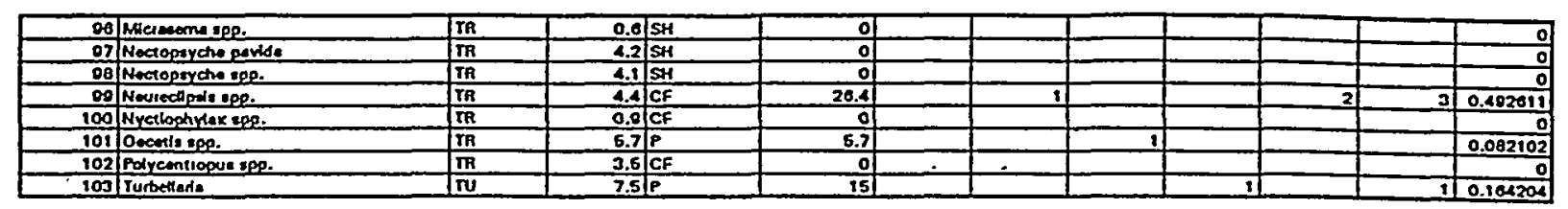


Station 8. Pen Branch at Road C. 20 September 1994

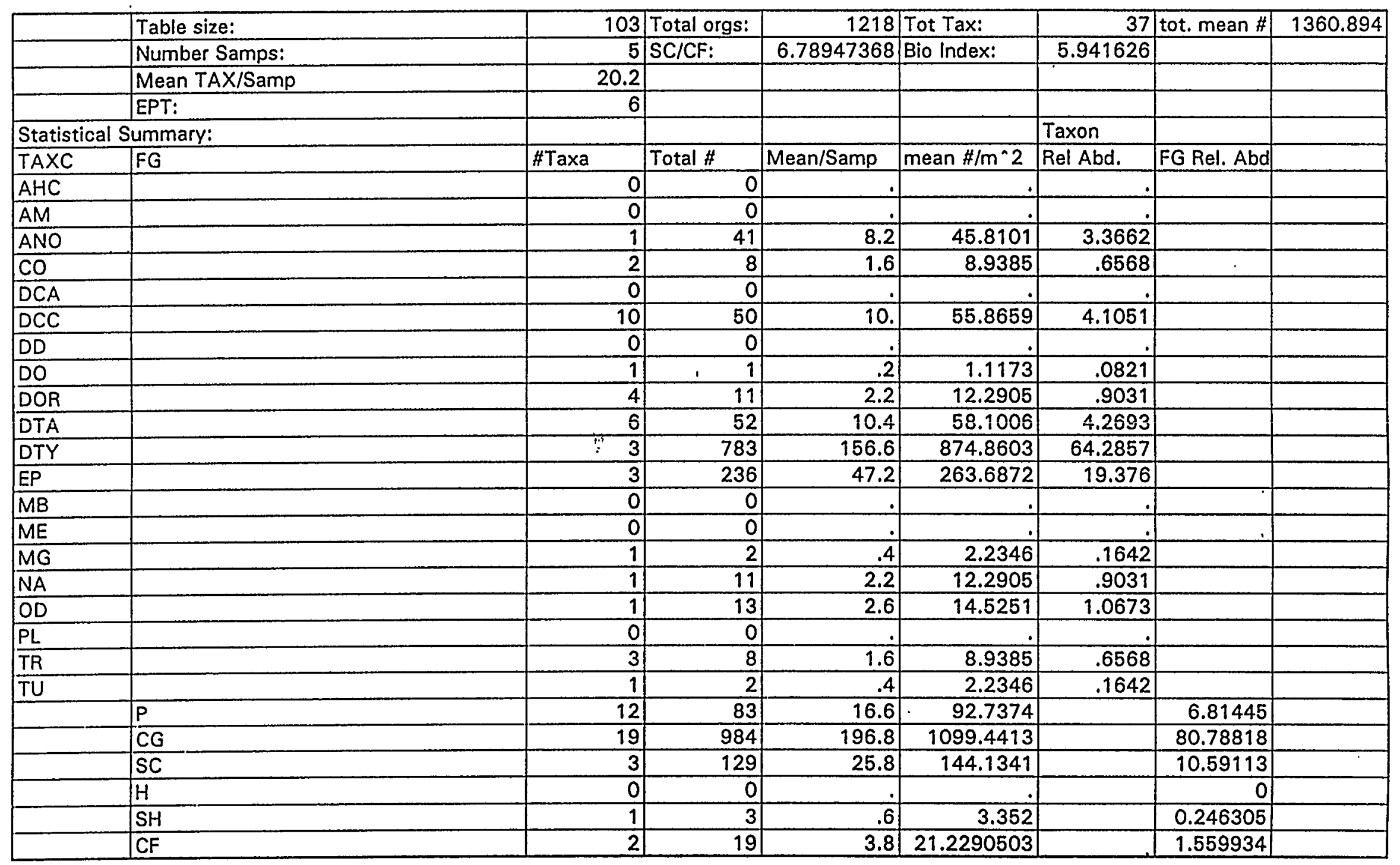


Station 8. Pen Branch at Road C. 20 September 1994

\begin{tabular}{|l|}
\hline Taxa List: \\
\hline Oligochaeta \\
\hline Ancyronyx variegatus \\
\hline Stemelmis hunerosa \\
\hline Chironomus spp. \\
\hline Cryptochironomus spp. \\
\hline Dicrotendipes spp. \\
\hline Goeldichironomus holoprasinus \\
\hline Kiefferulus dux \\
\hline Microtendipes rydalensis \\
\hline Paratendipes spp. \\
\hline Phaenopsectra flavipes \\
\hline Polypedilum fallax \\
\hline Polypedilum spp. \\
\hline Ceratopogonidae \\
\hline Corynoneura spp. \\
\hline Nanocladius spp. \\
\hline Rheocricotopus spp. \\
\hline Thienemanniella spp. \\
\hline Ablabesmyia spp. \\
\hline Conchapelopia spp. \\
\hline Labrundinia spp. \\
\hline Larsia spp. \\
\hline Nilotanypus spp. \\
\hline Pentaneura inconspicua \\
\hline Rheotanytarsus spp. \\
\hline Stempellinella spp. \\
\hline Tanytarsus spp. \\
\hline Eurylophella spp. \\
\hline Paraleptophlebia spp. \\
\hline Stenonema spp. \\
\hline Planorbidae \\
\hline Nemertea \\
\hline Argia spp. \\
\hline Lype diversa \\
\hline Neureclipsis spp. \\
\hline Oecetis spp. \\
\hline Turbellaria \\
\hline
\end{tabular}


Station 8. Pon Branch at Road C. 20 Soptember 1994

\begin{tabular}{|c|c|c|c|c|c|c|c|c|c|c|c|c|}
\hline Seq & Taxon & TAXC & NCBI & $F G$ & $($ for $B !)$ & Samplor Da & A & 8 & C & D & $E$ & Rol Abd \\
\hline 1 & Tonytarsus spp. & DTY & 6.710 & CG & 5011.6 & & 129 & 94 & 185 & 100 & 180 & 01.41215 \\
\hline 2 & Stononoma spp. & EP & $3.4 \mathrm{ss}$ & SC & 428.4 & & 20 & 28 & 14 & 15 & 51 & 10.34483 \\
\hline & Eurylophalla spp. & EP & 30 & $\overline{C G}$ & 225 & & 18 & 18 & 5 & 9 & 27 & 8.157835 \\
\hline
\end{tabular}




\begin{tabular}{|c|c|c|c|c|c|c|c|c|c|}
\hline Seg & Iexon & Iaxc & NCB & FGG & (for 에) & Semplox 0. & $A$ & $\mathrm{~B}$ & C \\
\hline 1 & Hydrocering & AHC & 5.7 & $p$ & 5.7 & & & & 1 \\
\hline 2 & Amphipode & AM - & 8 & CG & 0 & & & & \\
\hline 3 & Oropocheota & ANO & 8.4 & CG & 208.8 & & 13 & 4 & 8 \\
\hline 4 & Angronyx veriogetur & co & 0.9 & CG & 8.9 & & & $\because$ & 1 \\
\hline 5 & Eclopria nervose & $\mathrm{Co}$ & 4.3 & SC & 4.3 & & & & 1 \\
\hline a & Mecronychue olebratus & $\mathrm{Co}$ & 4.7 & CG & 58.4 & & -2 & 4 & 4 \\
\hline 7 & Stomolmis humerosa & $\mathrm{co}$ & 5.4 & CG & 10.8 & & & & $\square$ \\
\hline$\theta$ & Stenolmie spp. & $\mathrm{Co}$ & 5.4 & CG & o & & & & \\
\hline 9 & Cemberidea & $\overline{D C}$ & 8.8 & $\mathrm{H}$ & 의 & & & & \\
\hline 10 & Gryploctrionomut epp. & DCC & 7.3 & $P$ & of & & & & \\
\hline 11 & Dicrotendipoes epp. & $D C C$ & 8.1 & CG & of & & & & \\
\hline 12 & Microtendipoe rydalonitis & DCC & 6.2 & CG & 93 & & & II & 6 \\
\hline 13 & Miorotondiges cpp. & DCC & 6.2 & CG & 12.4 & & 2 & & \\
\hline 14 & Nesthoume babiri & DCC & 5.5 & CG & 5.5 & & & & \\
\hline 15) & Prtoonopectra flavipor & DCC & 8.5 & CG & 0 & & & & \\
\hline 10 & Pofypedingm lelex & OCC & 6.7 & SH & 33.5 & & 1 & 1 & 1 \\
\hline 17 & Potypodium ipp. & DCC & 6.9 & CG & 669.3 & & 13) & 43 & 18 \\
\hline 18) & IStolochom yie per pulctre & DCC & 4.6 & SH & 4.6 & & & & \\
\hline 19 & Stenoctionomus sp. & $\overline{\mathrm{DCC}}$ & 0.4 & SH & of & & & & $\div$ \\
\hline 20 & Iribolos ivaundim & DCC & 6.6 & CG & of & & & & $\cdot$ \\
\hline 21 & Potthostia bommana & 100 & 7.4 & CG & of & & & & \\
\hline 22 & Atherix Lanthe & 00 & 2.1 & $\mathrm{P}$ & of & & & & \\
\hline 23 & Coratopononid so & 00 & 6.5 & $\mathbf{p}$ & of & & & & \\
\hline 24 & Homerodromia spp. & wo & 8.1 & CG & of & & & & \\
\hline 25 & Hoxelome epp. & 00 & 4.7 & $P$ & 14.1 & & 2 & 1 & \\
\hline 26 & Simuleum cpp. & Do & 4.4 & CF & 70.4 & & 1 & 13 & \\
\hline 27 & Bita llavifions & DOR & 5.2 & SH & of & & & & \\
\hline 28 & Coryponouxe spp. & DOR & 8.2 & CG & 55.8 & & 2 & & 4 \\
\hline 29 & Cioolopue/Ortho epp. & DOA & 8.8 & CG & 114.4 & & 2 & 2 & 4 \\
\hline 30 & Eukiolferiako spp. & DOR & 5.7 & CG & 0 & & & & ב \\
\hline 31 & 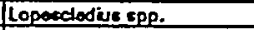 & DOR & 2.2 & $\mathrm{Cg}$ & 2.2 & & 1 & & \\
\hline 32 & Manocladiue spe. & DOR & $\mathbf{7 . 2}$ & CG & o & & & & \\
\hline 33 & Porakiofferialla op.1 & Don & 5.9 & CG & 35.4 & & it & & 2 \\
\hline 34 & Pecamotriocnemus ep. & DOR & 3.7 & CG & 103.6 & & 3 & 4 & 14 \\
\hline 35 & Aheocricolopent cpp. & DOR & 7.3 & $\mathbf{C G}$ & 51.1 & & & & 2 \\
\hline 36 & Synorthoclodius comivicone & DOR & 4.7 & CG & o) & & & & 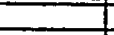 \\
\hline 37 & Thionomenniaka spp. & DOR & 6 & $\overline{C G}$ & so & & 2 & 1 & 4 \\
\hline 38 & Tretonia spp. & DOR & 4 & CG & of & & & & \\
\hline 39 & xylopue per & UOR & 6.6 & SH & 0 & & & & \\
\hline 40 & Ablabocmyie Gpe. & DIA & 6.4 & $\mathbf{P}$ & 57.6 & & 3 & & \\
\hline 41 & Conchuspoloplat spp. & DTA & 8.7 & $P$ & 17.4 & & & & \\
\hline 42 & Lobrundinis cop. & DIA & 6 & $\mathbf{P}$ & of & & & & \\
\hline 4.3. & Nabtanypus spp. & Dra & 4 & $P$ & of & & & & \\
\hline 41 & Peramerine sp. & DIA & 2.8 & $\mathbf{p}$ & of & & & & \\
\hline 45 & Pentanare inconspious & DIA & 4.6 & $\mathbf{P}$ & 32.2 & & 3 & 11 & 3 \\
\hline 16 & Pheotenyterase cpo. & DIY & 0.4 & CF & 1038.4 & & 39 & 30 & 73 \\
\hline 47 & Stompolinollo spe. & DrY & 5.3 & CG & 10.6 & & 1 & & 1 \\
\hline 48 & Tanyteraje spp. & DrY & 6.7 & CG & 3008.3 & & 204 & 13 & 81 \\
\hline 49 & Aoxporne prequeove & EP & 3.7 & CG & 3.7 & & 1 & & 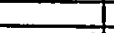 \\
\hline 50 & Beotis spp. & EP & 5.4 & CG & 297 & & 2 & 30 & 9) \\
\hline 59) & Coonis spp. & EP & 7.6 & CG & 30.4 & & & 1 & 1 \\
\hline 52 & Eurybophella app. & EP & 3 & CG & 9 & & & 2 & 1 \\
\hline 53 & Hepteoenis spp. & EF & 2.8 & SC & 0 & & & & 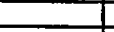 \\
\hline 54 & Ieonychie cpp. & EP & 3.8 & $C F$ & 61.6 & & 2 & & 5 \\
\hline 55 & Nooophemere youngi & EP & 2.1 & CG & 75.6 & & 7 & 11 & 5 \\
\hline 56 & Poraloptophlobie spg. & EF & 1.2 & $\mathrm{CG}$ & 4.8 & & .1 & & 2 \\
\hline 57 & Stenonomespg. & EF & 3.4 & SC & 489.6 & & 25 & 14) & 52 \\
\hline 58) & Irioox ythodes spp. & $E P$ & 5.4 & CG & 415.8 & & 21 & 7 & 22 \\
\hline 59 & Corydakus coxnutus & ME & 5.6 & $P$ & 0 & & & & 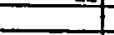 \\
\hline$\infty$ & Noronie corriconni & ME & 5.5 & $\mathbf{P}$ & of & & & & \\
\hline 61 & Siels.spp. & ME & 7.5 & $P$ & o) & & & $\because$ & \\
\hline 62 & Ferititis op. & MG & 6.9 & $\mathbf{S C}$ & 103.5 & & it & 1 & 6) \\
\hline 63 & Promorbidee & MG & 6.5 & SC & 6.5 & & & I. & 1 \\
\hline O4 & Plamertea & NA & & $P$ & of & & & & \\
\hline 65 & Argio spe. & OD & 8.7 & $\mathbf{P}$ & 8.7 & & & & \\
\hline 86 & Boyerie vinosa & OD & 0.3 & $\mathbf{P}$ & of & & & & \\
\hline 67 & Coloploryx meculale & 00 & 8.3 & $P$ & of & & & & \\
\hline 68 & Enakgema spp. & $O D$ & 9 & $P$ & 9 & & & & 1 \\
\hline 69 & Acconouxis obnormic & m & 2.2 & $P$ & 22 & & & 8 & \\
\hline 70 & Acronouria spe. & $\mathrm{FL}$ & 1.4 & $p$ & 2.8 & & II & & 1 \\
\hline 71 & Allocopnio kpp. & $F$ & 2.8 & SH & of & & & & \\
\hline 72 & Peregentins imm erfingte & $\mathrm{PL}$ & 2 & $p$ & 6 & & & & \\
\hline 73 & Perepentins spp. & $F$ & 2 & 8 & of & & & & \\
\hline 74 & Perbestespp. & FL & 4.9 & $P$ & o & & & & \\
\hline 75 & Porfinelle ephyro & $P$ & - & 8 & 0 & & & & \\
\hline 78 & Perkinelle spp. & $F$ & 0 & $P$ & of & & & & \\
\hline 77 & Pteronercye dorcata & $F$ & 1.6 & SH & of & & & & \\
\hline 78 & Tosniopleryx \&p. & Ft & 6.3 & SH & of & & & & \\
\hline 79 & Bechycontrus numerosue & IR & 1.8 & $C F$ & 1.8 & & & & 1 \\
\hline 80 & Choum stopsycho spe. & in & 6.6 & $C F$ & 79.2 & & & 2 & 5 \\
\hline 81 & Chimerre spp. & If & 2.8 & CF & o! & & & & \\
\hline 82 & Diploctrona modosta & In & 2.2 & CF & 2.2 & & & & \\
\hline 83 & Hydropsyctio spp. & In & 1 & CF & 의 & & & & \\
\hline 84) & Hydropila spp. & Iิ & 6.2 & $\mathrm{H}$ & of & & & & \\
\hline B5 & Lypo divorea & In & 4.3 & SC & 0 & & & & \\
\hline Bo & Mioracama ses. & in & 0.6 & SH & of & & & & \\
\hline 87 & Nociopeycho oxquisita & In & 4.2 & $\mathrm{SH}$ & 8.4 & & 1) & $\pi$ & \\
\hline An & Nomunclipsis spe. & If & 4.4 & CF & o & & & & \\
\hline
\end{tabular}




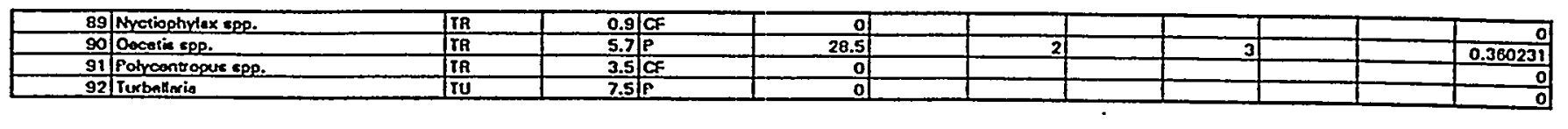




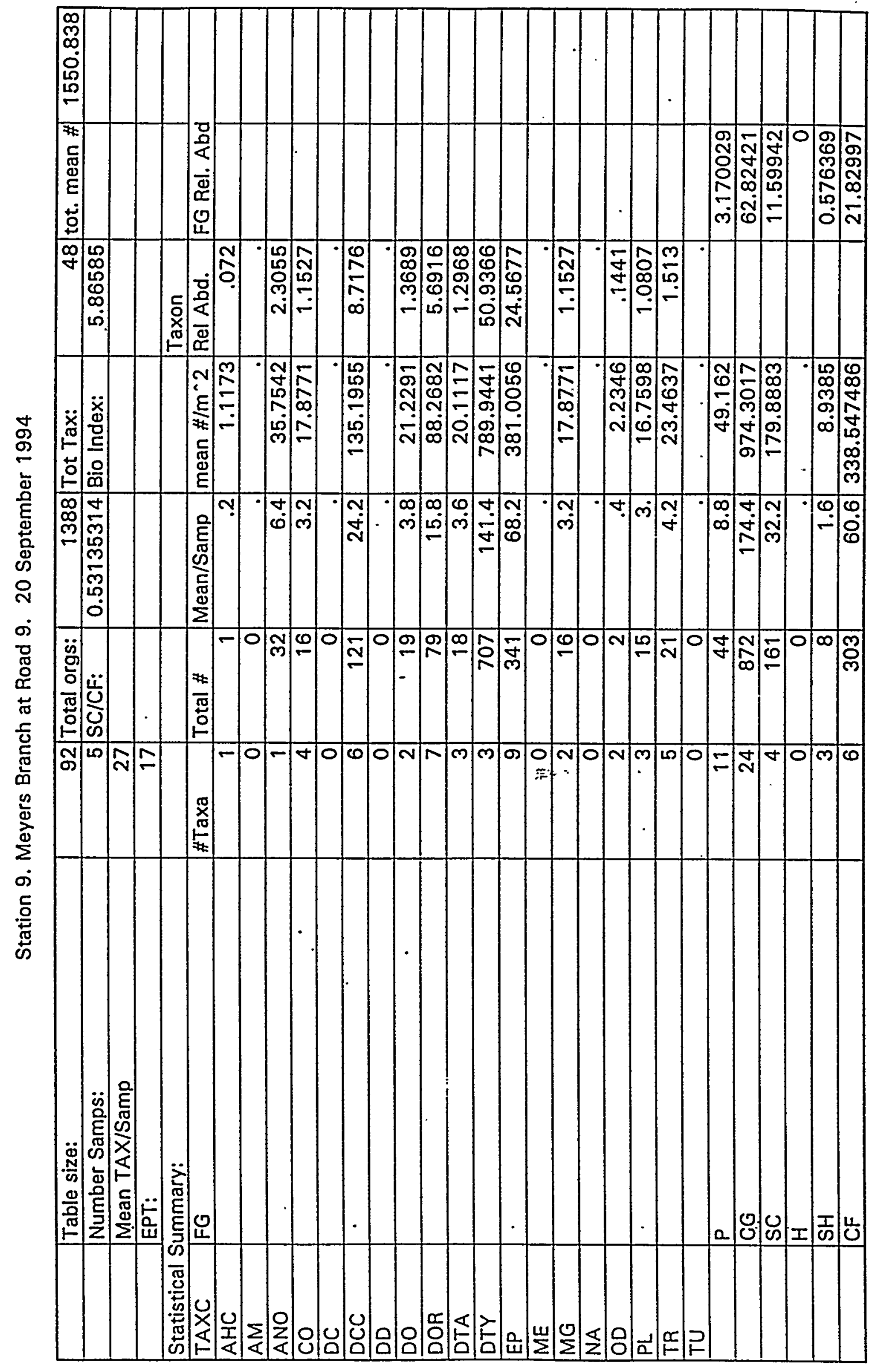


Station 9. Meyers Branch at Road $\overline{9} .20$ September 1994

\begin{tabular}{|l|}
\hline Taxa List: \\
\hline Hydracarina \\
\hline Oligochaeta \\
\hline Ancyronyx variegatus \\
\hline Ectopria nervosa \\
\hline Macronychus glabratus \\
\hline Stemelmis humerosa \\
\hline Microtendipes rydalensis \\
\hline Microtendipes spp. \\
\hline Nilothauma babiyi \\
\hline Polypedilum fallax \\
\hline Polypedilum spp. \\
\hline Stelechomyia perpulchra \\
\hline Hexatoma spp. \\
\hline Simulium spp. \\
\hline Corynoneura spp. \\
\hline Cricotopus/Ortho spp. \\
\hline Lopescladius spp. \\
\hline Parakiefferiella sp.1 \\
\hline Parametriocnemus sp. \\
\hline Rheocricotopus spp. \\
\hline Thienemanniella spp. \\
\hline Ablabesmyia spp. \\
\hline Conchapelopia spp. \\
\hline Pentaneura inconspicua \\
\hline Rheotanytarsus spp. \\
\hline Stempellinella spp. \\
\hline Tanytarsus spp. \\
\hline Acerpenna pygmaeus \\
\hline Baetis spp. \\
\hline Caenis spp. \\
\hline Eurylophella spp. \\
\hline Isonychia spp. \\
\hline Neoephemera youngi \\
\hline Paraleptophlebia spp. \\
\hline Stenonema spp. \\
\hline Tricorythodes spp. \\
\hline Ferrissia sp. \\
\hline Planorbidae \\
\hline Argia spp. I \\
\hline Enallagma spp. \\
\hline Acroneuria abnormis \\
\hline Acroneuria spp. \\
\hline Paragentina immarginata \\
\hline Cheumatopsyche spp. \\
\hline Nectopsyche exquisita \\
\hline
\end{tabular}




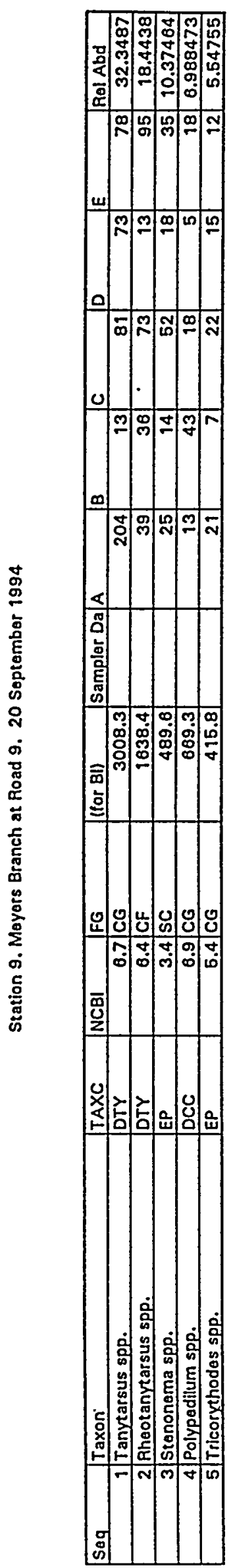

F* 


\begin{tabular}{|c|c|c|c|c|c|c|c|c|c|c|c|c|}
\hline Sog & Taxon & TAXC & NCBI & FG & (for BII & Sampler Do & A & B & C & D & EE & Rol Abd \\
\hline 1 & Hydracorina & AHC & \begin{tabular}{|l}
5.7 \\
\end{tabular} & $P$ & of & & & & & & & 0 \\
\hline 2 & Amphipoda & AM & 8 & CG & 0 & & & & & & & 0 \\
\hline 3 & Oligocheata & ANO & 8.2 & $2 \mathrm{CG}$ & 0371.4 & & 241 & 258 & 127 & 54 & 97 & 39.98971 \\
\hline 4 & Ancyronyx variogatus & CO & 8.9 & CG & . 0 & [- & & & & & & 0 \\
\hline 5 & Ectopria norvosa & co & 4.3 & $\mathrm{sc}$ & 0 & & & & & & & 0 \\
\hline 6 & Macronychus glabratus & co & 4.7 & $\mathrm{CG}$ & 4.7 & & & & & 1 & & 0.051487 \\
\hline 7 & Stenolmis humerosa & co & 5.4 & CG & of & & & & & & & 0 \\
\hline 8 & Stenolmis spp. & $\mathrm{Co}$ & 5.4 & CG & 0 & & & & & & & 0 \\
\hline 9 & Cambaridso & $D C$ & 8.8 & 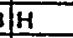 & 은 & & & & & & & 0 \\
\hline 10 & Cryptochironomus spp. & DCC & 7.3 & $P$ & 0 & & & & & & . & 0 \\
\hline 11 & Dicrotondipos spp. & DCC & 7.9 & CG & 0 & & & & & & & 0 \\
\hline 12 & Gooldichironomus holoprosinus & DCC & 10 & CG & 510 & & 28 & 11 & 5 & 2 & 5 & 2.624807 \\
\hline 13 & Microtondipos rydalonsis & DCC & 6.2 & CG & 0 & & & & & & & 0 \\
\hline 14 & Microtondipos spp. & DCC & 6.2 & CG & 6.2 & & 1 & & & & & 0.051467 \\
\hline 15 & Nilothauma bebiyi & DCC & 5.5 & CG & 0 & & & & & & & 0 \\
\hline 18 & Parachironomus spp. & DCC & 9.2 & CG & 9.2 & & & & 1 & & & 0.051467 \\
\hline 17 & Phaenopsoctra flavipes & DCC & 8.6 & $\mathbf{C G}$ & 0 & & & & & & & 0 \\
\hline 18 & Polypodilum fallax & DCC & 6.7 & SH & of & & & & & & & 0 \\
\hline 19 & Polypedilum spp. & DCC & 6.9 & CG & 5050.8 & & 190 & 147 & 124 & 123 & 148 & 37.6737 \\
\hline 20 & Stolochomyie porpulchra & DCC & 4.6 & SH & 0 & & & & & & & 0 \\
\hline 21 & Stenochironomus sp. & DCC & 6.4 & SH & 0 & & & & & & & $\overline{0}$ \\
\hline 22 & Tribolos jucundum & $\overline{\mathrm{OCC}}$ & 6.6 & CG & 0 & & & & & & & $\underline{0}$ \\
\hline 23 & Potthostis longmane & DD & 7.4 & CG & 0 & & & & & & & $\mathbf{0}$ \\
\hline 24 & Athorix lanthe & Do & 2.1 & $P$ & 0 & & & & & & & 0 \\
\hline 25 & Coratopogonidae & Do & 6.5 & $\mathbf{P}$ & 0 & & & & & & & 0 \\
\hline 26 & Hemorodtomia spp. & DO & 8.1 & CG & 24.3 & & 1 & 1 & 1 & & & 0.1544 \\
\hline 27 & Simulium spp. & DO & 4.4 & $\mathrm{CF}$ & 83.6 & & 15 & 3 & 1 & & & 0.977869 \\
\hline 28 & Brilla flavifrons & DOR & 5.2 & $\mathrm{SH}$ & 0 & & & & & & & 0 \\
\hline 29 & Corynonoura spe. & DOR & 6.2 & CG & 0 & & & & & & & 0 \\
\hline 30 & Cricotopus/Ortho spp. & DOR & 8.8 & CG & 17.6 & & 1 & & & (1) & & 0.102934 \\
\hline 31 & Eukiofferiolla spp. & DOR & 5.7 & CG & 0 & & & & & & & 0 \\
\hline 32 & Nenocladius spp. & DOR & 7.2 & CG & 0 & & & & & & & 0 \\
\hline 33 & Orthoctadius lignicolo & DOR & 5.4 & $\mathrm{SH}$ & 은 & & & & & & & 0 \\
\hline 34 & Parakiofforiolla sp. 1 & DOR & 5.9 & CG & 0 & & & & & & & $\overline{0}$ \\
\hline 35 & Paramotriocnomus sp. & DOR & 3.7 & CG. & 0 & & & & & & & 0 \\
\hline 36 & Rhoocricotopus spp. & DOR & 7.3 & CG & 657 & & 30 & 17 & 18 & 14 & 11 & 4.632012 \\
\hline 37 & Synorthocladius somivirons & DOR & 4.7 & CG & 0 & & & & & & & 0 \\
\hline 38 & Thionemanniolle spp. & DOR & 6 & CG & 308 & & 19 & 11 & 4 & 5 & 11 & 2.624807 \\
\hline 39 & Tvotonia spp. & DOA & 4 & CG & 0 & & & & & & & 0 \\
\hline 40 & Xylopus par & loon & 6.6 & $\mathrm{SH}$ & $\underline{z}$ & & & & & & & 0 \\
\hline 41 & Ablebosmyia spe. & DTA & 6.4 & $P$ & 12.8 & & & 1 & & & 1 & 0.102934 \\
\hline 42 & Conchopolopia spp. & DTA & 8.7 & $p$ & 1218 & & 31 & 38 & 22 & 23 & 26 & 7.205353 \\
\hline 43 & Labrundinia spp. & DTA & 6 & P & 0 & & & & & & & 0 \\
\hline 44 & Milotanypus spp. & DTA & 4 & $P$ & 0 & & & & & & & 0 \\
\hline 45 & Paramorina sp. & DTA & 2.8 & P & 0 & & & & & & & $\overline{0}$ \\
\hline 46 & Pontanoura inconspicus & DTA & 4.6 & $P$ & 0 & & & & & & & $\underline{0}$ \\
\hline 47 & Rhoolanytarsus spp. & DTY & 6.4 & $\mathrm{CF}$ & 0 & & & & & & & 0 \\
\hline 48 & Tonytarsuz spp. & DTY & 8.7 & $\mathrm{CG}$ & 67 & & 4 & 4 & 2 & & & 0.514688 \\
\hline 49 & Acorpenne pygmaous & EP & 3.7 & $\mathrm{CG}$ & 0 & & & & & & & 0 \\
\hline 50 & Baotis spp. & EP & 5.4 & CG & 16.2 & & & & & 2 & 1 & 0.1544 \\
\hline 51 & Caonis spp. & EP & 7.6 & CG & 0 & & & & & & & 0 \\
\hline 52 & Eurylophella spp. & EP & 3 & $\mathbf{C G}$ & 인 & & & & & & & 0 \\
\hline 53 & Heptagenia spp. & EP & 2.8 & $\mathrm{sc}$ & 0 & & & & & & & 0 \\
\hline 54 & Neoophemera youngi & EP & 2.1 & CG & 2.1 & & & 1 & & & & 0.051467 \\
\hline 55 & Paraloptophlobia spp. & EP & 1.2 & CG & 0 & & & & & & & 0 \\
\hline 56 & Stononome spp. & EP & 3.4 & sc & 13.6 & & & 1 & 2 & 1 & & $0.205 B 67$ \\
\hline 57 & Tricorythodes spp. & EP & 5.4 & CG & 0 & & & & & & & 0 \\
\hline 58 & Corydzlus comutus & IME & 5.6 & P & 33.6 & & & 3 & 1 & 1 & 1 & 0.308801 \\
\hline 59 & Nigronia sorricornis & ME & 5.5 & P & 0 & & & & & & & 0 \\
\hline 60 & Sialis spp. & ME & 7.5 & $P$ & 0 & & & & & & & 0 \\
\hline 61 & Forrissia sp. & MG & 6.9 & sc & 0 & & & & & & & 0 \\
\hline 62 & Physolla spp. & MG & 9.1 & sc & 9.1 & & & 1 & & & & 0.051467 \\
\hline 63 & Nemortes & NA & & $P$ & 0 & & 1 & 3 & 4 & & 1 & 0.463201 \\
\hline 64 & Argie spp. & 100 & 8.7 & $p$ & 0 & & & & & & & 0 \\
\hline 65 & Boyarie vinosa & 100 & 6.3 & $P$ & 0 & & & & & & & 0 \\
\hline 66 & Caloptoryx maculate & TOD & 8.3 & $P$ & 8.3 & & 1 & & & & & 0.051467 \\
\hline 67 & Enallagma spp & $O D$ & 9 & $p$ & 0 & & & & & & & 0 \\
\hline 68 & Acronouria abnarmis & $\mathrm{PL}$ & 2.2 & p & of & & & & & & & 0 \\
\hline 69 & Acronouria spp. & $P L$ & 1.4 & $P$ & 요 & & & & & & & 0 \\
\hline 70 & Allocapnia spp. & $P L$ & 2.8 & $\mathrm{SH}$ & of & & & & & & & 0 \\
\hline 71 & Paragontina kensonsis & TPL & 2 & P & 0 & & & & & & & 0 \\
\hline
\end{tabular}




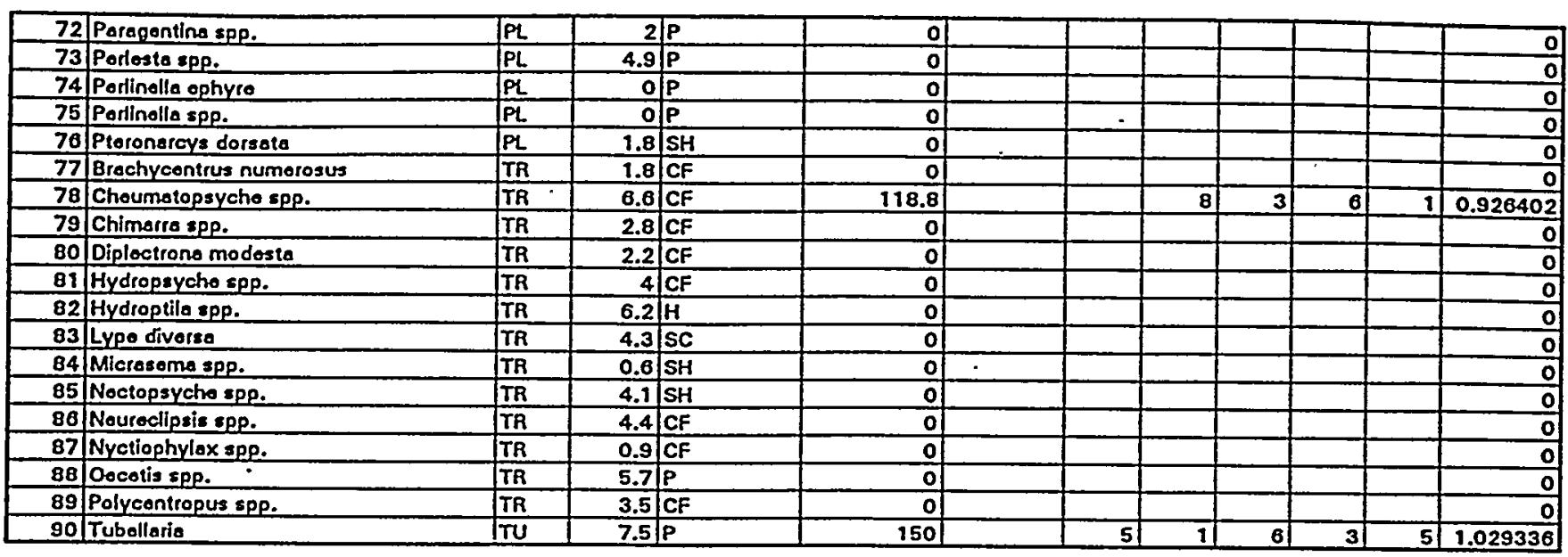




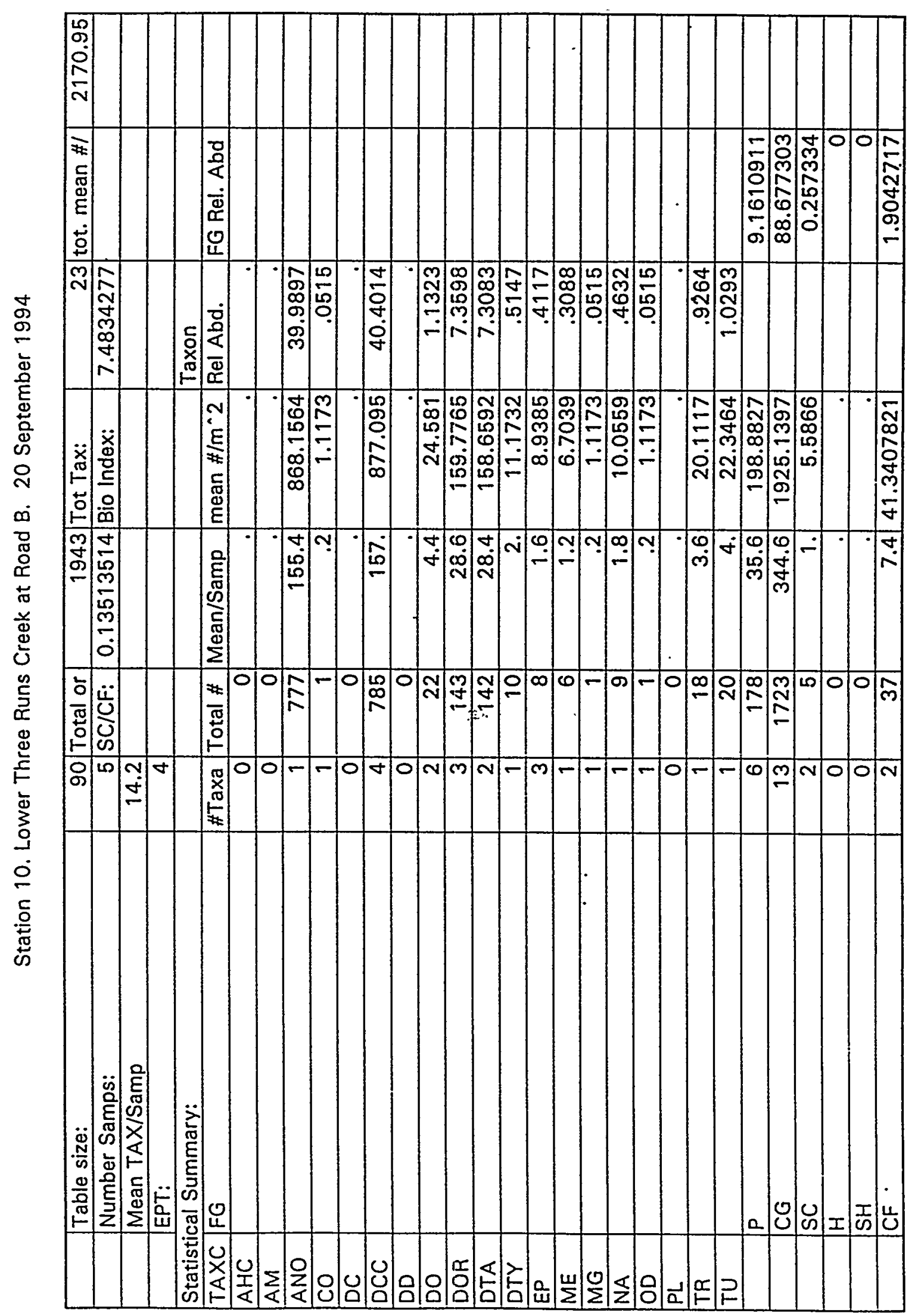


Station 10. Lower Three Runs Creek at Road B. 20 September 1994

Taxa List:

Oligochaeta

Macronychus glabratus

Goeldichironomus tioloprasinus

Microtendipes spp.

Parachironomus spp.

Polypedilum spp.

Hemerodromia spp.

Simulium spp.

Cricotopus/Ortho spp.

Rheocricotopus spp.

Thienemanniella spp.

Ablabesmyia spp.

Conchapelopia spp.

Tanytarsus spp.

Baetis spp.

Neoephemera youngi

Stenonema spp.

Corydalus cornutus

Physella spp.

Nemertea

Calopteryx maculata

Cheumatopsyche spp.

Tubellaria 


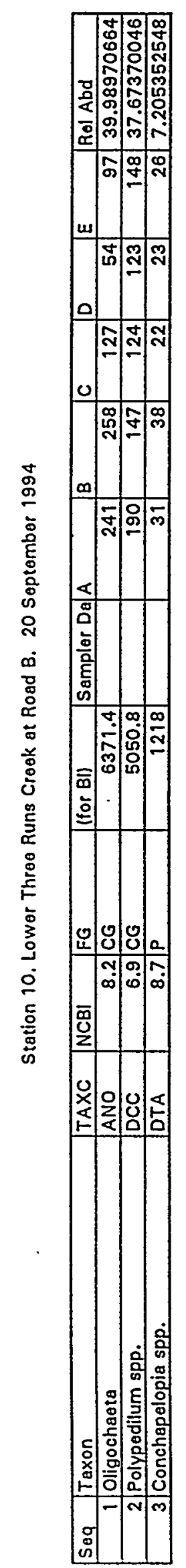




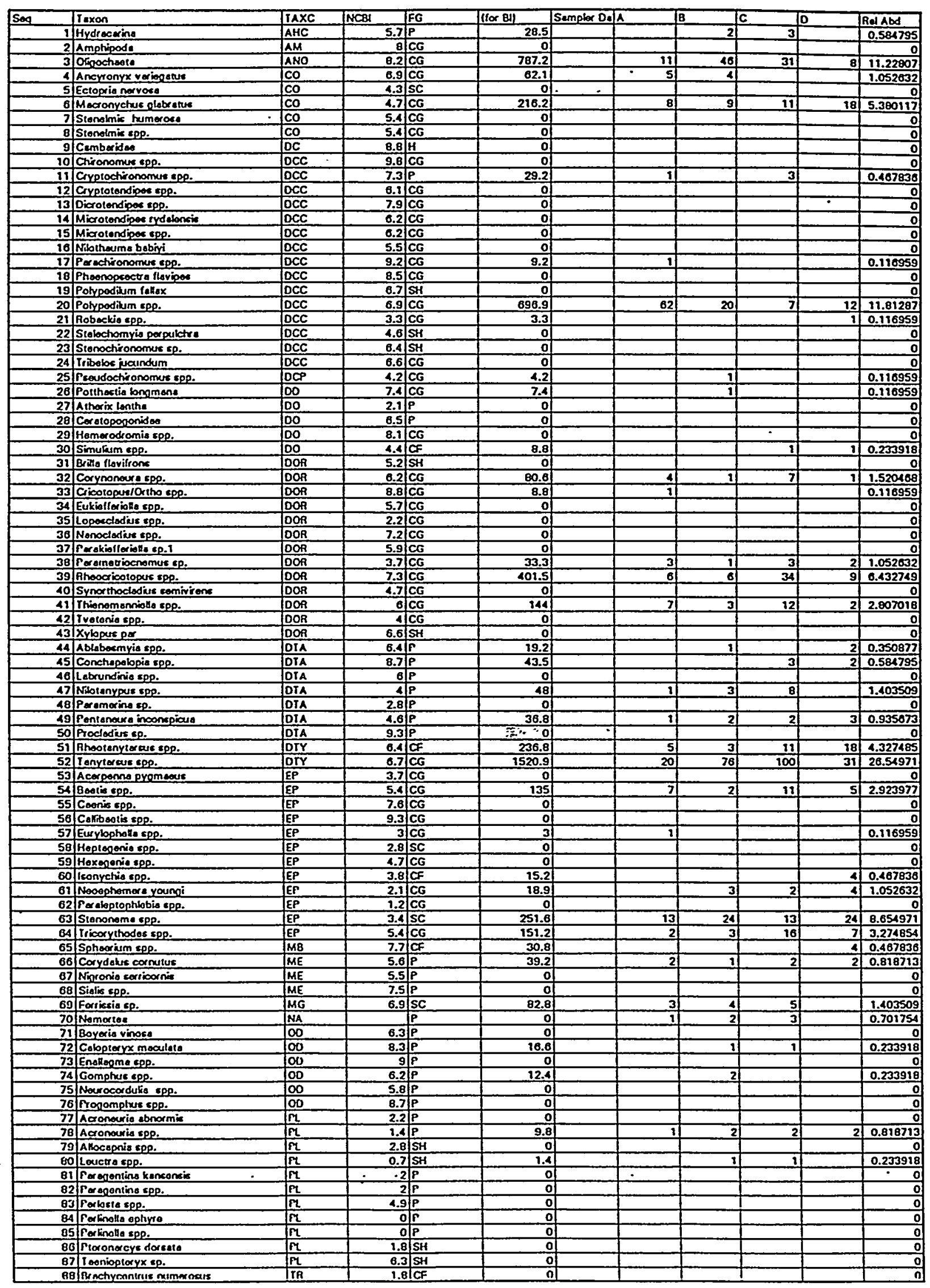




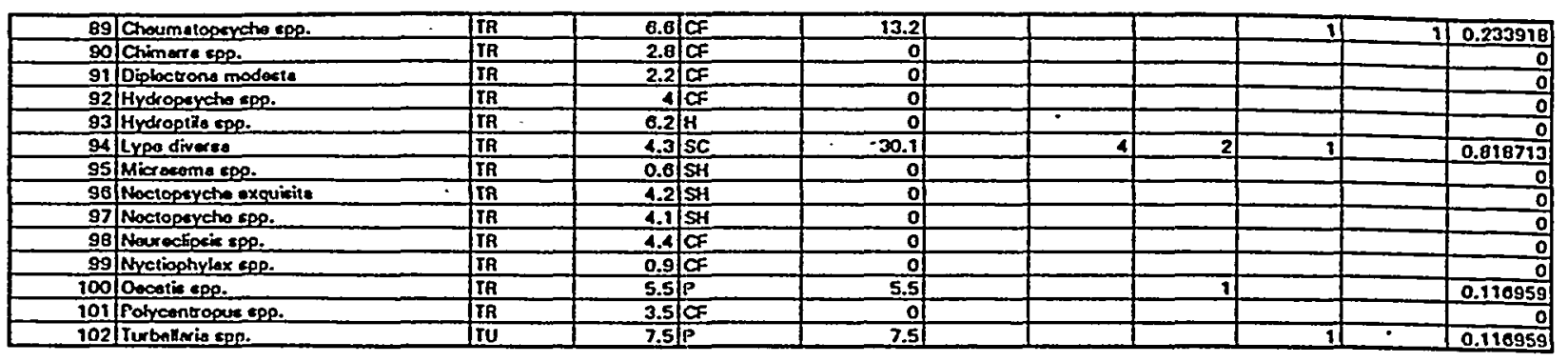




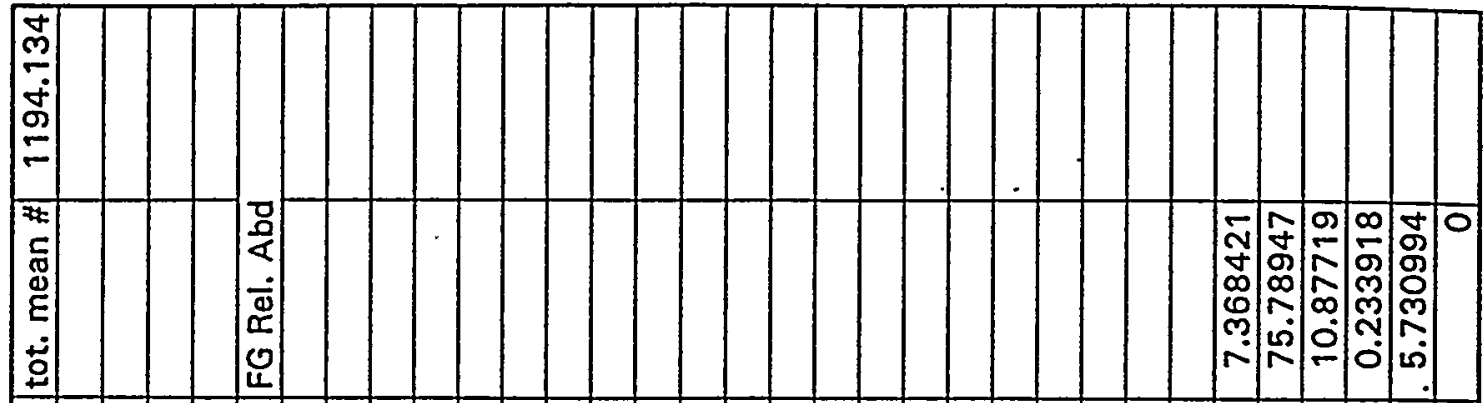

\begin{tabular}{|c|c|c|c|c|c|c|c|c|c|c|c|c|c|c|c|c|c|}
\hline 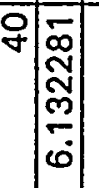 & 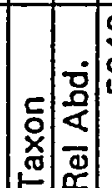 & 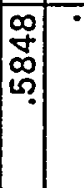 & 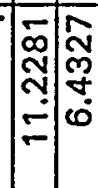 & & 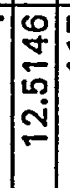 & $=:$ & $=\mid \begin{array}{c}n \\
\approx\end{array}$ & 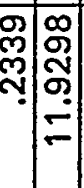 & 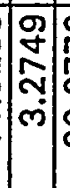 & 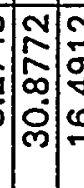 & 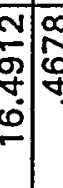 & $\begin{array}{l}\infty \\
0 \\
0 \\
0 \\
0\end{array}$ & $\mid$\begin{tabular}{l}
0 \\
0 \\
0 \\
\hdashline \\
\hdashline \\
\hdashline
\end{tabular} & : & $\mid$\begin{tabular}{l|l}
$\infty$ & 0 \\
0 & 0 \\
0 & 5 \\
4 & 0 \\
\hdashline & 0
\end{tabular} & 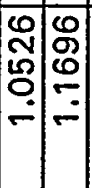 & \\
\hline
\end{tabular}

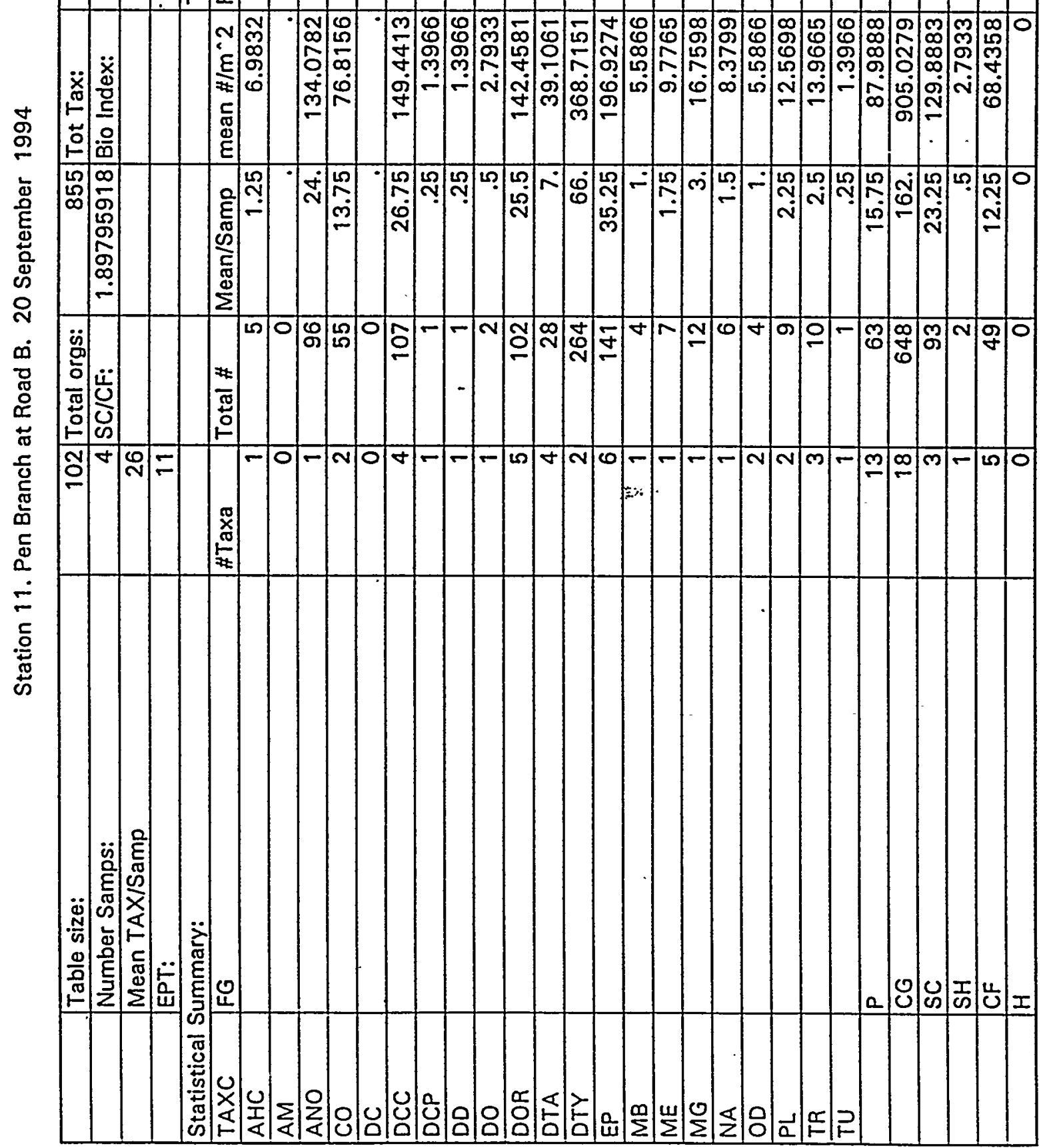




\begin{tabular}{|l|}
\hline Taxa List: \\
\hline Hydracarina \\
\hline Oligochaeta \\
\hline Ancyronyx variegatus \\
\hline Macronychus glabratus \\
\hline Cryptochironomus spp. \\
\hline Parachironomus spp. \\
\hline Polypedilum spp. \\
\hline Robackia spp. \\
\hline Pseudochironomus spp. \\
\hline Potthastia longmana \\
\hline Simulium spp. \\
\hline Corynoneura spp. \\
\hline Cricotopus/Ortho spp. \\
\hline Parametriocnemus sp. \\
\hline Rheocricotopus spp. \\
\hline Thienemanniella spp. \\
\hline Ablabesmyia spp. \\
\hline Conchapelopia spp. \\
\hline Nilotanypus spp. \\
\hline Pentaneura inconspicua \\
\hline Rheotanytarsus spp. \\
\hline Tanytarsus spp. \\
\hline Baetis spp. \\
\hline Eurylophella spp. \\
\hline Isonychia spp. \\
\hline Neoephemera youngi \\
\hline Stenonema spp. \\
\hline Tricorythodes spp. \\
\hline Sphaerium spp. \\
\hline Corydalus cornutus \\
\hline Ferrissia sp. \\
\hline Nemertea \\
\hline Calopteryx maculata \\
\hline Gomphus spp. \\
\hline Acroneuria spp. \\
\hline Leuctra spp. \\
\hline Cheumatopsyche spp. \\
\hline Lype diversa \\
\hline Oecetis spp. \\
\hline Turbellaria spp. \\
\hline
\end{tabular}


Station 11. Pon Branch at Road B. 20 September 1994

\begin{tabular}{|c|c|c|c|c|c|c|c|c|c|c|c|}
\hline Seq & Taxon & TAXC & $\mathrm{NCBI}$ & $\mathbf{F G}$ & \begin{tabular}{|l|l|} 
(for $\mathrm{B} !)$ \\
\end{tabular} & Sempler D & A & 8 & c & D & Rol Abd \\
\hline 1 & Tanytarsus spp. & DTY & 6.7 & CG & 1520.9 & & 20 & 76 & 100 & 31 & 26.54971 \\
\hline 2 & Polypedilum spp. & $D C C$ & 6.9 & CG & 696.9 & & 62 & 20 & 7 & 12 & 11.81287 \\
\hline 3 & Oligochaota & ANO & 8.2 & CG & 787.2 & & 11 & 46 & 31 & 8 & 11.22807 \\
\hline 4 & Stenonema spp. & EP & 3.4 & SC & 251.6 & & 13 & 24 & 13 & 24 & 8.654971 \\
\hline 5 & Rheocricotopus spp. & DOR & 7.3 & CG & 401.5 & & 6 & 6 & 34 & 9 & 6.432749 \\
\hline 6 & Macronychus glabratus & Co & 4.7 & CG & 216.2 & & 8 & 9 & 11 & 18 & 5.380117 \\
\hline
\end{tabular}




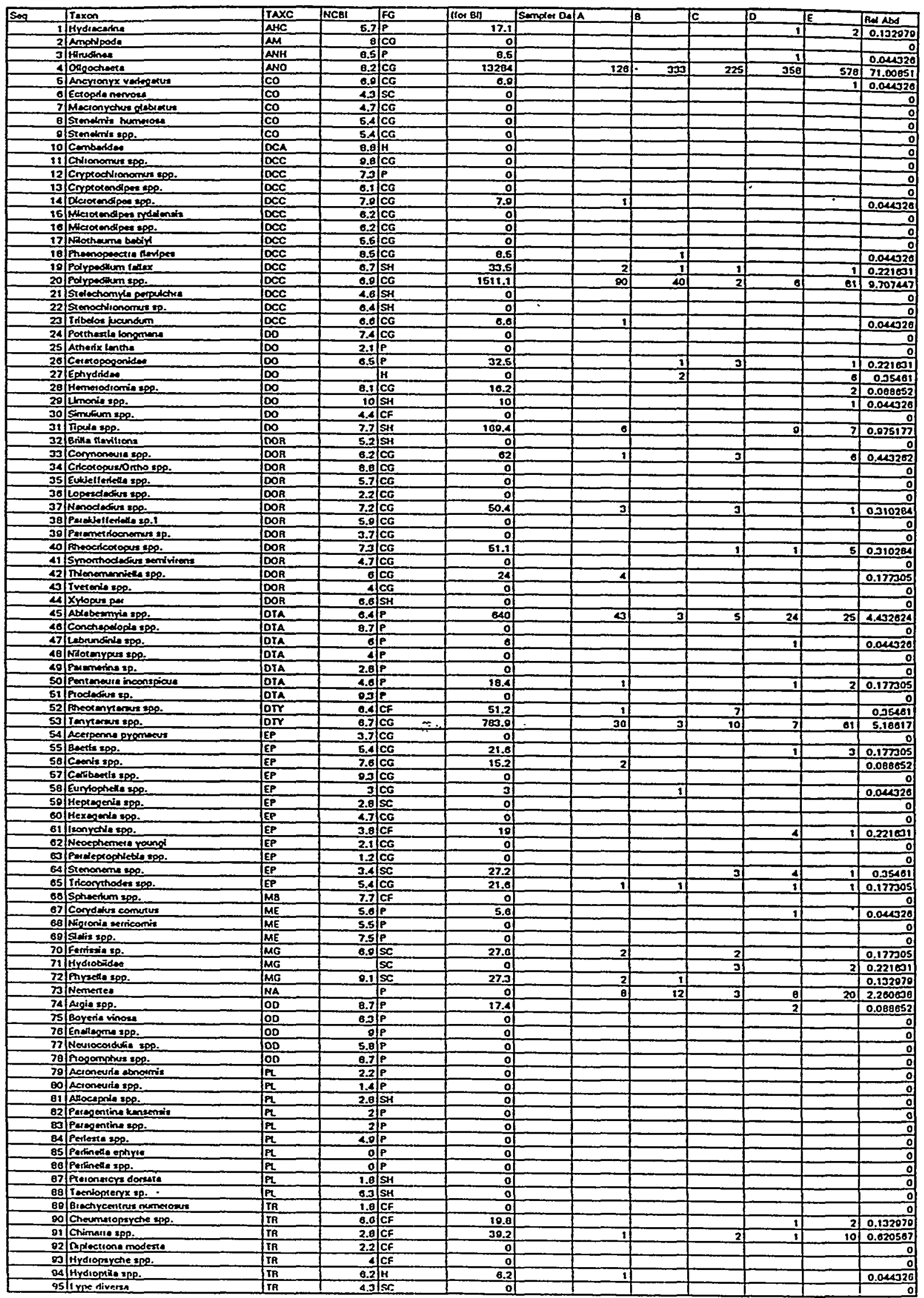




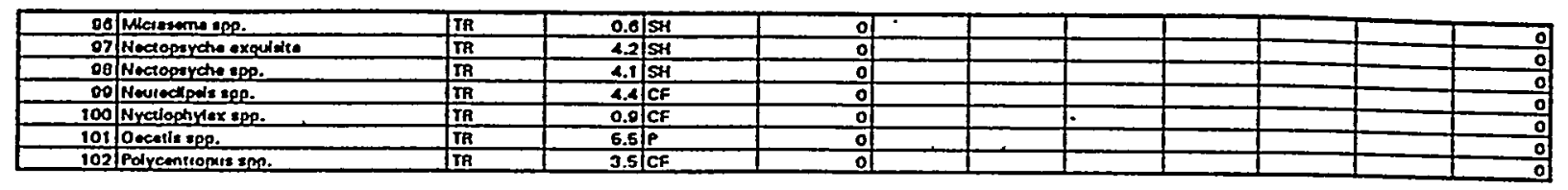

F* 
Station 12. Indian Grave Branch at Road B. 20 September 1994

\begin{tabular}{|c|c|c|c|c|c|c|c|c|}
\hline & Table size: & 102 & Total orgs: & 2256 & Tot Tax: & 38 & tot. mean \# & 2520.67 \\
\hline & Number Samps: & 5 & SC/CF: & 0.66666667 & Bio Index: & $\cdot 7.55758$ & & \\
\hline & Mean TAX/Samp & 18 & & & & & & \\
\hline & EPT: & 9 & & & & & & \\
\hline \multicolumn{2}{|c|}{ Statistical Summary: } & & & & & Taxon & & \\
\hline $\mathrm{TAXC}$ & $F G$ & \#Taxa & Total \# & Mean/Samp & mean $\# / \mathrm{m}^{\wedge} 2$ & Rel Abd. & FG Rel. Abd & \\
\hline $\mathrm{AHC}$ & & 1 & 3 & .6 & $\begin{array}{r}3.352 \\
\end{array}$ & .133 & & \\
\hline$A M$ & & 0 & 0 &. & &. & & \\
\hline $\mathrm{ANH}$ & & 1 & 1 & .2 & 1.1173 & .0443 & & \\
\hline ANO & . & 1 & 1620 & 324. & 1810.0559 & 71.8085 & & $\cdot$ \\
\hline $\mathrm{CO}$ & & 1 & 1 & .2 & 1.1173 & .0443 & & \\
\hline DCA & & 0 & 0 &. & & & & \\
\hline$D C C$ & & 5 & 227 & 45.4 & 253.6313 & 10.0621 & & \\
\hline DD & & 0 & $1 \quad 0$ &. &.+ &. & & \\
\hline $\mathrm{DO}^{-}$ & & 5 & 38 & 7.6 & 42.4581 & 1.6844 & & \\
\hline DOR & & $\therefore 4$ & 28 & 5.6 & 31.2849 & 1.2411 & & \\
\hline DTA & & 3 & 105 & 21. & 117.3184 & 4.6543 & & \\
\hline$\underset{D P T}{D}$ & 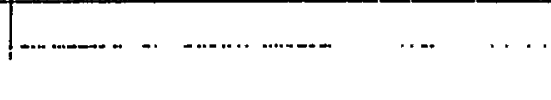 & $\cdots \quad \frac{2}{6}$ & $\ldots . \frac{125}{24}$ & $\begin{array}{l}25 \\
4.8\end{array}$ & ... $\frac{139.6648}{26.8156}$ & \begin{tabular}{|c|}
5.5408 \\
1.0638
\end{tabular} & & \\
\hline
\end{tabular}




\begin{tabular}{|l|}
\hline Taxa List: \\
\hline Hydracarina \\
\hline Hirudinea \\
\hline Oligochaeta \\
\hline Ancyronyx variegatus \\
\hline Dicrotendipes spp. \\
\hline Phaenopsectra flavipes \\
\hline Polypedilum fallax \\
\hline Polypedilum spp. \\
\hline Tribelos jucundum \\
\hline Ceratopogonidae \\
\hline Ephydridae \\
\hline Hemerodromia spp. \\
\hline LImonia spp. \\
\hline Tipula spp. \\
\hline Corynoneura spp. \\
\hline Nanocladius spp. \\
\hline Rheocricotopus spp. \\
\hline Thienemanniella spp. \\
\hline Ablabesmyia spp. \\
\hline Labrundinia spp. \\
\hline Pentaneura inconspicua \\
\hline Rheotanytarsus spp. \\
\hline Tanytarsus spp. \\
\hline Baetis spp. \\
\hline Caenis spp. \\
\hline Eurylophella spp. \\
\hline Isonychia spp. \\
\hline Stenonema spp. \\
\hline Tricorythodes spp. \\
\hline Corydalus cornutus \\
\hline Ferrissia sp. \\
\hline Hydrobiidae \\
\hline Physella spp. \\
\hline Nemertea \\
\hline Argia spp. \\
\hline Cheumatopsyche spp. \\
\hline Chimarra spp. \\
\hline Hydroptila spp. \\
\hline
\end{tabular}


Station 12. Indlan Gravo Branch at Road B. 20 Septembor 1994

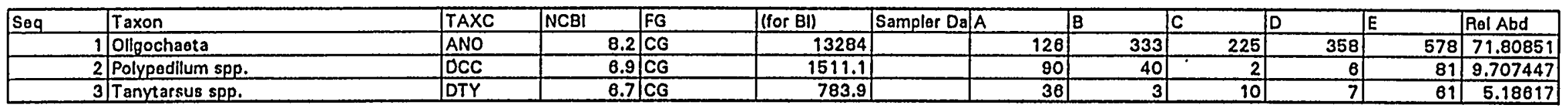




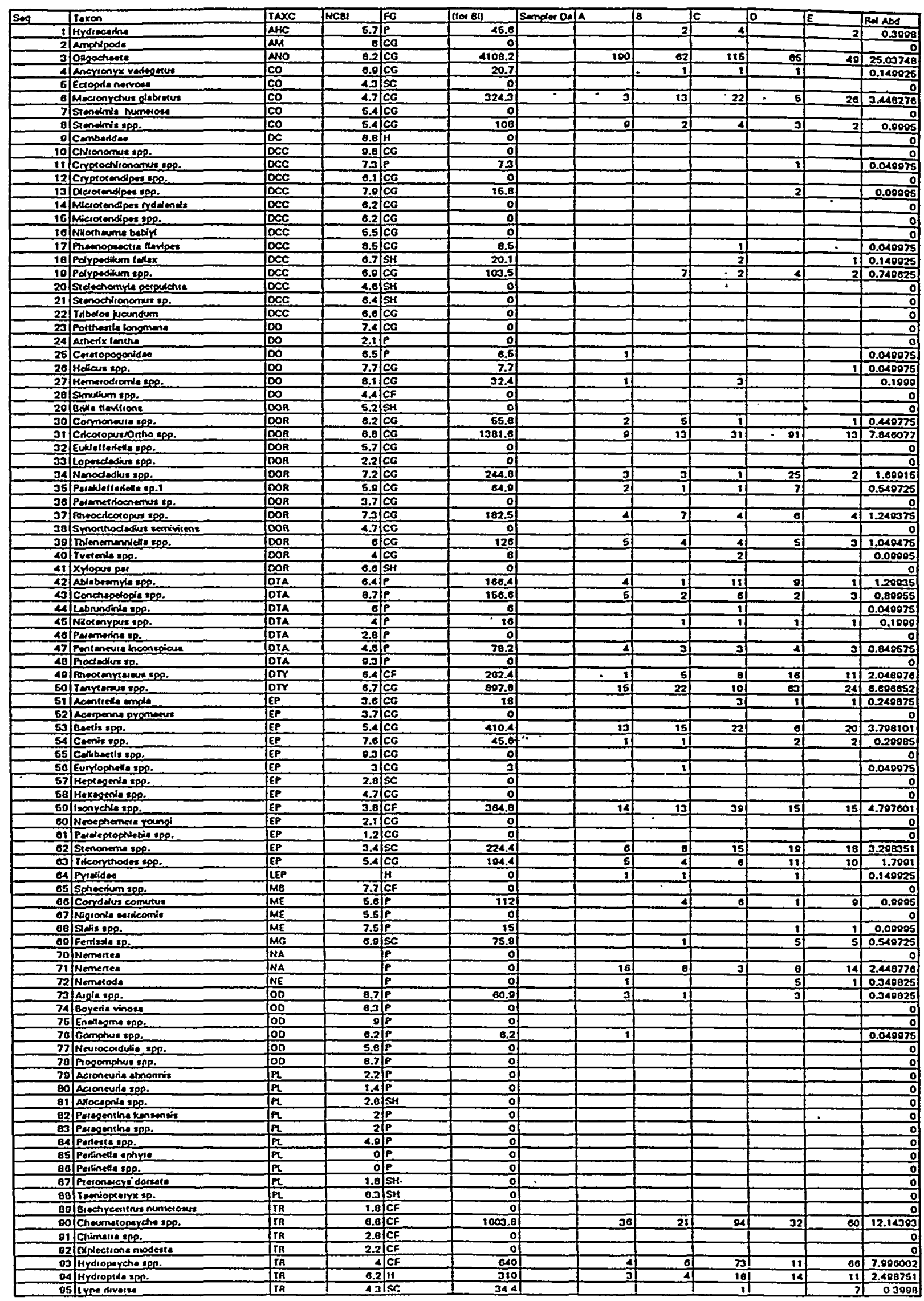




\begin{tabular}{|c|c|c|c|c|c|c|c|c|c|c|c|c|}
\hline 00 & 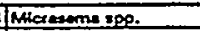 & $\pi$ & 0.0 & SSH & 0 & & & & & & & 0 \\
\hline 97 & Nocto prycthe exguidite & $T$ & 1.2 & SH & 20.4 & & & 1 & 1 & $\mathbf{5}$ & & $\frac{0}{0.240025}$ \\
\hline 9 & Nectoperyche spe. & TTR & 4.1 & SH & 0 & & & & & & & 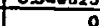 \\
\hline 09 & Neriodipelis spe. & $m$ & 4.4 & CF & 13.2 & & 2 & & 1 & & & 0.140025 \\
\hline 100 & Nratophydex sep. & IT & 0.0 & CF & 0 & & & & & & & 0.100000 \\
\hline 201 & ócella spo. & TA & 5.6 & P & 35 & & 1 & t & 1 & $\mathbf{3}$ & & 0.20006 \\
\hline 102 & Podreontiopue spp. & T & 3.5 & CF & 17.6 & - & & a) & & & $\overline{2}$ & 0.240075 \\
\hline 103 & Turbelferen & ITo & 7.5 & & 30 & & 3 & & & & 1 & 0.1000 \\
\hline
\end{tabular}


Station 13. Pen Branch at Road A. 21 September 1994

\begin{tabular}{|c|c|c|c|c|c|c|c|c|}
\hline & Table size: & 103 & Total orgs: & 2001 & Tot Tax: & 51 & tot. mean \# & 2235.754 \\
\hline & Number Samps: & 5 & SC/CF: & 0.15510949 & Bio Index: & 6.330585 & & \\
\hline & Mean TAX/Samp & 35 & & & & & & \\
\hline & EPT: & 15 & & & & & & \\
\hline \multicolumn{2}{|c|}{ Statistical Summary: } & & & & & Taxon & & $\cdot$ \\
\hline TAXC & $F G$ & \#Taxa & Total \# & Mean/Samp & mean $H / m^{\wedge} 2$ & Rel Abd. & \multicolumn{2}{|l|}{ FG Rel. Abd } \\
\hline $\mathrm{AHC}$ & & 1 & 8 & $\begin{array}{r}1.6 \\
\end{array}$ & 8.9385 & .3998 & & \\
\hline$A M$ & & 0 & 0 &. &. &. & & \\
\hline ANO & & 1 & 501 & 100.2 & 559.7765 & 25.0375 & & \\
\hline $\mathrm{CO}$ & & 3 & 92 & 18.4 & 102.7933 & 4.5977 & & \\
\hline$D C$ & & 0 & 0 &. &. &. & & \\
\hline DCC & & 5 & 22 & 4.4 & 24.581 & 1.0995 & & \\
\hline DD & & 0 & 0 &. &. & & & \\
\hline DO & & 3 & 6 & 1.2 & 6.7039 & .2999 & & \\
\hline DOR & & 7 & 259 & 51.8 & 289.3855 & 12.9435 & & \\
\hline DTA & & 5 & 66 & 13.2 & 73.743 & 3.2984 & & \\
\hline DTY & & 2 & 175 & 35. & 195.5307 & 8.7456 & & \\
\hline EP & & 7 & 286 & 57.2 & 319.5531 & 14.2929 & & \\
\hline LEP & & 1 & 3 & .6 & 3.352 & .1499 & & \\
\hline $\mathrm{MB}$ & $\therefore$ & ii 0 & 0 &. & & & & \\
\hline$M E$ & & $\therefore 2$ & 22 & 4.4 & 24.581 & 1.0995 & & \\
\hline$\overline{M G}$ & & 1 & 11 & 2.2 & 12.2905 & .5497 & & \\
\hline $\mathrm{NA}$ & & 1 & 49 & 9.8 & 54.7486 & 2.4488 & & \\
\hline NE & & $\therefore 1$ & 7 & 1.4 & 7.8212 & .3498 & & \\
\hline$O D$ & 1 & 2 & 8 & 1.6 & 8.9385 & .3998 & & \\
\hline PL & & 0 & 0 &. & . & & & \\
\hline TR & & 8 & 482 & 96.4 & 538.5475 & 24.088 & & \\
\hline \multirow[t]{7}{*}{ TU } & & 1 & 4 & .8 & 4.4693 & .1999 & & \\
\hline & $P$ & 16 & 172 & 34.4 & 192.1788 & & 8.595702 & \\
\hline & CG & 22 & 1133 & 226.6 & 1265.9218 & & 56.62169 & \\
\hline & SC & 3 & 85 & 17. & 94.9721 & & 4.247876 & \\
\hline & $\mathrm{H}$ & 2 & 53 & 10.6 & 59.2179 & & 2.648676 & \\
\hline & $\mathrm{SH}$ & 2 & 10 & 2. & 11.1732 & & 0.49975 & \\
\hline & $\mathrm{CF}$ & 6 & 548 & 109.6 & 612.290503 & & 27.38631 & \\
\hline
\end{tabular}




\begin{tabular}{|l|}
\hline Taxa List: \\
\hline Hydracarina \\
\hline Oligochaeta \\
\hline Ancyronyx variegatus \\
\hline Macronychus glabratus \\
\hline Stenelmis spp. \\
\hline Cryptochironomus spp. \\
\hline Dicrotendipes spp. \\
\hline Phaenopsectra flavipes \\
\hline Polypedilum fallax \\
\hline Polypedilum spp. \\
\hline Ceratopogonidae \\
\hline Helicus spp. \\
\hline Hemerodromia spp. \\
\hline Corynoneura spp. \\
\hline Cricotopus/Ortho spp. \\
\hline Nanocladius spp. \\
\hline Parakiefferiella sp.1 \\
\hline Rheocricotopus spp. \\
\hline Thienemanniella spp. \\
\hline Tvetenia spp. \\
\hline Ablabesmyia spp. \\
\hline Conchapelopia spp. \\
\hline Labrundinia spp. \\
\hline Nilotanypus spp. \\
\hline Pentaneura inconspicua \\
\hline Rheotanytarsus spp. \\
\hline Tanytarsus spp. \\
\hline Acentrella ampla \\
\hline Baetis spp. \\
\hline Caenis spp. \\
\hline Eurylophella spp. \\
\hline Isonychia spp. \\
\hline Stenonema spp. \\
\hline Tricorythodes spp. \\
\hline Pyralidae \\
\hline Corydalus cornutus \\
\hline Sialis spp. \\
\hline Ferrissia sp. \\
\hline Nemertea \\
\hline Nematoda \\
\hline Argia spp. \\
\hline Gomphus spp. \\
\hline Heureumatopsyche spp. \\
\hline Hydropsyche spp. \\
\hline
\end{tabular}


Oecetis spp.

Polycentropus spp.

Turbellaria

F. : 
Station 13. Pon Branch at Road A. 21 Soptember 1994

\begin{tabular}{|c|c|c|c|c|c|c|c|c|c|c|c|c|}
\hline Seg & Taxon & TTAXC & NCBI & FG & {$[($ for $\mathrm{Bl})$} & Sampler Da & A & B & C & D & $E$ & Rol Abd \\
\hline & Oligochaota & ANO & 8.2 & & 4108.2 & & 190 & 82 & 115 & 85 & 49 & 25.03748 \\
\hline 2 & Choumatopsycho spp. & $T R$ & 8.8 & CF & 1603.8 & & 30 & 21 & 94 & 32 & 60 & 12.14393 \\
\hline 3 & Hydropsycho spp. & $T A$ & & CF & 640 & & 4 & $\theta$ & 73 & 11 & 66 & 7.996002 \\
\hline 4 & Cricotopus/Ortho spp. & DOR & 8.8 & $C Q$ & 1381.6 & & 9 & 13 & 31 & 91 & 13 & 7.840077 \\
\hline 5 & Tanytarsus spp. & DTY & 6.7 & CG & 897.8 & & 15 & 22 & 10 & 83 & $24 \mid$ & 0.690052 \\
\hline
\end{tabular}




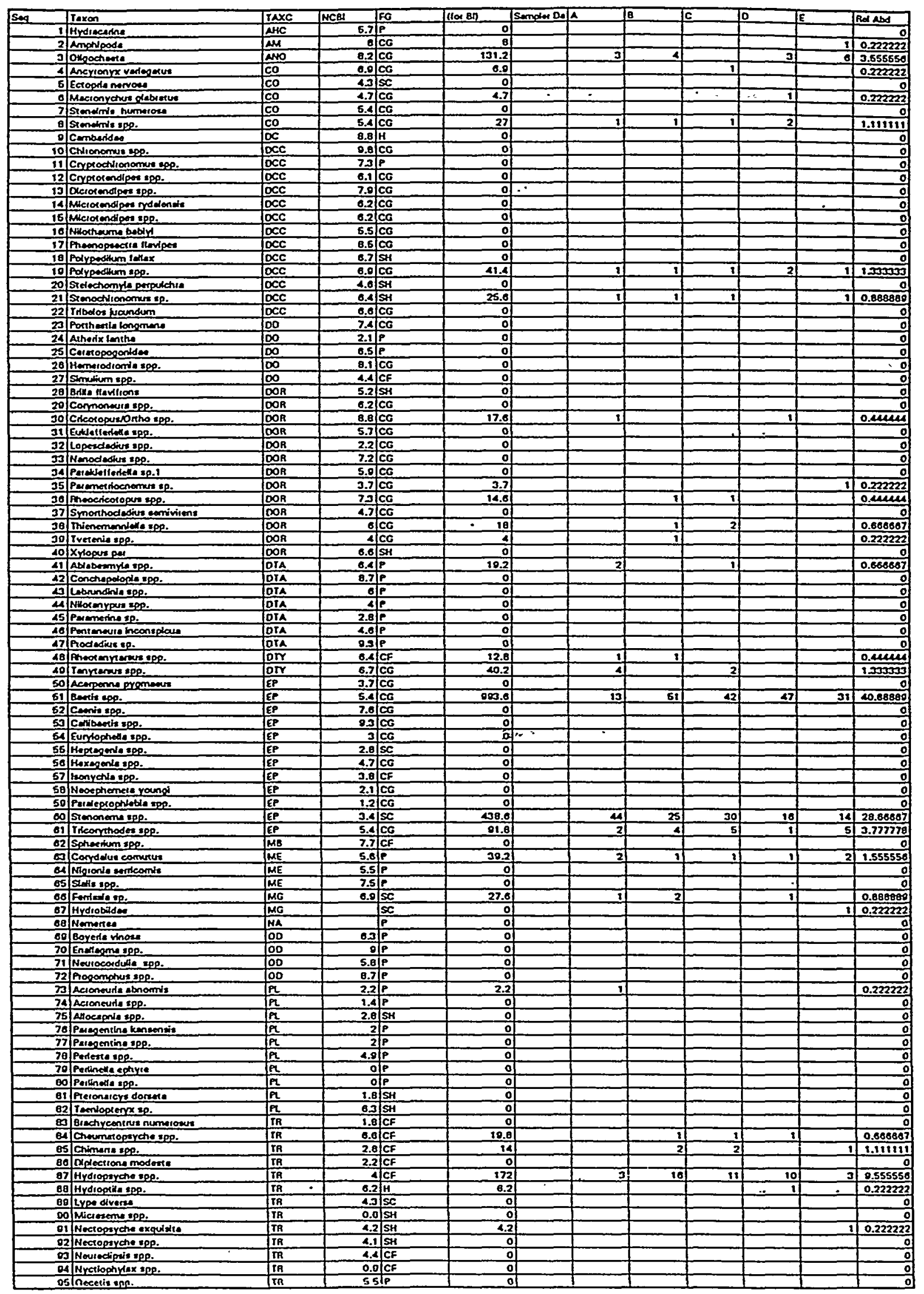



1

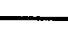

$1+1-1+0$


Station 14. Beaver Dam Creek at metal walkway. 21 September 1994

\begin{tabular}{|c|c|c|c|c|c|c|c|c|}
\hline & Table size: & 96 & Total orgs: & 450 & Tot Tax: & 27 & tot. mean \#I & 502.7933 \\
\hline & Number Samps: & 5 & SC/CF: & 2.52830189 & Bio Index: & 4.853556 & & \\
\hline & Mean TAX/Samp & 14.4 & & & & & & \\
\hline & EPT: & 9 & & & & & & \\
\hline \multicolumn{2}{|c|}{ Statistical Summary: } & & & & & Taxon & & \\
\hline TAXC & $F G$ & \#Taxa & Total \# & Mean/Samp & mean $\# / \mathrm{m}^{\wedge} 2$ & Rel Abd. & FG Rel. Abd & \\
\hline $\mathrm{AHC}$ & & 0 & 0 &.$\quad$. &. & . & & \\
\hline AM & & 1 & 1 & .2 & 1.1173 & .2222 & & \\
\hline ANO & & 1 & 16 & 3.2 & 17.8771 & 3.5556 & & \\
\hline $\mathrm{CO}$ & & 3 & 7 & 1.4 & 7.8212 & 1.5556 & & \\
\hline$D C$ & & 0 & 0 &. &. &. & & \\
\hline DCC & & 2 & 10 & 2. & 11.1732 & 2.2222 & & \\
\hline DD & & 0 & 0 &. &. &. & & \\
\hline DO & & 0 & 0 &. &. & . & & \\
\hline DOR & & 5 & 9 & 1.8 & 10.0559 & 2. & & \\
\hline DTA & & 1 & 3 & .6 & 3.352 & .6667 & & \\
\hline DTY & & 2 & 8 & 1.6 & 8.9385 & 1.7778 & & \\
\hline EP & & 3 & 330 & 66. & 368.7151 & 73.3333 & & \\
\hline $\mathrm{MB}$ & & 0 & 0 &. &. & & & \\
\hline $\mathrm{ME}$ & & 1 & 7 & 1.4 & 7.8212 & 1.5556 & & \\
\hline MG & & 2 & 5 & 1. & 5.5866 & 1.1111 & . & \\
\hline NA & & 0 & 0 &. &. &. & $\cdot$ & \\
\hline OD & 1 & 0 & 0 &. &. &. & $\cdot$ & \\
\hline $\mathrm{PL}$ & & 1 & 1 & .2 & 1.1173 & .2222 & & \\
\hline \multirow[t]{7}{*}{ TR } & & 5 & 53 & 10.6 & 59.2179 & 11.7778 & & \\
\hline & $\mathrm{P}$ & 3 & 11 & 2.2 & 12.2905 & & 2.4444444 & \\
\hline & $\mathrm{CG}$ & 14 & 246 & 49.2 & 274.8603 & & 54.666667 & \\
\hline & SC & 3 & 134 & 26.8 & 149.7207 & & 29.777778 & \\
\hline & $\mathrm{H}$ & 1 & 1 & .2 & 1.1173 & & 0.2222222 & \\
\hline & $\mathrm{SH}$ & 2 & 5 & 1. & 5.5866 & & 1.1111111 & \\
\hline & $C F$ & 4 & 53 & 10.6 & 59.2178771 & & 11.777778 & \\
\hline
\end{tabular}


Station 14. Beaver Dam Creek at metal walkway. 21 September 1994

\begin{tabular}{|l|}
\hline Taxa List: \\
\hline Amphipoda \\
\hline Oligochaeta \\
\hline Ancyronyx variegatus \\
\hline Macronychus glabratus \\
\hline Steneimis spp. \\
\hline Polypedilum spp. \\
\hline Stenochironomus sp. \\
\hline Cricotopus/Ortho spp. \\
\hline Parametriocnemus sp. \\
\hline Rheocricotopus spp. \\
\hline Thienemanniella spp. \\
\hline Tvetenia spp. \\
\hline Ablabesmyia spp. \\
\hline Rheotanytarsus spp. \\
\hline Tanytarsus spp. \\
\hline Baetis spp. \\
\hline Stenonema spp. \\
\hline Tricorythodes spp. \\
\hline Corydalus cornutus \\
\hline Ferrissia sp. \\
\hline Hydrobiidae \\
\hline Acroneuria abnormis \\
\hline Cheumatopsyche spp. \\
\hline Chimarra spp. \\
\hline Hydropsyche spp. \\
\hline Hydroptila spp. \\
\hline Nectopsyche exquisita \\
\hline
\end{tabular}


Station 14. Boavor Dam Crook at motal walkway, 21 Soptembor 1994

\begin{tabular}{|c|c|c|c|c|c|c|c|c|c|c|c|}
\hline Seq & Toxon. & TAXC & NCBI & (for Bl) & Samplor Do & A & $B$ & C & D & $E$ & Rol Abd \\
\hline & Baotis spp. & EP & 5.4 CG & 993.6 & & 13. & 51 & 42 & 47 & 31 & 40.88889 \\
\hline 2 & Stenonema spp. & EP & $3.4 \mathrm{SC}$ & 438.8 & & 44 & 25 & 30 & 96 & 14 & 28.68687 \\
\hline & Hydropsycho spp. & TTR & 4 CF & 172 & & 3 & 16 & 11 & 10 & 3 & 9.555556 \\
\hline
\end{tabular}




\begin{tabular}{|c|c|c|}
\hline $\operatorname{sen}$ & Texon & $\operatorname{Traxc}$ \\
\hline & Hroteacentine & aHC \\
\hline 2 & Anptipoode & AMS \\
\hline & OFocotume & ANO \\
\hline 4 & Anepronyx vedogerus: & $\infty$ \\
\hline 5) & Ectoporte nervose & co \\
\hline -1 & Mecronychuse oleberture & co \\
\hline 가 & I sionednle mumeroen & co \\
\hline 6) & Srendentespe. & co \\
\hline of & Combenderen & $D C$ \\
\hline 10 & Crilonomint tpe. & Doce \\
\hline 11 & Comprochlionomers spp. & IDCC \\
\hline 12 & Cryptorantipasepp. & Doce \\
\hline 13 & Decormotipen igp. & DOCC \\
\hline 14 & 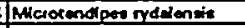 & DCC \\
\hline 15. & perecrotendipes spp. & Doce \\
\hline 18) & Ninorherme bebly & loce \\
\hline 17) & Itheenopectil Heviper & $D C C$ \\
\hline 28 & Folypedem felex & toce \\
\hline 10 & Folyodium spo. & Joce \\
\hline 201 & I sidectiomple perpedechis & DOCC \\
\hline 29 & Srenoctionomus ep. & DCC \\
\hline 22 & Tribed os pandum & DOCC \\
\hline 231 & Porthertle fongomente & 100 \\
\hline 24 & Tathorix Lenthe & 100 \\
\hline 25 & Cerstoperonddere & 100 \\
\hline 26 & Hermerodionie spo. & 100 \\
\hline 27 & Simufium spp. & $\infty$ \\
\hline 28 & Brite flevilions & Joon \\
\hline 201 & Commonourte spp. & DOA \\
\hline 301 & Ifiteolopusfortho sge. & DOR \\
\hline 311 & Eukbillotede sog. & IDOR \\
\hline 32 & Lopadediure spp. & Don \\
\hline 3 & Nenodedien spo. & DOR \\
\hline 34 & 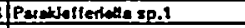 & IDOR \\
\hline 35 & Fumetiocnomen ip. & DOA \\
\hline 38 & 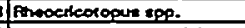 & DOR \\
\hline 37 & Ismorhodedivs senivitens & DOR \\
\hline 38 & Inienemmencielespp. & JDAR \\
\hline 391 & ITretonie spe. & JOR \\
\hline 401 & xpropus per & DOR \\
\hline 411 & Ablaberinglo spp. & IDIA \\
\hline 42 & Conchesopie spe. & Jora \\
\hline 4 & Leorunoinia spp. & JoTA \\
\hline 44 & Milorenyenz zpp. & Dia \\
\hline 45 & Premorine sp. & Dia \\
\hline 40 & Punteneure inconspiare & fora \\
\hline 47 & Prodedturs ip. & Dia \\
\hline 49 & Pheoxenrerese spo. & forr \\
\hline 40 & Tienrement spe. & DTr \\
\hline EO & 1 Acorpenne propreans & JEP \\
\hline 51 & | Bantis zog. & EF \\
\hline 52 & Cents spe. & EP \\
\hline 53 & Cortiberts spp. & IEP \\
\hline 5 & Eundophede spp. & EP \\
\hline 55 & Hegeregonie spe. & EP \\
\hline 50 & Hexeoendespo. & EP \\
\hline 57 & tronychio spo. & EP \\
\hline 58 & Nooephernete roungi & EP \\
\hline 50 & Perdepropthbie spe. & EP \\
\hline$\infty$ & Sernerefls defliens & IEP \\
\hline a1: & Sienoneme spp. & EPP \\
\hline 02) & Iriconthoden sep. & EP \\
\hline Q3) & Hydie & HirY \\
\hline 64 & ISphoriven spp. & Ms \\
\hline 65 & Soryderit compertus & $M E$ \\
\hline 08 & 3 Nigronie senticonts & $M E$ \\
\hline 67 & 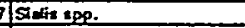 & ME \\
\hline 68 & Jernissie xp. & Mo \\
\hline og & I Nermeries & NA \\
\hline 70 & Nomertes & NA \\
\hline 71 & Nemerods & NNE \\
\hline 72 & 2) ANois spp. & lon \\
\hline 73 & 3 Boyeris vhoes: & 100 \\
\hline 74 & IEneiterme spp. & 100 \\
\hline 75 & 5 |Meciorris spp. & 100 \\
\hline 78 & g) Neurocordute spp. & Ton \\
\hline 27 & 7 Progompters app. & 100 \\
\hline 78 & B) Acronevunie ebnormis & 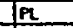 \\
\hline 79 & 9/Acroneurie spg. & Ip \\
\hline 80. & of Aloceponis spe. & $P_{2}$ \\
\hline 81 & IT Peieomtin knemis & PL \\
\hline 82 & 2 Peregentine spp. & $\overline{F L}$ \\
\hline Bo & 3) Penteres app. & $P_{2}$ \\
\hline B4 & 4 Perfinete ophyie: & $P L$ \\
\hline 85 & 5 Pertrinetie spp. & PL \\
\hline 88 & efferonereys doreate & $\mathbf{P L}$ \\
\hline 87 & \begin{tabular}{l|l} 
Imeniopiery sp. \\
\end{tabular} & $\bar{P}$ \\
\hline B日 & B) Brectrycentinn numberours & IR \\
\hline 89 & 9) Choumulopsycthe spp. & IR \\
\hline$\infty$ & of Chimerne spp. & In \\
\hline 91 & 1 Oiplectione nxodate & IR \\
\hline 92 & 2 Hydiopayctio $1 \mathrm{pp}$. & IR \\
\hline$\infty$ & 3 Hydiogkte spp. & $7 \pi$ \\
\hline os & A tree diverne & IR \\
\hline 95 & St Mictmberns $3 \mathrm{pP}$. & ITR \\
\hline
\end{tabular}




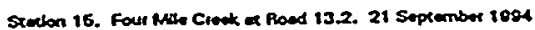

\begin{tabular}{|c|c|c|c|c|c|c|c|c|c|c|c|c|}
\hline$\infty$ & Hectoperyche erouctete & TR & 4.2 & & 40.2 & & 3 & 2 & i) & 2 & 3 & 0.007312 \\
\hline 07 & Nectopenche spp. & TA & 4.1 & SH & of & & & & & & & 0 \\
\hline 08 & Meuloctlpis spo. & $\pi$ & 4.4 & CF & 8.0 & & & If & & & 1 & 0.116876 \\
\hline 00 & Nrectophylex seg. & $\mathbf{T R}$ & 0.0 & CF & 0 & & & & & & & 0 \\
\hline 100 & Oecotis spp. & TR & 5.5 & $\mathbf{P}$ & 77 & & 5) & 4) & 3 & 1 & 1 & 0.811124 \\
\hline 101 & Oxyethlis spe. & Tra & 0.2 & $\mathbf{H}$ & 0.3 & & & 1 & & & & 0.057937 \\
\hline 102 & Podremitiopue spo. & TrR & 3.5 & CF & 7 & & & & 1 & 1 & & 0.116875 \\
\hline 109 & Tuctokerdo & ru & 7.5 & $\mathbf{P}$ & 30 & & 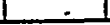 & 3) & 11 & & & 0.23175 \\
\hline
\end{tabular}
Tos Tutherente

ru

$\approx$. 
Station 15. Four Mile Creek at Road 13.2. 21 September 1994

\begin{tabular}{|c|c|c|c|c|c|c|c|c|}
\hline & Table size: & 103 & Total orgs: & 1726 & Tot Tax: & 48 & tot. mean \#l & 1928.492 \\
\hline & Number Samps: & 5 & SC/CF: & 1.10569106 & Bio Index: & 5.553244 & & \\
\hline & Mean TAX/Samp & 30.6 & & & & & & \\
\hline & EPT: & 17 & & & & & & \\
\hline \multicolumn{2}{|c|}{ Statistical Summary: } & & & & & Taxon & & \\
\hline TAXC & $F G$ & \#Taxa & Total \# & Mean/Samp & mean \#/m^2 & Rel Abd. & FG Rel. Abd & \\
\hline $\mathrm{AHC}$ & & 1 & 9 & 1.8 & 10.0559 & \begin{tabular}{|r|}
.5214 \\
\end{tabular} & & \\
\hline$\overline{A M}$ & & 의 & 0 & & & & & \\
\hline ANO & & 1 & 81 & 16.2 & 90.5028 & 4.6929 & & \\
\hline $\mathrm{CO}$ & & 2 & 34 & 6.8 & 37.9888 & 1.9699 & & \\
\hline DC & & 요 & 0 & . & 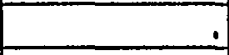 & & & \\
\hline$D C C$ & & 3 & 67 & 13.4 & 74.8603 & 3.8818 & & \\
\hline$D D$ & & of & 0 & & & & & \\
\hline DO & & 3 & 9 & 1.8 & 10.0559 & .5214 & & \\
\hline DOR & & 6 & 69 & 13.8 & 77.095 & 3.9977 & & \\
\hline DTA & & 6 & 34 & 18.8 & 105.0279 & 5.4461 & & \\
\hline DTY & & 2 & 344 & 68.8 & 384.3575 & 19.9305 & & \\
\hline$E P$ & & 6 & 771 & 154.2 & 861.4525 & 44.6698 & & \\
\hline HY & & 1 & 1 & .2 & 1.1173 & .0579 & & \\
\hline$M B$ & & 의 & 요 & $\ldots$ & & & & \\
\hline $\mathrm{ME}$ & & 1 & 1 & .2 & 1.1173 & .0579 & & \\
\hline$M G$ & & 요 & 0 &. & &. & & \\
\hline$\overline{N A}$ & & 1 & 14 & 2.8 & 15.6425 & .8111 & & \\
\hline $\mathrm{NE}$ & & 1 & 2 & .4 & 2.2346 & .1159 & & \\
\hline$\overline{O D}$ & & 2 & 5 & 1. & 5.5866 & .2897 & & \\
\hline $\mathrm{PL}$ & & 2 & 3 & .6 & 3.352 & .1738 & & \\
\hline TR & & 9 & 218 & 43.6 & 243.5754 & 12.6304 & & \\
\hline \multirow[t]{7}{*}{$\mathrm{TU}$} & & 1 & 4 & .8 & 4.4693 & .2317 & & \\
\hline & $P$ & 18 & 150 & 30. & 167.5978 & & 8.6906141 & \\
\hline & $\mathrm{CG}$ & 17 & 966 & 193.2 & 1079.3296 & & 55.967555 & \\
\hline & SC & 2 & 272 & 54.4 & 303.9106 & & 15.75898 & \\
\hline & $\mathrm{H}$ & 2 & 75 & 15. & 83.7989 & & 4.3453071 & \\
\hline & $\mathrm{SH}$ & 2 & 17 & 3.4 & 18.9944 & & 0.9849363 & \\
\hline & $\mathrm{CF}$ & $7 \mid$ & 246 & 49.2 & 274.860335 & & 14.252607 & \\
\hline
\end{tabular}




\begin{tabular}{|l|}
\hline Taxa List: \\
\hline Hydracarina \\
\hline Oligochaeta \\
\hline Macronychus glabratus \\
\hline Stenelmis spp. \\
\hline Dicrotendipes spp. \\
\hline Polypedilum fallax \\
\hline Polypedilum spp. \\
\hline Ceratopogonidae \\
\hline Hemerodromia spp. \\
\hline Simulium spp. \\
\hline Corynaneura spp. \\
\hline Cricotopus/Ortho spp. \\
\hline Nanocladius spp. \\
\hline Parakiefferiella sp.1 \\
\hline Rheocricotopus spp. \\
\hline Thienemanniella spp. \\
\hline Ablabesmyia spp. \\
\hline Conchapelopia spp. \\
\hline Labrundinia spp. \\
\hline Nilotanypus spp. \\
\hline Paramerina sp. \\
\hline Pentaneura inconspicua \\
\hline Rheotanytarsus spp. \\
\hline Tanytarsus spp. \\
\hline Baetis spp. \\
\hline Eurylophella spp. \\
\hline Isonychia spp. \\
\hline Serratella deficiens \\
\hline Stenonema spp. \\
\hline Tricorythodes spp. \\
\hline Hydra \\
\hline Corydalus cornutus \\
\hline Nemertea \\
\hline Nematoda \\
\hline Argia spp. \\
\hline Macromia spp. \\
\hline Acroneuria spp. \\
\hline Perlesta spp. \\
\hline Cheumatopsyche spp. \\
\hline Oectropsychetis spp. \\
\hline Polycentropus spp. \\
\hline
\end{tabular}


Station 15. Four Mile Creek at Road 13.2. 21 September 1994

\begin{tabular}{|c|c|c|c|c|c|c|c|c|c|c|c|}
\hline $\operatorname{seg}$ & Taxon & TAXC & $\mathrm{NCBI}$ & FG & (for Bl) & Sampler Da A & $B$ & C & D & $E$ & Rel Abd \\
\hline 1 & Baotis spp. & EP & 5.4 & CG & 1728 & 18 & 113 & 113 & 48 & 30 & 18.53998 \\
\hline 2 & Tanytarsus spp. & DTY & 0.7 & CG & 2010 & 21 & 30 & 37 & 10 & 202 & 17.38123 \\
\hline 3 & Stenonema spp. & $E P$ & 3.4 & SC & 921.4 & 56 & 80 & 73 & 31 & 31 & 15.70104 \\
\hline & Cheumatopsyche spp. & TR & 8.6 & CF & 627 & 51 & 21 & 15 & 8 & & 5.504056 \\
\hline
\end{tabular}


Rosemary Creek Downstream Williston WWTP, Hester Dendy Data. 17 December 1994

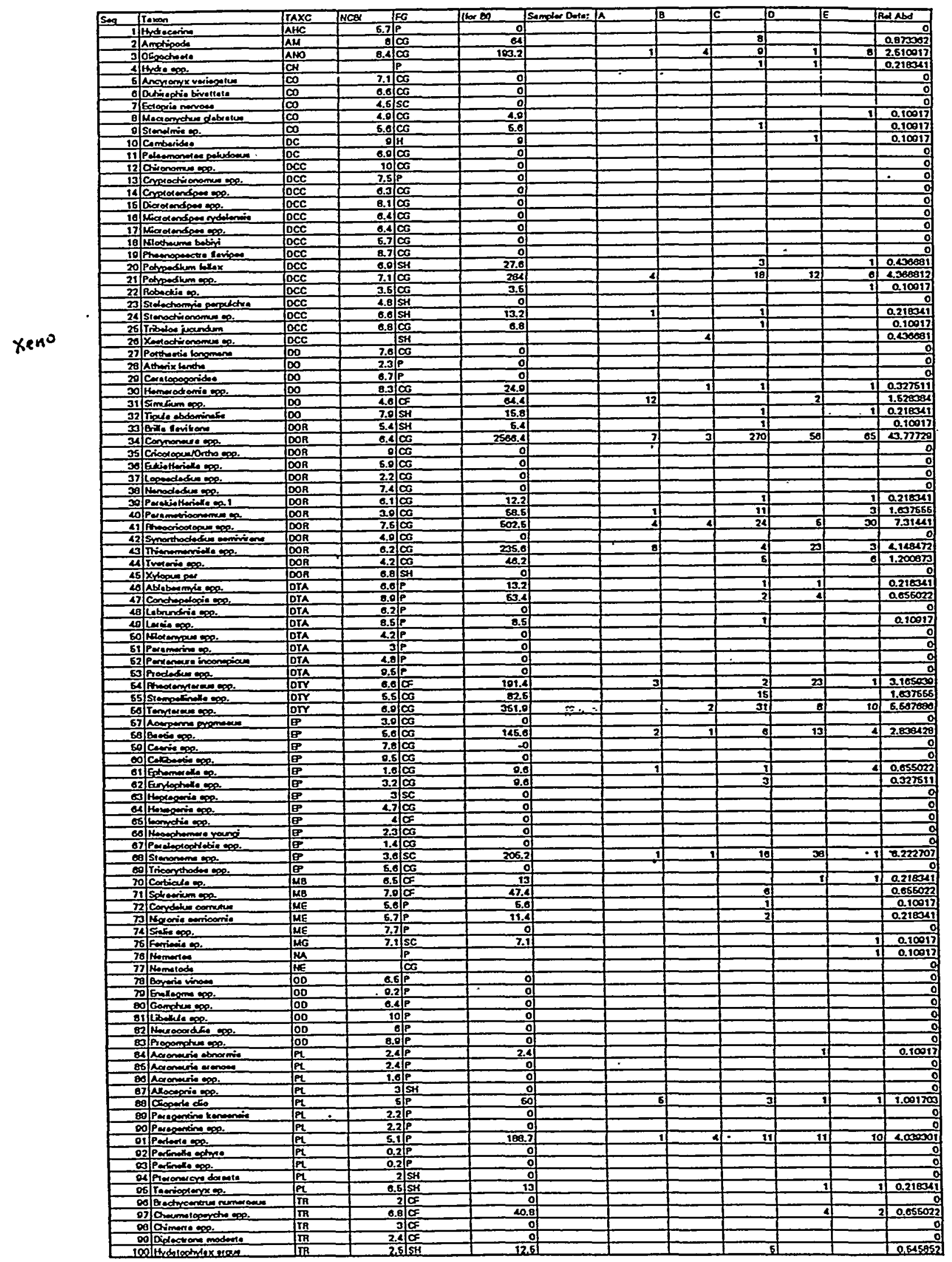


Rosemary Creek Downstream Williston WWTP, Hester Dendy Data. 17 December 1994

\begin{tabular}{|c|c|c|c|c|c|c|c|c|c|c|c|}
\hline 101 & 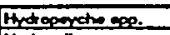 & IR & 1.21 & 0 & & & & & & & \\
\hline & 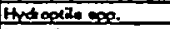 & $\sqrt{18}$ & & & & & & & & & \\
\hline 100 & 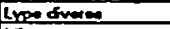 & IR & 4.55 & 1.6 & & & & & & & 0.10017 \\
\hline 104 & Miracenem spe. & 再 & 0.8 & 0 & & & & & & & 0 \\
\hline 105 & Hectogende enidh & $\pi \mathrm{R}$ & 4.4 & 0 & & & & & & & 0 \\
\hline 100 & Hectoperycteos. & IF & 4.3. & 0 & & & & & & & 0 \\
\hline 107 & 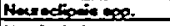 & IR & (.6) & 0 & & & & & & & 0 \\
\hline 108 & 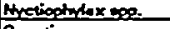 & $\frac{18}{12}$ & 1.11 & 0 & & & & & & & 0 \\
\hline 100 & Desotin pops. & IR & 5.9.1 & - & & & & & & & 0 \\
\hline$\frac{110}{111}$ & 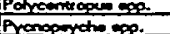 & $\frac{I R}{\pi R}$ & $\frac{3.76}{2.65}$ & $\frac{0}{7.8}$ & & & & & & & 0.32161 \\
\hline 112 & Tubetistit & Inv & $\overline{7 Z 1 F}$ & 0 & & & & & & & 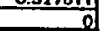 \\
\hline
\end{tabular}

7 IfP 
Rosemary Creek Downstream Williston WWTP, Hester Dendy Data. 17 December 1994

\begin{tabular}{|c|c|c|c|c|c|c|c|c|}
\hline & Table size: & 112 & Total orgs: & 916 & Tot Tax: & 46 & Tot. mean $\# / m^{\wedge} 2:$ & 1023.46 \\
\hline & Number Samps: & 5 & SC/CF: & 1.04 & Bio Index: & 6.18 & & \\
\hline & Mean TAX/Samp: & 20.6 & & & & & & \\
\hline & EPT Index: & 12 & & & & & & \\
\hline & & & & & & & & \\
\hline \multicolumn{2}{|c|}{ Statistical Summary: } & . & & & & Taxon . & & \\
\hline TAXC & & \#Taxa & Total \# & Mean/Samp & Mean $\# / \mathrm{m}^{\wedge} 2$ & Rel Abd. & & \\
\hline AHC & & 0 & 0 & 0.00 & 0.00 & 0.00 & & \\
\hline$A M$ & & 1 & 8 & 1.60 & 8.94 & 0.87 & & \\
\hline ANO & & 1 & .23 & 4.60 & 25.70 & 2.51 & & \\
\hline $\mathrm{CN}$ & & 1 & 2 & 0.40 & 2.23 & 0.22 & & \\
\hline $\mathrm{CO}$ & & 2 & 2 & 0.40 & 2.23 & 0.22 & & \\
\hline DC & $\cdot$ & 1 & 1 & 0.20 & 1.12 & 0.11 & $\therefore$ & \\
\hline$D C C$ & & 6 & 52 & 10.40 & 58.10 & 5.68 & & \\
\hline$D D$ & & 0 & 0 & 0.00 & 0.00 & 0.00 & & \\
\hline DO & & 3 & 19 & 3.80 & 21.23 & 2.07 & & \\
\hline DOR & & 7 & 535 & 107.00 & 597.77 & 58.41 & & \\
\hline DTA & & 3 & 9 & 1.80 & 10.06 & 0.98 & & \\
\hline DTY & $\dot{5}$ & 3 & 95 & 19.00 & 106.15 & 10.37 & & \\
\hline$E P$ & & 4 & 92 & 18.40 & 102.79 & 10.04 & & \\
\hline$\overline{M B}$ & & 2 & 8 & 1.60 & 8.94 & 0.87 & & \\
\hline ME & & 2 & 3 & 0.60 & 3.35 & 0.33 & & \\
\hline MG & & 1 & 1 & 0.20 & 1.12 & 0.11 & & \\
\hline NA & & 1 & 1 & 0.20 & 1.12 & 0.11 & & \\
\hline NE & & of & 0 & 0.00 & 0.00 & 0.00 & & \\
\hline$\overline{O D}$ & & of & 0 & 0.00 & 0.00 & 0.00 & & \\
\hline$P L$ & & 4 & 50 & 10.00 & 55.87 & 5.46 & & \\
\hline TR & & 4 & 15 & 3.00 & 16.76 & 1.64 & & \\
\hline \multirow[t]{8}{*}{ TU } & $\therefore$ & 요 & 0 & 0.00 & 0.00 & 0.00 & & \\
\hline & Functional Group & & & & & & FG Rel. Abd. & \\
\hline & CF & 5 & 57 & 11.40 & 63.69 & & 6.88 & \\
\hline & $\mathrm{CG}$ & 19 & 713 & 142.60 & 796.65 & & 77.84 & \\
\hline & $\mathrm{H}$ & 1 & 1 & 0.20 & 1.12 & & 6.44 & \\
\hline & $P$ & 10 & 63 & 12.60 & 70.39 & & 0.11 & . \\
\hline & SC & 3 & 59 & 11.80 & 65.92 & & 2.51 & \\
\hline & SH & 8 & 23 & 4.60 & 25.70 & & 6.22 & \\
\hline
\end{tabular}




\begin{tabular}{|c|}
\hline Taxa List: \\
\hline Amphipoda \\
\hline Oligochaeta \\
\hline Hydra spp. \\
\hline Macronychus glabratus \\
\hline Stenelmis sp. \\
\hline Cambaridae \\
\hline Polypedilum fallax \\
\hline Polypedilum spp. \\
\hline Robackia sp. \\
\hline Stenochironomus sp. \\
\hline Tribelos jucundum \\
\hline Xestochironomus sp. \\
\hline Hemerodromia spp. \\
\hline Simulium spp. \\
\hline Tipula abdominalis \\
\hline Brilla flavifrons \\
\hline Corynoneura spp. \\
\hline Parakiefferiella sp. 1 \\
\hline Parametriocnemus sp. \\
\hline Rheocricotopus spp. \\
\hline Thienemanniella spp. \\
\hline Tvetenia spp. \\
\hline Ablabesmyia spp. \\
\hline Conchapelopia spp. \\
\hline Larsia spp. \\
\hline Rheotanytarsus spp. \\
\hline Stempellinella spp. \\
\hline Tanytarsus spp. \\
\hline Baetis spp. \\
\hline Ephemerella sp. \\
\hline Eurylophella spp. \\
\hline Stenonema spp. \\
\hline Corbicula sp. \\
\hline Splraerium spp. \\
\hline Corydalus cornutus \\
\hline Nigronia serricornis \\
\hline Ferrissia sp. \\
\hline Nemertea \\
\hline Acroneuria abnormis \\
\hline Clioperla clio \\
\hline Perlesta spp. \\
\hline Taeniopteryx sp. \\
\hline Cheumatopsyche spp. \\
\hline Hydatophylax argus \\
\hline Lype diversa \\
\hline Pycnopsyche spp. \\
\hline
\end{tabular}


Rosemary Creek Downstream Williston WWTP, Hester Dendy Data- Dominant Taxa. 17 December 1994

\begin{tabular}{|c|c|c|c|c|c|c|c|c|c|c|c|}
\hline & Trexon & ITAXc & INCEI & Smingler Daces & I스 & Ta & Ic & to & TE & Tordes & TFed Abd \\
\hline-1 & Conmonevita lepe. & Don & $0.4 \mathrm{Cg}$ & & 7 & 3) & 270 & 6e & 65 & 401 & 40.72720 \\
\hline & Pheoctoosopess epe & DOR & $\begin{array}{l}7.5 \mathrm{CG} \\
\end{array}$ & & 4 & (4) & 24 & 6 & 30 & & $7.31 \mathrm{k1}$ \\
\hline 3 & Sremoneme tepe. & EP & $3.65 c$ & & 1 & 1 & 16) & 39] & 3 & & 0.222707 \\
\hline & Tennemers top. & Dorr & B.0.co & & & 2 & 31 & e & 101 & & $15.567 \mathrm{Ee6}$ \\
\hline
\end{tabular}


PART V

$\%$

a. 


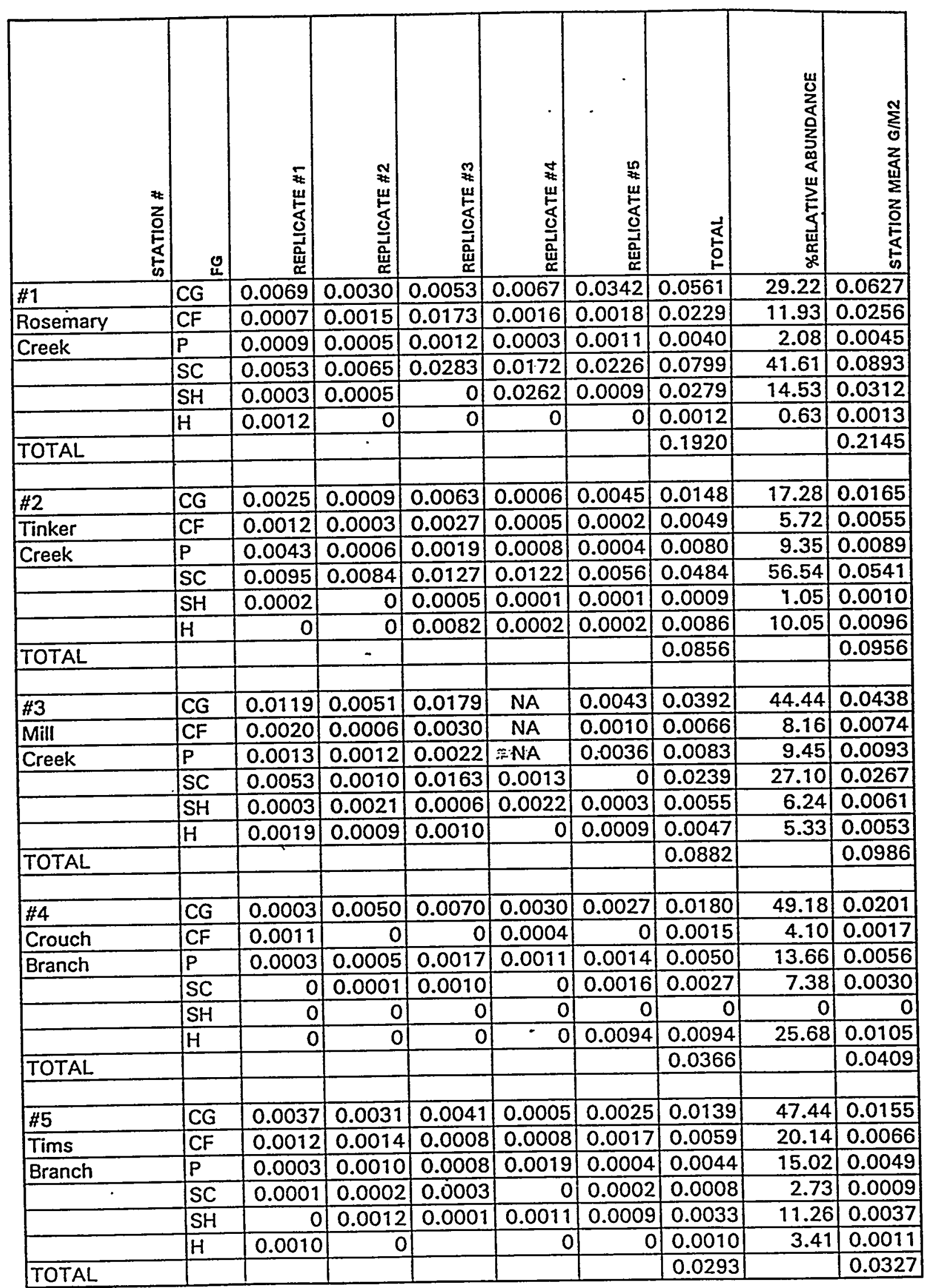

- All measures in grams

$\mathrm{NA}=$ weights less than $0.0001 \mathrm{~g}$. 


\begin{tabular}{|c|c|c|c|c|c|c|c|c|c|}
\hline 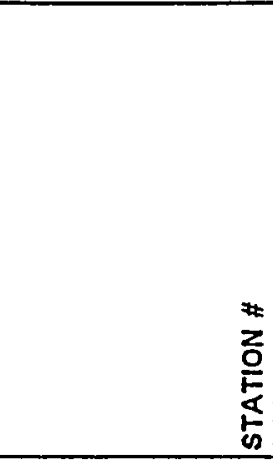 & 인 & 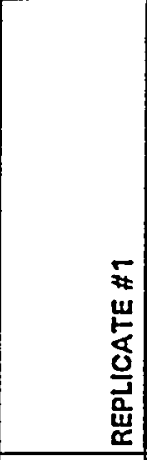 & 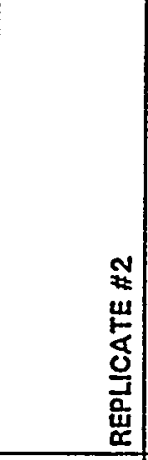 & 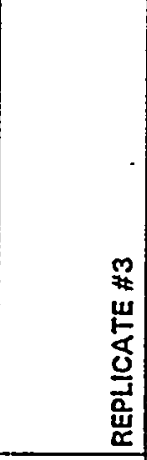 & 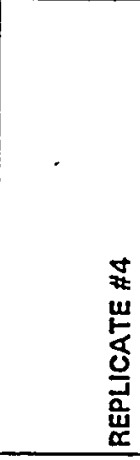 & 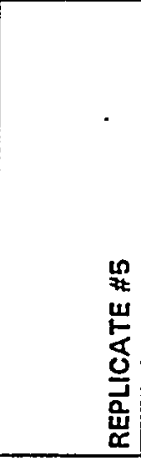 & $\begin{array}{r}\vec{a} \\
\stackrel{5}{\circ} \\
\end{array}$ & 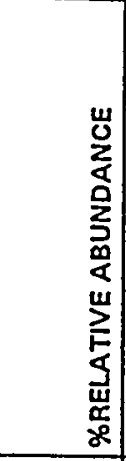 & 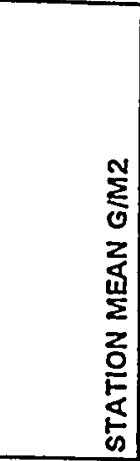 \\
\hline$\# 6$ & CG & 0.0016 & 0.0012 & 0.0003 & 0.0021 & & 0.0052 & 2.35 & 0.0073 \\
\hline Upper Three & CF & 0.0029 & 0.0001 & NA & 0.0021 & & 0.0051 & 2.31 & 0.0071 \\
\hline \multirow[t]{4}{*}{ Runs Creek } & $P$ & 0.0496 & 0.0142 & 0.1238 & 0.0100 & & 0.1976 & 89.33 & 0.2760 \\
\hline & SC & 0.0033 & 0.0048 & 0.0010 & 0.0004 & & 0.0095 & 4.29 & 0.0133 \\
\hline & $\mathrm{SH}$ & 0.0004 & 0 & 0.0001 & 0.0033 & & 0.0038 & 1.72 & 0.0053 \\
\hline & $\mathrm{H}$ & 0 & 0 & 0 & 0 & & 0 & 0 & 0 \\
\hline \multirow[t]{2}{*}{ TOTAL } & & & & & & & 0.2212 & & 0.3090 \\
\hline & & & & & & & & & \\
\hline$\# 7$ & CG & 0.0105 & 0.0067 & 0.0058 & 0.0020 & 0.0136 & 0.0386 & 47.71 & 0.0431 \\
\hline Four Mile & CF & 0.0015 & 0.0007 & 0.0005 & 0.0002 & 0.0006 & 0.0035 & 4.33 & 0.0039 \\
\hline \multirow[t]{4}{*}{ Cr. @ Rd. C } & $P$ & 0.0056 & 0.0072 & 0.0073 & 0.0055 & 0.0030 & 0.0286 & 35.35 & 0.0320 \\
\hline & SC & 0.0038 & 0.0009 & 0.0002 & 0 & 0.0003 & 0.0052 & 6.43 & 0.0058 \\
\hline & $\mathrm{SH}$ & 0 & 0 & NA & 0.0028 & 0 & 0.0028 & 3.46 & 0.0031 \\
\hline & $H$ & 0.0008 & 0.0014 & 0 & 0 & 0 & 0.0022 & 2.72 & 0.0025 \\
\hline \multirow[t]{2}{*}{ TOTAL } & & & - & & & & 0.0809 & & 0.0904 \\
\hline & & & & & & & & & \\
\hline$\# 8$ & $\mathrm{CG}$ & 0.0026 & 0.0023 & 0.0017 & 0.0026 & 0.0030 & 0.0122 & 40.53 & 0.0136 \\
\hline Pen Branch @ & $\mathrm{CF}$ & 0.0004 & 0.0002 & 0.0005 & 0.0006 & 0.0009 & 0.0026 & 8.64 & 0.0029 \\
\hline \multirow[t]{4}{*}{ Rd. C } & $P$ & 0.0004 & 0.0008 & $0 \% 0004$ & 0.0003 & 0.0007 & 0.0026 & 8.64 & 0.0029 \\
\hline & SC & 0.0028 & 0 & 0.0012 & 0.0019 & 0.0042 & 0.0101 & 33.55 & 0.0113 \\
\hline & $\mathrm{SH}$ & 0.0003 & 0.0019 & 0 & 0.0004 & 0 & 0.0026 & 8.64 & 0.0029 \\
\hline & $\mathrm{H}$ & 0 & 0 & 0 & 0 & 0 & 0 & 0 & 0 \\
\hline \multirow[t]{2}{*}{ TOTAL } & & & & & & & 0.0301 & & 0.0336 \\
\hline & & & & & & & & & \\
\hline$\# 9$ & $\mathrm{CG}$ & 0.0033 & 0.0061 & 0.0045 & 0.0024 & 0.0035 & 0.0198 & 20.65 & 0.0221 \\
\hline Meyers & CF & 0.0027 & 0.0016 & 0.0041 & 0.0006 & 0.0082 & 0.0172 & 17.94 & 0.0192 \\
\hline \multirow[t]{4}{*}{ Branch } & $P$ & 0.0007 & 0.0071 & 0.0014 & 0.0058 & 0.0002 & 0.0152 & 15.85 & 0.0170 \\
\hline & SC & 0.0105 & 0.0053 & 0.0109 & 0.0040 & 0.0109 & 0.0416 & 43.38 & 0.0465 \\
\hline & $\mathrm{SH}$ & 0.0004 & 0.0003 & 0.0003 & 0.0005 & 0.0006 & 0.0021 & 2.19 & 0.0023 \\
\hline & $\mathrm{H}$ & 0 & 0 & 0 & 0 & 0 & 0 & 0 & 0 \\
\hline \multirow[t]{2}{*}{ TOTAL } & & & & & & & 0.0959 & & 0.1071 \\
\hline & & & & & & & & & \\
\hline$\# 10$ & CG & 0.0044 & 0.0036 & 0.0041 & 0.0023 & 0.0047 & 0.0191 & 21.08 & 0.0213 \\
\hline Lower Three & CF & 0.0028 & 0.0017 & 0.0008 & 0.0018 & 0.0011 & 0.0082 & 9.05 & 0.0092 \\
\hline \multirow[t]{4}{*}{ Runs Creek } & $P$ & 0.0015 & 0.0017 & 0.0020 & 0.0489 & 0.0083 & 0.0624 & 68.87 & 0.0697 \\
\hline & SC & 0 & NA & 0.0009 & NA & 0 & 0.0009 & 0.99 & 0.0010 \\
\hline & $\mathrm{SH}$ & 0 & 0 & 0 & 0 & 0 & 0 & 0 & 0 \\
\hline & $\mathrm{H}$ & 0 & 0 & 0 & 0 & 0 & 0 & 0 & 0 \\
\hline TOTAL & & & & & & & 0.0906 & & 0.1012 \\
\hline
\end{tabular}

- All measures in grams

$N A=$ weights less than $0.0001 \mathrm{~g}$. 


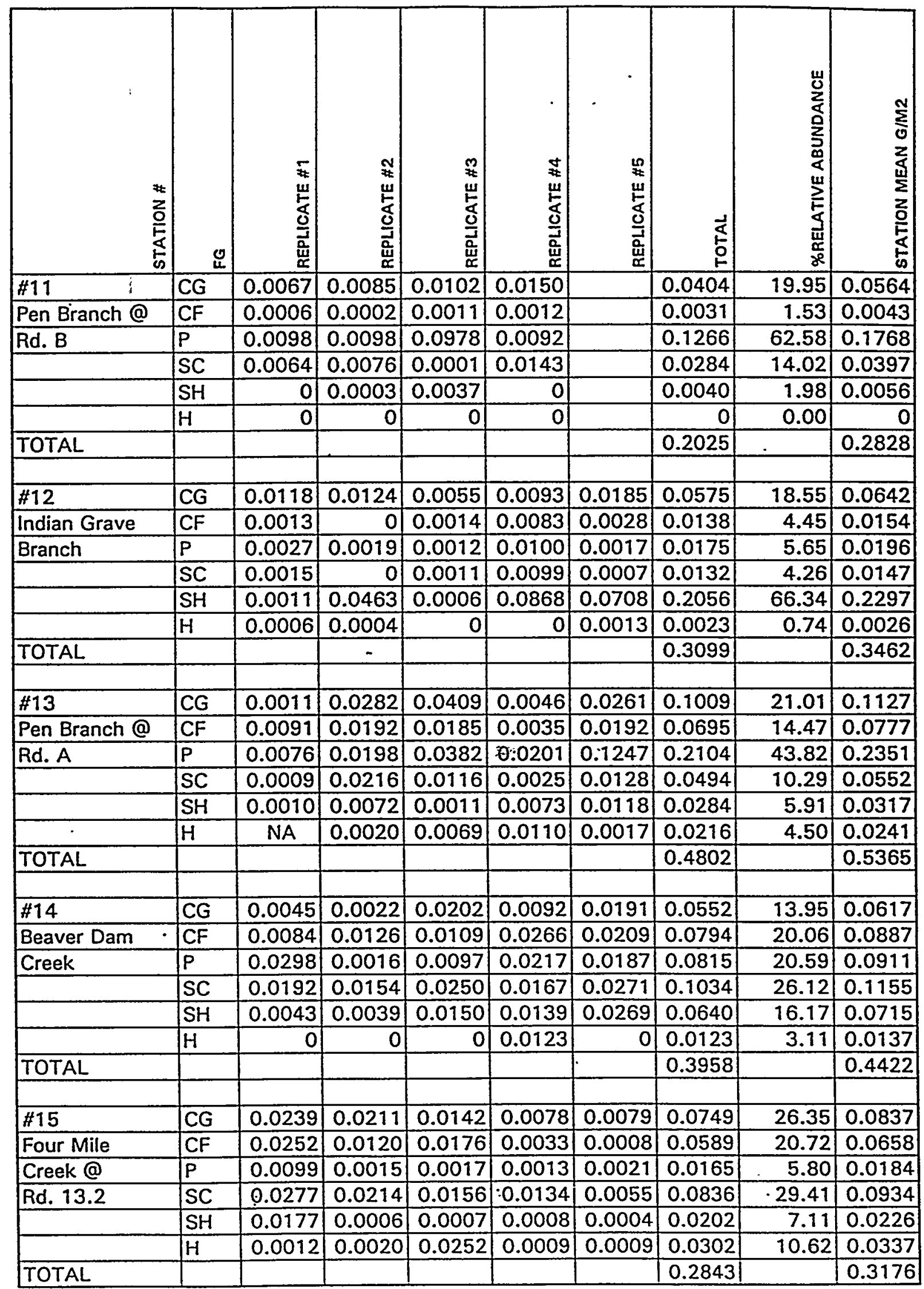

- All measures in grams

$\mathrm{NA}=$ weights less than $0.0001 \mathrm{~g}$. 
ASH FREE DRY WEIGHT (grams) DATA

Rosemary Creek downstream of Williston WWTP 17 Dec 1994

\begin{tabular}{|c|c|c|c|c|c|c|c|c|c|}
\hline 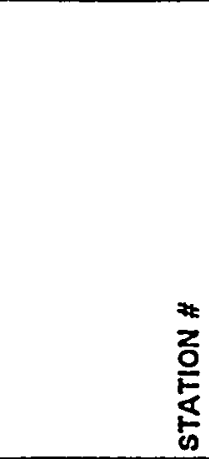 & O & 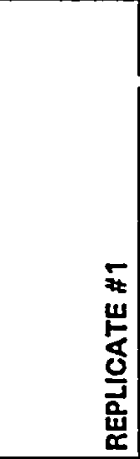 & 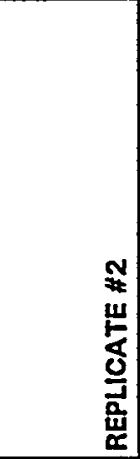 & 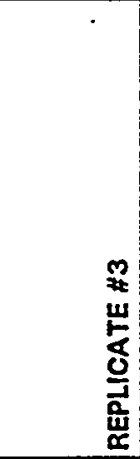 & 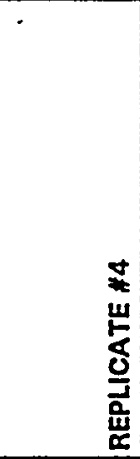 & 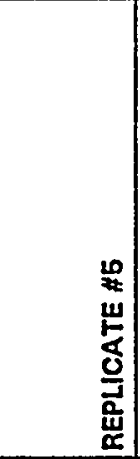 & $\begin{array}{l}\frac{1}{5} \\
\frac{5}{0}\end{array}$ & 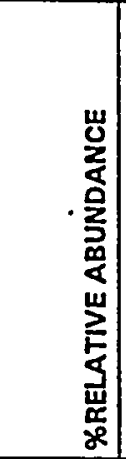 & 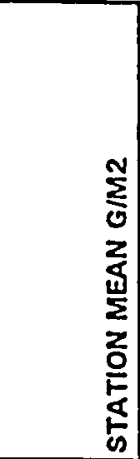 \\
\hline$\# 16$ & CF & 0.0015 & 0 & 0.0049 & 0.0081 & 0.0049 & 0.0194 & 2.59 & 0.0217 \\
\hline Rosemary & CG & 0.0008 & 0.0009 & 0.0126 & 0.0028 & 0.126 & 0.1431 & 19.07 & 0.1599 \\
\hline Creek & $\mathrm{H}$ & 0 & 0 & 0 & 0.2651 & 0 & 0.2651 & 35.34 & 0.2962 \\
\hline 17-Dec-94 & $P$ & 0.0043 & 0.0008 & 0.2183 & 0.0027 & 0.0017 & 0.2278 & 30.37 & 0.2545 \\
\hline & SC & 0.0001 & 0.0003 & 0.0045 & 0.0436 & 0.0010 & 0.0495 & 6.60 & 0.0553 \\
\hline & $\mathrm{SH}$ & NA & 0.0004 & 0.0259 & 0.0001 & 0.0189 & 0.0453 & 6.04 & 0.0506 \\
\hline TOTAL & & & & & & & 0.7502 & & 0.8382 \\
\hline
\end{tabular}

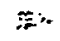


PART VI

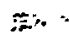

$\because$ 
Station 1. Rosemary Creek near Rosemary Chruch. RBP II. 20 September 1994

\begin{tabular}{|c|c|c|c|c|c|c|c|}
\hline Seq & Taxon & ITAXC & NCBI & IFG & For $\mathrm{BI}$ & A & Rel Abd \\
\hline 1 & Hydracarina & AHC & 6 & $P$ & 0.00 & & 0.00 \\
\hline 2 & Amphipoda & $A M$ & 6 & $\mathbf{C G}$ & 0.00 & & 0.00 \\
\hline 3 & Hirudinea & ANH & 10 & $p$ & 0.00 & & 0.00 \\
\hline 4 & Oligochaeta & ANO & 9 & CG & 0.00 & & 0.00 \\
\hline 5 & Hydra & $\mathrm{CN}$ & & P & & & 0.00 \\
\hline 6 & Elmidae & $\mathrm{CO}$ & 4 & CG & 12.00 & 3 & 1.66 \\
\hline 7 & Cambaridae & $\mathrm{DC}$ & 6 & $\mathrm{H}$ & 48.00 & 8 & 4.42 \\
\hline 8 & Palaemonidae & $D C$ & 6 & $\mathrm{H}$ & 240.00 & 40 & 22.10 \\
\hline 9 & Chironomini & DCC & 8 & CG & 48.00 & 6 & 3.31 \\
\hline 10 & Ceratopogonidae & DO & 6 & $P$ & 0.00 & & 0.00 \\
\hline 19 & Culicidae & DO & & CF & & & 0.00 \\
\hline 12 & Simuliidae & DO & 6) & $C F$ & 0.00 & & 0.00 \\
\hline 13 & Tabanidae & DO & 6 & $P$ & 0.00 & & 0.00 \\
\hline 14 & Tipulidae & DO & 3 & $\mathrm{SH}$ & 0.00 & & 0.00 \\
\hline 15 & Orthocladiinae & DOR & 8) & CG & 0.00 & & 0.00 \\
\hline 16 & Tanypodinae & DTA & 6 & $\mathrm{P}$ & 24.00 & 4 & 2.21 \\
\hline 17 & Tanytarsini & DTY & 6 & $C G$ & 222.00 & 37 & 20.44 \\
\hline 18 & Beetidae & EP & 4 & CG & 12.00 & 3 & 1.66 \\
\hline 19 & Caenidae & EP & 7 & CG & 273.00 & 39 & 21.55 \\
\hline 20 & Ephemerellidae & EP & 1 & CG & 0.00 & & 0.00 \\
\hline 21 & Ephemeridae & EP & 4 & CG & 4.00 & 1 & 0.55 \\
\hline 22 & Heptageniidae & EP & 4 & $\mathrm{sc}$ & 24.00 & 6 & 3.31 \\
\hline 23 & Leptophlebiidae & EP & 2 & CG & 18.00 & g| & 4.97 \\
\hline 24 & Neoephemeridae & $E P$ & & CG & & & 0.00 \\
\hline 25 & Oligoneuriidae & EP & 2 & CF & 0.00 & & 0.00 \\
\hline 26 & Siphlonuridae & $E P$ & 7 & CG & 0.00 & & 0.00 \\
\hline 27 & Tricorythidae & EP & 4 & CG & 80.00 & 20 & 11.05 \\
\hline 28 & Corixidae & HT & 9 & $\mathrm{H}$ & 0.00 & & 0.00 \\
\hline 29 & Isopoda & IS & 8 & CG & 0.00 & & 0.00 \\
\hline 30 & Pyralidae & LEP & 5 & $H$ & 0.00 & & 0.00 \\
\hline 31 & Sphaeriidae & $M B$ & 8 & CF & 0.00 & & 0.00 \\
\hline 32 & Corydalidae & $M E$ & of & $P$ & 0.00 & & 0.00 \\
\hline 33 & Sialidao & ME & 4 & $\mathrm{P}$ & 0.00 & & 0.00 \\
\hline 34 & Planorbidae & MG & 6 & Sc & 0.00 & & 0.00 \\
\hline 35 & Viviparides & MG & 7 & sc & 0.00 & & 0.00 \\
\hline 36 & Nemertea & NA & & $\mathrm{P}$ & & & 0.00 \\
\hline 37 & Nematoda & NE & & $P$ & 0.00 & & 0.00 \\
\hline 38 & Aeshnidae & OD & 3 & $\bar{P}$ & 0.00 & & 0.00 \\
\hline 39 & Calopterygidae & OD & 5 & $P$ & 5.00 & 1 & 0.55 \\
\hline 40 & Coenagrionidae & OD & & $P$ & 18.00 & 2 & 1.10 \\
\hline 41 & Corduliidae & TOD & & $P$ & 0.00 & & 0.00 \\
\hline 42 & Gomphidae & OD & & $P$ & 0.00 & & 0.00 \\
\hline 43 & Libellulidae & OD & & $P$ & 0.00 & & 0.00 \\
\hline 44 & Macromiidae & $O D$ & & $P$ & 0.00 & & 0.00 \\
\hline 45 & Capniidae & $P L$ & 1 & $\mathrm{SH}$ & 1.00 & 1 & 0.55 \\
\hline 46 & Leuctridae & $P L$ & o & SH & 0.00 & & 0.00 \\
\hline 47 & Perlidae & $P L$ & & $\mathrm{P}$ & 0.00 & & 0.00 \\
\hline 48 & Pteronarcyidae & $P L$ & o & $\mathrm{SH}$ & 0.00 & & 0.00 \\
\hline 49 & Brachycentridae & TR & 1 & CF & 0.00 & & 0.00 \\
\hline 50 & Hydropsychidae & TR & 4 & $\mathrm{CF}$ & 0.00 & & 0.00 \\
\hline 51 & Hydroptilidae & TR & 4 & $\mathrm{H}$ & 0.00 & & 0.00 \\
\hline 52 & Lepidostomatidae & TR & 1 & $\mathrm{SH}$ & 0.00 & & 0.00 \\
\hline 53 & Leptoceridae & TR & 4 & SH & 4.00 & 1 & 0.55 \\
\hline 54 & Philopotamidas & TR & 3 & $\mathrm{CF}$ & 0.00 & & 0.00 \\
\hline 55 & Polycentropodidae & TR & 6 & $\mathrm{CF}$ & 0.00 & & 0.00 \\
\hline 56 & Psychomyiidae & TR & & $\mathrm{SC}$ & 0.00 & & 0.00 \\
\hline 57 & Turbellaria & TTU & & $\mathbb{A P}$ & 0.00 & & 0.00 \\
\hline
\end{tabular}


Ṡtation 1. Rosemary Creek near Rosemary Chruch. RBP II. 20 September 1994

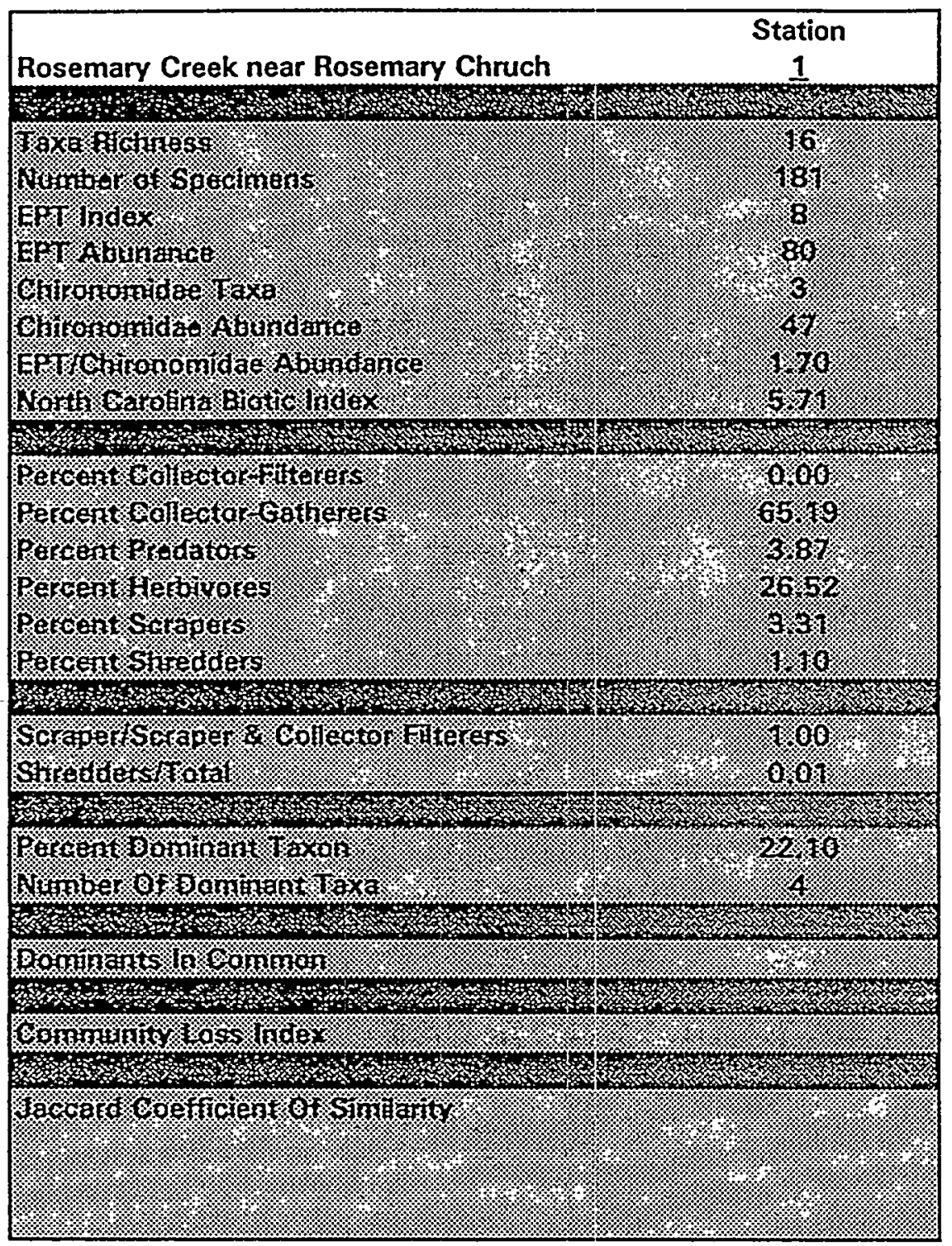




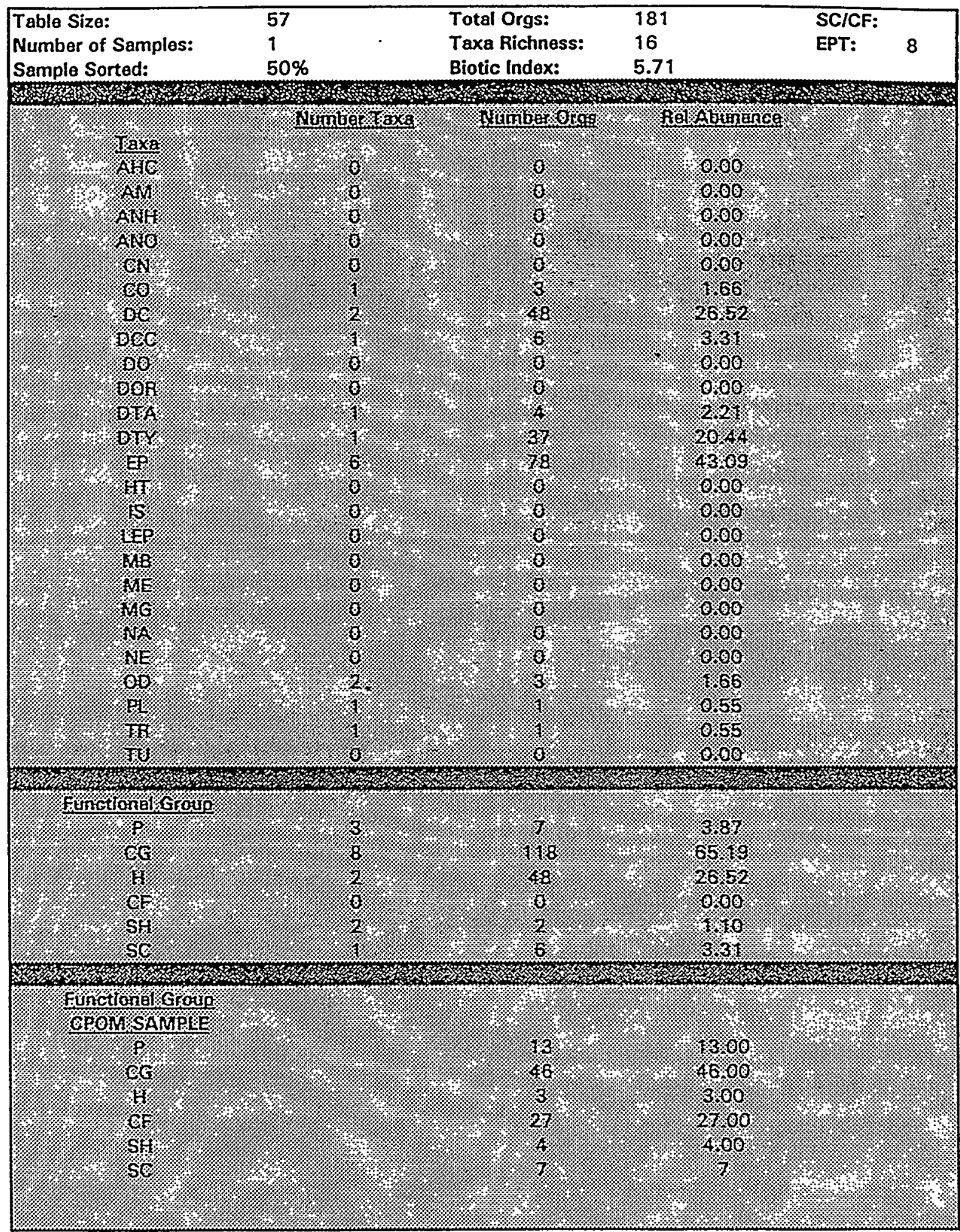


Station 1. Rosemary Creek near Rosemary Chruch. RBP II. 20 September 1994

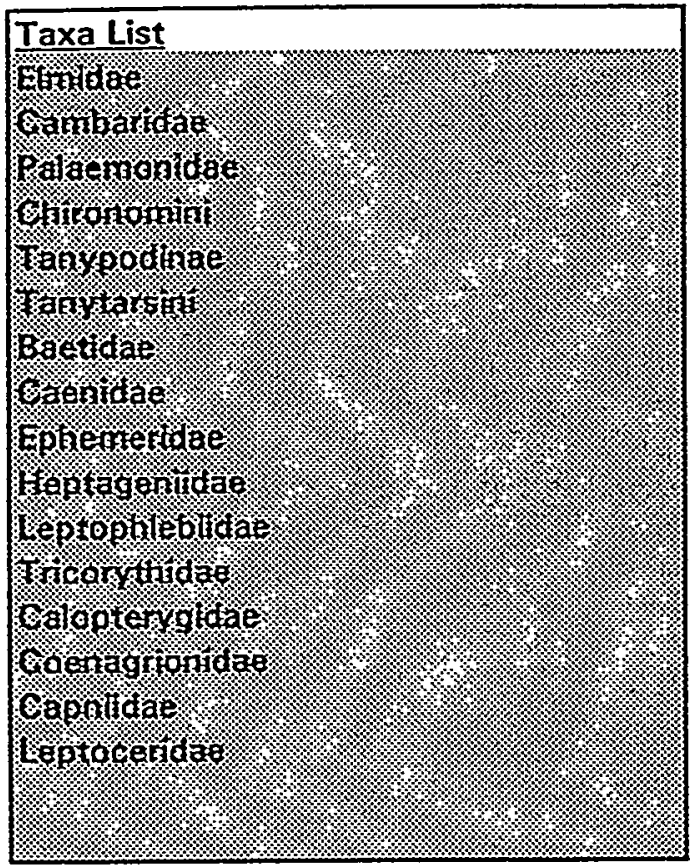

yo- 
Station 1. Rosemary Creek near Rosemary Chruch. RBP II. 20 September 1994

\begin{tabular}{|l|r|r|}
\hline Taxon & A & Rel Abd \\
\hline Palaemonidae & 40 & 22.10 \\
\hline Caenidae & 39 & 21.55 \\
\hline Tanytarsini & 37 & 20.44 \\
\hline Tricorythidae & 20 & 11.05 \\
\hline
\end{tabular}




\begin{tabular}{|c|c|c|c|c|c|c|c|}
\hline Seq & Taxon & TAXC & NCBI & FG & For BI & A & Rel Abd \\
\hline 3 & Hydracarina & $\overline{\mathrm{AHC}}$ & 8 & $\bar{P}$ & 6.00 & 1 & 0.79 \\
\hline 4 & Amphipoda & $A M$ & 6 & $\mathbf{C G}$ & 8.00 & 1 & 0.79 \\
\hline 5 & Hirudinea & ANH & 10 & $P$ & 0.00 & & 0.00 \\
\hline 6 & Oligochaeta & ANO & 9 & CG & 252.00 & 28 & 22.22 \\
\hline 7 & Hydra & $\mathrm{CN}$ & & $P$ & & & 0.00 \\
\hline 8 & Elmidae & $\mathrm{CO}$ & 4 & $C G$ & 0.00 & & 0.00 \\
\hline 9 & Cambaridae & $D C$ & 6 & $\mathrm{H}$ & 0.00 & & 0.00 \\
\hline 10 & Palaemonidae & $\overline{D C}$ & 6 & $\mathrm{H}$ & 38.00 & 6 & 4.76 \\
\hline 11 & Chironomini & DCC & 8 & CG & 168.00 & 21 & 16.67 \\
\hline 12 & Ceratopogonidae & DO & 6 & $P$ & 6.00 & 1 & 0.79 \\
\hline 13 & Culicidae & DO & & CF & & & 0.00 \\
\hline 14 & Simuliidae & DO & 6 & CF & 0.00 & & 0.00 \\
\hline 15 & Tabsnidae & DO & 6 & $\mathrm{P}$ & 6.00 & 1 & 0.79 \\
\hline 16 & Tipulidae & DO & 3 & $\mathrm{SH}$ & 6.00 & 2 & 7.59 \\
\hline 17 & Orthocladiinae & DOR & 6 & CG & 0.00 & & 0.00 \\
\hline 18 & Tanypodinae & DTA & 6 & $P$ & 78.00 & 13 & 10.32 \\
\hline 19 & Tanytarsini & DTY & 6 & CG & 30.00 & 5 & 3.97 \\
\hline 20 & Baetidae & EP & 4 & CG & 0.00 & & 0.00 \\
\hline 21 & Caenidae & EP & 7 & CG & 7.00 & 1 & 0.79 \\
\hline 22 & Ephemerellidae & EP & 1 & CG & 0.00 & & 0.00 \\
\hline 23 & Ephemeridae & EP & 4 & CG & 4.00 & 1 & 0.79 \\
\hline 24 & Heptageniidae & EP & 4 & SC & 0.00 & & 0.00 \\
\hline 25 & Leptophlebiidae & EP & 2 & CG & 0.00 & & 0.00 \\
\hline 26 & Neoephemeridae & EP & & CG & & & 0.00 \\
\hline 27 & Oligoneuriidae & EP & 2 & CF & 0.00 & & 0.00 \\
\hline 28 & Siphlonuridae & EP & 7 & CG & 49.00 & 7 & 5.58 \\
\hline 29 & Tricorythidae & EP & 4 & CG & 4.00 & 1 & 0.79 \\
\hline 30 & Corixidae & $\overline{\text { HT }}$ & 9 & $\mathrm{H}$ & 9.00 & 1 & 0.79 \\
\hline 31 & Isopoda & is & 8 & CG & 0.00 & & 0.00 \\
\hline 32 & Pyralidae & LEP & 5 & $\mathrm{H}$ & 0.00 & & 0.00 \\
\hline 33 & Sphaeriidae & MB & 8 & CF & 88.00 & 11 & 8.73 \\
\hline 34 & Corydalidae & $\mathrm{ME}$ & 이 & P & 0.00 & & 0.00 \\
\hline 35 & Sialides & ME & 4 & $P$ & 12.00 & 3 & 2.38 \\
\hline 36 & Planorbidae & MG & 6 & $\mathrm{SC}$ & 0.00 & & 0.00 \\
\hline 37 & Viviparidae & MG & 7 & $\mathrm{sc}$ & 28.00 & 4 & 3.17 \\
\hline 38 & Nemertea & $\overline{N A}$ & & $\bar{P}$ & & 5 & 3.97 \\
\hline 39 & Nematoda & $\overline{N E}$ & & $P$ & & 1 & 0.79 \\
\hline 40 & Aeshnidae & $\overline{O D}$ & 3 & P & 3.00 & 1 & 0.79 \\
\hline 41 & Calopterygidae & $\overline{O D}$ & 5 & P & 0.00 & & 0.00 \\
\hline 42 & Coenagrionidae & $O D$ & 9 & $\bar{P}$ & 45.00 & 5 & 3.97 \\
\hline 43 & Corduliidaae & $\overline{O D}$ & & $\mathbf{P}$ & 0.00 & & 0.00 \\
\hline 44 & Gomphidae & 00 & 1 & $\mathbf{P}$ & 4.00 & 4 & 3.17 \\
\hline 45 & Libellulidae & $O D$ & 9 & $P$ & 0.00 & & 0.00 \\
\hline 46 & Macromiidae & $\overline{O D}$ & 3 & $\mathrm{P}$ & 0.00 & & 0.00 \\
\hline 47 & Capniidae & $\mathrm{PL}$ & 1 & SH & 1.00 & 1 & 0.79 \\
\hline 48 & Leuctridae & $\mathrm{PL}$ & o & SH & 0.00 & & 0.00 \\
\hline 49 & Perlidae & $\mathrm{PL}$ & 1 & $P$ & 0.00 & & 0.00 \\
\hline 50 & Pteronarcyidae & $\overline{P L}$ & o & $\mathrm{SH}$ & 0.00 & & 0.00 \\
\hline 51 & Brachycentridae & ITR & 1 & CF & 0.00 & & 0.00 \\
\hline 52 & Hydropsychidae & ITR & 4 & $C F$ & 0.00 & & 0.00 \\
\hline 53 & Hydroptilidae & TR & 4 & $\mathrm{H}$ & 0.00 & & 0.00 \\
\hline 54 & Lepidostomatidae & TR & 1 & $\mathrm{SH}$ & 0.00 & & 0.00 \\
\hline 55 & Leptoceridae & TR & 4 & $\mathrm{SH}$ & 0.00 & & 0.00 \\
\hline 56 & Philopotamidae & $T R$ & 3 & CF & 0.00 & & 0.00 \\
\hline 57 & Polycentropodidae & TR & 6 & $\mathrm{CF}$ & 0.00 & & 0.00 \\
\hline 58 & 3 Psychomyiidae & TR & 2 & $\mathrm{SC}$ & 0.00 & & 0.00 \\
\hline 59 & Turbellaria & $T$ TU & & $P$ & 4.00 & 1 & 0.79 \\
\hline
\end{tabular}




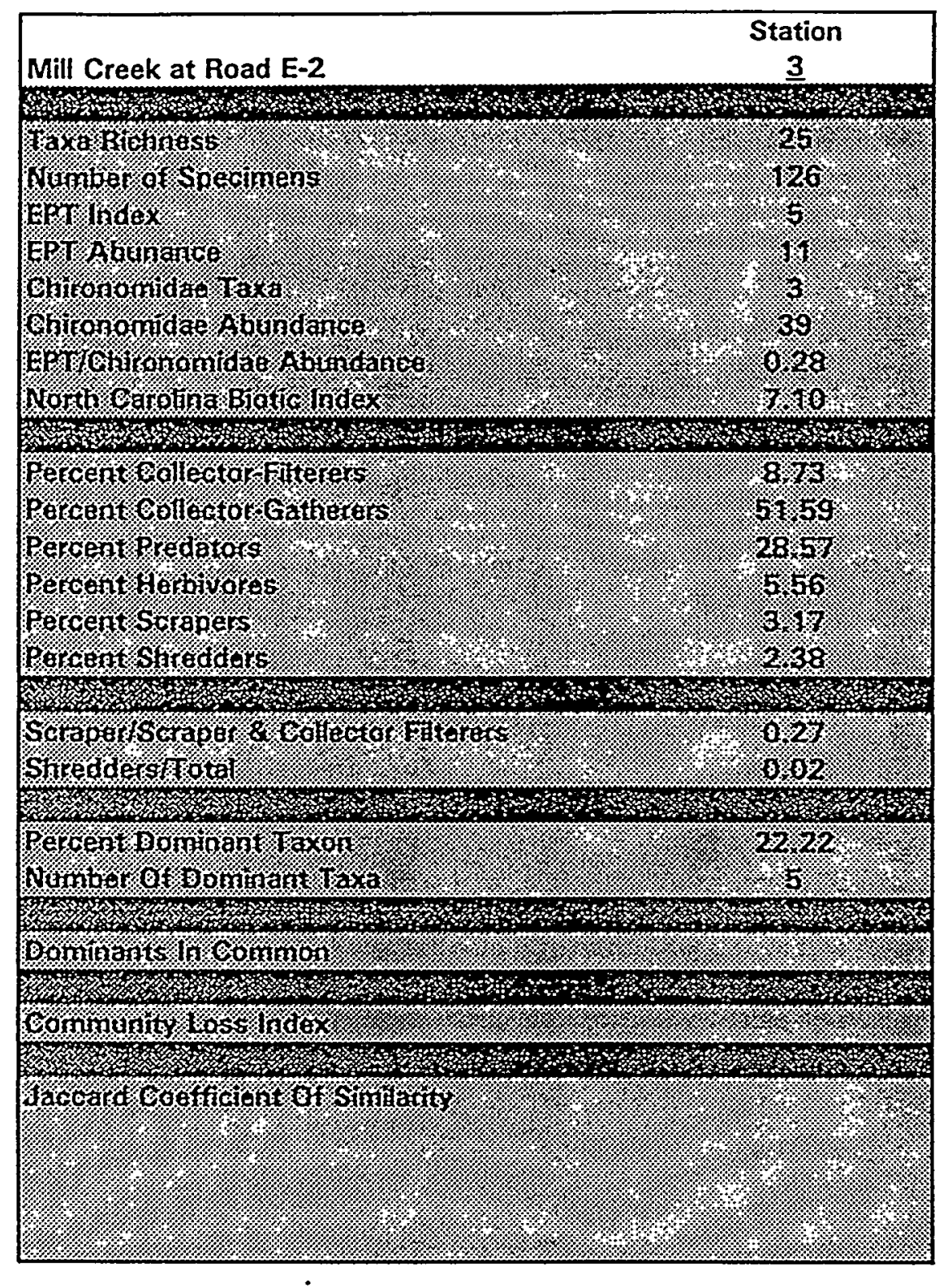




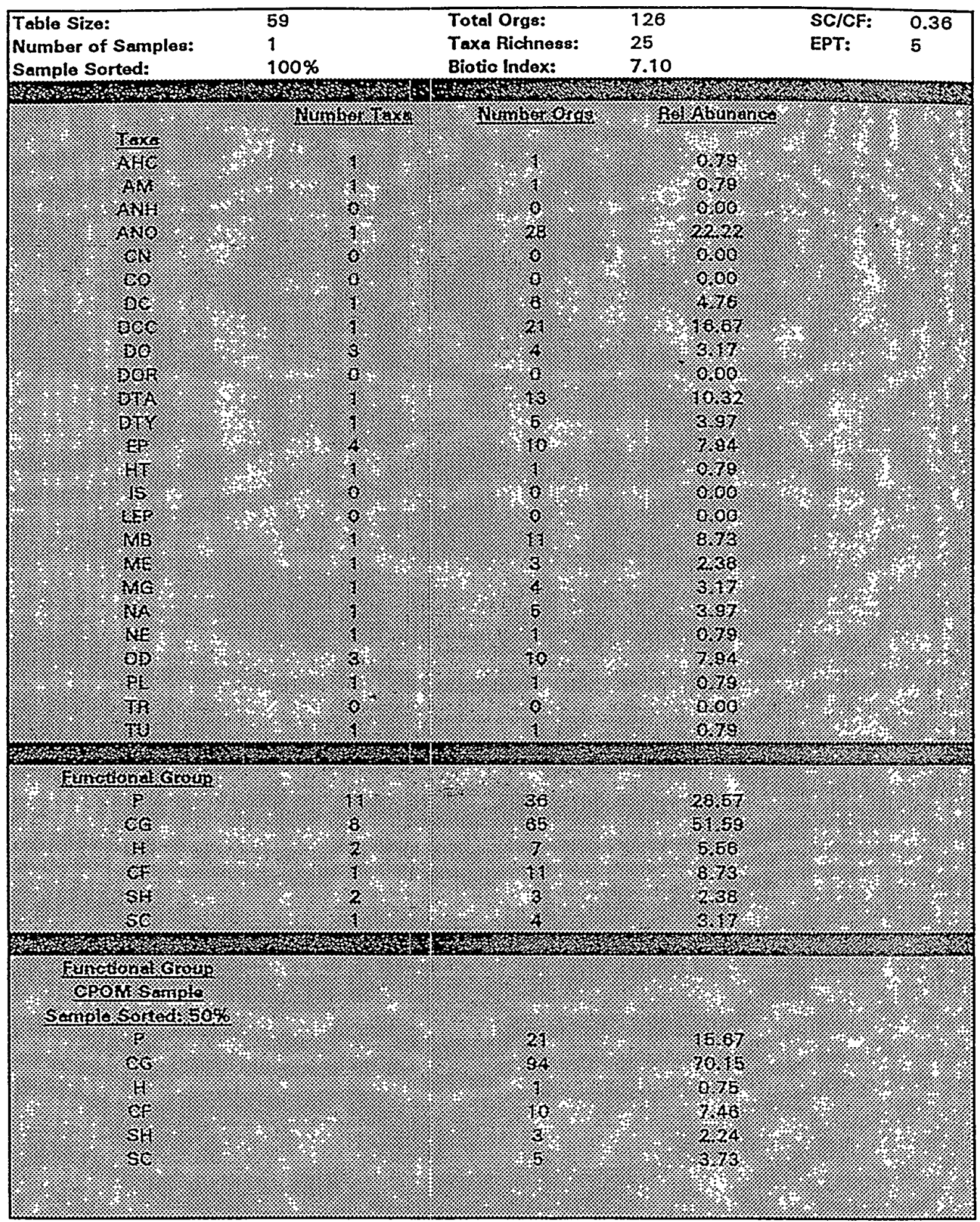


Station 3. Mill Creek at Road E-2. RBP II. 20 September 1994

\section{Taxa List}

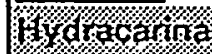

Amonopoia

6 Hog of o

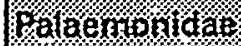

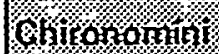

Cetatonocorition.

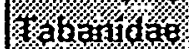

tratilition

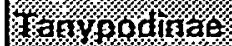

Ianv2 2atsho

C.3ininatio:

Eptentrentiae

Sinthionnitidsa

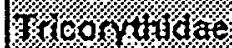

Corixinas:

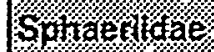

Sianitive

Jivonotidise

Viemertea

Heniztodia

A. Bstinitiaro

Conenatrontibe

Gomphidise

Cantitione

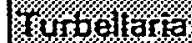

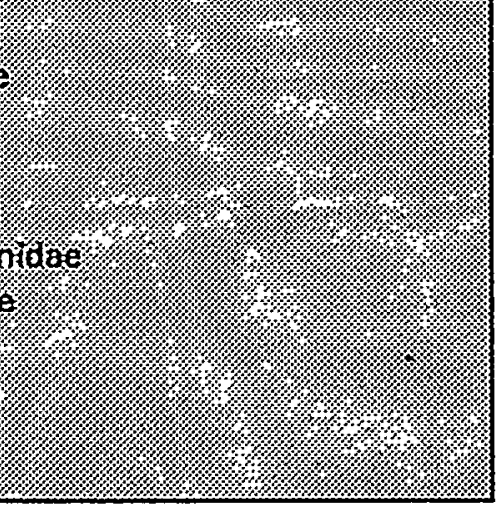


Station 3. Mill Creek at Road E-2. RBP II. 20 September 1994

\begin{tabular}{|l|r|r|}
\hline Taxon & A & Rel Abd \\
\hline Oligochaeta & 28 & 22.22 \\
\hline Chironomini & 21 & 16.67 \\
\hline Tanypodinae & 13 & 10.32 \\
\hline Sphaeriidae & 11 & 8.73 \\
\hline Siphlonuridae & 7 & 5.56 \\
\hline
\end{tabular}




\begin{tabular}{|c|c|c|c|c|c|c|c|}
\hline Seq & Taxan & TAXC & NCBI & FG & For $\mathrm{BI}$ & $A$ & Rel Abd \\
\hline 1 & Hydracarina & $A H C$ & 6 & $P$ & 0.00 & & 0.00 \\
\hline 2 & Amphipoda & AM & 6 & $C G$ & 0.00 & & 0.00 \\
\hline 3 & Hirudinea & ANH & 10 & $P$ & 0.00 & & 0.00 \\
\hline 4 & Oligochaeta & ANO & 9 & $C G$ & 495.00 & 55 & 67.07 \\
\hline 5 & Hydra & $\mathrm{CN}$ & & $P$ & & & 0.00 \\
\hline 6 & Elmidae & $\mathrm{Co}$ & 4 & CG & 0.00 & & 0.00 \\
\hline 7 & Cambaridae & $D C$ & 6 & $\mathrm{H}$ & 12.00 & 2 & 2.44 \\
\hline 8 & Palaemonidae & $D C$ & 6 & $\mathrm{H}$ & 0.00 & & 0.00 \\
\hline 9 & Chironomini & DCC & 8 & CG & 32.00 & 4 & 4.88 \\
\hline 10 & Ceratopogonidae & DO & $\overline{6}$ & $\mathbf{P}$ & 0.00 & & 0.00 \\
\hline 11 & Culicidae & DO & & CF & & 1 & 1.22 \\
\hline 12 & Simuliidae & 00 & 6 & CF & 0.00 & & 0.00 \\
\hline 13 & Tabenidae & 00 & 6 & $P$ & 0.00 & & 0.00 \\
\hline 14 & Tipulidae & DO & 3 & $\mathrm{SH}$ & 0.00 & & 0.00 \\
\hline 15 & Orthocladiinae & DOR & 6 & CG & 0.00 & & 0.00 \\
\hline 16 & Tanypodinae & DTA & 6 & $P$ & 18.00 & 3 & 3.66 \\
\hline 17 & Tanytarsini & DTY & $\overline{6}$ & CG & 0.00 & & 0.00 \\
\hline 18 & Baetidae & EP & 4 & CG & 0.00 & & 0.00 \\
\hline 19 & Caenidae & EP & 7 & CG & 0.00 & & 0.00 \\
\hline 20 & Ephemerallidae & EP & 1 & CG & 0.00 & & 0.00 \\
\hline 21 & Ephemeridae & EP & 4 & CG & 0.00 & & 0.00 \\
\hline 22 & Heptageniidae & $E P$ & 4 & $\mathrm{sc}$ & 0.00 & & 0.00 \\
\hline 23 & Leptophlebiidae & EP & 2 & CG & 0.00 & & 0.00 \\
\hline 24 & Neoephemeridae & EP & & CG & & & 0.00 \\
\hline 25 & Oligoneuriidae & EP & 2 & $\mathrm{CF}$ & 0.00 & & 0.00 \\
\hline 26 & Siphlonuridae & $E P$ & 7 & CG & 0.00 & & 0.00 \\
\hline 27 & Tricorythidae & EP & 4 & CG & 0.00 & & 0.00 \\
\hline 28 & Corixidae & HT & 9 & $\mathrm{H}$ & 0.00 & & 0.00 \\
\hline 29 & Isopoda & IS & 8 & CG & 0.00 & & 0.00 \\
\hline 30 & Pyralidae & LEP & 5 & $\mathrm{H}$ & 0.00 & & 0.00 \\
\hline 31) & Sphaeriidae & MB & 8 & CF & 8.00 & 1 & 1.22 \\
\hline 32 & Corydalidae & $\mathrm{ME}$ & $\overline{0}$ & $\bar{P}$ & 0.00 & & 0.00 \\
\hline 33 & Sialidae & $\mathrm{ME}$ & $\%=$ & $P$ & 0.00 & & 0.00 \\
\hline 34 & Planorbidae & MG & $\overline{6}$ & $\overline{S C}$ & 6.00 & 1 & 1.22 \\
\hline 35 & Viviparidae & MG & 7 & $\mathrm{sc}$ & 0.00 & & 0.00 \\
\hline 36 & Nemertea & NA & & $\mathrm{P}$ & & 4 & 4.88 \\
\hline 37 & Nematoda & $\mathrm{NE}$ & & P & & 1 & 1.22 \\
\hline 38 & Aeshnidae & $O D$ & 3 & P & 0.00 & & 0.00 \\
\hline 40 & Coenagrionidae & $O D$ & 9 & $P$ & 81.00 & 9 & 10.98 \\
\hline 41 & Corduliidaae & $O D$ & 5 & P & 0.00 & & 0.00 \\
\hline 42) & Gomphidae & $O D$ & 1 & P & 0.00 & & 0.00 \\
\hline 43 & Libellulidae & $O D$ & 9 & P & 9.00 & 1 & 1.22 \\
\hline 44 & Macromiidae & $O D$ & 3 & $P$ & 0.00 & & 0.00 \\
\hline 45 & Capniidae & $P L$ & 1 & $\mathrm{SH}$ & 0.00 & & 0.00 \\
\hline 46 & Leuctridae & $\mathrm{PL}$ & 0 & $\mathrm{SH}$ & 0.00 & & 0.00 \\
\hline 47 & Perlidae & $\mathrm{PL}$ & 1 & $\mathrm{P}$ & 0.00 & & 0.00 \\
\hline 48 & Pteronarcyidae & $\mathrm{PL}$ & 0 & $\mathrm{SH}$ & 0.00 & & 0.00 \\
\hline 49 & Brachycentridae & TR & 1 & $\mathrm{CF}$ & 0.00 & & 0.00 \\
\hline 50 & Hydropsychidae & TR & 4 & $C F$ & 0.00 & & 0.00 \\
\hline 51 & Hydroptilidae & TR & 4 & $H$ & 0.00 & & 0.00 \\
\hline 52 & Lepidostomatidae & TR & 1 & $\mathrm{SH}$ & 0.00 & & 0.00 \\
\hline 53 & Leptoceridae & TR & 4 & $\mathrm{SH}$ & 0.00 & & 0.00 \\
\hline 54 & Philopotamidae & TR & 3 & $\mathrm{CF}$ & 0.00 & & 0.00 \\
\hline 55 & Polycentropodidae & TR & 6 & $C F$ & 0.00 & & 0.00 \\
\hline 56 & Psychomyiidae & TR & 2 & $\mathrm{SC}$ & 0.00 & & 0.00 \\
\hline 57 & Turbellaria & TTU & 4 & $P$ & 0.00 & & 0.00 \\
\hline
\end{tabular}


Station 4. Crouch Branch at Road 4. RBP II. 20 September 1994.

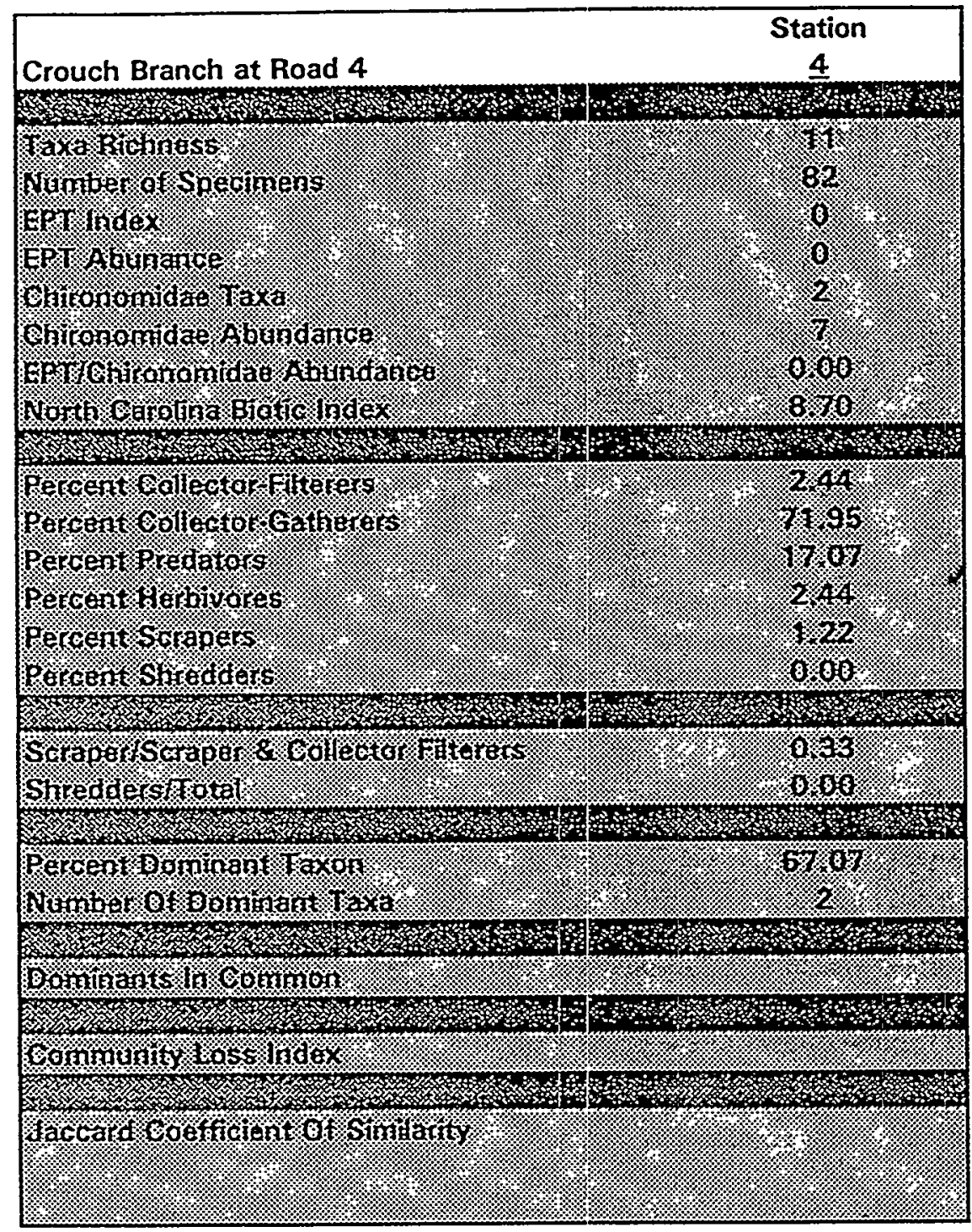




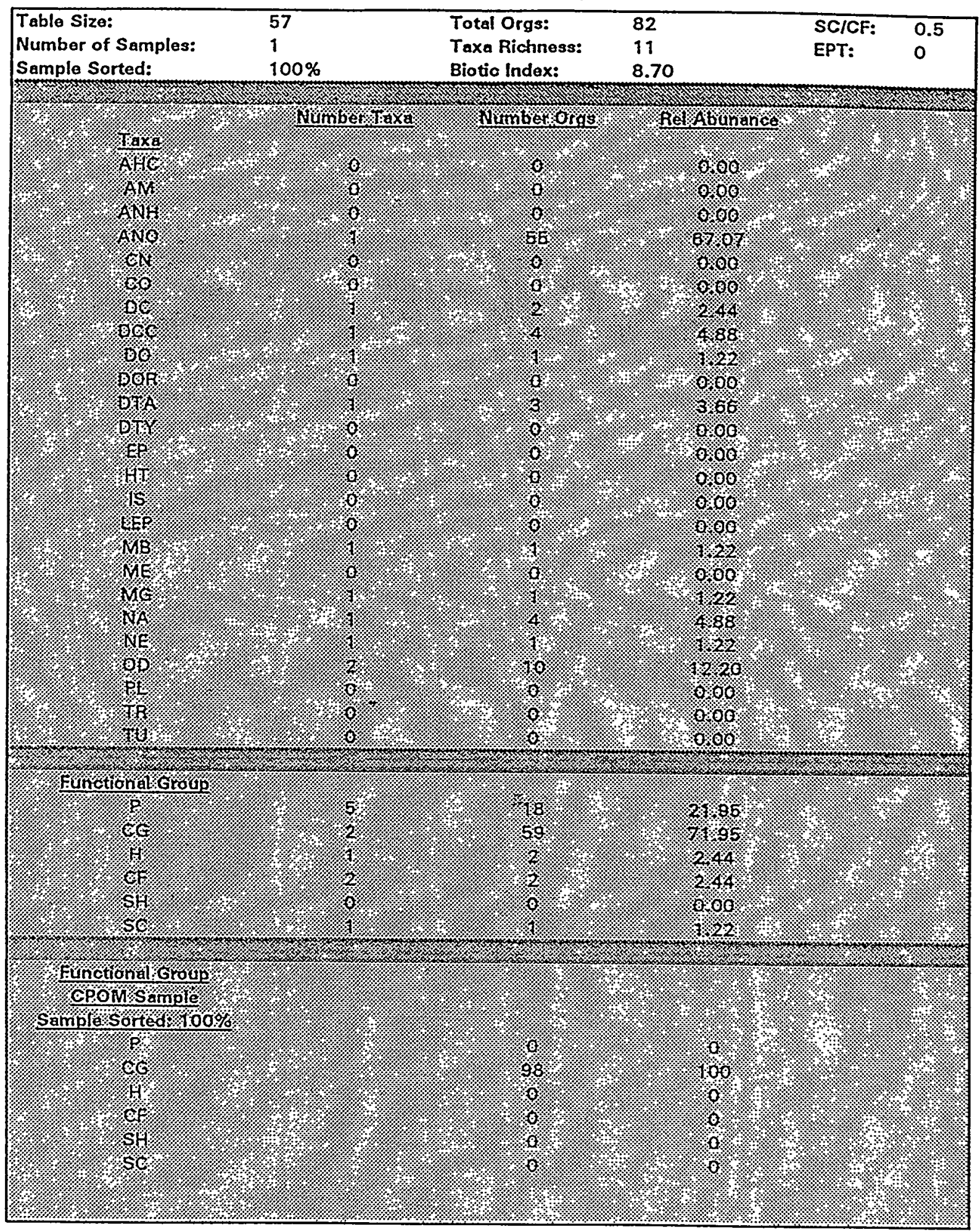


Station 4. Crouch Branch at Road 4. RBP II. -20 September 1994.

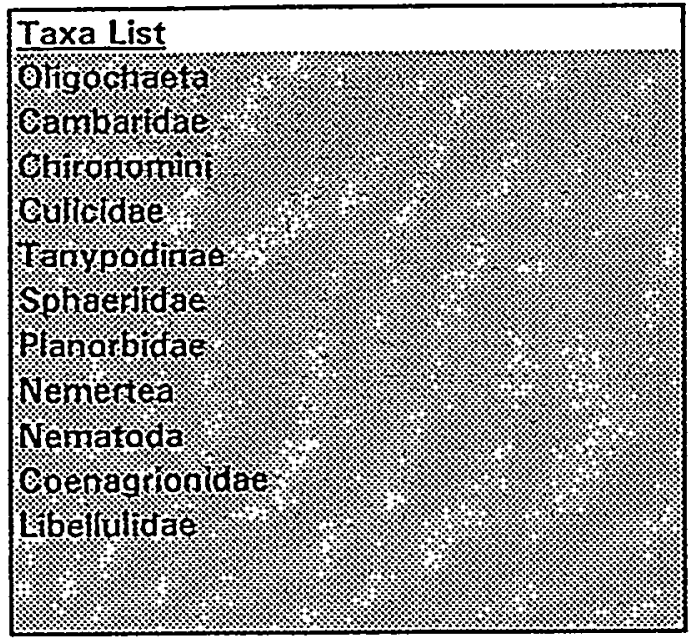

$\#$; 
Station 4. Crouch Branch at Road 4. RBP II. 20 September 1994.

\begin{tabular}{|l|r|r|}
\hline Taxon & A & Rel Abd \\
\hline Oligochaeta & 55 & 67.07 \\
\hline Coenagrionidae & 9 & 10.98 \\
\hline
\end{tabular}

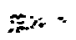




\begin{tabular}{|c|c|c|c|c|c|c|c|}
\hline Seq & Taxan & TAXC & NCBI & FG & \begin{tabular}{|l|l} 
For $\mathrm{BI}$ & $\mathrm{B}$ \\
\end{tabular} & $\mathbf{A}$ & Rel Abd \\
\hline 1 & Hydracarina & AHC & 6 & $P$ & 12.00 & 2 & 1.39 \\
\hline 2 & Amphipoda & $A M$ & 6 & CG & 66.00 & 11 & 7.64 \\
\hline 3 & Hirudinea & ANH & 10 & $\mathrm{P}$ & 0.00 & & 0.00 \\
\hline 4 & Oligochaeta & ANO & 9 & CG & 72.00 & 8 & 5.56 \\
\hline 5 & Hydra & $\mathrm{CN}$ & & $P$ & & 1 & 0.69 \\
\hline 6 & Elmidae & CO & 4 & $C G$ & 8.00 & 2 & 1.39 \\
\hline 7 & Cambaridae & $D C$ & 6 & $\mathrm{H}$ & 18.00 & 3 & 2.08 \\
\hline 8 & Palaemonidae & $D C$ & 6 & $\mathrm{H}$ & 6.00 & 1 & 0.69 \\
\hline 9 & Chironomini & DCC & 8 & CG & 104.00 & 13 & 9.03 \\
\hline 10 & Ceratopogonidae & DO & 6 & $P$ & 6.00 & 1 & 0.69 \\
\hline 11 & Culicidae & DO & & CF & & & 0.00 \\
\hline 12 & Simuliidae & $D O$ & 6 & CF & 6.00 & 1 & 0.69 \\
\hline 13 & Tabanidae & DO & 6 & $\mathrm{P}$ & 0.00 & & 0.00 \\
\hline 14 & Tipulidae & DO & 3 & $\mathrm{SH}$ & 0.00 & & 0.00 \\
\hline 15 & Orthocladiinae & DOR & 6 . & CG & 24.00 & 4 & 2.78 \\
\hline 16 & Tanypodinae & DTA & 6 & $\mathrm{P}$ & 126.00 & 21 & 14.58 \\
\hline 17 & Tanytarsini & DTY & 6 & CG & 126.00 & 21 & 14.58 \\
\hline 18 & Baetidae & EP & 4 & CG & 0.00 & & 0.00 \\
\hline 19 & Caenidae & EP & 7 & CG & 7.00 & 1 & 0.69 \\
\hline 20 & Ephemerellidae & EP & 1 & CG & 0.00 & & 0.00 \\
\hline 21 & Ephemeridae & EP & 4 & CG & 0.00 & & 0.00 \\
\hline 22 & Heptageniidae & EP & 4 & SC & 8.00 & 2 & 1.39 \\
\hline 23 & Leptophlebiidae & EP & 2 & CG & 0.00 & & 0.00 \\
\hline 24 & Neoephemeridae & EP & & CG & & & 0.00 \\
\hline 25 & Oligoneuriidae & EP & 2 & $\mathrm{CF}$ & 0.00 & & 0.00 \\
\hline 26 & Siphlonuridae & EP & 7 & CG & 0.00 & & 0.00 \\
\hline 27 & Tricorythidae & EP & 4 & CG & 0.00 & & 0.00 \\
\hline 28 & Corixidae & HT & 9 & $\mathrm{H}$ & 0.00 & & 0.00 \\
\hline 29 & Isopoda & IS & 8 & CG & 8.00 & 1 & 0.69 \\
\hline 30 & Pyralidae & LEP & 5 & $H$ & 30.00 & 6 & 4.17 \\
\hline 31 & Sphaeriidae & $M B$ & 8 & CF & 0.00 & & 0.00 \\
\hline 32 & Corydalidae & $\mathrm{ME}$ & & $P$ & 0.00 & & 0.00 \\
\hline 33 & Sialidae & $M E$ & 4 & P & 0.00 & & 0.00 \\
\hline 34 & Planorbidae & MG & 6 & SC & 6.00 & 1 & 0.69 \\
\hline 35 & Viviparidae & MG & 7 & SC & 0.00 & & 0.00 \\
\hline 36 & Nemertea & NA & & $P$ & & 5 & 3.47 \\
\hline 37 & Nematoda & NE & & P & & & 0.00 \\
\hline 38 & Aeshnidae & OD & 3 & P & 0.00 & & 0.00 \\
\hline 39 & Calopterygidae & $O D$ & 5 & $P$ & 5.00 & 1 & 0.69 \\
\hline 40 & Coenagrionidae & OD & & $P$ & 135.00 & 15 & 10.42 \\
\hline 41 & Corduliidaae & $O D$ & & P & 10.00 & 2 & 1.39 \\
\hline 42 & Gomphidae & TOD & 1 & $\mathrm{P}$ & 0.00 & & 0.00 \\
\hline 43 & Libellulidae & $O D$ & & P & 0.00 & & 0.00 \\
\hline 44 & Macromiidae & $O D$ & & $P$ & 3.00 & 1 & 0.69 \\
\hline 45 & Capniidae & PL & 1 & $\mathrm{SH}$ & 0.00 & & 0.00 \\
\hline 46 & Leuctridae & $\mathrm{PL}$ & 0 & $\mathrm{SH}$ & 0.00 & & 0.00 \\
\hline 47 & Perlidae & $\mathrm{PL}$ & 1 & $\mathrm{P}$ & 0.00 & & 0.00 \\
\hline 48 & Pteronarcyidae & $\mathrm{PL}$ & 의 & $\widehat{\mathrm{SH}}$ & 0.00 & & 0.00 \\
\hline 49 & Brachycentridae & TR & 1 & CF & 0.00 & & 0.00 \\
\hline 50 & Hydropsychidae & TR & 4 & $\mathrm{CF}$ & 0.00 & & 0.00 \\
\hline 51 & Hydroptilidae & TR & 4 & $\mathrm{H}$ & 0.00 & & 0.00 \\
\hline 52 & Lepidostomatidae & TR & 1 & $\mathrm{SH}$ & 0.00 & & 0.00 \\
\hline 53 & Leptoceridae & TR & 4 & $4 \mathrm{SH}$ & 0.00 & & 0.00 \\
\hline 54 & Philopotamidae & $T R$ & 3 & $\mathrm{CF}$ & 0.00 & & 0.00 \\
\hline 55 & Polycentropodidae & TR & 6 & $\mathrm{CF}$ & 0.00 & & 0.00 \\
\hline 56 & Psychomyiidae & TR & 2 & $\mathrm{SC}$ & 0.00 & & 0.00 \\
\hline 57 & \begin{tabular}{|l|} 
TTurbellaria \\
\end{tabular} & TTU & & $4 \mid \mathrm{P}$ & 80.00 & 20 & 13.89 \\
\hline
\end{tabular}


Station 7. Four Mile Creek at Road C. RBP II. 20 September 1994

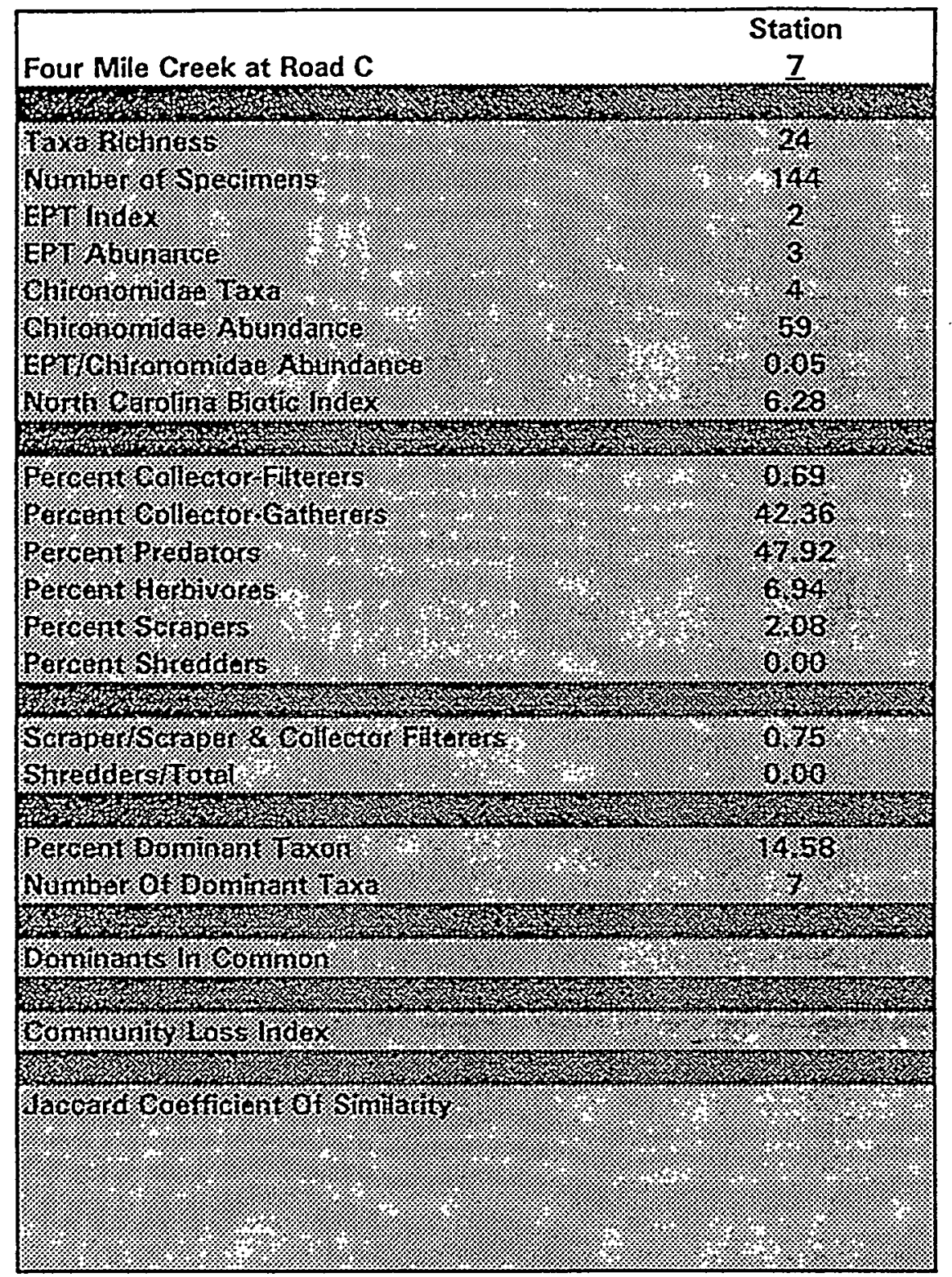


-

Station 7. Four Mile Creek at Rosd C. RBP II. 20 September 1994

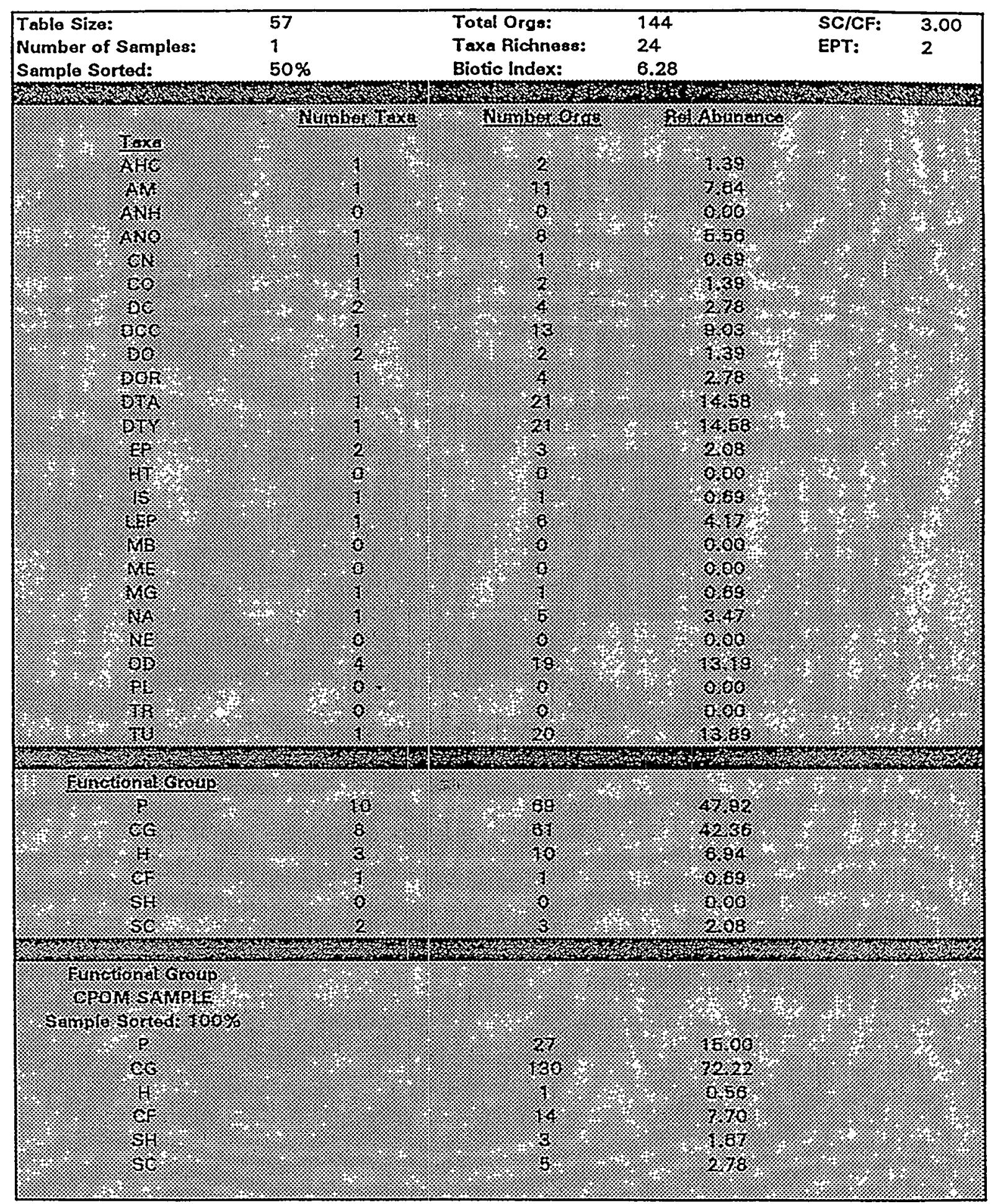


Station 7. Four Mile Creek at Road C. RBP II. 20 Sejptember 1994

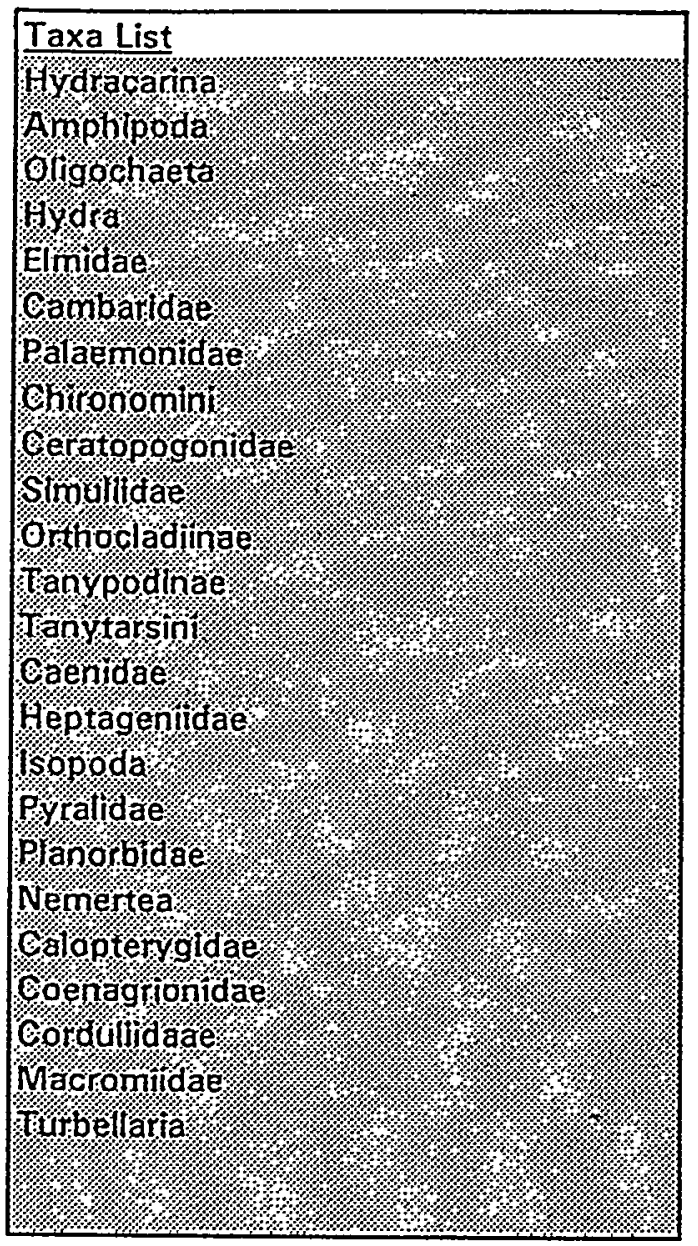


Station 7. Four Mile Creek at Road C. RBP II: 20 September 1994

\begin{tabular}{|l|r|r|}
\hline Taxon & A & \multicolumn{1}{|l|}{ Rel Abd } \\
\hline Tanypodinae & 21 & 14.58 \\
\hline Tanytarsini & 21 & 14.58 \\
\hline Turbellaria & 20 & 13.89 \\
\hline Coenagrionidae & 15 & 10.42 \\
\hline Chironomini & 13 & 9.03 \\
\hline Amphipoda & 11 & 7.64 \\
\hline Oligochaeta & 8 & 5.56 \\
\hline
\end{tabular}

緯. 
Station 12. Indian Grave Branch at Road B. RBP II. 21 September 1994

\begin{tabular}{|c|c|c|c|c|c|c|c|}
\hline \begin{tabular}{|l|l} 
Seq \\
\end{tabular} & Taxon & TAXC & NCBI & FG & For $\mathbf{B I}$ & A & Rel Abd \\
\hline 11 & Hydracarina & AHC & 6 & $\mathbf{P}$ & \begin{tabular}{|l|}
12.00 \\
\end{tabular} & 2 & 1.04 \\
\hline 2 & Amphipoda & $A M$ & 6 & CG & 0.00 & & 0.00 \\
\hline \begin{tabular}{l|l}
$3 \mid$ \\
\end{tabular} & Hirudinea & ANH & 10 & $\mathbf{P}$ & 0.00 & & 0.00 \\
\hline 4 & Oligochreta & ANO & 9 & CG & 72.00 & 8 & 4.17 \\
\hline 5 & Hydra & $\mathrm{CN}$ & & $P$ & & & 0.00 \\
\hline 6 & Elmidae & $\mathrm{CO}$ & 4 & CG & 12.00 & 3 & 1.56 \\
\hline 7 & Cambaridae & $\mathrm{DC}$ & 6 & $\mathrm{H}$ & 6.00 & 1 & 0.52 \\
\hline $8 \mid$ & Palaemonidae & $D C$ & 6 & $\mathrm{H}$ & 0.00 & $\cdot$ & 0.00 \\
\hline 9 & Chironomini & DCC & 8 & CG & 488.00 & 61 & 31.77 \\
\hline 10 & Ceratopogonidas & DO & 8 & $P$ & 0.00 & & 0.00 \\
\hline 11 & Culicidae & DO & & CF & & & 0.00 \\
\hline 12 & Simuliidae & DO & 6 & $C F$ & 102.00 & 17 & 8.85 \\
\hline 13 & Tabanidae & 00 & 6 & $\mathrm{P}$ & 0.00 & & 0.00 \\
\hline 14$]$ & Tipulidae & DO & 3 & $\mathrm{SH}$ & 0.00 & & 0.00 \\
\hline 15 & Orthocladiinae & DOR & 6 & CG & 66.00 & 11 & 5.73 \\
\hline 16[ & Tanypodinae & DTA & 6 & $P$ & 54.00 & 9 & 4.69 \\
\hline 17 & Tanytarsini & DTY & 6 & CG & 102.00 & 17 & 8.85 \\
\hline $18 \mid$ & Baetidae & EP & 4 & CG & 24.00 & 6 & 3.13 \\
\hline 19 & Caenidae & EP & 7 & $\mathbf{C G}$ & 14.00 & 2 & $\cdot 1.04$ \\
\hline 201 & Ephemerellidae & EP & 1 & $\mathbf{C G}$ & 5.00 & 5 & 2.60 \\
\hline 29 & Ephemeridae & EP & 4 & CG & 0.00 & & 0.00 \\
\hline 22 & Heptageniidae & EP & 4 & $S C$ & 24.00 & 6) & 3.13 \\
\hline 23 & Leptophlebiidae & EP & 2 & $\mathbf{C G}$ & 6.00 & 3 & 1.56 \\
\hline $24 \mid$ & Neoephemeridae & EP & & CG & & 3 & 1.56 \\
\hline 25 & Oligoneuriidae & EP & 2 & CF & 0.00 & & 0.00 \\
\hline 26 & Siphlonuridae & EP & 7 & CG & 0.00 & & 0.00 \\
\hline 27 & Tricorythidas & EP & 4 & CG & 0.00 & & 0.00 \\
\hline 28 & Corixidae & $\mathrm{HT}$ & 9 & $\mathrm{H}$ & 0.00 & & 0.00 \\
\hline 29 & Isopoda & is & 8 & $\mathbf{C G}$ & 0.00 & & 0.00 \\
\hline 30 & Pyralidae & LEPP & 5 & $\mathrm{H}$ & 0.00 & & 0.00 \\
\hline 31 & Sphaeriidae & $M B$ & 8 & CF & 0.00 & & 0.00 \\
\hline 32 & Corydelidae & ME & $5 ;$ & P. & 0.00 & & 0.00 \\
\hline 33 & \begin{tabular}{|l|} 
Sialidae \\
\end{tabular} & $M E$ & 4 & $\mathrm{P}$ & 0.00 & & 0.00 \\
\hline 34 & Planorbidae & MG & 6 & SC & 0.00 & & 0.00 \\
\hline 35 & Viviparidae & MG & 7 & SC & 0.00 & & 0.00 \\
\hline 36 & Nemertea & NA & & $P$ & & & 0.00 \\
\hline 37 & Nematoda & NE & & $P$ & & & 0.00 \\
\hline 38 & Aeshnidae & $O D$ & 3 & $P$ & 3.00 & 1 & 0.52 \\
\hline 39 & Calopterygidae & OD & 5 & $P$ & 0.00 & & 0.00 \\
\hline 40 & Coenagrionidae & OD & 9 & $P$ & 0.00 & & 0.00 \\
\hline 41 & Corduliidaae & 100 & 5 & $P$ & 0.00 & & 0.00 \\
\hline 42 & Gomphidae & $O D$ & 1 & $\mathrm{P}$ & 0.00 & & 0.00 \\
\hline 43 & Libellulidae & $O D$ & 9 & $P$ & 0.00 & & 0.00 \\
\hline 44 & Macromiidae & 00 & & $P$ & 6.00 & 2 & 1.04 \\
\hline 45 & Capniidee & $\mathrm{PL}$ & 1 & $\mathrm{SH}$ & 7.00 & 7 & 3.65 \\
\hline 46 & Leuctridae & $P L$ & 0 & $\mathrm{SH}$ & 0.00 & & 0.00 \\
\hline 47. & Perlidae & $\mathrm{PL}$ & 1 & P & 2.00 & 2 & 1.04 \\
\hline 48 & Pteronarcyidae & $P L$ & 인 & $\mathrm{SH}$ & 0.00 & & 0.00 \\
\hline 49 & Brachycentridae & TR & 1 & $\mathrm{CF}$ & 0.00 & & 0.00 \\
\hline 50 & Hydropsychidae & TR & 4 & $\mathrm{CF}$ & 88.00 & 22 & 11.46 \\
\hline 51 & Hydroptilidae & $T R$ & & $\mathrm{H}$ & 0.00 & & 0.00 \\
\hline 52 & Lepidostomatidae & TR & 1 & $\mathrm{SH}$ & 0.00 & & 0.00 \\
\hline 53 & Leptoceridae & TR & 4 & $\mathrm{SH}$ & 8.00 & 2 & 1.04 \\
\hline 54 & Philopotamidae & TR & 3 & CF & 3.00 & 1 & 0.52 \\
\hline 55 & Polycentropodidae & TR & 6 & $\mathrm{CF}$ & 0.00 & & 0.00 \\
\hline 56 & Psychomyiidae & TR & 2 & sc & 0.00 & & 0.00 \\
\hline 57 & Turbellaria & TU & & AP & 4.00 & 1 & 0.52 \\
\hline
\end{tabular}


Station 12. Indian Grave Branch at Road B. RBP-Il. 21 September 1994.

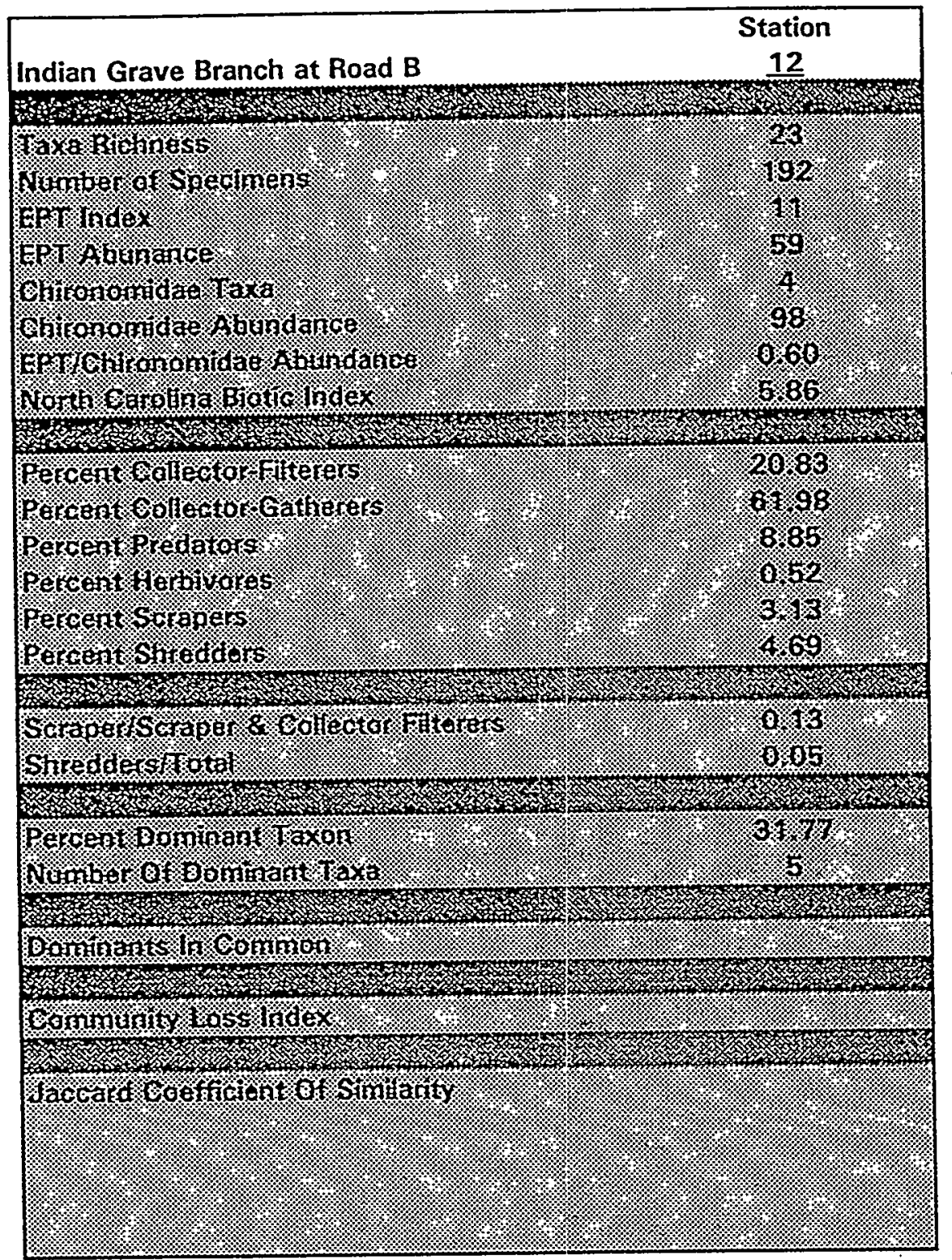


Rosemary Creek downstream of Williston WWTP. 17 December 1994. RBP II.

\begin{tabular}{|r|l|l|r|r|r|r|}
\hline Seq & Taxon & TAXC & NCBI & FG & NUMBER & Rel Abd \\
\hline 1 & Amphipoda & AM & 6 & CG & 1 & 0.37 \\
\hline 2 & Oligochaeta & ANO & 9 & CG & 3 & 1.12 \\
\hline 3 & Elmidae & CO & 4 & CG & 1 & 0.37 \\
\hline 4 & Cambaridae & DC & 6 & H & 1 & 0.37 \\
\hline 5 & Palaemonidae & DC & 6 & H & 10 & 3.73 \\
\hline 6 & Chironomini & DCC & 8 & CG & 15 & 5.60 \\
\hline 7 & Empedidae & DO & 6 & CG & 1 & 0.37 \\
\hline 8 & Simulidae & DO & 6 & CF & 2 & 0.75 \\
\hline 9 & Orthocladiinae & DOR & 6 & CG & 13 & 4.85 \\
\hline 10 & Tanypodinae & DTA & 6 & P & 3 & 1.12 \\
\hline 11 & Tanytarsini & DTY & 6 & CG & 79 & 29.48 \\
\hline 12 & Baetidae & EP & 4 & CG & 42 & 15.67 \\
\hline 13 & Ephemerellidae & EP & 1 & CG & 21 & 7.84 \\
\hline 14 & Heptageniidae & EP & 4 & SC & 11 & 4.10 \\
\hline 15 & Corbiculidae & MB & 6 & CF & 3 & 1.12 \\
\hline 16 & Sphaeriidae & MB & 8 & CF & 2 & 0.75 \\
\hline 17 & Ancylidae & MG & 6 & SC & 2 & 0.75 \\
\hline 18 & Aeshnidae & OD & 3 & P & 4 & 1.49 \\
\hline 19 & Calopterygidae & OD & 5 & P & 4 & 1.49 \\
\hline 20 & Coenagrionidae & OD & 9 & P & 1 & 0.37 \\
\hline 21 & Cordulegasteridae & OD & 3 & P & 1 & 0.37 \\
\hline 22 & Perlidae & PL & 1 & P & 15 & 5.60 \\
\hline 23 & Perlodidae & PL & 2 & P & 1 & 0.37 \\
\hline 24 & Taeniopterygidae & PL & 2 & SH & 1 & 0.37 \\
\hline 25 & Brachycentridae & TR & 1 & CF & 1 & 0.37 \\
\hline 26 & Hydropsychidae & TR & 4 & CF & 23 & 8.58 \\
\hline 27 & Léptoceridae & TR & 4 & SH & 3 & 1.12 \\
\hline 28 & Limnephilidae & TR & 4 & SH & 4 & 1.49 \\
\hline & & & & 11 \\
\hline
\end{tabular}


Rosemary Creek downstream of Williston WWTP. 17 December 1994. RBP II.

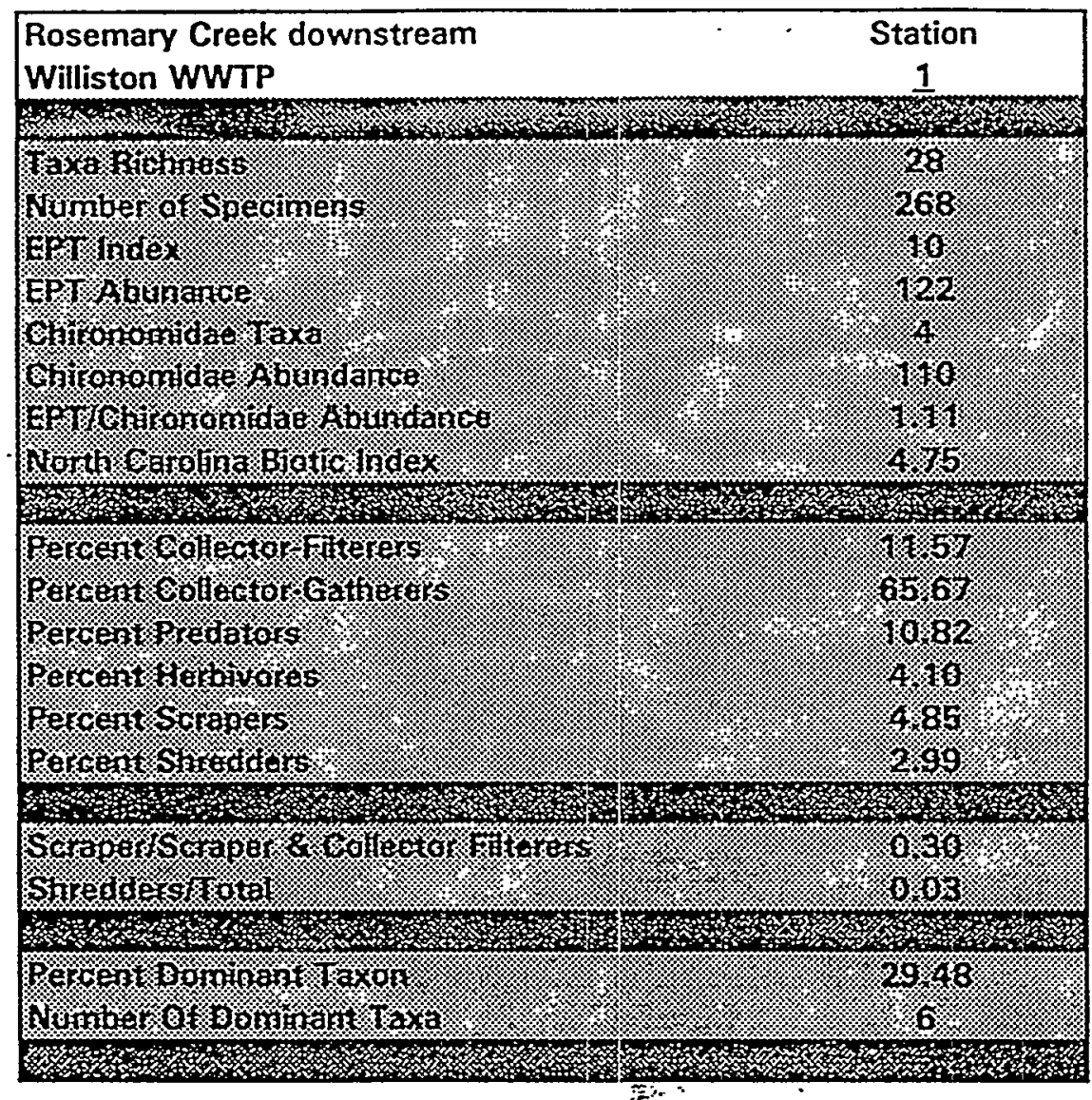


Rosemary Creek downstream of Williston WWTP. 17 December 1994. RBP II.

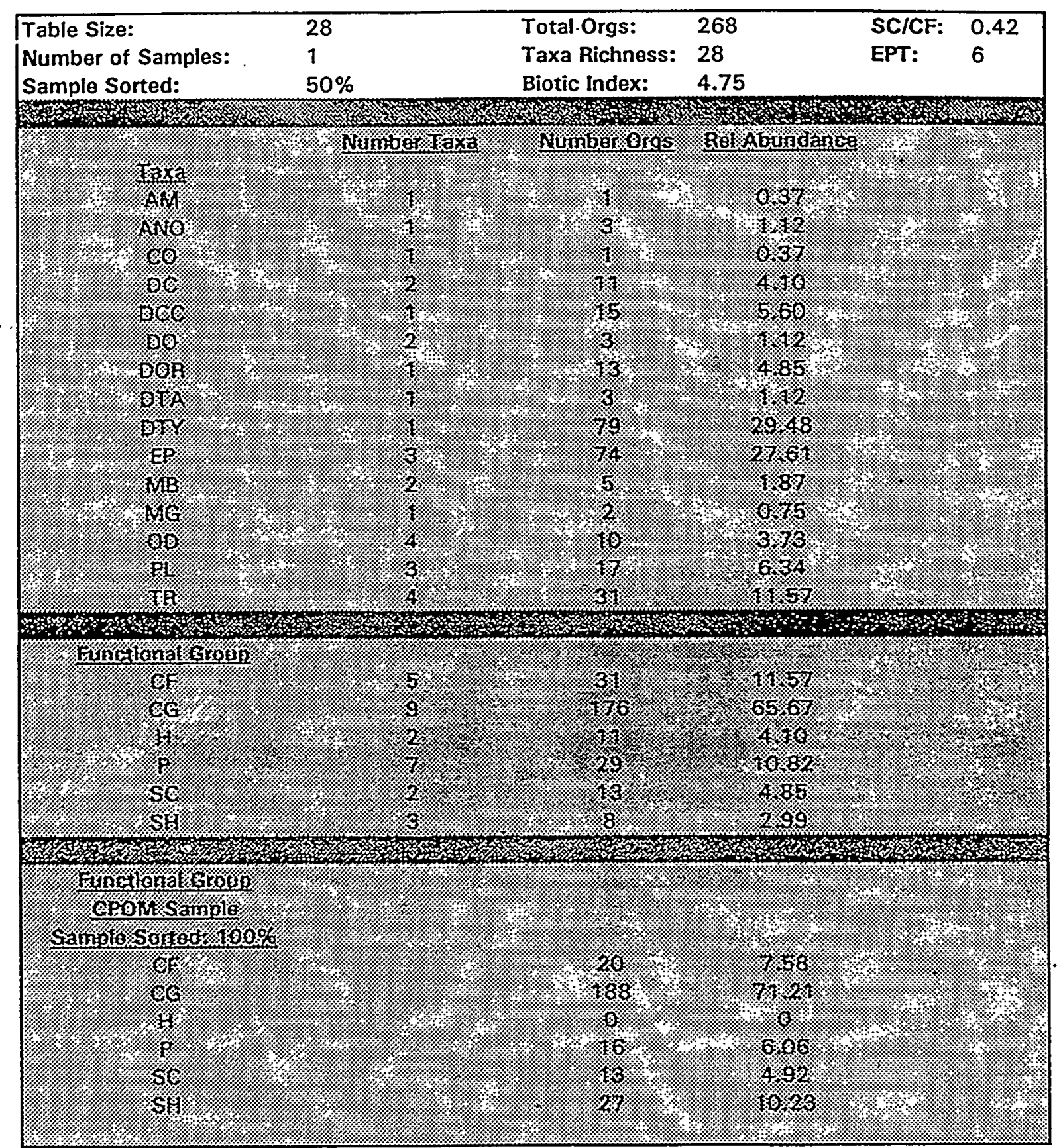


Rosemary Creek downstream of Williston WWTP. 17 December 1994. RBP II.

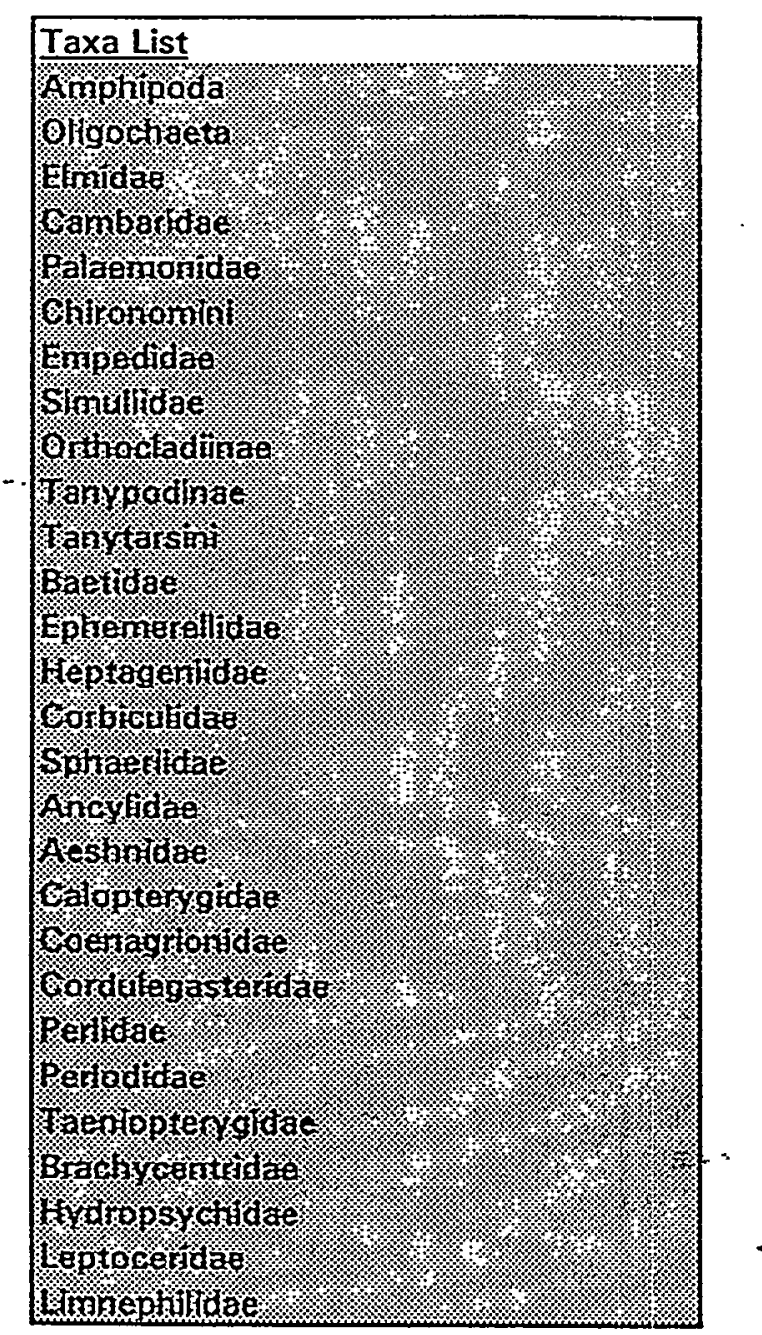


Rosemary Creek downstream of Williston WWTP. 17 December 1994. RBP II.

\begin{tabular}{|l|r|r|}
\hline Taxon & NUMBER & Rel Abd \\
\hline Tanyiü:ini & 79 & 29.48 \\
\hline Baetidae & 42 & 15.67 \\
\hline Hydropsychidae & 23 & 8.58 \\
\hline Ephemerellidae & 21 & 7.84 \\
\hline Chironomini & 15 & 5.60 \\
\hline Perlidae & 15 & 5.60 \\
\hline
\end{tabular}

标: 
Station 1. Rosemary Creek near Rosemary Chruch. RBP III. 20 September 1994

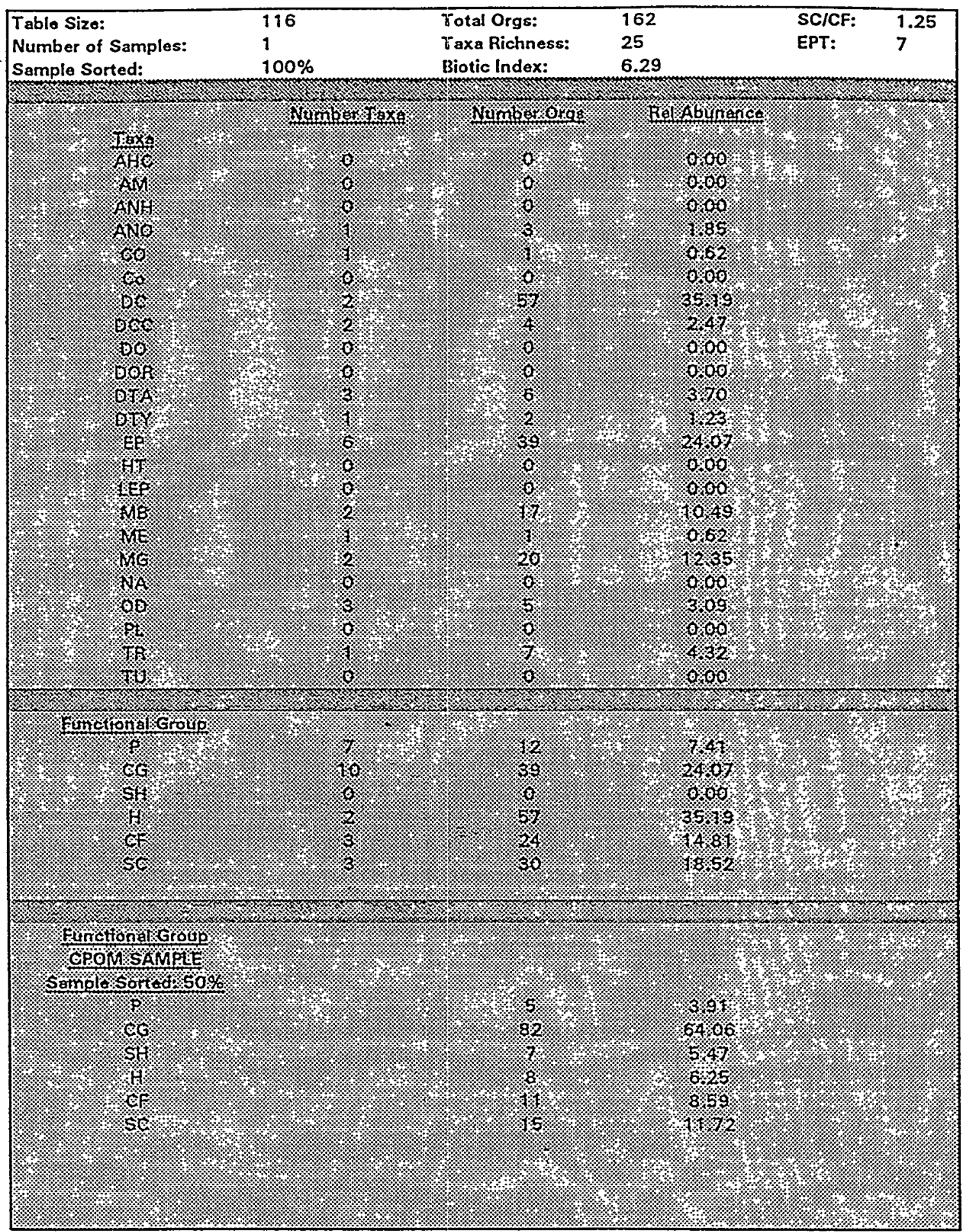


Station 1. Rosemary Creek near Rosemary Chruch. RBP III. 20 September 1994

\section{Taxa List}

Oinoontianta

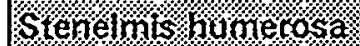

camborroas

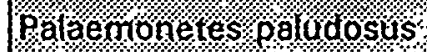

Microtendipes rodatensis

bolyoedilitn. spo.

Abrabesmy.ro.sop?

Apsectrotanypus ionnsont:

Glinotanypuss pringuis

78ny. or.sus son.

Baetis spp:

Gaenis spp

Hexagenio spp

Parateptophitebio spp.

Stenonema spo.

Ttrtcorvthodes.spo:

Corbicula sp.

Sphiveriun spo

S.,ilis:spp.

Camperomaspo

Ritiseiliaspo

Boyveria vinosa

Caloptenyx spo:

Gomphus spor

Phiv1ocentropus:spp: 
Station 1. Rosemary Creek near Rosemary Chruch. RḄp III. 20 September 1994

\begin{tabular}{|l|r|r|}
\hline Taxon & A & Rel Abd \\
\hline Palaemonetes paludosus & 52 & 32.10 \\
\hline Campeloma sp. & 19 & 11.73 \\
\hline Hexagenia spp. & 14 & .8 .64 \\
\hline Sphaerium spp. & 11 & 6.79 \\
\hline Stenonema spp. & 10 & 6.17 \\
\hline
\end{tabular}

$\cong$ 
Station 2. Tinker Creek at Kennedy Pond Roed. RBP III. 20 September 1994

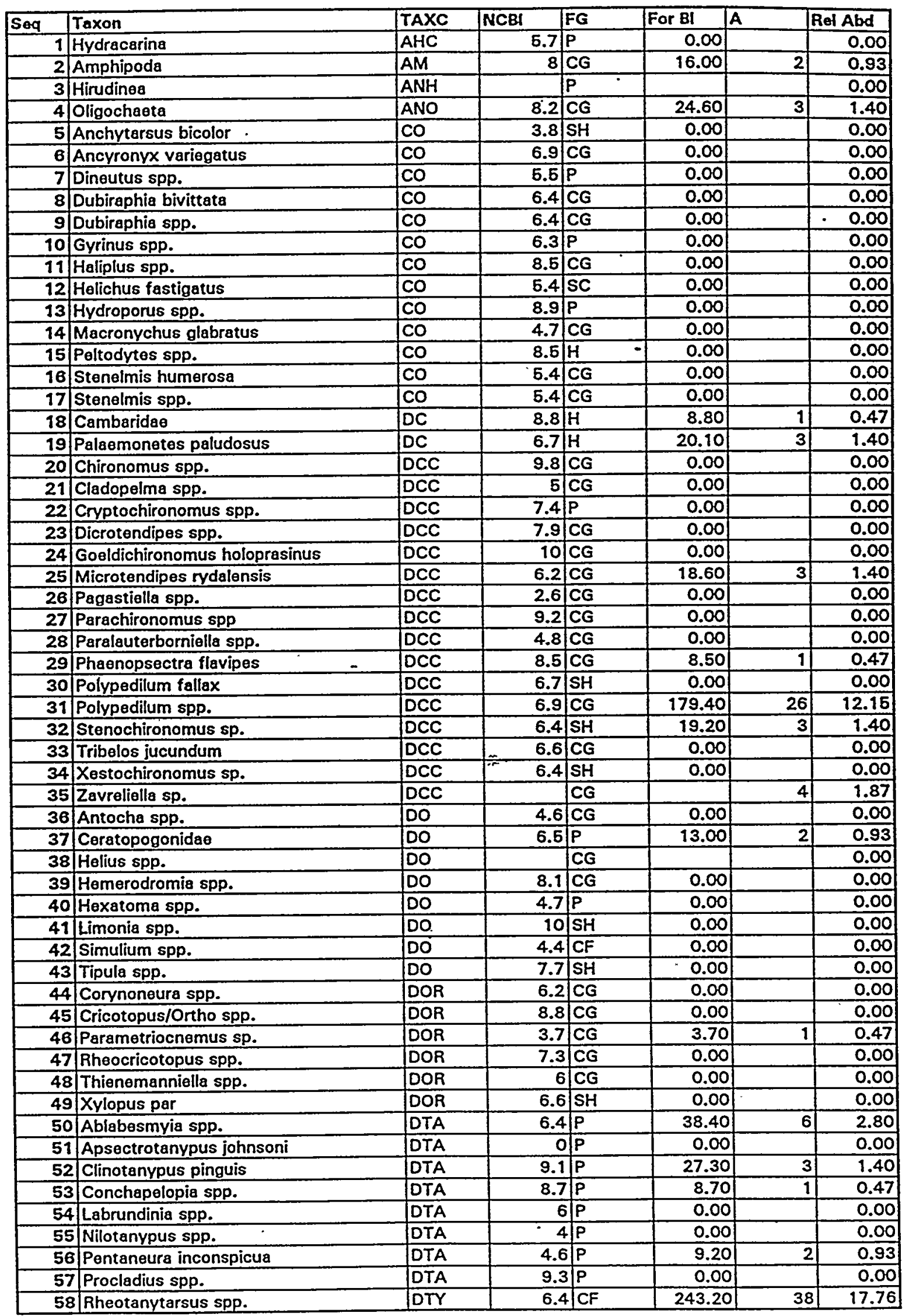


- Station 2. Tinker Creak at Kennedy Pond Road. RBP III. 20 September 1994

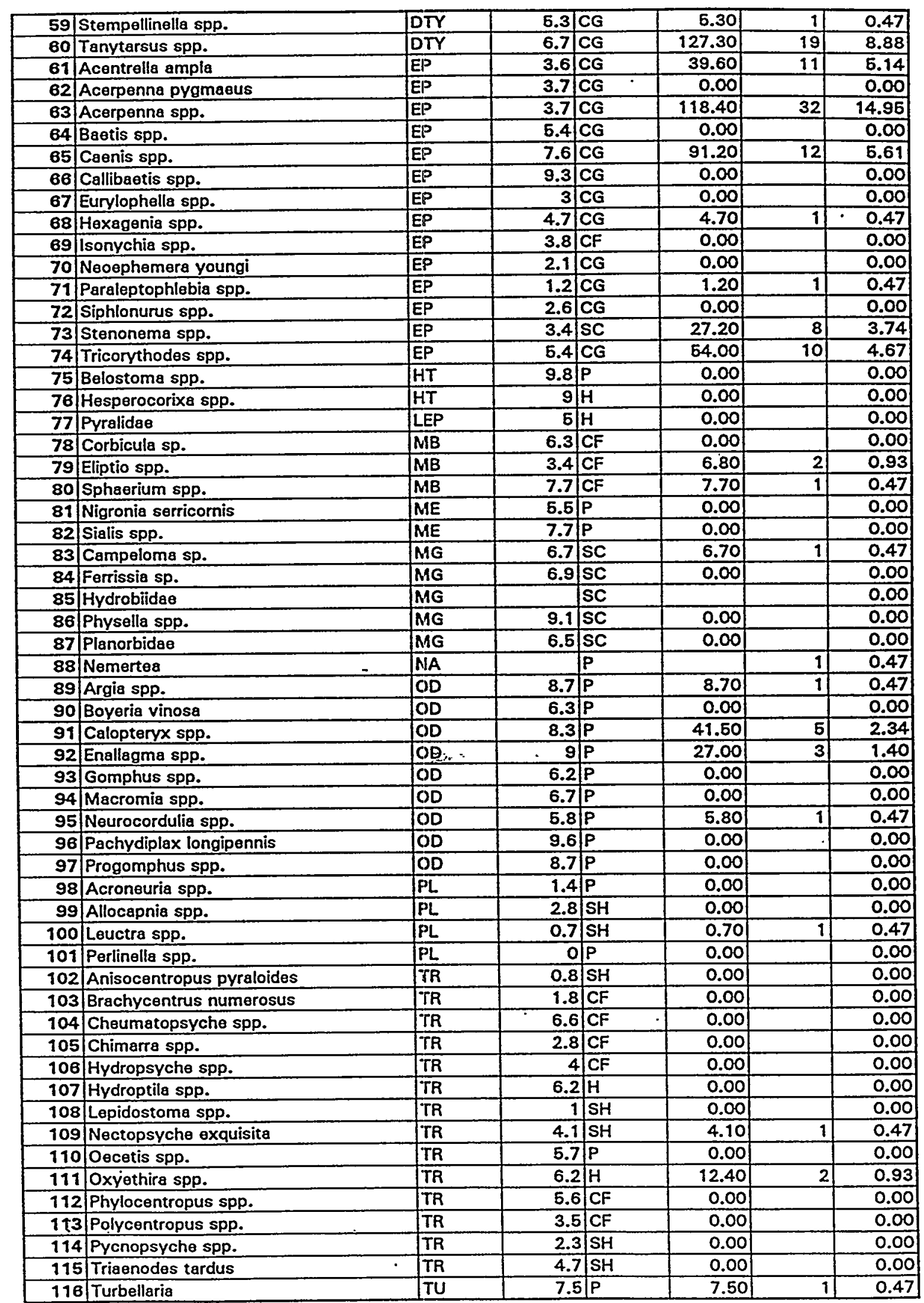


Station 2. Tinker Creek at Kennedy Pond Road. RBP III. 20 September 1994

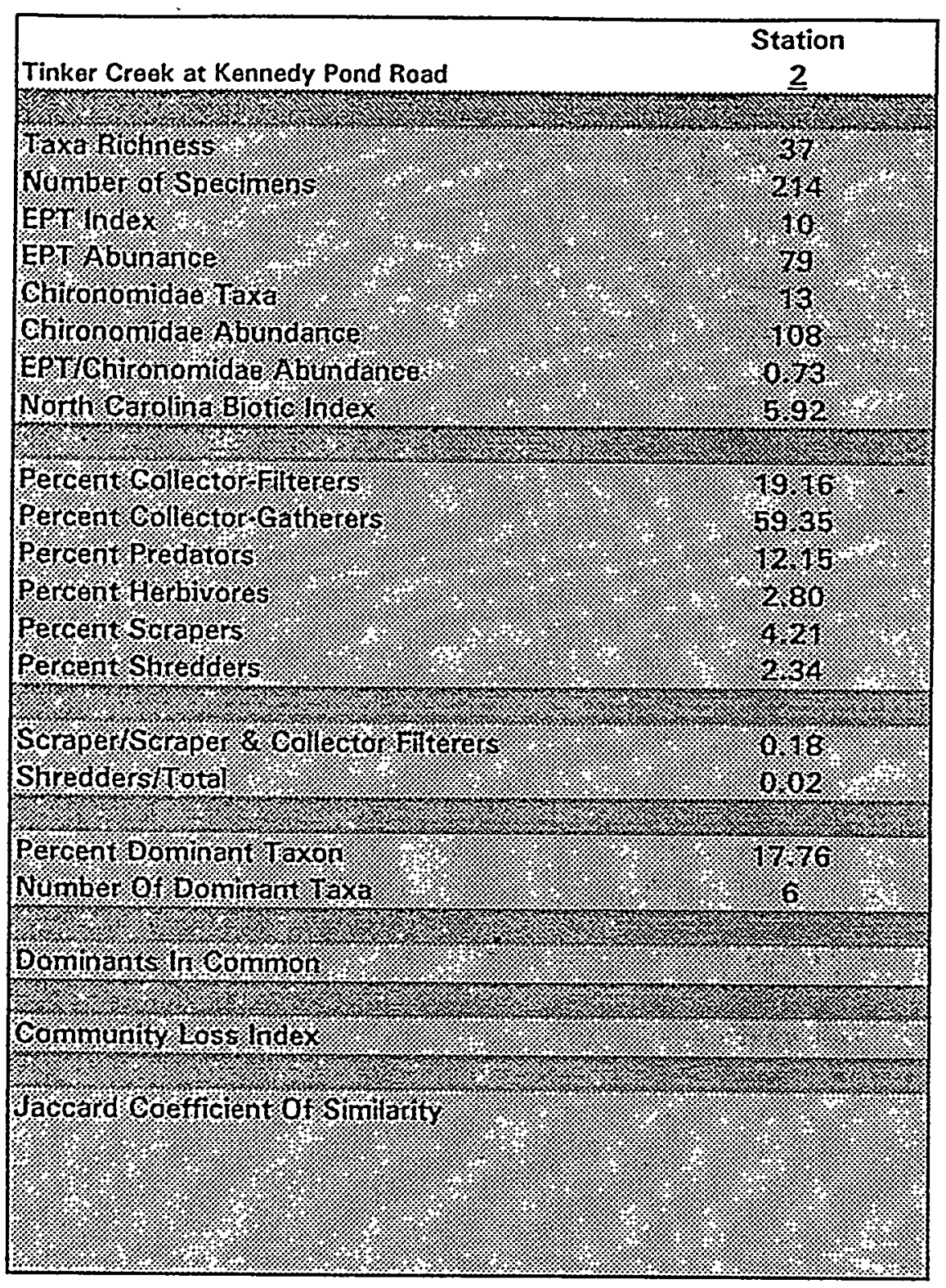


Station 2. Tinker Creek at Kennedy Pond Road. RBP III. 20 September 1994

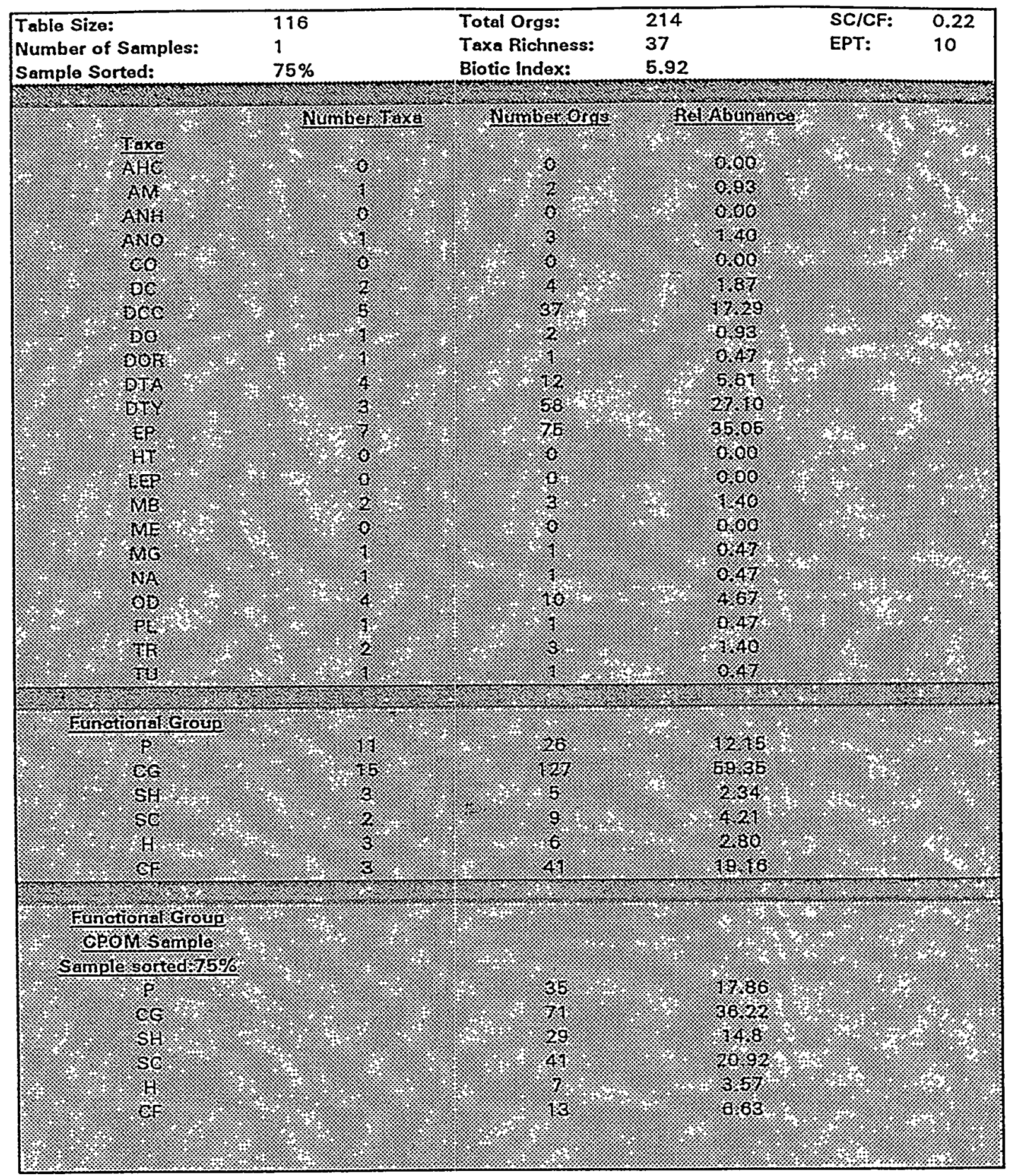




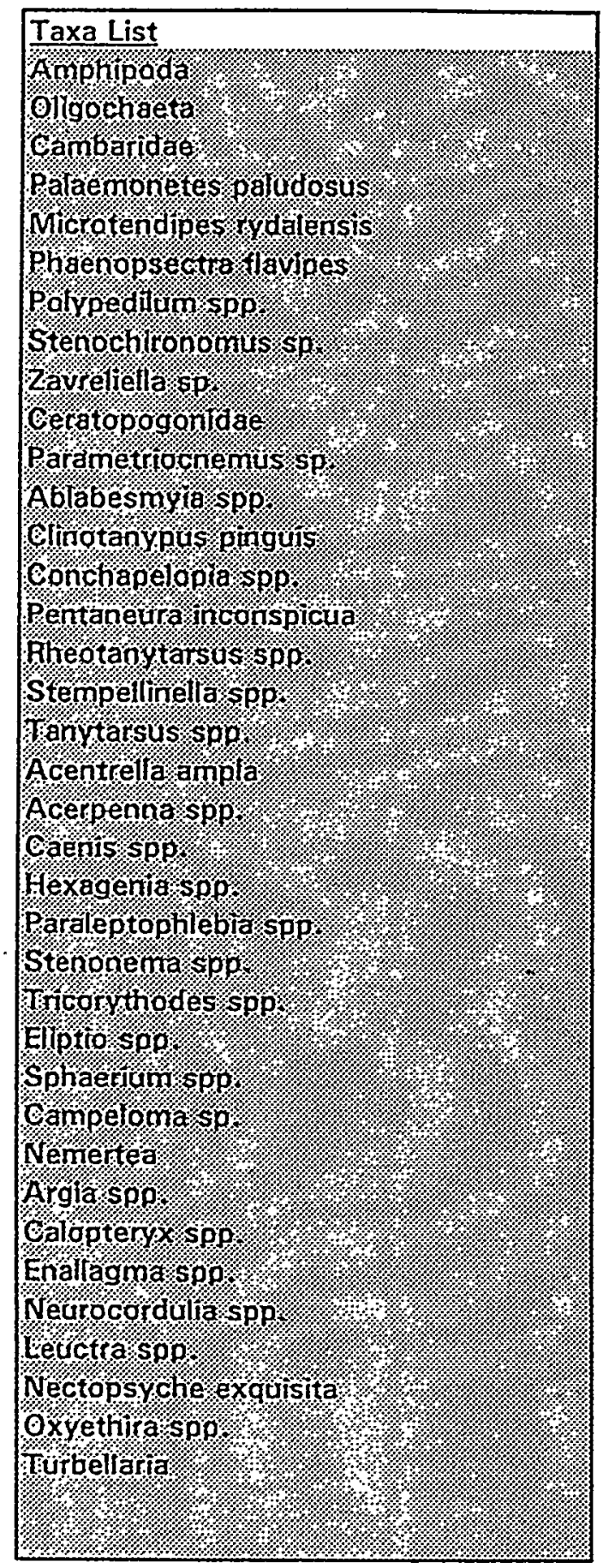

$\approx$ 
Station 2. Tinker Creek at Kennedy Pond Road. RBP III. 20 September 1994

\begin{tabular}{|l|r|r|}
\hline Taxon & A & Rel Abd \\
\hline Rheotanytarsus spp. & 38 & 17.76 \\
\hline Acerpenna spp. & 32 & 14.95 \\
\hline Polypedilum spp. & 26 & $12: 15$ \\
\hline Tanytarsus spp. & 19 & 8.88 \\
\hline Caenis spp. & 12 & 5.61 \\
\hline Acentrella ampla & 11 & 5.14 \\
\hline
\end{tabular}




\begin{tabular}{|c|c|c|c|c|c|c|c|}
\hline Seq & Taxon & TAXC & NCBA & FG & For 81 & $\mathbf{A}$ & Rol Abd \\
\hline 1 & Hydracerina & $\overline{A H C}$ & 5.7 & $\mathrm{P}$ & 0.00 & & 0.00 \\
\hline 2 & Amphipoda & $A M$ & 8 & CG & 16.00 & 2 & 1.30 \\
\hline 3 & Hirudinea & ANH & & $\mathrm{P}$ & & & 0.00 \\
\hline 4 & Oligochaeta & ANO & 8.2 & $C G$ & 442.80 & 54 & 35.06 \\
\hline 5 & Anchytarsus bicolor. & $\mathrm{CO}$ & 3.8 & $\mathrm{SH}$ & 0.00 & & 0.00 \\
\hline 6 & Ancyronyx variegatus & co & 6.9 & $C G$ & 0.00 & & 0.00 \\
\hline 7 & Dineutus spp. & co & 5.6 & $\mathrm{P}$ & 0.00 & & 0.00 \\
\hline 8 & Dubiraphia bivittata & co & 6.4 & $\mathbf{P}$ & 0.00 & & 0.00 \\
\hline 9 & Dubiraphia spp. & Co & 6.4 & $\overline{C G}$ & 0.00 & & 0.00 \\
\hline 10 & Gyrinus spp. & co & 6.3 & $\mathrm{P}$ & 0.00 & & 0.00 \\
\hline 11 & Haliplus sp. & $\mathrm{CO}$ & 8.6 & CG & 8.50 & 1 & 0.65 \\
\hline 12 & Helichus fastigatus & CO & 5.4 & Sc & 0.00 & & 0.00 \\
\hline 13 & Hydroporus spp. & co & 8.9 & $\mathbf{P}$ & 8.90 & 1 & 0.66 \\
\hline 14 & Macronychus glabratus & Co & 4.7 & $C G$ & 0.00 & & 0.00 \\
\hline 15 & Peltodytes spp. & Co & 8.5 & $\mathrm{H}$ & 0.00 & & 0.00 \\
\hline 16 & Stenelmis humerosa & Co & 5.4 & CG & 0.00 & & 0.00 \\
\hline 17 & Stenelmis spp. & Co & 5.4 & $C G$ & 0.00 & & 0.00 \\
\hline 18 & Cambaridae & DC & 8.8 & $H$ & 0.00 & & 0.00 \\
\hline 19 & Palaemonetes paludosus & $D C$ & 6.7 & $\mathrm{H}$ & 13.40 & 2 & 1.30 \\
\hline 20 & Chironomus spp. & DCC & 9.8 & CG & 0.00 & & 0.00 \\
\hline 21 & Cladopelme sp. & DCC & 5 & $\overline{C G}$ & 0.00 & & 0.00 \\
\hline 22 & Cryptochironomus spp. & DCC & 7.4 & $\mathrm{P}$ & 0.00 & & 0.00 \\
\hline 23 & Dicrotendipes spp. & DCC & 7.9 & $\mathbf{C G}$ & 15.80 & 2 & 1.30 \\
\hline 24 & Gooldichironomus holoprasinus & DCC & 10 & CG & 0.00 & & 0.00 \\
\hline 25 & Microtendipes rydalensis & DCC & 6.2 & CG & 31.00 & 5 & 3.25 \\
\hline 28 & Pegastiella sp. & $D C C$ & 2.6 & $C G$ & 0.00 & & 0.00 \\
\hline 27 & Parachironomus spp. & DCC & 9.2 & CG & 0.00 & & 0.00 \\
\hline 28 & Paralauterborniella sp. & DCC & 4.8 & CG & 0.00 & & 0.00 \\
\hline 29 & Phaenopsectra flavipes & $\overline{D C C}$ & 8.5 & CG & 0.00 & & 0.00 \\
\hline 30 & Polypedilum fallax & DCC & 6.7 & $\mathrm{SH}$ & 0.00 & & 0.00 \\
\hline 31 & Polypedilum spp. & DCC & 6.9 & CG & 27.60 & 4 & 2.60 \\
\hline 32 & Stenochironomus sp. & DCC & 6.4 & $\mathrm{SH}$ & 12.80 & 2 & 1.30 \\
\hline 33 & \begin{tabular}{|l} 
Tribelos jucundum \\
\end{tabular} & DCC & 6.6 & CG & 0.00 & & 0.00 \\
\hline 34 & Xestochironomus sp. & DCC & 6.4 & $\mathrm{SH}$ & 0.00 & & 0.00 \\
\hline 35 & Zavralliella sp. & $\overline{D C C}$ & & CG & & & 0.00 \\
\hline 36 & Antoche spp. & 00 & 4.6 & CG & 0.00 & & 0.00 \\
\hline 37 & \begin{tabular}{|l|} 
Ceratopogonidae \\
\end{tabular} & DO & 6.5 & $P$ & 62.00 & 8 & 5.19 \\
\hline 38 & $\begin{array}{l}\text { Helius spp. } \\
\end{array}$ & DO & & CG & & & 0.00 \\
\hline 39 & Hemerodromia spp. & DO & 8.1 & CG & 0.00 & & 0.00 \\
\hline 40 & Hexatoma spp. & DO & 4.7 & $P$ & 0.00 & & 0.00 \\
\hline 41 & Limonis spp. $\because$ & DO & 10 & $\mathrm{SH}$ & 30.00 & 3 & 1.95 \\
\hline 42 & Simulium spp. & DO & 4.4 & $\mathrm{CF}$ & 0.00 & & 0.00 \\
\hline 43 & Tipula spp. & DO & 7.7 & $\mathrm{SH}$ & 0.00 & & 0.00 \\
\hline 44 & \begin{tabular}{|l|} 
Corynoneura spp. \\
\end{tabular} & DOR & 6.2 & CG & 0.00 & & 0.00 \\
\hline 45 & Cricotopus/Ortho spp. & DOR & 8.8 & CG & 0.00 & & 0.00 \\
\hline 46 & Parametriocnemus sp. & DOR & 3.7 & CG & 0.00 & & 0.00 \\
\hline 47 & Rheocricotopus spp. & DOR & 7.3 & CG & 0.00 & & 0.00 \\
\hline 48 & Thienemanniella spp. & DOR & 6 & CG & 0.00 & & 0.00 \\
\hline 49 & \begin{tabular}{|l|} 
Xylopus par \\
\end{tabular} & DOR & 6.6 & $\mathrm{SH}$ & 0.00 & & 0.00 \\
\hline 50 & Ablabesmyia spp. & DTA & 6.4 & $P$ & 25.60 & 4 & 2.60 \\
\hline 51 & Apsectrotanypus johnsoni & DTA & 0 & $P$ & 0.00 & & 0.00 \\
\hline 52 & Clinotanypus pinguis & DTA & 9.1 & $P$ & 36.40 & 4 & 2.60 \\
\hline 53 & Conchapelopia spp. & DTA & 8.7 & $P$ & 8.70 & 1 & 0.65 \\
\hline 54 & Labrundinia spp. & DTA & $\because 6$ & $P$ & 0.00 & & 0.00 \\
\hline 55 & Nilotanypus spp. & DTA & & $\mathrm{P}$ & 0.00 & & 0.00 \\
\hline 56 & Pentaneura inconspicua & DTA & 4.6 & $P$ & 0.00 & & 0.00 \\
\hline 57 & Procladius spp. & DTA & 9.3 & $P$ & 18.60 & 2 & 1.30 \\
\hline 58 & Rheotanytarsus spp. & DTY & 6.4 & $\mathrm{CF}$ & 6.40 & 1 & 0.65 \\
\hline
\end{tabular}


Station 3. Mill Creek at Road Ė-2.. RBP III. 20 September 1994

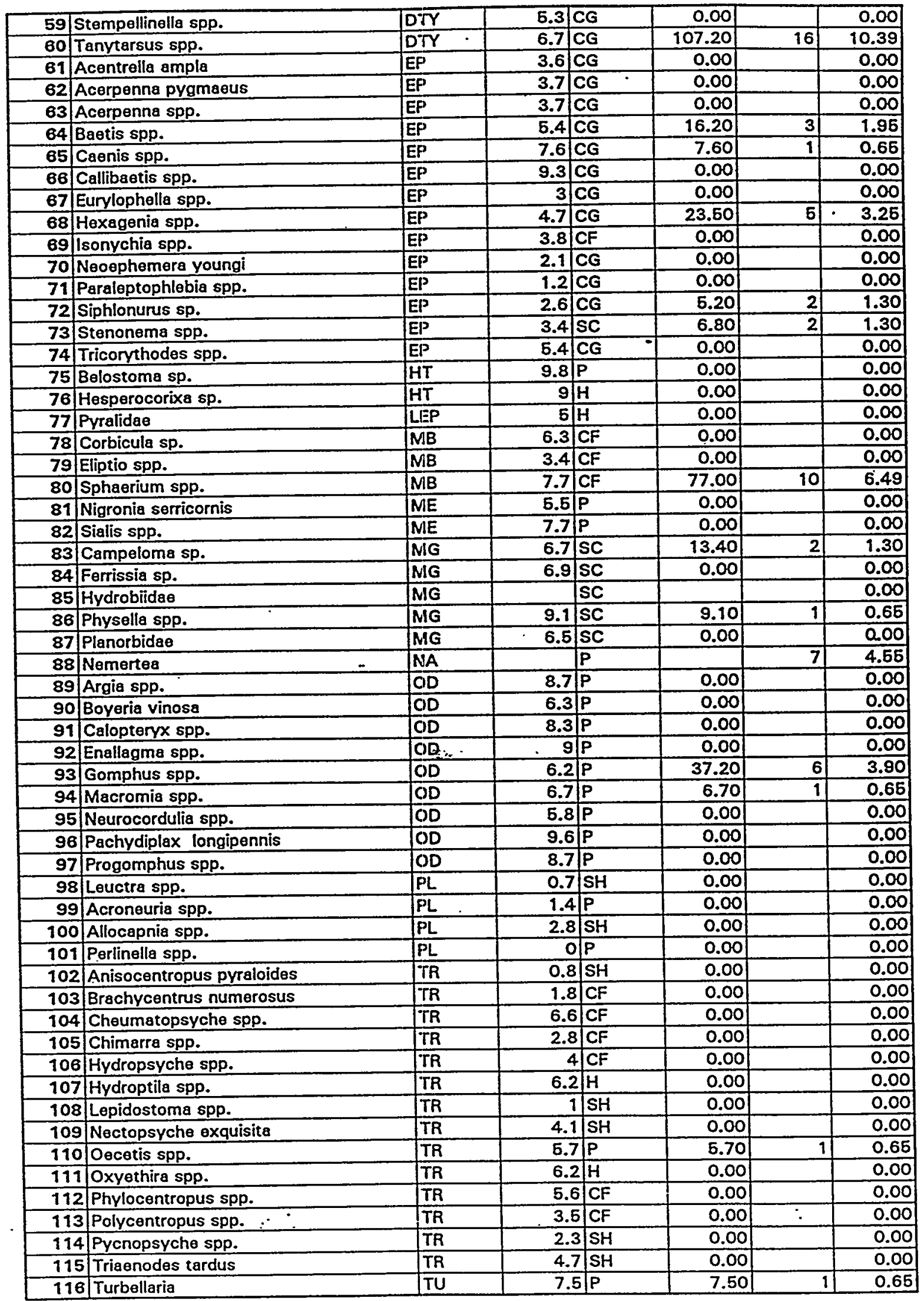




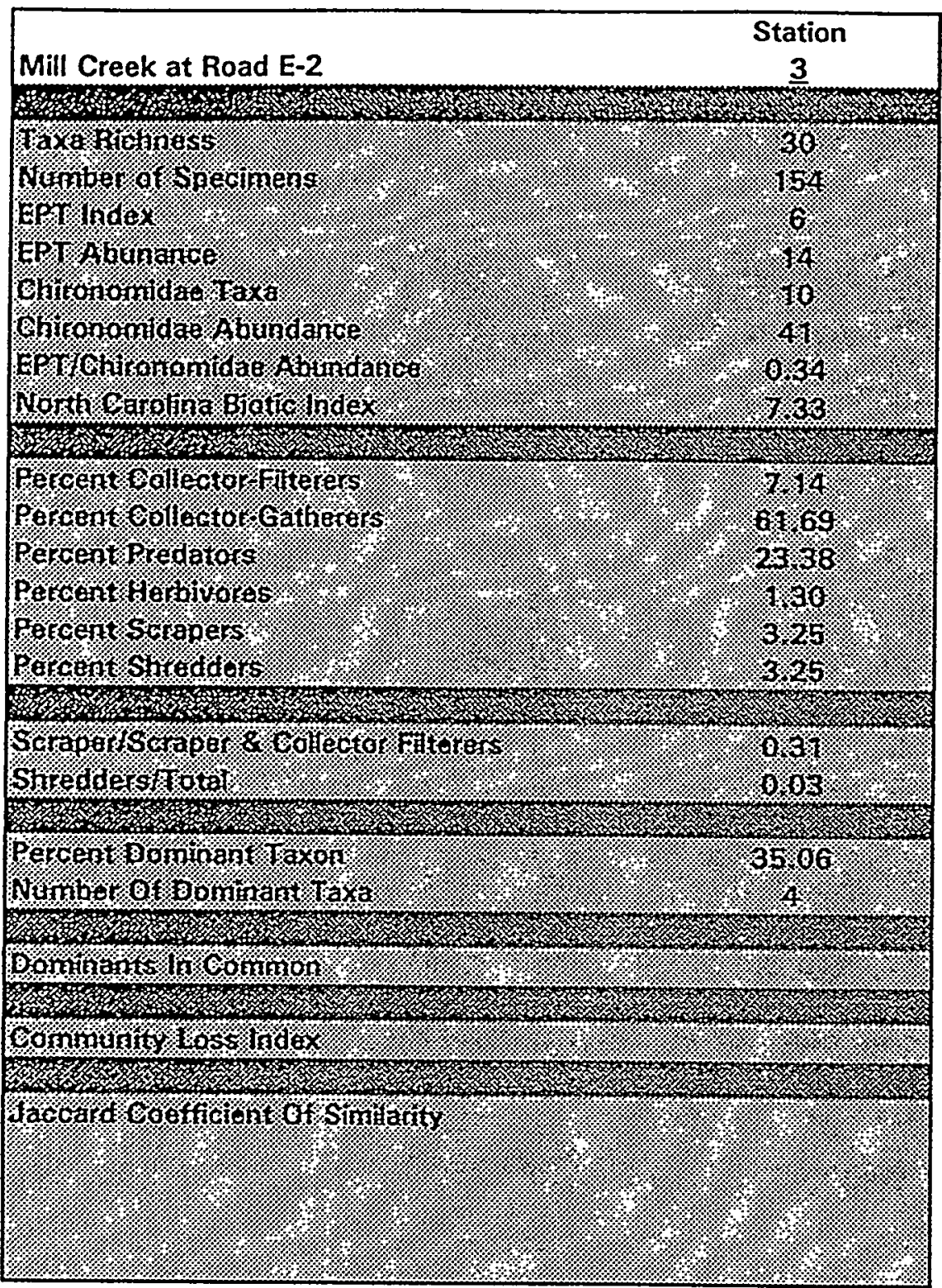




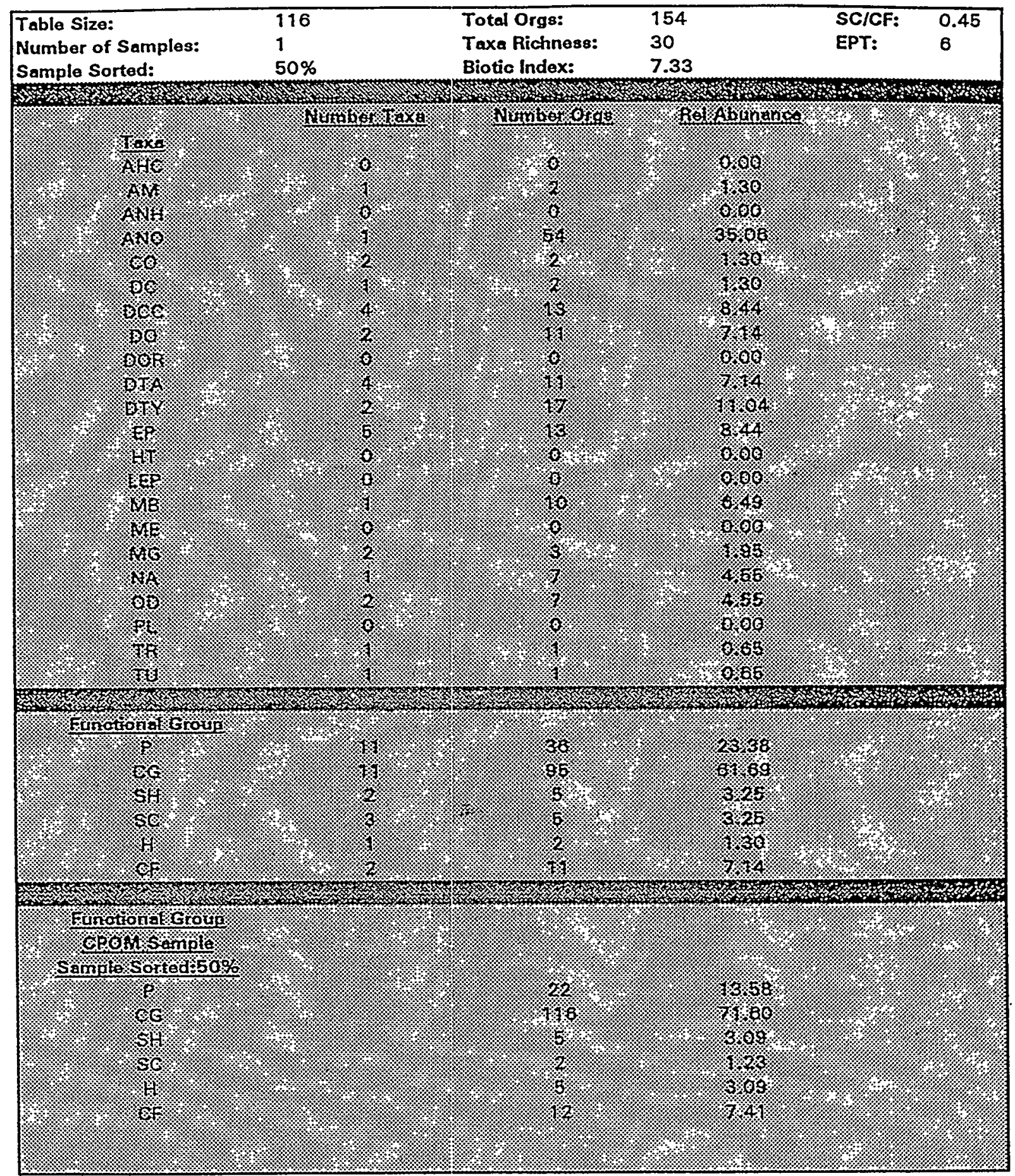




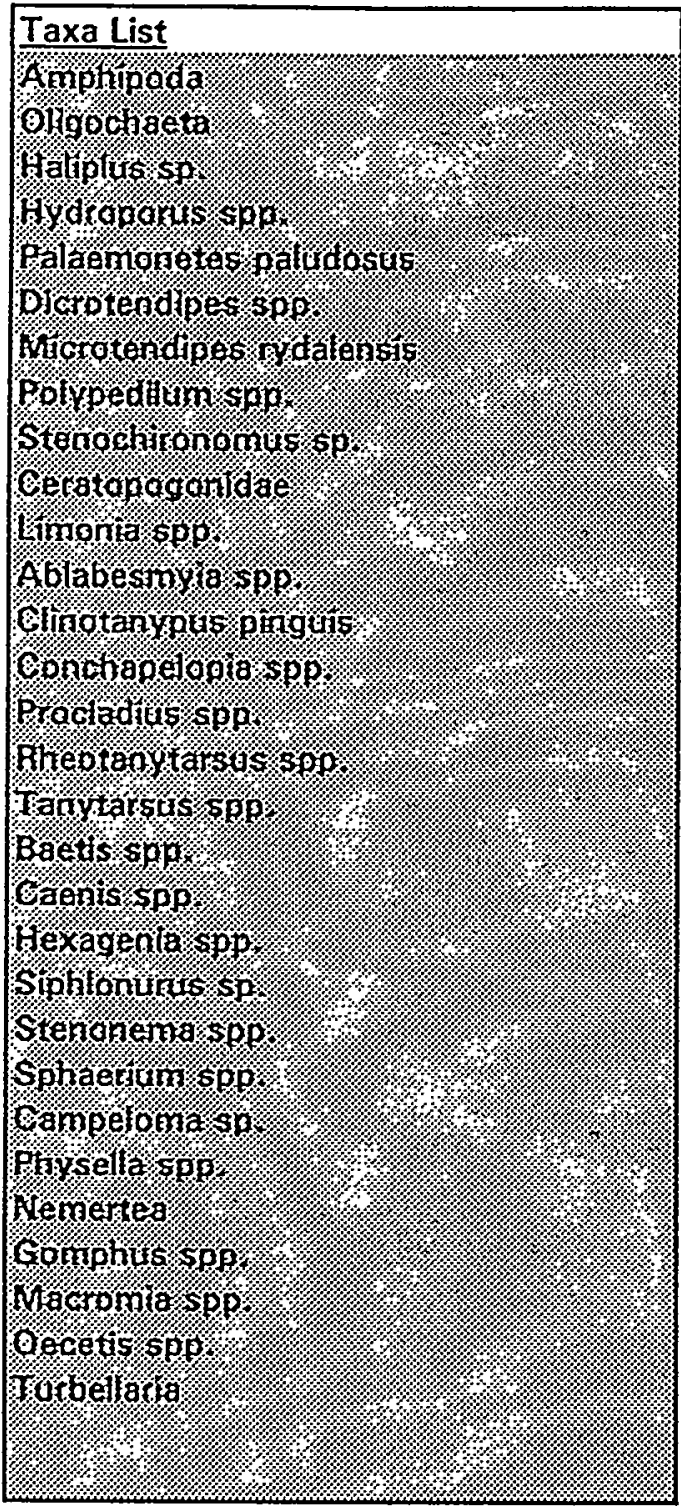

Fo. 
Station 3. Mill Creek at Road E-2. RBP III. 20 September 1994

\begin{tabular}{|l|r|r|}
\hline Taxon & A & Rel Abd \\
\hline Oligochaeta & 54 & 35.06 \\
\hline Tanytarsus spp. & 16 & 10.39 \\
\hline Sphaerium spp. & 10 & 6.49 \\
\hline Ceratopogonidae & 8 & 5.19 \\
\hline
\end{tabular}

Fo 


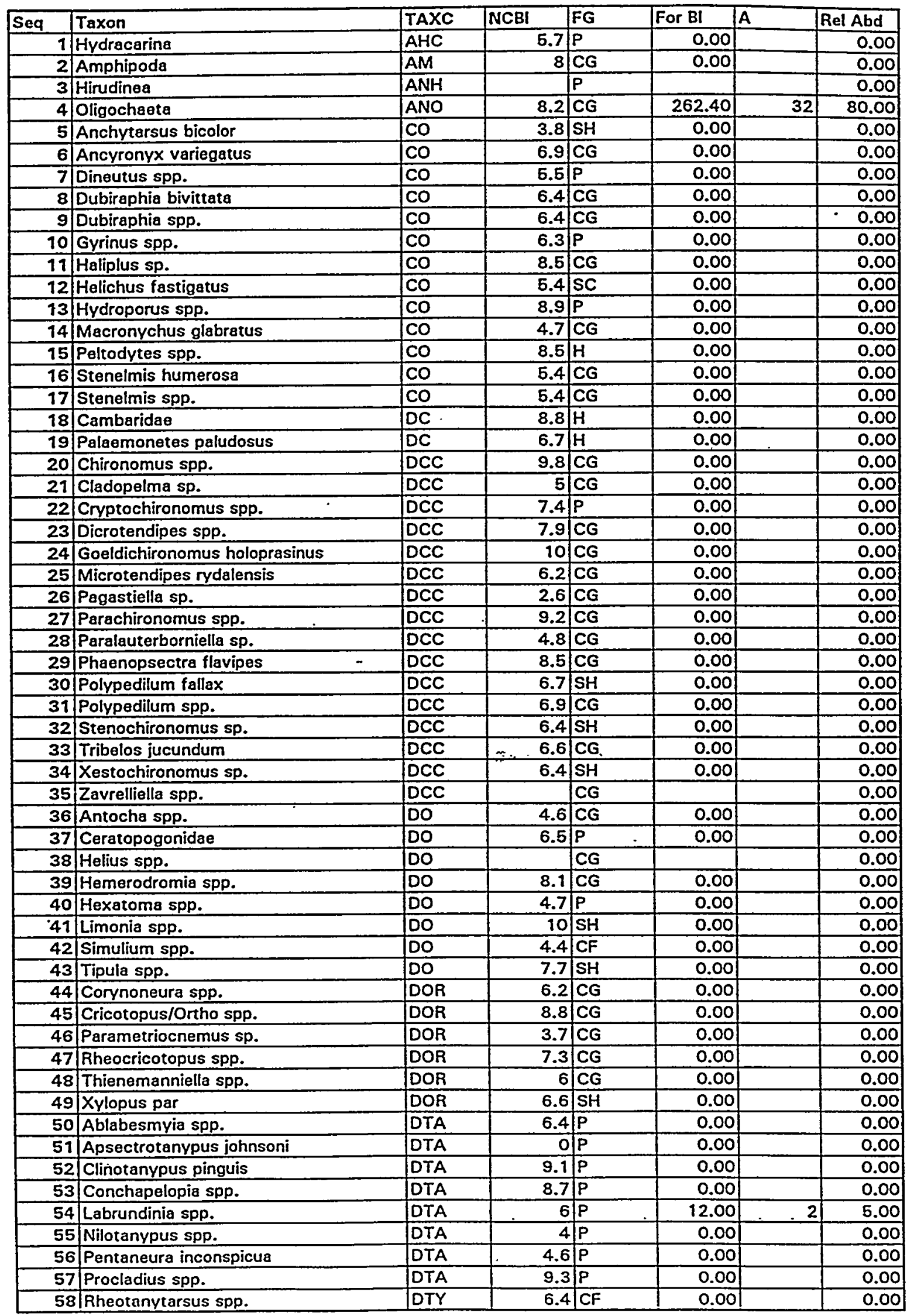


Station 4. Crouch Branch at Road 4. RBP III. 20 September 1994

\begin{tabular}{|c|c|c|c|c|c|c|c|}
\hline 59 & Stempellinella spp. & DTY & 5.3 & CG & 0.00 & & 0.00 \\
\hline 60 & Tanytarsus spp. & DTY & 6.7 & CG & 0.00 & & 0.00 \\
\hline 61 & Acentrella ampla & EP & 3.6 & CG & 0.00 & & 0.00 \\
\hline 62 & Acerpenna pygmaeus & EP & 3.7 & CG & 0.00 & & 0.00 \\
\hline 63 & Acerpenna spp. & EP & 3.7 & CG & 0.00 & & 0.00 \\
\hline 64 & Baetis spp. & EP & 5.4 & CG & 0.00 & & 0.00 \\
\hline 65 & Caenis spp. & EP & 7.6 & CG & 0.00 & & 0.00 \\
\hline 66 & Callibaetis spp. & EP & 9.3 & CG & 0.00 & & 0.00 \\
\hline 67 & Eurylophella spp. & EP & 3 & CG & 0.00 & & 0.00 \\
\hline 68 & Hexzgenia spp. & EP & 4.7 & CG & 0.00 & & 0.00 \\
\hline 69 & Isonychia spp. & EP & 3.8 & CF & 0.00 & & 0.00 \\
\hline 70 & Neoephemera youngi & EP & 2.1 & CG & 0.00 & & 0.00 \\
\hline 71 & Paraleptophlebia spp. & EP & 1.2 & CG & 0.00 & & 0.00 \\
\hline 72 & Siphlonurus sp. & EP & 2.6 & CG & 0.00 & & 0.00 \\
\hline 73 & Stenonema spp. & EP & 3.4 & SC & 0.00 & & 0.00 \\
\hline 74 & Tricorythodes spp. & EP & 5.4 & CG & 0.00 & & 0.00 \\
\hline 75 & Belostoma sp. & HT & 9.8 & $P$ & 0.00 & & 0.00 \\
\hline 76 & Hesperocorixa sp. & HT & 9 & $\mathrm{H}$ & 0.00 & & 0.00 \\
\hline 77 & Pyralidae & LEP & 5 & $\mathrm{H}$ & 0.00 & & 0.00 \\
\hline 78 & Corbicula sp. & $M B$ & 6.3 & CF & 0.00 & & 0.00 \\
\hline 79 & Eliptio spp. & $M B$ & 3.4 & CF & 0.00 & & 0.00 \\
\hline 80 & Sphaerium spp. & $M B$ & 7.7 & CF & 0.00 & & 0.00 \\
\hline 81 & Nigronia serricornis & ME & 5.5 & $P$ & 0.00 & & 0.00 \\
\hline 82 & Sialis spp. & $M E$ & 7.7 & $\bar{P}$ & 0.00 & & 0.00 \\
\hline 83 & Campeloma sp. & MG & 6.7 & SC & 0.00 & & 0.00 \\
\hline 84 & Ferrissia sp. & MG & 6.9 & SC & 0.00 & & 0.00 \\
\hline 85 & Hydrobiidae & $M G$ & & $S C$ & & & 0.00 \\
\hline 88 & Physella spp. & IMG & 9.1 & Sc & 0.00 & & 0.00 \\
\hline 87 & Planorbidae & IMG & 6.5 & SC & 13.00 & 2 & 5.00 \\
\hline 88 & Nemertea & INA & & $\bar{P}$ & & & 0.00 \\
\hline 89 & Argia spp. & OD & 8.7 & $P$ & 26.10 & 3 & 7.50 \\
\hline 901 & Boyeria vinosa & $O D$ & 6.3 & $\mathrm{P}$ & 0.00 & & 0.00 \\
\hline 91 & Calopteryx spp. & OD & 8.3 & P & 0.00 & & 0.00 \\
\hline 92 & Enallagma spp. & DQP, & 9 & $P$ & 9.00 & 1 & 2.50 \\
\hline 93 & Gomphus spp. & 100 & 6.2 & $P$ & 0.00 & & 0.00 \\
\hline 94 & Macromia spp. & OD & 6.7 & $P$ & 0.00 & & 0.00 \\
\hline 95 & Neurocordulia spp. & $\overline{D D}$ & 5.8 & P & 0.00 & & 0.00 \\
\hline 96 & Pachydiplax longipennis & OD & 9.6 & $P$ & 0.00 & & 0.00 \\
\hline 97 & Progomphus spp. & DD & 8.7 & P & 0.00 & & 0.00 \\
\hline 98 & Acroneuria spp & $P L$ & 1.4 & $P$ & 0.00 & & 0.00 \\
\hline 99 & Allocapnia spp. & $P L$ & 2.8 & $\mathrm{SH}$ & 0.00 & & 0.00 \\
\hline 100 & Leuctra spp. & $P L$ & 0.7 & $\mathrm{SH}$ & 0.00 & & 0.00 \\
\hline 101 & Perlinella spp. & PL & 0 & $P$ & 0.00 & & 0.00 \\
\hline 102 & Anisocentropus pyraloides & TR & 0.8 & $\mathrm{SH}$ & 0.00 & & 0.00 \\
\hline 103 & Brachycentrus numerosus & TR & 1.8 & CF & 0.00 & & 0.00 \\
\hline 104 & Cheumetopsyche spp. & TR & 6.6 & CF & 0.00 & & 0.00 \\
\hline 105 & Chimarra spp. & $T R$ & 2.8 & $\mathrm{CF}$ & 0.00 & & 0.00 \\
\hline 108 & Hydropsyche spp. & TR & 4 & $\mathrm{CF}$ & 0.00 & & 0.00 \\
\hline 107 & Hydroptila spp. & TR & 6.2 & $H$ & 0.00 & & 0.00 \\
\hline 108 & Lepidostoma spp. & TR & 1 & $\mathrm{SH}$ & 0.00 & & 0.00 \\
\hline 109 & Nectopsyche exquisita & TR & 4.1 & $\mathrm{SH}$ & 0.00 & & 0.00 \\
\hline 110 & Oecetis spp. & TR & 5.7 & $P$ & 0.00 & & 0.00 \\
\hline 117 & Oxyethira spp. & TR & 6.2 & $\mathrm{H}$ & 0.00 & & 0.00 \\
\hline 112 & Phylocentropus spp. & TR & 5.6 & $\mathrm{CF}$ & 0.00 & & 0.00 \\
\hline .113 & Polycentropus spp. & TR & 3.5 & $C F$ & 0.00 & & 0.00 \\
\hline 114 & Pycnopsyche spp. & TR & 2.3 & SH & 0.00 & & 0.00 \\
\hline 115 & Triaenodes tardus & TR & 4.7 & $\mathrm{SH}$ & 0.00 & & 0.00 \\
\hline 116 & TTurbellaria & TU & 7.5 & $P$ & 0.00 & & 0.00 \\
\hline
\end{tabular}




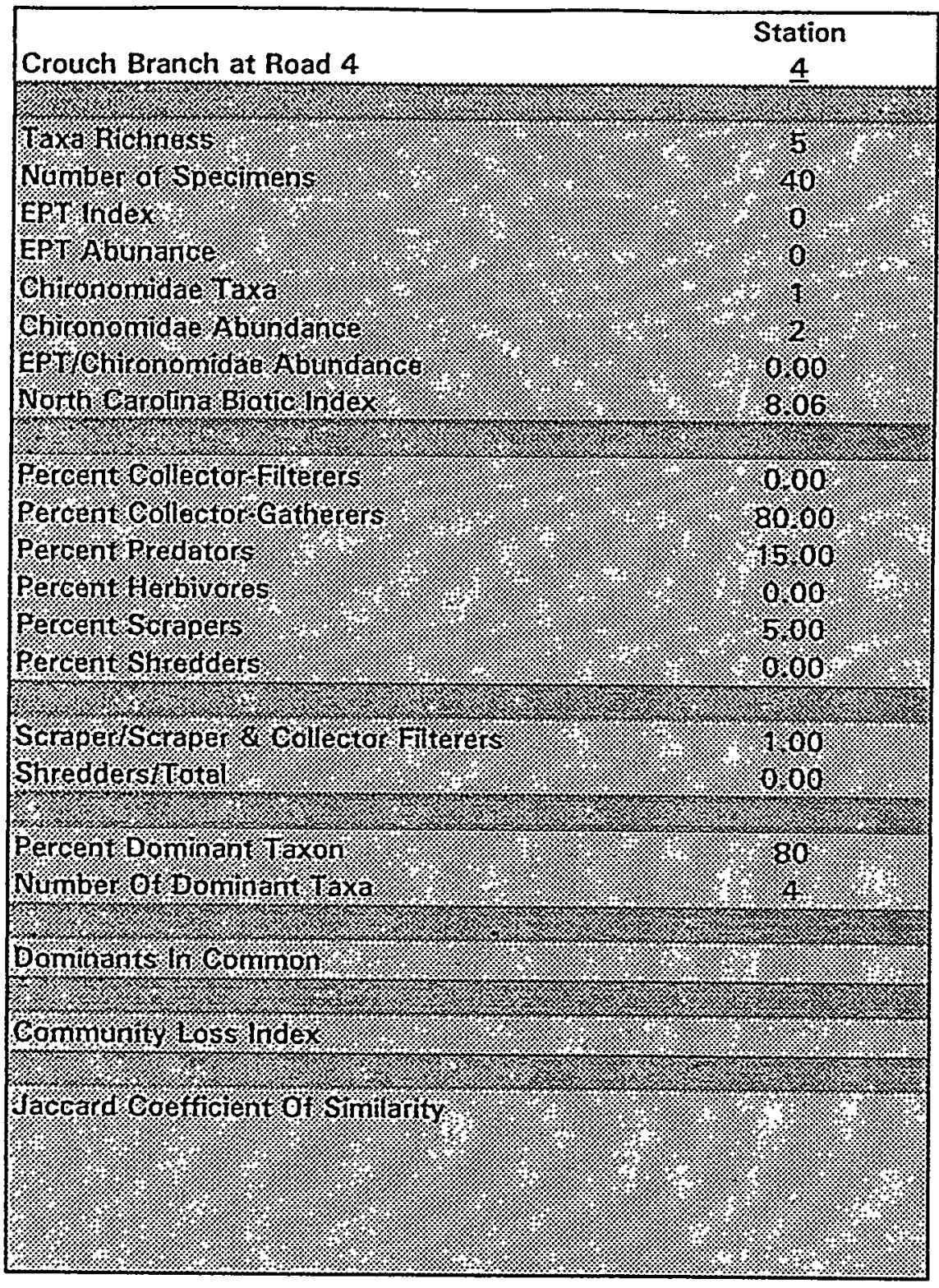




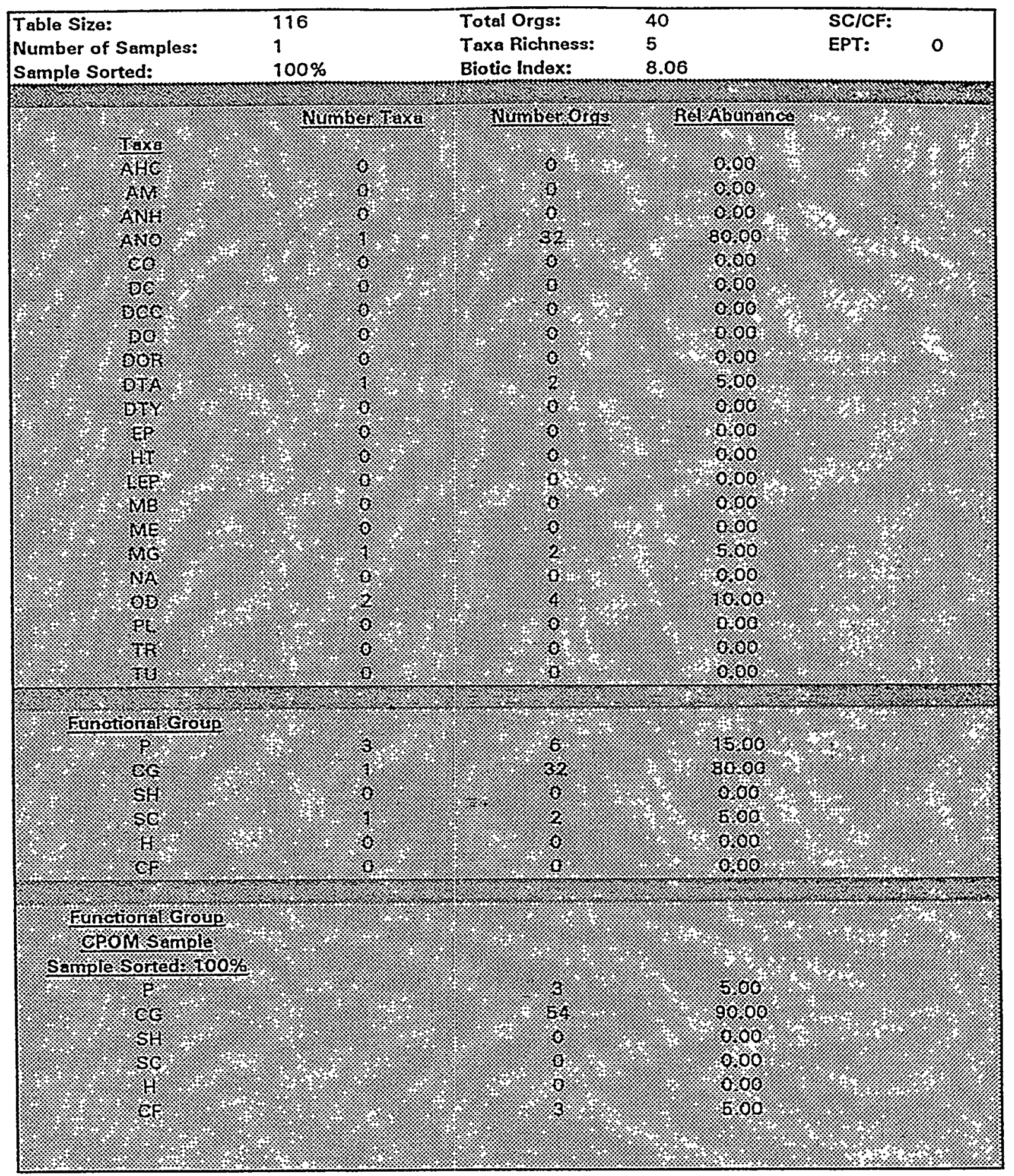


Station 12. Indian Grave Branch at Road B. RBP II. 21 September 1994

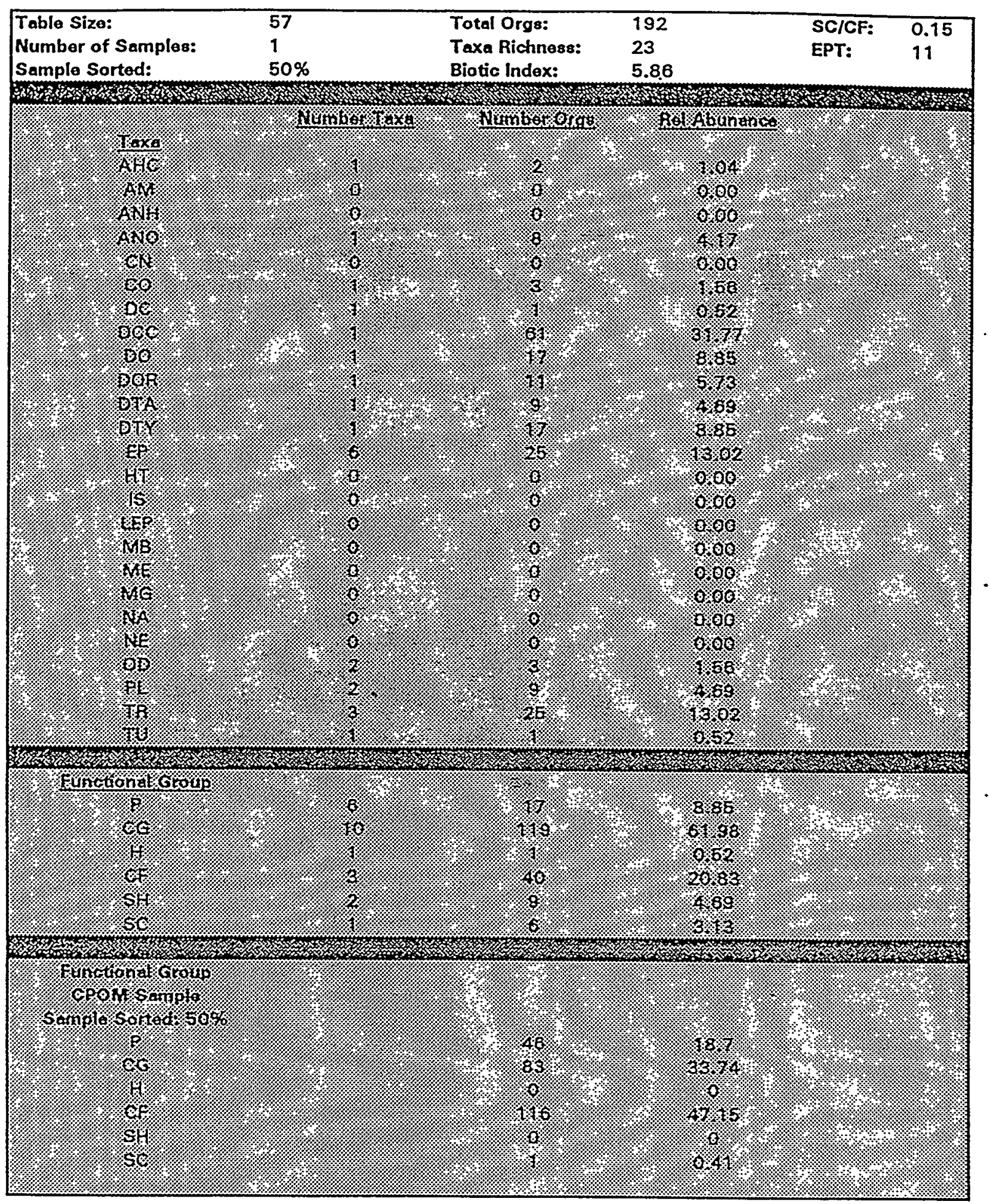


Station 12. Indian Grave Branch at Fioad B. RBP II. 21 September $1994^{\circ}$

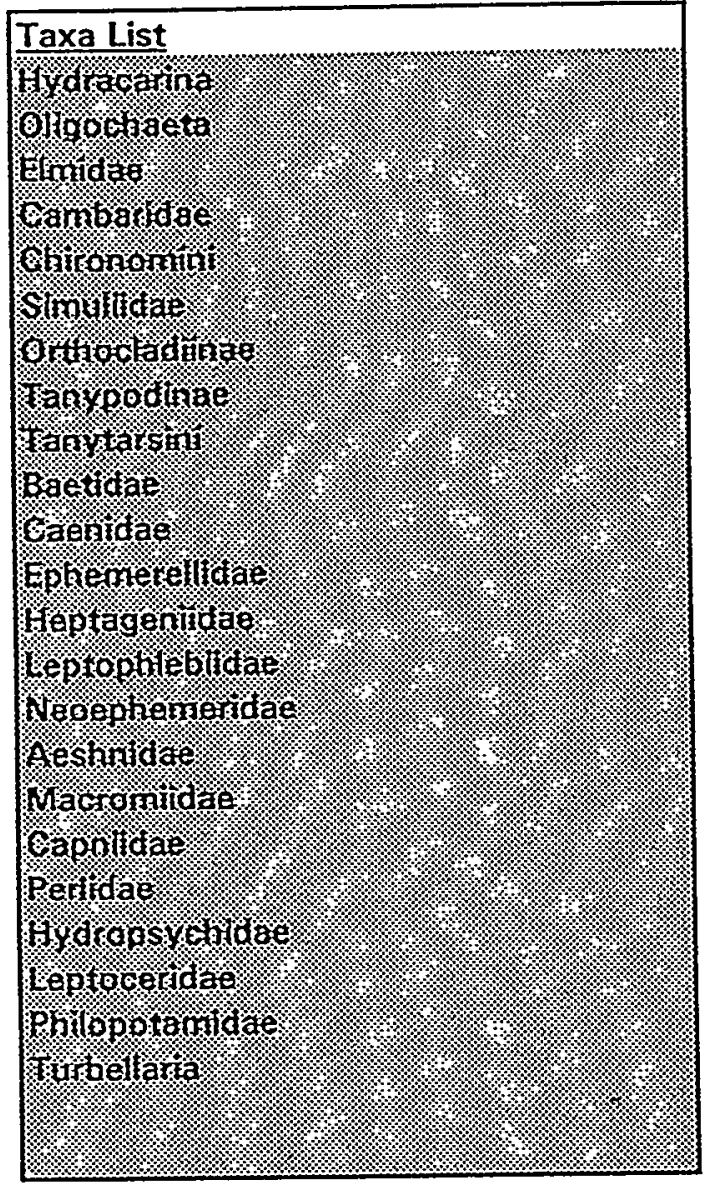

洨: 


\begin{tabular}{|l|r|r|}
\hline Taxon & A & Rel Abd \\
\hline Chironomini & 61 & 31.77 \\
\hline Hydropsychidae & 22 & 11.46 \\
\hline Simuliidae & 17 & 8.85 \\
\hline Tanytarsini & 17 & 8.85 \\
\hline Orthocladiinae & 11 & 5.73 \\
\hline
\end{tabular}




\section{PART VII}

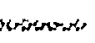

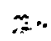


Station 1. Rosemary Creek near Rosemary Chruch. RBP III. 20 September 1994

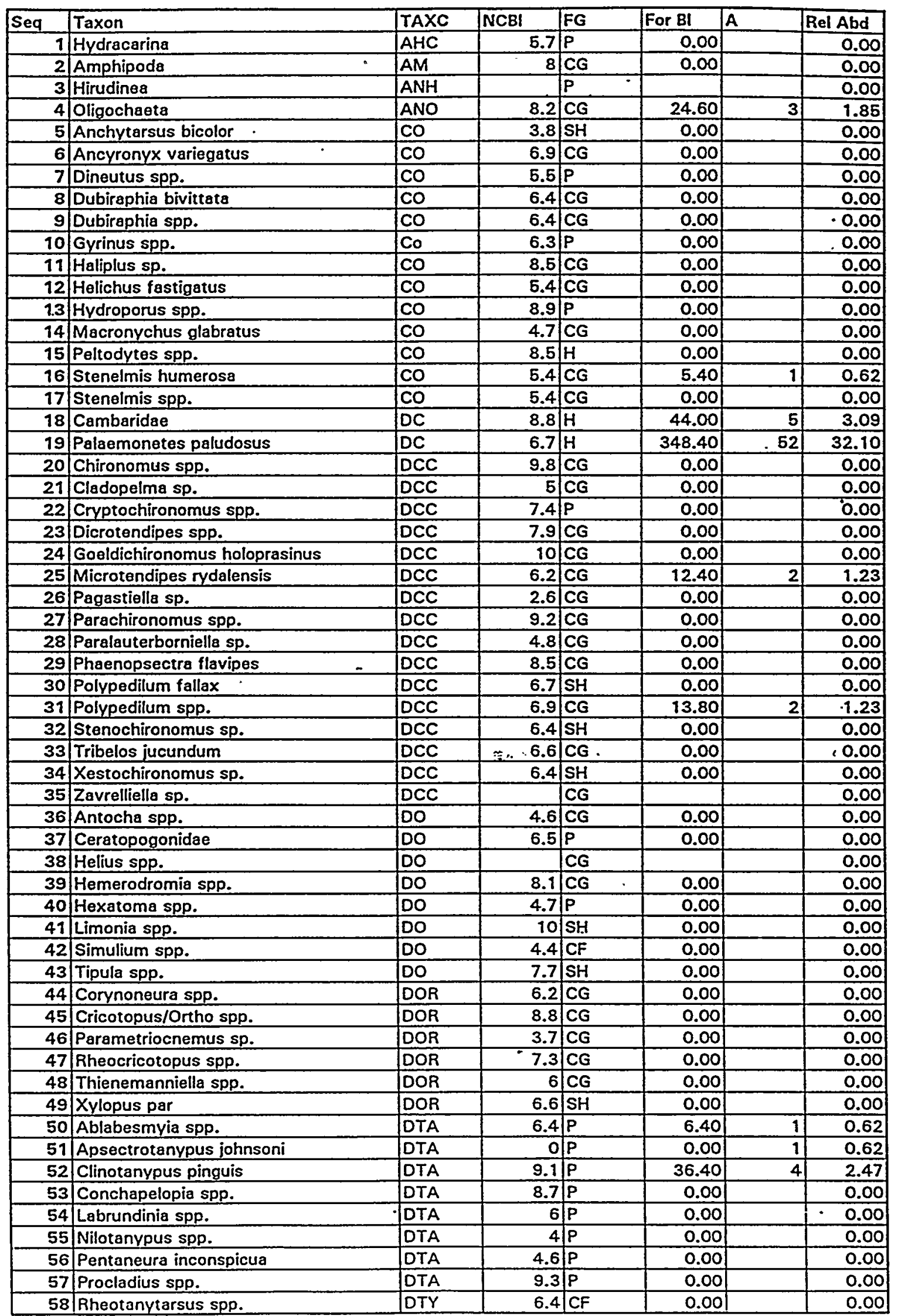




\begin{tabular}{|c|c|c|c|c|c|c|c|}
\hline 59 & Stempellinella spp. & DTY & 6.3 & $\mathbf{C G}$ & 0.00 & & 0.00 \\
\hline 60 & Tanytarsus spp. & DTY & 6.7 & CG & 13.40 & 2 & 1.23 \\
\hline 61 & Acentrella ampla & EP' & 3.6 & CG & 0.00 & & 0.00 \\
\hline 62 & Acerpenna pygmaeus & EP & 3.7 & $\overline{C G}$ & 0.00 & & 0.00 \\
\hline 63 & Acerpenna spp. & EP & 3.7 & $\mathbf{C G}$ & 0.00 & & 0.00 \\
\hline 64 & Baetis spp. & EP & 5.4 & CG & 16.20 & 3 & 1.86 \\
\hline 65 & Caenis spp. & $E P$ & 7.6 & CG & 22.80 & 3 & 1.85 \\
\hline 66 & Callibaetis spp. & $E P$ & 9.3 & $\overline{C G}$ & 0.00 & & 0.00 \\
\hline 67 & Eurylophella spp & $E P$ & 3 & CG & 0.00 & & 0.00 \\
\hline 68 & Hexagenia spp. & $E P$ & 4.7 & $\mathbf{C G}$ & 65.80 & 14 & 8.64 \\
\hline 69 & Isonychia spp. & EP & 3.8 & $\mathrm{CF}$ & 0.00 & & 0.00 \\
\hline 70 & Neoephemera youngi & $E P$ & 2.1 & CG & 0.00 & & 0.00 \\
\hline 71 & Paraleptophlebia spp. & $E P$ & 1.2 & CG & 3.60 & 3 & 1.86 \\
\hline 72 & Siphlonurus spp. & EP & 2.6 & CG & 0.00 & & 0.00 \\
\hline 73 & Stenonema spp. & EP & 3.4 & SC & 34.00 & 10 & 6.17 \\
\hline 74 & Tricorythodes spp. & EP & 5.4 & $\mathbf{C G}$ & 32.40 & 6 & 3.70 \\
\hline 75 & Belostoma sp. & $\mathrm{HT}^{-}$ & 9.8 & $P$ & 0.00 & & 0.00 \\
\hline 76 & Hesperocorixa sp. & $\mathrm{HT}^{-}$ & 9 & $H$ & 0.00 & & 0.00 \\
\hline 77 & Pyralidae & LEP & 5 & $\overline{C G}$ & 0.00 & & 0.00 \\
\hline 78 & Corbicula sp. & $M B$ & 6.3 & CF & 37.80 & 6 & 3.70 \\
\hline 79 & Eliptio spp. & MB & 3.4 & CF & 0.00 & & 0.00 \\
\hline 80 & Sphaerium spp. & MB & 7.7 & $\mathrm{CF}$ & 84.70 & 11 & 6.79 \\
\hline 81 & Nigronia serricornis & ME & 5.5 & $P$ & 0.00 & & 0.00 \\
\hline 82 & Sialis spp. & $M E$ & 7.7 & $P$ & 7.70 & 1 & 0.62 \\
\hline 83 & Campeloma sp. & MG & 6.7 & SC & 127.30 & 19 & 11.73 \\
\hline 84 & Ferrissia sp. & MG & 6.9 & SC & 0.00 & & 0.00 \\
\hline 85 & Hydrobiidae & MG & & SC & & & 0.00 \\
\hline 86 & Physella spp. & MG & 9.1 & Sc & 9.10 & 1 & 0.62 \\
\hline 87 & Planorbidae & MG & 6.5 & SC & 0.00 & & 0.00 \\
\hline 88 & Nemertea & NA & & $P$ & & & 0.00 \\
\hline 89 & Argia spp. & OD & 8.7 & $\mathrm{P}$ & 0.00 & & 0.00 \\
\hline 90 & Boyeria vinosa & OD & 6.3 . & $P$ & 12.60 & 2 & 1.23 \\
\hline 91 & Calopteryx spp. & OD & 8.3 & $P$ & 8.30 & 1 & 0.62 \\
\hline 92 & Enallagma spp. & OD洋: & .9 & $P$ & 0.00 & & 0.00 \\
\hline 93 & Gomphus spp. & OD & 6.2 & $P$ & 12.40 & 2 & 1.23 \\
\hline 94 & Macromia spp. & OD & 6.7 & $P$ & 0.00 & & 0.00 \\
\hline 95 & Neyrocordulia spp. & OD & 5.8 & $P$ & 0.00 & & 0.00 \\
\hline 96 & Pachydiplax longipennis & $O D$ & 9.6 & $\mathbf{P}$ & 0.00 & & 0.00 \\
\hline 97 & Progomphus spp. & $O D$ & 8.7 & $P$ & 0.00 & & 0.00 \\
\hline 98 & Acroneuria spp. & $P L$ & 1.4 & $P$ & 0.00 & & 0.00 \\
\hline 99 & Allocapnia spp. & $\mathrm{PL}$ & 2.8 & $\mathrm{SH}$ & 0.00 & & 0.00 \\
\hline 100 & Leuctra spp. & PL & 0.7 & $\mathrm{SH}$ & 0.00 & & 0.00 \\
\hline 101 & Perlinella spp. & $\mathrm{PL}$. & 0 & $P$ & 0.00 & & 0.00 \\
\hline 102 & Anisocentropus pyraloides & TR & 0.8 & $\mathrm{SH}$ & 0.00 & & 0.00 \\
\hline 103 & Brachycentrus numerosus & TR & 1.8 & CF & 0.00 & & 0.00 \\
\hline 104 & Cheumatopsyche spp. & $T R$ & 6.6 & $\mathrm{CF}$ & 0.00 & & 0.00 \\
\hline 105 & Chimarra spp. & $T R$ & 2.8 & CF & 0.00 & & 0.00 \\
\hline 106 & Hydropsyche spp. & $T R$ & 4 & $\mathrm{CF}$ & 0.00 & & 0.00 \\
\hline 107 & Hydroptila spp. & TR & 6.2 & $\mathrm{H}$ & 0.00 & & 0.00 \\
\hline 108 & Lepidostoma spp. & TR & 1 & $\mathrm{SH}$ & 0.00 & & 0.00 \\
\hline 109 & Nectopsyche exquisita & TR & 4.1 & $\mathrm{SH}$ & 0.00 & & 0.00 \\
\hline 110 & Oecetis spp. & TR & 5.7 & $P$ & 0.00 & & 0.00 \\
\hline 111 & Oxyethira spp. & TR & 6.2 & $\mathrm{H}$ & 0.00 & & 0.00 \\
\hline 112 & Phylocentropus spp. & TR & 5.6 & $\mathrm{CF}$ & 39.20 & 7 & 4.32 \\
\hline 113 & Polycentropus spp. & TR & 3.5 & CF & 0.00 & & 0.00 \\
\hline 114 & Pycnopsyche spp. & TR & 2.3 & $\mathrm{SH}$ & 0.00 & & 0.00 \\
\hline 715 & Triaenodes tardus & TR & 4.7 & $\mathrm{SH}$ & 0.00 & & 0.00 \\
\hline 116 & Turbellaria & TU & 7.5 & $P$ & 0.00 & & 0.00 \\
\hline
\end{tabular}




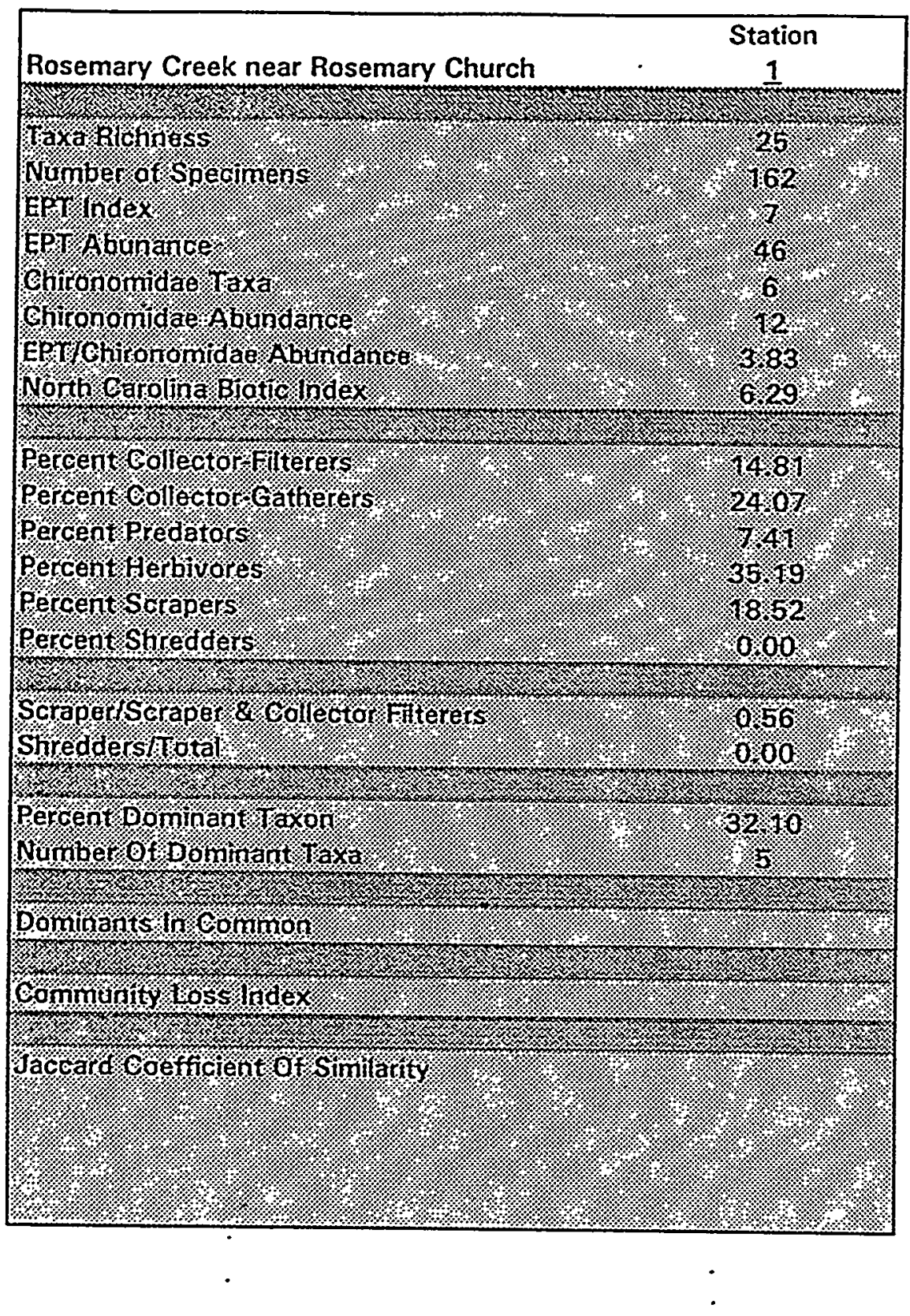


Station 4. Crouch Branch at Road 4. RBP III. 200 September 1994

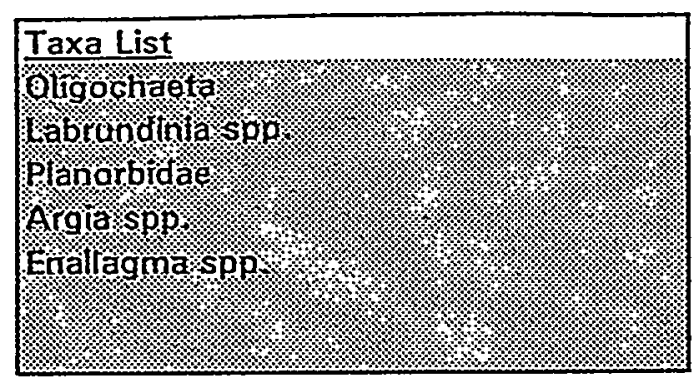

$\approx *$ 


\begin{tabular}{|l|r|r|}
\hline Taxon & A & Rel Abd \\
\hline Oligochaeta & 32 & 80.00 \\
\hline Argia spp. & 3 & 7.50 \\
\hline Labrundinia spp. & 2 & 5.00 \\
\hline Planorbidae & 2 & 5.00 \\
\hline
\end{tabular}




\begin{tabular}{|c|c|c|c|c|c|c|c|}
\hline Seq & Taxon & TAXC & \begin{tabular}{|l|l|}
$N C B I$ & $F$ \\
\end{tabular} & $\mathbf{F G}$ & For BI & A & Rel Abd \\
\hline 1 & Hydracarina & AHC & $6.7 / \mathrm{P}$ & $P$ & 0.00 & & 0.00 \\
\hline 2 & Amphipoda & AM & $8 / C$ & CG & 88.00 & 11 & 4.01 \\
\hline 3 & Hirudinea & ANH & & $P$ & & & 0.00 \\
\hline 4 & Oligochaeta & ANO & $8.21 \mathrm{C}$ & $C G$ & 49.20 & 6 & 2.19 \\
\hline 5 & Anchytarsus bicolor & Co & $3.8 \mathrm{~S}$ & SH & 0.00 & & 0.00 \\
\hline 6 & Ancryonyx veriegatus & $\mathrm{CO}$ & $6.9 \mathrm{C}$ & $\mathrm{CG}$ & 0.00 & & 0.00 \\
\hline 7 & Dineutus spp. & $\mathrm{co}$ & $5.5 / \mathrm{P}$ & $\bar{P}$ & 11.00 & 2 & 0.73 \\
\hline 8 & Dubiraphia bivittata & $\mathrm{CO}$ & \begin{tabular}{l|l|l}
6.4 & \\
\end{tabular} & & 0.00 & & 0.00 \\
\hline 9 & Dubiraphia spp. & Co & \begin{tabular}{l|c}
6.4 & $C$ \\
\end{tabular} & CG & 0.00 & & 0.00 \\
\hline 10 & Gyrinus spp. & $\mathrm{Co}$ & \begin{tabular}{l|l}
6.3 & $P$ \\
\end{tabular} & $P$ & 0.00 & & 0.00 \\
\hline 11 & Haliplus sp. & $\mathrm{CO}$ & $8.5 \mid \mathrm{C}$ & CG & 0.00 & & 0.00 \\
\hline 12 & Helichus fastigatus & co & 5.45 & SC & 0.00 & & 0.00 \\
\hline 13 & Hydroporus spp. & Co & $8.9 / P$ & $P$ & 0.00 & & 0.00 \\
\hline 14 & Macronychus glabratus & co & $4.7 / C$ & CG & 9.40 & 2 & 0.73 \\
\hline 15 & Peltodytes spp. & $\mathrm{co}$ & $8.5 / \mathrm{H}$ & $\mathrm{H}$ & 0.00 & & 0.00 \\
\hline 16 & Stenelmis humerosa & co & 5.410 & $C G$ & 16.20 & 3 & 1.09 \\
\hline 17 & Stenelmis spp. & co & 5.410 & $\overline{C G}$ & 0.00 & & 0.00 \\
\hline 18 & Cambaridae & $D C$ & $8 . 8 \longdiv { H }$ & $\mathrm{H}$ & 88.00 & 10 & 3.65 \\
\hline 19 & Palaemonetes paludosus & $D C$ & $6.7 / H$ & $\mathrm{H}$ & 0.00 & & 0.00 \\
\hline 20 & Chironomus spp. & DCC & $9.8 \mid \mathrm{C}$ & CG & 0.00 & & 0.00 \\
\hline 21 & Cladopelma sp. & $D C C$ & $5 \mid c$ & CG & 0.00 & & 0.00 \\
\hline 22 & Cryptochironomus spp. & DCC & $7.4 \mid \mathrm{P}$ & $\mathrm{P}$ & 44.40 & 6 & 2.19 \\
\hline 23 & Dicrotendipes spp. & DCC & \begin{tabular}{ll|l}
7.9 & $c$ \\
\end{tabular} & CG & 0.00 & & 0.00 \\
\hline 24 & Goeldichironomus holoprasinus & $D C C$ & $10 \mid c$ & CG & 0.00 & & 0.00 \\
\hline 25 & Microtendipes rydalensis & DCC & 6.210 & $\overline{C G}$ & 0.00 & & 0.00 \\
\hline 26 & Pagastiella sp. & DCC & 2.610 & CG & 0.00 & & 0.00 \\
\hline 27 & Parachironomus spp. & DCC & 9.210 & CG & 0.00 & & 0.00 \\
\hline 28 & Paralauterborniella sp. & DCC & 4.810 & CG & 0.00 & & 0.00 \\
\hline 29 & Phaenopsectra flavipes & DOCC & $8.51 \mathrm{C}$ & CG & 34.00 & 4 & 1.46 \\
\hline 30 & Polypedilum fallax & DCC & $6.7 / \mathrm{s}$ & $\mathrm{SH}$ & 0.00 & & 0.00 \\
\hline 31 & Polypedilum spp. & DCC & \begin{tabular}{l|c}
6.9 & 0 \\
\end{tabular} & CG & 255.30 & 37 & 13.50 \\
\hline 32 & Stenochironomus sp. & DCC & $6.4 \mathrm{~s}$ & $\mathrm{SH}$ & 6.40 & 1 & 0.36 \\
\hline 33 & Tribelos jucundum & Dec: & 6.610 & CG & 0.00 & & 0.00 \\
\hline 34 & Xestochironomus sp. & DCC & 6.45 & $\mathrm{SH}$ & 0.00 & & 0.00 \\
\hline 35 & Zavrelliella spp. & DCC & & $C G$ & & & 0.00 \\
\hline 36 & Antocha spp. & DO & 4.610 & $C G$ & 0.00 & & 0.00 \\
\hline 37 & Cerstopogonidae & DO & $6.5 \bar{P}$ & $\bar{P}$ & 0.00 & & 0.00 \\
\hline 38 & Helius spp. & DO & & CG & & 7 & 2.55 \\
\hline 39 & Hemerodromia spp & DO & $8.1 \mathrm{C}$ & $C G$ & 8.10 & 1 & 0.36 \\
\hline 40 & Hexatoma spp. & Do & $4.7 \mid \mathrm{P}$ & $P$ & 9.40 & 2 & 0.73 \\
\hline 41 & Limonia spp. & DO & 105 & SH & 0.00 & & 0.00 \\
\hline 42 & Simulium spp. & Do & $4.4 . \mathrm{C}$ & $\mathrm{CF}$ & 4.40 & 1 & 0.36 \\
\hline 43 & Tipula spp. & DO & 7.75 & SH & 0.00 & & 0.00 \\
\hline 44 & Corynoneura spp. & DOR & $6.2 \mathrm{C}$ & CG & 0.00 & & 0.00 \\
\hline 45 & Cricotopus/Ortho spp. & DOR & $8.8 \mathrm{C}$ & CG & 0.00 & & 0.00 \\
\hline 46 & Parametriocnemus sp. & DOR & $3.7 / \mathrm{C}$ & CG & 7.40 & 2 & 0.73 \\
\hline 47 & Rheocricotopus spp. & DOR & 7.315 & CG & 7.30 & 1 & 0.36 \\
\hline 48 & \begin{tabular}{|c|} 
Thienemanniella spp. \\
\end{tabular} & DOR & 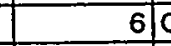 & $C G$ & 0.00 & & 0.00 \\
\hline 49 & Xylopus par & DOR & 6.65 & $\mathrm{SH}$ & 6.60 & 1 & 0.36 \\
\hline 50 & Ablabesmyia spp. & DTA & $6.4 \mathrm{~F}$ & $\mathbf{P}$ & 51.20 & 8 & 2.92 \\
\hline 51 & Apsectrotanypus johnsoni & DTA & off & $\mathbf{P}$ & 0.00 & & 0.00 \\
\hline 52 & Clinotanypus pinguis & DTA & $9.1 / \mathrm{f}$ & $P$ & 9.10 & 1 & 0.36 \\
\hline 53 & Conchapelopia spp. & DTA & $8.7 / 5$ & $\mathbf{P}$ & 104.40 & 12 & 4.38 \\
\hline 54 & Labrundinia spp. & DTA & $6 / 8$ & $P$ & 0.00 & & 0.00 \\
\hline 55 & \begin{tabular}{|l|} 
Nilotanypus spp. $\ldots$ \\
\end{tabular} & DTA & $4 / 5$ & $P$ & 0.00 & & 0.00 \\
\hline 56 & Pentaneura inconspicua & DTA & 4.65 & $P$ & 0.00 & & 0.00 \\
\hline 57 & Procladius spp. & DTA & $9.3 / \mathrm{f}$ & $\mathbf{P}$ & 0.00 & & 0.00 \\
\hline 58 & Rheotanytarsus spp. & DTY & 6.4 & CF & 300.80 & 47 & 17.15 \\
\hline
\end{tabular}




\begin{tabular}{|c|c|c|c|c|c|c|c|}
\hline 59 & Stempellinella spp. & DTY & 5.3 & CG & 0.00 & & 0.00 \\
\hline 60 & Tanytarsus spp. & DTY & 6.7 & CG & 455.60 & 68 & 24.82 \\
\hline 61 & Acentrella ampla & EP & 3.6 & CG & 0.00 & & 0.00 \\
\hline 62 & Acerpenna pygmaeus & EP. & 3.7 & CG & 0.00 & & 0.00 \\
\hline 63 & Acerpenna spp. & EP & 3.7 & CG & 0.00 & & 0.00 \\
\hline 64 & Baetis spp. & EP & 5.4 & $\mathrm{CG}$ & 37.80 & 7 & 2.65 \\
\hline 65 & Caenis spp. & EP & 7.6 & $C G$ & 7.60 & 1 & 0.36 \\
\hline 66 & Calliboetis spp. & EP & 9.3 & CG & 0.00 & & 0.00 \\
\hline 87 & Eurylophella spp. & EP & 3 & CG & 0.00 & & 0.00 \\
\hline 68 & Hexagenia spp. & EP & 4.7 & CG & 0.00 & & 0.00 \\
\hline 69 & Isonychia spp. & $E P$ & 3.8 & CF & 0.00 & & 0.00 \\
\hline 70 & Neoephemera youngi & EP & 2.1 & CG & 0.00 & & 0.00 \\
\hline 71 & Paraleptophlebia spp. & EP & 1.2 & $\overline{C G}$ & 0.00 & & 0.00 \\
\hline 72 & Siphlonurus sp. & EP & 2.6 & CG & 0.00 & & 0.00 \\
\hline 73 & Stenonema spp. & EP & 3.4 & SC & 0.00 & & 0.00 \\
\hline 74 & Tricorythodes spp. & EP & 5.4 & CG & 0.00 & & 0.00 \\
\hline 75 & Belostoma sp. & HT & 9.8 & $P$ & 0.00 & & 0.00 \\
\hline 76 & Hesperocorixa sp. & $H T$ & & $\mathrm{H}$ & 0.00 & & 0.00 \\
\hline 77 & Pyralidae & LEP & & $H$ & 0.00 & & 0.00 \\
\hline 78 & Corbicula sp. & $\mathrm{MB}$ & 6.3 & $\mathrm{CF}$ & 0.00 & & 0.00 \\
\hline 79 & Eliptio spp. & $M B$ & 3.4 & CF & 0.00 & & 0.00 \\
\hline 80 & Sphaerium spp. & MB & 7.7 & CF & 0.00 & & 0.00 \\
\hline 81 & Nigronia serricornis & ME & 5.5 & $\mathrm{P}$ & 0.00 & & 0.00 \\
\hline 82 & Sialis spp. & ME & 7.7 & $P$ & 0.00 & & 0.00 \\
\hline 83 & Campoloma sp. & MG & 6.7 & Sc & 0.00 & & 0.00 \\
\hline 84 & Ferrissia sp. & MG & 6.9 & SC & 0.00 & & 0.00 \\
\hline 85 & Hydrobiidae & MG & & SC & & & 0.00 \\
\hline 86 & Physella spp. & MG & 9.1 & SC & 0.00 & & 0.00 \\
\hline 87 & Planorbidae & MG & 6.5 & $S C$ & 0.00 & & 0.00 \\
\hline 88 & Nemertea & NA & & $\mathrm{P}$ & & 3 & 1.09 \\
\hline 89 & Argia spp. & OD & 8.7 & $\mathrm{P}$ & 104.40 & 12 & 4.38 \\
\hline 90 & Boyeria vinosa & $O D$ & 6.3 & $P$ & 6.30 & 1 & 0.36 \\
\hline 91 & Calopteryx spp. & 100 & 8.3 & P & 83.00 & 10 & 3.65 \\
\hline 92 & Enallagma spp. & OD & $2 \ldots=9$ & $\mathbf{P}$ & 0.00 & & 0.00 \\
\hline 93 & Gomphus spp. & OD & 6.2 & $P$ & 6.20 & 1 & 0.36 \\
\hline 94 & Macromia spp. & OD & 6.7 & $\mathbf{P}$ & 0.00 & & 0.00 \\
\hline 95 & Neurocordulia spp. & OD & 5.8 & $P$ & 0.00 & & 0.00 \\
\hline 96 & Pachydiplax longipennis & $O D$ & 9.6 & $P$ & 0.00 & & 0.00 \\
\hline 97 & Progomphus spp. & OD & 8.7 & $\bar{P}$ & 8.70 & 1 & 0.36 \\
\hline 98 & Acroneuria spp. & $\mathrm{PL}$ & 1.4 & $\mathrm{P}$ & 0.00 & & 0.00 \\
\hline 99 & Allocapnia spp. & PL & 2.8 & $\mathrm{SH}$ & 0.00 & & 0.00 \\
\hline 100 & Leuctra spp. & $\mathrm{PL}$ & 0.7 & SH & 2.80 & 4 & 1.46 \\
\hline 101 & Perlinella spp. & $\mathrm{PL}$ & 0 & $P$ & 0.00 & 1 & 0.36 \\
\hline 102 & Anisocentropus pyraloides & $T R$ & 0.8 & $\mathrm{SH}$ & 0.00 & & 0.00 \\
\hline 103 & Brachycentrus numerosus & TR & 1.8 & CF & 0.00 & & 0.00 \\
\hline 104 & Cheumatopsyche spp. & TR & 6.6 & $\mathrm{CF}$ & 0.00 & & 0.00 \\
\hline 105 & Chimarra spp. & TR & 2.8 & CF & 0.00 & & 0.00 \\
\hline 106 & Hydropsyche spp. & TR & 4 & CF & 0.00 & & 0.00 \\
\hline 107 & Hydroptila spp. & $T R$ & 6.2 & $\mathrm{H}$ & 0.00 & & 0.00 \\
\hline 108 & Lepidostoma spp. & TR & 1 & $\mathrm{SH}$ & 0.00 & & 0.00 \\
\hline 109 & Nectopsyche exquisita & TR & 4.1 & $\mathrm{SH}$ & 0.00 & & 0.00 \\
\hline 110 & Oecetis spp. & TR & 5.7 & $P$ & 0.00 & & 0.00 \\
\hline 111 & Oxyethira spp. & $T R$ & 6.2 & $H$ & 0.00 & & 0.00 \\
\hline 112 & Phylocentropus spp. & TR & 5.6 & $C F$ & 0.00 & & 0.00 \\
\hline 113 & Polycentropus spp. & TA & 3.5 & $\mathrm{CF}$ & 0.00 & & 0.00 \\
\hline 114 & Pycnopsyche spp. & TTR & 2.3 & $\mathrm{SH}$ & 0.00 & & 0.00 \\
\hline 115 & Trizenodes tardus & $T R$ & 4.7 & $\mathrm{SH}$ & 0.00 & & 0.00 \\
\hline 116 & Turbellaria & TTU & 7.5 & $\mathrm{P}$ & 0.00 & & 0.00 \\
\hline
\end{tabular}


Station 5. Tims Branch at Road 2. RBP III. 20 September 1994

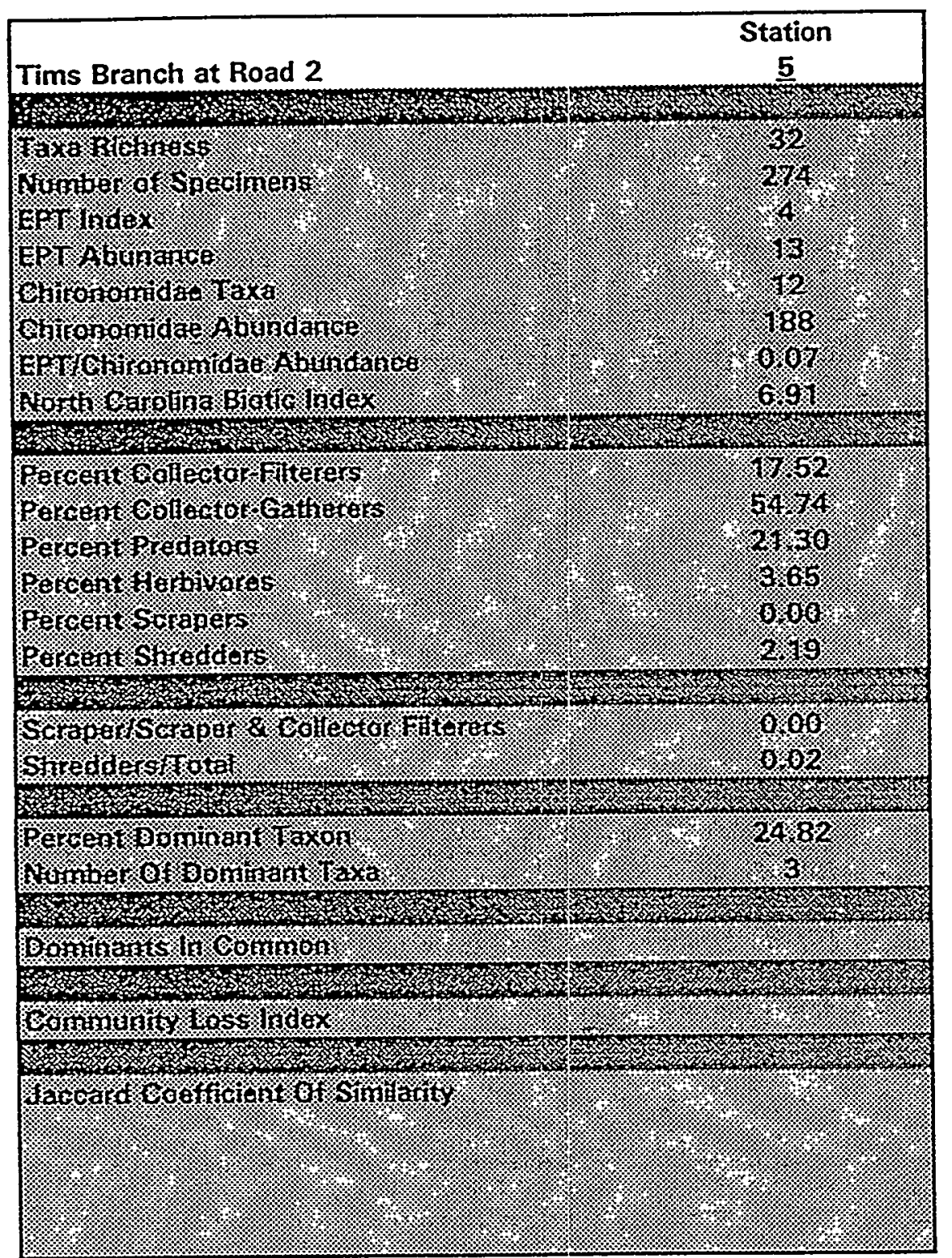


Station 5. Tims Branch at Road 2. RBP III. 20 September 1994

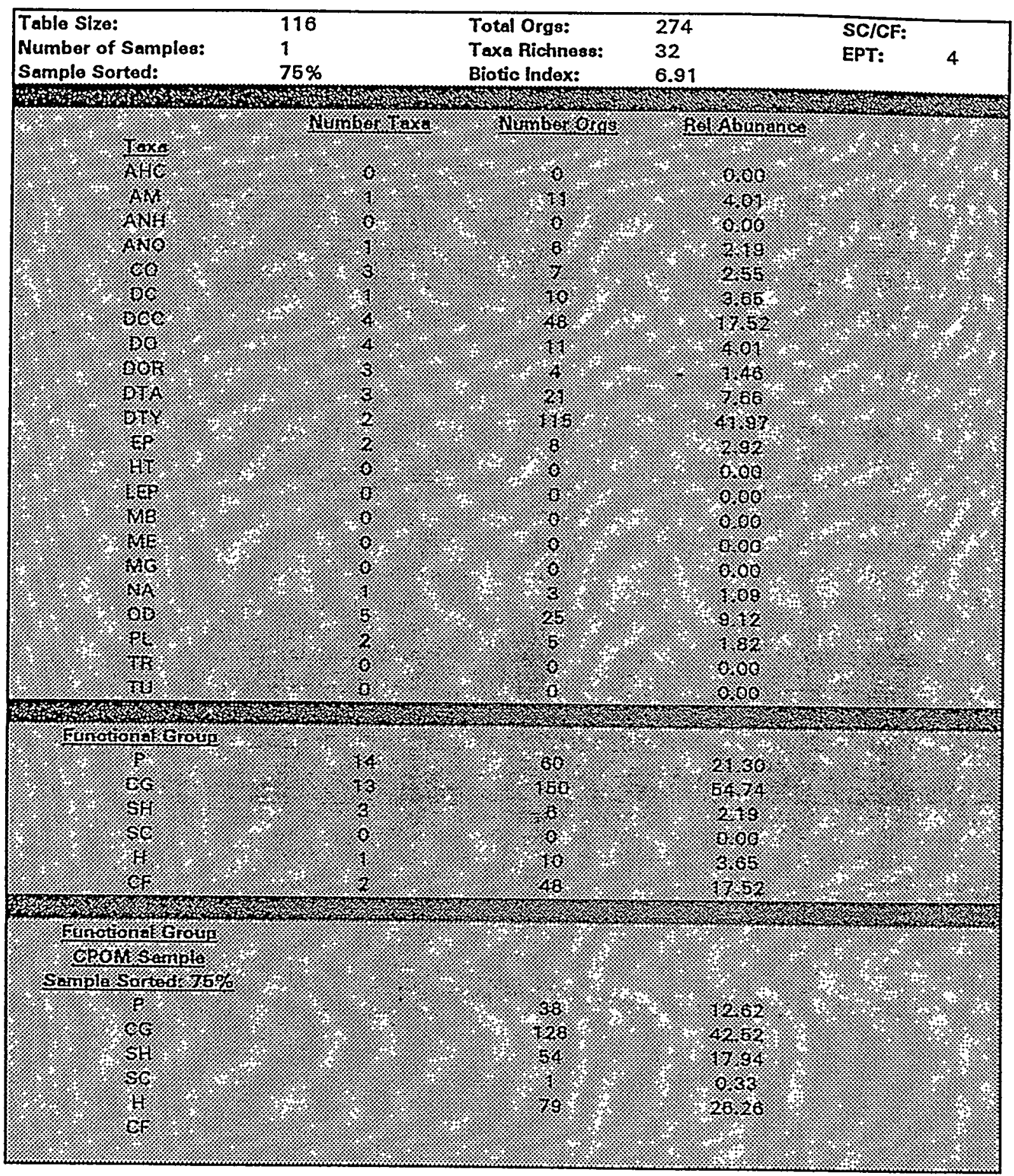


Station 5. Tims Branch at Road 2. RBP III. 20 September 1994

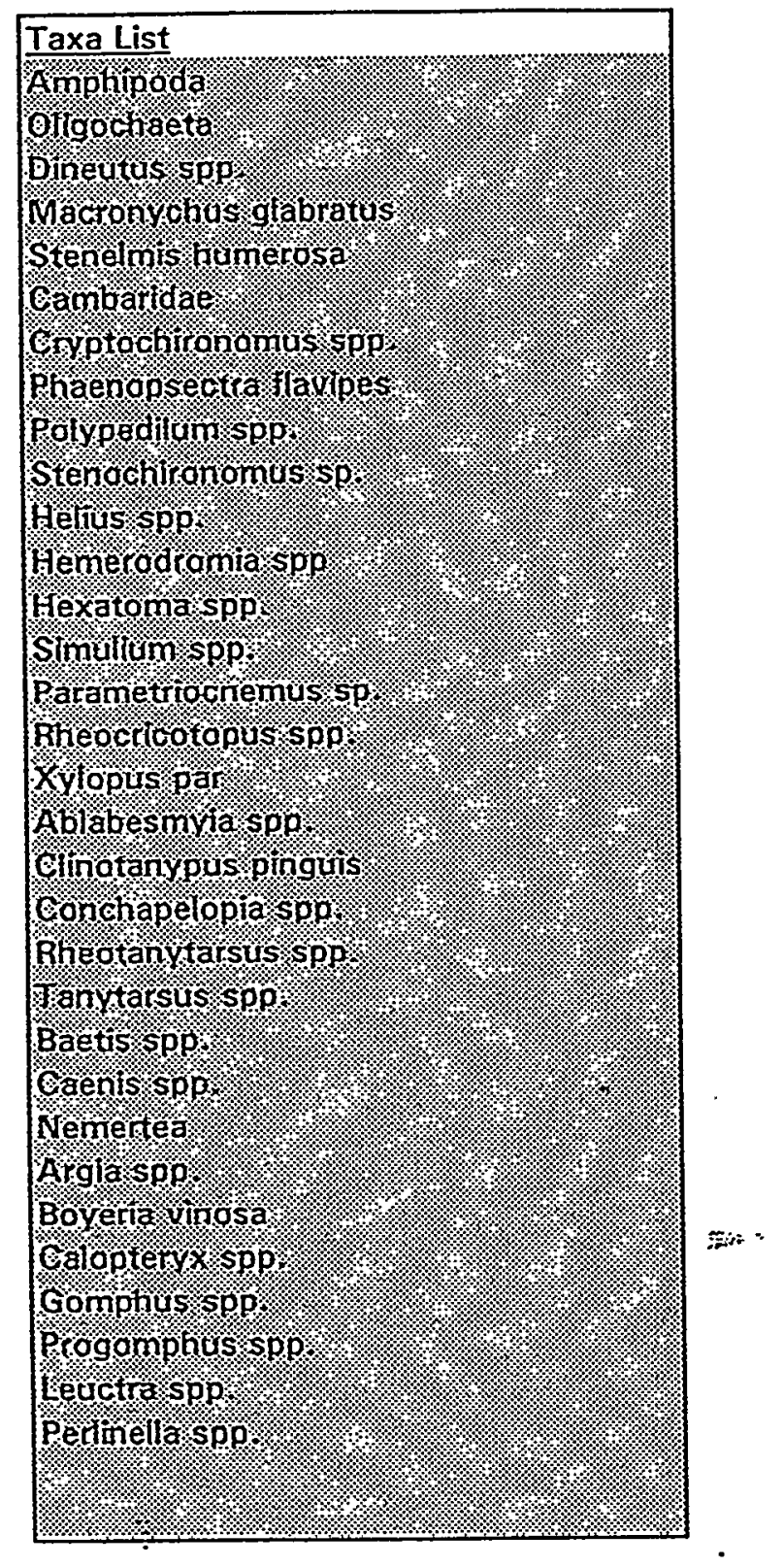


Station 5. Tims Branch at Road 2. RBP III. 20 September 1994

Taxon

A

Rel Abd

Tanytarsus spp.

Rheotanytarsus spp.

68

Polypedilum spp.

\begin{tabular}{l|l|}
47 & 17.15 \\
\hline
\end{tabular}

$47 \quad 17.15$

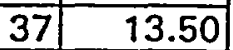




\begin{tabular}{|c|c|c|c|c|c|c|c|}
\hline Seq & Taxon & TAXC & NCBI & FG & For BI & A & Rel Abd \\
\hline 1 & Hydracarina & AHC & 6.7 & $\mathrm{P}$ & 11.40 & 2 & 0.86 \\
\hline 2 & Amphipoda & AM & 8 & CG & 24.00 & 3 & 1.28 \\
\hline 3 & Hirudinea & ANH & & $P$ & & & 0.00 \\
\hline 4 & Oligochaeta & ANO & 8.2 & CG & 106.60 & 13 & 5.66 \\
\hline 5 & Anchytarsus bicolor & Co & 3.8 & $\mathrm{SH}$ & 0.00 & & 0.00 \\
\hline 6 & Ancyronyx variegatus & $\mathrm{Co}$ & 6.9 & CG & 0.00 & & 0.00 \\
\hline 7 & Dineutus spp. & $\mathrm{Co}$ & 5.5 & $P$ & 0.00 & & 0.00 \\
\hline 8 & Dubiraphia bivittata & $\mathrm{CO}$ & 6.4 & $\mathbf{C G}$ & 0.00 & & 0.00 \\
\hline $\mathbf{9}$ & Dubiraphia spp. & $\mathrm{Co}$ & 6.4 & $\mathbf{C G}$ & 0.00 & & 0.00 \\
\hline 10 & Gyrinus spp. & $\mathrm{CO}$ & 6.3 & $\mathbf{P}$ & 0.00 & & 0.00 \\
\hline 11 & Haliplus sp. & $\mathrm{CO}$ & 8.5 & $\mathbf{C G}$ & 0.00 & & 0.00 \\
\hline 12 & Helichus fastigatus & $\mathrm{CO}$ & 5.4 & CG & 0.00 & & 0.00 \\
\hline 13 & Hydroporus spp. & Co & 8.9 & $P$ & 0.00 & & 0.00 \\
\hline 14 & Macronychus glabratus & $\mathrm{CO}$ & 4.7 & $\mathbf{C G}$ & 0.00 & & 0.00 \\
\hline 15 & Peltodytes spp. & Co & 8.5 & $\mathrm{H}$ & 42.50 & 5 & 2.14 \\
\hline 16 & Stenelmis humerosa & co & 5.4 & CG & 0.00 & & 0.00 \\
\hline 17 & Stenelmis spp. & co & 5.4 & $\mathbf{C G}$ & 0.00 & & 0.00 \\
\hline 18 & Cambaridae & DC & 8.8 & $\mathrm{H}$ & 0.00 & & 0.00 \\
\hline 19 & Palaemonetes paludosus & DC & 6.7 & $\mathrm{H}$ & 0.00 & & 0.00 \\
\hline 20 & Chironomus spp. & $D C C$ & 9.8 & CG & 0.00 & & 0.00 \\
\hline 21 & Cladopelma sp. & $D C C$ & 5 & $\mathbf{C G}$ & 0.00 & & 0.00 \\
\hline 22 & Cryptochironomus spp. & DCC & 7.41 & $P$ & 0.00 & & 0.00 \\
\hline 23 & Dicrotendipes spp. & $\mathrm{DCC}$ & 7.9 & $\mathbf{C G}$ & 0.00 & & 0.00 \\
\hline 24 & Gooldichironomus holoprasinus & DCC & 10 & $\mathbf{C G}$ & 0.00 & & 0.00 \\
\hline 25 & Microtendipes rydalensis & DCC & 6.2 & $\mathbf{C G}$ & 0.00 & & 0.00 \\
\hline 26 & Pagastiella sp. & DCC & 2.6 & CG & 0.00 & & 0.00 \\
\hline 27 & Parachironomus spp. & $\mathrm{DCC}$ & 9.2 & CG & 0.00 & & 0.00 \\
\hline 28 & Paralauterborniella sp. & DCC & 4.8 & CG & 0.00 & & 0.00 \\
\hline 29 & Phaenopsectra flavipes & DCC & 8.5 & CG & 0.00 & & 0.00 \\
\hline 30 & Polypedilum fallax & DCC & 6.7 & SH & 0.00 & & 0.00 \\
\hline 31 & Polypedilum spp. & DCC & 6.9 & CG & 96.60 & 14 & 5.98 \\
\hline 32 & Stenochironomus sp. & $D C C$ & 6.4 & $\mathrm{SH}$ & 0.00 & & 0.00 \\
\hline 33 & Tribelos jucundum & DCC & 6.6 & $\mathbf{C G}$ & 0.00 & & 0.00 \\
\hline 34 & Xestochironomus sp. & $D C C$ & 6.4 & $\mathrm{SH}$ & 0.00 & & 0.00 \\
\hline 35 & Zavrelliella spp. & $D C C$ & & $\mathbf{C G}$ & & & 0.00 \\
\hline 36 & Antocha spp. & DO & 4.6 & $\mathbf{C G}$ & 9.20 & 2 & 0.85 \\
\hline 37 & Ceratopogonidae & 10 & $6.5 \mid 1$ & $\mathrm{P}$ & 0.00 & & 0.00 \\
\hline 38 & Helius spp. & DO & & CG & & & 0.00 \\
\hline 39 & Hemerodromia spp. & DO & 8.1 & CG & 0.00 & & 0.00 \\
\hline 40 & Hexatoma spp. & DO & 4.7 & $P$ & 0.00 & & 0.00 \\
\hline 41 & Limonia spp. & Do & 10 & $\mathrm{SH}$ & 0.00 & & 0.00 \\
\hline 42 & Simulium spp. & DO & 4.4 & $\mathrm{CF}$ & 0.00 & & 0.00 \\
\hline 43 & Tipula spp. & DO & 7.7 & $\mathrm{SH}$ & 0.00 & & 0.00 \\
\hline 44 & Corynonoura spp. & DOR & 6.2 & CG & 0.00 & & 0.00 \\
\hline 45 & Cricotopus/Ortho spp. & DOR & 8.8 & CG & 0.00 & & 0.00 \\
\hline 46 & Parametriocnemus sp. & DOR & 3.7 & $\mathrm{CG}$ & 0.00 & & 0.00 \\
\hline 47 & Rheocricotopus spp. & DOR & 7.3 & CG & 0.00 & & 0.00 \\
\hline 48 & Thienemannielia spp. & DOR & 6 & CG & 0.00 & & 0.00 \\
\hline 49 & Xylopus par & DOR & 6.6 & $\mathrm{SH}$ & 0.00 & & 0.00 \\
\hline 50 & Ablabesmyia spp. & DTA & 6.4 & $\mathbf{P}$ & 38.40 & 6 & 2.66 \\
\hline 51 & Apsectrotanypus johnsoni & DTA & of & $\mathrm{P}$ & 0.00 & & 0.00 \\
\hline 52 & Clinotanypus pinguis & DTA & 9.1 & $\mathbf{P}$ & 0.00 & & 0.00 \\
\hline 53 & Conchapelopia spp. & DTA & 8.7 & $P$ & 0.00 & & 0.00 \\
\hline 54 & Labrundinia spp. & DTA & 6 & $P$ & 0.00 & & 0.00 \\
\hline 55 & Nilotanypus spp. & DTA & 4 & $P$ & 0.00 & & 0.00 \\
\hline 56 & Pentaneura inconspicua & DTA & 4.6 & $P$ & 0.00 & & 0.00 \\
\hline 57 & Procladius spp. & DTA & 9.3 & $P$ & 0.00 & & 0.00 \\
\hline 58 & Rheotanytarsus spp. & DTY & 6.4 & $\mathrm{CF}$ & 51.20 & 8 & 3.42 \\
\hline
\end{tabular}




\begin{tabular}{|c|c|c|c|c|c|c|c|}
\hline 59 & Stempellinella spp. & DTY & 5.3 & CG & 0.00 & & 0.00 \\
\hline 60 & Tanytarsus spp. & DTY & 6.7 & CG & 33.50 & 5 & 2.14 \\
\hline 61 & Acentrella ampla & EP & 3.6 & CG & 0.00 & & 0.00 \\
\hline 62 & Acerpenna pygmaeus & EP & 3.7 & CG & 0.00 & & 0.00 \\
\hline 63 & Acerpenna spp. & EP & 3.7 & CG & 0.00 & & 0.00 \\
\hline 64 & Beotis spp. & EP & 5.4 & CG & 464.40 & 86 & 36.76 \\
\hline 65 & Caenis spp. & EP & 7.6 & CG & 0.00 & & 0.00 \\
\hline 68 & Callibaetis spp. & EP & 9.3 & CG & 0.00 & & .0 .00 \\
\hline 67 & Eurylophella spp. & EP & 3 & $C G$ & 0.00 & & 0.00 \\
\hline 68 & Hexegenia spp. & EP & 4.7 & CG & 0.00 & & 0.00 \\
\hline 69 & Isonychia spp. & EP & 3.8 & $\mathrm{CF}$ & 0.00 & & 0.00 \\
\hline 70 & Neoephemera youngi & EP & 2.1 & CG & 0.00 & & 0.00 \\
\hline 71 & Paraleptophlebia spp. & EP & 1.2 & CG & 0.00 & & 0.00 \\
\hline 72 & Siphlonurus sp. & EP & 2.6 & CG & 0.00 & & 0.00 \\
\hline 73 & Stenonema spp. & EP & 3.4 & $\mathrm{sc}$ & 6.80 & 2 & 0.85 \\
\hline 74 & Tricorythodes spp. & EP & 5.4 & CG & 5.40 & 1 & 0.43 \\
\hline 75 & Belostoma sp. & $\mathrm{HT}$ & 9.8 & $P$ & 0.00 & & 0.00 \\
\hline 76 & Hesperocorixa sp. & $\mathrm{HT}$ & 9 & $\mathrm{H}$ & 0.00 & & 0.00 \\
\hline 77 & Pyralidae & LEP & 5 & $\mathrm{H}$ & 5.00 & 1 & 0.43 \\
\hline 78 & Corbicula sp. & $M B$ & 6.3 & $\mathrm{CF}$ & 6.30 & 1 & 0.43 \\
\hline 79 & Eliptio spp. & $M B$ & 3.4 & $\mathrm{CF}$ & 0.00 & & 0.00 \\
\hline 80 & Sphaerium spp. & MB & 7.7 & CF & 0.00 & & 0.00 \\
\hline 81 & Nigronia serricornis & ME & 5.5 & P & 0.00 & & 0.00 \\
\hline 82 & Sialis spp. & $\mathrm{ME}$ & 7.7 & $\mathbf{P}$ & 0.00 & & 0.00 \\
\hline 83 & Campeloma sp. & $M G$ & 6.7 & Sc & 0.00 & & 0.00 \\
\hline 84 & Ferrissia sp. & MG & 6.9 & sc & 0.00 & & 0.00 \\
\hline 85 & Hydrobiidae & $M G$ & & $\mathrm{sc}$ & & 68 & 24.79 \\
\hline 86 & Physells spp. & MG & 9.1 & Sc & 9.10 & 1 & 0.43 \\
\hline 87 & Planorbidae & $M G$ & 6.5 & sc & 0.00 & & 0.00 \\
\hline 88 & Nemertea & NA & & $\mathbf{P}$ & & & 0.00 \\
\hline 89 & Argia spp. & OD & 8.7 & $\mathbf{P}$ & 43.60 & 5 & 2.14 \\
\hline 90 & Boyeria vinosa & $O D$ & 6.3 & $P$ & 0.00 & $\cdot$ & 0.00 \\
\hline 91 & Calopteryx spp. & OD & 8.3 & $\mathbf{P}$ & 0.00 & & 0.00 \\
\hline 92 & Enallagma spp. & OD & $x_{i}=9$ & $\mathbf{P}$ & 135.00 & 15 & 6.41 \\
\hline 93 & Gomphus spp. & $O D$ & 6.2 & $\mathbf{P}$ & 0.00 & & 0.00 \\
\hline 94 & Mecromia spp. & $\overline{O D}$ & 6.7 & $P$ & 0.00 & & 0.00 \\
\hline 95 & Neurocordulia spp. & OD & 5.8 & $P$ & 0.00 & & 0.00 \\
\hline 96 & Pachydiplax longipennis & OD & 9.6 & $\mathbf{P}$ & 0.00 & & 0.00 \\
\hline 97 & Progomphus spp. & $O$ & 8.7 & $P$ & 0.00 & & 0.00 \\
\hline 98 & Acroneuris spp. & $P L$ & 1.4 & $\mathbf{P}$ & 0.00 & & 0.00 \\
\hline 99 & Allocapnia spp. & $\overline{P L}$ & 2.8 & $\mathrm{SH}$ & 0.00 & & 0.00 \\
\hline 100 & Leuctra spp. & $\mathrm{PL}$ & 0.7 & $\mathrm{SH}$ & 0.00 & & 0.00 \\
\hline 101 & Perlinella spp. & PL & 0 & $P$ & 0.00 & & 0.00 \\
\hline 102 & Anisocentropus pyraloides & TR & 0.8 & $\mathrm{SH}$ & 0.00 & & 0.00 \\
\hline 103 & Brachycentrus numerosus & TR & 1.8 & $\mathrm{CF}$ & 0.00 & & 0.00 \\
\hline 104 & Cheumatopsyche spp. & TR & 6.6 & $\mathrm{CF}$ & 0.00 & & 0.00 \\
\hline 105 & Chimarra spp. & TR & 2.8 & $\mathrm{CF}$ & 0.00 & & 0.00 \\
\hline 106 & Hydropsyche spp. & $T R$ & 4 & CF & 8.00 & 2 & 0.85 \\
\hline 107 & Hydroptila spp. & TR & 6.2 & $\mathrm{H}$ & 6.20 & 1 & 0.43 \\
\hline 108 & Lepidostome spp. & TR & 1 & $\mathrm{SH}$ & 0.00 & & 0.00 \\
\hline 109 & Nectopsyche exquisita & TR & 4.1 & $\mathrm{SH}$ & 0.00 & & 0.00 \\
\hline 110 & Oecetis spp. & TR & 5.7 & $P$ & 0.00 & & 0.00 \\
\hline 111 & Oxyethira spp. & TR & 6.2 & $\mathrm{H}$ & 0.00 & & 0.00 \\
\hline 112 & Phylocentropus spp. & TR & 5.6 & $\mathrm{CF}$ & 0.00 & & 0.00 \\
\hline 113 & Polycentropus spp. & TR & 3.5 & $\mathrm{CF}$ & 0.00 & & 0.00 \\
\hline 114 & Pycnopsyche spp. & TR & 2.3 & $\mathrm{SH}$ & 0.00 & & 0.00 \\
\hline 115 & Triaenodes tardus & TR & 4.7 & $\mathrm{SH}$ & 0.00 & & 0.00 \\
\hline 118 & Turbellaria & ITU & 7.5 & $P$ & 22.50 & 3 & 1.28 \\
\hline
\end{tabular}


Station 6. Upper Three Runs Creek at Road C. RBP. III. 20 September 1994

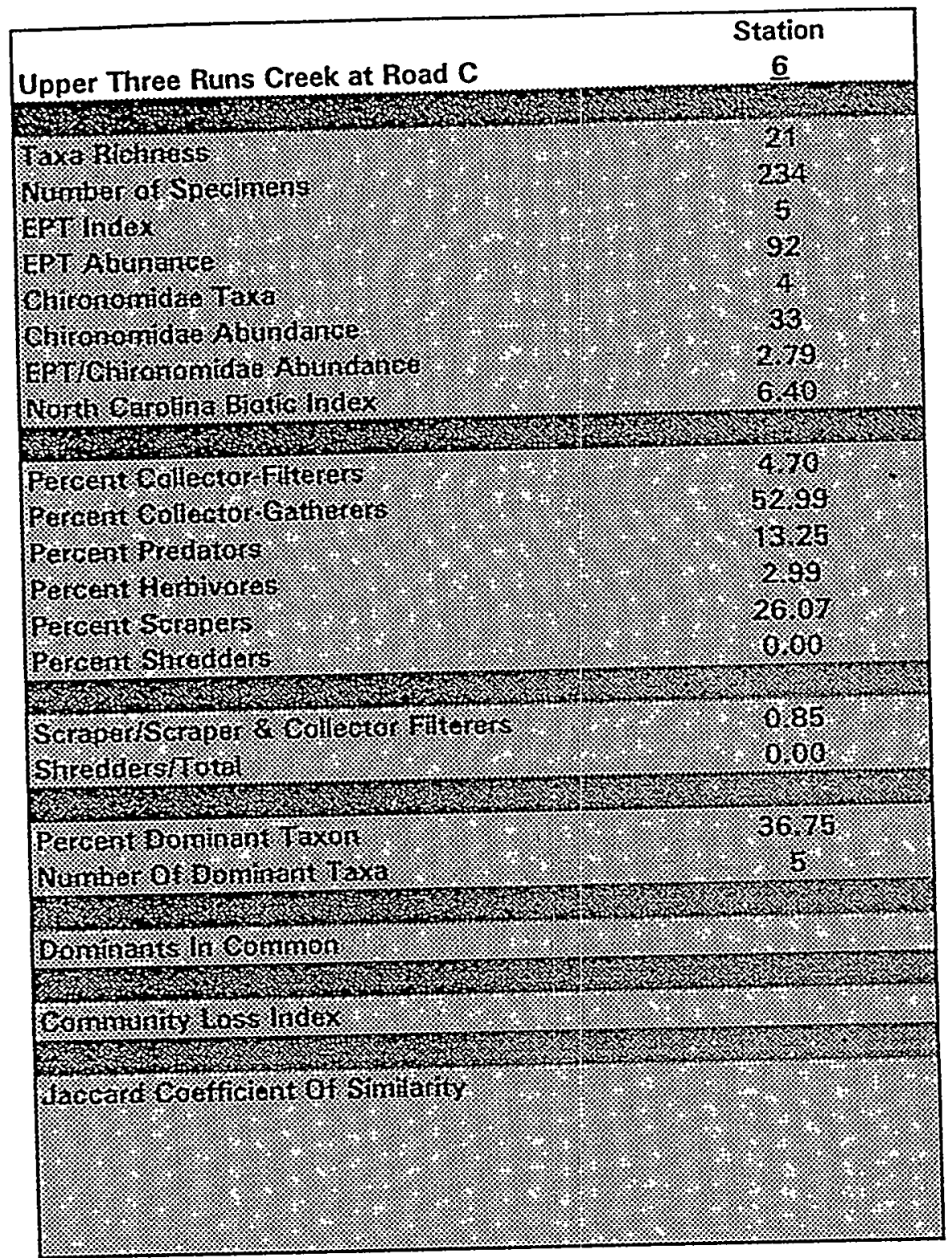


Station 6. Upper Three Runs Crreek at Road C. RBP III. 20 September 1994

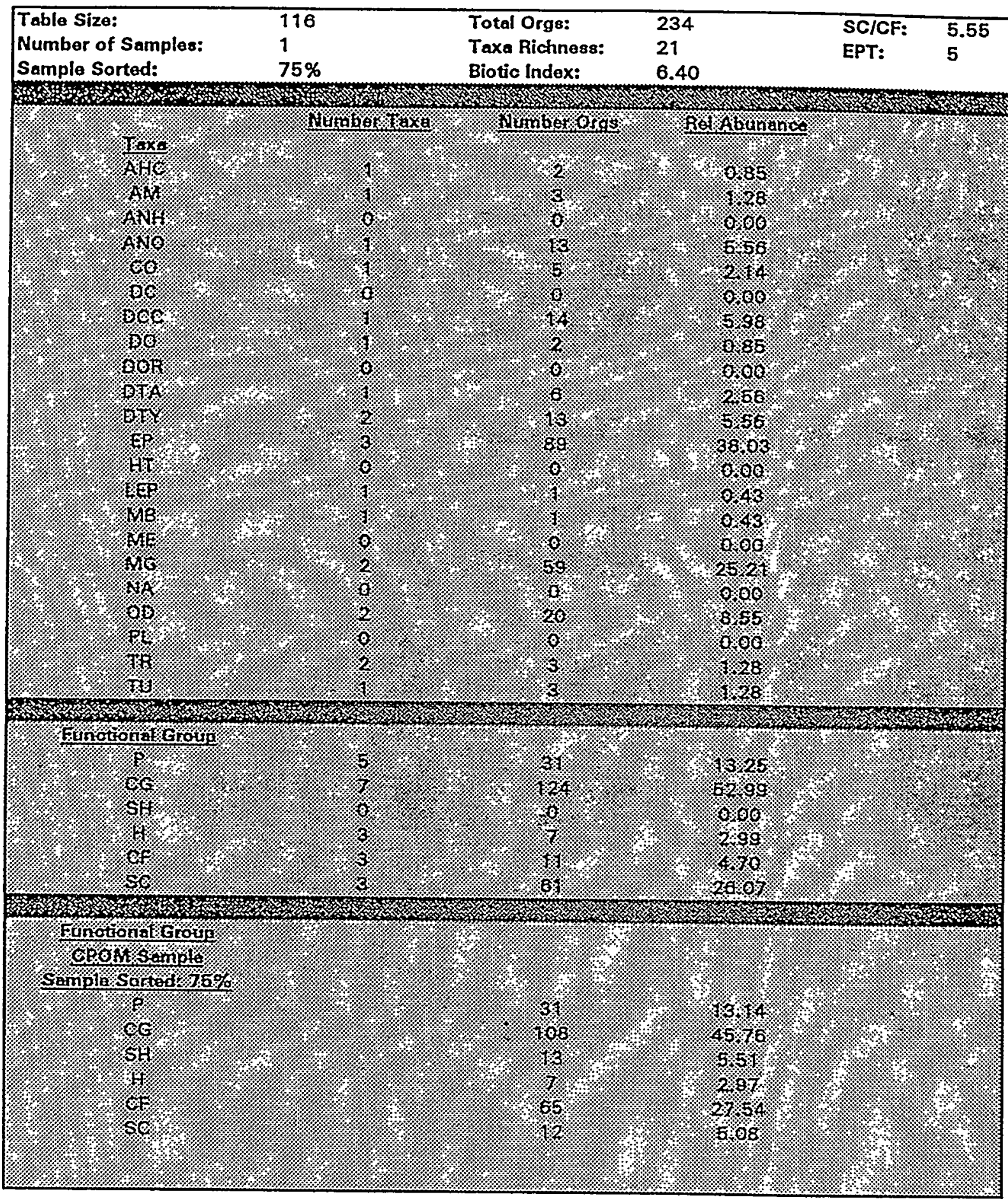


Station' 6. Upper Three Runs Creek at Road C. RBP III. 20 September 1994

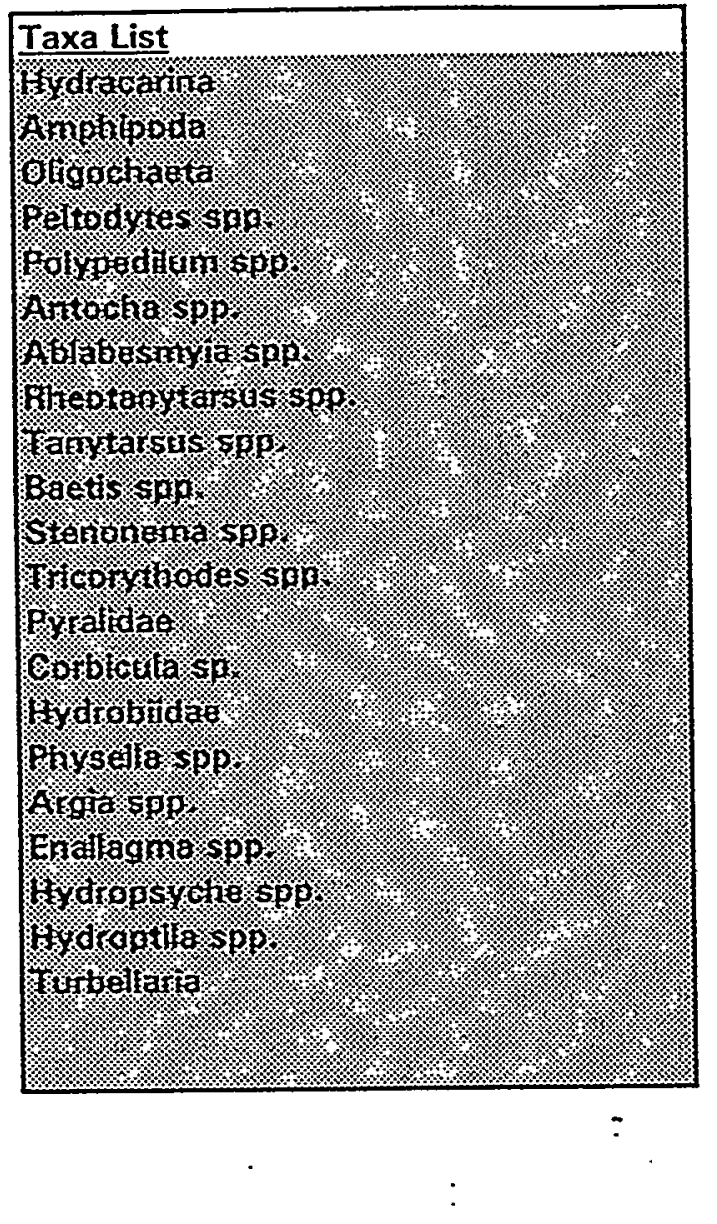


Station 6. Upper Three Runs Creek at Road C. RBP III. 20 September 1994

\begin{tabular}{|l|r|r|}
\hline Taxon & A & Rel Abd \\
\hline Baetis spp. & 86 & 36.75 \\
\hline Hydrobiidae & 58 & 24.79 \\
\hline Enallagma spp. & 15 & 6.41 \\
\hline Polypedilum spp. & 14 & 5.98 \\
\hline Oligochaeta & 13 & 5.56 \\
\hline
\end{tabular}


Station 7. Four Mile Creek at Road C. RBP III. 20 September 1994

\begin{tabular}{|c|c|c|c|c|c|c|c|}
\hline Seq & Taxon & ITAXC & \begin{tabular}{|l|l|} 
NCBI & $\mid F$ \\
\end{tabular} & $\mathbf{F G}$ & For $\mathrm{Bl}$ & A & Rel Abd \\
\hline 1 & Hydracarina & AHC & \begin{tabular}{|r|r}
5.7 & $\bar{P}$ \\
\end{tabular} & $P$ & 17.10 & 3 & 1.80 \\
\hline 2 & Amphipoda & $A M$ & $81 c$ & CG & 168.00 & 21 & 12.57 \\
\hline 3 & Hirudinea & ANH & & $\mathrm{P}$ & & & 0.00 \\
\hline 4 & Oligocheeta & ANO & 8.210 & $\mathbf{C G}$ & 237.80 & 29 & 17.37 \\
\hline 5 & Anchytarsus bicolor & CO & $3.8 \mathrm{~s}$ & $\mathrm{SH}$ & 0.00 & & 0.00 \\
\hline 6 & Ancyronyx variegatus & $\overline{\mathrm{CO}}$ & $6.9 \mid \mathrm{C}$ & $\mathbf{C G}$ & 0.00 & & 0.00 \\
\hline 7 & Dineutus spp. & Co & \begin{tabular}{ll|l}
5.5 & $\mathrm{~F}$ \\
\end{tabular} & $P$ & 0.00 & & 0.00 \\
\hline 8 & Dubiraphia bivittata & Co & $6.4 \mathrm{C}$ & CG & 0.00 & & 0.00 \\
\hline 9 & Dubiraphia spp. & Co & $6.4 \mathrm{C}$ & CG & 0.00 & & 0.00 \\
\hline 10 & Gyrinus spp. & co & $6.3 / \mathrm{F}$ & $\mathbf{P}$ & 0.00 & & 0.00 \\
\hline 111 & Haliplus sp. & co & 8.516 & CG & 0.00 & & 0.00 \\
\hline 12 & Helichus fastigatus & CO & $5.4 . \bar{C}$ & CG & 0.00 & & 0.00 \\
\hline 13 & Hydroporus spp. & 00 & $8.9 / F$ & $P$ & 0.00 & & 0.00 \\
\hline 14 & Macronychus glabratus & $\mathrm{Co}$ & 4.710 & CG & 0.00 & & 0.00 \\
\hline 15 & Peltodytes spp. & co & $8.5 / 1$ & $\mathrm{H}$ & 0.00 & & 0.00 \\
\hline 16 & Stenolmis humerosa & co & $5.41 \mathrm{C}$ & $\mathbf{C G}$ & 0.00 & & 0.00 \\
\hline 17 & Stenelmis spp. & CO & $5.4 \mathrm{C}$ & $\mathbf{C G}$ & 0.00 & & 0.00 \\
\hline 18 & Cambaridae & $D C$ & $8.8 / 5$ & $\mathrm{H}$ & 0.00 & & 0.00 \\
\hline 19 & Palaemonotes paludosus & $\mathrm{DC}$ & $6.7 / \mathrm{f}$ & $\mathrm{H}$ & 6.70 & 1 & 0.60 \\
\hline 20 & Chironomus spp. & DCC & $9.8 \mathrm{C}$ & CG & 0.00 & & 0.00 \\
\hline 21 & Cladopelma sp. & DCC & E) & $\mathbf{C G}$ & 0.00 & & 0.00 \\
\hline 22 & Cryptochironomus spp. & DCC & $7.4 \sqrt{F}$ & $\mathrm{P}$ & 0.00 & & 0.00 \\
\hline 23 & Dicrotendipes spp. & DCC & 7.96 & $\mathbf{C G}$ & 0.00 & & 0.00 \\
\hline 24 & Gooldichironomus holoprasinus & DCC & 1018 & $\mathbf{C G}$ & 0.00 & & 0.00 \\
\hline 25 & Microtendipes rydalensis & DCC & 6.26 & CG & 0.00 & & 0.00 \\
\hline 26 & Pagastialla sp. & DCC & 2.6 & CG & 0.00 & & 0.00 \\
\hline 27 & Parachironomus spp. & DCC & 9.2 & CG & 0.00 & & 0.00 \\
\hline 28 & Paralauterborniella sp. & DCC & 4.8 & CG & 0.00 & & 0.00 \\
\hline 29 & Pheenopsectra flavipes & DCC & 8.5 & CG & 0.00 & & 0.00 \\
\hline 30 & Polypedilum fallax & DCC & 6.75 & $\mathrm{SH}$ & 0.00 & & 0.00 \\
\hline 31 & Polypedilum spp. & DCC & $6.91 \mathrm{C}$ & CG & 27.60 & 4 & 2.40 \\
\hline 32 & Stenochironomus sp. & DCC & 6.45 & $\mathrm{SH}$ & 0.00 & & 0.00 \\
\hline 33 & Tribelos jucundum & DCC. & 6.6 & CG & 6.60 & 1 & 0.60 \\
\hline 34 & Xestochironomus sp. & $\overline{D C C}$ & 6.45 & $\mathrm{SH}$ & 0.00 & & 0.00 \\
\hline 35 & Zavrolliella spp. & $\overline{D C C}$ & & CG & & & 0.00 \\
\hline 36 & Antocha spp. & DO & 4.6 & $\overline{C G}$ & 0.00 & & 0.00 \\
\hline 37 & Ceretopogonidae & DO & 6.518 & $P$ & 0.00 & & 0.00 \\
\hline 38 & Helius spp. & $\mathrm{DO}$ & & CG & & & 0.00 \\
\hline 39 & Hemerodromis spp. & DO & 8.11 & CG & 0.00 & & 0.00 \\
\hline 40 & Hexatoma spp. & DO & 4.71 & $P$ & 0.00 & & 0.00 \\
\hline 41 & Limonie spp. & DO & $10 \mid$ & $\mathrm{SH}$ & 0.00 & & 0.00 \\
\hline 42 & Simulium spp. & 00 & 4.4 & CF & 0.00 & & 0.00 \\
\hline 43 & Tipula spp. & DO & 7.7 & SH & 0.00 & & 0.00 \\
\hline 44 & Corynoneura spp. & DOR & 6.2 & CG & 0.00 & & 0.00 \\
\hline 45 & Cricotopus/Ortho spp. & DOR & 8.8 & CG & 0.00 & & 0.00 \\
\hline 46 & Parametriocnemus sp. & DOR & 3.7 & CG & 0.00 & & 0.00 \\
\hline 47 & Rheocricotopus spp. & DOR & 7.3 & CG & 0.00 & & 0.00 \\
\hline 48 & Thienemanniella spp. & DOR & 6 & CG & 0.00 & & 0.00 \\
\hline 49 & Xylopus par & DOR & 6.6 & $\mathrm{SH}$ & 0.00 & & 0.00 \\
\hline 50 & Ablabesmyia spp. & DTA & 6.4 & $P$ & 76.80 & 12 & 7.19 \\
\hline 51 & Apsectrotanypus johnsoni & DTA & 0 & $\mathbf{P}$ & 0.00 & & 0.00 \\
\hline 52 & Clinotanypus pinguis & DTA & 9.11 & $\mathbf{P}$ & 0.00 & & 0.00 \\
\hline 53 & Conchapelopie spp. & DTA & 8.7 & $P$ & 34.80 & 4 & 2.40 \\
\hline 54 & Labrundinia spp. & DTA & 618 & $P$ & 12.00 & 2. & 1.20 \\
\hline 55 & Nilotanypus spp. & DTA & $4 \mid$ & $P$ & 0.00 & & 0.00 \\
\hline 56 & Pentaneura inconspicua & DTA & 4.6 & $P$ & 4.60 & 1 & 0.60 \\
\hline 57 & Procladius spp. & DTA & 9.3 & $\mathrm{P}$ & 0.00 & & 0.00 \\
\hline 58 & Rheotanytarsus spp. & DTY & 6.4 & $\mathrm{CF}$ & 6.40 & 1 & 0.60 \\
\hline
\end{tabular}




\begin{tabular}{|c|c|c|c|c|c|c|c|}
\hline 59 & Stempellinella spp. & DTY & 5.3 & $3 \longdiv { C G }$ & 0.00 & & 0.00 \\
\hline 80 & Tanytarsus spp. & DTY & 6.7 & $7 \longdiv { C G }$ & 107.20 & 16 & 9.68 \\
\hline 61 & Acentrella ampla & EP & 3.6 & $6 \longdiv { C G }$ & 0.00 & & 0.00 \\
\hline 62 & Acerpenna pygmaeus & EP & 3.7 & $\overline{C G}$ & 0.00 & & 0.00 \\
\hline 83 & Acerpenne spp. & EP & 3.7 & $7 \overline{C G}$ & 0.00 & & 0.00 \\
\hline 64 & Baotis spp. & EP & 5.4 & $\begin{array}{l}\mathbf{C G} \\
\end{array}$ & 10.80 & 2 & 1.20 \\
\hline 65 & Caenis spp. & EP & 7.6 & 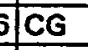 & 0.00 & & 0.00 \\
\hline 68 & Callibaetis spp. & EP & 9.3 & $\begin{array}{l}\text { B } \\
\text { GG }\end{array}$ & 0.00 & & 0.00 \\
\hline 67 & Eurylophelle spp. & EP & 3 & $3 \mid \mathbf{C G}$ & 0.00 & & 0.00 \\
\hline 68 & Hexagenia spp. & EP & 4.7 & CG & 0.00 & & 0.00 \\
\hline 69 & Isonychia spp. & EP & 3.8 & CF & 0.00 & & 0.00 \\
\hline 70 & Neoephemera youngi & EP & 2.1 & CG & 0.00 & & 0.00 \\
\hline 71 & Paraleptophlebia spp. & EP & 1.2 & $2 \longdiv { C G }$ & 0.00 & & 0.00 \\
\hline 7.2 & Siphlonurus sp. & EP & 2.6 & $\overline{C G}$ & 0.00 & & 0.00 \\
\hline 73 & Stenonema spp. & EP & 3.4 & SC & 3.40 & 1 & 0.60 \\
\hline 74 & Tricorythodes spp. & EP & 5.4 & $C G$ & $0 . \infty$ & & 0.00 \\
\hline 75 & Belostoma sp. & HT & 9.8 & $P$ & 0.00 & & 0.00 \\
\hline 76 & Hesperocorixa sp. & HT & & $H$ & 0.00 & & 0.00 \\
\hline 77 & Pyralidae & LEP & & $\mathrm{H}$ & 35.00 & 7 & 4.19 \\
\hline 78 & Corbicula sp. & $\mathrm{MB}$ & 6.3 & $\mathrm{CF}$ & 0.00 & & 0.00 \\
\hline 79 & Eliptio spp. & MB & 3.4 & CF & 0.00 & & 0.00 \\
\hline 80 & Sphaerium spp. & $M B$ & 7.7 & CF & 7.70 & 1 & 0.60 \\
\hline 81 & Nigronia serricornis & ME & 5.6 & $\mathbf{P}$ & 0.00 & & 0.00 \\
\hline 82 & Sialis spp. & ME & 7.7 & $\mathrm{P}$ & 15.40 & 2 & 1.20 \\
\hline 83 & Campeloma sp. & MG & 6.7 & Sc & 0.00 & & 0.00 \\
\hline 84 & Forrissia sp. & MG & 6.9 & SC & 0.00 & & 0.00 \\
\hline 85 & Hydrobiidae & MG & & sc & & & 0.00 \\
\hline 86 & Physella spp. & MG & 9.1 & SC & 9.10 & 1 & 0.60 \\
\hline 87 & Planorbidae & MG & 6.5 & Sc & 6.50 & 1 & 0.60 \\
\hline 88 & Nemertea & $\overline{N A}$ & & $p$ & & & 0.00 \\
\hline 89 & Argia spp. & OD & 8.7 & $P$ & 78.30 & 9 & .5 .39 \\
\hline 90 & Boyeria vinosa & OD & 6.3 & P & 0.00 & & 0.00 \\
\hline 91 & Calopteryx spp. & OD & 8.3 & $P$ & 33.20 & 4 & 2.40 \\
\hline 92 & Enallagma spp. & OD & 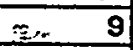 & $P$ & 72.00 & 8 & 4.78 \\
\hline 93 & Gomphus spp. & $O D$ & 6.2 & $\mathbf{P}$ & 0.00 & & 0.00 \\
\hline 94 & Macromia spp. & $O D$ & 6.7 & $P$ & 13.40 & 2 & 1.20 \\
\hline 95 & Neurocordulie spp. & $O D$ & 5.8 & $\mathbf{P}$ & 29.00 & 5 & 2.99 \\
\hline 96 & Pachydiplox longipennis & $O D$ & 9.6 & P & 0.00 & & 0.00 \\
\hline 97 & Progomphus spp. & $O D$ & 8.7 . & P & 0.00 & & 0.00 \\
\hline 98 & Acronourie spp. & $\mathrm{PL}$ & 1.4 & $P$ & 0.00 & & 0.00 \\
\hline 99 & Allocspnia spp. & $\mathrm{PL}$ & 2.8 & $\mathrm{SH}$ & 0.00 & & 0.00 \\
\hline 100 & Leuctra spp. & $\mathrm{PL}$ & 0.7 & $\mathrm{SH}$ & 0.00 & & 0.00 \\
\hline 101 & Perlinella spp. & $\mathrm{PL}$ & 0 & $P$ & 0.00 & & 0.00 \\
\hline 102 & Anisocentropus pyraloides & TR & 0.8 & $\mathrm{SH}$ & 0.00 & & 0.00 \\
\hline 103 & Brachycentrus numerosus & TR & 1.8 & $C F$ & 0.00 & & 0.00 \\
\hline 104 & Choumatopsyche spp. & TR & 6.6 & $\mathrm{CF}$ & 0.00 & & 0.00 \\
\hline 105 & Chimarra spp. & $T R$ & 2.8 & CF & 0.00 & & 0.00 \\
\hline 108 & Hydropsyche spp. & $T R$ & & $\mathrm{CF}$ & 0.00 & & 0.00 \\
\hline 107 & Hydroptile spp. & TR & 6.2 & $H$ & 0.00 & & 0.00 \\
\hline 108 & Lepidostoma spp. & $T R$ & & $\mathrm{SH}$ & 0.00 & & 0.00 \\
\hline 109 & Nectopsyche exquisita & TR & 4.1 & SH & 0.00 & & 0.00 \\
\hline 110 & Oecetis spp. & $T R$ & 5.7 & $\mathrm{P}$ & 0.00 & & 0.00 \\
\hline 111 & Oxyothira spp. & TR & 6.2 & $\mathrm{H}$ & 0.00 & & 0.00 \\
\hline 112 & Phylocentropus spp. & TR & 5.6 & $\mathrm{CF}$ & 0.00 & & 0.00 \\
\hline .113 & Polycentropus spp. & TR & 3.5 & CF & 0.00 & & 0.00 \\
\hline .114 & Pycnopsyche spp. & $T R$ & 2.3 & $\mathrm{SH}$ & 0.00 & & 0.00 \\
\hline 115 & Trieenodes tardus & TR & 4.7 & $\mathrm{SH}$ & 0.00 & & 0.00 \\
\hline 116 & Turbellaria & TU & 7.5 & P & 217.50 & 29 & 17.37 \\
\hline
\end{tabular}




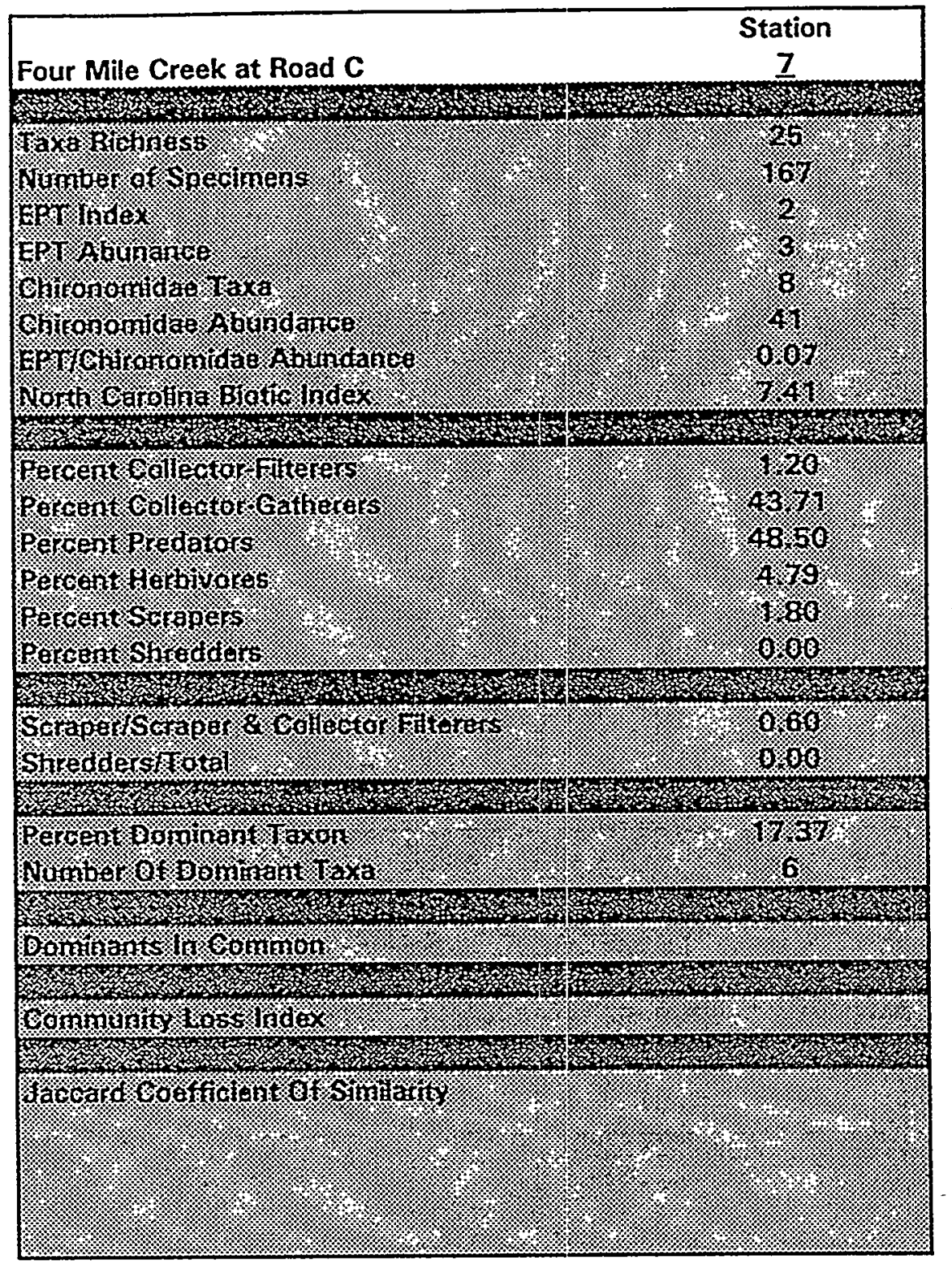




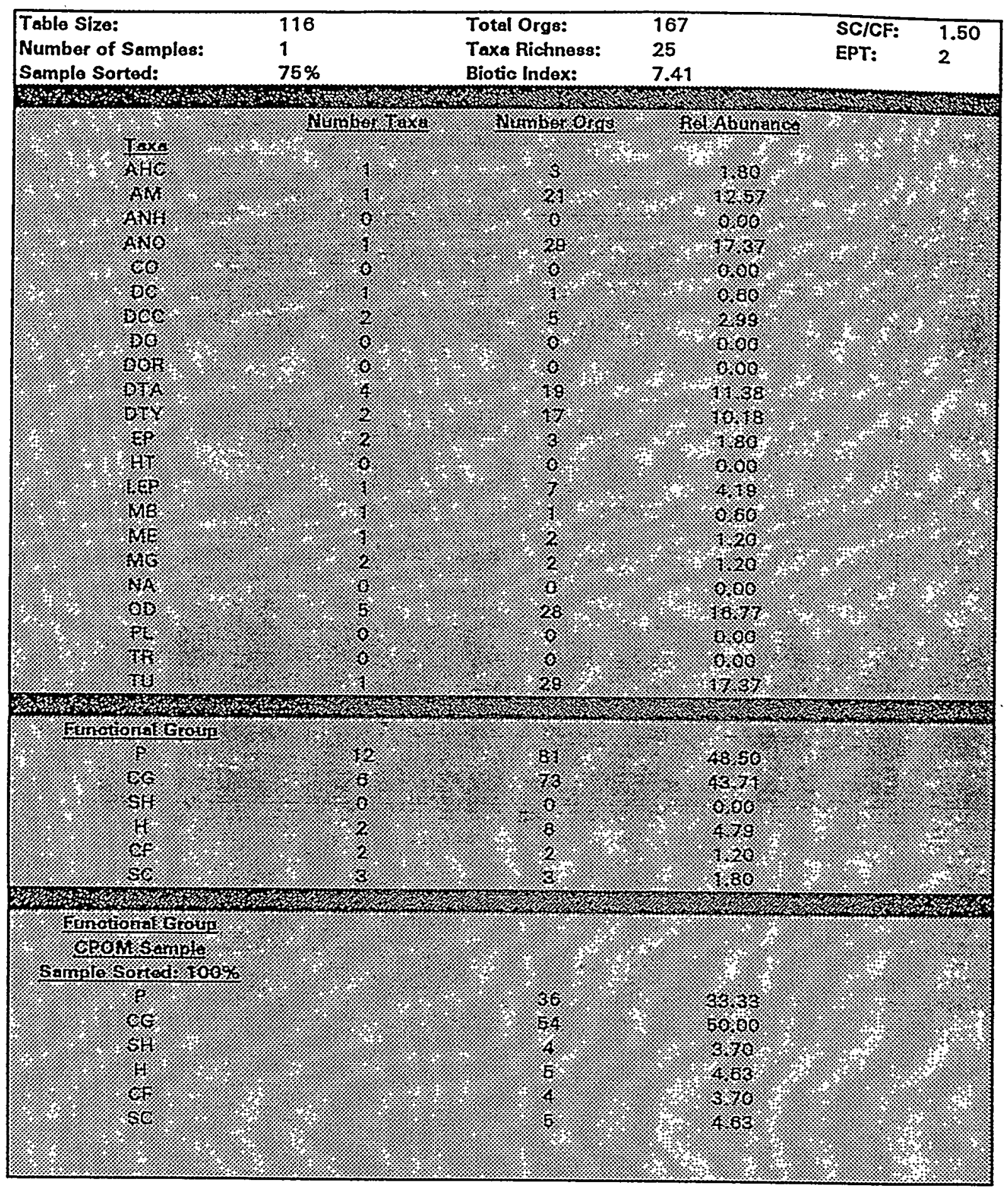




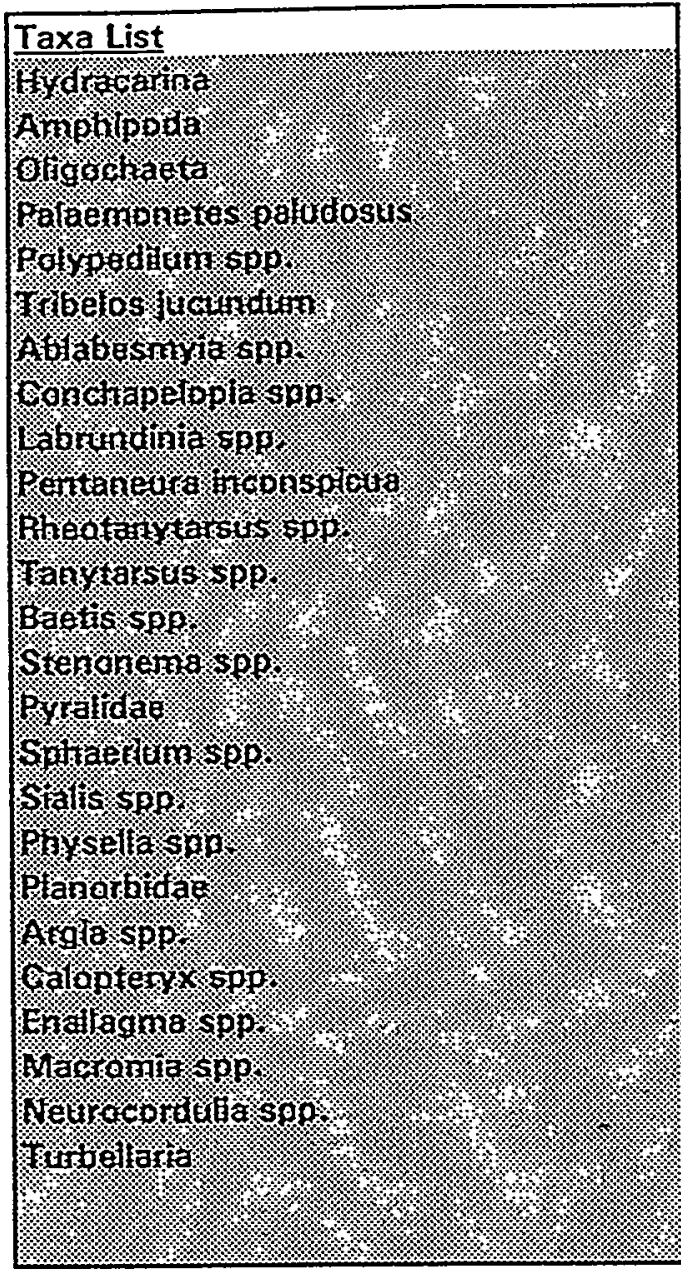

F: 
Station 7. Four Mile Creek at Road C. RBP III. 20 September 1994

\begin{tabular}{|l|r|r|}
\hline Taxon & A & Rel Abd \\
\hline Oligochaeta & 29 & 17.37 \\
\hline Turbellaria & 29 & 17.37 \\
\hline Amphipoda & 21 & 12.57 \\
\hline Tanytarsus spp. & 16 & 9.58 \\
\hline Ablabesmyia spp. & 12 & 7.19 \\
\hline Argia spp. & 9 & 5.39 \\
\hline
\end{tabular}




\begin{tabular}{|c|c|c|c|c|c|c|c|}
\hline Seq & Taxon & TTAXC & NCBI & FG & For 81 & C & Rel Abd \\
\hline 1 & Hydracarina & AHC & 5.7 & $\mathbf{P}$ & 0.00 & & 0.00 \\
\hline 2 & Amphipoda & $A M$ & 8 & CG & 0.00 & & 0.00 \\
\hline 3 & Hirudinea & ANH & & $P$ & & & 0.00 \\
\hline 4 & Oligochaeta & ANO & 8.2 & CG & 229.60 & 28 & 13.79 \\
\hline 5 & Anchytarsus bicolor - & $\mathrm{CO}$ & 3.8 & $\mathrm{SH}$ & 3.80 & 1 & 0.49 \\
\hline 8 & Ancyronyx variegatus & co & 6.4 & $\mathbf{C G}$ & 0.00 & & 0.00 \\
\hline 7 & Dineutus spp. & co & 5.5 & $P$ & 0.00 & & 0.00 \\
\hline 8 & Dubiraphia bivittata & co & 6.4 & $\overline{C G}$ & 12.80 & 2 & 0.99 \\
\hline 9 & Dubiraphia spp. & co & 6.4 & $\overline{C G}$ & 0.00 & & 0.00 \\
\hline 10 & Gyrinus spp. & co & 6.3 & $\mathbf{P}$ & 0.00 & & 0.00 \\
\hline 11 & Haliplus sp. & co & 8.6 & $\mathbf{C G}$ & 0.00 & & 0.00 \\
\hline 12 & Helichus fastigatus & co & 5.4 & SC & 0.00 & & 0.00 \\
\hline 13 & Hydroporus spp. & co & 8.9 & $P$ & 8.90 & 1 & 0.49 \\
\hline 14 & Macronychus glabratus & Co & 4.7 & CG & 9.40 & 2 & 0.99 \\
\hline 15 & Peltodytes spp. & co & 8.6 & $\mathrm{H}$ & 0.00 & & 0.00 \\
\hline 16 & Stenelmis humerosa & Co & 5.4 & CG & 16.20 & 3 & 1.48 \\
\hline 17 & Stenelmis spp. & co & 5.4 & $\mathrm{CG}$ & 0.00 & & 0.00 \\
\hline 18 & Cambaridae & $D C$ & 8.8 & $\mathrm{H}$ & 0.00 & & 0.00 \\
\hline 19 & Palaemonetes paludosus & $D C$ & 6.7 & $\mathrm{H}$ & 0.00 & & 0.00 \\
\hline 20 & Chironomus spp. & DCC & 9.8 & CG & 0.00 & & 0.00 \\
\hline 21 & Cladopelma sp. & DCC & 5 & $\overline{C G}$ & 0.00 & & 0.00 \\
\hline 22 & Cryptochironomus spp. & DCC & 7.4 & $\mathrm{P}$ & 7.40 & 1 & 0.49 \\
\hline 23 & Dicrotendipes spp. & DCC & 7.9 & $\mathrm{CG}$ & 0.00 & & 0.00 \\
\hline 24 & Goeldichironomus holoprasinus & DCC & 10 & CG & 0.00 & & 0.00 \\
\hline 25 & Microtendipes rydalensis & DDCC & 6.2 & CG & 0.00 & & 0.00 \\
\hline 26 & $\begin{array}{l}\text { Pagastiella sp. } \\
\end{array}$ & DCC & 2.6 & CG & 0.00 & & 0.00 \\
\hline 27 & Parachironomus spp. & DCC & 9.2 & $C G$ & 0.00 & & 0.00 \\
\hline 28 & Paralauterborniella sp. & DCC & 4.8 & CG & 0.00 & & 0.00 \\
\hline 29 & Phaenopsectra flavipes & DCC & 8.5 & CG & 0.00 & & 0.00 \\
\hline 30 & Polypadilum fallax & DCC & 6.7 & SH & 0.00 & & 0.00 \\
\hline 31 & Polypedilum spp. & DCC & 6.9 & CG & 117.30 & 17 & 8.37 \\
\hline 32 & Stenochironomus sp. & DCC & 6.4 & SH & 6.40 & 1 & 0.49 \\
\hline 33 & Tribelos jucundum & DEC. & 6.6 & $\overline{C G}$ & 0.00 & & 0.00 \\
\hline 34 & Xestochironomus sp. & DCC & 6.4 & $\mathrm{SH}$ & 0.00 & & 0.00 \\
\hline 35 & Zavrelliella spp. & DCC & & CG & & & 0.00 \\
\hline 36 & Antocha spp. & Do & 4.6 & CG & 0.00 & & 0.00 \\
\hline 37 & Ceratopogonidae & DO & 6.5 & $\mathbf{P}$ & 0.00 & & 0.00 \\
\hline 38 & Helius spp. & Do & & CG & & & 0.00 \\
\hline 39 & Hemerodromie spp. & DO & 8.1 & CG & 0.00 & & 0.00 \\
\hline 40 & Hexatoma spp. & DO & 4.7 & $\mathrm{P}$ & 0.00 & & 0.00 \\
\hline .41 & Limonia spp. & Do & 10 & SH & 0.00 & & 0.00 \\
\hline 42 & Simulium spp. & Do & 4.4 & CF & 26.40 & 6 & 2.96 \\
\hline 43 & Tipula spp. & DO & 7.7 & $\mathrm{SH}$ & 15.40 & 2 & 0.99 \\
\hline 44 & Corynoneura spp. & DOR & 6.2 & CG & 0.00 & & 0.00 \\
\hline 45 & Cricotopus/Ortho spp. & DOR & 8.8 & CG & 0.00 & & 0.00 \\
\hline 46 & Parametriocnemus sp. & DOR & 3.7 & CG & 0.00 & & 0.00 \\
\hline 47 & Rheocricotopus spp. & DOR & 7.3 & CG & 0.00 & & 0.00 \\
\hline 48 & \begin{tabular}{|l|} 
3. Thienemanniella spp. \\
.
\end{tabular} & DOR & 6 & CG & 0.00 & & 0.00 \\
\hline 49 & Xylopus par & DOR & 6.6 & $\mathrm{SH}$ & 0.00 & & 0.00 \\
\hline 50 & Ablabosmyia spp. & DTA & 6.4 & $P$ & 32.00 & 5 & 2.46 \\
\hline 51 & Apsectrotanypus johnsoni & DTA & 0 & P & 0.00 & & 0.00 \\
\hline 52 & Clinotanypus pinguis & $\overline{\text { DTA }}$ & 9.1 & $\mathrm{P}$ & 9.10 & 1 & 0.49 \\
\hline 53 & Conchapelopia spp. & DTA & 8.7 & $\bar{P}$ & 8.70 & 1 & 0.49 \\
\hline 54 & Labrundinia spp. & DTA & 6 & P & 6.00 & 1 & 0.49 \\
\hline 55 & 司 Nilotanypus spp. & DTA & 4 & $P$ & 0.00 & & 0.00 \\
\hline 56 & 8) Pentaneura inconspicua & DTA & 4.6 & $\bar{P}$ & 0.00 & & 0.00 \\
\hline 57 & \begin{tabular}{|l|} 
Procladius spp. \\
\end{tabular} & DTA & 9.3 & $\bar{P}$ & 9.30 & 1 & 0.49 \\
\hline 58 & \begin{tabular}{l|l}
8 Rheotanytarsus spp. \\
\end{tabular} & DTY & 6.4 & $\mathrm{CF}$ & 64.00 & 10 & 4.93 \\
\hline
\end{tabular}




\begin{tabular}{|c|c|c|c|c|c|c|c|}
\hline 59 & Stempellinella spp. & DTY & 6.3 & CG & 0.00 & & 0.00 \\
\hline 60 & Tanytarsus spp. & DTY & 6.7 & CG & 147.40 & 22 & 10.84 \\
\hline 61 & Acentrella ampla & EP & 3.6 & CG & 0.00 & & 0.00 \\
\hline 62 & Acerpenna pygmaeus & EP & 3.7 & CF & 25.90 & 7 & 3.46 \\
\hline 63 & Acerpenne spp. & EP & 3.7 & $\overline{\mathbf{C G}}$ & 0.00 & & 0.00 \\
\hline 64 & Baotis spp. & EP & 6.4 & $\overline{C G}$ & 27.00 & 5 & 2.46 \\
\hline 65 & Coenis spp. & EP & 7.6 & CG & 0.00 & & 0.00 \\
\hline 68 & Callibaetis spp. & EP & 9.3 & CG & 0.00 & & 0.00 \\
\hline 67 & Eurylopheilla spp. & EP & 3 & CG & 15.00 & 6 & 2.46 \\
\hline 68 & Hexagenia spp. & EP & 4.7 & $\overline{C G}$ & 0.00 & & 0.00 \\
\hline 69 & Isonychia spp. & EP & 3.8 & $\mathrm{CF}$ & 0.00 & & 0.00 \\
\hline 70 & Nooophemera youngi & EP & 2.1 & $\overline{C G}$ & 0.00 & & 0.00 \\
\hline 71 & Peraleptophlebia spp. & EP & 1.2 & CG & 0.00 & & 0.00 \\
\hline 72 & Siphlonurus sp. & EP & 2.6 & CG & 0.00 & & 0.00 \\
\hline 73 & Stenonema spp. & EP & 3.4 & Sc & 20.40 & 6 & 2.96 \\
\hline 74 & Tricorythodes spp. & EP & 5.4 & CG & 0.00 & & 0.00 \\
\hline 75 & Belostoma sp. & HT & 9.8 & $\mathrm{P}$ & 0.00 & & 0.00 \\
\hline 76 & Hesperocorixa sp. & $\overline{\mathrm{HT}}$ & 9 & $\mathrm{H}$ & 0.00 & & 0.00 \\
\hline 77 & Pyralides & LEP & 5 & $\mathrm{H}$ & 0.00 & & 0.00 \\
\hline 78 & Corbicula sp. & MB & 6.3 & CF & 0.00 & & 0.00 \\
\hline 79 & Eliptio spp. & MB & 3.4 & $\mathrm{CF}$ & 0.00 & & 0.00 \\
\hline 80 & Sphaerium spp. & MB & 7.7 & $\mathrm{CF}$ & 100.10 & 13 & 6.40 \\
\hline 81 & Nigronia serricornis & ME & 5.5 & $P$ & 5.50 & 1 & 0.49 \\
\hline 82 & Sialis spp. & ME & 7.7 & P & 0.00 & & 0.00 \\
\hline 83 & Campeloma sp. & MG & 6.7 & sc & 0.00 & & 0.00 \\
\hline 84 & Forrissia sp. & MG & 6.9 & sc & 20.70 & 3 & 1.48 \\
\hline 85 & Hydrobilidae & MG & & Sc & & & 0.00 \\
\hline 86 & Physella spp. & MG & 9.1 & $\overline{S C}$ & 0.00 & & 0.00 \\
\hline 87 & Planorbidae & MG & 6.5 & sc & 6.50 & 1 & 0.49 \\
\hline 88 & Nemertea & NA & & $\mathrm{P}$ & & 3 & 1.48 \\
\hline 89 & Argia spp. & $O D$ & 8.7 & $\mathbf{P}$ & 8.70 & 1 & 0.49 \\
\hline 90 & Boyeria vinosa & $O D$ & 6.3 & $\overline{\mathbf{P}}$ & $0 . \infty$ & & 0.00 \\
\hline 91 & Calopteryx spp. & OD & 8.3 & $\mathbf{P}$ & 0.00 & & 0.00 \\
\hline 92 & Enallagma spp. & OD & $\approx \quad 9$ & $\mathbf{P}$ & 180.00 & 20 & 9.85 \\
\hline 93 & Gomphus spp. & $O D$ & 6.2 & $\mathrm{P}$ & 18.60 & 3 & 1.48 \\
\hline 94 & Macromis spp. & OD & 6.7 & $P$ & 6.70 & 1 & 0.49 \\
\hline 95 & Naurocordulia spp. & OD & 5.8 & $P$ & 0.00 & & 0.00 \\
\hline 96 & Pachydiplax longipennis & OD & 9.6 & $\mathbf{P}$ & 9.60 & .1 & 0.49 \\
\hline 97 & Progomphus spp. & 100 & 8.7 & P & 8.70 & 1 & 0.49 \\
\hline 98 & Acroneuria spp. & $\overline{P L}$ & 1.4 & $P$ & 0.00 & & 0.00 \\
\hline 99 & Allocapnia spp. & $P L$ & 2.8 & SH & 0.00 & & 0.00 \\
\hline 100 & Leuctra spp. & PL & 0.7 & SH & 0.00 & & 0.00 \\
\hline 101 & Perlinella spp. & PL & 0 & $P$ & 0.00 & & 0.00 \\
\hline 102 & Anisocentropus pyraloides & TR & 0.8 & SH & 0.00 & & 0.00 \\
\hline 103 & \begin{tabular}{|l|} 
Brachycentrus numerosus \\
\end{tabular} & $T R$ & 1.8 & CF & 0.00 & & 0.00 \\
\hline 104 & Cheumatopsyche spp. & TR & 6.6 & CF & 92.40 & 14 & 6.90 \\
\hline 105 & Chimarre spp. & $T R$ & 2.8 & $\mathrm{CF}$ & 19.60 & 7 & 3.46 \\
\hline 106 & Hydropsyche spp. & TR & 4 & $\mathrm{CF}$ & 4.00 & 1 & 0.49 \\
\hline 107 & Hydroptila spp. & TR & 6.2 & $\mathrm{H}$ & 0.00 & & 0.00 \\
\hline 108 & SLepidostoma spp. & TR & 1 & $\mathrm{SH}$ & 0.00 & & 0.00 \\
\hline 109 & Nectopsyche exquisita & $T R$ & 4.1 & SH & 12.30 & $\overline{3}$ & 1.48 \\
\hline 110 & Oecetis spp. & TR & 5.7 & $\mathrm{P}$ & 0.00 & & 0.00 \\
\hline 111 & 1 Oxyethira spp. & TR & 6.2 & th & 0.00 & & 0.00 \\
\hline 112 & Phylocentropus spp. & $T R$ & 5.6 & CF & 5.60 & $\overline{1}$ & 0.49 \\
\hline 113 & 3 Polycentropus spp. & TR & 3.5 & CF & 0.00 & & 0.00 \\
\hline 114 & 7 Pycnopsyche spp. & $T R$ & 2.3 & SH & 2.30 & 1 & 0.49 \\
\hline 115 & \begin{tabular}{|c|c|} 
Triaenodes tardus \\
\end{tabular} & TR & 4.7 & SH & 0.00 & & 0.00 \\
\hline 116 & \begin{tabular}{l|l} 
8 & Turbellaria \\
\end{tabular} & TU & $\overline{7.5}$ & $P$ & 0.00 & & 0.00 \\
\hline
\end{tabular}




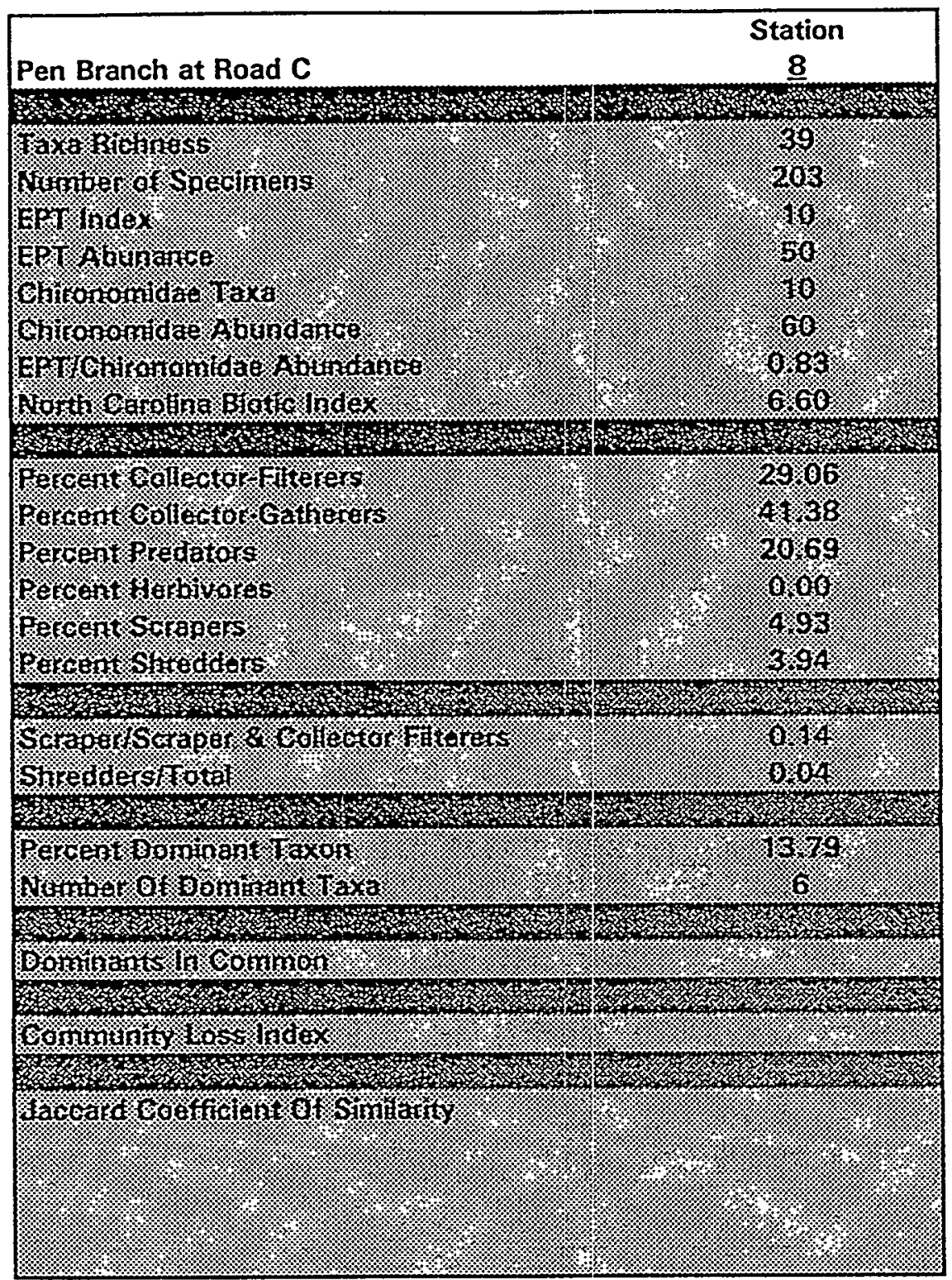


Station 8. Pen Branch at Road C. RBP III. 20 September 1994

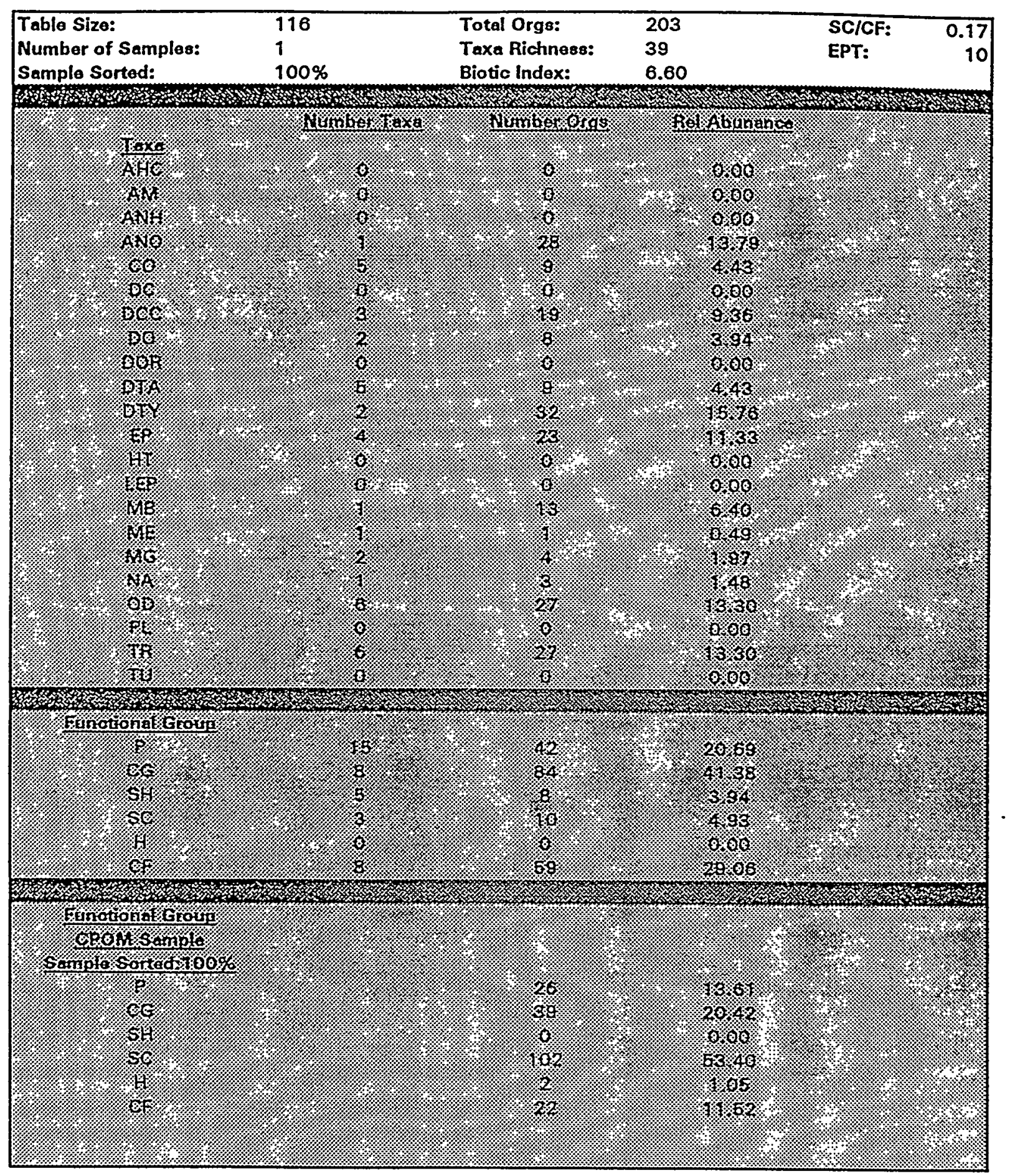




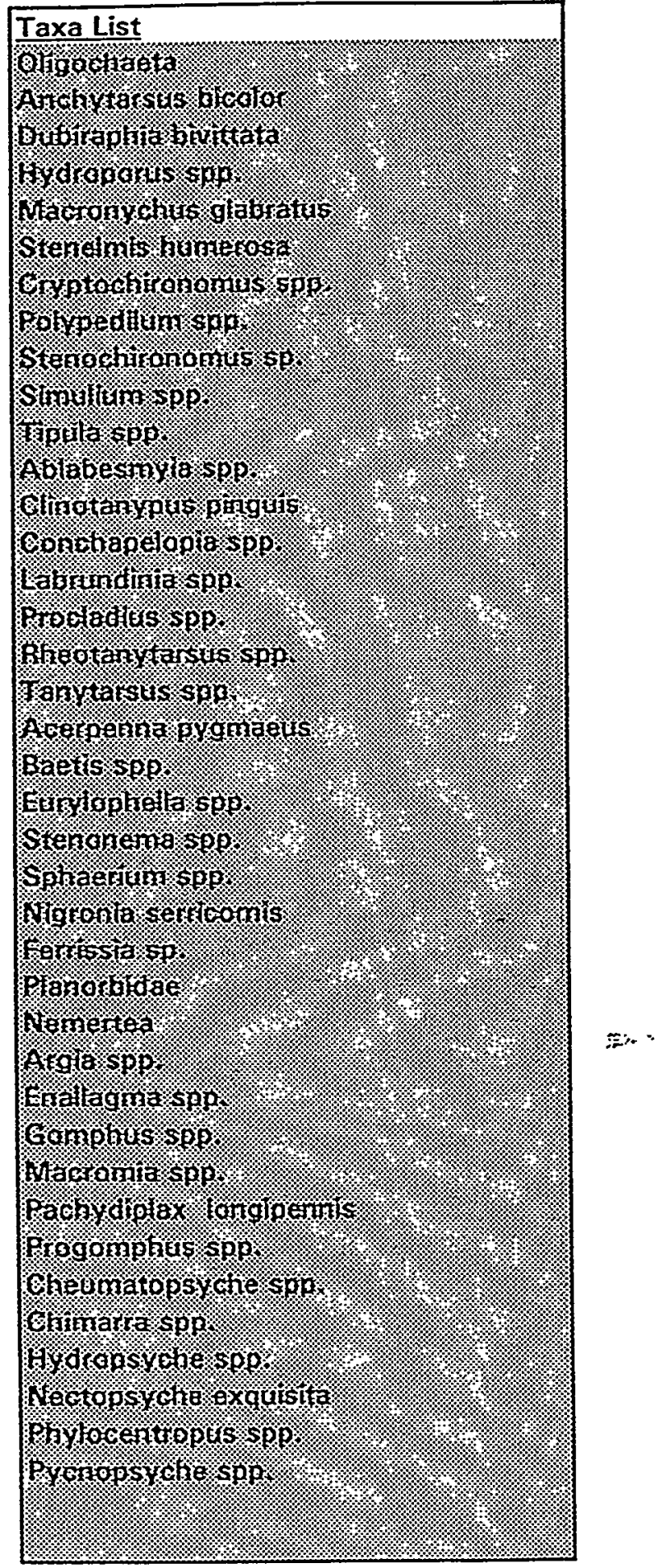




\begin{tabular}{|r|r|r|r|}
\hline & Taxon & C & Rel Abd \\
\hline & Oligochaeta & 28 & 13.79 \\
\hline & Tanytarsus spp. & 22 & 10.84 \\
\hline & Enallagma spp. & 20 & 9.85 \\
\hline & Polypedilum spp. & 17 & 8.37 \\
\hline & Cheumatopsyche spp. & 14 & 6.90 \\
\hline & Sphaerium spp. & 13 & 6.40 \\
\hline
\end{tabular}




\begin{tabular}{|c|c|c|c|c|c|c|c|}
\hline Seq & Taxon & TAXC & \begin{tabular}{|l|}
$\mathrm{NCBI}$ \\
\end{tabular} & |FG & For $\mathrm{BI}$ & A & Rel Abd \\
\hline 1 & Hydracarina & AHC & \begin{tabular}{|r|}
6.7 \\
\end{tabular} & $P$ & \begin{tabular}{|l|}
0.00 \\
\end{tabular} & & 0.00 \\
\hline 2 & Amphipoda & AM & 8 & CG & 0.00 & & 0.00 \\
\hline 3 & Hirudinea & ANH & & $P$ & & 1 & 0.61 \\
\hline 4 & Oligochaeta & ANO & 8.2 & CG & 188.60 & 23 & 11.68 \\
\hline 5 & Anchytarsus bicolor & $\mathrm{CO}$ & 3.8 & $\mathrm{SH}$ & 0.00 & & 0.00 \\
\hline 6 & Ancyronyx variegatus & $\mathrm{CO}$ & 6.9 & $\overline{C G}$ & 6.90 & 1 & 0.61 \\
\hline $7 \mid$ & Dineutus spp. & $\mathrm{CO}$ & 6.5 & $P$ & 0.00 & & 0.00 \\
\hline 8 & Dubiraphia bivittata & co & 6.4 & CG & 12.80 & 2 & 1.02 \\
\hline 9 & Dubiraphia spp. & CO & 6.4 & $\mathbf{C G}$ & 0.00 & & 0.00 \\
\hline 10 & Gyrinus spp. & $\mathrm{CO}$ & 6.3 & $P$ & 0.00 & & 0.00 \\
\hline 11 & Haliplus sp. & co & 8.6 & CG & 0.00 & & 0.00 \\
\hline 121 & Helichus fastigatus & Co & 5.4 & SC & 10.80 & 2 & 1.02 \\
\hline 13 & Hydroporus spp. & Co & 8.9 & $P$ & 8.90 & 1 & 0.51 \\
\hline 14 & Macronychus glabratus & $\mathrm{CO}$ & 4.7 & CG & 9.40 & 2 & 1.02 \\
\hline 15 & Peltodytes spp. & co & 8.5 & $H$ & 0.00 & & 0.00 \\
\hline 16 & Stenelmis humerosa & Co & 5.4 & $\mathbf{C G}$ & 0.00 & & 0.00 \\
\hline 17 & Stenelmis spp. & $\mathrm{CO}$ & 5.4 & CG & 5.40 & 1 & 0.51 \\
\hline 18 & Cambaridae & DC & 8.8 & $H$ & 17.60 & 2 & 1.02 \\
\hline 19 & Palaemonetes paludosus & DC & 6.7 & $H$ & 113.90 & 17 & 8.63 \\
\hline 20 & Chironomus spp. & DCC & 9.8 & CG & 0.00 & & 0.00 \\
\hline 21 & Cladopelma sp. & DCC & 5 & CG & 0.00 & & 0.00 \\
\hline 22 & Cryptochironomus spp. & DCC & 7.4 & $P$ & 0.00 & & 0.00 \\
\hline 23 & Dicrotendipes spp. & DCC & 7.9 & CG & 0.00 & & 0.00 \\
\hline 24 & Goeldichironomus holoprasinus & DCC & 10 & $C G$ & 0.00 & & 0.00 \\
\hline 25 & Microtendipes rydalensis & DCC & 6.2 & CG & 0.00 & & 0.00 \\
\hline 26 & Pagastiella sp. & $D C C$ & 2.6 & CG & 2.60 & 1 & 0.51 \\
\hline 27 & Parachironomus spp. & DCC & 9.2 & CG & 0.00 & & 0.00 \\
\hline 28 & Paralauterborniella sp. & DCC & 4.8 & CG & 4.80 & 1 & 0.61 \\
\hline 29 & Phaenopsectra flavipes & DCC & 8.5 & CG & 0.00 & & 0.00 \\
\hline 30 & Polypedilum fallax & DCC & 6.7 & SH & 6.70 & 1 & 0.51 \\
\hline 31 & Polypedilum spp. & ICC & 6.9 & CG & 82.80 & 12 & 6.09 \\
\hline 32 & Stenochironomus sp. & CICC & 6.4 & $\mathrm{SH}$ & 12.80 & 2 & 1.02 \\
\hline 33 & Tribelos jucundum & CIGG. & 6.6 & $\overline{C G}$ & 6.60 & 1 & 0.61 \\
\hline 34 & Xestochironomus sp. & occ & 6.4 & $\mathrm{SH}$ & 0.00 & & 0.00 \\
\hline 35 & Zavrelliella spp.. & IICC & & CG & & & 0.00 \\
\hline 36 & Antocha spp. & 00 & 4.6 & $\overline{C G}$ & 0.00 & & 0.00 \\
\hline 37 & Ceratopogonidae & 00 & 6.5 & $P$ & 6.50 & 1 & 0.61 \\
\hline 38 & Helius spp. & 00 & & CG & & 1 & 0.51 \\
\hline 39 & Hemerodromia spp. & 0 & 8.1 & $\mathbf{C G}$ & 0.00 & & 0.00 \\
\hline 40 & Hexatoma spp. & 00 & 4.7 & $P$ & 0.00 & & 0.00 \\
\hline 41 & Limonia spp. & DO & 10 & $\mathrm{SH}$ & 0.00 & & 0.00 \\
\hline 42 & Simulium spp. & 00 & 4.4 & CF & 4.40 & 1 & 0.51 \\
\hline 43 & Tipula spp. & 00 & 7.7 & $\mathrm{SH}$ & 0.00 & & 0.00 \\
\hline 44 & Corynoneura spp. & DOR & 6.2 & CG & 0.00 & & 0.00 \\
\hline 45 & Cricotopus/Ortho spp. & DOR & 8.8 & CG & 0.00 & & 0.00 \\
\hline 46 & Parametriocnemus sp. & DOR & 3.7 & CG & 0.00 & & 0.00 \\
\hline 47 & Rheocricotopus spp. & DOR & 7.3 & $\overline{C G}$ & 0.00 & & 0.00 \\
\hline 48 & Thienemanniella spp. & DOR & 6 & CG & 0.00 & & 0.00 \\
\hline 49 & Xylopus par & DOR & 6.6 & $\mathrm{SH}$ & 0.00 & & 0.00 \\
\hline 50 & Ablabesmyia spp. & DTA & 6.4 & $P$ & 12.80 & 2 & 1.02 \\
\hline 51 & Apsectrotanypus johnsoni & DTA & 0 & $P$ & 0.00 & 2 & 1.02 \\
\hline 52 & Clinotanypus pinguis & DTA & 9.1 & $P$ & 0.00 & & 0.00 \\
\hline 53 & Conchapelopia spp. & DTA & 8.7 & $P$ & 0.00 & & 0.00 \\
\hline 54 & Labrundinia spp. & DTA & 6 & $P$ & 18.00 & 3 & 1.52 \\
\hline 55 & Nilotanypus spp. & DTA & 4 & $P$ & 0.00 & & 0.00 \\
\hline 56 & Pentaneura inconspicue & DTA & 4.6 & $P$ & 0.00 & & 0.00 \\
\hline 57 & Procladius spp. & DTA & 9.3 & $P$ & 0.00 & & 0.00 \\
\hline 58 & Rheotanytarsus spp. & DTY & 6.4 & $\mathrm{CF}$ & 19.20 & 3 & 1.52 \\
\hline
\end{tabular}




\begin{tabular}{|c|c|c|c|c|c|c|c|}
\hline 59 & Stempellinella spp. & DTY & 6.3 & CG & 0.00 & & 0.00 \\
\hline 60 & Tanytarsus spp. & DTY & 6.7 & CG & 120.60 & 18 & 9.14 \\
\hline 61 & Acentralla ampla & EP & 3.6 & CG & 0.00 & & 0.00 \\
\hline 62 & Acerpenna pvgmaeus & EP & 3.7 & $\overline{C G}$ & 0.00 & 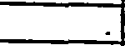 & 0.00 \\
\hline 63 & Acerpenna spp. & EP & 3.7 & $\mathbf{C G}$ & 0.00 & & 0.00 \\
\hline 64 & Beotis spp. & EP & 5.4 & CG & 21.60 & 4 & 2.03 \\
\hline 65 & Caenis spp. & EP & 7.6 & CG & 0.00 & & 0.00 \\
\hline 68 & Callibaetis spp. & $E P$ & 9.3 & CG & 0.00 & & 0.00 \\
\hline 67 & Eurylophelle spp. & EP & 3 & CG & 0.00 & & 0.00 \\
\hline 68 & Hexagenia spp. & EP & 4.7 & CG & 23.60 & 5 & 2.54 \\
\hline 69 & Isonychia spp. & EP & 3.8 & CF & 3.80 & 1 & 0.51 \\
\hline 70 & Neoephemers youngi & EP & 2.1 & $\mathbf{C G}$ & 23.10 & 11 & 5.58 \\
\hline 71 & Paraleptophlebia spp. & EP & 1.2 & CG & 1.20 & 1 & 0.51 \\
\hline 72 & Siphlonurus sp. & EP & 2.6 & CG & 0.00 & & 0.00 \\
\hline 73 & Stenonema spp. & EP & 3.4 & sc & 17.00 & 5 & 2.54 \\
\hline 74 & Tricorythodes spp. & EP & 5.4 & CG & 140.40 & 26 & 13.20 \\
\hline 75 & Belostama sp. & HT & 9.8 & $P$ & 0.00 & & 0.00 \\
\hline 76 & Hesperocorixa sp. & HT & 9 & $\mathrm{H}$ & 0.00 & & 0.00 \\
\hline 77 & Pyralidae & LEP & 5 & $\mathrm{H}$ & 0.00 & & 0.00 \\
\hline 78 & Corbicule sp. & $\mathrm{MB}$ & 6.3 & $\mathrm{CF}$ & 0.00 & - & 0.00 \\
\hline 79 & Eliptio spp. & MB & 3.4 & $\mathrm{CF}$ & 0.00 & & 0.00 \\
\hline 80 & Sphoorium spp. & MB & 7.7 & $\mathrm{CF}$ & 30.80 & 4 & 2.03 \\
\hline 81 & Nigronia serricornis & $M E$ & 5.5 & $\mathbf{P}$ & 0.00 & & 0.00 \\
\hline 82 & Sialis spp. & ME & 7.7 & $\mathbf{P}$ & 7.70 & 1 & 0.61 \\
\hline 83 & Campoloms sp. & MG & 6.7 & sc & 0.00 & & 0.00 \\
\hline 84 & Ferrissia sp. & MG & 6.9 & SC & 13.80 & 2 & 1.02 \\
\hline 85 & Hydrobiidae & MG & & SC & & 2 & 1.02 \\
\hline 86 & Physella spp. & MG & 9.1 & SC & 0.00 & & 0.00 \\
\hline 87 & Planorbidae & $M G$ & 6.5 & SC & 0.00 & & 0.00 \\
\hline 88 & Nemertea & NA & & $\mathbf{P}$ & & & 0.00 \\
\hline 89 & Argia spp. & OD & 8.7 & $\mathbf{P}$ & 0.00 & & 0.00 \\
\hline 90 & Boyeria vinosa & $O D$ & 6.3 & $P$ & 0.00 & & 0.00 \\
\hline 91 & Calopteryx spp. & OD & 8.3 & $\mathbf{P}$ & 16.60 & 2 & 1.02 \\
\hline 92 & Enallagma spp. & OD & 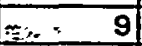 & $\mathbf{P}$. & 0.00 & & 0.00 \\
\hline 93 & Gomphus spp. & OD & 6.2 & $\mathbf{P}$ & 18.60 & 3 & 1.52 \\
\hline 94 & Macromia spp. & OD & 6.7 & P & 0.00 & & 0.00 \\
\hline 95 & Neurocordulia spp. & $O D$ & 5.8 & $\mathbf{P}$ & 11.60 & 2 & 1.02 \\
\hline 98 & Pechydiplex longipennis & OD & 9.6 & $\mathbf{P}$ & 0.00 & & 0.00 \\
\hline 97 & Progomphus spp. & $O D$ & 8.7 & $\mathbf{P}$ & 0.00 & & 0.00 \\
\hline 98 & Acroneuria spp. & $P L$ & 1.4 & $\mathbf{P}$ & 2.80 & 2 & 1.02 \\
\hline 99 & Allocapnia spp. & PL & 2.8 & SH & 0.00 & & 0.00 \\
\hline 100 & Leuctra spp. & PL & 0.7 & $\mathrm{SH}$ & 0.00 & & 0.00 \\
\hline 101 & Perlinella spp. & PL & 0 & $P$ & 0.00 & & 0.00 \\
\hline 102 & Anisocentropus pyraloides & TR & 0.8 & SH & 1.60 & 2 & 1.02 \\
\hline 103 & Brachycentrus numerosus & TR & 1.8 & $\mathrm{CF}$ & 19.80 & 11 & 6.58 \\
\hline 104 & Cheumatopsyche spp. & TR & 6.6 & CF & 13.20 & 2 & 1.02 \\
\hline 105 & Chimarra spp. & TR & 2.8 & $\overline{C F}$ & 0.00 & & 0.00 \\
\hline 106 & Hydropsyche spp. & TR & 4 & CF & 0.00 & & 0.00 \\
\hline 107 & Hydroptila spp. & TR & 6.2 & $\mathrm{H}$ & 0.00 & & 0.00 \\
\hline 108 & Lepidostoma spp. & TR & 1 & $\mathrm{SH}$ & 2.00 & 2 & 1.02 \\
\hline 109 & Nectopsyche exquisite & TR & 4.1 & $\mathrm{SH}$ & 0.00 & & 0.00 \\
\hline 110 & Oecetis spp. & TR & 5.7 & $P$ & 5.70 & 1 & 0.51 \\
\hline 111 & Oxyethira spp. & TR & 6.2 & $H$ & 0.00 & & 0.00 \\
\hline 112 & Phylocentropus spp. & TR & 5.6 & CF & 33.60 & 6 & 3.05 \\
\hline 113 & Polycentropus spp. & TR & 3.5 & $\mathrm{CF}$ & 0.00 & & 0.00 \\
\hline 114 & Pycnopsyche spp. & TR & 2.3 & $\mathrm{SH}$ & 0.00 & & 0.00 \\
\hline 115 & Triaenodes tardus & TR & 4.7 & $\mathrm{SH}$ & 4.70 & 1 & 0.51 \\
\hline 116 & Turbellaria & TTU. & 7.5 & $P$ & 0.00 & & 0.00 \\
\hline
\end{tabular}


Station 9. Meyers Branch at Road 9. RBP III. .20 Septeriber 1994

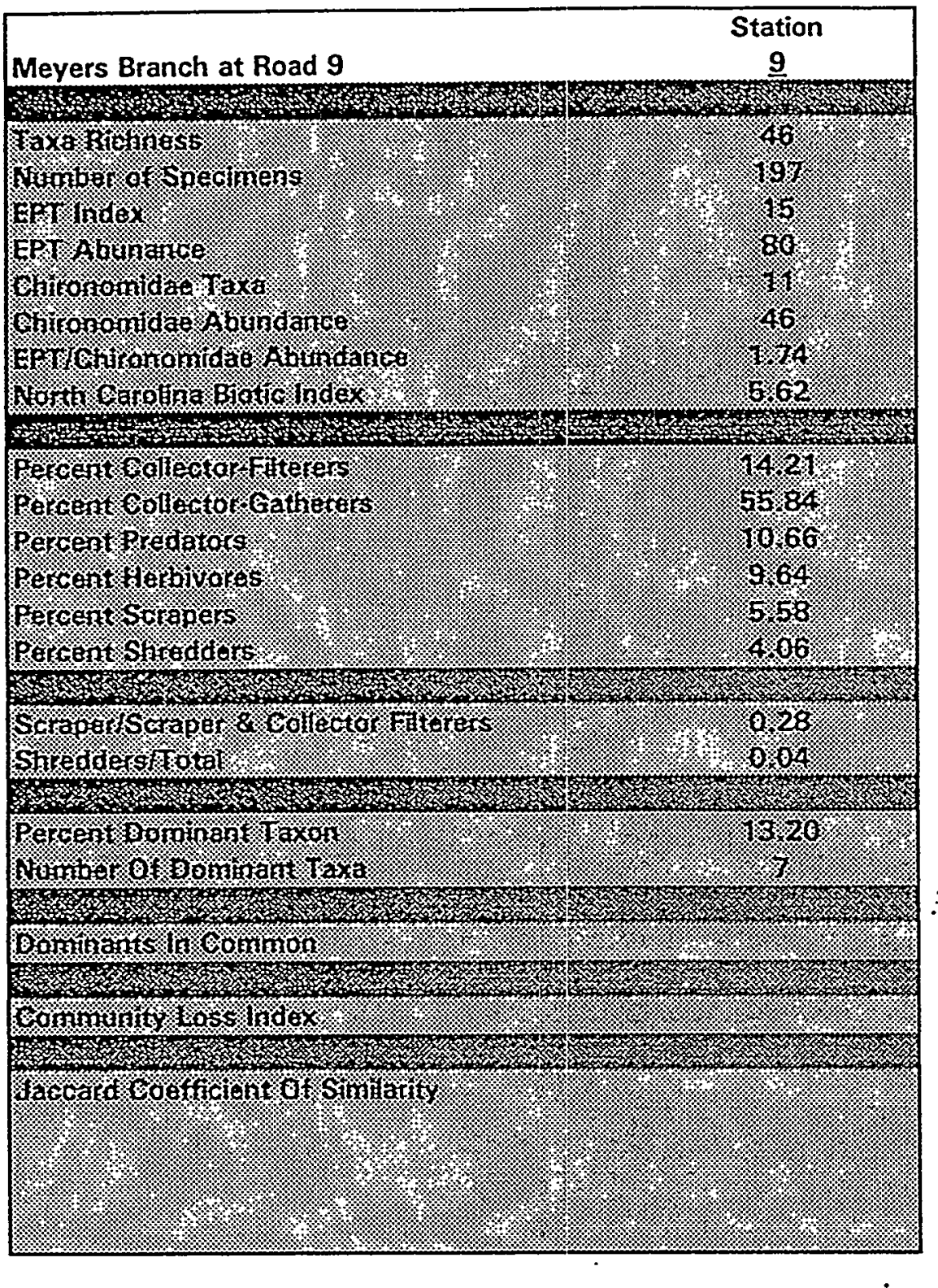




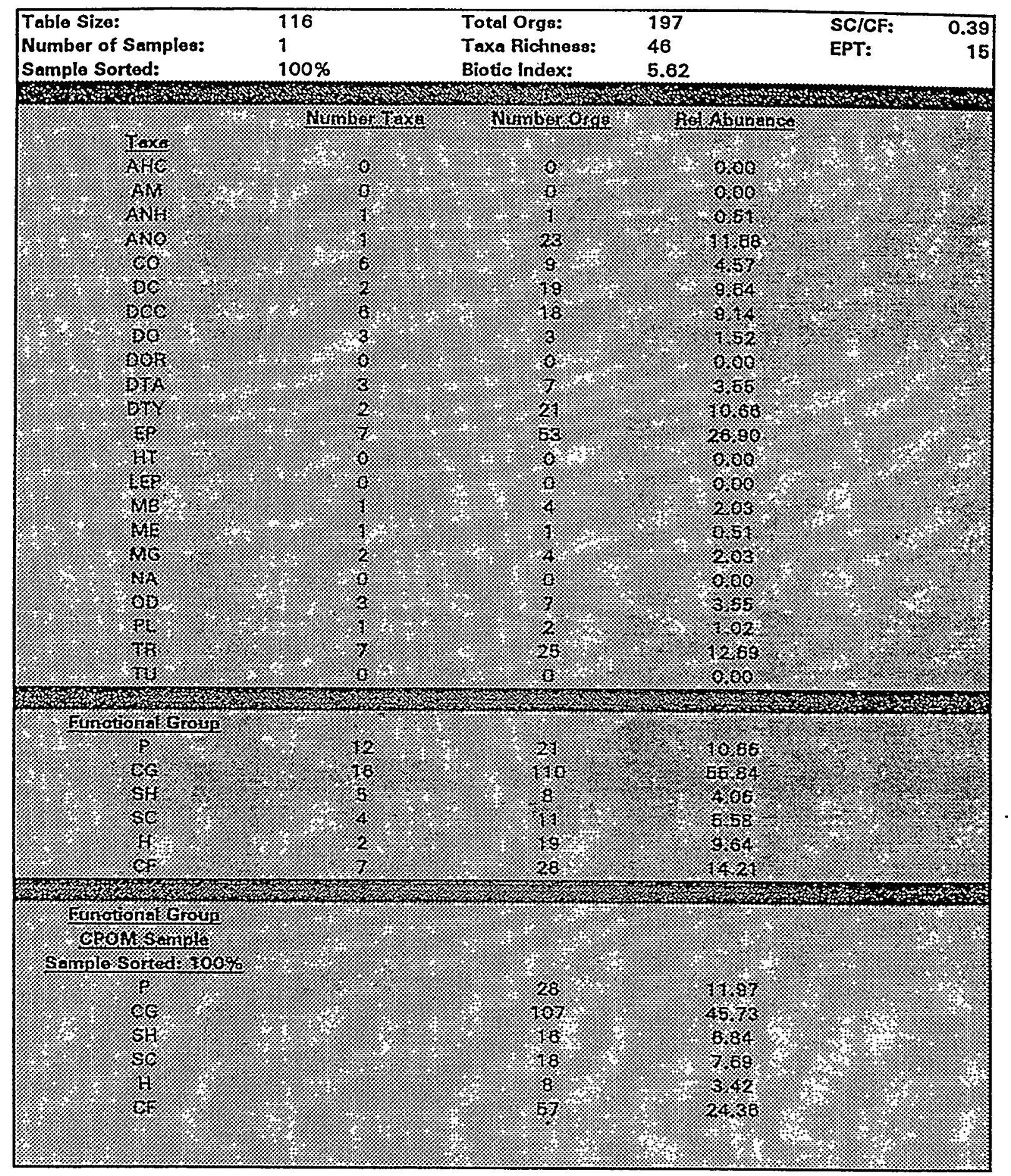




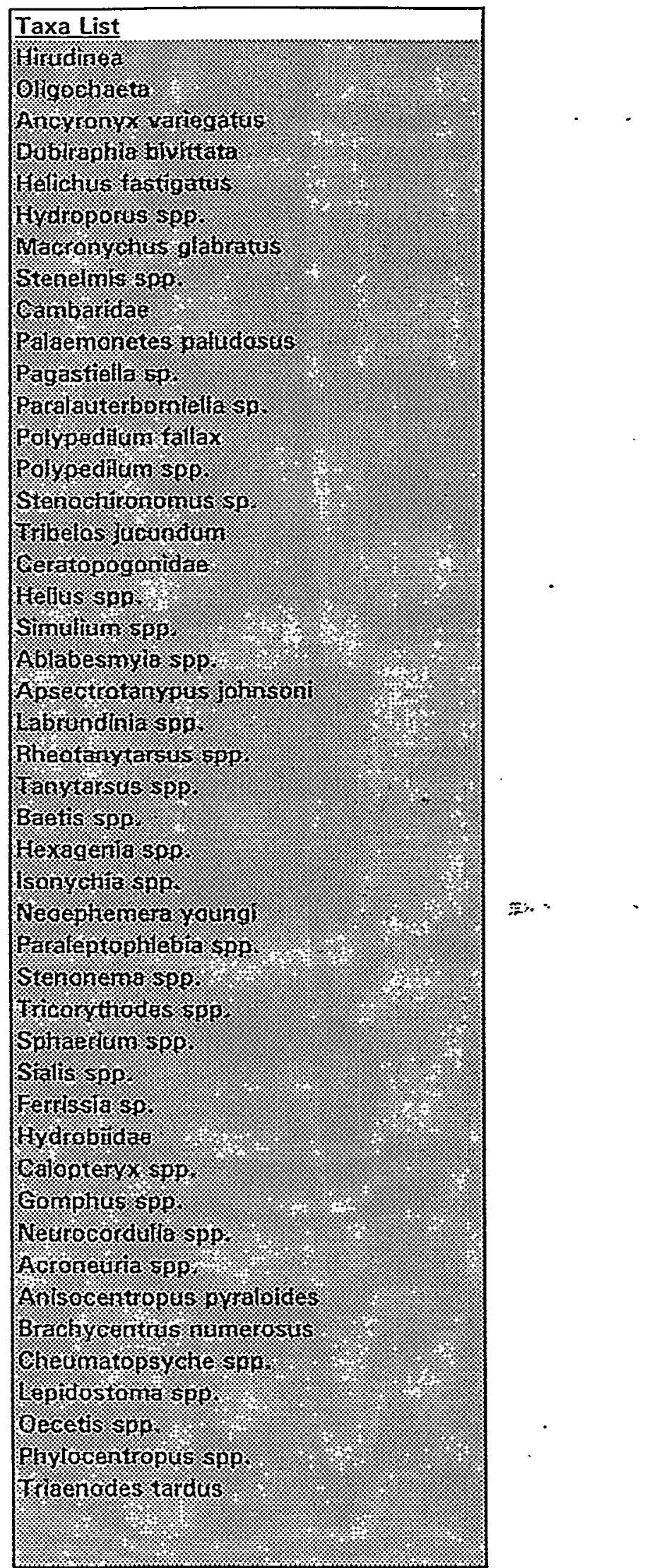




\begin{tabular}{|l|r|r|}
\hline Taxon & A & Rel Abd \\
\hline Tricorythodes spp. & 26 & 13.20 \\
\hline Oligochaeta & 23 & 11.68 \\
\hline Tanytarsus spp. & 18 & 9.14 \\
\hline Palaemonetes paludosus. & 17 & 8.63 \\
\hline Polypedilum spp. & 12 & 6.09 \\
\hline Neoephemera youngi & 11 & 5.58 \\
\hline Brachycentrus numerosus & 11 & 5.58 \\
\hline
\end{tabular}


Station 10. Lower Three Runs Creek at Road B. RBP III. 20 September 1994

\begin{tabular}{|c|c|c|c|c|c|c|c|}
\hline Soq & Taxon & TAXXC & NCBI & FG & For $\mathrm{BI}$ & $\mathbf{A}$ & Rel Abd \\
\hline 1 & Hydracarina & $\overline{A H C}$ & 5.7 & $\bar{P}$ & 0.00 & & 0.00 \\
\hline 2 & Amphipoda & AM & 8 & CG & 0.00 & & 0.00 \\
\hline 3 & Hirudinea & ANH & & $P$ & & & 0.00 \\
\hline 4 & Oligochaeta & ANO & 8.2 & CG & 188.60 & 23 & 8.96 \\
\hline 5 & Anchytarsus bicolor - & Co & 3.8 & $\mathrm{SH}$ & 0.00 & & 0.00 \\
\hline 6 & Ancyronyx variegatus & CO & 6.9 & $\overline{C G}$ & 0.00 & & 0.00 \\
\hline 7 & Dineutus spp. & co & 5.5 & $\bar{P}$ & 0.00 & & 0.00 \\
\hline 8 & Dubiraphia bivittata & $\mathrm{CO}$ & 6.4 & CG & 0.00 & & 0.00 \\
\hline 9 & Dubiraphia spp. & CO & 6.4 & CG & 0.00 & & 0.00 \\
\hline 10 & Gyrinus spp. & Co & 6.3 & $P$ & 25.20 & 4 & 1.66 \\
\hline 11 & Haliplus sp. & CO & 8.5 & CG & 0.00 & & 0.00 \\
\hline 12 & Helichus fastigatus & $\mathrm{CO}$ & 5.4 & $\mathrm{sc}$ & 0.00 & & 0.00 \\
\hline .13 & Hydroporus spp. & CO & 8.9 & $\mathrm{P}$ & 0.00 & & 0.00 \\
\hline 14 & Macronychus glabratus & CO & 4.7 & CG & 0.00 & & 0.00 \\
\hline 15 & Peltodytes spp. & Co & 8.5 & $\mathrm{H}$ & 0.00 & & 0.00 \\
\hline 16 & Stenelmis humerosa & CO & 5.4 & CG & 0.00 & & 0.00 \\
\hline 17 & Stenelmis spp. & CO & 5.4 & $\overline{C G}$ & 0.00 & & 0.00 \\
\hline 18 & Cambaridae & DC & 8.8 & $\mathrm{H}$ & 17.60 & 2 & 0.78 \\
\hline 19 & Palaemonotes paludosus & DC & 6.7 & $\mathrm{H}$ & 6.70 & 1 & 0.39 \\
\hline 20 & Chironomus spp. & DCC & 9.8 & CG & 0.00 & & 0.00 \\
\hline 21 & Cladopolma sp. & DCC & 6 & CG & 0.00 & & 0.00 \\
\hline 22 & Cryptochironomus spp. & DCC & 7.4 & $\mathbf{P}$ & 0.00 & & 0.00 \\
\hline 23 & Dicrotendipes spp. & DCC & 7.9 & CG & 0.00 & & 0.00 \\
\hline 24 & Goeldichironomus holoprasinus & DCC & 10 & CG & 30.00 & 3 & 1.17 \\
\hline 25 & Microtendipes rydalensis & DCC & 6.2 & CG & 0.00 & & 0.00 \\
\hline 28 & Pagastialla sp. & DCC & 2.6 & CG & 0.00 & & 0.00 \\
\hline 27 & Parachironomus spp & DCC & 9.2 & CG & 9.20 & 1 & 0.39 \\
\hline 28 & Paralauterborniella sp. & $\overline{D C C}$ & 4.8 & CG & 0.00 & & 0.00 \\
\hline 29 & Phaenopsectra flavipes & DCC & 8.5 & $\overline{C G}$ & 0.00 & & 0.00 \\
\hline 30 & Polypedilum fallax & DCC & 6.7 & $\mathrm{SH}$ & 0.00 & & 0.00 \\
\hline 31 & Polypedilum spp. & DCC & 6.9 & CG & 289.80 & 42 & 16.34 \\
\hline 32 & Stenochironomus sp. & DCC & 6.4 & $\mathrm{SH}$ & 0.00 & & 0.00 \\
\hline 33 & Tribelos jucundum & DCG & 6.6 & CG & 0.00 & & 0.00 \\
\hline 34 & Xestochironomus sp. & DCC & 6.4 & $\mathrm{SH}$ & 0.00 & & 0.00 \\
\hline 35 & Zavrelliella spp. & DCC & & CG & & & 0.00 \\
\hline 38 & Antocha spp. & Do & 4.6 & CG & 0.00 & & 0.00 \\
\hline 37 & Ceratopogonidae & DO & 6.5 & $\mathbf{P}$ & 0.00 & & 0.00 \\
\hline 38 & Helius spp. & DO & & CG & & & 0.00 \\
\hline 39 & Hemerodromia spp. & DO & 8.1 & CG & 0.00 & & 0.00 \\
\hline 40 & Hexatoma spp. & DO & 4.7 & $P$ & 0.00 & & 0.00 \\
\hline 41 & Limonia spp. & DO & 10 & SH & 0.00 & & 0.00 \\
\hline 42 & Simulium spp. - & DO & 4.4 & $\mathrm{CF}$ & 4.40 & 1 & 0.39 \\
\hline 43 & Tipula spp. & DO & 7.7 & SH & 0.00 & & 0.00 \\
\hline 44 & Corynoneura spp. & DOR & 6.2 & CG & 0.00 & & 0.00 \\
\hline 45 & Cricotopus/Ortho spp. & DOR & 8.8 & $\overline{C G}$ & 0.00 & & 0.00 \\
\hline 46 & Parametriocnemus sp. & DOR & 3.7 & CG & 0.00 & & 0.00 \\
\hline 47 & Rheocricotopus spp. & DOR & 7.3 & CG & 0.00 & & 0.00 \\
\hline 48 & Thienemanniella spp. & DOR & 6 & CG & 0.00 & & 0.00 \\
\hline 49 & Xylopus par & DOR & 6.6 & SH & 0.00 & & 0.00 \\
\hline 50 & Ablabesmyia spp. & DTA & 6.4 & $P$ & 89.60 & 14 & 5.46 \\
\hline 51 & Apsectrotanypus johnsoni & DTA & 0 & $P$ & 0.00 & & 0.00 \\
\hline 52 & Clinotanypus pinguis & DTA & 9.1 & P & 0.00 & & 0.00 \\
\hline 53 & Conchapelopia spp. & DTA & 8.7 & TP & 113.10 & 13 & 5.06 \\
\hline 54 & Labrundinia spp. & DTA & 6 & $\sqrt[P]{P}$ & 0.00 & & 0.00 \\
\hline 55 & Nilotanypus spp. & DTA & 4 & 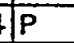 & 0.00 & & 0.00 \\
\hline 56 & Pentaneura inconspicua & DTA & 4.6 & $\mid P$ & 0.00 & & 0.00 \\
\hline 57 & Procladius spp. & DTA & 9.3 & $3 \mid \mathbf{P}$ & 0.00 & & 0.00 \\
\hline 58 & Rheotanytarsus spp. & DTY & 6.4 & CF & 19.20 & 3 & 1.17 \\
\hline
\end{tabular}




\begin{tabular}{|c|c|c|c|c|c|c|c|}
\hline 59 & Stempellinelle spp. & DTY & 5.3 & CG & 0.00 & & 0.00 \\
\hline 60 & Tanytarsus spp. & DTY & 6.7 & CG & 0.00 & & 0.00 \\
\hline 61 & Acentrella ample & EP & 3.6 & CG & 0.00 & & 0.00 \\
\hline 62 & Acerpenna pygmaeus & EP & 3.7 & CG & 0.00 & & 0.00 \\
\hline 63 & Acerpenna spp. & EP & 3.7 & CG & 0.00 & & 0.00 \\
\hline 64 & Baotis spp. & EP & 5.4 & CG & 0.00 & & 0.00 \\
\hline 65 & Caenis spp. & EP & 7.6 & CG & 0.00 & & 0.00 \\
\hline 68 & Callibsetis spp. & EP & 9.3 & CG & 0.00 & & 0.00 \\
\hline 67 & Eurylophelle spp. & EP & 3 & CG & 0.00 & & 0.00 \\
\hline 68 & Hexagenia spp. & EP & 4.7 & CG & 0.00 & & 0.00 \\
\hline 69 & Isonychia spp. & EP & 3.8 & $\overline{C F}$ & 0.00 & & 0.00 \\
\hline 70 & Neoephemera youngi & EP & 2.1 & CG & 0.00 & & 0.00 \\
\hline 71 & Paraleptophlebia spp. & EP & 1.2 & CG & 0.00 & & 0.00 \\
\hline 72 & Siphlonurus sp. & EP & 2.6 & CG & 0.00 & & 0.00 \\
\hline 73 & Stenonema spp. & EP & 3.4 & sc & 40.80 & 12 & 4.67 \\
\hline 74 & Tricorythodes spp. & EP & 5.4 & CG & 0.00 & & 0.00 \\
\hline 75 & Bolostoma sp. & HT & 9.8 & $P$ & 0.00 & & 0.00 \\
\hline 76 & Hesperocorixe sp. & HT & 9 & $\mathrm{H}$ & 0.00 & & 0.00 \\
\hline 77 & Pyralidae & LEP & 5 & $H$ & 0.00 & & 0.00 \\
\hline 78 & Corbicula sp. & MB & 6.3 & $\mathrm{CF}$ & 564.40 & 88 & 34.24 \\
\hline 79 & Eliptio spp. & $\mathrm{MB}$ & $\overline{3.4}$ & $\mathrm{CF}$ & 0.00 & & 0.00 \\
\hline 80 & Sphaerium spp. & MB & 7.7 & $\overline{C F}$ & 38.50 & $\overline{5}$ & 1.96 \\
\hline 81 & Nigronia serticornis & ME & 5.5 & $\bar{P}$ & 0.00 & & 0.00 \\
\hline 82 & Sialis spp. & ME & 7.7 & $\mathbf{P}$ & 0.00 & & 0.00 \\
\hline 83 & Campeloma sp. & MG & 6.7 & sc & 0.00 & & 0.00 \\
\hline 84 & Ferrissia sp. & MG & 6.9 & sc & 0.00 & & 0.00 \\
\hline 85 & Hydrobiidea & MG & & $\mathrm{sc}$ & & & 0.00 \\
\hline 88 & Physolla spp. & MG & 9.1 & sc & 45.50 & 5 & 1.96 \\
\hline 87 & Planorbidae & MG & 6.5 & sc & 0.00 & & 0.00 \\
\hline 88 & Nomertea & NA & & $P$ & & 13 & 5.06 \\
\hline 89 & Argia spp. & OD & 8.7 & P & 52.20 & 6 & 2.33 \\
\hline 90 & Boyeria vinosa & $O D$ & 6.3 & $P$ & 12.60 & 2 & 0.78 \\
\hline 91 & Calopteryx spp. & OD & 8.3 & P & 0.00 & & 0.00 \\
\hline 92 & Enallagma spp. & OD & $=9$ & $\mathrm{P}$ & 36.00 & 4 & 1.56 \\
\hline 93 & Gomphus spp. & $\overline{O D}$ & 6.2 & $P$ & 6.20 & 1 & 0.39 \\
\hline 94 & Macromie spp. & $\overline{O D}$ & 6.7 & P & 6.70 & 1 & 0.39 \\
\hline 95 & Neurocordulia spp. & $\overline{O D}$ & 5.8 & $\bar{P}$ & 0.00 & & 0.00 \\
\hline 98 & Pachydiplax longipennis & $O D$ & 9.6 & $P$ & 0.00 & & 0.00 \\
\hline 97 & Progomphus spp. & $\overline{O D}$ & 8.7 & P & 0.00 & & 0.00 \\
\hline 98 & Acroneuria spp. & $\mathrm{PL}$ & 1.4 & $P$ & 0.00 & & 0.00 \\
\hline 99 & Allocapnia spp. & PL & 2.8 & $\mathrm{SH}$ & 0.00 & & 0.00 \\
\hline 100 & Leuctra spjp. & $P L$ & 0.7 & SH & 0.00 & & 0.00 \\
\hline 101 & Perlinella spp. & PL & 0 & $P$ & 0.00 & & 0.00 \\
\hline 102 & Anisocentropus pyraloides & TR & 0.8 & $\widehat{\mathrm{SH}}$ & 0.00 & & 0.00 \\
\hline 103 & Brachycentrus numerosus & TR & 1.8 & $\mathrm{CF}$ & 0.00 & & 0.00 \\
\hline 104 & Cheumatopsyche spp. & $T R$ & 6.6 & $\mathrm{CF}$ & 6.60 & 1 & 0.39 \\
\hline 105 & Chimarre spp. & TR & 2.8 & $\mathrm{CF}$ & 0.00 & & 0.00 \\
\hline 106 & Hydropsyche spp. & TR & 4 & $\mathrm{CF}$ & 0.00 & & 0.00 \\
\hline 107 & Hydroptila spp. & TR & 6.2 & $\mathrm{H}$ & 0.00 & & 0.00 \\
\hline 108 & Lepidostoma spp. & TR & 1 & $\mathrm{SH}$ & 0.00 & & 0.00 \\
\hline 109 & Nectopsyche exquisita & $T R$ & 4.1 & $\mathrm{SH}$ & 0.00 & & 0.00 \\
\hline 110 & Oecetis spp. & TR & 5.7 & $P$ & 0.00 & & 0.00 \\
\hline 111 & Oxyethira spp. & TR & 6.2 & $\mathrm{H}$ & 0.00 & & 0.00 \\
\hline 112 & Phylocentropus spp. & $T R$ & 5.6 & $\mathrm{CF}$ & 0.00 & & 0.00 \\
\hline 113 & Polycentropus spp. & TR & 3.5 & $\overline{C F}$ & 0.00 & & 0.00 \\
\hline 114 & Pycnopsyche spp. & TR & 2.3 & $\mathrm{SH}$ & 0.00 & & 0.00 \\
\hline 115 & Triaenodes tardus & $T R$ & 4.7 & $\mathrm{SH}$ & 0.00 & & 0.00 \\
\hline 116 & \begin{tabular}{|l|l|} 
Turbellaria \\
\end{tabular} & TU & 7.5 & P & 90.00 & 12 & 4.67 \\
\hline
\end{tabular}


Station 10. Lower Three Runs Creek at: Road B. RBP III. 20 September 1994

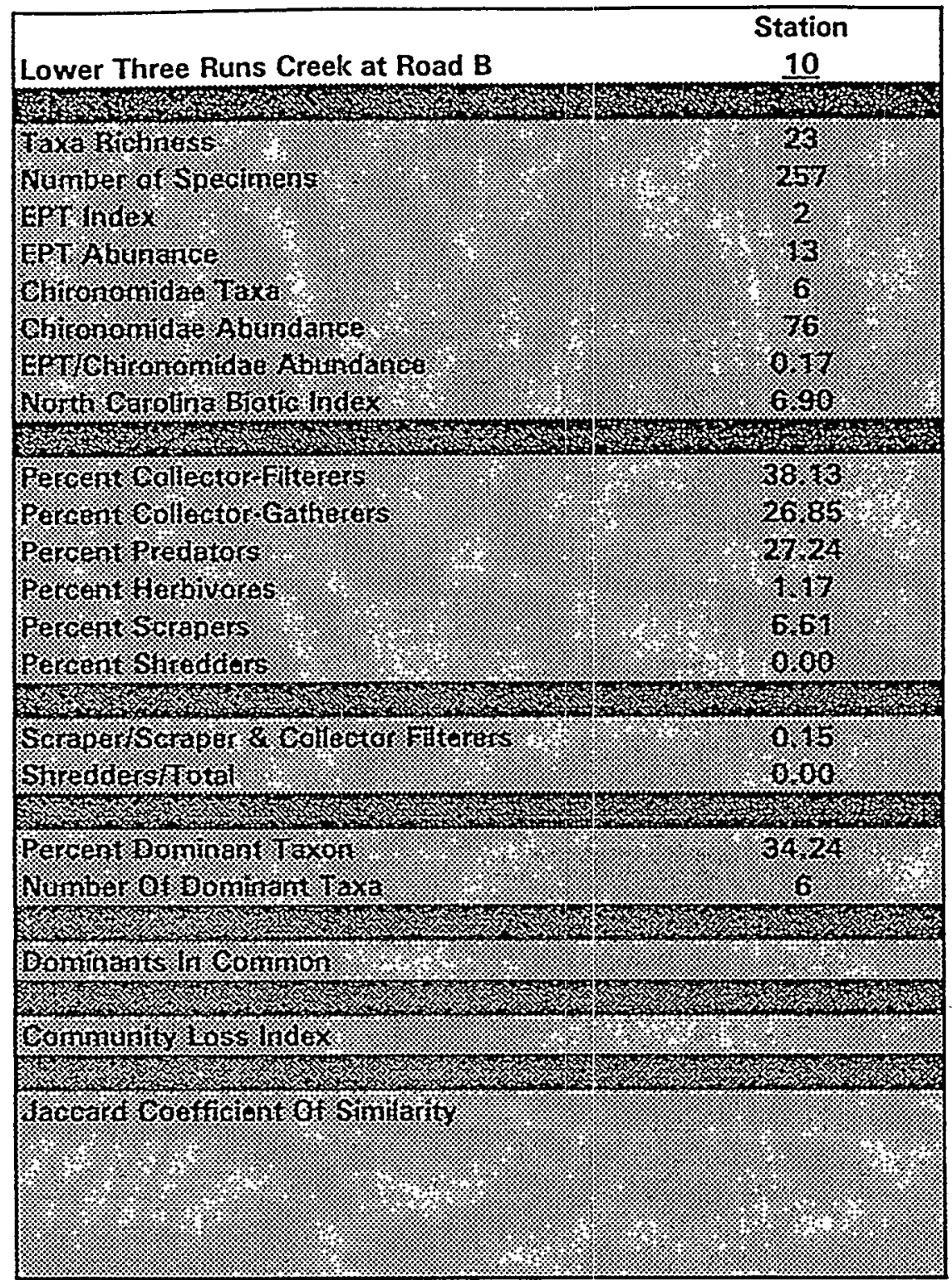


Station 10. Lower Three Runs Creek at Road B. RBP III. 20 September 1994

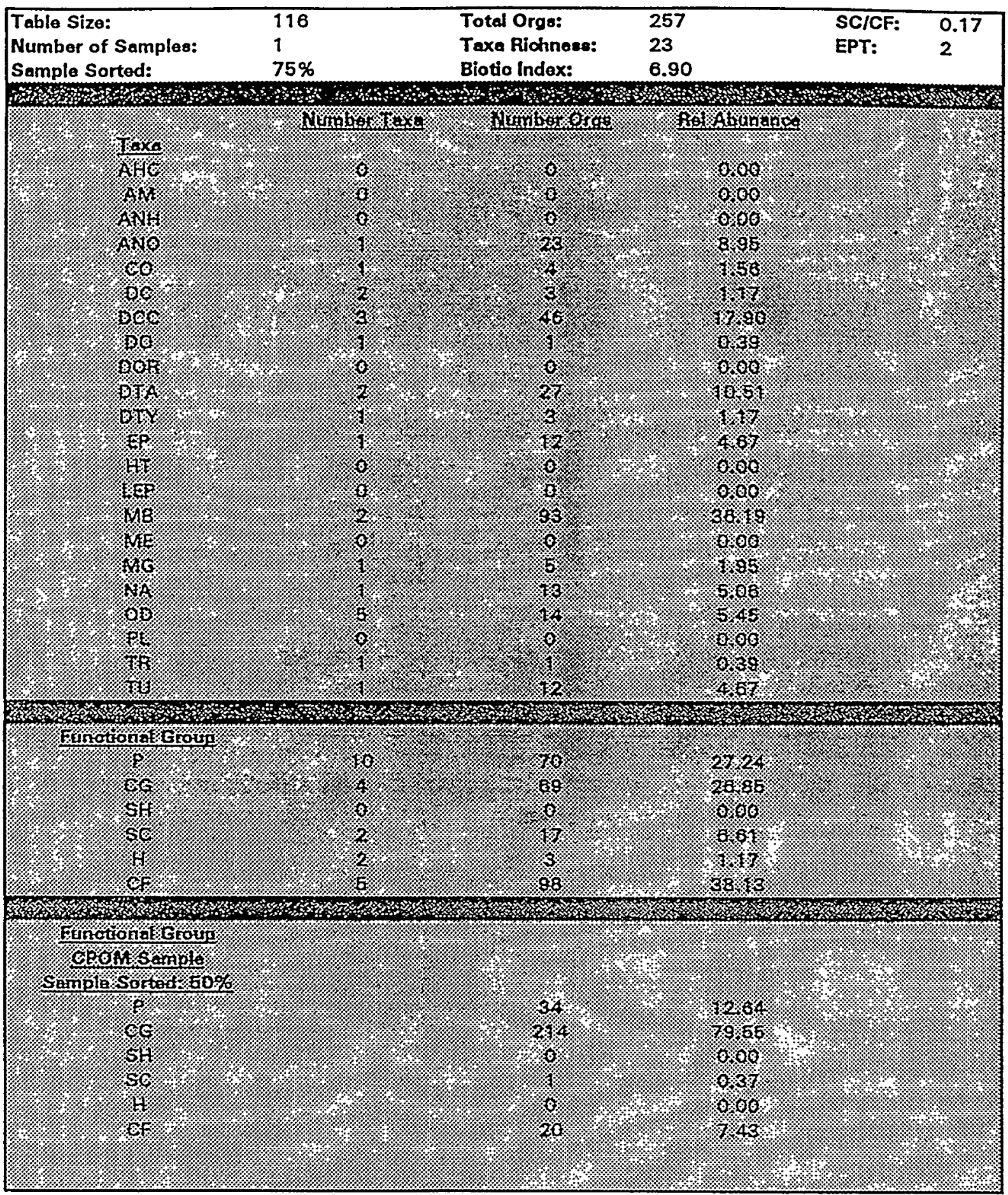




\section{Station 10. Lower Three Runs Creek at Road B. RBP III. 20 September 1994}

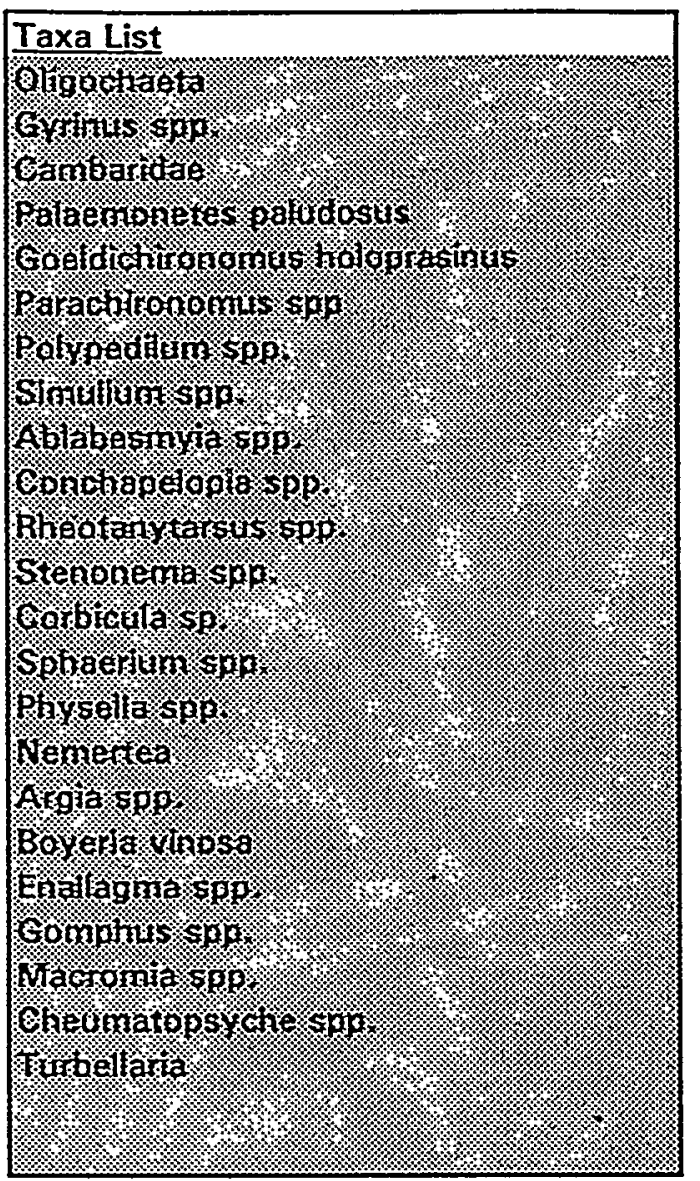


Station 10. Lower Three Runs Creek at Road B. RBP III. 20 September 1994

\begin{tabular}{|l|r|r|}
\hline Taxon & A & Rel Abd \\
\hline Corbicula sp. & 88 & 34.24 \\
\hline Polypedilum spp. & 42 & 16.34 \\
\hline Oligochaeta & 23 & 8.95 \\
\hline Ablabesmyia spp. & 14 & 5.45 \\
\hline Conchapelopia spp. & 13 & 5.06 \\
\hline Nemertea & 13 & 5.06 \\
\hline
\end{tabular}

$\approx$ 
Station 11. Pen Branch at Road B. RBP III. 21 September 1994

\begin{tabular}{|c|c|c|c|c|c|c|c|}
\hline 59 |s & Stempellinella spp. & DTYY & 6.3 & & 0.00 & & 0.00 \\
\hline 607 & Tanytarsus spp. & IDTY & 6.7 & CG & 80.40 & 12 & 5.08 \\
\hline 61 & Acentrella ampla & EP & 3.6 & CG & 0.00 & & 0.00 \\
\hline 62 & Acerpenna pygmaeus & EP & 3.7 & CF & 0.00 & & 0.00 \\
\hline \begin{tabular}{l|l}
63 & 1 \\
\end{tabular} & Acerpenna spp. & EP & 3.7 & CG & 0.00 & & 0.00 \\
\hline $64 / E$ & Baetis spp. & $E P$ & 6.4 & $\mathbf{C G}$ & 59.40 & 11 & 4.66 \\
\hline 65 & Caenis spp. & EP & 7.6 & CG & 0.00 & & 0.00 \\
\hline 68 & Callibaetis spp. & EP & 9.3 & $\mathbf{C G}$ & 0.00 & & 0.00 \\
\hline 67 & Eurylophelle spp. & EP & 3 & $\mathbf{C G}$ & 0.00 & & 0.00 \\
\hline 68 & Hexagenia spp. & EP & 4.7 & CG & 0.00 & & 0.00 \\
\hline \begin{tabular}{l|l}
69 & 1 \\
\end{tabular} & Isonychia spp. & EP & 3.8 & $\overline{C F}$ & 0.00 & & 0.00 \\
\hline 701 & Neoephemera youngi & EP & 2.1 & $\mathbf{C G}$ & 29.40 & 14 & 5.93 \\
\hline 71 & Paraleptophlebia spp. & EP & 1.2 & CG & 0.00 & & 0.00 \\
\hline 72 & Siphlonurus sp. & EP & 2.6 & $\mathbf{C G}$ & 0.00 & & 0.00 \\
\hline 73 & Stenonema spp. & EP & 3.4 & SC & 0.00 & & 0.00 \\
\hline 74 & Tricorythodes spp. & EP & 5.4 & $\overline{C G}$ & 162.00 & 30 & 12.71 \\
\hline 75 & Belostoma sp. & HT & 9.8 & $\bar{P}$ & 0.00 & & 0.00 \\
\hline 76 & Hesperocorixa sp. & $\mathrm{HT}$ & 9 & $\bar{H}$ & 0.00 & & 0.00 \\
\hline 77 & Pyralidao & LLEP & 5 & $\mathrm{H}$ & 0.00 & & 0.00 \\
\hline 78 & Corbicula sp. & $M B$ & 6.3 & CF & 6.30 & 1 & 0.42 \\
\hline 79 & Eliptio spp. & MB & 3.4 & $\mathrm{CF}$ & 0.00 & & 0.00 \\
\hline 80 & Spheerium spp. & MB & 7.7 & CF & 215.60 & 28 & 11.86 \\
\hline 81 & Nigronia serricornis & ME & 5.5 & $\mathrm{P}$ & 0.00 & & 0.00 \\
\hline 82 & $\begin{array}{l}\text { Sialis spp. } \\
\end{array}$ & ME & 7.7 & $\mathbf{P}$ & 0.00 & & 0.00 \\
\hline 83 & Campeloma sp. & MG & 6.7 & SC & 0.00 & & 0.00 \\
\hline 84 & Ferrissia sp. & MG & 6.9 & SC & 27.60 & 4 & 1.69 \\
\hline 85 & Hydrobiidae & $M G$ & & SC & & & 0.00 \\
\hline 86 & Physella spp. & MG & 9.1 & SC & 0.00 & & 0.00 \\
\hline 87 & Planorbidae & MG & 6.5 & SC & 0.00 & & 0.00 \\
\hline 88 & Nemertea & NA & & $\mathbf{P}$ & & 4 & 1.69 \\
\hline 89 & Argia spp. & OD & 8.7 & $\mathbf{P}$ & 69.60 & $\overline{8}$ & 3.39 \\
\hline 90 & Boyeria vinosa & TOD & 6.3 & $\mathbf{P}$ & 6.30 & 1 & 0.42 \\
\hline 91 & Calopteryx spp. & OD & 8.3 & $P$ & 66.40 & 8 & 3.39 \\
\hline 92 & Enallagma spp. & OQ & 9 & $\bar{P}$ & 9.00 & 1 & 0.42 \\
\hline 93 & Gomphus spp. & 100 & 6.2 & $P$ & 37.20 & 6 & 2.64 \\
\hline 94 & Macromia spp. & OD & 6.7 & $\bar{P}$ & 6.70 & 1 & 0.42 \\
\hline 95 & Neurocordulia spp. & OD & 5.8 & $\mathbf{P}$ & 0.00 & & 0.00 \\
\hline 96 & Pachydiplax longipennis & $O D$ & 9.6 & $P$ & 0.00 & & 0.00 \\
\hline 97 & Progomphus spp. & $\overline{O D}$ & 8.7 & $P$ & 8.70 & 1 & 0.42 \\
\hline 98 & Acroneuria spp. & PL & 1.4 & $P$ & 0.00 & & 0.00 \\
\hline 99 & Allocapnia spp. & PL & 2.8 & $\mathrm{SH}$ & 0.00 & & 0.00 \\
\hline 100 & Leuctra spp. & PL & 0.7 & $\mathrm{SH}$ & 0.00 & & 0.00 \\
\hline 101 & Perlinella spp. & FE & 0 & $\mathrm{P}$ & 0.00 & & 0.00 \\
\hline 102 & Anisocentropus pyraloides & TR & 0.8 & $\mathrm{SH}$ & 0.00 & & 0.00 \\
\hline 103 & Brachycentrus numerosus & TR & 1.8 & CF & 0.00 & & 0.00 \\
\hline 104 & Cheumatopsyche spp. & TR & 6.6 & CF & 0.00 & & 0.00 \\
\hline 105 & Chimarre spp. & $T R$ & 2.8 & CF & 0.00 & & 0.00 \\
\hline 106 & Hydropsyche spp. & $T R$ & 4 & $\mathrm{CF}$ & 0.00 & & 0.00 \\
\hline 107 & Hydroptila spp. & $T R$ & 6.2 & $\mathrm{H}$ & 0.00 & & 0.00 \\
\hline 108 & Lepidostoma spp. & TR & 1 & $\mathrm{SH}$ & 0.00 & & 0.00 \\
\hline 109 & Nectopsyche exquisita & TR & 4.1 & $\mathrm{SH}$ & 0.00 & & 0.00 \\
\hline 110 & Oecetis spp. & TR & 5.7 & $P$ & 0.00 & & 0.00 \\
\hline 111 & Oxyethira spp. & TR & 6.2 & $\mathrm{H}$ & 0.00 & & 0.00 \\
\hline 112 & Phylocentropus spp. & TR & 5.6 & CF & 5.60 & 1 & 0.42 \\
\hline 113 & Polycentropus spp. & TR & 3.5 & CF & 0.00 & & 0.00 \\
\hline 114 & Pycnopsyche spp. & $T R$ & 2.3 & $\mathrm{SH}$ & 0.00 & & 0.00 \\
\hline 115 & Triaenodes tardus & $T R$ & 4.7 & $\mathrm{SH}$ & 28.20 & $\overline{6}$ & 2.54 \\
\hline 116 & Turbellaria & Tu & 7.5 & $\mathrm{P}$ & 0.00 & & 0.00 \\
\hline
\end{tabular}




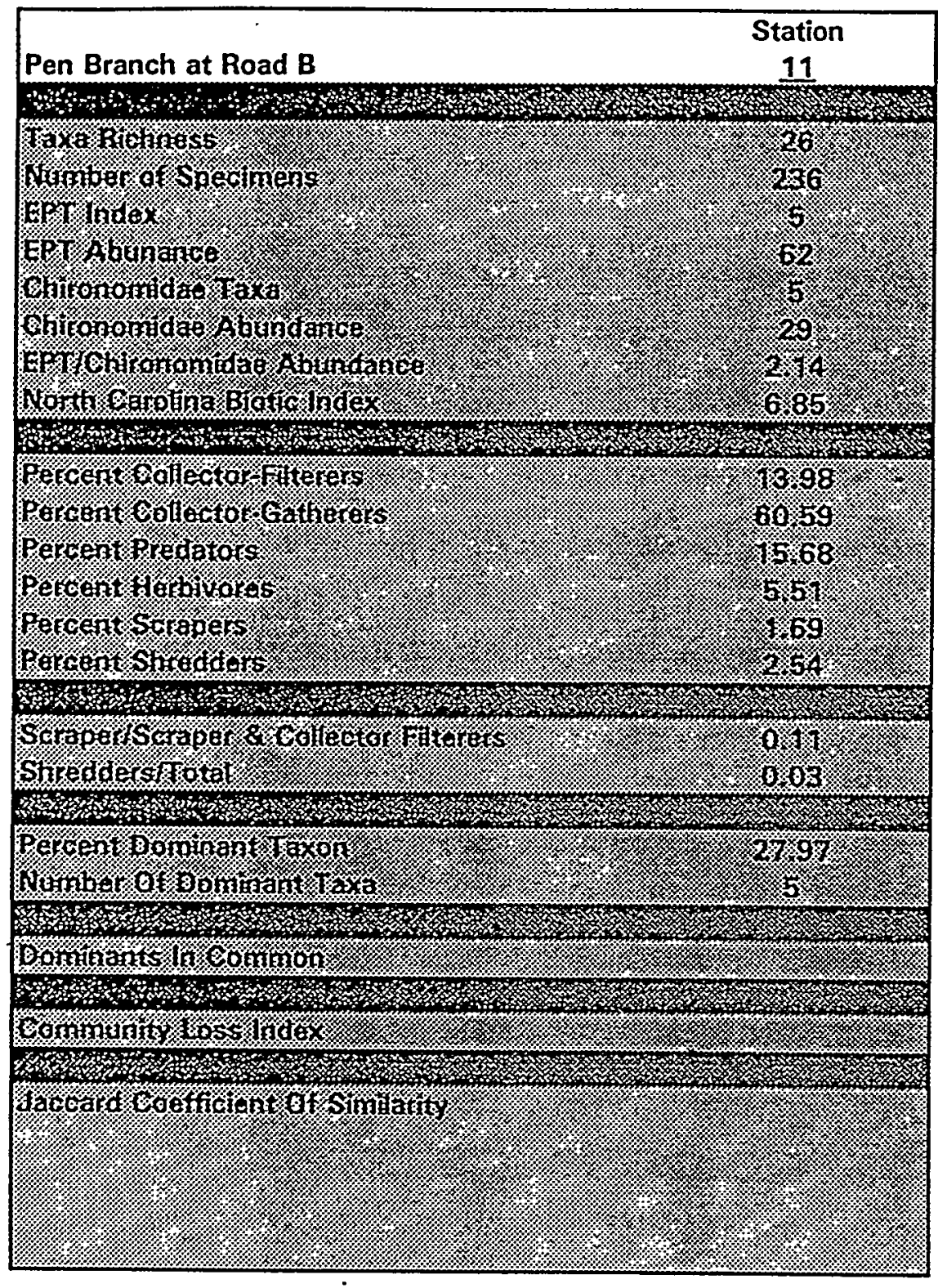


Station 11. Pen Branch at Road B. RBP III. 21 September 1994

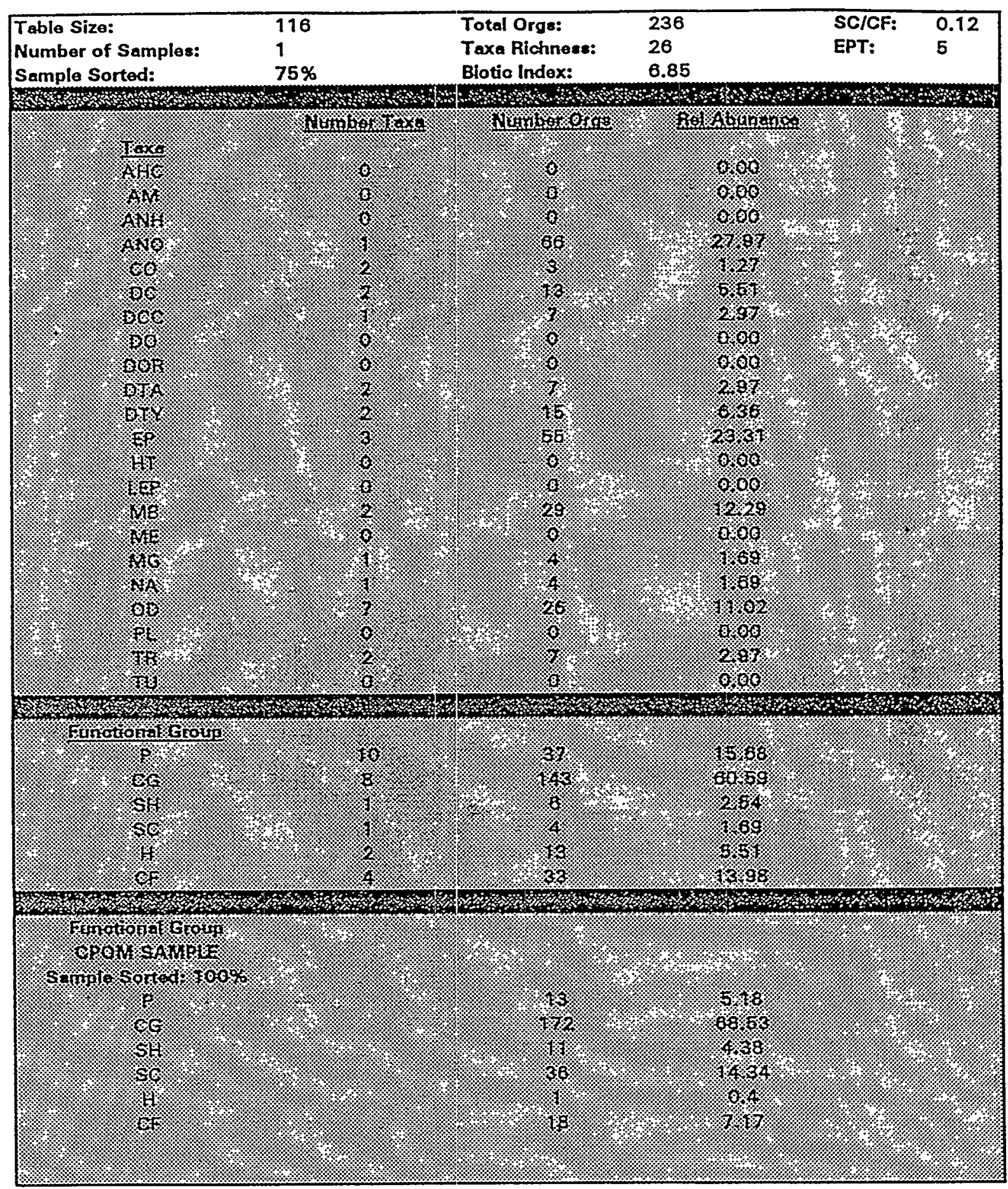




\section{Taxa List}

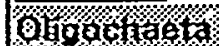

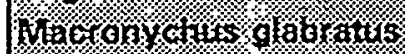

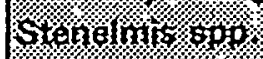

canivanotion

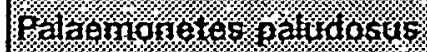

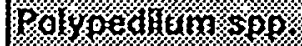

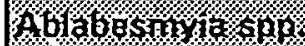

Oonciapeippi 2 soo

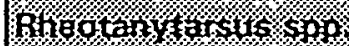

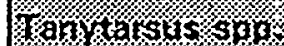

Bastis 500 .

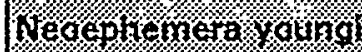

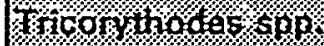

Cotbict.1. 1 11:

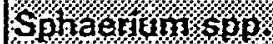

Fen1.5.510.81.

Hennotied

21.010 o 50 .0.

Boo,etian.inos:

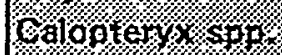

Enatitagno: spow.

Gantonos stop

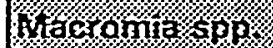

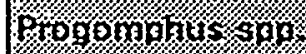

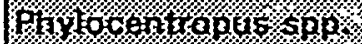

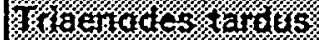

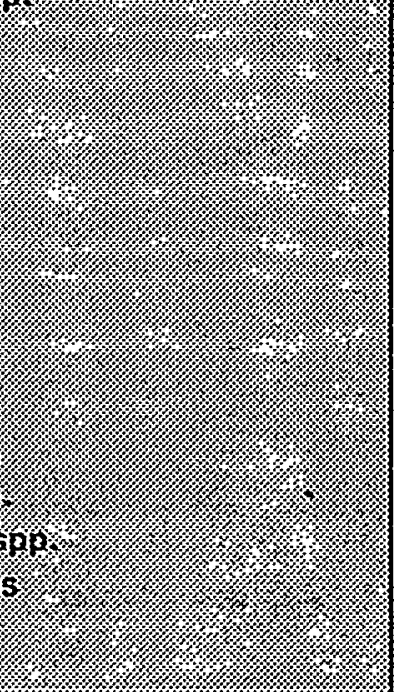


Station 11. Pen Branch at Road B. RBP III. 21 September 1994

\begin{tabular}{|l|r|r|}
\hline Taxon & B & Rel Abd \\
\hline Oligochaeta & 66 & 27.97 \\
\hline Tricorythodes spp. & 30 & 12.7 .1 \\
\hline Sphaerium spp. & 28 & 11.86 \\
\hline Neoephemera youngi & 14 & 5.93 \\
\hline Tanytarsus spp. & 12 & 5.08 \\
\hline
\end{tabular}




\begin{tabular}{|c|c|c|c|c|c|c|c|}
\hline Seq & Taxon & TAXC & NCBI & FG & For B & A & Rel Abd \\
\hline 1 & Hydracarina & $\mathrm{AHC}$ & 5.7 & $P$ & 0.00 & & 0.00 \\
\hline 2 & Amphipoda & AM & 8 & $\mathbf{C G}$ & 88.00 & 11 & 6.82 \\
\hline 3 & Hirudinea & ANH & $\cdot$ & $P$ & & & 0.00 \\
\hline 4 & Oligochaeta & ANO & 8.2 & $\mathbf{C G}$ & 114.80 & 14 & 7.41 \\
\hline $\mathbf{5}$ & Anchytarsus bicolor & $\mathrm{CO}$ & 3.8 & $\mathrm{SH}$ & 0.00 & & 0.00 \\
\hline 6 & Ancyronyx variegatus & $\mathrm{CO}$ & 6.9 & CG & 0.00 & & 0.00 \\
\hline 7 & Dineutus spp. & $\mathrm{CO}$ & 5.5 & $\mathbf{P}$ & 0.00 & & 0.00 \\
\hline 8 & Dubiraphia bivittata & $\mathrm{CO}$ & 6.4 & CG & 0.00 & & 0.00 \\
\hline 9 & Dubiraphia spp. & $\mathrm{CO}$ & 6.4 & CG & 0.00 & & 0.00 \\
\hline 10 & Gyrinus spp. & $\mathrm{CO}$ & 6.3 & $P$ & 0.00 & & 0.00 \\
\hline 11 & Heliplus sp. & $\mathrm{CO}$ & 8.6 & CG & 0.00 & & 0.00 \\
\hline 12 & Helichus fastigatus & $\mathrm{CO}$ & 5.4 & SC & 0.00 & & 0.00 \\
\hline 13 & Hydroporus spp. & $\mathrm{CO}$ & 8.9 & $P$ & 0.00 & & 0.00 \\
\hline 14 & Macronychus glabratus & $\mathrm{CO}$ & 4.7 & $\overline{C G}$ & 0.00 & & 0.00 \\
\hline 15 & Peltodytes spp. & $\mathrm{CO}$ & 8.5 & $\mathrm{H}$ & 0.00 & & 0.00 \\
\hline 16 & Stenelmis humerose & $\mathrm{CO}$ & 5.4 & $\mathbf{C G}$ & 0.00 & & 0.00 \\
\hline 17 & Stenolmis spp. & $\mathrm{CO}$ & 5.4 & $\mathbf{C G}$ & 0.00 & & 0.00 \\
\hline 18 & Cambaridae & $D C$ & 8.8 & $\mathrm{H}$ & 8.80 & 1 & 0.53 \\
\hline 19 & Palaemonetes paludosus & $D C$ & 6.7 & $\mathrm{H}$ & 0.00 & & 0.00 \\
\hline 20 & Chironomus spp. & DCC & 9.8 & $\mathbf{C G}$ & 0.00 & & 0.00 \\
\hline 21 & Cladopeima sp. & DCC & 5 & CG & 0.00 & & 0.00 \\
\hline 22 & Cryptochironomus spp. & $D C C$ & 7.4 & $\mathbf{P}$ & 0.00 & & 0.00 \\
\hline 23 & Dicrotendipes spp. & $\mathrm{DCC}$ & 7.9 & CG & 0.00 & & 0.00 \\
\hline 24 & Gooldichironomus holoprasinus & DCC & 10 & CG & 0.00 & & 0.00 \\
\hline 25 & Microtendipes rydalensis & $D C C$ & 6.2 & $\overline{\mathbf{C G}}$ & 0.00 & & 0.00 \\
\hline 26 & Pagastiella sp. & DCC & 2.6 & CG & 0.00 & & 0.00 \\
\hline 27 & Parachironomus spp. & DCC & 9.2 & $\mathbf{C G}$ & 0.00 & & 0.00 \\
\hline 28 & Paralouterbornielle sp. & $\mathrm{DCC}$ & 4.8 & CG & 0.00 & & 0.00 \\
\hline 29 & Phaenopsectra flavipes & DCC & 8.5 & C.G & 0.00 & & 0.00 \\
\hline 30 & Polypedilum fallax & $\mathrm{DCC}$ & 6.7 & $\mathrm{SH}$ & 0.00 & & 0.00 \\
\hline 31 & Polypedilum spp. & DCC & 6.9 & CG & 65.20 & 8 & 4.23 \\
\hline 32 & Stenochironomus sp. & DCC & 6.4 & $\mathrm{SH}$ & 6.40 & 1 & 0.53 \\
\hline 33 & Tribelos jucundum & DCC & 6.6 & CG & 0.00 & & 0.00 \\
\hline 34 & Xestochironomus sp. & DCC & 6.4 & $\mathrm{SH}$ & 0.00 & & 0.00 \\
\hline 35 & Zavrelliella spp. & DCC & & CG & & & 0.00 \\
\hline 36 & Antocha spp. & DO & 4.6 & $\mathbf{C G}$ & 9.20 & 2 & 1.06 \\
\hline 37 & Ceratopogonidae & DO & 6.5 & $P$ & 0.00 & & 0.00 \\
\hline 38 & Helius spp. & DO & & CG & & & 0.00 \\
\hline 39 & Hemerodromia spp. & DO & 8.1 & $\mathbf{C G}$ & 0.00 & & 0.00 \\
\hline 40 & Hexatoma spp. & DO & 4.7 & $P$ & 0.00 & & 0.00 \\
\hline 41 & Limonia spp. & DO & 10 & $\mathrm{SH}$ & 0.00 & $\cdot$ & 0.00 \\
\hline 42 & Simulium spp. & DO & 4.4 & CF & 0.00 & & 0.00 \\
\hline 43 & Tipula spp. & DO & 7.7 & $\mathrm{SH}$ & 0.00 & & 0.00 \\
\hline 44 & Corynoneura spp. & DOR & 6.2 & $\overline{C G}$ & 0.00 & & 0.00 \\
\hline 45 & Cricotopus/Ortho spp. & DOR & 8.8 & CG & 0.00 & & 0.00 \\
\hline 46 & Parametriocnemus sp. & DOR & 3.7 & CG & 0.00 & & 0.00 \\
\hline 47 & Rheocricotopus spp. & DOR & 7.3 & CG & 0.00 & & 0.00 \\
\hline 48 & Thienemanniella spp. & DOR & 6 & CG & 0.00 & & 0.00 \\
\hline 49 & Xylopus par & DOR & 6.6 & $\mathrm{SH}$ & 0.00 & & 0.00 \\
\hline 50 & Ablabesmyia spp. & DTA & 6.4 & $\mathbf{P}$ & 6.40 & 1 & 0.53 \\
\hline 51 & Apsectrotanypus johnsoni & DTA & .0 & $\mathbf{P}$ & 0.00 & & 0.00 \\
\hline 52 & Clinotanypus pinguis & DTA & 9.1 & $P$ & 0.00 & & 0.00 \\
\hline 53 & Conchapelopia spp. & DTA & 8.7 & $P$ & 0.00 & & 0.00 \\
\hline 54 & Läbrundinia spp. & DTA & 6 & $\mathbf{P}$ & 0.00 & & 0.00 \\
\hline 55 & Nilotanypus spp. & DTA & 4 & $P$ & 4.00 & 1 & 0.53 \\
\hline 56 & Pentaneura inconspicua & DTA & 4.6 & $P$ & 13.80 & 3 & 1.59 \\
\hline 57 & Procladius spp. & DTA & 9.3 & $\mathbf{P}$ & 0.00 & & 0.00 \\
\hline 58 & Rheotanytarsus spp. & DTY & 6.4 & $\mathrm{CF}$ & 44.80 & 7 & 3.70 \\
\hline
\end{tabular}


Station 12. Indian Grave Branch at Road B. R8P III. -21 September 1994

\begin{tabular}{|c|c|c|c|c|c|c|c|}
\hline 59 & Stempellinella spp. & DTY & 5.3 & $\mathrm{CG}$ & 0.00 & & 0.00 \\
\hline 60 & Tanytarsus spp. & DTY & 6.7 & $C G$ & 26.80 & 4 & 2.12 \\
\hline 61 & Acentrella ampla & $E P$ & 3.6 & CG & 3.60 & 1 & 0.53 \\
\hline 62 & Acerpenna pygmaeus & EF' & -3.7 & $\mathrm{CG}$ & 0.00 & & 0.00 \\
\hline 63 & Acerpenna spp. & $\mathrm{EF}^{-}$ & 3.7 & $\mathrm{CG}$ & 0.00 & & 0.00 \\
\hline 64 & Baotis spp. & $E F$ & 5.4 & $\mathbf{C G}$ & 480.60 & 89 & 47.09 \\
\hline 65 & Coenis spp. & $E F$ & 7.6 & CG & 7.60 & 1 & 0.63 \\
\hline 66 & Collibaetis spp. & $E F$ & 8.3 & CG & 0.00 & & 0.00 \\
\hline 67) & Eurylophella spp. & EF' & 3 & CG & 0.00 & & 0.00 \\
\hline 68 & Hexagenia spp. & EP & 4.7 & CG & 0.00 & & 0.00 \\
\hline 69 & Isonychia spp. & $\mathrm{EP}$ & 3.8 & $\mathrm{CF}$ & 0.00 & & 0.00 \\
\hline 70 & Neoephemera youngi & $E F$ & 2.1 & CG & 0.00 & & 0.00 \\
\hline 71 & Paraleptophlebia spp. & $E^{P}$ & 1.2 & CG & 0.00 & & 0.00 \\
\hline 72 & Siphlonurus sp. & $E P$ & 2.6 & CG & 0.00 & & 0.00 \\
\hline 73 & Stenonema spp. & EP & 3.4 & $\mathrm{sc}$ & 0.00 & & 0.00 \\
\hline 74 & Tricorythodes spp. & EP & 5.4 & CG & 16.20 & 3 & 1.59 \\
\hline 75 & Bolostoma sp. & HT & 9.8 & $P$ & 9.80 & 1 & 0.53 \\
\hline 76 & Hesperocorixa sp. & HT & 9 & $H$ & 0.00 & & 0.00 \\
\hline 77 & Pyralidas & LE:P & 5 & $H$ & 5.00 & 1 & 0.53 \\
\hline 78 & Corbicula sp. & $M B$ & 6.3 & $\mathrm{CF}$ & 0.00 & & 0.00 \\
\hline 79 & Eliptio spp. & $M B$ & 3.4 & $\mathrm{CF}$ & 0.00 & & 0.00 \\
\hline 80 & Spheerium spp. & $\mathrm{MB}$ & 7.7 & $\mathrm{CF}$ & 0.00 & & 0.00 \\
\hline 81 & Nigronia serricornis & $M E$ & 5.5 & $\mathbf{P}$ & 0.00 & & 0.00 \\
\hline 82 & Sialis spp. & ME & 7.7 & $\mathrm{P}$ & 0.00 & & 0.00 \\
\hline 83 & Campeloma sp. & $\overline{M G}$ & 6.7 & $\mathrm{sc}$ & 0.00 & & 0.00 \\
\hline 84 & Ferrissia sp. & MG & 6.9 & Sc & 0.00 & & 0.00 \\
\hline 85 & Hydrobiidae & $\overline{M G}$ & & Sc & & 1 & 0.53 \\
\hline 88 & Physella spp. & MG & 9.1 & Sc & 0.00 & & 0.00 \\
\hline 87 & Planorbidae & MG & 6.5 & SC & 0.00 & & 0.00 \\
\hline 88 & Nemertea & NA & & $P$ & & 1 & 0.53 \\
\hline 89 & Argis spp. & OD & 8.7 & $\mathbf{P}$ & 147.90 & 17 & 8.99 \\
\hline 90 & Boyeria vinosa & OD & 6.3 & $P:$ & 6.30 & 1 & 0.63 \\
\hline 91 & Calopteryx spp. & OD & 8.3 & $P$ & 0.00 & & 0.00 \\
\hline 92 & Enallagma spp. & O० & 9 & $P$ & 36.00 & 4 & 2.12 \\
\hline 93 & Gomphus spp. & OD & 6.2 & $P$ & 0.00 & & 0.00 \\
\hline 94 & Macromia spp. & OD & 6.7 & $\mathbf{P}$ & 0.00 & & 0.00 \\
\hline 95 & Neurocordulia spp. & OOD & 5.8 & $P$ & 0.00 & & 0.00 \\
\hline 96 & Pachydiplax longipennis & 100 & 9.6 & $\bar{P}$ & 0.00 & & 0.00 \\
\hline 97 & Progomphus spp. & OD & 8.7 & $P$ & 0.00 & & 0.00 \\
\hline 98 & Acroneurie spp. & $P L$ & 1.4 & $P$ & 0.00 & & 0.00 \\
\hline 99 & Allocapnia spp. & PL & 2.8 & $\mathrm{SH}$ & 0.00 & & 0.00 \\
\hline 100 & Leuctre spp. & $P L$ & 0.7 & SH & 0.00 & $\dot{.}$ & 0.00 \\
\hline 101 & Perlinella spp. & $P L$ & 0 & $P$ & 0.00 & & 0.00 \\
\hline 102 & Anisocentropus pyraloides & TR & 0.8 & $\mathrm{SH}$ & $0: 00$ & & 0.00 \\
\hline 103 & Brachycentrus numerosus & TR & 1.8 & $\mathrm{CF}$ & 0.00 & & 0.00 \\
\hline 104 & Cheumatopsyche spp. & TR & 6.6 & $\mathrm{CF}$ & 0.00 & & 0.00 \\
\hline 105 & Chimarra spp. & TR & 2.8 & $\overline{C F}$ & 0.00 & & 0.00 \\
\hline 106 & Hydropsyche spp. & TR & 4 & CF & 0.00 & & 0.00 \\
\hline 107 & Hydroptila spp. & TR & 6.2 & $\mathrm{H}$ & 18.60 & 3 & 1.69 \\
\hline 108 & Lepidostoma spp. & TR & 1 & $\mathrm{SH}$ & 0.00 & & 0.00 \\
\hline 109 & Nectopsyche exquisita & TR & 4.1 & $\mathrm{SH}$ & 0.00 & & 0.00 \\
\hline 110 & Oecetis spp. & TR & 5.7 & $P$ & 0.00 & & 0.00 \\
\hline 111 & Oxyethira spp. & TR & 6.2 & H & 0.00 & & 0.00 \\
\hline 112 & Phylocentropus spp. & TR & 5.6 & CF & 0.00 & & 0.00 \\
\hline 113 & Polycentropus spp. & TR & 3.5 & $\mathrm{CF}$ & 3.50 & 1 & 0.53 \\
\hline 114 & Pycnopsyche spp. & TR & 2.3 & $\mathrm{SH}$ & 0.00 & $\therefore$ & 0.00 \\
\hline 115 & Triaenodes tardus & TR & 4.7 & $\mathrm{SH}$ & 4.70 & 1 & 0.63 \\
\hline 116 & Turbellaria & TU & 7.6 & $P$ & 82.50 & 11 & 5.82 \\
\hline
\end{tabular}




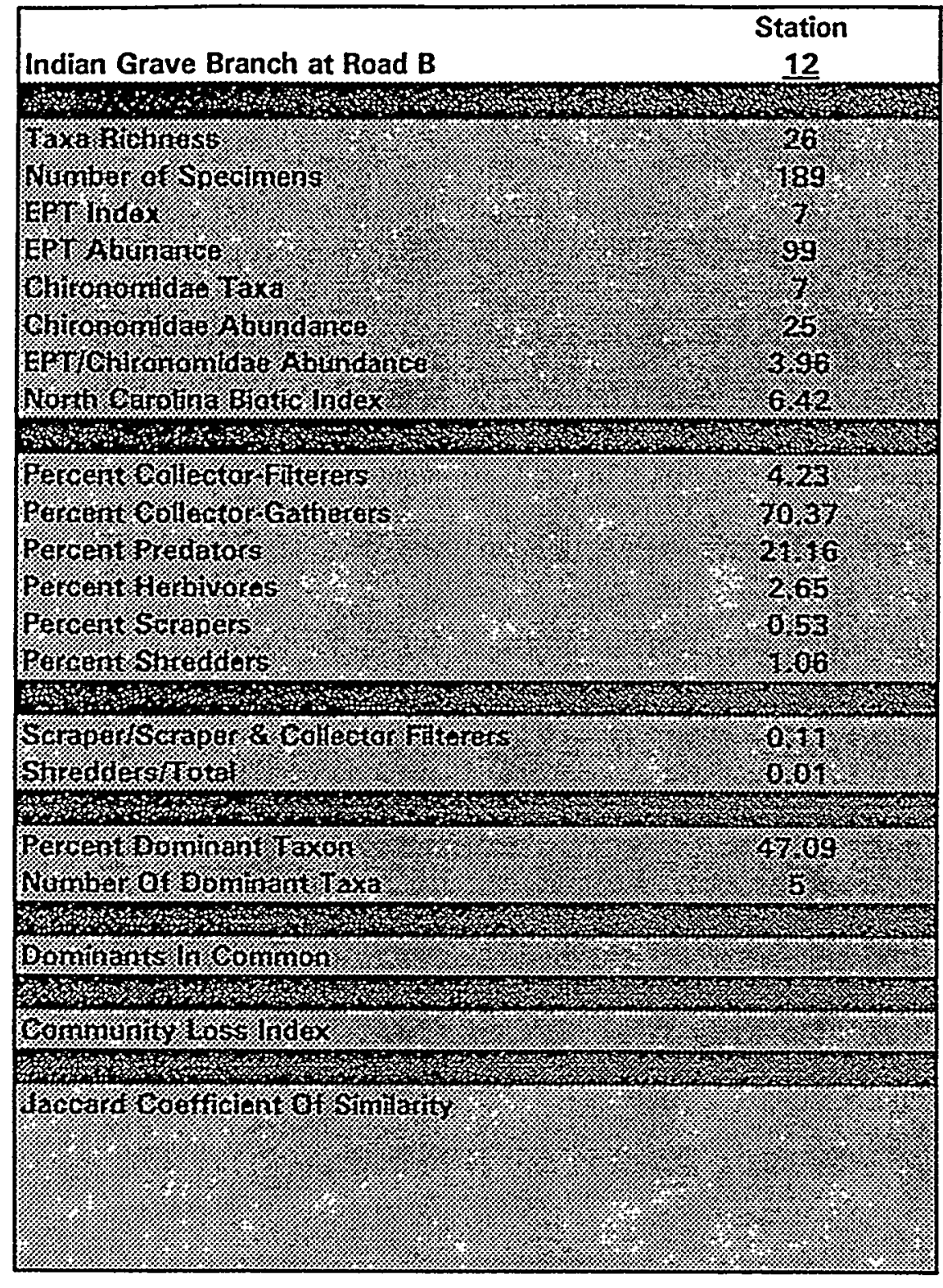


Station 12. Indian Grave Branch at Rosd B. R8P III. 21 September 1994

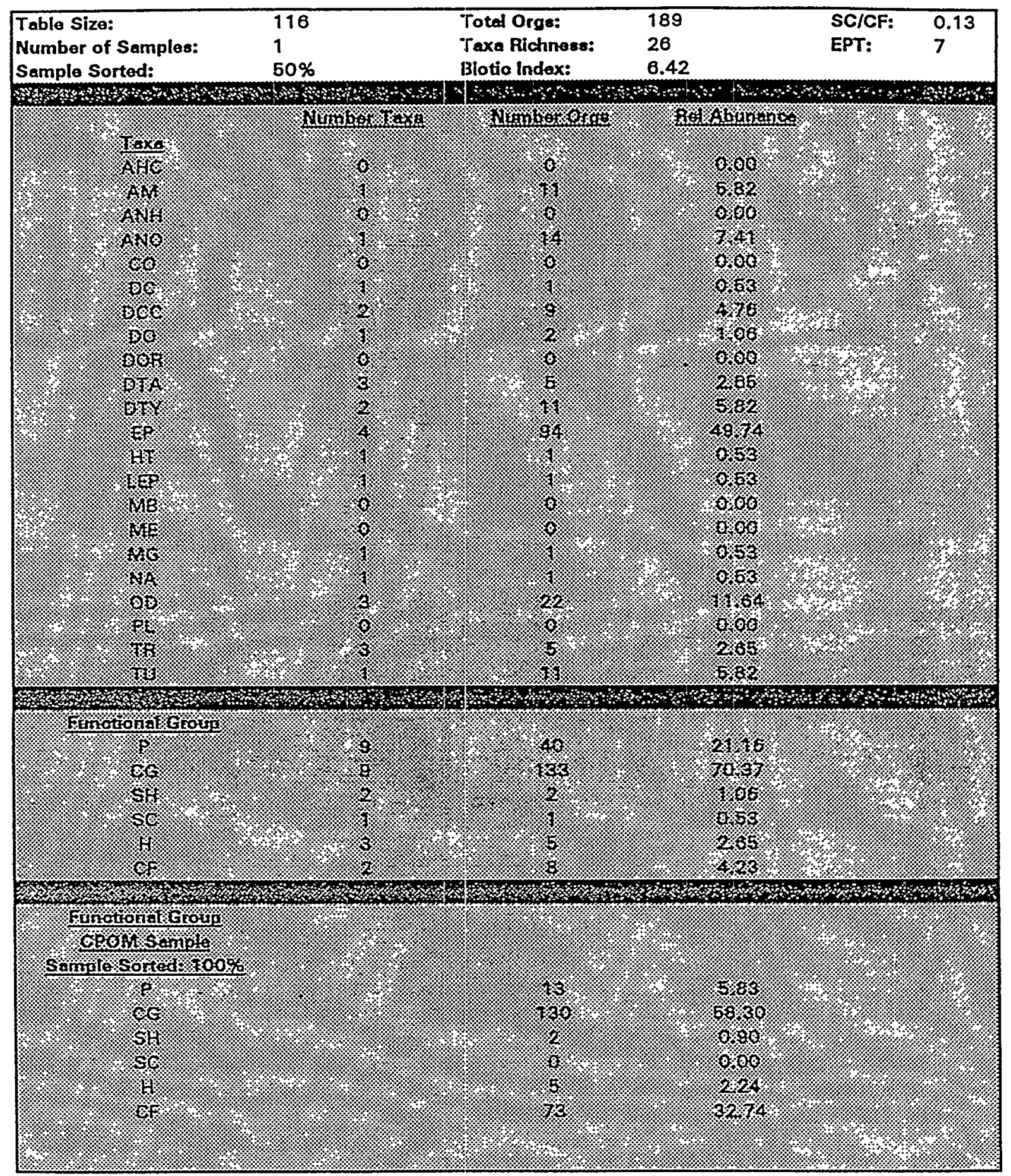


Station 12. Indian Grave Branch at Road B. RBP III. 21 September 1994

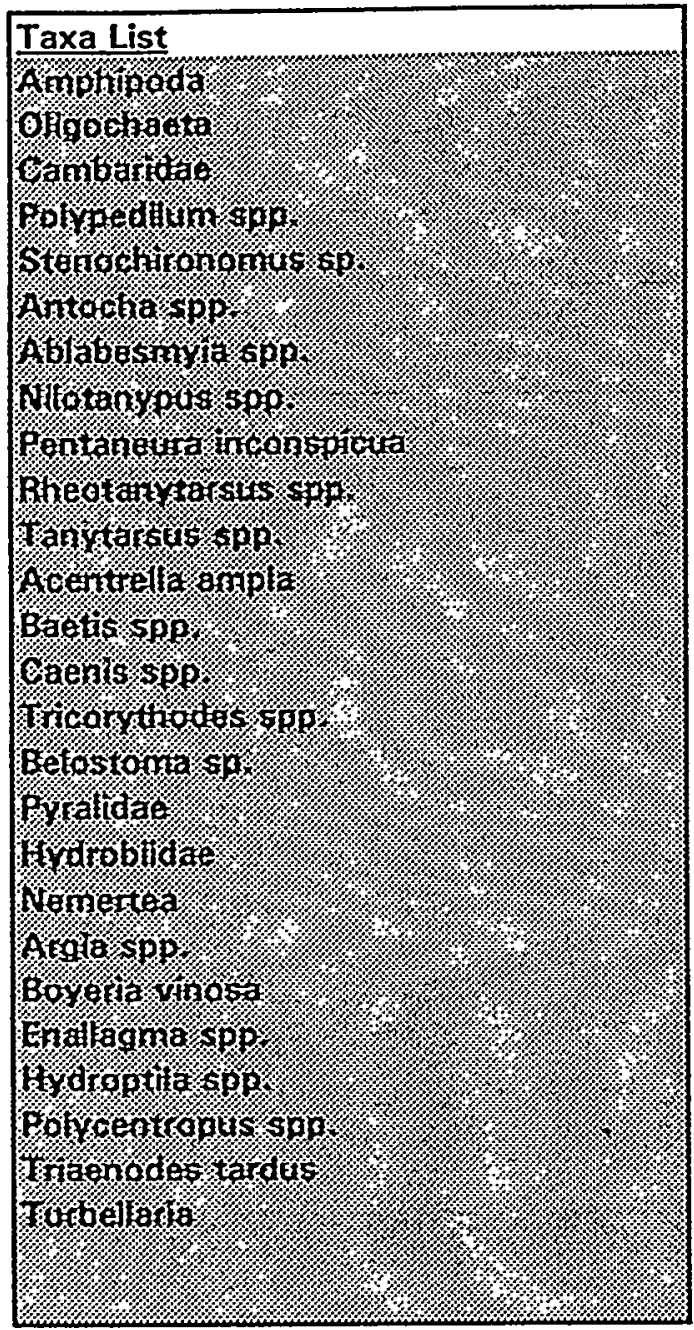

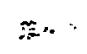


Station 12. Indian Grave Branch at Road B. RBP III. 21 September 1994

\begin{tabular}{|l|r|r|}
\hline Taxon & A & Rel Abd \\
\hline Baetis spp. & 89 & 47.09 \\
\hline Argia spp. & 17 & 8.99 \\
\hline Oligochaeta & 14 & 7.41 \\
\hline Amphipoda & 11 & 5.82 \\
\hline Turbellaria & 11 & 5.82 \\
\hline
\end{tabular}

F.. 


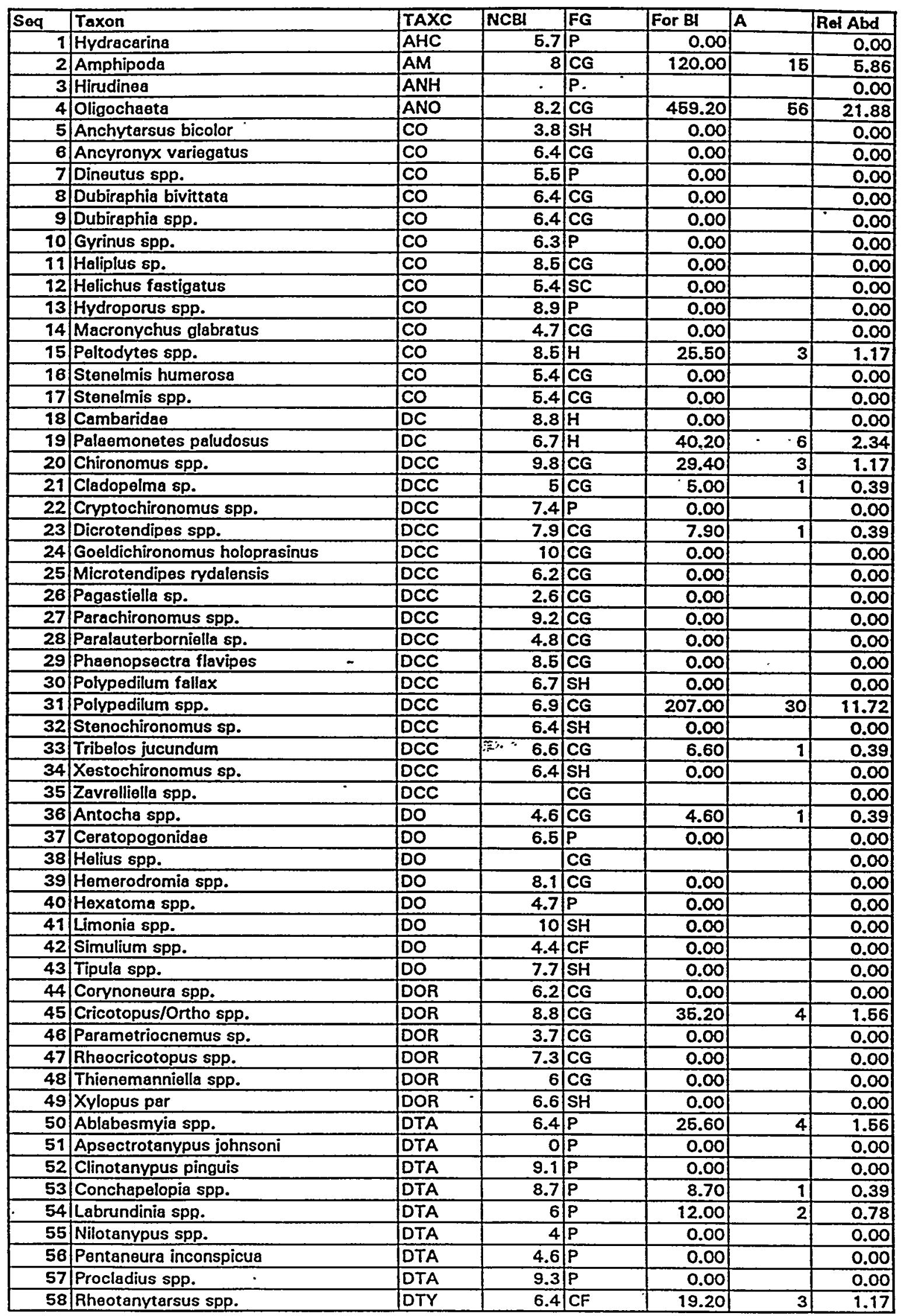




\begin{tabular}{|c|c|c|c|c|c|c|c|}
\hline 59 & Stempellinella spp. & DTY & 5.3 & CG & 0.00 & & 0.00 \\
\hline 60 & Tanytarsus spp. & $D T Y$ & 6.7 & CG & 301.60 & 45 & 17.68 \\
\hline 61 & Acentrella ampla & EP & 3.6 & CG & 0.00 & & 0.00 \\
\hline 62 & Acerpenna pygmaeus & EP & 3.7 & CF & 0.00 & & 0.00 \\
\hline 63 & Acerpenna spp. - & EP & 3.7 & CG & 0.00 & & 0.00 \\
\hline 64t & Baetis spp. & EP & 5.4 & $C G$ & 124.20 & 23 & 8.98 \\
\hline 65 & Caenis spp. & EP & 7.6 & $\overline{C G}$ & 7.60 & 1 & 0.39 \\
\hline 86 & Callibeetis spp. & EP & 9.3 & $C G$ & 18.60 & 2 & 0.78 \\
\hline 67 & Eurylophella spp. & EP & 3 & CG & 0.00 & & 0.00 \\
\hline 68 & Hexagenia spp. & EP & 4.7 & CG & 0.00 & & 0.00 \\
\hline 69 & Isonychie spp. & EP & 3.8 & CF & 0.00 & & 0.00 \\
\hline 70 & Neoophemera youngi & EP & 2.1 & $\mathbf{C G}$ & 0.00 & & 0.00 \\
\hline 71 & Paraleptophlebia spp. & EP & 1.2 & CG & 0.00 & & 0.00 \\
\hline 72 & Siphlonurus sp. & EP & 2.6 & CG & 0.00 & & 0.00 \\
\hline 73 & Stenonems spp. & EP & 3.4 & SC & 0.00 & & 0.00 \\
\hline 74 & Tricorythodes spp. & EP & 5.4 & $\overline{C G}$ & 10.80 & 2 & 0.78 \\
\hline 75 & Belostoma sp. & HT & 9.8 & $\mathbf{P}$ & 0.00 & & 0.00 \\
\hline $78 \mid 1$ & Hesperocorixa sp. & HT & & $\mathrm{H}$ & 9.00 & 1 & 0.39 \\
\hline 77 & Pyralidae & LEEP & 5 & $\mathrm{H}$ & 5.00 & 1 & 0.39 \\
\hline 78 & Corbicula sp. & $M B$ & 6.3 & CF & $6: 30$ & 1 & 0.39 \\
\hline $79 \mid$ & Eliptio spp. & $M B$ & 3.4 & $\mathrm{CF}$ & 0.00 & & 0.00 \\
\hline 80 & Sphaerium spp. & $\mathrm{MB}$ & 7.7 & $\mathrm{CF}$ & 115.60 & 15 & 5.86 \\
\hline 89 & Nigronia serricornis & $M E$ & $5.5 / \mathrm{F}$ & $\mathbf{P}$ & 0.00 & & 0.00 \\
\hline 82 & Sialis spp. & $\mathrm{ME}$ & 7.711 & $\mathbf{P}$ & 0.00 & & 0.00 \\
\hline 83 & Campeloma sp. & MG & 6.7 & SC & 0.00 & & 0.00 \\
\hline 84 & Forrissia sp. & MG & 6.95 & SC & 0.00 & & 0.00 \\
\hline 85 & Hydrobiidas & MG & & SC & & 11) & 4.30 \\
\hline 86 & Physella spp. & MG & 9.11 & SC & 0.00 & & 0.00 \\
\hline 87 & Planorbidae & MG & $6.5:$ & SC & 0.00 & & 0.00 \\
\hline 88 & Nomertea & NA & & $\mathbf{P}$ & & हा & 1.96 \\
\hline 89 & Argia spp. & TOD & 8.7 & $\mathbf{P}$ & 60.90 & 7 & 2.73 \\
\hline 90 & Boyeria vinosa & OOD & 6.3 & $\bar{P}$ & 0.00 &. & 0.00 \\
\hline 91 & Calopteryx spp. & OD & 8.3 & $\mathbf{P}$ & 0.00 & & 0.00 \\
\hline 92 & Enallagma spp. & OD= & 9f & $\mathbf{P}$ & 36.00 & 4 & 1.56 \\
\hline 93 & Gomphus spp. & OD & 6.2 & $\mathbf{P}$ & 0.00 & & 0.00 \\
\hline 94 & Mecromia spp. & OD & 6.7 & $\mathbf{P}$ & 13.40 & 2 & 0.78 \\
\hline 95 & \begin{tabular}{|l} 
Neurocordulia spp. \\
\end{tabular} & OD & 5.8 & $\mathbf{P}$ & 0.00 & & 0.00 \\
\hline 98 & Pachydiplax longipennis & OD & 9.6 & $\mathbf{P}$ & 0.00 & & 0.00 \\
\hline 97 & Progomphus spp. & OD & 8.7 & $P$ & 0.00 & & 0.00 \\
\hline 98 & Acroneuria spp. & $P L$ & 1.4 & $\bar{P}$ & 0.00 & & .0 .00 \\
\hline 99 & Allocapniz spp. & $\overline{P L}$ & 2.8 & SH & 0.00 & & 0.00 \\
\hline 100 & Leuctra spp. & PL & 0.7 & $\mathrm{SH}$ & 0.00 & & 0.00 \\
\hline 101 & Perlinelle spp. & $P L$ & of & $\mathrm{P}$ & 0.00 & & 0.00 \\
\hline 102 & Anisocentropus pyraloides & TR & 0.8 & $\mathrm{SH}$ & 0.00 & & 0.00 \\
\hline 103 & Brachycentrus numerosus & TR & 1.8 & $\overline{C F}$ & 0.00 & & 0.00 \\
\hline 104 & Cheumatopsyche spp. & TR & 6.6 & $\mathrm{CF}$ & 19.80 & 3 & 1.17 \\
\hline 105 & Chimarre spp. & TR & 2.8 & CF & 0.00 & & 0.00 \\
\hline 106 & Hydropsyche spp. & TR & 4 & CF & 0.00 & & 0.00 \\
\hline 107 & Hydroptila spp. & TR & 6.2 & $\mathrm{H}$ & 0.00 & & 0.00 \\
\hline 108 & Lepidostoma spp. & TR & 1 & $\mathrm{SH}$ & 0.00 & & 0.00 \\
\hline 109 & Nectopsyche exquisita & TR & 4.1 & $\overline{\mathrm{SH}}$ & 8.20 & 2 & 0.78 \\
\hline 110 & Oecetis spp. & TR & 5.7 & $\mathrm{P}$ & 0.00 & & 0.00 \\
\hline 111 & Oxyethira spp. & TR & 6.2 & $\mathrm{H}$ & 0.00 & & 0.00 \\
\hline 112 & Phylocentropus spp. & TR & 5.6 & CF & 0.00 & & 0.00 \\
\hline 113 & Polycentropus spp. & TR & 3.5 & $\mathrm{CF}$ & 0.00 & & 0.00 \\
\hline 114 & Pycnopsyche spp. & TR & 2.3 & $\mathrm{SH}$ & 0.00 & & 0.00 \\
\hline 115 & Triaenodes tardus & $7 R$ & 4.7 & $\mathrm{SH}$ & 0.00 & & 0.00 \\
\hline 116 & Turbellaria & TTU & 7.5 & $\mathrm{P}$ & 0.00 & & 0.00 \\
\hline
\end{tabular}




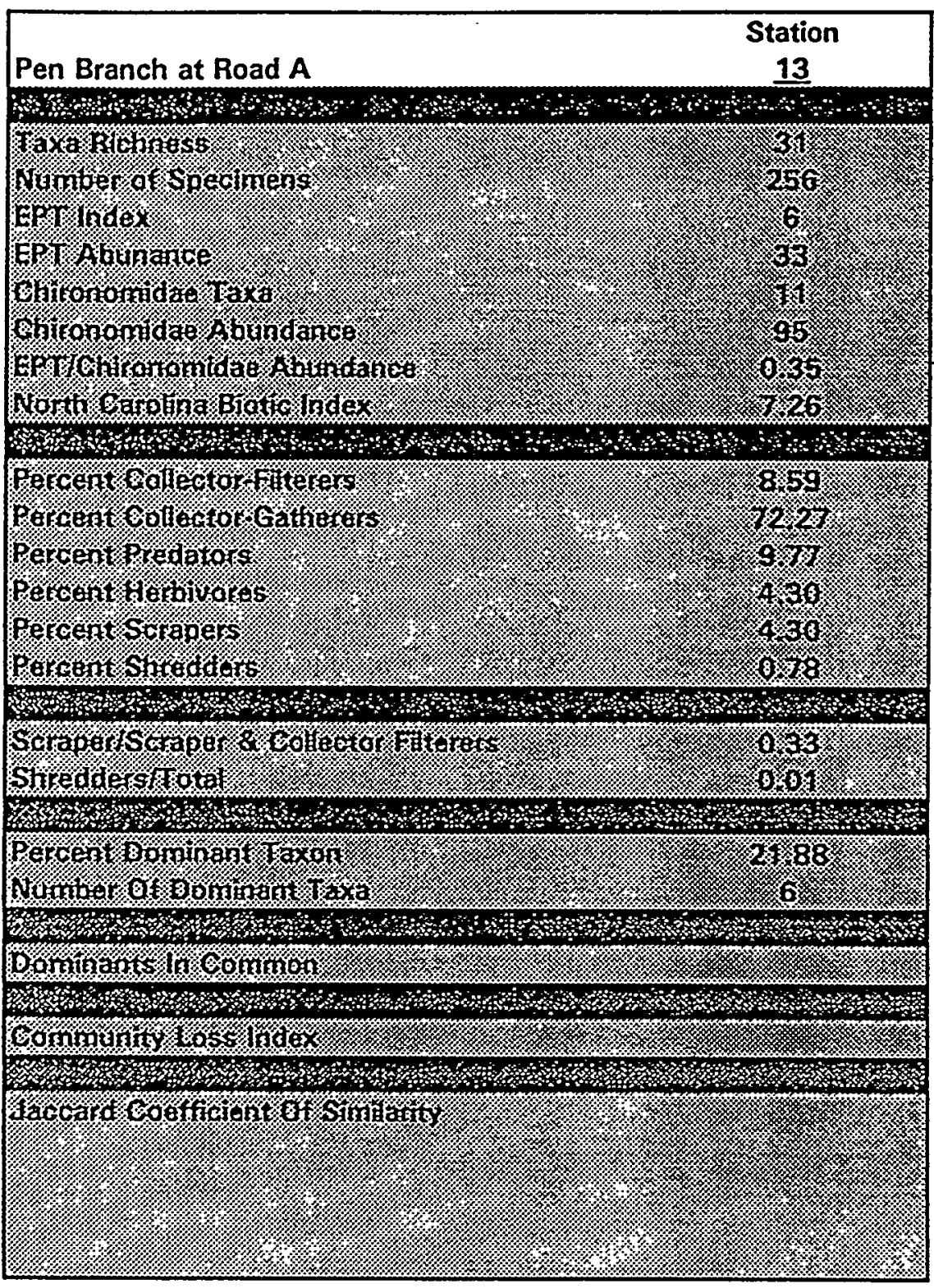


Station 13. Pen Branch á Road A. RBP III. 21 September 1994

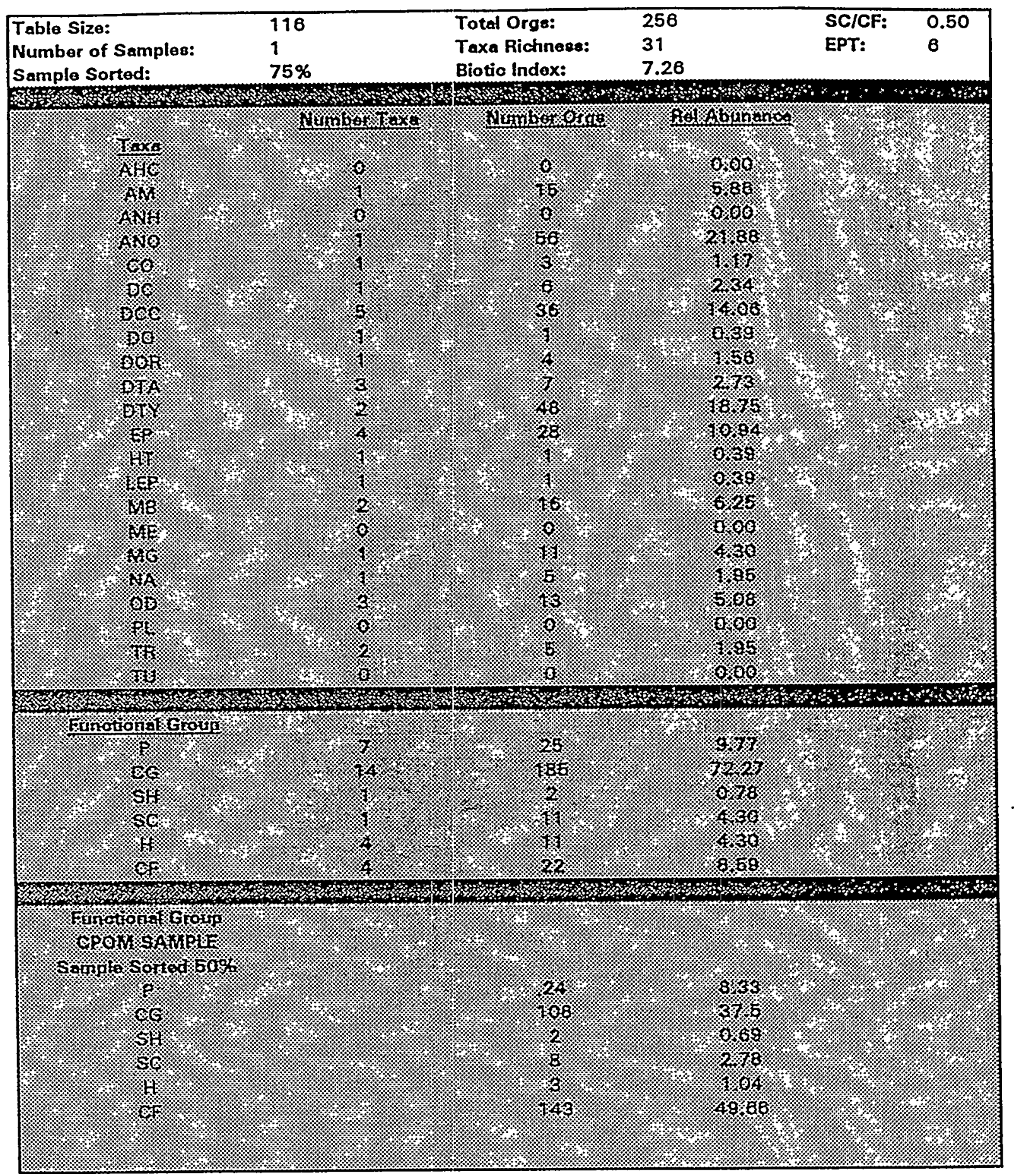


Taxa List

Anoinorora

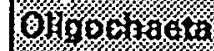

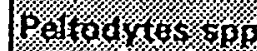

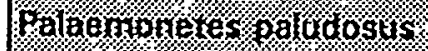

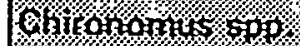

Clanopein. : 5 :

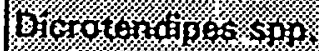

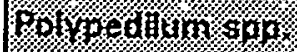

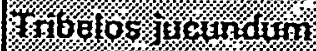

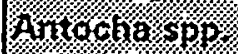

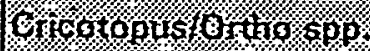

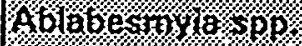

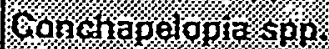

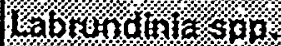

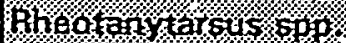

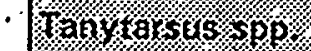

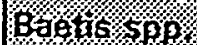

Gaenis:soo:

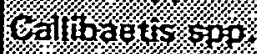

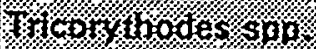

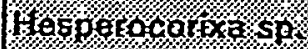

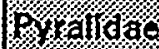

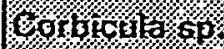

Sininativin. ser.

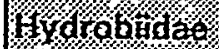

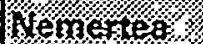

Aroio: 500 .

Entitivona 5 opo

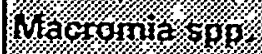

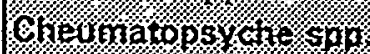

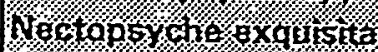




\begin{tabular}{|l|r|r|}
\hline Taxon & A & Rel Abd \\
\hline Oligochaeta & 56 & 21.88 \\
\hline Tanytarsus spp. & $\mathbf{4 5}$ & 17.58 \\
\hline Polypedilum spp. & 30 & 11.72 \\
\hline Baetis spp. & 23 & 8.98 \\
\hline Amphipoda & 15 & 5.86 \\
\hline Sphaerium spp. & 15 & 5.86 \\
\hline
\end{tabular}

F: 


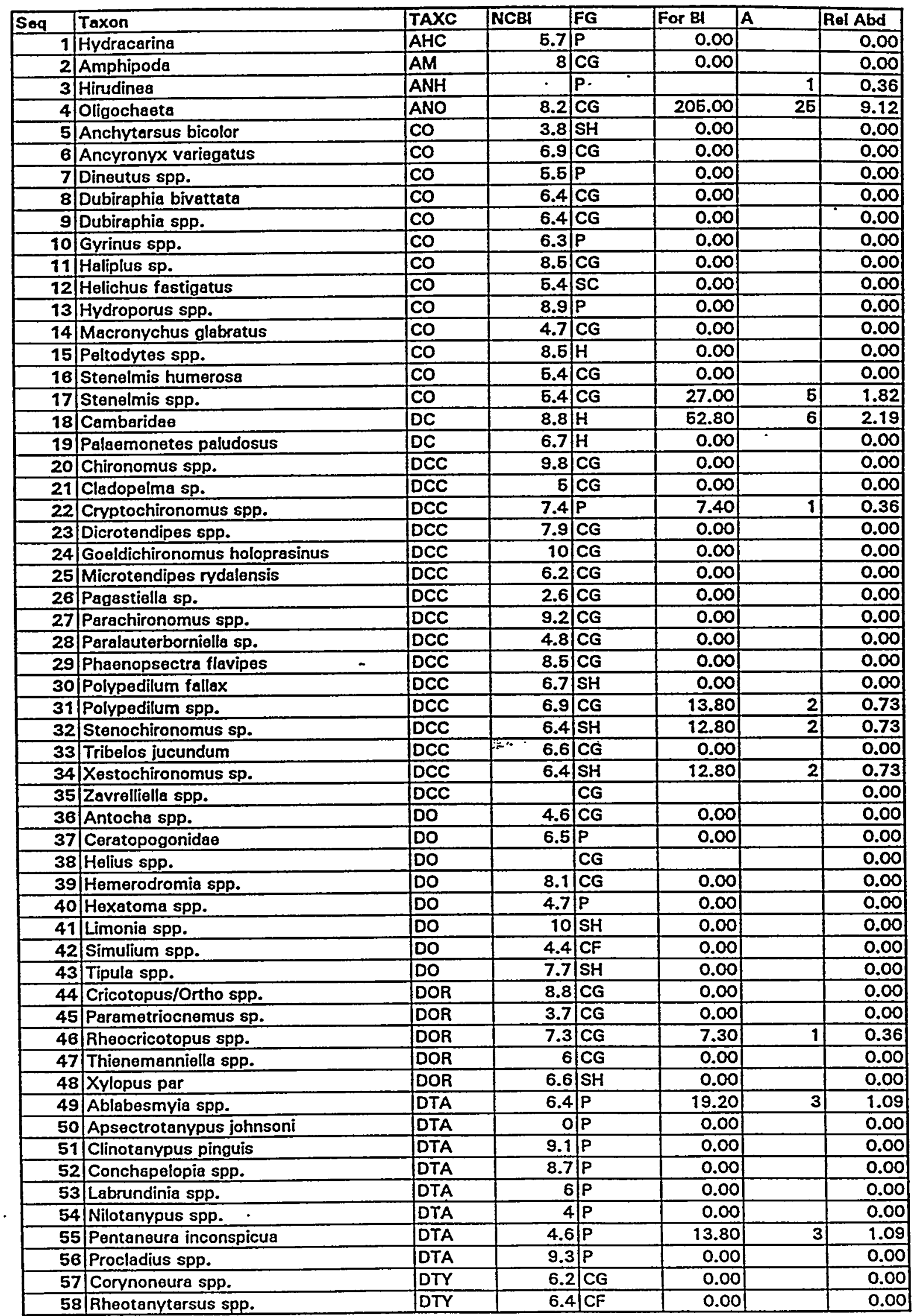


Station 14. Beaver Dam Creok at Metal Walkway. RBPIIl. 21 September 1994

\begin{tabular}{|c|c|c|c|c|c|c|c|}
\hline 59 & Stempellinella spp. & DTY & 6.3 & CG & 0.00 & & 0.00 \\
\hline 60 & Tanytarsus spp. & DTY & 6.7 & CG & 26.80 & 4 & 1.46 \\
\hline 61 & Acentrella ampla & EF & 3.6 & CG & 0.00 & & 0.00 \\
\hline 62 & Acerpenne pygmaeus & EF & 3.7 & $\mathbf{C G}$ & 0.00 & & 0.00 \\
\hline 63 & Acerpenna spp. & EP & 3.7 & CG & 0.00 & & 0.00 \\
\hline 64 & Baetis spp. & $\mathrm{EP}$ & 5.4 & $\mathbf{C G}$ & 102.60 & 19 & 6.93 \\
\hline 65 & Caenis spp. & EP & 7.6 & $\mathbf{C G}$ & 0.00 & & 0.00 \\
\hline 68 & Callibeetis spp. & $E P$ & 9.3 & CG & 0.00 & & 0.00 \\
\hline 67 & Eurylophalla spp. & EP & 3 & $\mathbf{C G}$ & 3.00 & 1 & 0.36 \\
\hline 68 & Hexagenis spp. & $E P$ & 4.7 & $\overline{C G}$ & 0.00 & & 0.00 \\
\hline 69 & Isonychia spp. & $E P^{2}$ & 3.8 & $\mathrm{CF}$ & 0.00 & & 0.00 \\
\hline 70 & Neoephemera youngi & $E P^{2}$ & 2.1 & CG & 0.00 & & 0.00 \\
\hline 71 & Paraleptophlebia spp. & $E P$ & 1.2 & $\mathbf{C G}$ & 0.00 & & 0.00 \\
\hline 72 & Siphlonurus sp. & EP & 2.6 & CG & 0.00 & & 0.00 \\
\hline 73 & Stenonema spp. & $E P$ & 3.4 & SC & 340.00 & 100 & 36.50 \\
\hline 74 & Tricorythodes spp. & $E P^{2}$ & 5.4 & CG & 361.00 & 66 & 23.72 \\
\hline 75 & Belostoma sp. & $\mathrm{HT}$ & 9.8 & $P$ & 0.00 & & 0.00 \\
\hline 76 & Hesperocorixa sp. & HT & 9 & $\mathrm{H}$ & 0.00 & & 0.00 \\
\hline 77 & Pyralidae & LLEP & 6) & $\mathrm{H}$ & 10.00 & 2 & 0.73 \\
\hline 78 & Corbicula sp. & $\mathrm{NB}$ & 6.3 & $\mathrm{CF}$ & 0.00 & & 0.00 \\
\hline 79 & Eliptio spp. & $\mathrm{NB}$ & 3.4 & $\mathrm{CF}$ & 0.00 & & 0.00 \\
\hline 80 & Sphaerium spp. & $\mathrm{MB}$ & 7.7 & $\overline{C F}$ & 7.70 & 1 & 0.36 \\
\hline 81 & Nigronia serricornis & ME & 5.5 & $P$ & 0.00 & & 0.00 \\
\hline 82 & Sialis spp. & ME & 7.7 & $P$ & 0.00 & & 0.00 \\
\hline 83 & Campeloma sp. & MG & 6.7 & SC & 0.00 & & 0.00 \\
\hline 84 & Ferrissia sp. & NIG & 6.9 & SC & 13.80 & 2 & 0.73 \\
\hline 85 & Hycirobiidae & NIG & & SC & & & 0.00 \\
\hline 86 & Physella spp. & MG & 9.1 & SC & 0.00 & & 0.00 \\
\hline 87 & Planorbidae & MG & 6.5 & SC & 0.00 & & 0.00 \\
\hline 88 & Nemertea & NA & & $\mathrm{P}$ & & & 0.00 \\
\hline 89 & Argia spp. & CD & 8.7 & $\mathbf{P}$ & 60.90 & 7 & 2.55 \\
\hline 90 & Boyeria vinosa & OD & 6.3 & $P$ & 0.00 & & 0.00 \\
\hline 91 & Calopteryx spp. & $O D$ & 8.3 & 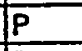 & 16.60 & 2 & 0.73 \\
\hline 92 & Enallagma spp. & $00^{\prime \prime}$ & 9 & $P$ & 99.00 & 11 & 4.01 \\
\hline 93 & Gomphus spp. & OD & 6.2 & $P$ & 0.00 & & 0.00 \\
\hline 94 & Macromia spp. & $O D$ & 6.7 & $P$ & 0.00 & & 0.00 \\
\hline 95 & Neurocordulia spp. & 00 & 5.8 & $\mathbf{P}$ & 5.80 & 1 & 0.36 \\
\hline 96 & Pachydiplax longipennis & OD & 9.6 & $\bar{P}$ & 0.00 & & 0.00 \\
\hline 97 & Progomphus spp. & $O D$ & 8.7 & $P$ & 8.70 & 1 & 0.36 \\
\hline 98 & Acroneuria spp. & F'L & 1.4 & $\mathbf{P}$ & 0.00 & & 0.00 \\
\hline 99 & Allocapnia spp. & $F^{\prime \prime L}$ & 2.8 & $\mathrm{SH}$ & 0.00 & & 0.00 \\
\hline 100 & Louctra spp. & $P L$ & 0.7 & $\mathrm{SH}$ & 0.00 & & 0.00 \\
\hline 101 & Perlinella spp. & $P L$ & 0 & $P$ & 0.00 & & 0.00 \\
\hline 102 & Anisocentropus pyraloides & TR & 0.8 & $\mathrm{SH}$ & 0.00 & & 0.00 \\
\hline 103 & Brachycentrus numerosus & TR & 1.8 & CF & 0.00 & & 0.00 \\
\hline 104 & Cheumatopsyche spp. & Th & 6.6 & $\mathrm{CF}$ & 0.00 & & 0.00 \\
\hline 105 & Chimarra spp. & TR & 2.8 & $\mathrm{CF}$ & 2.80 & 1 & 0.36 \\
\hline 108 & Hydropsyche spp. & TR & 4 & $\mathrm{CF}$ & 8.00 & 2 & 0.73 \\
\hline 107 & Hydroptila spp. & TR & 6.2 & $\mathrm{H}$ & 0.00 & & 0.00 \\
\hline 108 & Lepidostoma spp. & TR & 1 & $\mathrm{SH}$ & 0.00 & & 0.00 \\
\hline 109 & Nectopsyche exquisita & TR & 4.1 & SH & 0.00 & & 0.00 \\
\hline 110 & Oecetis spp. & TR & 5.7 & $P$ & 0.00 & & 0.00 \\
\hline 111 & Oxyethira spp. & TR & 6.2 & $\mathrm{H}$ & 0.00 & & 0.00 \\
\hline 112 & Phylocentropus spp. & $T R$ & 5.6 & CF & 0.00 & & 0.00 \\
\hline 113 & Polycentropus spp. & TR & 3.5 & CF & 0.00 & & 0.00 \\
\hline 114 & Pycnopsyche spp. & TR & 2.3 & $\mathrm{SH}$ & 0.00 & $\therefore$ & 0.00 \\
\hline 115 & Triaenodes tardus & TR & 4.7 & $\mathrm{SH}$ & 1.4.10 & 3 & 1.09 \\
\hline 116 & Turbellaris & TU & 7.5 & $P$ & 7.50 & 1 & 0.36 \\
\hline
\end{tabular}


Station 14. Beaver Dam Creek at Metal Walkway. RBP III. 21 September 1994

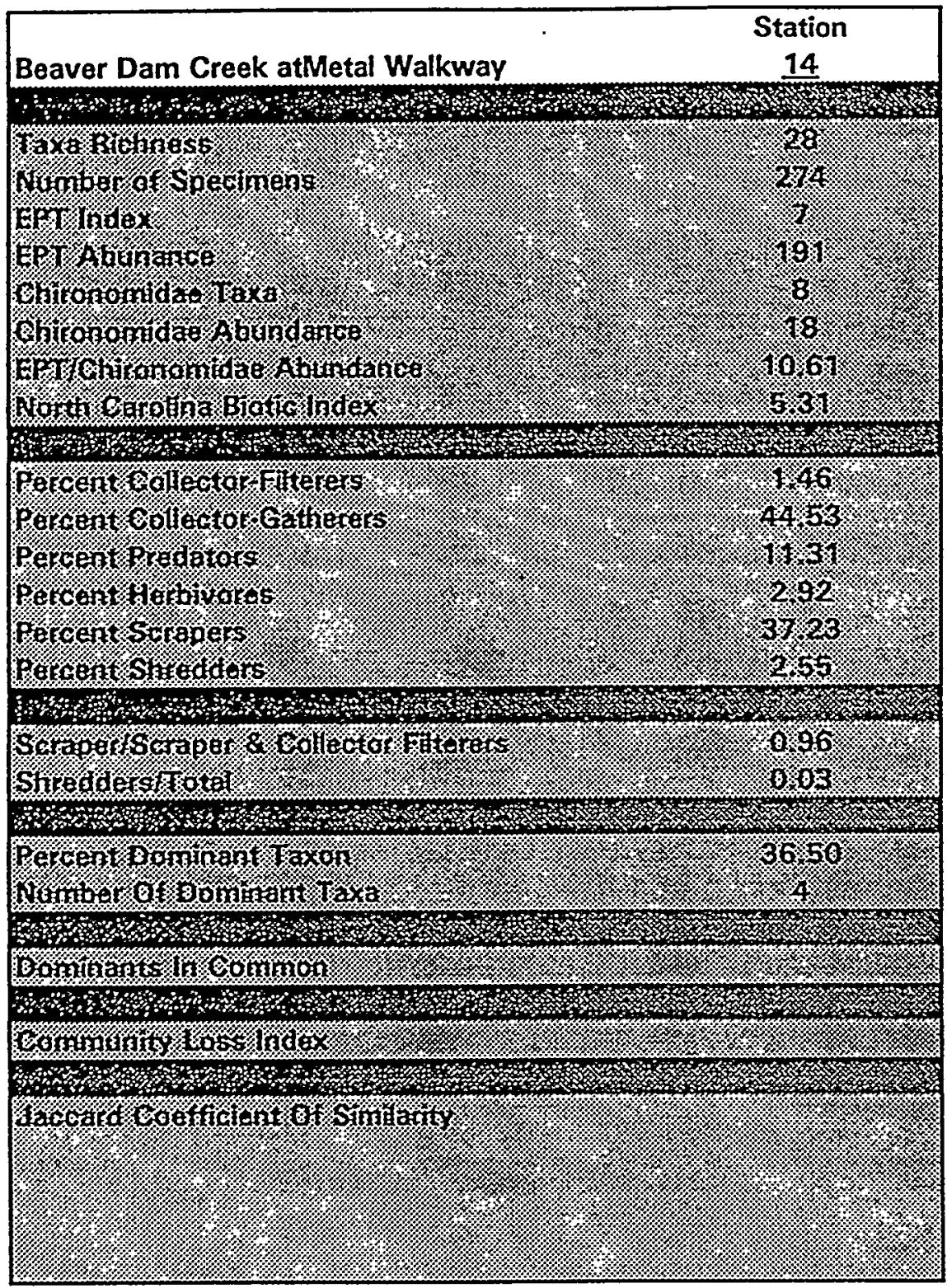


Station 14. Beaver Dam Creek at Metal Walkway. RBP. Ill. 21 September 1994

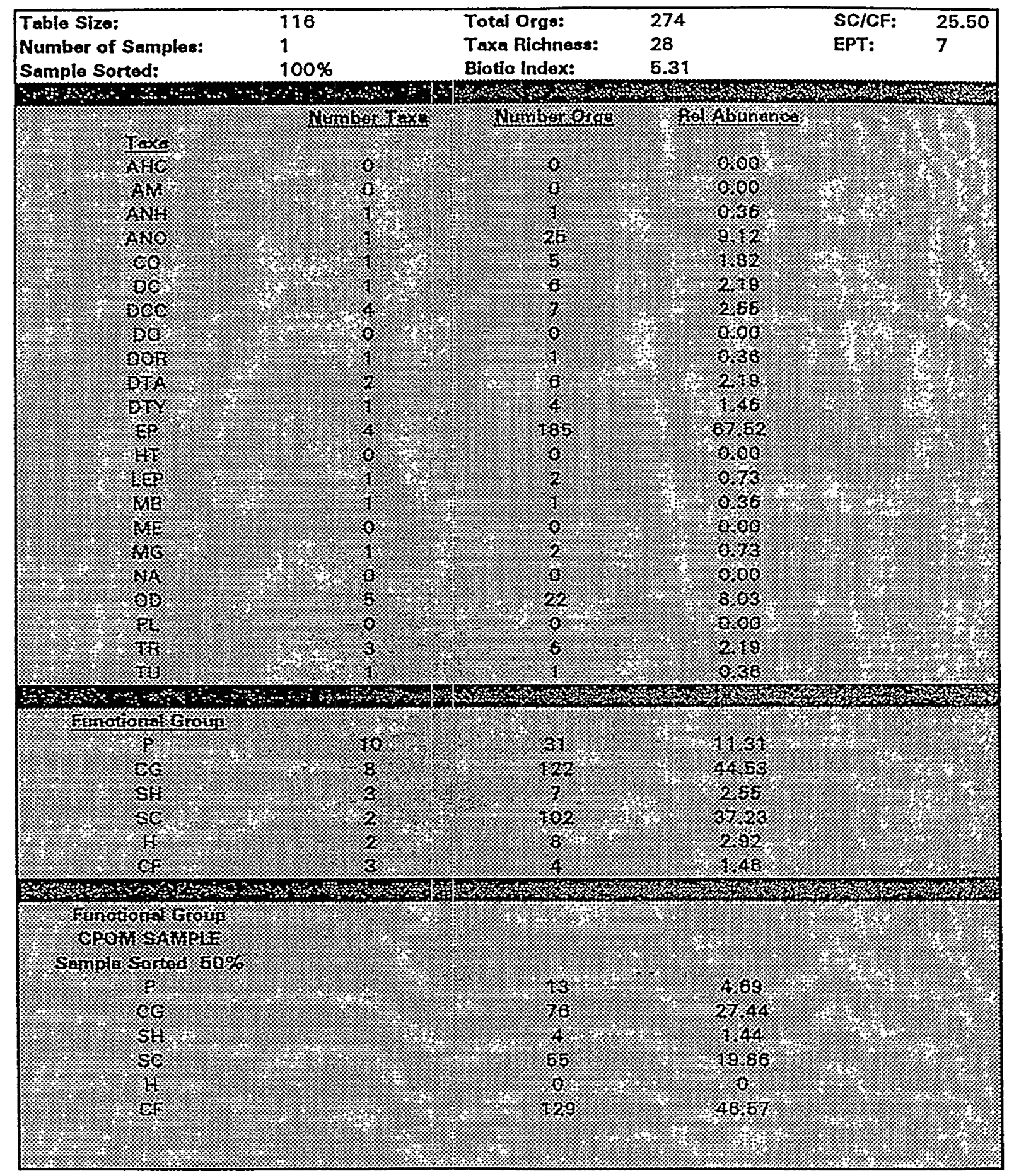




\section{Rapid Bioassessment Protocol III}

Blosurvey Fleld Data Sheet

RELATIVE ABUNOANCE OF AQUATIC BIOTA

\begin{tabular}{|c|c|c|c|c|c|c|c|c|c|c|}
\hline Pariphyton & 0 & 1 & 2 & 3 & 4 & Slimes & 0 & 1 & 2 & 3 \\
\hline Fllamentous Algae & 0 & 1 & 2 & 3 & 4 & Hecrolinvertebrates. & 0 & 1 & 2 & 3 \\
\hline Macrophytes & 0 & 1 & 2 & 3 & 4 & Fish & 0 & 1 & 2 & 3 \\
\hline
\end{tabular}

$$
\text { , }
$$

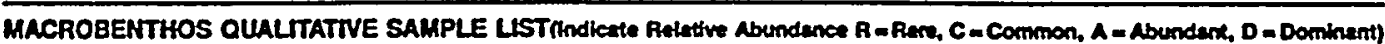

\begin{tabular}{|c|c|c|}
\hline Porifen & Anisopter & Chitronomides \\
\hline Hydrosenen & Zyoptera & Plecopten \\
\hline Pintyhielminthes & Hemipten & Eptremeroptern \\
\hline Turbellarta & Coleoptern & Irichoptera \\
\hline Hirudinea & Lepidoptere & Other \\
\hline Ollgocheete & Stalldee & \\
\hline Isopoda & Corydalldes & \\
\hline Amphlpoda & Fo: & - \\
\hline Decapoda & Empididae- & \\
\hline Gastropoda & Simullidae- & \\
\hline \multirow[t]{2}{*}{ Blvaluie } & Tabanidae. & S. \\
\hline & Cullictane. & \\
\hline
\end{tabular}

\begin{tabular}{llll}
\hline Rare $<3$ & Common 3-9 & Abundant $>10$ & Dominamt $>50$ (Estimate) \\
\hline CPOM SAMPLE
\end{tabular}

CPOM SAMPLE FUNCTIONAL FEEDING GROUPS (Indkente Na. of Indivtouts Repreventing Group)

\begin{tabular}{l|l}
\hline Stroddere & Total Org. In Smpine \\
\hline
\end{tabular}

Oberventions:

Figure 6.3-1. Biosurvey Field Data Sheet for use with Rapid Bioassessment Protocol III. 
dure consists of evenly distributing the composite sample in a gridded pan with a light-colored bottom. As grids are randomly selected, all organisms within those grids are removed, until at least 100 organisms have been selected from the sample. This method of subsampling provides a representative estimate of the benthic fauna as well as a consistent unit of effort. A more detailed description of this technique may be found in Appendix B. Although pilot study results (Section 6.4.6) indicated that a 100-organism subsample is sufficient, a 200 - or 300-organism subsample may be preferred, depending on investigator preference, budget constraints, and individual sample characteristics. Some agencies may prefer to expend additional resources to process whole samples instead of subsampling.

All benthic macroinvertebrates in the subsample (or sample) should be identified to the lowest positively identified taxonomic level (generally genus or species), enumerated, and recorded on the Laboratory Bench Sheet (Figure 6.3-2). Based on the taxonomic identifications, Functional Feeding Group classifications can be assigned for most aquatic insects using a reference such as Merritt and Cummins (1984). Once a Functional Feeding Group classification list has been established, it can be incorporated into the com: puter analysis for computation of the metrics. Care should be taken to note the presence of early instars which may represent different Functional Feeding Groups from later instars. The Scraper and Filtering Collector Functional Groups are considered the important indicators in the riffle/run community; if this metric is not calculated using a computer program, numbers of individuals representing each of these two groups are recorded on the Laboratory Bench Sheet (Figure 6.3-2).

\subsubsection{Data Analysis Techniques}

Based on observations made in assessing habitat, water quality, physical characteristics, and the qualitative biosurvey, the investigator makes a preliminary judgment on the presence or absence of biological impairment and an estimation of probable cause and source on the Impairment Assessment Sheet (Figure 6.1-2).

The integrated benthic data analysis is performed as follows. Using the raw benthic data, a numerical value is calculated for each metric. Calculated values are then compared to values"derived from either an unimpaired reference site within the same region or a suitable control station on the same stream. Each metric is then assigned a score according to the comparability (percent similarity) of calculated and reference values. Scores for the eight metrics are then totaled and compared to the total metric score for the reference station. The percent comparison between the total scores provides a final evaluation of biological condition.

Criteria to be used for scoring the eight metrics were derived from an evaluation of pilot study results (Section 6.4), certain project compliance monitoring requirements now in use (Vermont Department of Environmental Conservation 1987), and discussions with various aquatic biologists regarding the level of detection considered dependable for certain metrics. However, it is envisioned that these criteria may need to be adjusted for use in particular regions.

Inherent variability in each metric was considered in establishing percent comparability criteria. The metrics based on taxa richness, HBI, and EPT indices have low variability (Resh 1988). This variability is accounted for in the criteria for characterization of biological condition (Figure 6.2-3) based on existing data. For metrics based on standard taxa richness and HBI and EPT Indices, differences of 10-20 percent relative to the reference condition would be considered nomiral, and the station being assessed would receive the maximum metric score. Because increasing HBI values denote worsening biological condition, percent difference for this metric is calculated by dividing the reference value by the value for the station of comparison.

Metrics that utilize ratios will fluctuate more widely, however, and comparing percent differences between ratios (ratios of ratios) will compound the variabiffity. Scoring increments are therefore set at broad intervals of 25 percent or greater. For metrics based on Functional Feeding Group ratios, Cummins (1987, personal communication) contends that differences as great as $\mathbf{5 0}$ percent from the reference may be acceptable, but differences in the range of 50-100 percent are not only important but discriminate degrees of impact more clearly.

The percent contribution of the dominant taxon to total abundance is a simple estimator of evenness. Scoring criteria are based on theoretical considerations rather than direct comparison with a reference.

The Community Loss Index already incorporates comparison with a reference. Therefore, actual index values are used in scoring.

Analysis of the benthic data combines several community population and functional parameters. An integrated assessment is used, based on eight metrics (Table 6.3-1). Each metric has a different range of sensitivity measuring a slightly different component of comrnunity structure (Figure 8.2-1). The data collected in the 100-organism riffle/run subsample and the CPOM sample are summarized according to the information required for each metric and entered on the 


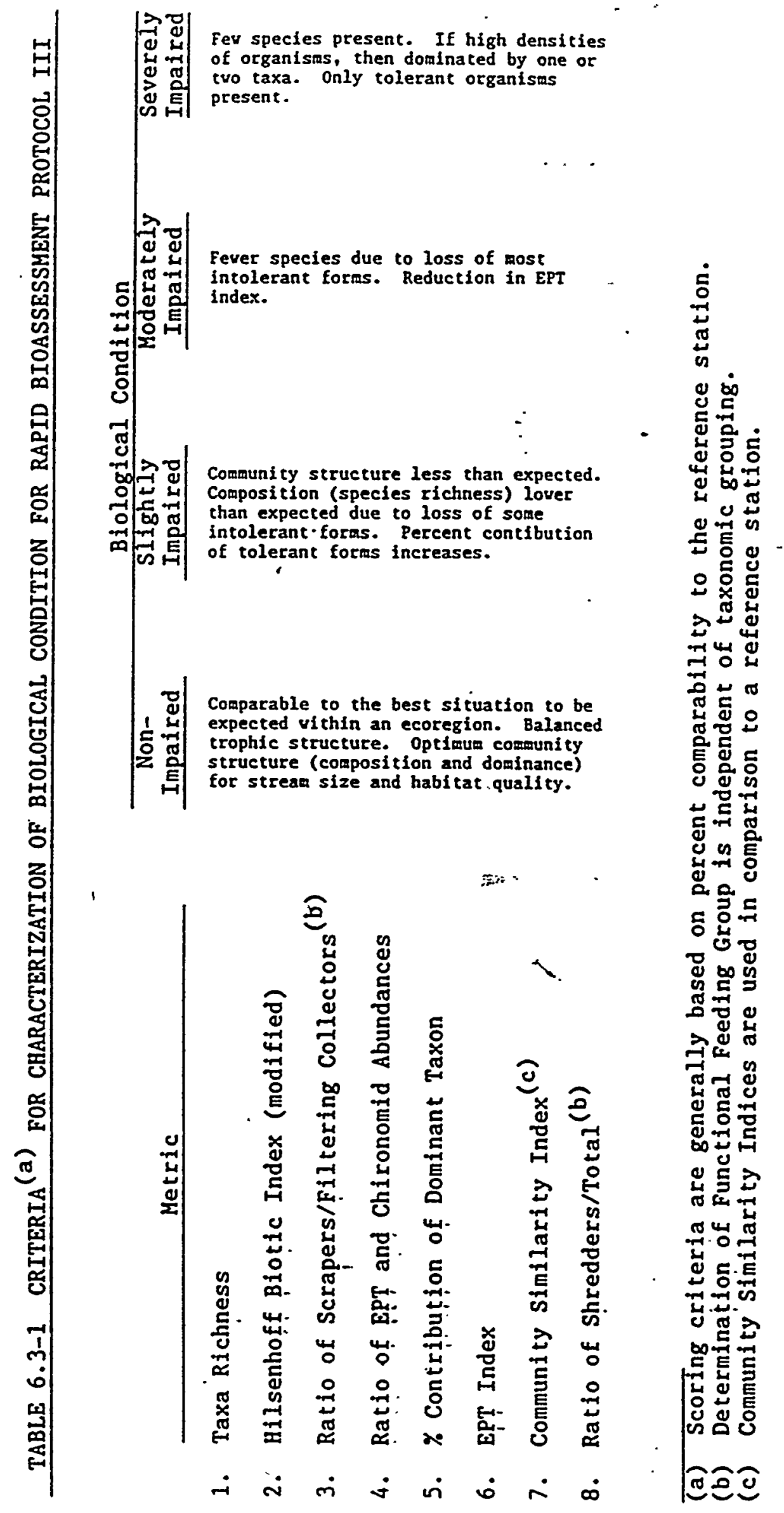




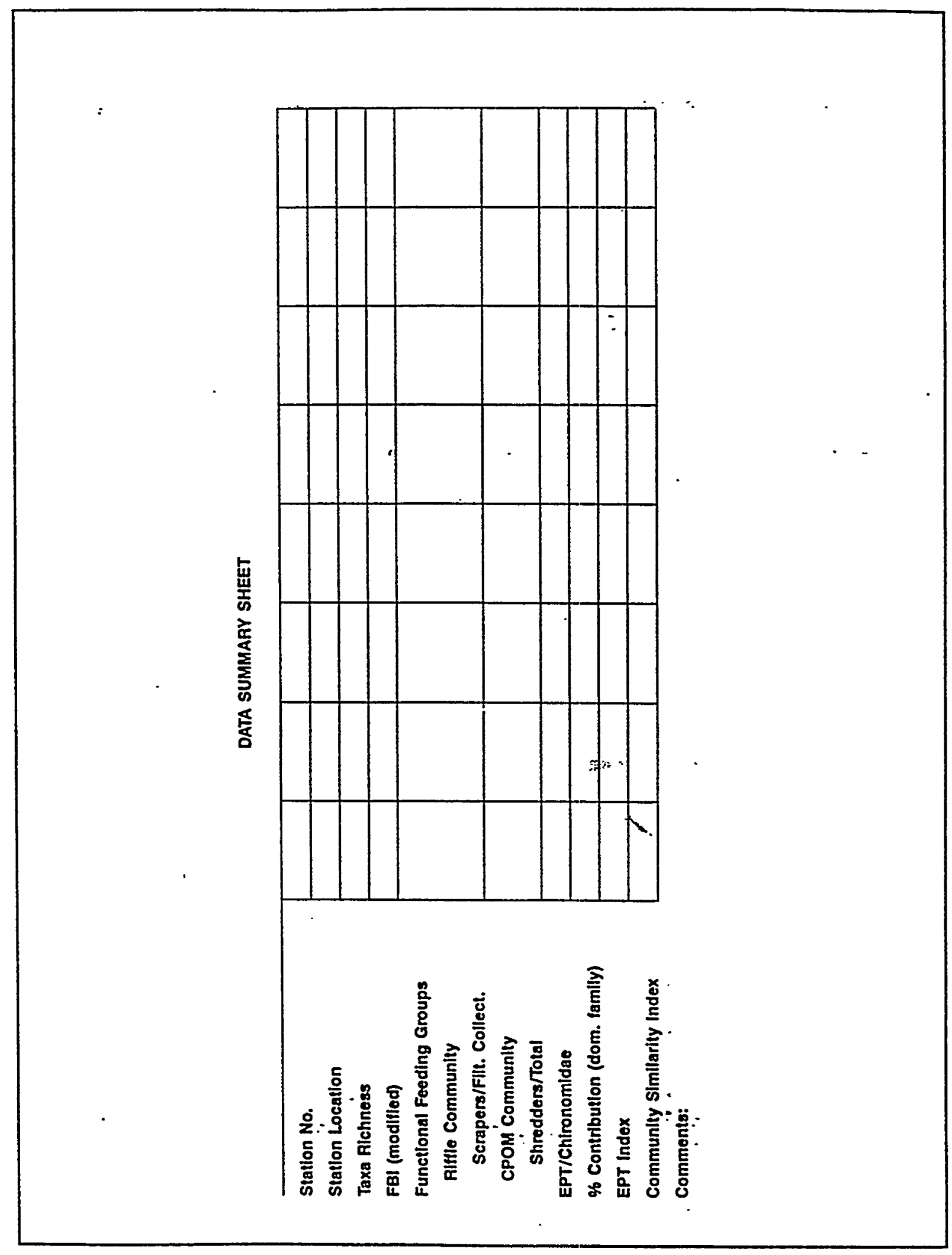

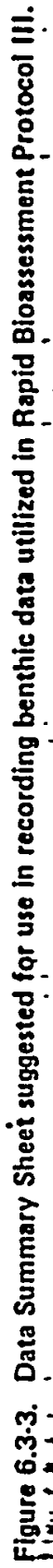


Metric 6. EPT Index

The EPT Index generally increases with increasing water quality. The EPT Index is the total number of distinct taxa within the orders Ephemeroptera, Plecoptera, and Trichoptera. This value summarizes taxa richness within the insect orders that are generally considered to be pollution sensitive.

Headwater streams which are naturally unproductive may experience an increase in taxa (including EPT taxa) in response to organic enrichment. In this situation, a "missing genera" approach may be more valuable. Shackleford (1988) uses a "missing genera" metric to evaluate the loss of EPT taxa from upstream to downstream to avoid the complication in data interpretation resulting from the addition or replacement of genera.

Metric 7. Community Similarity Indices

Community Similarity Indices are used in situations where reference communities exist. The reference community can be derived through sampling or prediction for a region using a reference database. Data sources or ecological data files may be available to establish a reference community for comparison. The combined information provided through a regional analysis and EPA's ERAPT ecological database (Dawson and Hellenthal 1986) may be useful for this analysis. Three of the many similarity indices available are discussed below:

- Community Loss Index-Measures the loss of benthic species between a reference station and the station of comparison. The Community Loss Index was developed by Courtemanch and Davies (1987) and is an index of dissimilarity with values increasing as the degree of dissimilarity from the reference station increases. Values range from 0 to "infinity." Based on preliminary data analysis, this index provides greater discrimination than the following two community similarity indices.

- Jaccard Coefficient of CommunityMeasures the degree of similarity in taxonomic composition between two stations in terms of taxion presence or absence.
The Jaccard Coefficient discriminates between highly similar collections. Coefficient values, ranging from 0 to 1.0 , increase as the degree of similarity with the reference station increases. See Jaccard (1912), Boesch (1977), and U.S. EPA (1983) for more detail. The formulae for the Community Loss Index and the Jaccard Coefficient are

$$
\begin{aligned}
\text { Community Loss } & =\frac{d-a}{e} \\
\therefore \quad \text { Jaccard Coefficient } & =\frac{a}{a+b+c}
\end{aligned}
$$

where

$a=$ number of species common to both samples

b $=$ number of species present in Sample B but not $\mathrm{A}$

$c=$ number of species present in Sample A but not $\mathrm{B}$

$d=$ total number of species present in Sample A

$e=$ total number of species present in Sample B

Sample $A=$ reference station

Sample B = station of comparison

- Pinkham and Pearson Community

Similarity Index-Measures the degree of simllarity in taxonomic composition in terms of taxon abundances and can be calculated with either percentages or numbers. A weighting factor can be. added that assigns more significance to dominant species. See Pinkham and Pearson (1976) and U.S. EPA (1983) for more detail. The formula is

$$
\begin{aligned}
& \text { S.I. } a b .=\sum \frac{\ln \left(x_{1 a}, x_{1 b}\right)}{\operatorname{anx}\left(x_{1 a}, x_{1 b}\right)}\left[\frac{x_{1 a}}{x_{a}} \cdot \frac{x_{1 b}}{x_{b}} / 2\right] \\
& \text { where } \\
& \text { veighting factor }
\end{aligned}
$$

$$
\begin{gathered}
x_{i 3} . x_{i b}=\text { number of individuals in the ith } \\
\text { species in Sample A or B }
\end{gathered}
$$

Other community similarity indices suggested by reviewers of this document include Spearmaris Rank Correlation 


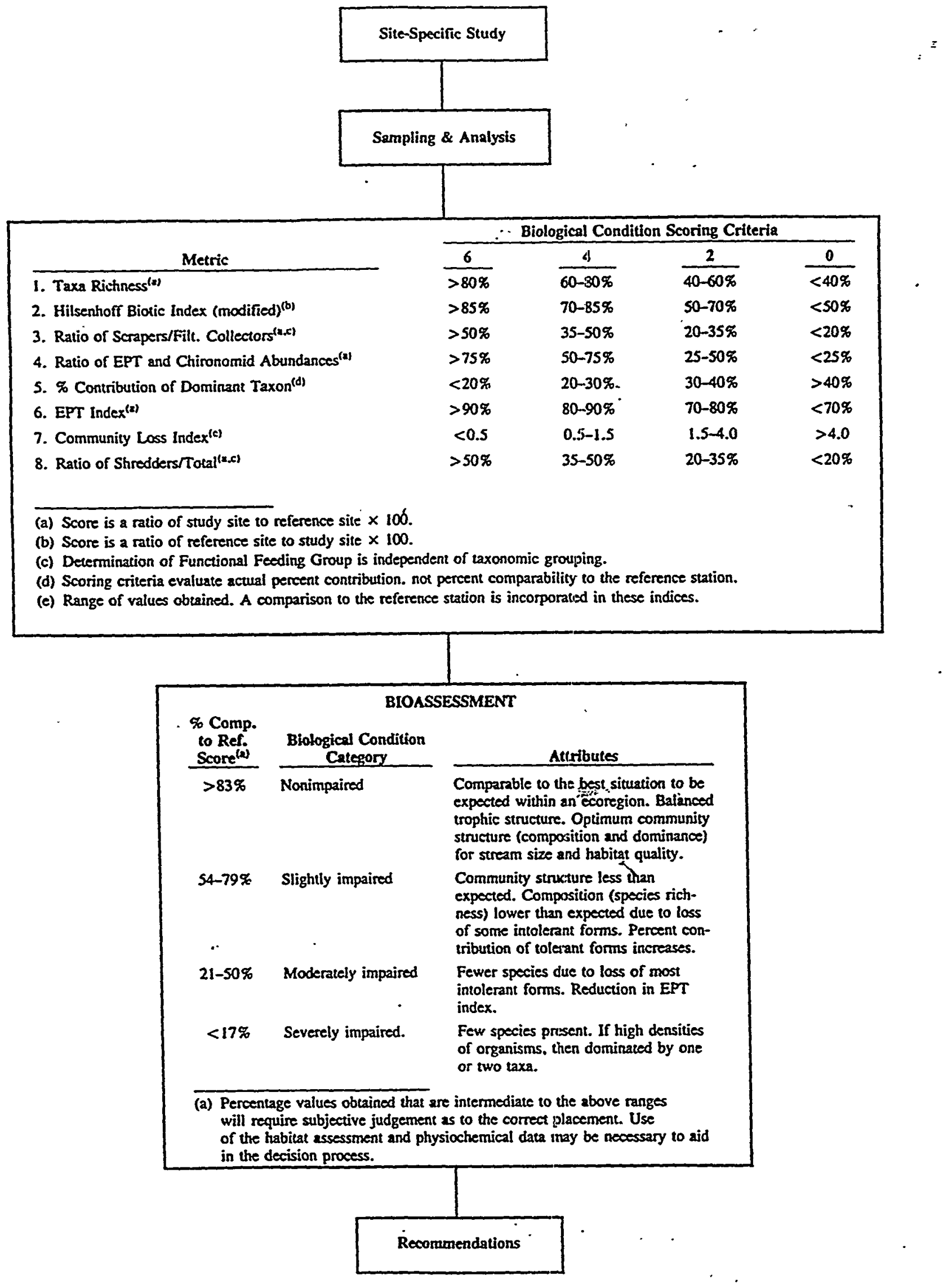

Figure 6.3-4. Flowchart of bioassessment approach adrocated for Rapid Bioassessment Protocol III. 
Station 14. Beaver Dam Creek at Metal Walkway. RBP III. 21 September 199

Taxa List

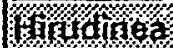

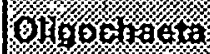

Steneinitiv spo:

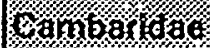

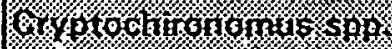

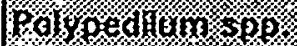

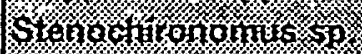

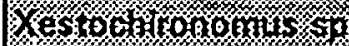

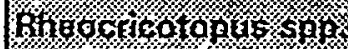

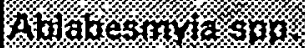

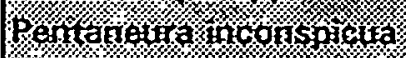

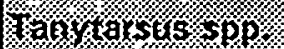

Bastirs 5po:

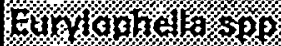

Stenanenta Spa.

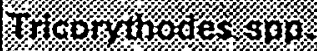

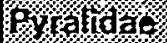

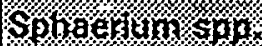

Fentisstitisn.

Atipio spp

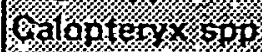

Ginainaonovspo?

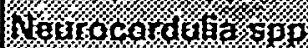

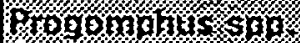

Givinorfo: spov

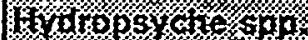

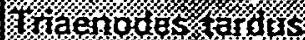

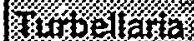

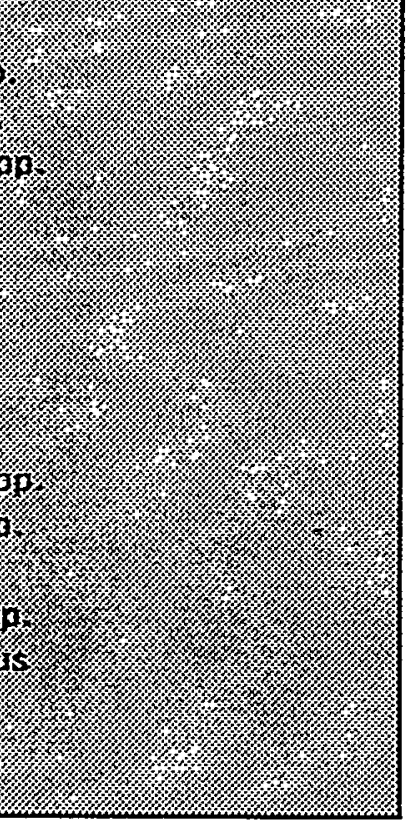

$E *$ 


\begin{tabular}{|c|c|c|c|c|c|c|c|}
\hline 59 & Stempellinella spp. & DTY & 5.3 & CG & 0.00 & & 0.00 \\
\hline 60 & Tanytarsus spp. & DTY & 6.7 & CG & 569.60 & 85 & 25.84 \\
\hline 61 & Acentrella ampla & EP & 3.6 & CG & 0.00 & & 0.00 \\
\hline 62 & Acerpenna pygmaeus & EP & 3.7 & CG & 0.00 & & 0.00 \\
\hline 63 & Acerpenna spp. & EP & 3.7 & $\overline{C G}$ & 0.00 & & 0.00 \\
\hline 64 & Baetis spp. & EP & 5.4 & CG & 81.00 & 15 & 4.66 \\
\hline 65 & Caenis spp. & EP & 7.6 & CG & 0.00 & & 0.00 \\
\hline 66 & Callibaetis spp. & EP & 9.3 & $\mathbf{C G}$ & 27.90 & 3 & 0.91 \\
\hline 67 & Eurylophells spp. & EP & 3 & CG & 0.00 & & 0.00 \\
\hline 68 & Hexagenia spp. & EP & 4.7 & CG & 0.00 & & 0.00 \\
\hline 69 & Isonychia spp. & EP & 3.8 & $\mathrm{CF}$ & 0.00 & & 0.00 \\
\hline 70 & Neoephemera youngi & EP & 2.1 & CG & 0.00 & & 0.00 \\
\hline 71 & Paraleptophlebia spp. & EP & 1.2 & $\overline{C G}$ & 0.00 & & 0.00 \\
\hline 72 & Siphlonurus sp. & EP & 2.6 & CG & 0.00 & & 0.00 \\
\hline 73 & Stenonema spp. & EP & 3.4 & SC & 3.40 & 1 & 0.30 \\
\hline 74 & Tricorythodes spp. & EP & 5.4 & $\mathbf{C G}$ & 27.00 & 5 & 1.52 \\
\hline 75 & Belostoma sp. & $\overline{H T}$ & 9.8 & $P$ & 0.00 & & 0.00 \\
\hline 76 & Hesperocorixa sp. & HT & 9 & $\mathrm{H}$ & 0.00 & & 0.00 \\
\hline 77 & Pyralidee & LEP & 5 & $H$ & 5.00 & 1. & 0.30 \\
\hline 78 & Corbicula sp. & $\mathrm{MB}$ & 6.3 & $\mathrm{CF}$ & 0.00 & & 0.00 \\
\hline 79 & Eliptio spp. & MB & 3.4 & $\mathrm{CF}$ & 0.00 & 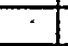 & 0.00 \\
\hline 80 & Sphaerium spp. & $M B$ & 7.7 & $\overline{C F}$ & 53.90 & 7 & 2.13 \\
\hline 81 & Nigronia serricornis & ME & 5.5 & $P$ & 0.00 & & 0.00 \\
\hline 82 & Sialis spp. & $\mathrm{ME}$ & 7.7 & $P$ & 0.00 & & 0.00 \\
\hline 83 & Campeloms sp. & MG & 6.7 & sc & 0.00 & & 0.00 \\
\hline 84 & Ferrissia sp. & MG & 6.9 & SC & 0.00 & & 0.00 \\
\hline 85 & Hydrobiidae & MG & & SC & & & 0.00 \\
\hline 86 & Physella spp. & MG & 9.1 & SC & 0.00 & & 0.00 \\
\hline 87 & Planorbidae & MG & 6.5 & Sc & 0.00 & & 0.00 \\
\hline 88 & Nemertea & NA & & $P$ & & 3 & 0.91 \\
\hline 89 & Argia spp. & $O D$ & 8.7 & $P$ & 60.90 & 7 & 2.13 \\
\hline 90 & Boyeria vinosa & $\overline{O D}$ & 6.3 & P & 0.00 & & 0.00 \\
\hline 91 & Calopteryx spp. & OD & 8.3 & $P$ & 0.00 & & 0.00 \\
\hline 92 & Enallagma spp. & OD & 9 & $P$ & 27.00 & 3 & 0.91 \\
\hline 93 & Gomphus spp. & $\overline{O D}$ & 6.2 & P & 6.20 & 1 & 0.30 \\
\hline 94 & Macromis spp. & $\overline{O D}$ & 6.7 & $P$ & 0.00 & & 0.00 \\
\hline 95 & Neurocordulia spp. & $O D$ & 5.8 & $P$ & 5.80 & 1 & 0.30 \\
\hline 96 & Pachydiplex longipennis & $O D$ & 9.6 & $P$ & 0.00 & & 0.00 \\
\hline 97 & Progomphus spp. & OD & 8.7 & P & 0.00 & & 0.00 \\
\hline 98 & Acroneuria spp. & $\mathrm{PL}$ & 1.4 & $P$ & 0.00 & & 0.00 \\
\hline 99 & Allocapnia spp. & $\mathrm{PL}$ & 2.8 & SH & 0.00 & & 0.00 \\
\hline 100 & Leuctra spp. & $\mathrm{PL}$ & 0.7 & $\mathrm{SH}$ & 0.00 & & 0.00 \\
\hline 101 & Perlinella spp. & PL & 0 & $P$ & 0.00 & & 0.00 \\
\hline 102 & Anisocentropus pyraloides & $\overline{T R}$ & 0.8 & $\mathrm{SH}$ & 0.00 & & 0.00 \\
\hline 103 & Brachycentrus numerosus & TR & 1.8 & CF & 0.00 & & 0.00 \\
\hline 104 & Cheumatopsyche spp. & TR & 6.6 & $\mathrm{CF}$ & 0.00 & & 0.00 \\
\hline 105 & Chimarra spp. & TR & 2.8 & $\mathrm{CF}$ & 0.00 & & 0.00 \\
\hline 106 & Hydropsyche spp. & $T R$ & 4 & CF & 0.00 & & 0.00 \\
\hline 107 & Hydroptila spp. & TR & 6.2 & $H$ & 0.00 & & 0.00 \\
\hline 108 & Lepidostoma spp. & TR & 1 & SH & 0.00 & & 0.00 \\
\hline 109 & Nectopsyche exquisita & TR & 4.1 & $\mathrm{SH}$ & 8.20 & 2 & 0.61 \\
\hline 110 & Oecetis spp. & $T R$ & 5.7 & $P$ & 0.00 & & 0.00 \\
\hline 111 & Oxyethira spp. & TR & 6.2 & $H$ & 37.20 & 6 & 1.82 \\
\hline 112 & Phylocentropus spp. & TR & 5.6 & $\mathrm{CF}$ & 0.00 & & 0.00 \\
\hline 113 & Polycentropus spp. & TR & 3.5 & CF & 0.00 & & 0.00 \\
\hline 114 & Pycnopsyche spp. & TR & 2.3 & SH & 0.00 & & 0.00 \\
\hline 115 & Trizenodes tardus & TR & 4.7 & $\mathrm{SH}$ & 9.40 & 2 & 0.61 \\
\hline 116 & Turbellaria & TU & 7.5 & $P$ & 97.50 & 13 & 3.95 \\
\hline
\end{tabular}




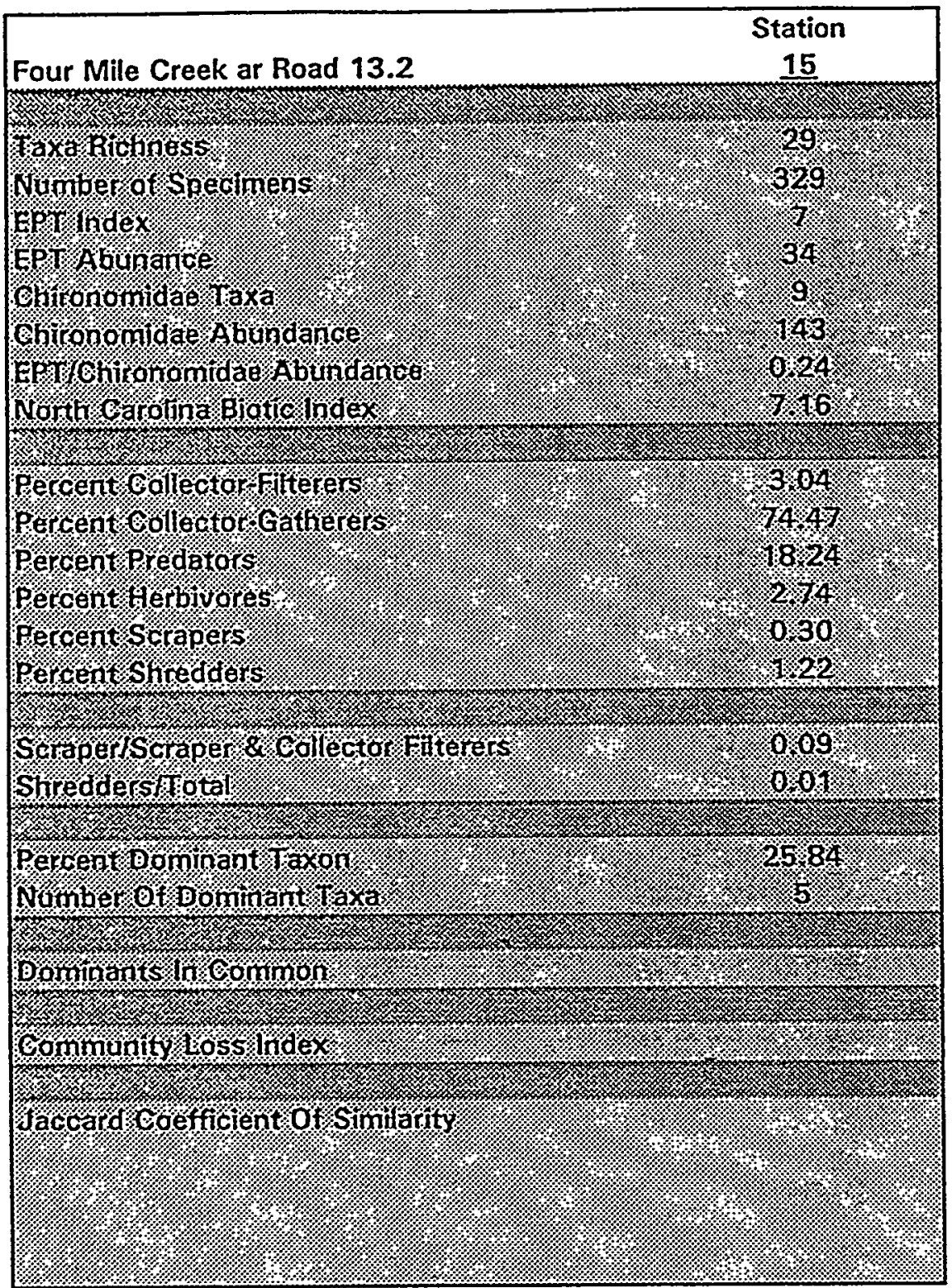




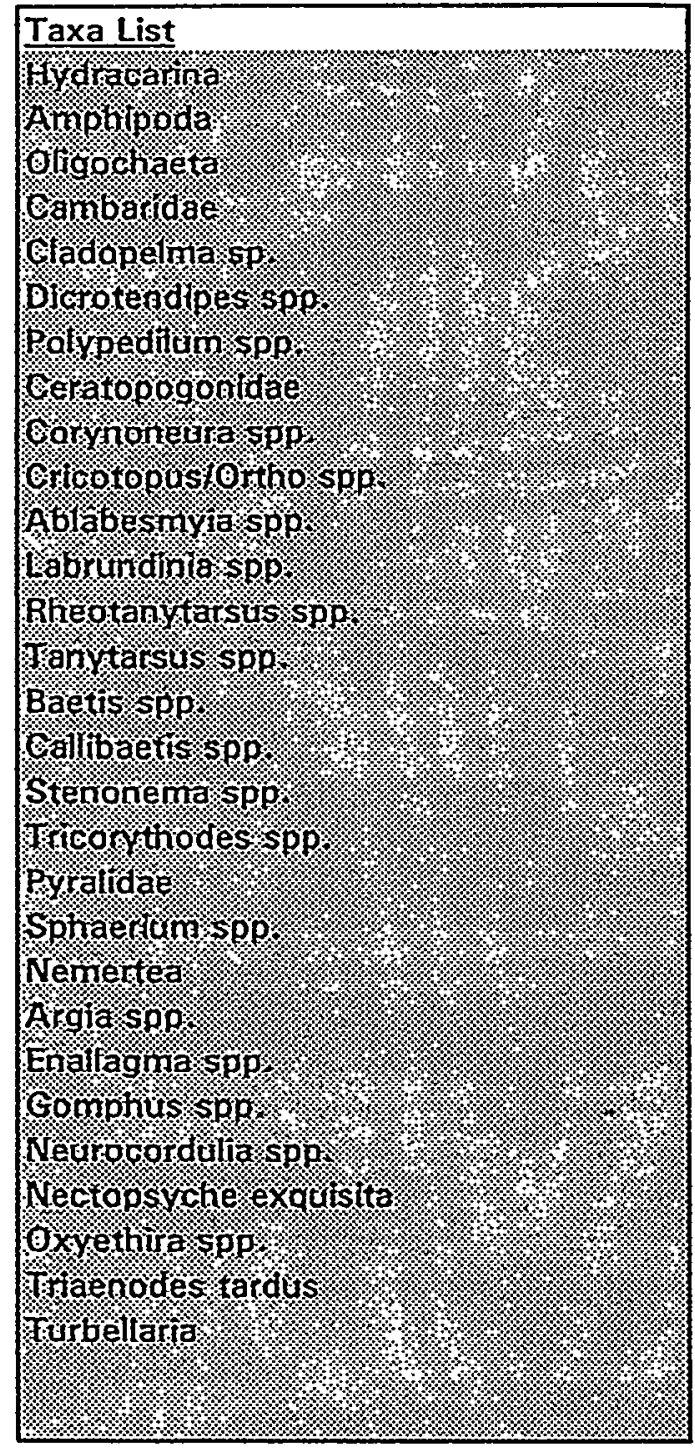

sises 
Rosemary Creek Downstream of Williston WWTP. 17 December 1994. RBP III.

\begin{tabular}{|c|c|c|c|c|c|c|c|}
\hline Seq & Taxon & TAXC & \begin{tabular}{|l|}
$\mathrm{NCBI}$ \\
\end{tabular} & FG & For $\mathrm{Bl}$ & A & Rel Abd \\
\hline 1 & Hydracarina & $\overline{A H C}$ & 5.7 & $P$ & 0.00 & & 0.00 \\
\hline 2 & Amphipoda & $A M$ & 8 & CG & 8.00 & 1 & 0.41 \\
\hline 3 & Oligocnaeta & ANO & 8.4 & CG & 8.40 & 1 & 0.41 \\
\hline 4 & Hydra spp. & CN & & $\mathbf{P}$ & & & 0.00 \\
\hline 5 & Ancyronyx variegatus & $\mathrm{CO}$ & 7.1 & CG & 0.00 & & 0.00 \\
\hline 6 & Dubiraphia bivattata & $\mathrm{CO}$ & 6.6 & CG & 0.00 & & 0.00 \\
\hline 7 & Ectopria nervosa & $\mathrm{CO}$ & 4.5 & Sc & 4.50 & 1 & 0.41 \\
\hline 8 & Macronychus glabratus & co & 4.9 & CG & 0.00 & & 0.00 \\
\hline 9 & Stonolmis sp. & $\mathrm{CO}$ & 5.6 & CG & 5.60 & 1 & 0.41 \\
\hline 10 & Cambaridae & DC & 9 & $\vec{H}$ & 36.00 & 4 & 1.64 \\
\hline 11 & Palaemonates paludosus & $D C$ & 6.9 & CG & 41.40 & 6 & 2.46 \\
\hline 12 & Chironomus spp. & DCC & 10 & $\mathbf{C G}$ & 0.00 & & 0.00 \\
\hline 13 & Cryptochironomus spp. & DCC & 7.5 & $\mathbf{P}$ & 0.00 & & 0.00 \\
\hline 14 & Cryptotendipes spp. & DCC & 6.3 & CG & 0.00 & & 0.00 \\
\hline 15 & Dicrotendipes spp. & DCC & 8.1 & CG & 0.00 & & 0.00 \\
\hline 16 & Microtondipos rydalensis & DCC & 6.4 & CG & 0.00 & - & 0.00 \\
\hline 17 & Microtendipes spp. & DCC & 6.4 & CG & 0.00 & & 0.00 \\
\hline 18 & Nilothauma babiyi & DCC & 5.7 & $\mathbf{C G}$ & 0.00 & & 0.00 \\
\hline 19 & Phaenopsectra flavipes & DCC & 8.7 & CG & 0.00 & & 0.00 \\
\hline 20 & Polypodilum fallax & DCC & 6.9 & $\mathrm{SH}$ & 0.00 & & 0.00 \\
\hline 21 & Polypodilum spp. & DCC & 7.1 & CG & 142.00 & 20 & 8.20 \\
\hline 22 & Robackia sp. & DCC & 3.5 & CG & 0.00 & & 0.00 \\
\hline 23 & Stelechomyia perpulchra & DCC & 4.8 & SH & 0.00 & & 0.00 \\
\hline 24 & Stonochironomus sp. & DCC & 6.6 & SH & 0.00 & & 0.00 \\
\hline 25 & Tribelos jucundum & DCC & 6.8 & CG & 6.80 & 1 & 0.41 \\
\hline 26 & Xostochironomus sp. & DCC & & $\mathrm{SH}$ & & & 0.00 \\
\hline 27 & Potthastia longmana & DD & 7.6 & CG & 0.00 & & 0.00 \\
\hline 28 & Atherix lantha & DO & 2.3 & $\mathbf{P}$ & 0.00 & & 0.00 \\
\hline 29 & Ceratopogonidae & DO & 6.7 & $\mathbf{P}$ & 0.00 & & 0.00 \\
\hline 30 & Hemerodromia spp. & DO & 8.3 & CG & 0.00 & & 0.00 \\
\hline 31 & Simulium spp. & DO & 4.6 & CF & 27.60 & 6) & 2.46 \\
\hline 32 & Tipula abdominalis & DO & 7.9 & SH & 7.90 & 1 & 0.41 \\
\hline 33 & Brilla flavifrons & DOR - & 5.4 & SH & 0.00 & & 0.00 \\
\hline 34 & Corynoneura spp. & DOR & 6.4 & CG & 32.00 & 5 & 2.05 \\
\hline 35 & Cricotopus/Ortho spp. & DOR & 9 & CG & 18.00 & 2 & 0.82 \\
\hline 36 & Eukiofforiolla spp. & DOR & 5.9 & CG & 0.00 & & 0.00 \\
\hline 37 & Lopescladius spp. & DOR & 2.2 & $\mathbf{C G}$ & 0.00 & & 0.00 \\
\hline 38 & Nanocladius spp. & DOR & 7.4 & CG & 0.00 & & 0.00 \\
\hline 39 & Parakiofforiolla sp.1 & DOR & 6.1 & CG & 0.00 & & 0.00 \\
\hline 40 & Parametriocnemus sp. & DOR & 3.9 & CG & 3.90 & 1 & 0.41 \\
\hline 41 & Rheocricotopus spp. & DOR & 7.5 & CG & 105.00 & 14 & 5.74 \\
\hline 42 & Synorthocladius semivirons & DOR & 4.9 & CG & 0.00 & & 0.00 \\
\hline 43 & Thienemanniella spp. & DOR & 6.2 & CG & 12.40 & 2 & 0.82 \\
\hline 44 & Tvotenia spp. & DOR & 4.2 & CG & 37.80 & 9 & 3.69 \\
\hline 45 & Xylopus par & DOR & 6.8 & $\mathrm{SH}$ & 0.00 & & 0.00 \\
\hline 46 & Ablebesmyia spp. & DTA & 6.6 & $\mathbf{P}$ & 13.20 & 2 & 0.82 \\
\hline 47 & Conchapelopia spp. & DTA & 8.9 & $P$ & 26.70 & 3 & 1.23 \\
\hline 48 & Labrundinia spp. & DTA & 6.2 & $P$ & 6.20 & 1 & 0.41 \\
\hline 49 & Larsia spp. & DTA & 8.5 & $P$ & 8.50 & 1 & 0.41 \\
\hline 50 & Nilotenypus spp. & DTA & 4.2 & $\mathbf{P}$ & 0.00 & & 0.00 \\
\hline 51 & Paramerina sp. & DTA & 3 & $P$ & 0.00 & & 0.00 \\
\hline 52 & Ponteneura inconspicua & DTA & 4.8 & $\mathbf{P}$ & 0.00 & & 0.00 \\
\hline 53 & Procladius spp. & DTA & 9.5 & $P$ & 0.00 & & 0.00 \\
\hline 54 & Rheotanytarsus spp. & DTY & 6.6 & $\mathrm{CF}$ & 191.40 & 29 & 11.89 \\
\hline 55 & Stempellinella spp. & DTY & 5.5 & CG & 5.50 & 1 & 0.41 \\
\hline 56 & Tanytarsus spp. & DTY & 6.9 & CG & 200.10 & 29 & 11.89 \\
\hline 57 & Acarpenna pygmaeus & EP & 3.9 & CG & 0.00 & & 0.00 \\
\hline 58 & Boetis spp. & EP & 5.6 & CG & 84.00 & 15 & 6.15 \\
\hline
\end{tabular}


Rosemary Creek Downstream of Williston WWTP. 17 December 1994. RBP III.

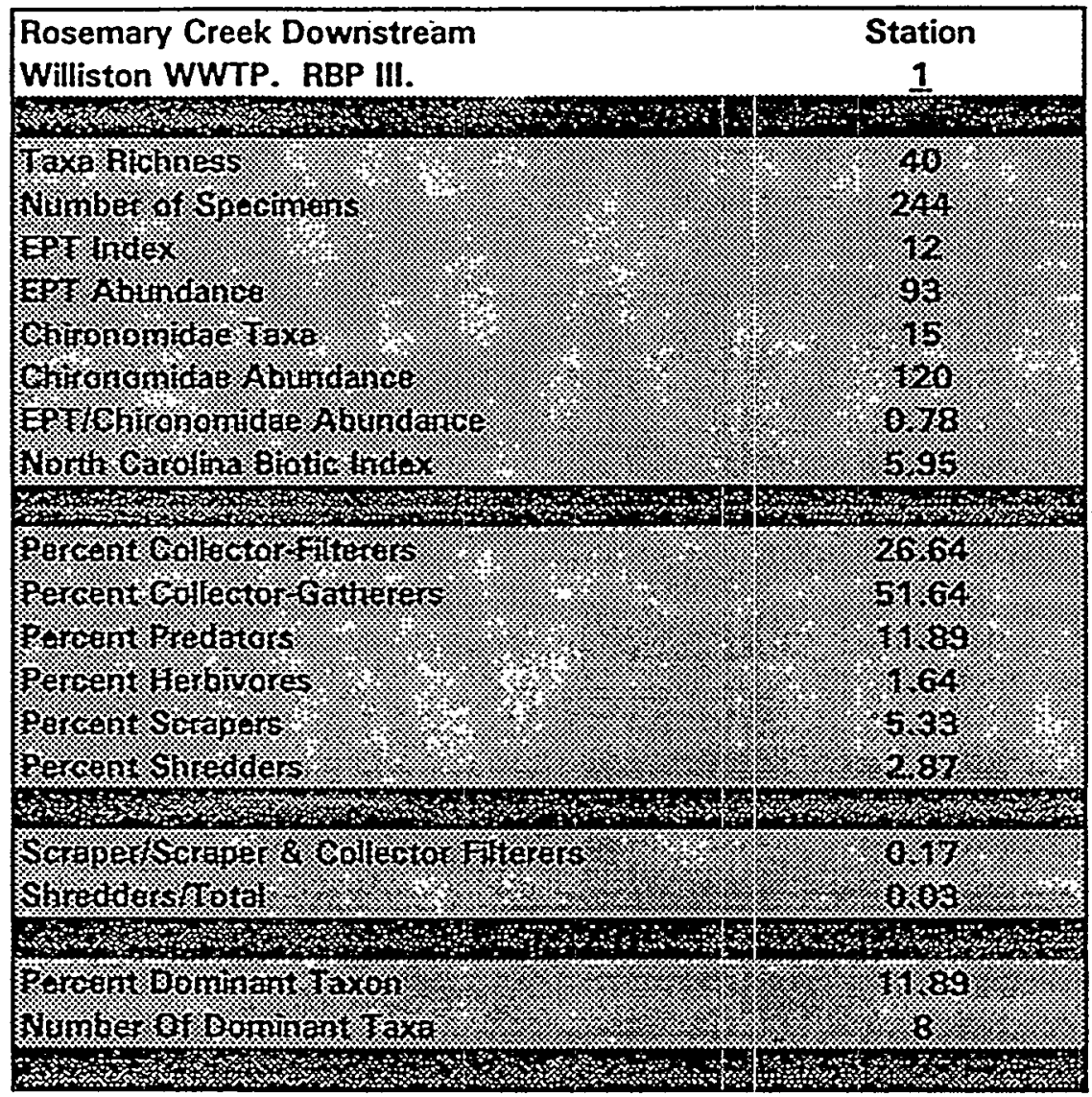


Rosemary Creek Downstream of Williston WWTP. 17 December 1994. RBP III.

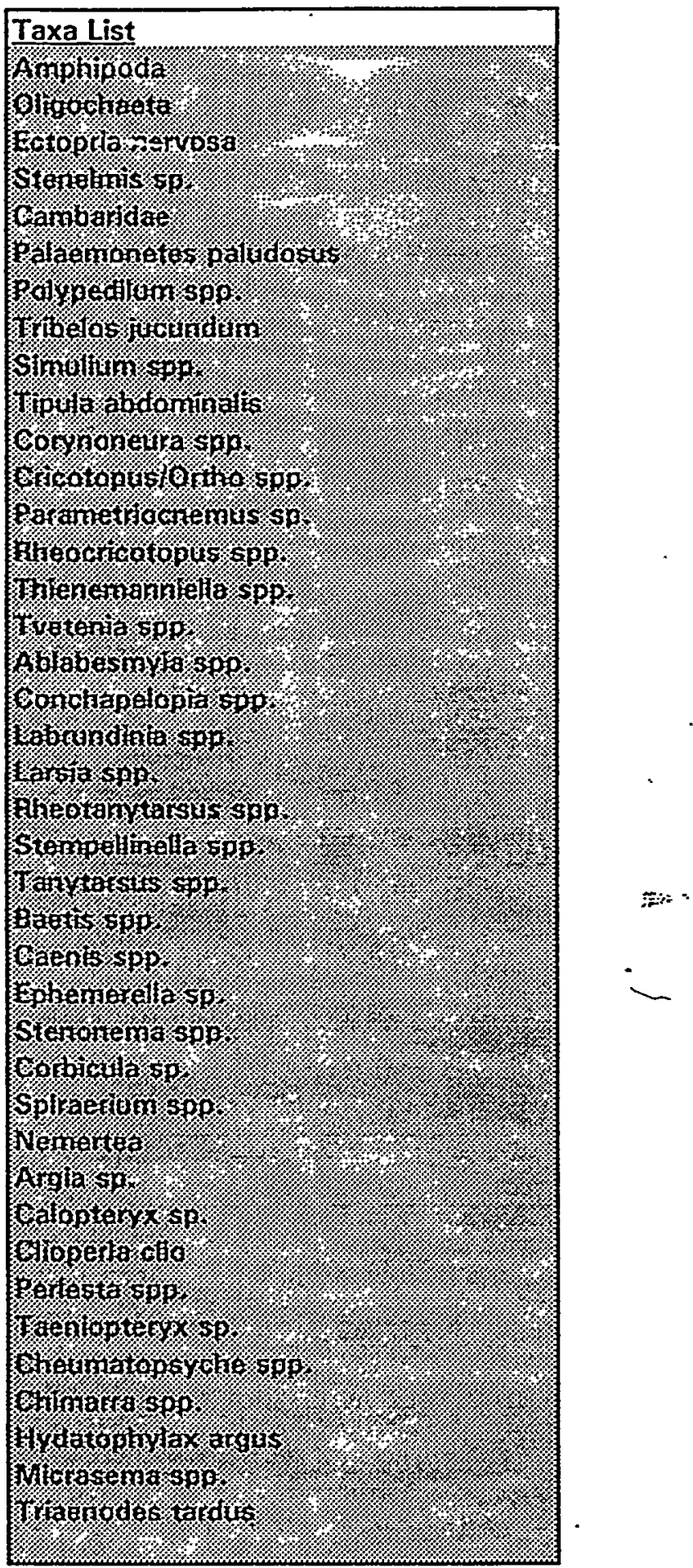


APPENDIX B

\section{EPA RAPID BIOASSESSMENT PROTOCOL METHODS}




\section{BENTHUC MACROINVERTEBRATE BIOSURVEY AND DATA ANALYSIS}

The biosurvey and data anaiysis components of the three benthic bioassessment protocols are presented below. All three protocols have common biosurvey and data analysis elements. Common elements and discussions are repeated in each protocol to maintain discrete protocol integrity.

Examples of field and laboratory data sheets referred to in this chapter are presented for guidance. The example data sheets do not include headers for documenting identifier information, and may be modified for the needs of different agencies. Descriptive guidance for use with each data sheet is found in Appendix A.

The three protocols consist of three basic components: water quality/physical characteristics (Figure 5.1-1), habitat assessment (Figure 5.2-1), and a biosurvey (Figures 6.1-1, 6.2-1, and 6.3-1). The overall habitat assessment evaluates habitat quality using the key environmental parameters described in Chapter 5. If a degraded community is found from the results of the biosurvey, habitat information will aid interpretation of effects relative to the biotic potential of a site. The water quality and physical characterizations provide data on stream habitat quality as well as potential sources and/or causes of impairment.

\subsection{RAPID BIOASSESSMENT PROTOCOL I-Benthic Macroinvertebrates}

Rapid Bioassessment Protocol I (RBP I) is a screening or reconnaissance assessmeint that involves... systematic documentation of specific visual observations made in the field by a trained professional. RBP I is used to discriminate obviously impacted and non-impacted areas from potentially affected areas requiring further investigation. Use of RBP I allows rapid screening of a large number of sites. Areas identified for further study can then be rigorously evaluated using RBPs II, III, and V; quantitative fish . or benthic surveys; or ambient toxicity studies.

Because RBP I involves limited data generation, its effectiveness depends largely on the experience ("best professional judgment") of the professional biologist performing the assessment. The biologist conducting
RBP I should have professional impact assessment experience with a knowledge of aquatic ecology and basic expertise in benthic macroinvertebrate taxonomy.

\subsubsection{Field Methods}

The biosurvey component of RBP I focuses on qualitative sampling of benthic macroinvertebrates, supplemented by a preliminary field examination of other aquatic biota (periphyton, macrophytes, slimes, and fish). Qualitative benthic samples are collected from all available habitats using a dip net or kick net, or by hand. Benthic macroinvertebrate orders/families (e.g., families for Megaloptera and Diptera) collected are listed on the Biosurvey Field Data Sheet (Figure 6.1-1), with an estimate of their relative abundance

- in the sampling area. Each State agency should develop its own definitions for abundance categories. Lower levels of identification, if they are easily determined, can enhance the assessment. Any observations on the relative abundance of other aquatic biota are also noted; these observations provide additional information on the presence or absence of impact.

\section{6:1:2 Data Analysis Techniques}

Impairment may be indicated by the absence of generally pollution-sensitive benthic macroinvertebrate taxa such as Ephemeroptera, Plecoptera, and Trichoptera (EPT); dominance of generally pollution-tolerant groups such as Oligochaeta or Chironomidae; or overall low benthic abundance or taxa richness. Benthic abundance or taxa richness indicative of impairment is variable and must be evaluated with respect to the waterbody being evaluated. Some headwater streams are naturally unproductive and will be characterized by low benthic abundance and taxa richness in their pristine state. Impairment may also be indicated by an overabundance of slimes or filamentous algae in the area or an absence of expected fish populations.

On the basis of the observations made on habitat, water quality, physical characteristics, and the qualitative biosurvey, the investigator determines whether -impairment is detected. The determination of impairment requires the judgment of an experienced professional. If impairment is detected, the investigator provides an estimation of the probable cause and source on the Impairment Assessment Sheet (Figure 6.1-2). The aquatic biota that indicated an impair- 
IHPAIRKENT ASSESSHENT SHEET

1. Detection of impairment: Impairment detected (Complete itens 2-6)
No Impaitment
detected
(Stop here)

2. Biological impairment indicator:

Benthic macroinvertebrates absence of EPT taxa dowinance of colerant groups

lov benthic abundance

_lov raxa richness

other
Other aquatic communities

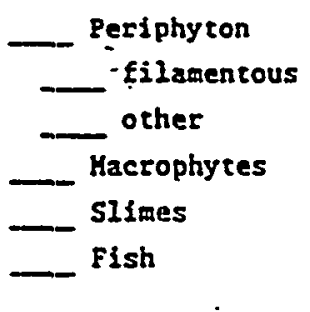

3. Brief description of problem: Year and dace of previous surveys: Survey datz available in:

4. Cause: (indicare major cause) organic: enrichment toxicants flor habitat linitacions other

5. Estimated areal extent of problen $\left(m^{2}\right)$ and length of strean reach affected (m), where applicable:

6. Suspected source(s) of problem: 洋: point source discharge (name, type of facility, location) construction site runoff combined sever outfall silviculture runoff animal feedlot agricultural runoff urban runoff ground vater other unknoun

Briefly explain:

Figure 6.1-2. Impairment Assessment Sheet for use with macroinvertebrate Rapid Biosssessinent Protocols. 

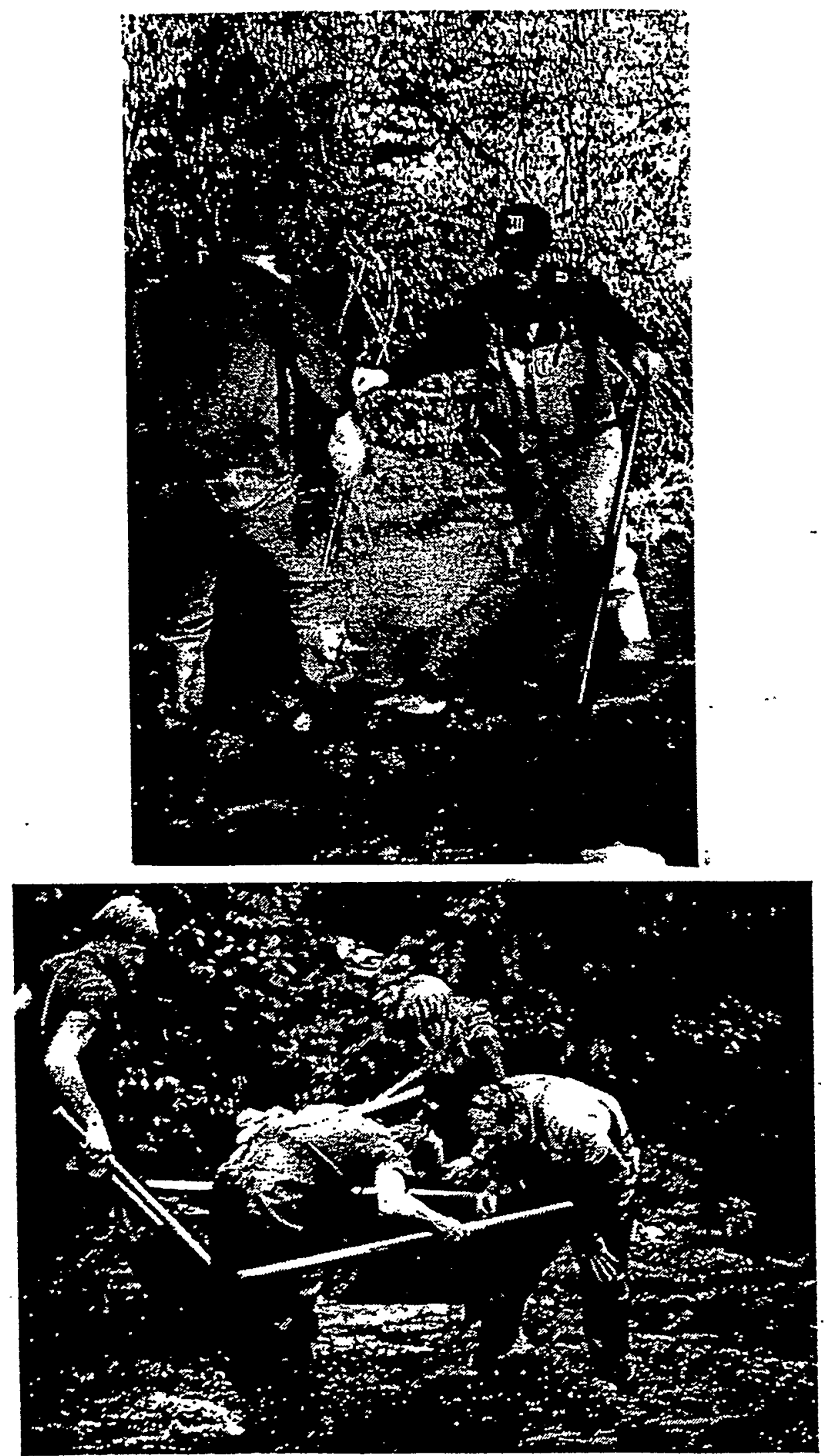

Kick net sampling in riffle area. 
The CPOM sample is processed separately from the riffle/run sample and used only for characterizing the Functional Feeding Group representation. Sampling the CPOM component requires a composite collection of various plant parts such as leaves, needles, twigs, bark, or their fragments. Potential sample sources include leaf packs, shorezones, and other depositional areas where CPOM may accumulate. Only the upper surface of litter accumulation in depositional areas should be sampled to ensure that they are from the aerobic zone. For the Shredder community analysis, several handfuls of material should be adequate. A variety of CPOM forms should be collected if available. CPOM collected may be washed in a dip net or a sieve bucket.

Shredder abundance is maximum when the CPOM is about 50 percent decomposed (Cummins et al. 1989). Çare must be taken to avoid collecting recent or fully decomposed leaf litter to optimize collection of the Shredder community. For this CPOM, collection technique, seasonality may have an important influence on Shredder abundance data. For instance, fast-processing litter (e.g., basswood, alder, maples, birch) would have the highest Shredder representation in the winter (Cummins et al. 1989). The slowprocessing litter (e.g., oaks, thododendrons, beech, conifers) would have the highest Shredder representation in the summer.

\subsubsection{Sample Sorting and Identification}

\section{Riffle/Run Sample}

Sorting and enumeration in the field to obtain a 100 -count organism subsample is recommended for the riffle/run sample. After processing in the field, the organisms and sample residue should be preserved for archiving. Thus, a re-analysis (quality control) or more thorough processing (e.g., larger counts, more detailed taxonomy) would be possible. The subsam- pling method described in this protocol is based on Hilsenhoff's Improved Biotic Index (Hilsenhoff 1987b) and is similar to that used by New York DEC (Bode 1988). This subsampling technique provides for a consistent unit of effort and a representative estimate of the benthic fauna.

The subsampling procedure consists of evenly distributing the composite sample into a gridded pan with a light colored bottom. Grids are randomly selected and all organisms within those grids are removed until approximately 100 organisms are picked out. Because this subsampling technique is being * applied to samples with live organisms, narcotization using club soda or tobacco is recommended. A more detailed description of this technique may be found in Appendix B.
An alternative method of subsampling live samples in the field. is to simply sort 100 organisms in a random rnanner. Narcotization to slow the organisms is less important with this subsampling technique. To lessen sampling bias, the investigator should pick smaller, cryptic organisms, as well as the larger, more obvious organisms.

All organisms in the subsample should be classified according to Functional Feeding Group. Field classification is impqrtant because many families comprise genera and species representing a variety of functional groups. Knowing the family-level identification of the organisms will generally be insufficient for categorization by Functional Feeding Group. Functional Feeding Group classification can be-done in the field, on the basis of morphological and behavioral - features, using Cummins and Wilzbach (1985). Care should be taken in noting early instars, which may constitute different Functional Feeding Groups from the later instars.

The Scraper and Filtering Collector Functional Groups are the most important indicators in the rifflel run community. Numbers of individuals representing each of these two groups are recorded on the Biosurvey Field Data Sheet (Figure 6.2-1). All organisms in the subsample should be identified to family or order, enumerated, and recorded, along with any observations on abundance of other aquatic biota, on the Biosurvey Field Data Sheet. A summary of all benthic data to be used in the final analysis will be recorded on the Data Summary Sheet (Figure 6.2-2) upon return to the laboratory.

The use of family-level identification in this protocol is based on Hilsenhoff's Family Biotic Index which uses higher taxonomic levels of identification (Hilsenhoff 1988). Tolerance characterizations for the Family Biotic Index (FBI) and excerpts from Hilsenhoff's paper describing the index are inciuded in Appendix C. Assessment based on family-level identifications has been used successfully by the States of Virginia and Illinois.

\section{CPOM Sample}

Organisms collected in the supplemental CPOM sample are classified as Shredders or Non-Shredders. Taxonornic identification is not necessary for this component. The composited CPOM sample may befield sorted in a small pan with a light colored bottom .or in the net or sieve through which it was rinsed. (If a large number of benthic macroinvertebrates have been collected, a representative subsampling of 20-60 organisms may be removed for Functional Feeding Group classification.) Numbers of individuals representing the Shredder Functional Group, as well 

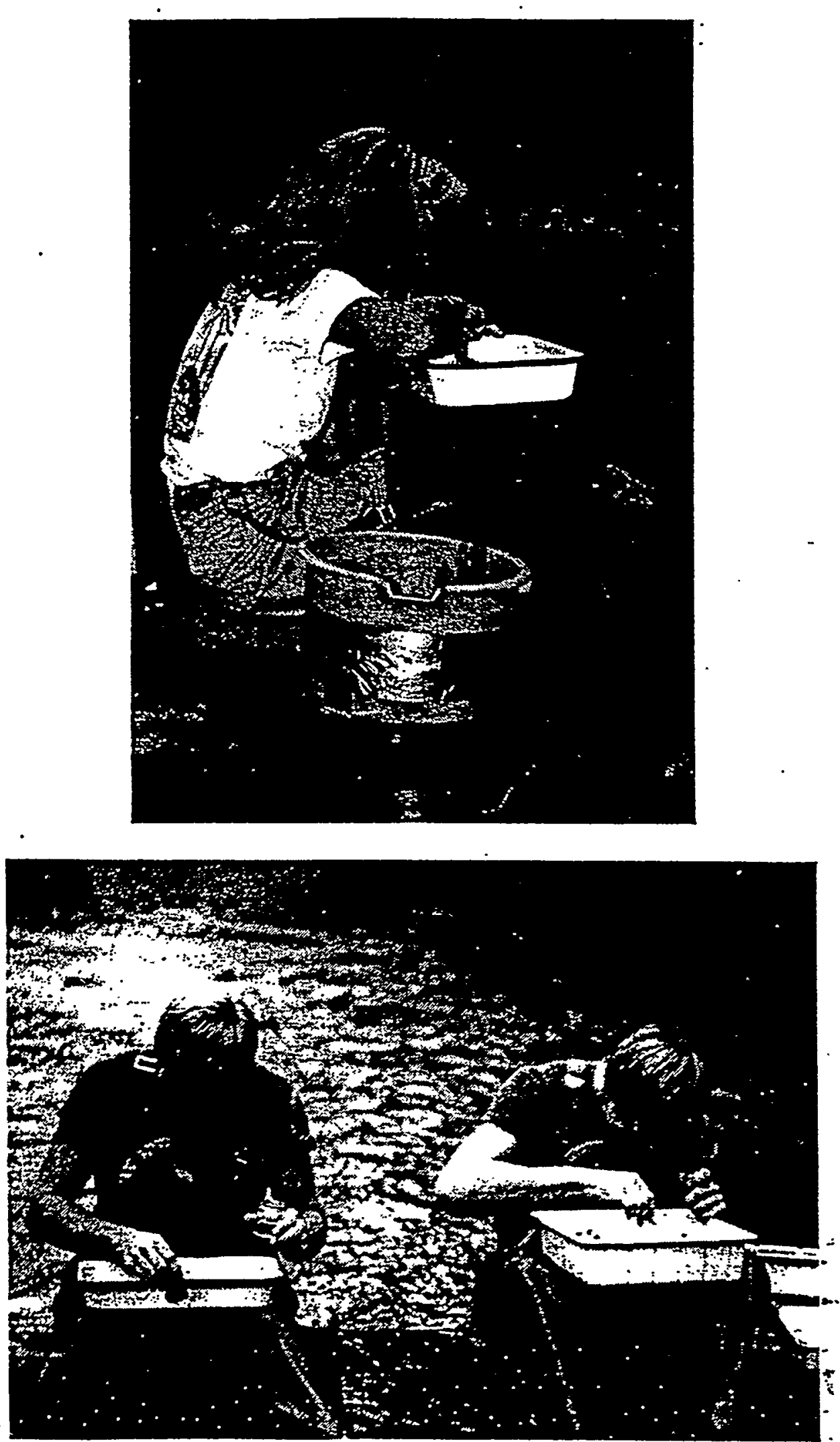

Field sorting of benthic macroinvertebrate samples for Rapid Bioassessment Protocol II. 


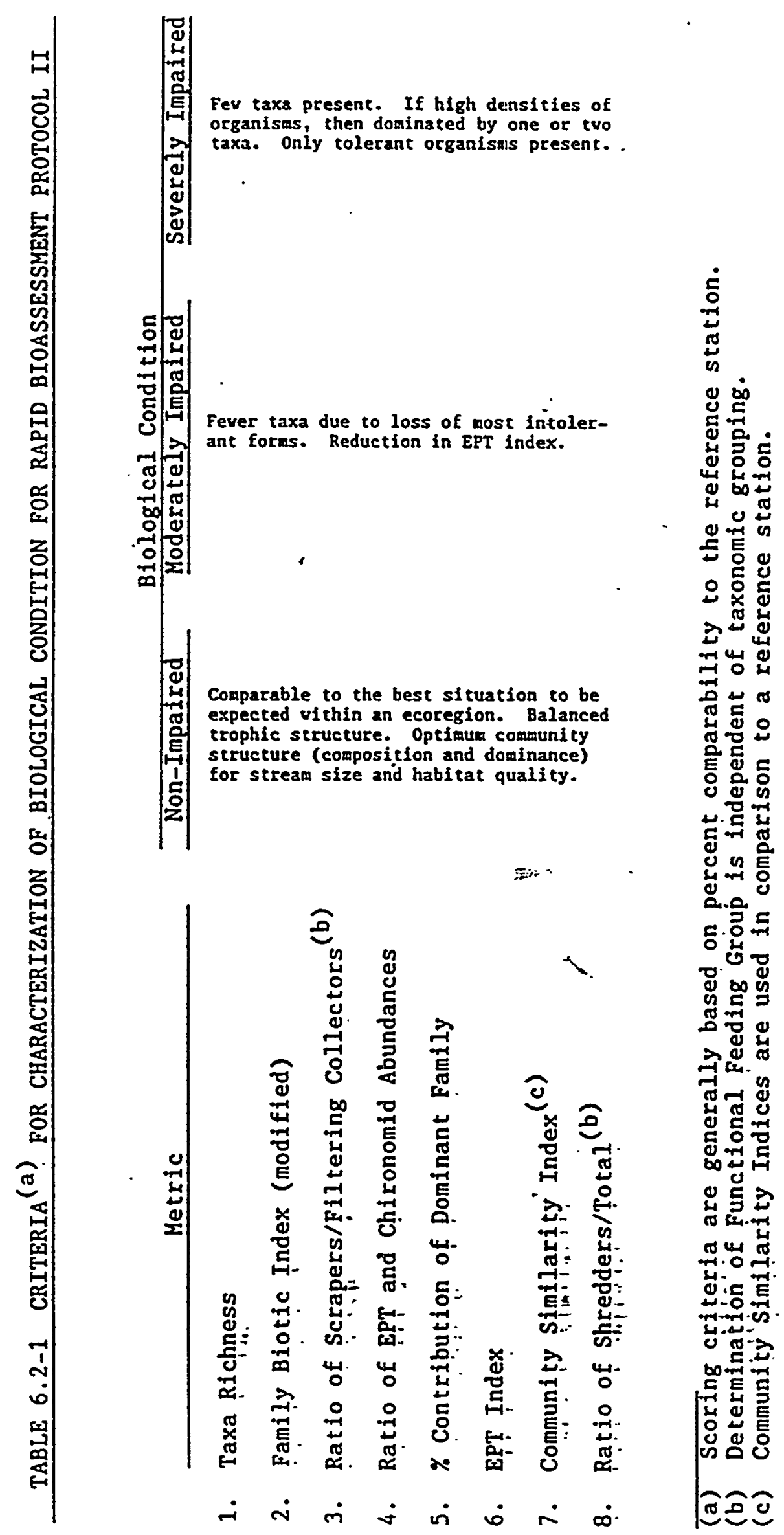




\section{Riffle/Run Sample}

Metric 1. Taxa Richness

Reflects health of the community through a measurement of the variety of taxa (total number of families) present. Generally increases with increasing water quality, habitat diversity, and habitat suitability. Sampling of highly similar habitats will reduce the variability in this metric attributable to factors such as current speed and substrate type. Some pristine headwater streams may be naturally unproductive, supporting only a very limited number of taxa. In these situations, organic enrichment may result in an increased number of taxa (including EPT taxa).

\section{Metric 2. Modified Family Biotic Index}

Tolerance values range from 0 to 10 for families and increase as water quality decreases. The index was developed by Hilsenhoff (Hilsenhoff 1988) to summarize the various tolerances of the benthic arthropod community with a single value. The Modified Family Biotic Index was developed to detect organic pollution and is based on the original species-level index (Hilsenhoff 1982). Tolerance values for each family were developed by weighting species according to their relative abundance in the State of Wisconsin.

The family-level index has been modified for this document to include organisms other than just arthropods using the genus and species-level biotic index developed by the State of New York (Bode 1988). The formula for calculating the Family Biotic Index is:

$$
F B I=\Sigma \frac{x_{i} t_{i}}{n}
$$

where

$x_{i}=$ number of individuals within a taxon:

$t_{i}=$ tolerance value of a taxon

$\mathbf{n}=$ total number of organisms in the sample

Hilsenhoff's family-level tolerance values may require modification for some regions. Alternative tolerance classifications and biotic indices have been developed by some State agencies (Appendix C). Additional biotic indices are listed in U.S. EPA (1983).

Although the FBI may be applicable for toxic pollutants, it has only been evaluated for organic pollutants. The State of Wisconsin is conducting a study to evaluate the ability of Hilsenhoff's index to detect nonorganic effects.

Metric 3. Ratio of Scraper and Filtering Collector Functional Feeding Groups

- The Scraper and Filtering Collector metric reflects the riffle/run community foodbase. When compared to a reference site, shifts in the dominance of a particular feeding type indicate a community responding to an overabundance of a particular food source. The predominant feeding strategy reflects the type of impact detected. Assignment of individuals to Functional Feeding Groups is independent of taxonomy, with some families representing several functional groups.

A description of the Functional Feeding Group concept can be found in Cummins . (1973) and Merritt and Cummins (1984). Functional Feeding Group designations for most aquatic insect families may be found

. in Merritt and Cummins (1984). Most aquatic insects can also be classified to Functional Feeding Group in the field, on the basis of morphological and behavioral features, using Cummins and Wilzbach (1985).

The relative abundance of Scrapers and Filtering Collectors in the riffle/run habitat is an indication of the periphyton community composition, availability of suspended Fine Particulate Organic Material (FPOM), and availability of attachment sites for filter- ing. Scrapers increase with increased diatom abundance and decrease as filamentous: algae and aquatic mosses (which scrapers cannot efficiently harvest) increase. How-. ever, filamentous.algae and aquatic mosses: provide good attachment sites for-Filtering $\$$ Collectors, and the-organic enrichment often responsible for overabundarice of filamentous algae can also provide FPOM that is utilized by the Filterers.

Filtering Collectors are also sensitive to toxicants bound to fine particles and should be the first group to decrease when exposed 
- Community Loss Index-Measures the loss of benthic taxa between a reference station and the station of comparison. The Community Loss Index was developed by Courtemanch and Davies (1987) and is an index of compositional dissimilarity, with values increasing as the degree of dissimilarity with the reference station increases. Values range from 0 to "infinity." Based on preliminary data analysis, this index provides greater discrimination than either of the following two community similarity indices.

- Jaccard Coefficient of Community Similarity-Measures the degree of similarity in taxonomic composition between two stations in terms of taxon presence or absence. The Jaccard Coefficient discriminates between highly similar collections. Coefficient values, ranging from 0 to 1.0, increase as the degree of similarity with the reference station increases. See Jaccard (1912), Boesch (1977), and U.S. EPA (1983) for more detail. The formulae for the Community Loss Index and the Jaccard Coefficient are

$$
\begin{aligned}
\text { Community Loss } & =\frac{d-a}{e} \\
\text { Jaccard Coefficient } & =\frac{a}{a+b+c}
\end{aligned}
$$

where

$$
\begin{aligned}
& a=\text { number of taxa common to both } \\
& \text { samples } \\
& \mathrm{b}=\text { number of taxa present in Sample } \\
& \text { B but not } A \\
& C=\text { number of taxa present in Sample } \\
& \text { A but not } B \\
& d=\text { total number of taxa present in } \\
& \text { Sample A } \\
& e=\text { total number of taxa present in } \\
& \text { Sample B - } \\
& \text { Sample } A=\text { reference:station (or mean } \\
& \text { of reference database) } \\
& \text { Sample } B=\text { station of comparison }
\end{aligned}
$$

be calculated with either percentages or numbers. A weighting factor can be added that assigns more significance to dominant taxa. See Pinkham and Pearson (1976) and U.S. EPA (1983) for more detail. The formula is

$$
\begin{aligned}
& \text { S.I. } a b=\Sigma \frac{m i n\left(x_{1 a^{\prime}} x_{1 b}\right)}{\max \left(x_{1 a^{\prime}} x_{1 b}\right)}\left[\frac{x_{1 a}}{x_{a}} \cdot \frac{x_{1 b}}{x_{b}} / 2\right] \\
& \text { velghting factor } \\
& \text { where } \\
& x_{i a,} x_{i b}=\text { number of individuals in the ith } \\
& \text { taxon in Sample A or B } \\
& \text { Other community similarity indices sug- } \\
& \text { gested by reviewers of this document } \\
& \text { include Spearman's Rank Correlation } \\
& \text { (Snedecor and Cochran 1967), Morisita's } \\
& \text { Index (Morisita 1959), Biotic Condition } \\
& \text { Index (Winget and Mangum 1979), and } \\
& \text { Bray-Curtis Index (Bray and Curtis 1957, } \\
& \text { Whittaker 1952). Calculation of a chi- } \\
& \text { square "goodness of fit" (Cochran 1952) } \\
& \text { may also be appropriate. }
\end{aligned}
$$

\section{CPOM Sample}

Metric 8. Ratio of Shredder Functional Feeding Group and Total Number of Individuals Collected :Fi: -

Also based on the Functional Feeding Group concept, the abundance of the Shredder-Functional Group relative to the abundance of all other Functional Groups allows evaluation of potential impairment as indicated by the CPOM-based Shredder community. Shredders are sensitive to riparian. zone impacts and are particularly good indicators of toxic effects when the toxicants. involved are readily adsorbed to the CPOM and either affect microbial communities colonizing the CPOM or the Shredders directly (Cummins 1987, personal. communication).

The degree of toxicant effects on Shred:ders versus. Filterers depends on the natureof the:toxicants and the organic particle= adsorption efficiency. Generally, as the:size: of the particle decreases, the adsorption efficiency increases as a function of the:increased surface to volume ratio (Hargrove1972). Because water-borne toxicants are readily adsorbed to FPOM, toxicants of a 